\title{
Chiny
}

w polityce zagranicznej Stanów Zjednoczonych w latach 1911-1918 


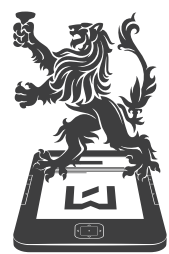

WYDAWNICTWO

UNIWERYYTETU
LODZKKIEGO 


\section{Jan Pajor}

\section{Chiny}

\section{w polityce zagranicznej Stanów Zjednoczonych w latach 1911-1918}


Jan Pajor - Uniwersytet Łódzki, Wydział Filozoficzno-Historyczny, Instytut Historii 90-219 Łódź, ul. A. Kamińskiego 27a

\author{
RECENZENT \\ Jakub Polit \\ REDAKTOR INICJUJĄCY \\ Iwona Gos \\ OPRACOWANIE REDAKCYJNE \\ Tomasz Baudysz \\ SKŁAD I ŁAMANIE \\ AGENT PR \\ KOREKTA TECHNICZNA \\ Leonora Gralka \\ PROJEKT OKŁADKI \\ Katarzyna Turkowska
}

Zdjęcie wykorzystane na okładce: (C Depositphotos.com/m.j.h1nkle

(C) Copyright by Jan Pajor, Łódź 2019

(C) Copyright for this edition by Uniwersytet Łódzki, Łódź 2019

\begin{abstract}
Wydane przez Wydawnictwo Uniwersytetu Łódzkiego
Wydanie I. W.08552.18.0.M
\end{abstract}

Ark. wyd. 23,0; ark. druk. 21,5

ISBN 978-83-8142-086-0
e-ISBN 978-83-8142-087-7

Wydawnictwo Uniwersytetu Łódzkiego

90-131 Łódź, ul. Lindleya 8

www.wydawnictwo.uni.lodz.pl

e-mail: ksiegarnia@uni.lodz.pl

tel. (42) 6655863 


\section{SPIS TREŚCI}

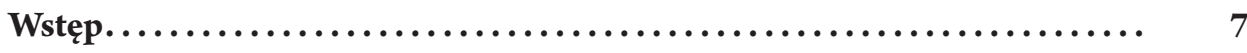

\section{Rozdział I}

Polityka Stanów Zjednoczonych wobec Chin na przełomie XIX i XX wieku.....

\section{Rozdział II}

Chińska polityka rządu Williama $H$. Tafta w latach $1911-1913 \ldots \ldots \ldots \ldots \ldots \ldots \quad 45$

1. Stany Zjednoczone wobec rewolucji Xinhai ................. 45

2. Stany Zjednoczone a pożyczka reorganizacyjna i kwestia uznania Republiki Chińskiej.

\section{Rozdział III}

Chińska polityka administracji Thomasa Woodrowa Wilsona do wybuchu I wojny światowej (marzec 1913 roku - sierpień 1914 roku) ................ 109

1. Wycofanie się USA z konsorcjum mocarstw ................. 115

2. Uznanie przez Stany Zjednoczone Republiki Chińskiej ............. 124

3. Waszyngton wobec „drugiej rewolucji” w Chinach i wzrostu dążeń autorytarnych Yuan Shikaia ............................... 129

4. Nominacja Paula Reinscha na posła w Chinach (15 sierpnia 1913 roku) . 150

5. Nieudane próby zwiększenia amerykańskiej aktywności w Chinach (listopad 1913 roku - sierpień 1914 roku $) \ldots \ldots \ldots \ldots \ldots \ldots \ldots \ldots \ldots \ldots \ldots \ldots$

\section{Rozdział IV}

Polityka Stanów Zjednoczonych wobec Chin w pierwszych latach Wielkiej Woj-

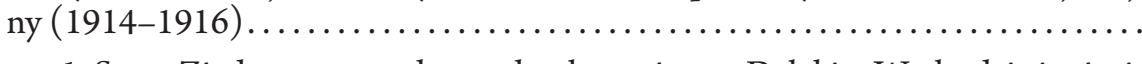

1. Stany Zjednoczone wobec wybuchu wojny na Dalekim Wschodzie i zajęcia

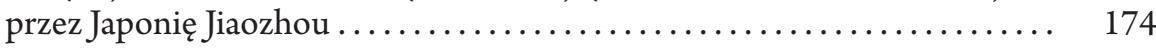

2. Reakcja USA na japońskie 21 żądań ...................... 186

3. Waszyngton wobec amerykańskich inwestycji w Chinach (1914-1915) .. 216

4. Waszyngton wobec ruchu na rzecz restauracji cesarstwa i „trzeciej rewolucji” w Chinach (połowa 1915 roku - czerwiec 1916 roku) 


\section{Spis treści}

\section{Rozdział V}

Polityka USA wobec Chin od śmierci Yuan Shikaia do zakończenia I wojny świa-

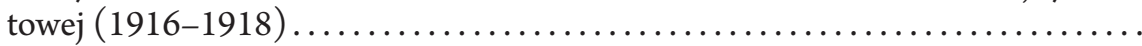

1. Amerykańska ocena wewnętrznej i międzynarodowej sytuacji Chin (czer-

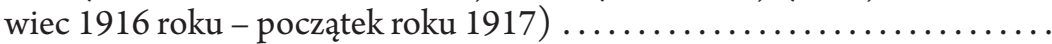

2. Fiasko amerykańskiego programu inwestycyjnego w Chinach......... 251

3. Stanowisko Waszyngtonu w kwestii przystąpienia Chin do I wojny świa-

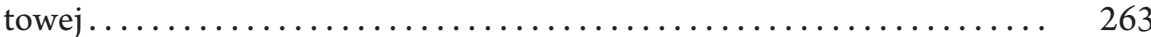

4. Polityka Stanów Zjednoczonych wobec chińskiego sojusznika ........ 279

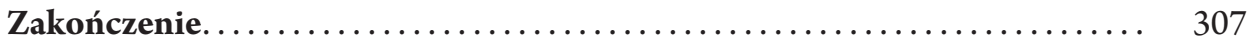

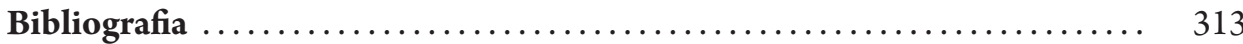

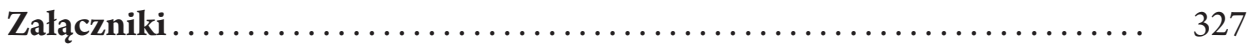

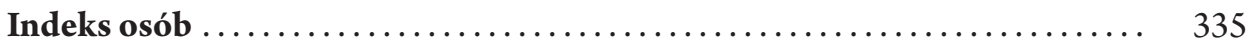

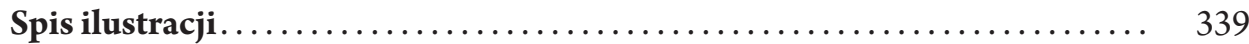




\section{WSTĘP}

Centrum świata przeniosło się [... do Chin. Ktokolwiek rozumie to potężne imperium, [... posiada klucz do polityki światowej na następne pięć wieków ${ }^{1}$.

John Hay, sekretarz stanu USA, 1899 rok

Sądzę, że prawdopodobnie nic tak bardzo nie wpłynie na przyszły rozwój świata jak to, co wydarzy się na [Dalekim - J.P.] Wschodzie, a powinno się to zdarzyć, tak daleko, jak sięgają nasze wpływy, pod przewodnictwem najlepszym z możliwych ${ }^{2}$.

Thomas Woodrow Wilson, prezydent elekt USA, styczeń 1913 roku

Uważam, że wielkie przedstawienie przyszłości zostanie rozegrane w krajach Orientu. Jest wiele punktów stycznych między [Stanami Zjednoczonymi - J.P.]

a nową Republiką Chińską. Sądzę, że obecny okres ma olbrzymie znaczenie dla naszego kraju - to właśnie teraz przemysł amerykański musi zdobyć kontrolę nad ogromnymi i niewykorzystanymi zasobami Orientu ${ }^{3}$.

Paul Reinsch, amerykański poseł w Chinach, sierpień 1913 roku

Powyższe wypowiedzi wskazują, jak istotną rolę na przełomie XIX i XX wieku przypisywali Chinom amerykańscy politycy i dyplomaci oraz za jak ważną uważali politykę wobec tego państwa. Chociaż wiele współczesnych im osób uznałoby takie przewidywania za niedorzeczne, gdyż Chiny znajdowały się $\mathrm{w}$ tym czasie bardziej na skraju przepaści niż u progu rozkwitu, to obecnie, ponad sto lat później, można stwierdzić, że opinie te nie były pozbawione sensu. Znajomość dziejów Chin i polityki, jaką prowadziły wobec nich mocarstwa, zwłaszcza wyrosłe później na największą potęgę Stany Zjednoczone, może zatem pomóc zrozumieć przemiany zachodzące we współczesnym świecie.

1 J. Bailey, Great Power Strategy in Asia: Empire, Culture and Trade, 1905-2005, London 2007, s. 22.

2 Wilson to Eliot, January 20, 1913, [w: The Papers of Woodrow Wilson (dalej: $P W W$ ), (opr.) A.S. Link, t. 27, Princeton 1978, s. 65.

3 P.J. Scanlan, No Longer a Treaty Port: Paul S. Reinsch and China 1913-1919, nieopublikowany doktorat, University of Wisconsin, Madison 1973, s. 17. 
W niniejszej książce starałem się zaprezentować stanowisko USA wobec Chin oraz miejsce Pekinu w amerykańskiej polityce zagranicznej w latach 1911-1918. Dążyłem do naświetlenia założeń chińskiej polityki Waszyngtonu, sposobów jej realizacji, rezultatów i przemian, jakim podlegała w okresie wyznaczonym przez ramy czasowe. $\mathrm{W}$ centrum mojego zainteresowania znajdował się amerykański punkt widzenia, pominąłem zaś kwestie, które były ważne dla Pekinu (jak sprawa chińskich imigrantów w Stanach Zjednoczonych), ale nie wpłynęły znacząco na postawę i działania Waszyngtonu.

Z tak zarysowanej tematyki wyłonił się szereg bardziej szczegółowych pytań badawczych. Pierwsze z nich dotyczyły reakcji rządu amerykańskiego na wydarzenia rozgrywające się w Chinach. W 1911 roku wybuchła tam rewolucja Xinhai, która doprowadziła do upadku panującej dynastii, jak i samego Cesarstwa. Przez kolejnych kilkanaście lat sytuacja $\mathrm{w}$ tym kraju zmieniała się wielokrotnie, nierzadko w zawrotnym tempie. Zmuszało to inne państwa do ustosunkowania się do zachodzących przemian, często także do podjęcia konkretnych działań. Moim zamiarem było określenie, w jaki sposób i w jakim zakresie Stany Zjednoczone angażowały się w wydarzenia w Chinach. Jak zareagowały na rewolucję Xinhai i późniejszą walkę o władzę? Czy zachowały wówczas ścisłą neutralność, czy ingerowały w konflikt, pomagając walczącym? Czy rozważały możliwość interwencji militarnej? Jak postrzegały uczestników walk? Z którym z nich sympatyzowały? Czy dążyły do wzmocnienia, czy dalszego osłabienia Państwa Środka? Jak oceniaty jego kolejne transformacje ustrojowe? Czy starały się na nie wplywać?

Druga grupa pytań odnosiła się do okresu I wojny światowej. Do 1914 roku w Chinach, mających właściwie status półkolonii, krzyżowały się wpływy niemal wszystkich mocarstw europejskich (Wielkiej Brytanii, Francji, Niemiec, Rosji) oraz Japonii. W tym gronie znalazły się też Stany Zjednoczone, które pod koniec XIX wieku weszły na arenę polityki światowej, a jednym z przejawów ich nowej pozycji była aktywna działalność w Państwie Środka. Stopniowo, wraz z narastaniem zagrożenia wojennego na Starym Kontynencie, mocarstwa europejskie zaczęły poświęcać mniej uwagi Dalekiemu Wschodowi, co spowodowało, że wzrosło tam znaczenie Waszyngtonu i Tokio. Rozpoczęcie I wojny światowej pogłębiło jeszcze ten proces. Interesowało mnie zatem, czy Stany Zjednoczone próbowały wykorzystać dogodną okazję do rozszerzania swoich wpływów w Chinach, jaka pojawiła się podczas Wielkiej Wojny. Czy dążyły do uzyskania nowych koncesji, czy raczej utrzymania status quo ante bellum?

W tym kontekście istotne wydało mi się też zbadanie stanowiska rządu waszyngtońskiego wobec agresywnych poczynań Tokio w Państwie Środka. Czy jawnie lub nieformalnie aprobował on japońskie plany podporządkowania Chin podczas I wojny światowej? Czy może starał się im przeciwstawić, a jeśli tak, to w jaki sposób i z jakim skutkiem? Czy był gotowy pomóc Chinom, nawet jeżeli doprowadziłoby to do pogorszenia jego stosunków z Japonią? 
To ostatnie pytanie stanowiło też część bardziej ogólnego zagadnienia: jak działania Stanów Zjednoczonych w Państwie Środka wpływały na ich relacje z innymi mocarstwami? I vice versa - na ile chińska polityka mocarstw przyczyniała się do zmiany ich notowań w Waszyngtonie? Wreszcie: czy nad Potomakiem rozważano pójście na ustępstwa w Chinach, aby odnieść korzyść w innych sprawach międzynarodowych? A może było na odwrót? Znalezienie odpowiedzi na te pytania pozwoliło lepiej określić miejsce Chin w polityce zagranicznej USA.

Wśród zagadnień, które poruszyłem w książce, znalazła się również kwestia koherentności amerykańskiej polityki wobec Chin. Chciałem sprawdzić, czy była ona spójna i konsekwentna, zważywszy, że w omawianym okresie kierowało nią trzech sekretarzy stanu podlegających dwóm prezydentom, którzy wywodzili się ponadto z przeciwnych partii. Starałem się ustalić, czy zmiany gospodarzy w Białym Domu i Departamencie Stanu wpłynęły na pozycję Pekinu w amerykańskiej polityce zagranicznej.

Kolejnym problemem badawczym, na który zwróciłem uwagę, był stopień zaangażowania rządu waszyngtońskiego w Chinach. Na początku kontaktów dwustronnych powstał w USA mit rynku chińskiego, i choć w XIX wieku nie udało się go urzeczywistnić, to Waszyngton prowadził aktywną politykę chińską. Próbowałem więc sprawdzić, czy w latach 1911-1918 jego zaangażowanie w Chinach, podobnie jak we wcześniejszym okresie, było nadal większe niż rzeczywiste interesy gospodarcze amerykańskich obywateli. Jeżeli tak, to czy rząd starał się temu zaradzić, zachęcając ich do większej aktywności?

Obok mitu rynku chińskiego w Stanach Zjednoczonych panowało przekonanie o specjalnej więzi łączącej oba narody. Chciałem przyjrzeć się, na ile poczynania amerykańskiej dyplomacji w omawianym okresie wynikały jedynie z interesu państwowego, a na ile obecna była w nich tradycyjna motywacja - chęć pomocy Chinom i ochrony ich przed zbytnim osłabieniem.

Zakres chronologiczny monografii obejmuje lata 1911-1918, jednak w rozdziale wprowadzającym uznałem za zasadne cofnąć się do przełomu XIX i XX wieku, aby przedstawić źródła późniejszych działań Stanów Zjednoczonych. Cezurę początkową właściwych rozważań wyznacza rewolucja Xinhai, która w znaczący sposób zmieniła sytuację w Chinach i rzutowała na politykę mocarstw mających swoje interesy w tym państwie. Wydarzeniem zamykającym pracę jest podpisanie rozejmu w Compiègne kończącego Wielką Wojnę, co również miało wpływ na międzynarodowy układ sił w Chinach i amerykańską politykę tamże.

W książce dominują zagadnienia polityczno-dyplomatyczne, chociaż poruszyłem także inne kwestie, zwłaszcza gospodarcze, które akurat w Państwie Środka dość mocno splatały się z polityką i dyplomacją. Kolejna uwaga dotyczy perspektywy przyjętej w pracy. Ze względu na jej tematykę koncentrowałem się na stanowisku i działaniach władz amerykańskich, ale musiałem również uwzględnić osoby i podmioty prywatne, skoro np. administracja Williama Tafta w ramach 
„dyplomacji dolarowej” zawiązała swoisty sojusz z Wall Street. Osoby i grupy pozarządowe, wywodzące się głównie ze środowisk biznesowych lub misjonarskich, pojawiają się w pracy wówczas, gdy mogły mieć wpływ na oficjalną politykę państwa. To samo założenie dotyczy reakcji amerykańskiej opinii publicznej na decyzje rządu w odniesieniu do Chin.

W książce wykorzystałem różne metody badawcze. Ze względu na bogactwo dokumentów bezpośrednio odnoszących się do zakreślonej w temacie problematyki zastosowałem przede wszystkim podejście indukcyjne, polegające na wyprowadzaniu wniosków o charakterze ogólnym z licznych informacji szczegółowych. Gdy jednak materiał źródłowy nie pozwalał w pełni zrekonstruować danego fragmentu przeszłości, posługiwałem się metodami pośrednimi - retrogresywną i progresywną oraz porównawczą. Za pomocą pierwszej starałem się uzupełnić luki faktograficzne, wnioskując na podstawie wcześniejszych lub późniejszych wydarzeń. Metody porównawczej używałem w dwojaki sposób - zestawiałem amerykańską politykę wobec Chin z polityką wobec innych państw, a także analizowałem ją na tle chińskiej polityki pozostałych mocarstw. Wnioski sformułowane na podstawie źródeł i z użyciem różnych metod konfrontowałem następnie z opiniami innych badaczy.

Ustalenia poczynione $\mathrm{w}$ książce opierają się $\mathrm{w}$ znakomitej większości na źródłach. Znaczną część z nich stanowią archiwalia, do których miałem dostęp podczas kwerendy w Stanach Zjednoczonych. Przebadałem wówczas materiały zgromadzone w National Archives w College Park oraz w Library of Congress w Waszyngtonie. W pierwszej instytucji znajdują się przepastne zbiory Departamentu Stanu dotyczące Chin, podzielone w interesującym mnie okresie na trzy zmikrofilmowane serie: Records of the Department of State Relating to Internal Affairs of China, 1910-1929, Records of the Department of State Relating to Political Relations Between China and Other States, 1910-1929 oraz Records of the Department of State Relating to Political Relations Between the United States and China, 1910-1929. W Bibliotece Kongresu przechowywane są z kolei spuścizny po amerykańskich prezydentach, członkach rządu, czołowych urzędnikach i dyplomatach. W książce wykorzystałem dokumenty z niezwykle zasobnych kolekcji: Williama H. Tafta, Philandera C. Knoxa, Thomasa Woodrowa Wilsona, Williama Jenningsa Bryana i Roberta Lansinga. Sięgnąłem ponadto do udostępnionych w internecie fragmentów kolekcji Willarda Straighta i Roberta Lansinga, których oryginały znajdują się w bibliotekach Cornell University i Princeton University.

Oprócz archiwaliów cennych materiałów źródłowych dostarczyły opublikowane zbiory dokumentów, z których najważniejsze były Papers Relating to the Foreign Relations of the United States oraz The Papers of Woodrow Wilson ${ }^{4}$.

4 Papers Relating to the Foreign Relations of the United States 1899-1918, Washington 1901-1930; Papers Relating to the Foreign Relations of the United States 1914-1918, 
Wartościowe okazały się też: The Intimate Papers of Colonel House, Congressional Records, Treaties and Agreements with and Concerning China, 1894-1919 oraz The Sino-Japanese Negotiations of 1915. Japanese and Chinese Documents and Chinese Official Statement ${ }^{5}$. Wydana korespondencja dyplomatyczna z innych państw - Wielkiej Brytanii, Francji, Japonii i Chin - miała nie tylko wartość informacyjną, ale także pozwoliła zweryfikować część wiadomości ze źródeł amerykańskich ${ }^{6}$.

Pokaźne uzupełnienie stanowiła literatura memuarystyczna. Warto wymienić tutaj dzieła: Paula Reinscha, Davida F. Houstona, Josephusa Danielsa, Williama Jenningsa Bryana, Roberta Lansinga, Huntingtona Wilsona i Williama Phillipsa ${ }^{7}$. Równie ciekawe i barwne, chociaż mniej istotne z punktu widzenia mojej pracy, były wspomnienia i autobiografie: Theodore'a Roosevelta, Herberta Hoovera, sir Edwarda Greya, cesarza Puyi czy Sun Yat-sena.

Jedynie sporadycznie korzystałem z tytułów prasowych. Nie zdecydowałem się na przeprowadzenie gruntownej kwerendy prasowej ze względu na ogrom materiałów oraz fakt, że dla tematyki pracy miałaby ona drugorzędne znaczenie. $\mathrm{Z}$ kolei z powodów organizacyjnych nie przebadałem rozsianych po różnych bibliotekach amerykańskich spuścizn po niektórych dyplomatach zaangażowanych w kształtowanie chińskiej polityki USA (m.in. Huntingtona Wilsona, Johna

Supplement: The World War, Washington 1928-1933; Papers Relating to the Foreign Relations of the United States, The Lansing Papers, 1914-1920, t. 1-2, Washington 1939-1940; $P W W$, t. 23-53, Princeton 1977-1986.

5 The Intimate Papers of Colonel House, (opr.) Ch. Seymour, t. 1-4, Boston-New York 1926-1928; Congressional Records, t. 48-56, Washington 1912-1918; Treaties and Agreements with and Concerning China, 1894-1919, zebrał i opracował J.V.A. MacMurray, t. 1-2, New York 1921; The Sino-Japanese Negotiations of 1915. Japanese and Chinese Documents and Chinese Official Statement, Washington 1921.

${ }^{6}$ British Documents on the Origins of the War 1898-1914, (opr.) G.P. Gooch, H. Temperley, t. 1-11, London 1926-1938; Documents Diplomatiques Français, 18711914, $2^{\text {e }}$ série: 1901-1911, t. 14, $3^{\text {e }}$ série: 1911-1914, t. 1-11, Paris 1929-1955; M. Kajima, The Diplomacy of Japan 1894-1922, t. 2-3, Tokyo 1978-1980; V.K. Wellington Koo's Foreign Policy. Some Selected Documents, zebrał W. King, Shanghai 1931.

P. Reinsch, An American Diplomat in China, Garden City 1922; D.F. Houston, Eight Years with Wilson's Cabinet, 1913 to 1920, t. 1-2, New York 1926; The Cabinet Diaries of Josephus Daniels, (opr.) E.D. Cronon, Lincoln 1963; W.J. Bryan, M.B. Bryan, The Memoirs of William Jennings Bryan, Chicago 1925; R. Lansing, War Memoirs of Robert Lansing, Secretary of State, Westport 1970; F.M. Huntington Wilson, Memoirs of an Ex-Diplomat, Boston 1945; W. Phillips, Ventures in Diplomacy, Boston 1953.

8 T. Roosevelt, An Autobiography, New York 1914; H. Hoover, The Memoirs of Herbert Hoover, t. 1: Years of Adventure, 1874-1920, New York 1952; E. Grey, Twenty-five Years 1892-1916, t. 1-2, New York 1925; Pu Yi, Bytem ostatnim cesarzem Chin, przeł. J. Mach, t. 1, Łódź 1988; Yat-sen Sun, Memoirs of a Chinese Revolutionary: A Programme of National Reconstruction for China, New York 1970. 
V.A. MacMurraya, Paula Reinscha, Edwarda T. Williamsa). Wiele z napisanych przez nich dokumentów znajduje się zresztą w zbiorach National Archives, Library of Congress i w wydanych materiałach. W książce nie wykorzystałem też źródeł chińskich, których nie mogłem użyć z powodu nieznajomości języka. Wydaje się jednak, że nie byłyby one kluczowe dla monografii, która nie traktuje o stosunkach dwustronnych, lecz o amerykańskiej postawie wobec Chin.

Ogólna literatura przedmiotu jest bardzo bogata. Wynika to z faktu, że lata 1911-1918 obfitowały w doniosłe wydarzenia, które przykuwały uwagę historyków. W skali światowej były to narastający antagonizm między zwalczającymi się blokami w Europie oraz Wielka Wojna; w perspektywie dalekowschodniej i stricte chińskiej - wzrost pozycji Japonii, rewolucja Xinhai, dyktatura Yuan Shikaia i początek ery tzw. panów wojny. Pierwsze dekady XX wieku to także przełomowy moment w dziejach Stanów Zjednoczonych i ich dyplomacji. Szczególne miejsce $\mathrm{w}$ historiografii nie tylko tego okresu zajmuje Woodrow Wilson - jeden z najważniejszych amerykańskich prezydentów - któremu historycy poświęcili niezliczoną liczbę studiów. Interesowali się również osobami z otoczenia prezydenta, takimi jak: William Jennings Bryan, Edward House i Robert Lansing. Mniejszą, lecz nadal całkiem sporą popularnością cieszyła się postać Williama Tafta i jego współpracowników politycznych. W imponującym dorobku historiograficznym poświęconym obu prezydentom i ich gabinetom wyróżniają się książki: Paola Coletty, Lewisa Goulda, Ralpha Mingera, Davida Burtona, Arthura Linka, Johna Miltona Coopera jr., Raya Stannarda Bakera, Lloyda Ambrosiusa, Johna Mortona Bluma, Kendricka Clementsa, Augusta Heckschera, Harleya Nottera, Michaela Kazina, Daniela Smitha i Godfreya Hodgsona9.

9 P. Coletta, William Jennings Bryan, t. 1-3, Lincoln 1964-1969; idem, The Presidency of William Howard Taft, Lawrence 1987; L. Gould, The William Howard Taft Presidency, Lawrence 2009; R.E. Minger, William Howard Taft and American Foreign Policy: The Apprenticeship Years, 1900-1908, Urbana 1975; D.H. Burton, Taft, Wilson and World Order, Madison 2003; idem, William Howard Taft: Confidential Peacemaker, Philadelphia 2004; A.S. Link, Wilson: The Road to the White House, Princeton 1947; idem, Woodrow Wilson and the Progressive Era, 1910-1917, New York 1954; idem, Wilson: The New Freedom, Princeton 1956; idem, Wilson the Diplomatist: A Look at His Major Foreign Policies, Baltimore 1957; idem, Wilson: The Struggle for Neutrality, 1914-1915, Princeton 1960; idem, Wilson: Confusions and Crises, 1915-1916, Princeton 1964; idem, Wilson: Campaigns for Progressivism and Peace, 1916-1917, Princeton 1965; J.M. Cooper jr., Woodrow Wilson: A Biography, New York 2011; R.S. Baker, Woodrow Wilson. Life and Letters, t. 1-5, Garden City 1927-1935, t. 6-8, New York 1946; L.E. Ambrosius, Woodrow Wilson and the American Diplomatic Tradition: The Treaty Fight in Perspective, Cambridge 1987; J.M. Blum, Woodrow Wilson and the Politics of Morality, Boston 1956; K.A. Clements, The Presidency of Woodrow Wilson, Lawrence 1992; A. Heckscher, Woodrow Wilson, New York 1991; H. Notter, The Origins of the Foreign Policy of Woodrow Wilson, New York 1965; 
Amerykańska polityka wobec Chin również doczekała się wielu rzetelnych i interesujących opracowań naukowych. Wśród pozycji, które omawiają ją w dłuższej perspektywie lub w okresie poprzedzającym główny tok moich rozważań, szczególnie wartościowe były monografie: Michaela H. Hunta, Paula A. Varga, Davida M. Pletchera, Thomasa J. McCormicka, Marilyn Blatt Young, Alfreda Whitneya Griswolda i Akiry Iriye' ${ }^{10} . \mathrm{Z}$ publikacji ujmujących szczegółowo wybrany przeze mnie okres najbardziej przydatne okazały się studia: Daniela M. Crane’a i Thomasa A. Breslina, Waltera V. Scholesa i Marie V. Scholes, Charlesa Veviera, Jamesa Reeda, Lloyda Gardnera, Tien-yi Li, Roya Watsona Curry'ego i Russella H. Fifielda ${ }^{11}$. Bardzo pomocne były też opracowania Burtona Beersa, Noela Pugacha, Dimitriego Daniela Laza i Patricka Johna Scanlana, prezentujące amerykańską politykę z punktu widzenia poszczególnych dramatis personae $^{12}$. Cenne uzupełnienie stanowiły książki autorstwa Petera Lowe’a, Mariusa

M. Kazin, A Godly Hero: The Life of William Jennings Bryan, New York 2007; D.M. Smith, Aftermath of War: Bainbridge Colby and Wilsonian Diplomacy, 1920-1921, Philadelphia 1970; idem, Robert Lansing and American Neutrality, 1914-1917, New York 1972; G. Hodgson, Woodrow Wilson's Right Hand: The Life of Colonel Edward M. House, New Haven 2006.

${ }_{10}$ M.H. Hunt, Frontier Defense and the Open Door. Manchuria in Chinese-American Relations 1895-1911, New Haven 1973; idem, The Making of a Special Relationship: The United States and China to 1914, New York 1983; P.A. Varg, Open Door Diplomat. The Life of W.W. Rockhill, Urbana 1952; idem, The Making of a Myth: the United States and China, 1897-1912, Westport 1980; D.M. Pletcher, The Diplomacy of Involvement: American Economic Expansion Across the Pacific, 1784-1900, Columbia 2001; T.J. McCormick, China Market. America's Quest for Informal Empire, 1893-1901, Chicago 1970; M.B. Young, The Rhetoric of Empire: American China Policy, 1895-1901, Cambridge 1968; A.W. Griswold, The Far Eastern Policy of the United States, New York 1938; A. Iriye, Pacific Estrangement: Japanese and American Expansion, 1897-1911, Chicago 1994.

${ }^{11}$ D.M. Crane, T.A. Breslin, An Ordinary Relationship: American Opposition to Republican Revolution in China, Gainesville 1986; W. Scholes, M. Scholes, The Foreign Policies of the Taft Administration, Columbia 1970; Ch. Vevier, The United States and China, 1906-1913: A Study in Finance and Diplomacy, New York 1968; J. Reed, The Missionary Mind and American East Asia Policy, 1911-1915, Cambridge 1983; L.C. Gardner, Safe for Democracy: The Anglo-American Response to Revolution, 1913-1923, New York 1984; Tien-yi Li, Woodrow Wilson's China Policy, 1913-1917, Kansas City 1952; R.W. Curry, Woodrow Wilson and Far Eastern Policy, 1913-1921, New York 1968; R. H. Fifield, Woodrow Wilson and the Far East. The Diplomacy of the Shantung Question, Hamden 1965.

12 B. Beers, Vain Endeavor. Robert Lansing's Attempts to End the American-Japanese Rivalry, Durham 1962; N. Pugach, Paul S. Reinsch: Open Door Diplomat in Action, Millwood 1979; D.D. Lazo, An Enduring Encounter: E.T. Williams, China, and the United States, nieopublikowany doktorat, University of Illinois at Urbana-Champaign, Urbana 1977; P.J. Scanlan, No Longer a Treaty Port... 
B. Jansena i Madeleine Chi, dotyczące zarówno polityki prowadzonej przez inne mocarstwa w Chinach, jak i przez same Chiny ${ }^{13}$.

Problematyka amerykańskiej polityki wobec Chin na początku XX wieku znalazła niewielkie odzwierciedlenie w piśmiennictwie polskim, aczkolwiek sytuacja pod tym względem powoli się zmienia. W pierwszej kolejności wypada wymienić książki Jakuba Polita, Wojciecha Rojka i Tadeusza Dmochowskie$\mathrm{go}^{14}$. Prezentują one szczegółowo jednak tylko pewne elementy polityki amerykańskiej, która nie stanowi sedna ich rozważań. Zagadnienia postawy i działań Waszyngtonu wobec Pekinu podejmuje też Longin Pastusiak, lecz jego prace przedstawiające rozległą historię dyplomacji amerykańskiej i sylwetki wszystkich prezydentów są z konieczności jedynie szkicowe ${ }^{15}$. Równie ogólny charakter mają syntezy dziejów Chin autorstwa Witolda Rodzińskiego i Jakuba Polita ${ }^{16}$. Wiele ciekawych informacji uzupełniających zawierają monografie Krzysztofa Michałka, Andrzeja Mani, Wojciecha Materskiego i Jakuba Polita ${ }^{17}$.

Książka podzielona jest na pięć rozdziałów, które ujmują zagadnienia chronologicznie. W ramach poszczególnych rozdziałów układ bywa różny - chronologiczny lub chronologiczno-problemowy.

Rozdział I stanowi wprowadzenie do właściwych rozważań i kreśli obraz amerykańskiej polityki wobec Chin na przełomie XIX i XX wieku. Znaczną część rozdziału poświęciłem doktrynie „otwartych drzwi” - jej genezie, celom i przemianom, jakie przechodziła od momentu inauguracji w 1899 roku. Zaprezentowałem ponadto reakcję Waszyngtonu zarówno na wydarzenia rozgrywające się w Chinach, jak i poza nimi, a rzutujące na ich sytuację międzynarodową. Scharakteryzowałem również podejście administracji Theodore’a Roosevelta i Williama

13 P. Lowe, Great Britain and Japan 1911-1915: A Study of British Far Eastern Policy, London-New York 1969; M.B. Jansen, The Japanese and Sun Yat-sen, Cambridge 1954; M. Chi, China Diplomacy, 1914-1918, Cambridge 1970.

${ }_{14}$ J. Polit, Odwrót znad Pacyfiku? Wielka Brytania wobec Dalekiego Wschodu (19141922), Kraków 1999; W. Rojek, Ekspansja mocarstw w Chinach $i$ jej wplyw na rozwój stosunków międzynarodowych w latach 1895-1914, Kraków 1990; T. Dmochowski, Walka polityczna mocarstw o dominację w dorzeczu Amuru, Toruń 1999.

${ }_{15}$ L. Pastusiak, Pót wieku dyplomacji amerykańskiej 1898-1945, Warszawa 1974; idem, Prezydenci Stanów Zjednoczonych Ameryki, Warszawa 2002; idem, Droga Stanów Zjednoczonych do mocarstwowości, Łódź 2007.

16 W. Rodziński, Historia Chin, Wrocław 1992; J. Polit, Chiny, Warszawa 2004.

${ }^{17}$ K. Michałek, Poza granice kontynentu. Teoria pogranicza Fredericka Jacksona Turnera a idea ekspansji dalekowschodniej w amerykańskiej polityce zagranicznej 1893-1922, Warszawa 1992; A. Mania, Department of State 1789-1939. Pierwsze 150 lat udziatu w polityce zagranicznej USA, Kraków 2011; W. Materski, Bolszewicy i samuraje. Walka dyplomatyczna i zbrojna o rosyjski Daleki Wschód (1917-1925), Warszawa 1990; J. Polit, Japonska polityka zagraniczna 1895-1945, Kraków 2015. 
Tafta do Chin oraz wskazałem na ograniczenia i atuty chińskiej polityki Stanów Zjednoczonych.

Rozdział II dotyczy okresu od października 1911 roku do marca roku 1913. Opisałem w nim stanowisko i działania USA podczas rewolucji Xinhai oraz w pierwszym roku funkcjonowania Republiki Chińskiej, kiedy to przede wszystkim rozważano kwestie związane z uznaniem jej nowych władz i udzieleniem pożyczki reorganizacyjnej.

Początek rozdziału III traktuje o reorientacji amerykańskiej polityki wobec Chin, gdy prezydentem został Woodrow Wilson. Jego administracja, hołdująca innym zasadom niż poprzednie rządy i mająca odmienną wizję polityki zagranicznej, zerwała z dotychczasowym kursem. Scharakteryzowałem następnie, jak ustosunkowała się ona do "drugiej rewolucji” w Chinach i zaprowadzenia autorytarnych rządów przez Yuan Shikaia. Opisałem ponadto jej działania na rzecz zwiększenia amerykańskiej aktywności w Państwie Środka.

Dwa ostatnie rozdziały ukazują miejsce Chin w polityce zagranicznej USA podczas I wojny światowej. Rozdział IV obejmuje początkowe lata walk, do śmierci Yuana w czerwcu 1916 roku. W pierwszej części rozdziału skupiłem się na stosunku Waszyngtonu do wybuchu wojny na Dalekim Wschodzie i próby podporządkowania Chin przez Japonię w 1915 roku. Następnie zaprezentowałem jego podejście do kampanii na rzecz restauracji cesarstwa w Chinach oraz „trzeciej rewolucji”, podczas której zmarł Yuan.

$\mathrm{W}$ rozdziale $\mathrm{V}$ podjąłem narrację w połowie 1916 roku i doprowadziłem ją do końca Wielkiej Wojny. Amerykańska dyplomacja musiała się wówczas zmierzyć z coraz mocniej zazębiającymi się problemami: zmieniającą się wręcz kalejdoskopowo sytuacją polityczną w Państwie Środka, wzrastającymi tam wpływami Japonii i sprawą przystąpienia Chin do wojny. Opisałem reakcje i działania Stanów Zjednoczonych wobec wspomnianych zagadnień, obejmujące m.in. takie inicjatywy jak program inwestycyjny czy porozumienie Lansing-Ishii.

Na zakończenie chciałbym wyjaśnić kilka kwestii formalnych. W książce zastosowałem transkrypcję pinyin (w wersji uproszczonej - bez znaków tonalnych), która jest już powszechnie przyjęta i w literaturze przedmiotu coraz bardziej wypiera wcześniejsze systemy latynizacji znaków chińskich. W odniesieniu do nazw i nazwisk japońskich posłużyłem się transkrypcją międzynarodową. Wyjątek uczyniłem dla egzonimów i nazw zakorzenionych w języku polskim (np. Pekin, Szanghaj, Tokio, Kuomintang). Nazwisko słynnego polityka chińskiego Wellingtona Koo podałem w zanglizowanej formie i zgodnie z kolejnością zachodnią. W przypadku pozostałych nazwisk chińskich i japońskich zachowałem ich oryginalny szyk, w którym nazwisko poprzedza imię. Nie dotyczyło to jednak nazwisk autorów azjatyckich, które zapisywałem zgodnie z konwencją przypisów i bibliografii. 
Oprócz tekstu znajdującego się w załączniku nr 2 wszystkie pozostałe tłumaczenia w pracy są mojego autorstwa. Starałem się jak najwierniej oddać zarówno sens, jak i styl wypowiedzi, ale w zawiłych fragmentach tekstu, które mogłyby się stać niezrozumiałe lub dwuznaczne, zawsze przedkładałem pierwszą wartość nad drugą.

Prezentowana książka stanowi nieco zmodyfikowaną wersję mojej rozprawy doktorskiej. Pragnę serdecznie podziękować mojemu Promotorowi prof. dr. hab. Andrzejowi M. Brzezińskiemu, na którego cenne rady i wsparcie zawsze mogłem liczyć. Za wszelką okazaną mi pomoc oraz inspirujące rozmowy dziękuję również pozostałym pracownikom i doktorantom Katedry Historii Powszechnej Najnowszej Instytutu Historii Uniwersytetu Łódzkiego. Niezmiernie wdzięczny jestem Recenzentom mojej pracy - prof. dr hab. Jadwidze Kiwerskiej, dr. hab. Radosławowi Żurawskiemu vel Grajewskiemu, prof. UŁ oraz dr. hab. Jakubowi Politowi. Ich uwagi i sugestie pozwoliły mi uniknąć części błędów oraz ulepszyć niniejszą monografię.

Kolejne podziękowania kieruję w stronę Dyrektorów Roosevelt Study Center w Middelburgu i John F. Kennedy Institute w Berlinie za przyznanie stypendiów badawczych, które umożliwily mi przeprowadzenie kwerend w tych instytucjach. Pracownikom obu instytutów, a także National Archives i Library of Congress winien jestem podziękowania za życzliwą pomoc w poszukiwaniu dokumentów i literatury przedmiotu. Wdzięczny jestem ponadto wszystkim pracownikom Wydawnictwa Uniwersytetu Łódzkiego zaangażowanym w publikację tej książki, Pani Annie Wosiak za sporządzenie mapy Chin oraz Agacie Maryniak za konsultacje z języka angielskiego. Dziekanowi Wydziału Filozoficzno-Historycznego UŁ prof. dr. hab. Maciejowi Kokoszce dziękuję za dofinansowanie wydania mojej pracy.

Nie mogę wreszcie pominąć Najbliższych mi osób, bez których wsparcia i wyrozumiałości ta książka by nie powstała. Z całego serca dziękuję mojej Mamie, mojemu Tacie, a także Narzeczonej. Książkę dedykuję Tacie, któremu niestety nie dane było doczekać jej wydania. 


\section{RozDZIAE I}

\section{POLITYKA STANÓW ZJEDNOCZONYCH WOBEC CHIN NA PRZEŁOMIE XIX I XX WIEKU}

Na przełomie XIX i XX wieku amerykańska polityka wobec Chin przeszła istotne zmiany, spowodowane niemal jednoczesnym wystąpieniem dwóch procesów - wyznaczaniem przez mocarstwa stref wpływów w Państwie Środka i wkraczaniem Stanów Zjednoczonych na arenę polityki światowej.

Porażka w wojnie z Japonią (1894-1895) obnażyła słabość Chin i niepowodzenie prowadzonej przez nie polityki „samoumocnienia”, polegającej na wąsko zakrojonej modernizacji. Konsekwencje przegranej okazały się dla Chin bardzo poważne. Nie tylko musiały się zgodzić na ciężkie warunki traktatu pokojowego w Shimonoseki ${ }^{1}$, ale szybko stanęły nawet wobec widma utraty niepodległości. Mocarstwa europejskie i Japonia, dostrzegając łatwą możliwość uzyskania nowych nabytków i przywilejów, przystąpiły bowiem ochoczo do tworzenia w Cesarstwie stref wpływów, a więc obszarów zarezerwowanych dla swej penetracji gospodarczej i przygotowanych do potencjalnej aneksji. W wyniku prowadzonej w latach 1895-1899 walki o koncesje (nazywanej też bardziej obrazowo „krajaniem chińskiego arbuza") Rosja zdobyła silną pozycję w Mandżurii, Niemcy w Shandongu, a Francja w Yunnanie, Guangxi i Guangdongu. Strefa brytyjska rozciągała się wzdłuż doliny Jangcy, chociaż Londyn wykazywał też zainteresowanie Tybetem, zdobył punkt oparcia na północy Chin i rozszerzył swój stan posiadania na południu. Japonia zastrzegła sobie z kolei prawo do Fujianu (znajdującego się naprzeciwko przejętego przez nią Tajwanu), a ponadto interesowała się Mandżurią i Koreą. Ta ostatnia, uprzednio podporządkowana rządzącej w Pekinie mandżurskiej dynastii Qing, przekształcała się stopniowo w kondominium rosyjsko-japońskie ${ }^{2}$.

1 Warunki traktatu pokojowego: Doc. no. 1895/3: Japan and China. Treaty of peace (with separate articles and Convention to prolong Armistice), April 17, 1895, [w:] Treaties and Agreements with and Concerning China, 1894-1919, zebrał i opracował J.V.A. MacMurray, t. 1: Manchu Period (1894-1911), New York 1921, s. 18-24.

2 W. Rodziński, Historia Chin, Wrocław 1992, s. 480-492; T. Dmochowski, Walka polityczna mocarstw o dominację $w$ dorzeczu Amuru, Toruń 1999, s. 44-55; W. Rojek, Ekspansja mocarstw $w$ Chinach $i$ jej wptyw na rozwój stosunków międzynarodowych $w$ latach 1895-1914, Kraków 1990, s. 21-28. 
Najbardziej widoczny element procesu wytyczania stref wpływów stanowiły dzierżawy dokonywane przez mocarstwa. Sygnał do tego dały w marcu 1898 roku Niemcy, które na 99 lat objęły we władanie Jiaozhou w Shandongu. Ich śladem podążyły Rosja i Francja. Pierwsza otrzymała na 25 lat Port Artur i Dalian w Mandżurii, druga zaś uzyskała na 99 lat Guangzhouwan w Guangdongu. Poniekąd w odpowiedzi na te posunięcia Wielka Brytania, której nie zależało na rozczłonkowaniu Chin, ale która musiała reagować na działania rywali, wystarała się o dzierżawę przylegającego do Hongkongu półwyspu Jiulong (standardowo na 99 lat) oraz znajdującego się w Shandongu Weihaiwei (zdecydowanie niestandardowo, bo na tak długo, jak Port Artur pozostanie pod rosyjskim zwierzchnictwem) ${ }^{3}$.

Oprócz dzierżaw do wytyczenia stref wpływów doprowadziły, jak wymienia Mingchien J. Bau, cztery inne czynniki: porozumienia międzynarodowe, prawo pierwszeństwa przy ubieganiu się o możliwość eksploatacji gospodarczej danego terenu, deklaracje Chin o „nieodstępowaniu” innym państwom różnych prowincji oraz koncesje kolejowe ${ }^{4}$.

Międzynarodowe położenie Chin stawało się wyjątkowo niekorzystne - w szybkim tempie przekształcały się one we wspólną kolonię mocarstw. Niepodległość „chorego człowieka Azji”, jak zaczęto je nazywać per analogiam do zmierzchającego Imperium Osmańskiego, była zagrożona. Przed rozbiorem chroniła je na razie przede wszystkim równowaga sił między mocarstwami ${ }^{5}$.

Rozwojowi sytuacji na Dalekim Wschodzie z niepokojem przyglądały się Stany Zjednoczone, które w tym czasie zaczęły aspirować do grona światowych potęg i chciały prowadzić adekwatną politykę zagraniczną. Jednym z obszarów ich wzmożonej aktywności miały być Chiny.

Pod koniec XIX wieku w amerykańskiej historii nastąpił zwrot. USA, koncentrujące się dotychczas na zagospodarowywaniu wnętrza państwa i stroniące od angażowania się w sprawy poza własnym kontynentem, wkroczyły na arenę polityki światowej. Na ten przełom złożyły się rozmaite czynniki. Jednym z nich była chęć

3 Doc. no. 1898/4: Germany and China. Convention respecting the lease of Kiaochow, March 6, 1898, [w: ] Treaties and Agreements..., s. 112-116; Doc. no. 1898/5: Russia and China. Convention for the lease of the Liaotung Peninsula, March 27, 1898, [w: ] ibidem, s. 119-121; Doc. no. 1898/7: France and China. Agreement in regard to a concession to build a railway from Tongking to Yunnan, the lease of Kuang-chou-wan, and the organization of the Chinese postal service, April 10, 1898, [w: ibidem, s. 124-125; Doc. no. 1898/11: Great Britain and China. Convention respecting an extension of the Hongkong territory, June 9, 1898, [w:] ibidem, s. 130-131; Doc. no. 1898/14: Great Britain and China. Convention for the lease of Wei-hai Wei, July 1, 1898, [w: ibidem, s. 152-153. Chiny odrzucity tylko żądanie wydzierżawienia zatoki Sanmen, gdyż wiedziały, że występujące z nim Włochy nie były w stanie zbrojnie narzucić swej woli. W. Rodziński, Historia Chin ..., s. 492.

${ }_{4}$ M.J. Bau, The Open Door Doctrine in Relation to China, New York 1923, s. 16.

5 O powodach fiaska rozbioru Chin piszą: W. Rodziński, Historia Chin ..., s. 494; J. Polit, Chiny, Warszawa 2004, s 30-31. 
zdobycia prestiżu i statusu mocarstwa, tak aby wpływy polityczne odzwierciedlały pozycję gospodarczą państwa, zaczynającego pod tym względem przodować w skali świata. Wśród Amerykanów popularność zyskiwała koncepcja darwinizmu społecznego, a także umocniło się przekonanie o ich misji dziejowej, mającej polegać na cywilizowaniu zacofanych ludów, szerzeniu demokracji i chrześcijaństwa. Impuls do działania dawali też Europejczycy, którzy podporządkowywali sobie liczne tereny w Afryce i Azji. Nad Potomakiem zdawano sobie sprawę, że to ostatni moment, aby włączyć się do wyścigu kolonialnego. Równie istotne były powody ekonomiczne. Uważano, że prężnie rozwijająca się gospodarka amerykańska potrzebowała nowych rynków zbytu i miejsc do lokowania kapitału. Miało to utrzymać rozkwit „pozłacanego wieku”, dać bodziec do dalszego rozwoju i złagodzić pojawiające się cyklicznie osłabienia koniunktury.

Wysuwano ponadto argumenty społeczno-polityczne. W 1891 roku agenda federalna Census Bureau oznajmiła, że w kraju nie ma już wolnej ziemi do osiedlania się, co stanowiło symboliczny kres ekspansji wewnętrznej. Skłoniło to różne osoby - na czele z profesorem historii Frederickiem Jacksonem Turnerem, który wystąpił ze słynną teorią pogranicza - by postulować rozpoczęcie ekspansji zagranicznej. Turner obawiał się, że skoro dotychczas przemożny wpływ na mentalność Amerykanów, ustrój państwa i kształt instytucji państwowych miało przesuwające się pogranicze, to jego zanik mógł doprowadzić do marazmu i degeneracji. Turner i inni autorzy, m.in. Josiah Strong, Brooks Adams, Alfred Thayer Mahan i Charles Conant, stworzyli naukową i ideologiczną podbudowę „Nowego Boskiego Przeznaczenia”, które rozwijając pierwotną koncepcję, miało uzasadnić konieczność prowadzenia ekspansji zewnętrznej. W tym celu należało zaktywizować politykę zagraniczną, rozbudować flotę handlową i wojenną, skonstruować kanał międzyoceaniczny oraz zdobyć nowe bazy i punkty oparcia ${ }^{7}$.

6 W niektórych pracach New Manifest Destiny tłumaczone jest jako „Nowe Objawione Przeznaczenie”. Na temat „Boskiego Przeznaczenia” patrz: Manifest Destiny and Empire: American Antebellum Expansionism, (red.) S.W. Haynes, Ch. Morris, College Station 1997; S. LeMenager, Manifest and Other Destinies: Territorial Fictions of the Nineteenth Century United States, Lincoln 2004; A.K. Weinberg, Manifest Destiny: A Study of Nationalist Expansionism in American History, Baltimore 1935.

Ten i poprzedni akapit na podstawie: L. Pastusiak, Dyplomacja Stanów Zjednoczonych (XVIII-XIX w.), Warszawa 1978, s. 735-755; idem, Pót wieku dyplomacji amerykańskiej 1898-1945, Warszawa 1974, s. 7-14; D. Healy, US Expansionism. The Imperialist Urge in the 1890s, Madison 1970, s. 9-47, 194-209; K. Michałek, Poza granice kontynentu. Teoria pogranicza Fredericka Jacksona Turnera a idea ekspansji dalekowschodniej $w$ amerykańskiej polityce zagranicznej 1893-1922, Warszawa 1992, s. 39-58; A. DeConde, A History of American Foreign Policy, New York 1978, s. 317-319; F.R. Dulles, America's Rise to World Power, 1898-1954, New York 1963, s. 1-39; A.T. Mahan, The Influence of Sea Power upon History 1660-1783, Boston 1890, s. 25-88; F.J. Turner, The Frontier in American History, New York 1948, s. 1-38. 
Kluczowe znaczenie dla realizacji tych założeń i przełamania amerykańskiej izolacji miała zwycięska wojna z Hiszpanią w 1898 roku. W jej wyniku Stany Zjednoczone uzyskały Puerto Rico, Guam i Filipiny (te ostatnie odkupiono od Madrytu za 20 milionów dol.). Zależna od Amerykanów stała się również Kuba ${ }^{8}$. Ponadto w latach 1898-1899 przejęli oni Hawaje i różne inne wyspy na Oceanie Spokojnym - Palmyrę, Johnston, Wake i część Samoa9.

W dość krótkim czasie Stany Zjednoczone zdobyły dominującą pozycję na Morzu Karaibskim i pierwsze posiadłości na Pacyfiku. Zwłaszcza nabycie Filipin, wywołujące skądinąd wiele kontrowersji, stwarzało im dogodne warunki do włączenia się do rywalizacji o wpływy polityczne i handlowe w południowej i wschodniej Azji ${ }^{10}$. Myślano przede wszystkim o Chinach, którymi Amerykanie interesowali się od dawna.

U zarania kontaktów bilateralnych, których początek datuje się na rok 1784, kiedy to do Kantonu przypłynął pierwszy statek amerykański - „Empress of China" ${ }^{11}$, powstał w USA mit rynku chińskiego. Obok przekonania o specjalnej więzi łączącej oba narody stanowił on najważniejsze passe-partout amerykańskiej polityki wobec Chin. Uważano, że skoro imperium Qingów miało największą populację na świecie, można tam było sprzedać nieograniczoną liczbę produktów, o ile tylko zapewniłoby się swobodę działalności gospodarczej. Przez cały XIX wiek wizja intratnej wymiany handlowej, mimo eliminacji kolejnych barier, nie urzeczywistniła się, m.in. dlatego, że Amerykanie koncentrowali się na rozwoju

8 Przyczyny i przebieg wojny przedstawiają m.in.: P. Olender, Wojna amerykańsko-hiszpańska na morzu 1898, Warszawa 1995; B. Winid, Santiago 1898, Warszawa 1995; L. Gould, The Spanish-American War and President McKinley, Lawrence 1982; H.W. Morgan, America's Road to Empire: The War with Spain and Overseas Expansion, New York 1965.

9 F.R. Dulles, America's Rise..., s. 57-58; L. Pastusiak, Dyplomacja ..., s. 653-668; A. DeConde, A History of American ..., s. 319-330.

10 Taki argument wysuwali zwolennicy przejęcia archipelagu. Zob. A.W. Griswold, The Far Eastern Policy of the United States, New York 1938, s. 3-35; P.A. Varg, Open Door Diplomat. The Life of W.W. Rockhill, Urbana 1952, s. 26-27; D. Healy, US Expansionism ..., s. 66-67. Niektórzy badacze widzą związek między zajęciem Filipin i innych wysp a poczynaniami mocarstw w Chinach. Por. T. Dennett, Americans in Eastern Asia: A Critical Study of the Policy of the United States with reference to China, Japan and Korea in the $19^{\text {th }}$ Century, New York 1922, s. 622; J.K. Fairbank, The United States and China, Cambridge 1972, s. 295-296. Inne zdanie prezentuje Rojek. W. Rojek, Ekspansja mocarstw ..., s. 30.

11 Dzieje stosunków amerykańsko-chińskich do końca XIX wieku przybliżają m.in.: D.M. Pletcher, The Diplomacy of Involvement: American Economic Expansion Across the Pacific, 1784-1900, Columbia 2001, s. 9-32, 97-152; M.H. Hunt, The Making of a Special Relationship: The United States and China to 1914, New York 1983, s. 1-184; L. Pastusiak, Dyplomacja ..., s. 479-490, 629-643. 
wewnętrznym. Kiedy jednak pod koniec stulecia ich rynek zaczął wykazywać pewne oznaki nasycenia, ponownie zwrócili uwagę na Państwo Środka ${ }^{12}$. W latach 90. amerykański eksport i inwestycje zaczęły tam powoli rosnąć, i chociaż wyniki nie były na razie imponujące ${ }^{13}$, to bardziej liczyło się potencjalne niż aktualne znaczenie rynku chińskiego. Trzeba było jednak zadbać, aby ekspansja była w przyszłości możliwa. Akurat w tym czasie poważnie zaczął jej zagrażać nasilający się proces tworzenia stref wpływów. Amerykanie obawiali się, że mocarstwa w ich obrębie będą faworyzowały swoich obywateli, kontynuacja zaś samego procesu mogła doprowadzić do rozbioru Chin, który zapewne oznaczałby definitywny koniec swobodnej rywalizacji gospodarczej.

Nad Potomakiem zorientowano się, że trzeba działać niezwłocznie, zwłaszcza że o wsparcie władz federalnych coraz usilniej upominały się środowiska biznesowe i misjonarskie. Te pierwsze uważały, że bez aktywnej polityki rządu trudno im będzie skutecznie konkurować w Chinach z europejskimi i japońskimi rywalami, mającymi przewagę dzięki strefom wpływów ${ }^{14}$. Misjonarze, choć mieli jeszcze kilka innych powodów do zmartwień, o których piszę poniżej, obawiali się, że rozwój owych stref może doprowadzić do wzrostu znaczenia duchownych katolickich kosztem protestanckich ${ }^{15}$. W 1899 roku administracja Williama McKinleya była już skłonna podjąć działania, ale zastanawiała się nad ich kierunkiem i metodami. Część dyplomatów, polityków, publicystów i wojskowych opowiadała się za wzięciem udziału w podziale łupów i wystaraniem się o amerykańską

${ }^{12}$ K. Michałek, Poza granice kontynentu ..., s. 313-314, 401-403; D.M. Pletcher, The Diplomacy of Involvement ..., s. 17-18.

13 Obroty handlowe Stanów Zjednoczonych z Chinami wzrosły z 19 milionów dol. w 1892 roku do 32 milionów w 1899 roku. Zwyżkę zanotował też amerykański eksport do Chin, którego wartość wzrosła w ostatniej dekadzie XIX wieku z 3 do 14 milionów dol. Były to jednak nadal wyniki mało satysfakcjonujące. Udział handlu z Chinami w całej zagranicznej wymianie handlowej USA wynosił raptem $2 \%$, a udział inwestycji w Chinach stanowił $3 \%$ wszystkich amerykańskich inwestycji zagranicznych. Z perspektywy Państwa Środka wspólpraca gospodarcza wyglądała trochę lepiej - handel z USA stanowił 9\% całego handlu zagranicznego, ale już amerykańskie inwestycje tylko 2,5\% wszystkich zagranicznych inwestycji w Cesarstwie. W. Rojek, Ekspansja mocarstw..., s. 35; M.H. Hunt, The Making of a Special Relationship..., s. 148, 152.

${ }^{14}$ By promować swoje interesy, a także oddziaływać na rząd i opinię publiczną, w styczniu 1898 roku biznesmeni powołali Committee on American Interests in China, który w czerwcu tegoż roku przekształcił się w American Asiatic Association. Genezę i dzieje tych organizacji przybliżają: J.L. Lorence, Organized Business and the Myth of the China Market: The American Asiatic Association, 1898-1937, „Transcriptions of the American Philosophical Society" 1981, t. 71, cz. 4, s. 1-112; Ch.S. Campbell jr., American Business Interests and the Open Door in China, [w:] W.A. Williams (red.), The Shaping of American Diplomacy, Chicago 1956, s. 414-424.

15 P.A. Varg, Open Door Diplomat ..., s. 28-29. 
strefę wpływów. Rząd odrzucił jednak ten pomysł, uznając, że - jak stwierdził sekretarz stanu John Hay - nie pozwoliłaby mu na to opinia publiczna ${ }^{16}$. Zdecydował się w zamian na dyplomatyczną inicjatywę akceptowalną zarówno dla zwolenników, jak i przeciwników polityki imperialnej. Remedium na całą sytuację miała być doktryna „otwartych drzwi”, która umożliwiała wykorzystanie potencjału gospodarczego Stanów Zjednoczonych bez zbytniego angażowania ich politycznego i militarnego. Do koncepcji „otwartych drzwi” próbowali wcześniej przekonać Amerykanów Brytyjczycy. Gdy jednak wystąpili z propozycją kooperacji w Chinach, Waszyngton odmówił, ponieważ nie był jeszcze gotowy do podjęcia odpowiednich kroków, a poza tym wolał działać samemu, zgodnie z jedną ze swych naczelnych zasad dyplomatycznych - niezawierania sojuszów ${ }^{17}$.

W drugiej połowie 1899 roku Hay zaproponował Rosji, Wielkiej Brytanii, Niemcom, Francji, Japonii i Włochom porozumienie gwarantujące równość traktowania wszystkich kupców w Chinach. Miało ono dotyczyć tylko handlu (braku dyskryminacji przy ustalaniu taryf celnych, opłat portowych i kolejowych), nie starano się na razie rozszerzyć go na pozostałe sprawy gospodarcze (np. pożyczki czy inwestycje przemysłowe). Waszyngton nie zamierzał też podważać istnienia stref wpływów, uznając je za fait accompli. Mocarstwa zareagowały umiarkowanie przychylnie na amerykańską inicjatywę, chociaż zwłaszcza odpowiedzi z Paryża i Petersburga mogły budzić wiele wątpliwości. Niezrażony tym Hay w marcu 1900 roku ogłosil, że wszyscy adresaci ustosunkowali się pozytywnie do jego propozycji ${ }^{18}$.

Niedługo później 3 lipca 1900 roku sekretarz stanu rozesłał drugą serię not w sprawie „otwartych drzwi”, w której dobitniej wyraził, zasygnalizowaną już $\mathrm{w}$ niektórych notach z poprzedniego roku, chęć szanowania integralności terytorialnej $\mathrm{Chin}^{19}$. Ich rozparcelowanie lub całkowity rozbiór byłyby bowiem niekorzystne dla Waszyngtonu, który nie posiadając strefy wpływów i wiedząc o oporze własnego społeczeństwa, raczej nie wziąłby udziału w podziale. Zaborcy z kolei zapewne utrudniliby Amerykanom działanie na byłym rynku chińskim. Obrona Chin przed zakusami mocarstw wpisywała się ponadto w tradycyjną

${ }^{16}$ W.R. Thayer, The Life and Letters of John Hay, t. 2, Boston-New York 1915, s. 241; M.B. Young, The Rhetoric of Empire: American China Policy, 1895-1901, Cambridge 1968, s. 98-106; M.H. Hunt, The Making of a Special Relationship ..., s. 176-177, 182-183.

${ }_{17}$ Więcej na ten temat patrz: J. Pajor, Wielka Brytania wobec ksztattowania się amerykańskiej polityki „otwartych drzwi” w Chinach (1898-1900), „Acta Universitatis Lodziensis. Folia Historica" 2012, t. 89, s. 7-21.

18 Papers Relating to the Foreign Relations of the United States (dalej PRFRUS) 1899, Washington 1901, s. 128-143. Znamienne było, że początkowo Waszyngton nawet nie powiadomił o całej inicjatywie Chin, które traktował przedmiotowo.

${ }_{19}$ Circular note of the July 3, 1900, to the powers cooperating in China, defining the purposes and policy of the United States, July 3, 1900, [w: ] PRFRUS 1901, Appendix: Affairs in China, Washington 1902, s. 12. 
politykę amerykańską, która miała zapobiec zbytniemu osłabieniu Chin i pomóc im $\mathrm{w}$ rozwoju ${ }^{20}$. Wynikała ona głównie z przekonania o specjalnych relacjach łączących oba narody ${ }^{21}$. Przekonanie to powstało na początku kontaktów dwustronnych i przez kolejne dziesięciolecia było kultywowane m.in. przez amerykańskich misjonarzy mających kapitalny wpływ na kształtowanie się wizerunku Orientu w swej ojczyźnie i po części też na jej politykę na tym obszarze $^{22}$. Misjonarze dostrzegali w Chinach olbrzymie możliwości ewangelizacji, ale w XIX wieku ich nadzieje spełniły się w nikłym stopniu. Tłumaczyli to niechęcią władz qingowskich, wrogością części Chińczyków, ograniczeniami w działaniu i ogólnie skostniałą strukturą społeczeństwa. Uważali, że gdyby Państwo Środka zaczęło się zmieniać, to i oni odnieśliby większy sukces w nawracaniu. Dlatego też byli orędownikami jego modernizacji i aby zaskarbić sobie przychylność miejscowej ludności i pozyskać nowych wiernych, podejmowali rozmaite działania dobroczynne ${ }^{23}$. Nacisk na unowocześnienie Chin przybrał na sile, gdy na przełomie XIX i XX wieku w Stanach Zjednoczonych doszli do głosu progresywiści (do których zalicza się trzech kolejnych prezydentów: Theodore’a Roosevelta, Williama Tafta i Woodrowa Wilsona), dążący do postępu w różnych dziedzinach.

Od momentu rozesłania drugiej serii not polityka „otwartych drzwi” obejmowała już dwie zasady: równego traktowania kupców oraz szanowania integralności terytorialnej Chin. Nie były to jednak zasady równorzędne - istotniejszą pozostawała pierwsza z nich, druga zaś stanowiła poniekąd środek do jej spełnienia ${ }^{24}$. Stany Zjednoczone zdecydowały się na lipcową enuncjację, gdy w Chinach nasiliło się powstanie „bokserów” (Yihetuan), a mocarstwa szykowały się właśnie do interwencji zbrojnej, która mogła zagrozić funkcjonowaniu polityki „otwartych drzwi” i przerodzić się w wyprawę łupieżczą.

${ }^{20}$ M.H. Hunt, The Making of a Special Relationship..., s. 115-142, 170-183; J.K. Fairbank, The United States ..., s. 298.

${ }^{21}$ Abstrahuję tutaj od problemu, czy przekonanie o specjalnych relacjach było zasadne. Ważniejsze jest, że wierzyła w nie część Amerykanów i Chińczyków.J. K. Fairbank, The United States ..., s. 293, 402; M.H. Hunt, The Making of a Special Relationship ..., s. x, 170-172, 299-313; D.M. Crane, T.A. Breslin, An Ordinary Relationship: American Opposition to Republican Revolution in China, Gainesville 1986, s. ix-xxii.

${ }^{22}$ Misjonarze nie tylko wpływali na amerykańską opinię publiczną oraz decydentów w Waszyngtonie, ale nierzadko zostawali też dyplomatami lub pracownikami poselstwa w Pekinie. M.H. Hunt, The Making of a Special Relationship ..., s. 30-32, 169; The Cambridge History of China, t. 12: Republican China, 1912-1949, cz. 1, (red.) J.K. Fairbank, Cambridge 1983, s. 157.

${ }^{23}$ M.H. Hunt, The Making of a Special Relationship..., s. 27-29; J.K. Fairbank, The United States... s. 285-286.

${ }^{24}$ N. Peffer, The Far East: A Modern History, Ann Arbor 1958, s. 188; M.H. Hunt, Frontier Defense and the Open Door. Manchuria in Chinese-American Relations 1895-1911, New Haven 1973, s. 65; M.B. Young, The Rhetoric of Empire ..., s. 217. 
Samo powstanie było reakcją na kryzys, w jakim znalazło się Cesarstwo pod koniec XIX wieku. Wzrosło wówczas niezadowolenie społeczne z powodu szybko postępującego uzależnienia od mocarstw oraz aroganckiego i wyniosłego zachowania cudzoziemców, w tym także misjonarzy, których uważano dodatkowo za zagrożenie dla tradycyjnych wierzeń, sposobu życia i modelu społecznego. Drastycznie podupadł również autorytet Qingów, którzy chociaż ulegli znacznemu schińszczeniu, nadal postrzegani byli jako obca dynastia. Zarzucano im przedkładanie własnych interesów nad dobro państwa i troszczenie się jedynie o pozostanie u władzy. Słabi, niedołężni i skorumpowani nie potrafili zapobiec panoszeniu się mocarstw ani zreformować państwa (niepowodzeniem zakończyła się próba odgórnej modernizacji - tzw. sto dni reform ${ }^{25}$ ). Na to wszystko nałożyła się trudna sytuacja gospodarcza spotęgowana przez klęski żywiołowe.

W tych okolicznościach uaktywniły się tajne stowarzyszenia, a jedno z nich - Yihetuan, skrajnie obskuranckie i ksenofobicznie nastawione, wznieciło w 1898 roku powstanie w Shandongu, które z czasem rozprzestrzeniło się na inne prowincje Cesarstwa. W początkowej fazie insurgenci występowali przeciwko Qingom, cudzoziemcom, chrześcijanom i stosunkom feudalnym. W wyniku zręcznej polityki urzędników lokalnych zarzucili jednak hasła antydynastyczne i przystąpili do rozprawy z „zamorskimi diabłami” i chrześcijanami (także rodzimymi). W 1900 roku powstanie nasiliło się, a poparcia udzielił mu dwór, prowadzący uprzednio niejednoznaczną politykę. W czerwcu, po przybyciu „bokserskich” bojowników do Pekinu, rozpoczął się najgłośniejszy epizod całego wydarzenia - oblężenie dzielnicy zagranicznych poselstw. 21 czerwca Chiny wypowiedziały wojnę ośmiu państwom, w tym także Stanom Zjednoczonym ${ }^{26}$.

25 Sto dni reform to trwający od czerwca do września 1898 roku okres wzmożonej modernizacji Chin w wielu dziedzinach. Zmiany wprowadzała grupka wykształconych Chińczyków, na czele z Kang Youweiem, Liang Qichao i Tan Sitongiem. Pozyskali oni do swojego programu młodego cesarza Guangxu, który wyswobodził się spod kurateli konserwatywnie nastawionej cesarzowej wdowy Cixi. Kres epizodu nastąpił, kiedy stronnicy Cixi dokonali przewrotu pałacowego i przejęli władzę. Guangxu został uwięziony (wolności nie odzyskał aż do swej śmierci w 1908 roku), a jego edykty odwołane. Represje dotknęły też pozostałych reformatorów, z których część została stracona (m.in. Tan). Śmierci uniknęli Kang i Liang, którzy uciekli do Japonii, skąd kontynuowali działalność polityczną.

${ }^{26}$ Genezę i przebieg powstania „bokserów” przedstawiają m.in.: V. Purcell, The Boxer Uprising: A Background Study, Cambridge 1963; Ch. Tan, The Boxer Catastrophe, New York 1955; P.A. Cohen, History in Three Keys: The Boxers as Event, Experience and Myth, New York 1997; J.W. Esherick, The Origins of the Boxer Uprising, Berkeley 1987; G.N. Steiger, Chi$n a$ and the Occident: The Origin and Development of the Boxer Movement, New Haven 1927; P.H. Clements, The Boxer Rebellion. A Political and Diplomatic Review, New York 1915; W. Rodziński, Historia Chin ..., s. 512-529; T. Halik, Powstanie Yihetuan (1898-1901), [w:] R. Sławiński (red.), Nowożytna historia Chin, Kraków 2005, s. 95-105. 
Waszyngton odegrał aktywną rolę podczas powstania. Z oczywistych względów zależało mu na oswobodzeniu Amerykanów znajdujących się w oblężeniu i zapewnieniu bezpieczeństwa wszystkim swoim obywatelom. W tym celu we współpracy z innymi rządami wysłał żołnierzy, którzy uczestniczyli w nieudanej ekspedycji ratunkowej z czerwca 1900 roku oraz weszli w skład Sojuszniczego Korpusu Ekspedycyjnego przybyłego do Pekinu z odsieczą w połowie sierpnia. Nad Potomakiem chciano także uniknąć wojny z Chinami, i to mimo wypowiedzenia jej przez władze qingowskie. Stany Zjednoczone nie tylko nie odpowiedziały taką samą deklaracją, lecz oświadczyły, że brały jedynie udział w interwencji ratunkowej i zamierzały utrzymać pokojowe stosunki z Pekinem. Próbowały też nakłonić pozostałych interwentów, aby postąpili w ten sam sposób i nie podejmowali pochopnych decyzji. Wszystkie te cele udało się amerykańskiej dyplomacji osiągnąć. Cudzoziemców uratowano, interwencja miała ograniczony charakter i nie przerodziła się w otwartą wojnę, a dzięki nocie z 3 lipca uzupełniono politykę „otwartych drzwi” i podkreślono chęć jej kontynuowania.

Po stłumieniu rebelii rozpoczęly się negocjacje między zwycięzcami a stroną chińską zakończone we wrześniu 1901 roku podpisaniem tzw. protokołu końcowego („bokserskiego”). Jego warunki były surowe - Chiny miały m.in. zapłacić olbrzymie odszkodowanie wynoszące 450 milionów taeli, ukarać dygnitarzy winnych antycudzoziemskich wystąpień, zburzyć fortyfikacje Dagu, zakazać importu broni i amunicji przez dwa lata oraz zezwolić na stacjonowanie cudzoziemskich wojsk w dzielnicy poselstw w Pekinie i wzdłuż linii kolejowej łączącej stolicę z morzem ${ }^{27}$. Podczas negocjacji Waszyngton opowiadał się za bardziej umiarkowanymi żądaniami, ale większość mocarstw dążyła do narzucenia srogich warunków i ostatecznie to ich głos przeważy ${ }^{28}$.

W tym czasie amerykańska dyplomacja poniosła jeszcze jedno niepowodzenie. W listopadzie 1900 roku Hay, pod naciskiem Departamentu Marynarki, podjąl próbę wydzierżawienia bazy morskiej w zatoce Sansha. Ponieważ znajdowała się ona w japońskiej strefie wpływów w Fujianie, Waszyngton zwrócił się najpierw o zgodę do Tokio. Jego stanowcza odmowa położyła kres całej inicjatywie, która niemniej pokazała, że w łonie rządu amerykańskiego nie było jednomyślności co do kształtu polityki chińskiej, koncepcja „otwartych drzwi” dopiero

27 Doc. no. 1901/3: Austria-Hungary, Belgium, France, Germany, Great Britain, Italy, Japan, the Netherlands, Russia, Spain, the United States and China. Final Protocol for the settlement of the disturbances of 1900, September 7, 1901, [w: ] Treaties and Agreements..., s. 278-284.

28 Na temat polityki prowadzonej przez Waszyngton podczas powstania „bokserów” patrz: T.J. McCormick, China Market. America's Quest for Informal Empire, 1893-1901, Chicago 1970, s. 155-195; M.B. Young, The Rhetoric of Empire ..., s. 137-218; J. Pajor, Stanowisko USA wobec Chin podczas powstania Yihetuan, „Azja-Pacyfik” 2011, t. 14, s. 183-210. 
się krystalizowała, a zasada szanowania integralności terytorialnej Chin nie stanowila imperatywu ${ }^{29}$.

Możliwość odstąpienia od tej zasady Waszyngton zasygnalizował również parokrotnie podczas kryzysu wywołanego okupacją Mandżurii przez wojska rosyjskie. Intensyfikacja powstania „bokserów” na obszarze Północnego-Wschodu $^{30}$ skłoniła władze carskie do wysłania tam żołnierzy, którzy do października 1900 roku opanowali wszystkie trzy prowincje. Politycy nad Newą zdecydowali się ostatecznie nie anektować zajętych terenów, ale przed zwróceniem ich Chinom domagali się przyznania nowych przywilejów ekonomicznych i politycznych. Qingowie, dla których odzyskanie Mandżurii było bardzo istotne (m.in. ze względów prestiżowych - była to kolebka dynastii), jednak nie mieli szans walczyć o nią militarnie, starali się skłonić mocarstwa do interwencji w swojej obronie. Te nadzieje do jakiegoś stopnia spełniły m.in. Stany Zjednoczone, które podczas całego kryzysu (lata 1900-1904) kilkakrotnie wyrażały sprzeciw wobec rosyjskich żądań i ostrzegały władze pekińskie przed zawieraniem niekorzystnych porozumień. W Waszyngtonie obawiano się bowiem, że działania Rosji mogły doprowadzić do oderwania Mandżurii, a nawet dać sygnał do rozbioru Chin. Obawiano się również dyskryminacji i wyparcia amerykańskich kupców z Mandżurii, którą byli oni akurat żywo zainteresowani ${ }^{31}$.

Stany Zjednoczone nie prowadzily bynajmniej konsekwentnej polityki. Wystosowały co prawda stanowcze protesty, ale niejednokrotnie ze spokojem przyglądały się rozwojowi wydarzeń lub sugerowały Rosji, że mogłyby przestać nalegać na zachowanie integralności terytorialnej Chin, gdyby otrzymały zapewnienie, że prawa ich kupców będą w Mandżurii przestrzegane. Departament Stanu lawirował między różnymi stanowiskami, starając się znaleźć optymalną strategię. Raz deklarował poparcie dla obu zasad polityki „otwartych drzwi”, innym razem koncentrował się tylko na pierwszej z nich. W lutym 1902 roku podjął też - raczej nieudaną - próbę rozszerzenia zakresu owej polityki o kwestie inwestycyjne $^{32}$. Wszystkie te manewry okazały się mało skuteczne. Do 1904 roku żołnierze rosyjscy nadal stacjonowali w Mandżurii, a rosnące w Imperium Romanowów wpływy kliki Bezobrazowa, grupującej zwolenników agresywnej polityki na Dalekim Wschodzie, znacząco oddalały szanse na rychłą ewakuację wojsk ${ }^{33}$.

29 J. Pajor, Stanowisko ..., s. 206-207.

30 Inna nazwa Mandżurii. Obie nazwy będą używane w pracy wymiennie.

${ }^{31}$ M.H. Hunt, Frontier ..., s. 20-21; D.G. Munro, American Commercial Interests in Manchuria, [w:] The Shaping..., s. 466-472; L. Pastusiak, Pót wieku ..., s. 61.

${ }^{32}$ Zob. J. Pajor, Memorandum Johna Haya z 1 lutego 1902 r. Kontynuacja i próba rozszerzenia zakresu polityki ,otwartych drzwi” w Chinach, "Acta Universitatis Lodziensis. Folia Historica" 2012, t. 88, s. 161-175.

${ }^{33}$ Kryzys mandżurski i amerykańską politykę wobec niego opisują: E.H. Zabriskie, American-Russian Rivalry in the Far East: A Study in Diplomacy and Power Politics, 
Podczas kryzysu mandżurskiego rząd amerykański rozważał też możliwość militarnego wsparcia polityki „otwartych drzwi”. Theodore Roosevelt, który po śmierci McKinleya (14 września 1901 roku) został jego sukcesorem, w lipcu 1903 roku stwierdzil, że nie ustąpi wobec Rosji w Mandżurii, choćby miało to doprowadzić do wybuchu wojny ${ }^{34}$. Wziąwszy pod uwagę energiczne usposobienie nowego prezydenta i ogólnie dużą aktywność amerykańskiej dyplomacji za jego urzędowania, takie stanowisko nie było zaskakujące. Ale nawet Roosevelt szybko powrócił do swojej wcześniejszej opinii, że amerykańskie interesy w Chinach nie były na tyle żywotne, aby walczyć o nie zbrojnie, społeczeństwo zaś nie poparłoby takiej konfrontacji ${ }^{35}$. Ograniczenia polityki „otwartych drzwi” doskonale rozumiał Hay, który mimo zmiany w Białym Domu pozostał szefem Departamentu Stanu. Wielokrotnie zaznaczał on, że amerykańska pozycja opierała się na sile „moralnej” i militarne zaangażowanie w jej obronie było wykluczone ${ }^{36}$. Polityka „otwartych drzwi” pozostała więc doktryną o jedynie dyplomatycznym charakterze, co zawężało Waszyngtonowi pole manewru, zwłaszcza że pozostałe mocarstwa zdawały sobie $\mathrm{z}$ tego sprawę.

Takich dylematów nie miała Japonia, gdyż rosyjskie poczynania i plany wobec Mandżurii i Korei godziły w jej interes narodowy. Postawa Petersburga, nieprzejawiającego chęci do kompromisu, skłoniła Japonię do przeciwstawienia się mu zbrojnie. 8 lutego 1904 roku wojska tennō - bez wypowiedzenia wojny, co zaczynało się stawać ich tradycją - zaatakowały rosyjskie pozycje na Dalekim Wschodzie ${ }^{37}$.

1895-1914, Philadelphia 1946, s. 65-100; P.P. Damski, „Najbliższe narody”. Stosunki brytyjsko-amerykańskie $w$ dobie prezydentury Theodore'a Roosevelta (1901-1909), Warszawa 2014, s. 132-161; W. Rojek, Ekspansja mocarstw ..., s. 57-75; T. Dmochowski, Walka polityczna mocarstw ..., s. 85-143; M.H. Hunt, Frontier ..., s. 53-84.

${ }^{34}$ Roosevelt to Hay, July 18, 1903, [w: ] The Letters of Theodore Roosevelt, (opr.) E.E. Morison, t. 3, Cambridge 1951, s. 520; Roosevelt to Hay, July 29, 1903, [w: ibidem, s. 532-533.

35 M.H. Hunt, Frontier..., s. 80-81. Wcześniejsza opinia Roosevelta na temat pozycji Rosji w Mandżurii: Roosevelt to Hay, May 22, 1903, [w:] The Letters ..., t. 3, s. 478; Roosevelt to Shaw, June 22, 1903, [w: ] ibidem, s. 497-498; Roosevelt to Abbott, June 22, 1903, [w: ] ibidem, s. 500-502.

36 T. Dennett, John Hay: From Poetry to Politics, New York 1934, s. 403-406; A.L.P. Dennis, Adventures in American Diplomacy, 1896-1906, New York 1928, s. 376377; W.R. Thayer, The Life and Letters ..., s. 241, 367-369; M.B. Young, The Rhetoric of Empire..., s. 186; A. DeConde, A History of American ..., s. 366-367.

37 Zainteresowanych genezą, przebiegiem i skutkami wojny rosyjsko-japońskiej odsyłam do: J.W. Dyskant, A. Michałek, Port Artur. Cuszima 1904-1905, Warszawa 2005; P. Olender, Wojna rosyjsko-japońska 1904-1905. Działania na morzu, Kraków 2010; The Russo-Japanese War in Global Perspective: World War Zero, (red.) J.W. Steinberg, 
W Stanach Zjednoczonych wybuch wojny przyjęto raczej z zadowoleniem. Z Japonią sympatyzowało zarówno społeczeństwo (z wyjątkiem osób obawiających się „żółtej zarazy”), jak i Roosevelt, który stwierdził, że „gra ona w naszą grę”38. Podczas konfliktu dyplomacja amerykańska starała się zabezpieczyć poszanowanie chińskiej neutralności i integralności terytorialnej, które mogły zostać naruszone nie tylko przez walczące strony, ale i pozostałe mocarstwa. Już 10 lutego Waszyngton wystosował do Rosji i Japonii notę, w której wzywał, by respektowały one neutralność i „administracyjną jedność” Państwa Środka. Nie udało sięjednak uzyskać takich zapewnień. Chociaż obaj adwersarze ogólnie zgodzili się na proponowane zasady, to spod ich działania wyłączyli Mandżurię ${ }^{39}$. Niemal rok później 13 stycznia 1905 roku Departament Stanu, w wyniku niemieckich sugestii, rozesłał kolejną notę, tym razem do części państw neutralnych. Podkreślił w niej przywiązanie do polityki „otwartych drzwi”, wyrzekł się terytorialnych ambicji w Chinach i prosił o wyrażenie opinii. Odpowiedzi były pozytywne - wszyscy adresaci zgodzili się z amerykańskim stanowiskiem ${ }^{40}$. Wcześniej jednak Wielka Brytania uczyniła kolejny wyłom we władztwie Qingów. We wrześniu 1904 roku Brytyjczycy, w wyniku ekspedycji Francisa Younghusbanda, która w sierpniu wkroczyła do Lhasy, zawarli konwencję przekształcającą Tybet w zalążek ich protektoratu ${ }^{41}$. W 1905 roku Stany Zjednoczone uzyskały jeszcze jedno potwierdzenie polityki „otwartych drzwi”. Stanowiło ono warunek, jaki postawil Japonii Roosevelt przed rozpoczęciem rokowań pokojowych, w których miał być mediatorem ${ }^{42}$. Same negocjacje, także dzięki zabiegom prezydenta, zakończyły się zawarciem

B.W. Menning, D. Schimmelpenninck van der Oye, D. Wolff, S. Yokote, LeidenBoston 2005; R.A. Esthus, Double Eagle and Rising Sun: The Russians and Japanese at Portsmouth in 1905, Durham 1988; E.P. Trani, The Treaty of Portsmouth: An Adventure in American Diplomacy, Lexington 1969; I.H. Nish, The Origins of the Russo-Japanese War, London 1985; J.A. White, The Diplomacy of the Russo-Japanese War, Princeton 1964; R.M. Connaughton, The War of the Rising Sun and the Tumbling Bear: A Military History of the Russo-Japanese War 1904-5, London 1988; T. Dennett, Roosevelt and Russo-Japanese War, Garden City 1925.

${ }^{38}$ Roosevelt to Roosevelt, Jr., February 10, 1904, [w: ] The Letters ..., t. 4, Cambridge 1951, s. 723-724; P.P. Damski, „Najblizsze narody”..., s. 161-162.

${ }^{39}$ Hay to all diplomatic representatives of the United States, February 20, 1904, [w:] PRFRUS 1904, Washington 1905, s. 2-3. W sierpniu 1904 roku carski poseł w Pekinie stwierdził, że działania Japonii uzasadniały rozszerzenie strefy wojennej na całe Chiny, a Rosja przestała uważać je za państwo neutralne. A.L.P. Dennis, Adventures ..., s. 366367, 371-372; A.W. Griswold, The Far Eastern ..., s. 102.

${ }^{40}$ PRFRUS 1905, Washington 1906, s. 1-4.

${ }^{41}$ Doc. no. 1906/2: Great Britain and China. Annex: Convention between the Governments of Great Britain and Tibet, September 7, 1904, [w:] Treaties and Agreements..., s. $577-581$.

${ }^{42}$ A.W. Griswold, The Far Eastern ..., s. 103-104. 
5 września 1905 roku traktatu pokojowego, na mocy którego Korea znalazła się w japońskiej strefie wpływów ${ }^{43}$, Mandżuria powróciła do Chin, a Rosja przekazała zwycięzcy południowy Sachalin, swoje dzierżawy na półwyspie Guandong (Port Artur i Dalian) oraz część sieci kolejowej w Mandżurii ${ }^{44}$.

Wojna rosyjsko-japońska zmieniła układ sił na Dalekim Wschodzie i wpłynęła na amerykańską politykę w Chinach. Nad Potomakiem zaczęto się obawiać wzrostu pozycji Japonii i jej rozpalonych zdecydowanym zwycięstwem ambicji ekspansywnych. Stopniowo to ona stawała się w amerykańskiej opinii głównym rywalem i potencjalnym naruszycielem polityki „otwartych drzwi”, zajmując pod tym względem miejsce Rosji. To wówczas po raz pierwszy amerykańscy wojskowi zaczęli ją uwzględniać w planach wojennych jako hipotetycznego wroga. Na Honsiu zaszły zresztą podobne zmiany. W 1907 roku cesarska armia uznała USA za drugiego najbardziej prawdopodobnego przeciwnika po Rosji, a przed np. Fran$\mathrm{cją}^{45}$. Stosunki między oboma państwami rzeczywiście bardzo szybko uległy pogorszeniu, mimo że jeszcze w 1905 roku pojawiały się nawet pomysły przekształcenia sojuszu japońsko-brytyjskiego z 1902 roku w sojusz trójstronny ${ }^{46}$. Apogeum napięć na linii Waszyngton-Tokio nastąpiło w latach 1907-1908, kiedy to część osób po obu stronach Pacyfiku wyrażała opinię, że może dojść do wybuchu wojny. Źródło niepokojów i tarć stanowiła polityka chińska, rosnąca potęga Japonii, amerykańskie obawy o los Filipin i przede wszystkim sposób traktowania japońskich imigrantów w USA. Sytuację pogarszał fakt, że na Roosevelta spadło w Japonii odium za niewykorzystanie przez nią w pełni zwycięstwa nad Rosją.

Podczas kryzysu Stany Zjednoczone zaczęły działać dwutorowo: postanowiły zademonstrować siłę, wysyłając w rejs dookoła świata Wielką Białą Flotę, ale szukały również porozumienia z Chryzantemowym Tronem, aby załagodzić konflikt. Pierwszą próbę podjęły jeszcze w trakcie wojny rosyjsko-japońskiej. W lipcu 1905 roku William Howard Taft, wówczas sekretarz wojny, w rozmowie z premierem Katsurą Tarō (niektórzy historycy piszą o układzie Taft-Katsura) oświadczył, że akceptuje japońskie zwierzchnictwo nad Koreą, a w zamian otrzymał zapewnienie, że Japonia nie ma agresywnych zamierzeń wobec Filipin ${ }^{47}$.

43 Pod koniec 1905 roku Korea została ogłoszona japońskim protektoratem.

44 Doc. no. 1905/8: Russia and Japan. Treaty of Peace, September 5, 1905, [w:] Treaties and Agreements ..., s. 522-526. Na temat negocjacji pokojowych i amerykańskiego w nie zaangażowania patrz np. E.P. Trani, The Treaty of Portsmouth...

45 S. Pash, The Currents of War: A New History of American-Japanese Relations, 18991941, Lexington 2014, s. 20.

46 Doc. no. 1902/2: Great Britain and Japan. Agreement relative to China and Corea, January 30, 1902, [w: ] Treaties and Agreements ..., s. 324-325; P.P. Damski, „Najbliższe narody”..., s. 172-174; R.A. Esthus, Taft-Katsura Agreement - Reality or Myth?, „The Journal of Modern History" 1959, t. 31, nr 1, s. 47.

47 R.A. Esthus, Taft-Katsura ..., s. 46-51. 
Nie uśmierzyło to wszelkich wątpliwości i konieczne stało się ponowne ułożenie stosunków. 30 listopada 1908 roku zawarto układ Root-Takahira (Elihu Root - drugi sekretarz stanu w gabinecie Roosevelta, Takahira Kogorō - japoński ambasador w Waszyngtonie), w którym sygnatariusze zadeklarowali utrzymanie status quo na Dalekim Wschodzie i wzajemne poszanowanie swoich tamtejszych posiadłości. Wyrazili też wolę wspierania niepodległości i integralności terytorialnej imperium Qingów oraz równości szans w handlu i przemyśle na jego obsza$\mathrm{rze}^{48}$. Chociaż układ, wbrew temu, co twierdzą niektórzy historycy, nie przyznawał Japonii swobody działania w Mandżurii w zamian za potwierdzenie polityki „otwartych drzwi” na pozostałych terenach i zapewnienie bezpieczeństwa Filipinom $^{49}$, to administracja Roosevelta akceptowała szczególną pozycję Japonii w Mandżurii. Najlepiej podsumował to sam Roosevelt, który już po opuszczeniu Białego Domu napisał do swojego następcy, że Japonia miała żywotne interesy w Mandżurii i Stany Zjednoczone nie powinny starać się ich kwestionować, chyba że „były gotowe iść na wojnę”. Roosevelt konstatował dalej:

Polityka „otwartych drzwi” w Chinach była wspaniałą sprawą i mam nadzieję, że w przyszłości nadal nią będzie, jeśli tylko można ją utrzymać za pomocą porozumień dyplomatycznych. Jak jednak dowiodła cała historia Mandżurii, zarówno pod [dominacją - J.P.] Rosji, jak i Japonii, polityka „otwartych drzwi” [...] zupełnie przestaje istnieć, gdy tylko potężny naród zdecyduje się ją zignorować i woli narazić się na ryzyko wojny, niż zrezygnować ze swoich zamiarów ${ }^{50}$.

Wzrost pozycji Japonii nie był jedynym zagrożeniem dla chińskiej polityki Stanów Zjednoczonych w tamtym okresie. Coraz mocniej zacieśniały się też więzy sojusznicze i współpraca między mocarstwami w wymiarze światowym, w tym dalekowschodnim. Jeszcze podczas wojny rosyjsko-japońskiej Londyn i Paryż zawarty entente cordiale, a Londyn i Tokio odnowily sojusz z 1902 roku. Kolejne układy podpisano w roku 1907. Najpierw Japonia porozumiała się z Francją

48 Doc. no. 1908/19: Japan and the United States. Exchange of notes declaring their policy in the Far East, November 30, 1908, [w:] Treaties and Agreements ..., s. 769-771. Wcześniej Waszyngton zawarł z Tokio porozumienie o ograniczeniu napływu Japończyków do USA oraz pięcioletni układ arbitrażowy. A. DeConde, A History of American ..., s. 372 .

49 R.A. Esthus, The Changing Concept of the Open Door, „The Mississippi Valley Historical Review” 1959, t. 46, nr 3, s. 444-450.

50 Cytat za: A.W. Griswold, The Far Eastern ..., s. 131-132. Grenville i Young, porównując politykę „otwartych drzwi” i doktrynę Monroego, stwierdzają, że gdy USA ogłaszały je, nie były w stanie wesprzeć ich militarnie. Później jednak rozwinęły swój potencjał wojskowy i mogły wyegzekwować przestrzeganie drugiej z nich, ale nie pierwszej. J.A.S. Grenville, G.B. Young, Politics, Strategy, and American Diplomacy: Studies in Foreign Policy, 1873-1917, London-New Haven 1969, s. 308-309. 
(10 czerwca) i Rosją (30 lipca) na temat wzajemnego uznania stref wpływów w Chinach, a następnie 31 sierpnia Wielka Brytania ułożyła stosunki kolonialne $\mathrm{z}$ Rosją ${ }^{51}$. Zakończył się tym samym proces formowania się trójporozumienia oraz tzw. poczwórnego porozumienia dalekowschodniego. Utrudniało to prowadzenie skutecznej polityki Stanom Zjednoczonym, które jako jedyne z mocarstw aktywnych w Chinach pozostawały poza systemem aliansów. O sile sojuszów przekonała się administracja kolejnego amerykańskiego prezydenta, Williama Tafta.

Chińska polityka USA dostała nowy impuls, gdy w 1909 roku prezydentem został Taft. Miał on rozległą wiedzę prawniczą i stosunkowo duże doświadczenie administracyjne i dyplomatyczne. Historycy skłonni są nawet uznać, że w swoim czasie był najlepiej przygotowanym do prowadzenia polityki zagranicznej amerykańskim prezydentem ${ }^{52}$. Doświadczenie zdobył jako zarządca Filipin (1900-1904) i sekretarz wojny (1904-1908). Oprócz typowych zadań nadzorował wówczas budowę Kanału Panamskiego oraz jeździł ze specjalnymi misjami zagranicznymi do papieża, na Kubę i Daleki Wschód ${ }^{53}$. Szczególnie interesował się Chinami, ich sytuacją międzynarodową i wewnętrzną. Podczas wizyty w 1907 roku wygłosił w Szanghaju mowę, która zwiastowała, jak będą wyglądały późniejsze działania i nastawienie jego administracji. Taft podkreślił w swym przemówieniu przywiązanie Stanów Zjednoczonych do obu zasad polityki „otwartych drzwi”. Deklarowal, że Amerykanie nie dążyli do uzyskania wpływów lub terytoriów w Chinach, chcieli jedynie respektowania przysługujących im praw. Zależało im też, aby Chiny rozwijały się wewnętrznie i modernizowały. Taft wierzyl, że amerykańsko-chińska wymiana handlowa, która już wtedy była niemała, w niedalekiej przyszłości jeszcze bardziej rozkwitnie. Rząd waszyngtoński musiał jednak $\mathrm{z}$ większym zaangażowaniem chronić interesy swoich obywateli przed nieuczciwą ingerencją polityczną ze strony mocarstw posiadających strefy wplywów ${ }^{54}$.

51 Doc. no. 1905/6: Great Britain and Japan. Agreement respecting the integrity of Chi$n a$, the general peace of Eastern Asia and India, and the territorial rights and special interests of the parties in those regions, August 12, 1905, [w: ] Treaties and Agreements ..., s. 516-518; Doc. no. 1907/7: France and Japan. Agreement in regard to the continent of Asia, June 10, 1907, [w: ] ibidem, s. 640; Doc. no. 1907/11: Japan and Russia. Political Convention, July 30, 1907, [w: ibidem, s. 657-658; Doc. no. 1907/16: Great Britain and Russia. Convention relating to Persia, Afghanistan, and Thibet, August 31, 1907, [w:] ibidem, s. 674-678.

52 L. Gould, The William Howard Taft Presidency, Lawrence 2009, s. 79; R.E. Minger, William Howard Taft and American Foreign Policy: The Apprenticeship Years, 19001908, Urbana 1975, s. 164; D.H. Burton, William Howard Taft: Confidential Peacemaker, Philadelphia 2004, s. 27.

53 O doświadczeniu dyplomatycznym Tafta przed objęciem urzędu prezydenta piszą: D.H. Burton, William Howard Taft ..., s. 27-57; R.E. Minger, William Howard Taft and American ...

${ }^{54}$ China and Her Relations with the United States. Address by Taft delivered at a Banquet Tendered by the American Association of China, October 8, 1907, [w:] The Collected 
Zapatrywania Tafta na temat Chin podzielał Philander Knox, który został nowym sekretarzem stanu. Nie miał on doświadczenia dyplomatycznego, miał za to wieloletnią praktykę prawniczą. Uznanie zdobył jako radca prawny reprezentujący korporacje, uczestniczył m.in. w stworzeniu w 1901 roku amerykańskiego giganta stalowego - U.S. Steel Corporation. Za prezydentury McKinleya i Roosevelta sprawował urząd prokuratora generalnego (1901-1904), a następnie został senatorem (1904-1909). Dotychczasowa kariera wpłynęła na jego poglądy i działania, gdy stanął na czele amerykańskiej dyplomacji. Przykładał on znaczną wagę do międzynarodowych zobowiązań i przedsięwzięć biznesowych. Taft dał mu dużą swobodę w prowadzeniu polityki zagranicznej, często też konsultując się z nim w sprawach wewnętrznych ${ }^{55}$.

Wydawało się, że jako współpracownik i protegowany Roosevelta Taft będzie raczej kontynuował dotychczasową linię polityki zagranicznej. Nowy prezydent i jego sekretarz stanu mieli jednak inną wizję - chcieli realizować „dyplomację dolarową”. Polegała ona na ścisłej współpracy między Departamentem Stanu a prywatnymi przedsiębiorcami i finansistami. Liczono na sprzężenie działań - dyplomacja miała zachęcać i wspierać wysiłki biznesmenów w poszukiwaniu zagranicznych możliwości handlu i inwestycji, a to z kolei miało skutkować wzrostem pozycji politycznej państwa. Zawiązany został swoisty „sojusz dyplomacji z przemysłem, handlem i finansami” ${ }^{66}$, który pozwoliłby lepiej wykorzystać wzrastający potencjał gospodarczy państwa przy jego nadal umiarkowanych możliwościach militarnych ${ }^{57}$. Warto zauważyć, że inauguracja "dyplomacji dolarowej” zbiegła się w czasie z rozpoczęciem kolejnej fali wzmożonych inwestycji zagranicznych kapitału amerykańskiego ${ }^{58}$. Nowa polityka, którą Taft scharakteryzował jako "zastąpienie kul dolarami”, oznaczała chęć udziału Stanów Zjednoczonych w wyścigu imperialnym, ale jednocześnie zakładała prowadzenie przez nie bardziej ekonomicznej niż terytorialnej ekspansji.

Works of William Howard Taft, (opr.) D.H. Burton, A.E. Campbell, t. 1, Athens 2001, s. 106-114.

55 W. Scholes, M. Scholes, The Foreign Policies of the Taft Administration, Columbia 1970, s. 6-15; A. Mania, Department of State 1789-1939. Pierwsze 150 lat udziału w polityce zagranicznej USA, Kraków 2011, s. 170.

56 W. Straight, China's Loan Negotiations, „The Journal of Race Development” 1913, t. 3, nr 4, s. 372 .

57 T.J. McCormick zauważa, że jeśli pojęcie „siły” rozumieć także w kategoriach ekonomicznych, a nie tylko militarnych, to „dyplomację dolarową” można by uznać za próbę użycia siły w celu wsparcia polityki „otwartych drzwi”. T.J. McCormick, China Market..., s. 193.

58 A.W. Griswold, The Far Eastern ..., s. 133.

59 Message of the president, December 3, 1912, [w:] PRFRUS 1912, Washington 1919, s. X. 


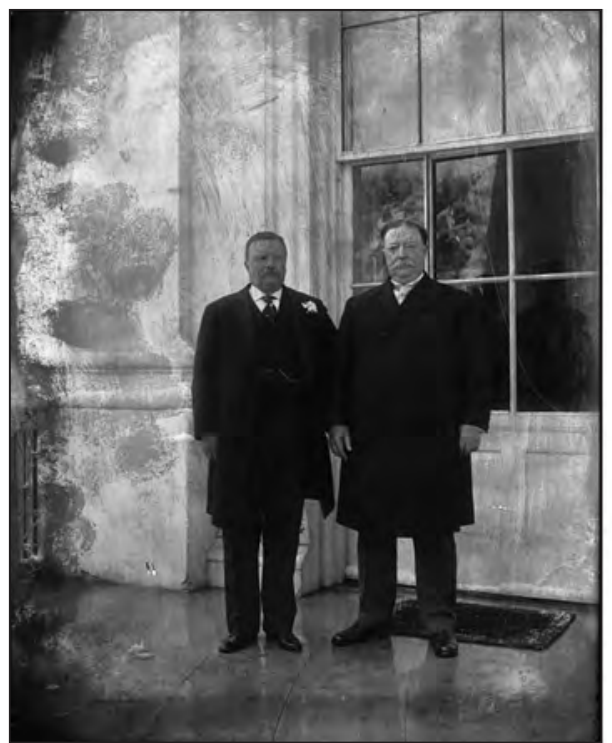

1. Theodore Roosevelt i William Taft

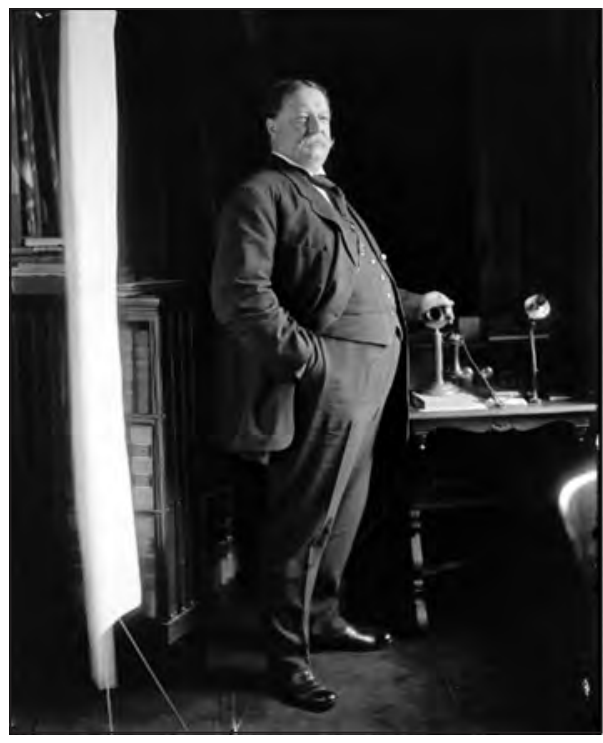

3. William Taft

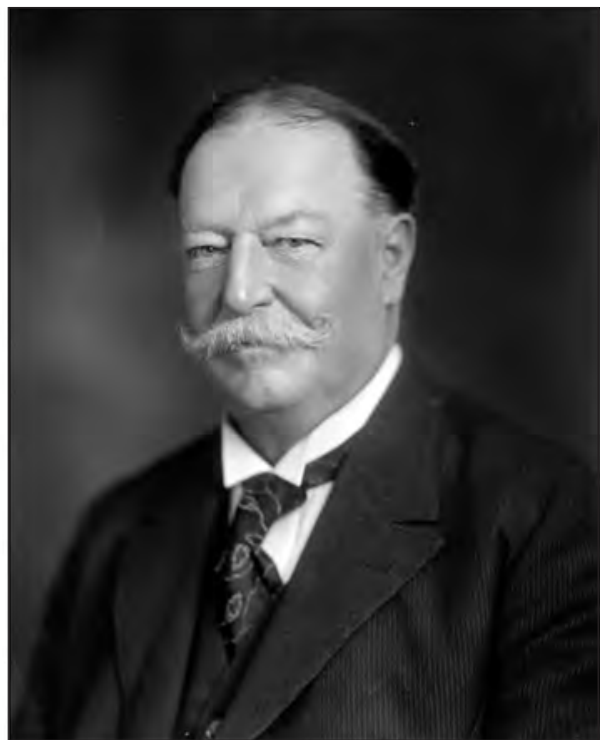

2. William Taft

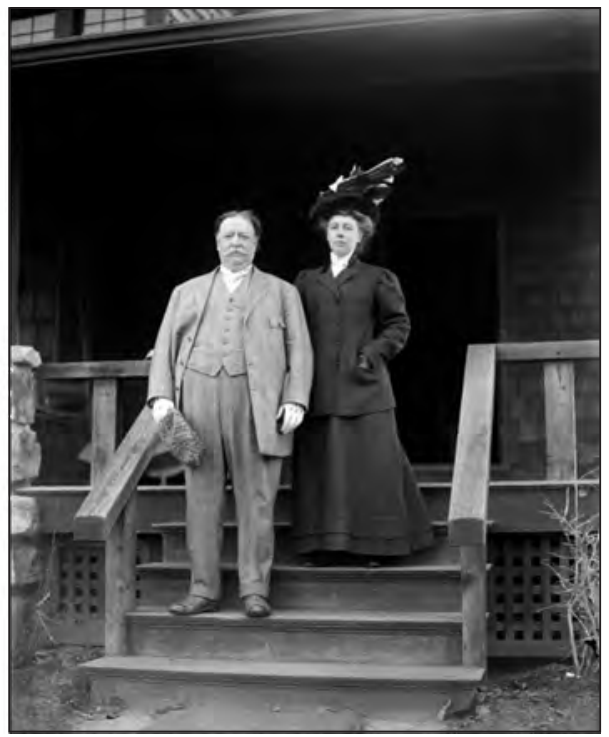

4. William Taft z żoną Helen Taft 
34 Chiny w polityce zagranicznej Stanów Zjednoczonych w latach 1911-1918

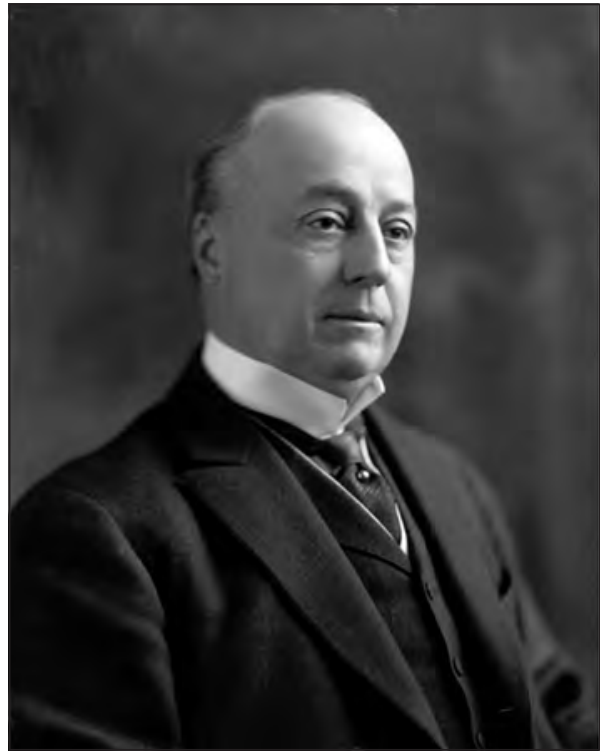

5. Philander Knox

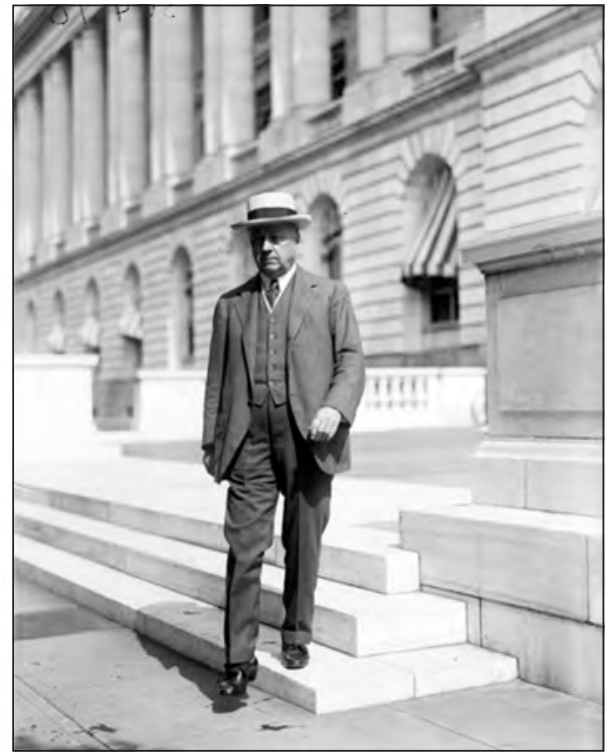

6. Philander Knox

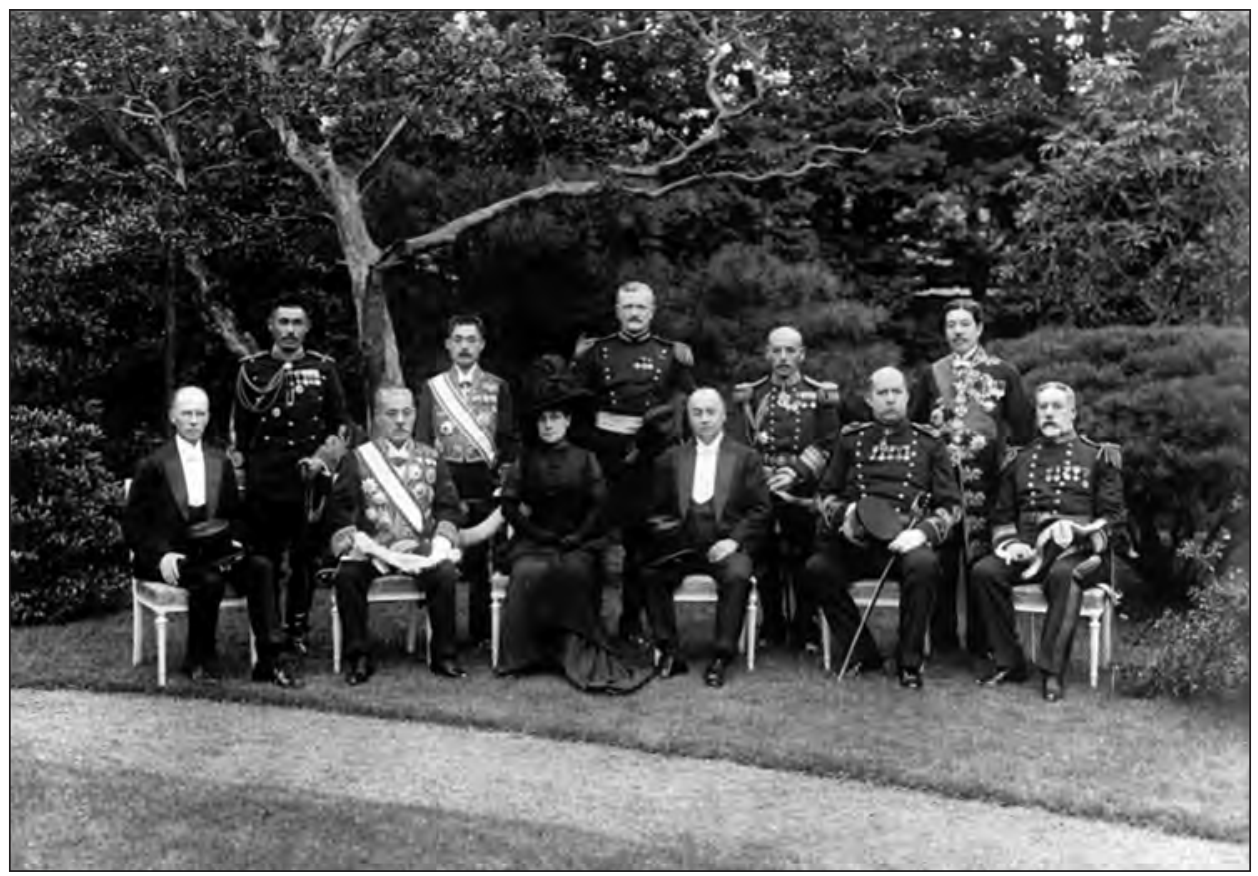

7. Amerykańska delegacja na pogrzebie cesarza Meiji w 1912 roku W środku siedzą Philander Knox z żoną. Za nimi stoi gen. John Pershing 
Jednym z głównych obszarów, obok Ameryki Środkowej, na którym starano się realizować „dyplomację dolarową”, były $\mathrm{Chiny}^{60}$. Miała ona tam osiągnąć kilka celów wpisujących się w doktrynę „otwartych drzwi”. Administracja Tafta chciała, aby jej strategia, którą prezydent określił jako „praktyczne następstwo naszej historycznej polityki na Dalekim Wschodzie" ${ }^{61}$, nie tylko przyśpieszyła urzeczywistnienie mitu rynku chińskiego ${ }^{62}$ i rozszerzyła amerykańskie wpływy, ale także wzmocniła Chiny, pobudzając ich rozwój wewnętrzny, dostarczając funduszy na przeprowadzenie reform oraz, co najistotniejsze, pomagając im utrzymać suwerenność i integralność terytorialną. Waszyngton, starając się rozszerzyć zakres polityki „otwartych drzwi”, zaczął się bowiem domagać równości traktowania w kwestiach inwestycyjnych, czym de facto podważał system stref wpływów. Jego działania wymierzone były głównie przeciwko rosyjsko-japońskim próbom zdominowania Mandżurii ${ }^{63}$.

Początki „dyplomacji dolarowej” miały miejsce jeszcze za urzędowania poprzedniej administracji. Wówczas to magnat kolejowy Edward Harriman staral się wykupić rosyjskie i japońskie linie kolejowe w Mandżurii. Jego wysiłki wspierał młody dyplomata - Willard Straight, który wierzył, że zainwestowanie amerykańskiego kapitału w Mandżurii pozwoli wyswobodzić ją z rąk Japonii i Ro$\mathrm{sj}^{64}$. Zwolennikami takiej polityki byli młodzi pracownicy Departamentu Stanu - William Phillips i Huntington Wilson ${ }^{65}$. Do współpracy dążyła także strona chińska, zwłaszcza czołowy dostojnik Cesarstwa Yuan Shikai i jego polityczni

60 „Dyplomację dolarową” w Ameryce Środkowej przedstawiają m.in.: D.G. Munro, In tervention and Dollar Diplomacy in the Caribbean, 1900-1921, Princeton 1964; W. Scholes, M. Scholes, The Foreign Policies ..., s. 35-106.

${ }^{61}$ Message of the president, December 7, 1909, [w:] PRFRUS 1909, Washington 1914, s. XIX.

${ }^{62}$ Uważano, że inwestycje, zwłaszcza kolejowe, pomogłyby też rozwinąć handel, ułatwiając dostęp do różnych części Cesarstwa.

63 A.W. Griswold, The Far Eastern..., s. 136, 138, 140, 143-146; M.H. Hunt, The Making..., s. 209-211; A. DeConde, A History of American ..., s. 407-408, 410; R.A. Esthus, The Changing..., s. 437, 451-454.

64 Sylwetkę i działania Willarda Straighta przybliżają m.in.: H.D. Kahn, Willard D. Straight and the Great Game of Empire, [w:] F.J. Merli, T.A. Wilson (red.), Makers of American Diplomacy. From Benjamin Franklin to Henry Kissinger, New York 1974, s. 333-358; H. Croly, Willard Straight, New York 1924.

${ }^{65}$ W 1922 roku Huntington Wilson zmienił imię na Francis Mairs Huntington-Wilson. Zob. przypis nr $1 \mathrm{w}$ The Papers of Woodrow Wilson, (opr.) A.S. Link, t. 27, Princeton 1978, s. 197. Ponieważ w latach, których dotyczy ta praca, nosił on poprzednie imię, pod nim będzie też w niej występował (wyjątek będą stanowić jego wspomnienia Memoirs of an Ex-Diplomat wydane w roku 1945, a więc już po zmianie imienia). Aby odróżnić go od prezydenta Wilsona, będę w tekście głównym i przypisach podawał jego imię i nazwisko. Samo nazwisko Wilson będzie się zatem odnosiło do Woodrowa Wilsona. 
protegowani, którzy starali się nakłonić Stany Zjednoczone do finansowej i dyplomatycznej pomocy w odzyskaniu Mandżurii, wiedząc, że nie miały one ambicji terytorialnych i nie były skrępowane żadnym sojuszem. Obie strony snuły plany budowy linii kolejowych i utworzenia w Mandżurii banku inwestycyjnego z amerykańskim kapitałem. W celu omówienia szczegółów współpracy, a być może nawet zaproponowania cokolwiek niedorzecznego sojuszu, który miał jeszcze objąć Niemcy, jesienią 1908 roku przyjechał do Waszyngtonu Tang Shaoyi, związany politycznie z Yuanem. Jego misja, z wyjątkiem sprawy zwrotu części odszkodowania „bokserskiego”, zakończyła się niepowodzeniem. Root ledwo znalazł czas na rozmowę z chińskim wysłannikiem, finalizując wówczas porozumienie z Takahirą, które przekreśliło nadzieje na antyjapońską kompanię w Chinach i stanowiło wyraźny sygnał, że administracja Roosevelta chciała ułożyć stosunki z Japonią, a nie je zaostrzać ${ }^{66}$.

Sytuacja zmieniła się wraz z inauguracją kolejnego gabinetu. Taft i Knox zaczęli prowadzić w Chinach „dyplomację dolarową, która miała przede wszystkim ostrze antyjapońskie. Nie krył tego Knox, stwierdzając, że należy „wykurzyć” Japonię z Mandżurii ${ }^{67}$. Znamienne były też wytyczne dla nowego posła w Pekinie, który miał zastopować wdzieranie się Japonii do Chin i usilnie starać się o korzystne kontrakty dla amerykańskich kupców i inwestorów. Taft, który poselstwo w Pekinie postrzegał ponoć jako najistotniejszą placówkę dyplomatyczną, uznal, że do wypełnienia takiego zadania będzie potrzebował osoby energicznej i odważnej ${ }^{68}$. Nie był nią dotychczasowy poseł William Rockhill, autorytet w sprawach chińskich, wspóltwórca polityki „otwartych drzwi”, niezbyt jednak zainteresowany rozwijaniem kontaktów biznesowych ${ }^{69}$. Został on więc mianowany ambasadorem w Petersburgu, a na jego miejsce wybrano przedsiębiorcę Charlesa Crane’a - ze względu na jego zdolności biznesowe i kosmopolityzm. Zanim Crane opuścił USA, ujawnił dziennikarzowi treść wspomnianych instrukcji, co spowodowało cofnięcie jego nominacji. Ostatecznie nowym posłem został William Calhoun - prawnik z pewnym doświadczeniem dyplomatycznym zdobytym w Wenezueli i na Kubie ${ }^{70}$.

66 A.W. Griswold, The Far Eastern ..., s. 135-141; M.H. Hunt, The Making..., s. 202-209; idem, Frontier ..., s. 100-178; A. DeConde, A History of American ... , s. 408410; R.A. Esthus, The Changing ..., s. 440-451; T. Dmochowski, Walka polityczna mocarstw..., s. 177-179. Do niepowodzenia misji Tanga przyczyniło się także popadnięcie Yuana w niełaskę na dworze qingowskim.

67 Cytat za: A. DeConde, A History of American ..., s. 411.

68 W. Scholes, M. Scholes, The Foreign Policies ..., s. 21-22.

${ }^{69}$ Na temat życia i dokonań Rockhilla patrz: P.A. Varg, Open Door Diplomat...

70 W. Scholes, M. Scholes, The Foreign Policies ..., s. 21-23; F.M. Huntington Wilson, Memoirs of an Ex-Diplomat, Boston 1945, s. 204-207; L. Gould, The William..., s. $83-85$. 


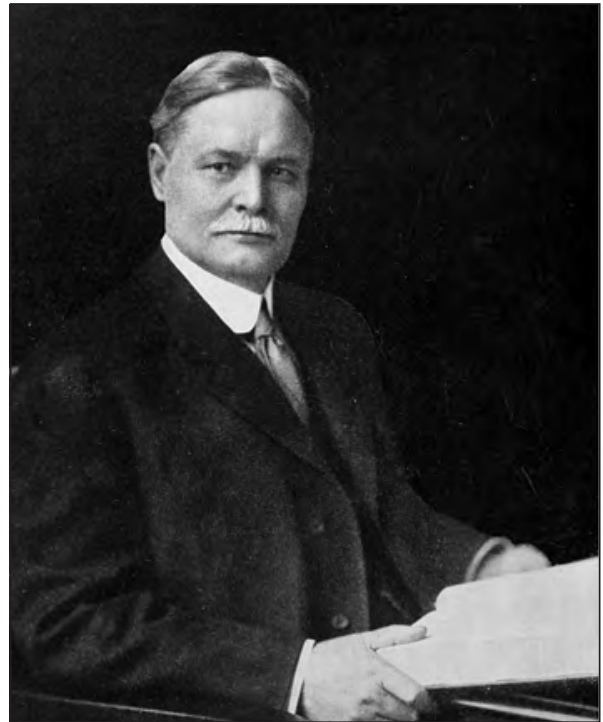

8. William Calhoun

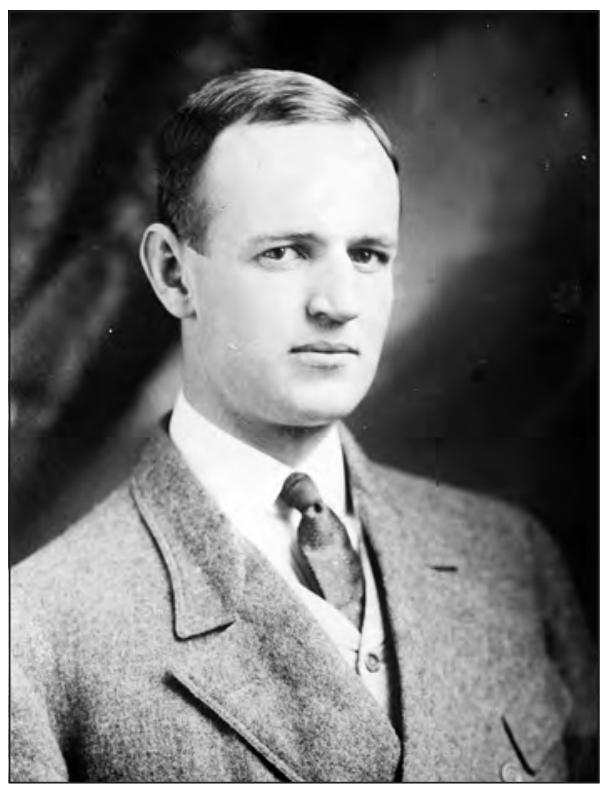

10. Willard Straight

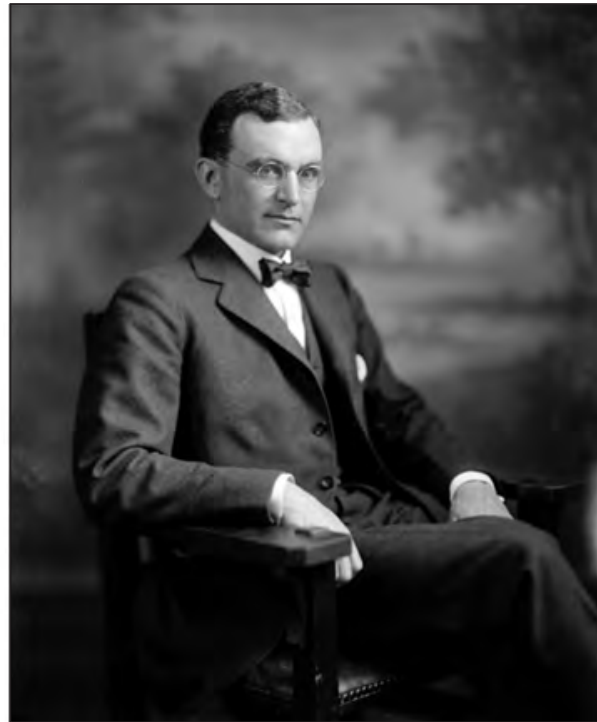

9. Huntington Wilson

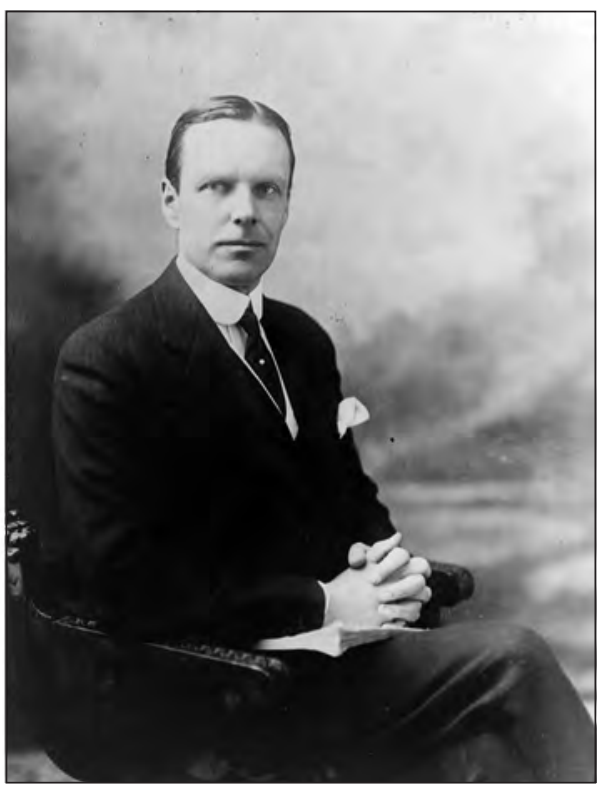

11. William Phillips 


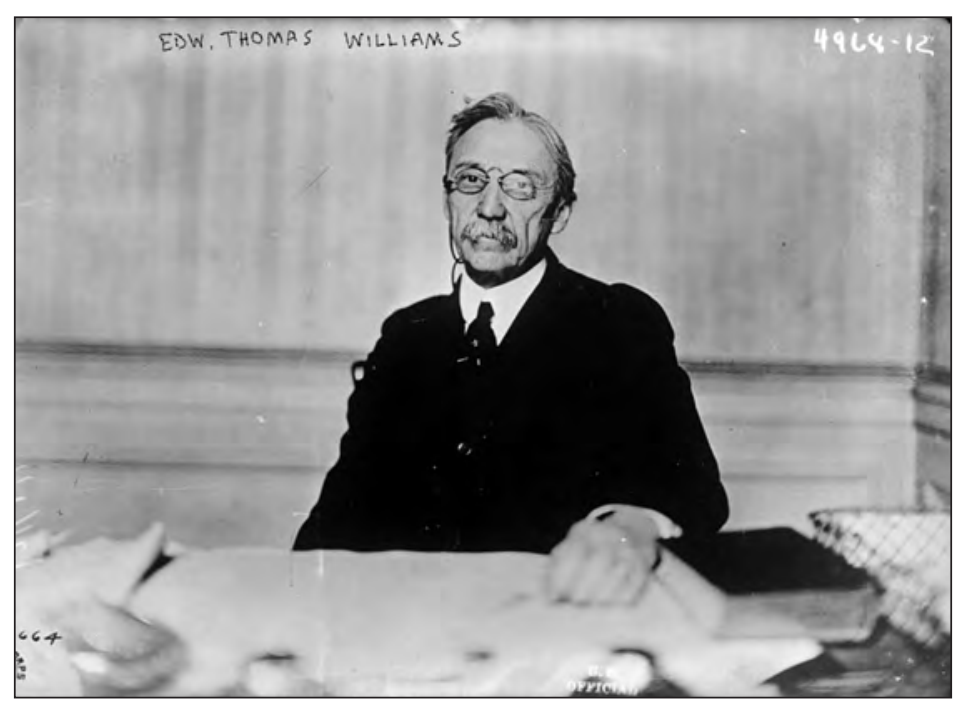

12. Edward T. Williams

Za czasów Knoxa większy wpływ na kształt amerykańskiej polityki wobec Chin uzyskali wcześniejsi zwolennicy bardziej zdecydowanych działań w Departamencie Stanu - Phillips oraz Huntington Wilson (ten drugi awansowany teraz na asystenta sekretarza stanu). Wynikało to nie tylko z faktu, że Knox się z nimi zgadzał, ale i z jego stylu zarządzania - zazwyczaj wyznaczał on jedynie główny kierunek polityki, a realizacją wytycznych i załatwianiem bieżących problemów zajmował się Huntington Wilson i pozostali pracownicy Departamentu Stanu ${ }^{71}$. Wzrosło również znaczenie utworzonego w 1908 roku Wydziału ds. Dalekiego Wschodu (Division of Far Eastern Affairs). Szefem tegoż został Ransford Miller, a jego zastępcą oddelegowany z Chin Edward T. Williams (uprzednio pracownik poselstwa w Pekinie i konsul w Tianjinie), który ze względu na swą misjonarską przeszłość starał się uwypuklać reformatorski aspekt „dyplomacji dolarowej”72. Z Departamentu Stanu odszedł natomiast Straight, który został przedstawicielem amerykańskiej grupy bankowej (o niej poniżej), stając się swoistym łącznikiem między Departamentem a światem finansjery. Także bankierzy z Wall Street mieli pewien wpływ na decyzje podejmowane w Waszyngtonie, skoro rząd prosił ich o zainwestowanie własnych środków, nie zamierzając angażować pieniędzy

${ }^{71}$ W. Scholes, M. Scholes, The Foreign Policies..., s. 8-9, 14-17; M.H. Hunt, Frontier..., s. 181-183.

72 D.D. Lazo, An Enduring Encounter: E. T. Williams, China, and the United States, nieopublikowany doktorat, University of Illinois at Urbana-Champaign, Urbana 1977, s. $158-159,161,169-173$. 
publicznych ${ }^{73}$. Wszystkie te osoby i środowiska popierały prowadzenie „dyplomacji dolarowej” w Chinach, chociaż różnie rozkładały akcenty - jedni bardziej podkreślali jej wymiar ekonomiczny, inni - polityczny, jeszcze inni - postępowy.

Administracja Tafta przystąpiła $\mathrm{z}$ animuszem do wdrażania swoich planów. Jednym z pierwszych jej działań było sformowanie amerykańskiej grupy bankowej, w skład której weszły: J.P. Morgan and Company; Kuhn, Loeb and Company; The First National Bank of the City of New York; The National City Bank of New York oraz Harriman. Grupa zrzeszała najpotężniejsze banki w kraju i miała odtąd stanowić finansowy instrument „dyplomacji dolarowej” w Chinach. Waszyngton zażądał następnie, aby dopuszczono ją do tzw. pożyczki huguangskiej, zawartej w czerwcu 1909 roku przez Pekin z bankami niemieckimi, francuskimi i brytyjskimi w celu sfinansowania budowy linii kolejowych w południowej i środkowej części Cesarstwa. Miesiąc później trzy grupy porozumiały się na temat współpracy przy innych pożyczkach kolejowych ${ }^{74}$. Ukształtowało się $\mathrm{w}$ ten sposób konsorcjum trzech mocarstw, dążące do uzyskania monopolu na rynku chińskim. Stany Zjednoczone zaczęły stanowczo domagać się udziału swoich bankierów na równych prawach w pożyczce i w konsorcjum, interweniując w stolicach europejskich i w Pekinie. W tym ostatnim przypadku osobisty list do regenta Chin napisał Taft. Nalegania przyniosły satysfakcjonujące efekty. Władze qingowskie odmówiły zatwierdzenia umowy, dopóki spór nie zostanie rozstrzygnięty, a Europejczycy po dłuższych negocjacjach zgodzili się spełnić amerykańskie postulaty. Porozumienie osiągnięto w maju $1910 \mathrm{roku}$ a w listopadzie grupy ustaliły warunki współpracy na zasadzie równości przy wszystkich pożyczkach na cele kolejowe w Chinach. Konsorcjum oficjalnie przekształciło się z trójstronnego w czteropodmiotowe. 20 maja 1911 roku mimo protestów wewnętrznych Pekin zgodził się podpisać z nim umowę dotyczącą pożyczki na kolej huguangską ${ }^{75}$.

73 Ibidem, s. 165-167.

${ }^{74}$ Doc. no. 1911/5: Note 1: Agreement with British, French and German Banks for Hukuang Railways, June 6, 1909, [w:] Treaties and Agreements..., s. 880-885; Doc. no. 1910/5: Note: Memorandum of Agreement among British, French and German Groups in regard to Railway Loans, July 6, 1909, [w: ] ibidem, s. 833-835.

${ }_{75}$ Doc. no. 1911/5: Note 1: Inter-Bank Railway Agreement among American, British, French and German Banks, May 23, 1910, [w:] Treaties and Agreements..., s. 886-887; Doc. no. 1910/5: France (Banque de l'Indo-Chine), Germany (Deutsch-Chinesische Eisenbahn Gesellschaft), Great Britain (British \& Chinese Corporation, Limited, and Chinese Central Railways, Limited) and United States (American Group). Agreement concerning Loans for Railway Purposes, November 10, 1910, [w:] ibidem, s. 828-832; Doc. no. 1911/5: France (Banque de l'Indo-Chine), Great Britain (Hongkong \& Shanghai Banking Corporation), Germany (Deutsch-Asiatische Bank), United States (American Group) and China. Final Agreement for the Hukuang Imperial Government Railways, May 20, 1911, [w:] ibidem, s. $866-877$. 
Zdecydowanie mniej korzystnie potoczyły się próby podważenia nieformalnego kondominium Rosji i Japonii w Mandżurii. W 1909 roku Harriman podjął kolejne bezowocne starania, aby przekonać Rosję do sprzedaży sieci kolejowej. Już po jego śmierci (we wrześniu 1909 roku) udało się amerykańskiej grupie i brytyjskiej firmie podpisać wstępną umowę na sfinansowanie i konstrukcję linii kolejowej Jinzhou-Aigun, która przebiegając przez całą Mandżurię, stanowiłaby konkurencję dla linii rosyjskich i japońskich oraz mogłaby się stać punktem wyjścia do penetracji dalszych obszarów ${ }^{76}$. Sama perspektywa jej wybudowania miała skłonić Tokio i Petersburg do większej przychylności wobec amerykańskich propozycji.

W tym momencie na scenę wkroczył z impetem Knox, który wystąpił z tzw. planem neutralizacji, zakładającym wykupienie ze środków międzynarodowych wszystkich linii kolejowych w Mandżurii i przekazanie ich Chinom. Wariant zapasowy, gdyby nie udało się urzeczywistnić pierwszego, polegał na budowie linii Jinzhou-Aigun z udziałem kapitału z różnych państw i przy dyplomatycznej pomocy rządów ${ }^{77}$. Plan Knoxa okazał się kompletną porażką. Na początku 1910 roku stanowczo odrzuciły go Rosja i Japonia, co zapewne nie zaskoczyło sekretarza stanu. Rozczarowująca była dla niego natomiast postawa Wielkiej Brytanii i Francji, na wsparcie których liczył, a które nie zdecydowały się poprzeć inicjatywy godzącej w żywotne interesy swoich aliantów ${ }^{78}$. Knox wykazał się naiwnością dyplomatyczną i brakiem przenikliwości - zignorował zupełnie realia międzynarodowe i nie docenił istoty sojuszów. Dla Rosji i Japonii Mandżuria stanowiła wszak obszar, o który nie zawahały się walczyć zbrojnie, Wielka Brytania i Francja patrzyły z kolei na całokształt swoich interesów i wobec narastającego widma wybuchu wojny w Europie nie chciały zrazić sojuszników. Działania Departamentu Stanu nie tylko okazały się zupełnie chybione, lecz przyczyniły się jeszcze do zacieśnienia współpracy niegdysiejszych rywali - Rosji i Japonii. W lipcu 1910 roku oba państwa zawarly kolejne porozumienie w sprawie Mandżurii, zaciskając wokół niej pętlę, a w sierpniu

76 Doc. no. 1909/12: Great Britain (Pauling \& Company), United States (American Group) and China. Preliminary Agreement Providing for the Financing, Construction and Operation of the Railway from Chinchou to Aigun, October 2, 1909, [w: ] Treaties and Agreements..., s. 800-802.

77 The Secretary of State to Ambassador Reid, November 6, 1909, [w:] PRFRUS 1910, Washington 1915, s. 234-235.

78 Przychylnie na plan Knoxa zareagowały za to Pekin i Berlin. Nad Sprewą liczono, że może on doprowadzić do nieporozumień rosyjsko-japońskich i większego zaangażowania Rosji na Dalekim Wschodzie, co odciągnęłoby ją od spraw europejskich. W. Rojek, Ekspansja mocarstw ..., s. 112; T. Dmochowski, Walka polityczna mocarstw..., s. $183-184$. 
Japonia ogłosiła aneksję Korei ${ }^{79}$. Działania obliczone na otwarcie gospodarcze Mandżurii i przywrócenia tam faktycznego zwierzchnictwa Chin doprowadziły zatem do zgoła odmiennych rezultatów. Obrazu niepowodzeń dopełniało niezadowolenie amerykańskiej grupy, która domagała się porzucenia przez Departament Stanu agresywnej polityki.

Kiedy wydawało się, że sprawa mandżurska została pogrzebana, jesienią 1910 roku Chiny wystąpiły z propozycją, którą USA podchwyciły. Chodziło mianowicie o udzielenie pożyczki na dwa cele: reformę walutową i rozwój przemysłowy Mandżurii. Po szybkim ustaleniu wstępnych warunków Stany Zjednoczone zaprosily do udziału w przedsięwzięciu inne mocarstwa. Mimo pewnych wątpliwości chęć partycypacji wyrazily Wielka Brytania, Francja oraz Niemcy i 15 kwietnia 1911 roku bankierzy czterech mocarstw podpisali z Chinami ostateczną umowę pożyczki na 10 milionów funtów szterlingów ${ }^{80}$. Protesty Rosji i Japonii, które od początku się temu sprzeciwiały, oraz wybuch niedługo później rewolucji Xinhai poważnie skomplikowały jej realizację ${ }^{81}$.

Do rozpoczęcia rewolucji Xinhai, istotnie zmieniającej sytuację w Chinach, bilans dokonań „dyplomacji dolarowej” w tym kraju prezentował się umiarkowanie. Chociaż dane dotyczące amerykańskiego handlu i inwestycji w imperium Qingów wyglądały ciągle nader skromnie ${ }^{82}$, a Departament Stanu nie ustrzegł się błędów (plan neutralizacji Knoxa), to dał on wyraźny sygnal, że wspiera przedsięwzięcia swych obywateli. Bez tego cały czas znajdowaliby się oni w o wiele gorszym położeniu niż ich konkurenci i mit rynku chińskiego prawie na pewno pozostałby mirażem. Obiektywnie patrząc, osiągnięto też wymierne efekty - Amerykanie zostali dopuszczeni do konsorcjum mocarstw i pożyczki huguangskiej oraz doprowadzili do podpisania umowy pożyczki na dwa cele. Przyszłość tych przedsięwzięć była sprawą otwartą i nie należy oceniać ich przez pryzmat późniejszych losów.

79 Doc. no. 1910/1: Japan and Russia. Convention in regard to Manchuria, July 4, 1910, [w: ] Treaties and Agreements ..., s. 803-804.

80 Doc. no. 1911/2: France (Banque de l'Indo-Chine), Germany (Deutsch-Asiatische Bank), Great Britain (Hongkong \& Shanghai Banking Corporation), United States (American Group) and China. Chinese Currency Reform and Industrial Development Loan Agreement, April 15, 1911, [w: ] Treaties and Agreements ..., s. 841-849.

81 O wszystkich działaniach w ramach „dyplomacji dolarowej” na podstawie: Ch. Vevier, The United States and China, 1906-1913: A Study in Finance and Diplomacy, New York 1968, s. 88-191; W. Scholes, M. Scholes, The Foreign Policies ..., s. 124-220; A.W. Griswold, The Far Eastern ..., s. 142-165; M.H. Hunt, Frontier ..., s. 181-244.

82 Szczegółowe dane podają: C.F. Remer, Foreign Investments in China, New York 1968, s. 76, 249-274, 338; J. Reed, The Missionary Mind and American East Asia Policy, 1911-1915, Cambridge 1983, s. 42-56; D.M. Pletcher, The Diplomacy of Involvement ..., s. 307-308; A.W. Griswold, The Far Eastern ..., s. 174. 
Waszyngtonowi udało się uzyskać rezultaty nie tylko dzięki własnym staraniom, ale również za sprawą przychylności strony chińskiej. Chociaż relacje bilateralne nie były pozbawione zadrażnień i kwestii zapalnych (np. sprawa chińskich imigrantów w USA ${ }^{83}$ ), to Chiny i tak postrzegały Stany Zjednoczone jako mocarstwo najbardziej im przyjazne ${ }^{84}$. Wynikało to z przyczyn już wspomnianych - braku ambicji terytorialnych i występowania w obronie Państwa Środka.

Na pozytywny wizerunek Stanów Zjednoczonych wpływały ponadto różne inicjatywy dobroczynne i prorozwojowe podejmowane przez rząd, prywatne organizacje lub zwykłych obywateli. Przykładem może być tu amerykańskie zaangażowanie w kampanię antyopiumową. Kiedy w 1906 roku władze qingowskie postanowiły rozprawić się z plagą toczącą kraj, Stany Zjednoczone wsparły te wysiłki, pomagając stworzyć międzynarodowy front przeciwko opium. Ich starania sprawiły, że w lutym 1909 roku zebrała się w Szanghaju komisja złożona z przedstawicieli dwunastu państw, która przyjęła różne rekomendacje dotyczące opium i morfiny. Waszyngton chcial, aby nabrały one mocy wiążącej, i dlatego dążył do zwołania międzynarodowej konferencji, która uchwaliłaby konwencję obligującą sygnatariuszy do ich przestrzegania. Udało się to osiągnąć już po wybuchu rewolucji Xinhai - w grudniu 1911 roku w Hadze rozpoczęła obrady I Międzynarodowa Konferencja Opiumowa ${ }^{85}$. Innym działaniem, które wpłynęło na dobrą reputację Stanów Zjednoczonych, było oddanie przez nie części odszkodowania „bokserskiego”, które przeznaczono na edukację chińskich studentów w USA ${ }^{86}$. Chociaż oddziaływanie na młode chińskie elity, kształcące się zarówno za granicą, jak i w kraju w szkołach prowadzonych przez Amerykanów, należało bardziej do kategorii imponderabiliów, mogło szybko przełożyć się na bardziej wymierne wpływy. W 1911 roku wybuchła bowiem w Chinach zwycięska rewolucja, której wielu uczestników miało związki ze Stanami Zjednoczonymi.

83 Na ten temat patrz: M.H. Hunt, The Making..., s. 61-114, 227-257; A. DeConde, A History of American ..., s. 301-306; L. Pastusiak, Dyplomacja ..., s. 632-639.

${ }^{84}$ Document written by the Division of Far Eastern Affairs, December 5, 1910, William H. Taft Papers (dalej TP), Manuscript Division, Library of Congress, Washington, (mikrofilm), series 6: case files, 102, reel 366; M.H. Hunt, The Making..., s. 189, 202-216.

85 PRFRUS 1906, Washington 1909, s. 352-369; PRFRUS 1907, Washington 1910, s. 140-174; PRFRUS 1908, Washington 1912, s. 75-116; PRFRUS 1909, s. 95-115.

${ }^{86}$ Więcej na ten temat patrz: M.H. Hunt, The American Remission of the Boxer Indemnity: A Reappraisal, „The Journal of Asian Studies” 1972, t. 31, nr 3, s. 539-559. Amerykanie interesowali się także edukacją małoletniego cesarza Puyi. Obawiali się, że zostanie on wychowany i wykształcony według dawnych, konserwatywnych wzorców zamiast na modłę zachodnią. Wielce pożądane było ich zdaniem, aby cesarz nauczył się języka angielskiego. Knox to the President, April 19, 1910, TP, series 6: case files, 272, reel 378; Memorandum "Education of the Emperor of China”, undated, ibidem. 
Przez całą prezydenturę Tafta, a zwłaszcza w początkowym jej okresie, Chiny zajmowały poczesne miejsce $\mathrm{w}$ amerykańskiej polityce zagranicznej. Najlepiej potwierdzał to fakt, że to właśnie na ich obszarze, obok Ameryki Środkowej, realizowano „dyplomację dolarową", stanowiącą trzon działań zagranicznych urzędującej administracji. O ile aktywność Waszyngtonu w państwach Ameryki Środkowej ze względu na ich położenie geograficzne była zrozumiała i zgodna z tradycyjną polityką, to wzmożone zainteresowanie znajdującymi się po drugiej stronie Pacyfiku Chinami dowodziło ich dużego awansu i bardzo wysokiej pozycji w hierarchii Departamentu Stanu. Na dodatek rząd amerykański był gotowy prowadzić „dyplomację dolarową” w Chinach, chociaż musiał sobie zdawać sprawę, że pogorszy to jego relacje z Rosją i Japonią - państwami, które raptem kilka lat wcześniej nie zawahały się zbrojnie walczyć o swoje interesy w Mandżurii. W przypadku Japonii było to tym bardziej wymowne, że USA dopiero co zażegnały z nią poważny kryzys i zawarły układ Root-Takahira, dotyczący Dalekiego Wschodu. Skoro w tych okolicznościach administracja Tafta zdecydowała się jednak realizować swoje zamysły w Kraju Smoka, musiało to świadczyć o tym, że odgrywał on znaczną rolę w jej polityce zagranicznej. Warto też przytoczyć słowa samego Knoxa, który - zapewne wyolbrzymiając - stwierdzil, że za jego urzędowania popularne było powiedzenie, iż Departament Stanu cały swój czas poświęcał Chinom, a innym państwom tylko tyle, ile mu zostało ${ }^{87}$. Jednym z wydarzeń mocno absorbujących uwagę zarówno amerykańskiej dyplomacji, jak i opinii publicznej była rewolucja, która wybuchła w Chinach w 1911 roku.

${ }^{87}$ D.H. Burton, William Howard Taft ..., s. 73-74. 



\section{RozDZIAE II}

\section{CHIŃSKA POLITYKA RZĄDU WILLIAMA H. TAFTA W LATACH 1911-1913}

\section{Stany Zjednoczone wobec rewolucji Xinhai}

W październiku 1911 roku wybuchła w Chinach rewolucja Xinhai ${ }^{1}$ (zwana też rewolucją 1911 roku), która w znacznym stopniu zmieniła oblicze tego państwa. Doniosłość wydarzenia najlepiej obrazuje skala przemian. Po czterech miesiącach walk i negocjacji dynastia Qingów, zasiadająca na Tronie Smoka od przeszło dwustu pięćdziesięciu lat, abdykowała, wielowiekowe Cesarstwo upadło, a zastąpiła je jedna z pierwszych republik w Azji².

Geneza rewolucji była złożona. Zainicjowany przez dwór po powstaniu „bokserów” program odgórnej modernizacji kraju, mający w zamyśle zaskarbić przychylność poddanych, przyniósł odwrotne skutki - rozczarowanie i wzrost niezadowolenia. Chińczyków, którzy Qingów uważali za obcą dynastię, nie satysfakcjonowało tempo wprowadzanych zmian, zwłaszcza dotyczących organizacji państwa. Pod wpływem nacisków dynastia zdecydowała się skrócić okres przygotowawczy do uchwalenia konstytucji i zwołania parlamentu ogólnonarodowego, który ostatecznie miał się zebrać w 1913 roku. Wcześniej, w latach 1909-1910, powołano do życia zgromadzenia prowincjonalne i pierwszy parlament, mające jednak ograniczone kompetencje. Na ich forum zaczęto głośniej domagać się kolejnych reform. Między innymi w odpowiedzi na te żądania wiosną 1911 roku powstał pierwszy w historii Chin rząd, ale jego skład tylko wzmógł niezadowolenie społeczne. Zdecydowaną przewagę mieli w nim bowiem Mandżurowie. Premierem został nieudolny i skorumpowany książę Qing (Yikuang), stryj księcia Chuna (Zaifenga), sprawującego regencję w imieniu małoletniego cesarza Puyi. Wśród ministrów również dominowali Mandżurowie, z których większość należała do rodziny cesarskiej.

Jednym z pierwszych posunięć rządu była nacjonalizacja linii kolejowej Huguang, do której prawa przekazano szybko konsorcjum czterech mocarstw. Wywołało to silne poruszenie w państwie, gdyż w budowę linii zainwestowano już

1 Nazwa rewolucji wywodzi się od nazwy roku w tradycyjnym kalendarzu chińskim.

2 K. Gawlikowski, Cechy szczególne Rewolucji Xinhai $i$ jej paradoksy, „Azja-Pacyfik” 2011, t. 14, s. 31 . 
znaczny kapitał rodzimy. Niezadowolenie doprowadziło do rozruchów, których epicentrum znajdowało się w Sichuanie.

Murszenie władzy qingowskiej przyśpieszały nie tylko wydarzenia wewnętrzne, ale i ataki inicjowane z zewnątrz. Różne środowiska chińskiej emigracji regularnie organizowały kolejne spiski i powstania mające doprowadzić do obalenia Qingów, choć niekoniecznie do upadku Cesarstwa. Największą aktywność przejawiała na tym polu republikańska Chińska Liga Związkowa założona w 1905 roku w Tokio przez Sun Yat-sena, Huang Xinga i Song Jiaorena. Do połowy 1911 roku wszczęła ona dziesięć buntów, które zostały jednak dość łatwo stłumione przez dynastię. Raczej niespodziewanym sukcesem zakończyło się kolejne powstanie, które wybuchło 10 października 1911 roku w Wuchangu33.

Ponieważ na początku XX wieku Chiny stanowiły właściwie półkolonię, w której krzyżowały się interesy mocarstw europejskich, Japonii i Stanów Zjednoczonych, rewolucja Xinhai miała istotne międzynarodowe implikacje. Zaangażowane mocarstwa musiały zająć stanowisko wobec tego wydarzenia. Palących problemów było kilka. Jak zareagować na wybuch powstania w Wuchangu i następującą po nim walkę o władzę w Chinach? Czy zachować ścisłą neutralność, czy może ingerować w konflikt, oficjalnie lub zakulisowo pomagając walczącym? A może interweniować militarnie na rzecz jednej ze stron lub by stłumić rewolucję w ogóle? Jak zapewnić bezpieczeństwo swoim obywatelom i ich interesom? Czy zaakceptować transformację ustrojową Państwa Środka, czy sprzeciwić jej się lub starać się na nią wpłynąć? Czy współpracować z pozostałymi mocarstwami, czy prowadzić samodzielną politykę? Czy starać się wykorzystać okres zawieruchy i ubiegać się o nowe przywileje, czy dążyć do utrzymania dotychczasowego stanu?

Z powyższymi pytaniami musiały się zmierzyć mocarstwa, w tym także Stany Zjednoczone. Na szczęście dyplomacja amerykańska miała doświadczenie, jak postępować podczas takich kryzysów, gdyż odegrała ważną rolę w trakcie powstania „bokserów”. Część z celów, które naówczas chciała osiągnąć, okazała się wciąż aktualna, chociaż między dwoma wystąpieniami była istotna różnica. W przeciwieństwie bowiem do powstania „bokserów” rewolucja Xinhai nie była wymierzona przeciwko cudzoziemcom ${ }^{4}$, choć na początku nikt nie mógł być tego

3 Więcej na temat genezy i przebiegu rewolucji Xinhai patrz: China in Revolution: The First Phase, 1900-1913 (dalej ChiR), (red.) M.C. Wright, New Haven-London 1968; The Cambridge History of China, t. 11: Late Ch'ing, 1800-1911, cz. 2, (red.) J.K. Fairbank, Kwang-Ching Liu, Cambridge 1980, s. 339-602; L.E. Armentrout Ma, Revolutionaries, Monarchists, and Chinatowns: Chinese Politics in the Americas and the 1911 Revolution, Honolulu 1990; E.S.K. Fung, The Military Dimension of the Chinese Revolution: The New Army and its Role in the Revolution of 1911, Vancouver 1980; Ching Hwang Yen, The Overseas Chinese and the 1911 Revolution. With Special Reference to Singapore and Malaya, Kuala Lumpur 1976.

4 Odnoszę się tutaj do faktycznych działań rewolucjonistów, nie zaś do ich retoryki czy długofalowych celów. Część historyków twierdzi, że rewolucjoniści byli w istocie 
pewien, jak i tego, czy głębokie przeobrażenia nie doprowadzą do załamania państwowości, co również zagroziłoby bezpieczeństwu cudzoziemców.

Stany Zjednoczone, podobnie jak pozostałe mocarstwa, były zaskoczone wybuchem i przebiegiem rewolucji Xinhai, mimo że amerykańscy dyplomaci informowali o niepokojach społecznych od połowy rokus. Na przykład 5 czerwca poseł William Calhoun pisał, że polityka wewnętrzna i zagraniczna Qingów wywołała powszechne niezadowolenie poddanych. Stanowcze działania rządu „zdenerwowały radykalnie nastawionych ludzi w najwyższym stopniu”. Calhoun konkludował, że „sytuacja może się łatwo stać krytyczna”. Podobne ostrzeżenia stały się częstsze we wrześniu, kiedy nasiliły się rozruchy w Sichuanie i Hunanie. Sytuacja okazała się na tyle napięta i niebezpieczna, że 14 tegoż miesiąca dyplomaci poinstruowali Amerykanów i Brytyjczyków przebywających w Sichuanie, aby natychmiast udali się w bezpieczne miejsce?

Gdy niespełna miesiąc później, 10 października, wybuchła rewolucja Xinhai, amerykański chargé d’affaires Edward T. Williams niezwłocznie powiadomił

nastawieni antycudzoziemsko, gdyż chcieli wzmocnić Chiny, a to nie mogło zostać osiągnięte bez wykorzenienia obcych wpływów. Rewolucjoniści nie byli jednak w stanie zaatakować jednocześnie dynastii i mocarstw. J. Reed, The Missionary Mind and American East Asia Policy, 1911-1915, Cambridge 1983, s. 111-113; M.C. Wright, Introduction: The Rising Tide of Change, [w: ] ChiR, s. 3-19, 47-48, 54-58; D.M. Crane, T.A. Breslin, An Ordinary Relationship: American Opposition to Republican Revolution in China, Gainesville 1986, s. 32-33, 41, 55.

5 V.P. Dutt, The First Week of Revolution: The Wuchang Uprising, [w:] ChiR, s. 411; J. Polit, Mocarstwa wobec Rewolucji Xinhai, „Azja-Pacyfik” 2011, t. 14, s. 90; M. Ikei, Japan's Response to the Chinese Revolution of 1911, „The Journal of Asian Studies” 1966, t. 25, nr 2, s. 213; M.B. Jansen, The Japanese and Sun Yat-sen, Cambridge 1954, s. 131, 141; P. Lowe, Great Britain and Japan 1911-1915: A Study of British Far Eastern Policy, London-New York 1969, s. 62; W. Rodziński, Historia Chin, Wrocław 1992, s. 612-613. Właściwie od 1909 roku amerykańscy dyplomaci ostrzegali Departament Stanu o narastającej opozycji Chińczyków wobec dynastii i cudzoziemców. P.A. Varg, The Making of a Myth: the United States and China, 1897-1912, Westport 1980, s. 167-169; M.H. Hunt, The Making of a Special Relationship: The United States and China to 1914, New York 1983, s. 271; D.M. Crane, T.A. Breslin, An Ordinary Relationship ..., s. 37-38.

6 The American Minister to the Secretary of State, June 5, 1911, [w:] Papers Relating to the Foreign Relations of the United States (dalej PRFRUS) 1912, Washington 1919, s. 46-47. Zob. także: The American Chargé d'Affaires to the Secretary of State, July 25, 1911, [w: ] ibidem, s. 161.

7 The American Chargé d'Affaires to the Secretary of State, September 3, 1911, [w: ] PRFRUS 1912, s. 47-48; Williams to the Secretary of State, September 7, 1911, Philander C. Knox Papers (dalej KP), Manuscript Division, Library of Congress, Washington, container 32; Williams to the Secretary of State, September 10, 1911, ibidem; Williams to the Secretary of State, September 14, 1911, ibidem; Williams to the Secretary of State, September 15, 1911, ibidem. 
o tym Departament Stanu. Jego pierwsze wrażenia były częściowo trafne. Zdając sobie sprawę z powagi sytuacji, uznał, że jest to najgroźniejsze wystąpienie od czasu powstania tajpingów (1851-1864). Nieco później pisal, że „dynastia mandżurska stoi oko w oko z najpoważniejszym kryzysem w swojej historii”. Dyplomata przecenił jednak rebeliantów, twierdząc, że wydawali się „,dobrze zorganizowani i dobrze dowodzeni", gdy w rzeczywistości było zgoła odmiennie ${ }^{8}$.

Warto w tym miejscu zauważyć, że sukces rewolucji Xinhai był cokolwiek zaskakujący. Nawet pomijając fakt, że poprzednie powstania zostały bez większych problemów stłumione, powstanie w Wuchangu było po prostu źle przygotowane. Jego wybuch przyśpieszyła przypadkowa eksplozja bomby w kryjówce konspiratorów (jeden $\mathrm{z}$ nich palił, gdy inni testowali amunicję). Kiedy władze lokalne odkryły w kryjówce listę buntowników, ci byli zmuszeni działać, aby uniknąć uwięzienia i niechybnej śmierci. Niespodziewanie udało im się stosunkowo łatwo zwyciężyć, chociaż początkowo nie mieli przewagi militarnej. Innym czynnikiem, który nie wróżył dobrze insurgentom, był brak dowódców. Główni przedstawiciele środowiska rewolucyjnego albo nie chcieli dowodzić, ponieważ nie wierzyli w powodzenie powstania, albo byli nieobecni. Znamienne było, że Sun Yat-sen, lider rewolucjonistów, przebywał w tym czasie w Stanach Zjednoczonych, gdzie zbierał fundusze od chińskich emigrantów. Nie wiedział o powstaniu, dopóki nie przeczytał o nim w amerykańskiej gazecie. Twierdził, że co prawda otrzymał zaszyfrowany telegram informujący o przygotowaniach do kolejnego buntu, ale nie mógł go odczytać przez kilka dni, gdyż nie miał przy sobie kodu. Udało mu się w końcu odcyfrować wiadomość na kilka godzin przed zakupieniem gazety. Co gorsze, buntownicy mieli nawet problem ze znalezieniem odpowiedniego dowódcy na poziomie lokalnym - jeden potencjalny kandydat był ranny, dwóch zaginęło, a jeszcze inny był nieobecny. Podczas pierwszej nocy walk mianowali więc dowódcę ad hoc - Wu Zhaolina, a trzy dni później „przekonali” (gdyby odmówił, zostałby zabity) Li Yuanhonga, jawnego przeciwnika sprawy rewolucyjnej, aby stanął na czele rządu wojskowego. W tych okolicznościach wydaje się pewną ironią losu, że rewolucja ostatecznie się powiodła9.

${ }^{8}$ Williams to the Secretary of State, October 11 (1 a.m.), 1911, KP, container 32; Williams to the Secretary of State, October 11 (8 p.m.), 1911, ibidem; Williams to the Secretary of State, October 12, 1911, ibidem; The American Chargé d'Affaires to the Secretary of State, October 26, 1911, [w: ] PRFRUS 1912, s. 52. Cytaty pochodzą z dwóch ostatnich dokumentów. Do 12 listopada to Williams, który latem został mianowany chargé d'affaires, stał na czele poselstwa, ponieważ Calhoun był na urlopie. Calhoun to the Secretary of State, November 12, 1911, KP, container 32; D.D. Lazo, An Enduring Encounter: E.T. Williams, China, and the United States, nieopublikowany doktorat, University of Illinois at UrbanaChampaign, Urbana 1977, s. 199.

9 V.P. Dutt, The First Week of Revolution..., s. 383-416; Yat-sen Sun, Memoirs of a Chinese Revolutionary: A Programme of National Reconstruction for China, New York 
W początkowym jej okresie Waszyngton był, co zrozumiałe, zaabsorbowany głównie problemem, czy nie nabierze ona antycudzoziemskiego charakteru. Chociaż szef dyplomacji Philander Knox i wysocy rangą urzędnicy w Departamencie Stanu uważali to za mało prawdopodobne (w pierwszej chwili sądzili, że powstanie nie stanowiło w ogóle realnego zagrożenia i z łatwością mogło zostać stłumione przez dynastię $)^{10}$, nie można było ich przypuszczeń brać za pewnik. We wspomnianym liście z 5 czerwca Calhoun pisal, że od jakiegoś już czasu wśród Chińczyków krążyły nieprawdziwe pogłoski, jakoby obce mocarstwa poważnie zastanawiały się nad możliwością rozczłonkowania Cesarstwa. Podburzyło to Chińczyków i wzmogło antycudzoziemskie resentymenty rozpalone dodatkowo przez różne przeszłe i obecne sprawy (np. niekorzystne zagraniczne pożyczki, żądania terytorialne mocarstw czy fakt, że zdecydowaną większość linii kolejowych w kraju zbudowali i kontrolowali cudzoziemcy).

Wiadomość, że rewolucja skierowana była wyłącznie przeciwko Mandżurom, musiała więc zostać z satysfakcją przyjęta w Waszyngtonie. Według pierwszych komunikatów cudzoziemcy w Chinach nie byli zagrożeni ${ }^{11}$. Potwierdzili to wkrótce sami rewolucjoniści, którzy już 13 października wzięli odpowiedzialność za bezpieczeństwo i mienie cudzoziemców oraz zadeklarowali, że będą respektować zobowiązania finansowe swego państwa i traktaty uprzednio zawarte. W grudniu ponownie zapewnili, że będą chronić cudzoziemców. Podobne gwarancje dały niektóre lokalne władze rewolucyjne ${ }^{12}$. Otrzymawszy takie informacje

1970, s. 219-220; J. Polit, Mocarstwa ..., s. 87-91. O paradoksach rewolucji pisze: K. Gawlikowski, Cechy szczególne rewolucji ..., s. 31-48.

${ }_{10}$ D.M. Crane, T.A. Breslin, An Ordinary Relationship ..., s. 39. W grudniu 1910 roku Knox był bardziej przejęty doniesieniami na temat antycudzoziemskich nastrojów w Chinach. Document written by the Division of Far Eastern Affairs, December 5, 1910, William H. Taft Papers (dalej TP), Manuscript Division, Library of Congress, Washington, (mikrofilm), series 6: case files, 102, reel 366.

${ }_{11}$ Williams to the Secretary of State, October 11 (1 a.m.), 1911, KP, container 32; Williams to the Secretary of State, October 12, 1911, ibidem; Knox to the President, October 13, 1911, TP, series 6: case files, 397, reel 383; Williams to the Secretary of State, October 17, 1911, KP, container 32; PRFRUS 1912, s. 163-166. Pomimo własnych zapewnień, że cudzoziemcom nic nie groziło, dyplomaci w Pekinie - jak zauważyła żona Willarda Straighta Dorothy - byli „śmiertelnie przestraszeni” i obawiali się, że powtórzy się sytuacja z powstania „bokserów”. W listopadzie bali się, że może dojść do „powszechnej masakry". Calhoun to the Secretary of State, November 25, 1911, TP, series 6: case files, 397, reel 383; H. Croly, Willard Straight, New York 1924, s. 412.

12 Williams to the Secretary of State, October 14, 1911, KP, container 32; The Minister for Foreign Affairs of the Revolutionary Government to the Secretary of State, undated, received December 13, 1911, [w:] PRFRUS 1912, s. 106; L. Pomerantz-Zhang, Wu Tingfang (1842-1922): Reform and Modernization in Modern Chinese History, Hong Kong 1992, s. 200, 202-203. Chociaż rewolucjoniści raczej ściśle przestrzegali danego słowa, 
i zapewnienia, Stany Zjednoczone oficjalnie odrzuciły możliwość interwencji militarnej, aby stłumić rewolucję - pomysł, który pojawił się w prasie i był faktycznie rozważany nad Potomakiem ${ }^{13}$.

Chociaż rewolucja nie była wymierzona w cudzoziemców, nadal stanowiła, jak każdy konflikt zbrojny, zagrożenie dla życia i mienia, w tym również amerykańskiego. Dlatego też Waszyngton podjął działania, aby chronić swych obywateli. Od początku uważał, że należy zalecić, aby Amerykanie przebywający na terenach objętych walkami udali się do portów łatwo dostępnych dla cudzoziemskich okrętów. Przez kilka tygodni decyzja była zawieszona ze względu na opozycję poselstwa i pozostałych mocarstw (tylko Rosja była gotowa poprzeć amerykańską propozycję). Ostatecznie 18 listopada Calhoun, dostrzegając wzrost antycudzoziemskich incydentów, zmienił zdanie i poinstruował rodaków, aby wypełnili zalecenie. Nie wszyscy się do niego zastosowali, głównie dlatego, że niektórzy rezydowali w tak odległych miejscach, iż podróż na wybrzeże byłaby długa (do dwóch miesięcy) i równie, jeśli nie bardziej, niebezpieczna ${ }^{14}$.

Kolejne działanie ochronne polegało na wzmocnieniu straży poselstwa. 28 listopada Calhoun, zgodnie z ustaleniami poczynionymi przez korpus dyplomatyczny w Pekinie, posłał po 70 marines, którzy uzupełnili wcześniejszą grupę posiłkową przybyłą w październiku w sile 95 żołnierzy ${ }^{15}$. Tego samego dnia

obawiali się, że tajne stowarzyszenia mogły zaatakować cudzoziemców, doprowadzając tym samym do interwencji mocarstw. M.C. Wright, Introduction: The Rising Tide of Change..., s. 54, 56. Qingowie byli równie zdeterminowani, jak rewolucjoniści, by chronić cudzoziemców. The American Chargé d'Affaires at Tokyo to the Secretary of State, October 16, 1911, [w:] PRFRUS 1912, s. 163; Williams to the Secretary of State, October 17, 1911, KP, container 32; The American Chargé d'Affaires to the Secretary of State, October 26, 1911, [w: ] PRFRUS 1912, s. 165-166.

${ }^{13}$ Knox to the American Embassy at St. Petersburg, October 16, 1911, KP, container 32; Knox to the President, October 17, 1911, TP, series 6: case files, 397, reel 383; D.M. Crane, T.A. Breslin, An Ordinary Relationship ..., s. 40, 47-48; R.D. Challener, Admirals, Generals, and American Foreign Policy, 1898-1914, Princeton 1973, s. 284-288. Lokalne władze chińskie poprosiły cudzoziemców o podjęcie działań przeciwko rebeliantom, ale ich prośba została zignorowana. Williams to the Secretary of State, October 11 (8 p.m.), 1911, KP, container 32; Yat-sen Sun, Memoirs of a Chinese Revolutionary ..., s. $217-218$.

${ }_{14}$ Williams to the Secretary of State, October 17, 1911, KP, container 32; Document written by Miller, January 2, 1912, KP, container 16; PRFRUS 1912, s. 162-167.

15 Knox to the American Legation at Peking, October 19, 1911, KP, container 32; Calhoun to the Secretary of State, November 25, 1911, TP, series 6: case files, 397, reel 383; Calhoun to the Secretary of State, November 28, 1911, ibidem. Liczba żołnierzy ochraniających amerykańskie poselstwo zmieniała się następująco: 138 (16 października), około 240 (na początku listopada), 320 (16 grudnia). Memorandum by General Edwards, October 16, 1911, KP, container 32; Memorandum, 
Waszyngton oświadczył, że 500 do 2500 amerykańskich żołnierzy na Filipinach pozostanie w gotowości do natychmiastowego wysłania do Chin, gdyby zaistniała taka potrzeba. Stany Zjednoczone razem z innymi mocarstwami skierowały również swoje wojska w górę Jangcy, aby chroniły znajdujących się tam cudzoziemców ${ }^{16}$. Generalnie jednak starały się postępować ostrożnie, nie chcąc dać powodu innym mocarstwom do wysłania nowych oddziałów ani nie chcąc narazić Amerykanów przebywających na obszarach kontrolowanych przez rebeliantów, którzy mogliby odebrać przybycie posiłków do Pekinu jako wyraz wsparcia dla Qingów ${ }^{17}$.

Prezydent Taft rozkazał także pięciu okrętom, mającym pierwotnie płynąć na Hawaje, udać się do Chin. Gdy te i pozostałe amerykańskie jednostki w Chinach zostały rozmieszczone, przede wszystkim wzdłuż Jangcy, USA miały do dyspozycji znaczące siły morskie - dziewiętnaście okrętów na miejscu i jeden w Hongkongu ${ }^{18}$.

Poza tym na początku 1912 roku, po długich dyskusjach i kilkukrotnych zapytaniach ze strony innych mocarstw, Stany Zjednoczone zgodzily się wysłać swoje wojska do ochrony linii kolejowej łączącej Pekin z morzem (zezwalał na to protokół „bokserski”), co miało zapewnić otwartą komunikację z miastem. Wysłano jedynie 500 żołnierzy z 1200, których pierwotnie planowano i o których poprosił Calhoun, ale Departament Stanu poinformował, że pozostali mogą być przetransportowani do Chin, kiedy tylko poseł uzna to za wskazane ${ }^{19}$.

undated, probably written at the beginning of November, ibidem; Calhoun to the Secretary of State, December 16, 1911, ibidem.

16 The Secretary of State to the American Minister, November 28, 1911, [w: ] PRFRUS 1912, s. 168; D.M. Crane, T.A. Breslin, An Ordinary Relationship ..., s. 40.

17 Williams to the Secretary of State, October 15, 1911, KP, container 32; Knox to the American Legation at Peking, October 19, 1911, ibidem; Williams to the Secretary of State, October 22, 1911, ibidem; Knox to the American Legation at Peking, November 23, 1911, ibidem; Calhoun to the Secretary of State, November 25, 1911, TP, series 6: case files, 397, reel 383. Dynastia mandżurska zachęcała Amerykanów do wysłania nowych wojsk, licząc - według Williamsa - że powściągnie to rewolucjonistów oraz Japonię, której stanowisko było niepewne. Williams to the Secretary of State, October 15, 1911, KP, container 32; Calhoun to the Secretary of State, November 22, 1911, ibidem.

18 Williams to the Secretary of State, October 23, 1911, KP, container 32; Note from the Division of Far Eastern Affairs, October 26, 1911, ibidem; Knox to the President, October 27, 1911, ibidem; Map "U.S. and Foreign Naval Vessels on China Station", November 1911, KP, container 43; Murdock to the Secretary of the Navy, January 25, 1912, KP, container 32; D.M. Crane, T.A. Breslin, An Ordinary Relationship ..., s. 40; R.D. Challener, Admirals, Generals..., s. 283.

19 Williams to the Secretary of State, November 10, 1911, KP, container 32; Calhoun to the Secretary of State, November 22, 1911, ibidem; Knox to the American Legation at Peking, November 23, 1911, ibidem; Calhoun to the Secretary of State, November 25, 1911, 
Wszystkie te działania okazały się wystarczające, chociaż nie wyeliminowały całkowicie niebezpieczeństwa wynikającego z wojny domowej, tylko je zmniejszyły. Amerykańscy obywatele stracili życie, zostali ranni czy zaatakowani podczas rewolucji Xinhai, ale liczba poszkodowanych byłaby z pewnością większa, gdyby nie działania podjęte przez Waszyngton ${ }^{20}$.

Oprócz ochrony obywateli Stany Zjednoczone zamierzały przestrzegać ścisłej neutralności podczas wojny w Państwie Środka, co samo w sobie wzmacniało bezpieczeństwo cudzoziemców ${ }^{21}$. Chociaż nie przyznały rewolucjonistom statusu strony wojującej, zgodziły się na propozycję zgłoszoną w październiku przez sir Johna Jordana, brytyjskiego posła w Pekinie, która zezwalała konsulom na kontaktowanie się z rewolucjonistami, o ile dotyczyło to bezpieczeństwa cudzoziemców. Ocenę, czy dana sprawa spełniała to kryterium, pozostawiono w gestii konsulów ${ }^{22}$. W styczniu 1912 roku Departament Stanu wydał własne instrukcje dla amerykańskich dyplomatów, które były bardzo podobne. Mówiły one, że: „[... zachowanie [...] ścisłej neutralności ma aprobatę Departamentu, [który - J.P.] nie sprzeciwia się również nawiązaniu nieformalnych stosunków z rewolucyjnymi przywódcami, kiedy tylko może się to wydać wskazane $[\ldots]$ dla [zapewnienia - J.P.] bezpieczeństwa osób i ochrony własności amerykańskich

TP, series 6: case files, 397, reel 383; Calhoun to the Secretary of State, January 3, 1912, KP, container 32; Knox to the American Legation at Peking, January 5, 1912, ibidem; Calhoun to the Secretary of State, January 8, 1912, ibidem; Knox to Calhoun, January 9, 1912, TP, series 6: case files, 397, reel 383. Decyzja o wysłaniu żołnierzy do Chin zaalarmowała Kongres. Congressional Records, 62 Cong., 2 sess., t. 48, Washington 1912, s. 962.

${ }^{20} \mathrm{Nie}$ dotarłem do zbiorczych danych na temat liczby Amerykanów, którzy ucierpieli podczas rewolucji, podaję zatem odniesienia do indywidualnych przypadków. The American Minister to the Secretary of State, November 21, 1911, [w:] PRFRUS 1912, s. 166-167; Calhoun to the Secretary of State, November 27, 1911, TP, series 6: case files, 397, reel 383; Extracts from a personal letter received from Mr. Williams at Peking, December 8, 1911, KP, container 16; Greene to the Secretary of State (with enclosures), February 16, 1912, Records of the Department of State Relating to Internal Affairs of China, 1910-1929 (dalej RDSRIACh), The National Archives at College Park, College Park, (mikrofilm), roll 10; The Acting Secretary of State to the Consul General at Hankow, April 4, 1912, [w:] PRFRUS 1912, s. 172; D.M. Crane, T.A. Breslin, An Ordinary Relationship ..., s. 53. Podczas powstania jeden z amerykańskich okrętów został omyłkowo ostrzelany, za co rewolucjoniści niezwłocznie przeprosili. The Commander-in-chief of the Asiatic Squadron to the Secretary of the Navy, December 4, 1911, [w: ] PRFRUS 1912, s. 175; The Commanderin-chief of the Asiatic Squadron to the Secretary of the Navy, December 12, 1911, [w:] ibidem.

${ }_{21}$ The Division of Far Eastern Affairs to the Secretary of State, October 14, 1911, KP, container 32.

22 The American Chargé d'Affaires to the Secretary of State, October 26, 1911, [w: ] PRFRUS 1912, s. 52; The Commander-in-chief of the Asiatic Squadron to the Secretary of the Navy, December 2, 1911, [w:] ibidem, s. 175. 
obywateli”. Podkreślono jednocześnie, że nawiązanie kontaktu nie oznaczało uznania władz rewolucyjnych ${ }^{23}$.

Zasada ścisłej neutralności i ograniczenia kontaktów z insurgentami wyznaczała w wielu przypadkach sposób postępowania dyplomacji amerykańskiej. Zaraz po wybuchu powstania w Wuchangu Knox odrzucil prośbę o spotkanie ze strony przebywającego wówczas w USA Sun Yat-sena ${ }^{24}$. Podobnie postąpił Calhoun, który parokrotnie odmówil przekazania wiadomości rewolucjonistów do władz cesarskich ${ }^{25}$. Z kolei Departament Stanu zalecił dyplomatom, aby podczas udzielania Chińczykom tymczasowego schronienia w amerykańskich konsulatach „skrupulatnie unikali działań, które mogą się wydawać stronnicze”26.

Zasada neutralności określała też amerykańskie stanowisko wobec pożyczki dla dworu, a właściwie dla gen. Yuan Shikaia, który został w październiku wezwany przez Qingów, aby zdławić rewolucję, lecz wkrótce stał się faktycznie trzecią stroną konfliktu, sytuującą się gdzieś pomiędzy dwiema dotychczas walczący$\mathrm{mi}^{27}$. Próbując przywrócić władzę w całym kraju, rząd centralny stale potrzebował funduszy, a ponieważ jego skarbiec był niemal pusty, zabiegał o pomoc finansową z zagranicy ${ }^{28}$. Udało mu się uzyskać pożyczkę od brytyjsko-francusko-belgijskiego

23 The Secretary of State to the American Consul General at Hankow, January 13, 1912, [w:] PRFRUS 1912, s. 61.

${ }^{24}$ Sun to Knox, October 18, 1911, KP, container 15; Jusserand à Poincaré, 30 janvier 1912, [w: Documents Diplomatiques Français, 1871-1914 (dalej DDF), $3^{\mathrm{e}}$ série: 19111914, t. 1, Paris 1929, s. 573-574; K.R. Chong, Americans and Chinese Reform and Revolution, 1898-1922: The Role of Private Citizens in Diplomacy, Lanham 1984, s. 149; J. Polit, Mocarstwa ..., s. 91. Sun udał się następnie do Londynu i Paryża, gdzie starał się uzyskać wsparcie dla rewolucji. H.Z. Schiffrin, The Enigma of Sun Yat-sen, [w: ChiR, s. $470-472$.

25 The American Minister to the Secretary of State, November 22, 1911, [w: ] PRFRUS 1912, s. 53; The American Minister to the Secretary of State, November 28, 1911, [w:] ibidem, s. 54; The Secretary of State to the American Minister, November 28, 1911 [w:] ibidem; Calhoun to the Secretary of State, November 28, 1911, TP, series 6: case files, 397, reel 383; Calhoun to the Secretary of State, December 21, 1911, KP, container 32; Knox to the American Legation at Peking, December 21, 1911, ibidem.

${ }^{26}$ The Acting Secretary of State to the Vice Consul at Foochow, November 7, 1911 [w:] PRFRUS 1912, s. 174.

27 The American Chargé d'Affaires to the Secretary of State, October 14, 1911, [w:] PRFRUS 1912, s. 49. Mandżurowie wezwali Yuana już 14 października, ale odrzucił on wstępną ofertę i czekał na przyznanie większej władzy. Jego warunki zostały ostatecznie zaakceptowane i w połowie listopada obją̨ on urząd premiera. E.P. Young, Yuan Shih-k'ai's Rise to the Presidency, [w: ChiR, s. 420-421.

${ }_{28}$ Calhoun to the Secretary of State, November 27, 1911, TP, series 6: case files, 397, reel 383 . 
syndykatu ${ }^{29}$, ale miał nadzieję na otrzymanie kolejnej od konsorcjum mocarstw, które miało w Chinach specjalną pozycję finansową i polityczną ${ }^{30}$. Nie były to nadzieje bezpodstawne, gdyż ogólnie rzecz biorąc, interes konsorcjum, które zawarło różne kontrakty $\mathrm{z}$ dynastią i potrzebowało stabilnego rządu do prowadzenia biznesu, zazębiał się z interesem Qingów ${ }^{31}$. Jednakże 8 listopada na konferencji w Paryżu członkowie konsorcjum zdecydowali, że: „z uwagi na obecną niepewność sytuacji $[\ldots]$ nie są $\mathrm{w}$ tej chwili skłonni rozważyć prośby o pomoc finansową", co znacznie skomplikowało położenie Mandżurów ${ }^{32}$.

Waszyngton na początku uchylił się od odpowiedzialności, stwierdzając, że pożyczka była „czysto biznesową propozycją” i amerykańskie banki same musiały zdecydować, czy chciały jej udzielić3 ${ }^{33}$. Było to raczej zaskakujące stanowisko, jako że dopuszczało naruszenie neutralności oraz oznaczało, iż w trudnych chwilach banki nie mogły liczyć na poparcie administracji. Bez tego zaś amerykańska grupa nie była skłonna angażować się w całą sprawę, przynajmniej dopóki pozostali członkowie konsorcjum nie zdecydowaliby inaczej ${ }^{34}$. Z czasem jednak wszystkie cztery grupy wykazały gotowość do pożyczenia pieniędzy. Na początku listopada, gdy zbliżała się konferencja bankierów, Wall Street ponownie zwróciło się do Departamentu Stanu po wytyczne. Tym razem odpowiedź była bardziej jednoznaczna - pożyczka dla Chin byłaby w tym momencie nierozsądna ${ }^{35}$.

Uzgodnienia poczynione w trakcie spotkania w Paryżu usatysfakcjonowały zatem Waszyngton, lecz inne mocarstwa i reprezentanci konsorcjum w Pekinie

29 The American Chargé d'Affaires to the Secretary of State, October 28, 1911, [w: ] PRFRUS 1912, s. 101; The Secretary of State to the American Chargé d'Affaires, November 1, 1911, [w:] ibidem. Konsorcjum czterech mocarstw stanowczo zaprotestowało przeciwko tej pożyczce. Ch. Vevier, The United States and China, 1906-1913: A Study in Finance and Diplomacy, New York 1968, s. 194-195. Pojawily się również pogłoski, że Yokohama Specie Bank starał się zaaranżować pożyczkę, ale okazało się to nieprawdą. Adee to the American Embassy at Tokyo, October 23, 1911, KP, container 32; Schuyler to the Secretary of State, October 25, 1911, ibidem; Schuyler to the Secretary of State, October 31, 1911, ibidem; Schuyler to the Secretary of State, November 9, 1911, ibidem.

${ }^{30}$ Williams to the Secretary of State, October 15, 1911, KP, container 32; Williams to the Secretary of State, October 19, 1911, ibidem; Morgan, Grenfell and Co. to J.P. Morgan and Co., November 2, 1911, ibidem.

${ }^{31}$ H. Croly, Willard Straight ..., s. 415-416.

${ }^{32}$ Harjes to J.P. Morgan and Co., November 8, 1911, KP, container 32.

${ }_{33}$ Miller to the Secretary of State, October 17, 1911, KP, container 32.

${ }^{34}$ Document written by the Division of Far Eastern Affairs, October 21, 1911, KP, container 32 .

${ }^{35}$ The Division of Far Eastern Affairs to the Secretary of State, November 4, 1911, KP, container 32; The Division of Far Eastern Affairs to the Secretary of State, November 6, 1911, ibidem; Document written by Miller, undated, ibidem. 
byli coraz bardziej przekonani, aby dać pożyczkę Yuanowi, w którym pokładali jedyną nadzieję na przywrócenie porządku w Chinach $^{36}$. Knox 18 listopada odpowiedział raczej negatywnie, stanowczo odrzucając możliwość pożyczenia pieniędzy „na cele wojenne” i stawiając różne warunki wobec pożyczek na inne cele, z których najistotniejszy polegał na ścisłej neutralności takiego wsparcia. Oznaczało to konieczność uzyskania dla niego akceptacji obu walczących stron ${ }^{37}$.

Jednak w miarę jak pozostałe mocarstwa utwierdzały się w przekonaniu, że finansowa pomoc dla Yuana była konieczna, a Calhoun i inni Amerykanie w Chinach również wypowiadali się w tym duchu, Knox złagodził w grudniu swoje stanowisko. Decydującym argumentem było zapewne przekonanie, że bez poparcia Yuan nie byłby w stanie prowadzić rozmów pokojowych, które miały się właśnie rozpocząć, a jego upadek spowodowałby pogrążenie się Chin w chaosie ${ }^{38}$. 11 grudnia Stany Zjednoczone oświadczyły, że nie sprzeciwią się niewielkiej pożyczce, o ile zaakceptują ją obie strony konfliktu i będzie ona miała „szeroki międzynarodowy charakter"39.

Sytuacja skomplikowała się dwa dni później, gdy rewolucjoniści zdecydowanie odrzucili pomysł pożyczki ${ }^{40}$. Spowodowało to rozdźwięk między mocarstwami, albowiem część z nich uważała, że pożyczki należy udzielić pomimo sprzeciwu. USA powróciły do wcześniejszego stanowiska i 18 grudnia zadeklarowały, że moment był „nieodpowiedni” dla chińskiej pożyczki ${ }^{41}$. W kolejnych tygodniach

${ }^{36}$ Morgan, Grenfell and Co. to J.P. Morgan and Co., November 2, 1911, KP, container 32; Calhoun to the Secretary of State, November 17, 1911, ibidem; H. Croly, Willard Straight ... , s. 416-418, 421-423; D.M. Crane, T.A. Breslin, An Ordinary Relationship ..., s. 49-50; W. Rojek, Ekspansja mocarstw w Chinach i jej wpływ na rozwój stosunków międzynarodowych w latach 1895-1914, Kraków 1990, s. 119.

37 The Secretary of State to the American Minister, November 18, 1911, [w:] PRFRUS 1912, s. 102.

38 Document written by Miller, December 5, 1911, KP, container 32; The American Minister to the Secretary of State, December 6, 1911, [w:] PRFRUS 1912, s. 102; The British Ambassador to the Secretary of State, December 8, 1911, [w:] ibidem, s. 103-104; Calhoun to the Secretary of State, December 11, 1911, TP, series 6: case files, 397, reel 383; Huntington Wilson to German Ambassador, December 11, 1911, KP, container 32; L.C. Gardner, Safe for Democracy: The Anglo-American Response to Revolution, 19131923, New York 1984, s. 73.

39 The Acting Secretary of State to the British Ambassador, December 11, 1911, [w:] PRFRUS 1912, s. 104; The Secretary of State to the American Minister, December 12, 1911, [w: ] ibidem, s. 105.

40 The Minister for Foreign Affairs of the Revolutionary Government to the Secretary of State, undated, received December 13, 1911, [w: ] PRFRUS 1912, s. 106.

${ }^{41}$ Bacon to the Secretary of State, December 15, 1911, KP, container 32; Calhoun to the Secretary of State, December 17, 1911, ibidem; The British Ambassador to the Secretary of State, December 18, 1911, [w: ] PRFRUS 1912, s. 106-107; The Assistant Secretary of 
mocarstwa kontynuowały rozmowy na jej temat, ale ponieważ nie mogły się porozumieć, żadnej pożyczki nie udzielono ${ }^{42}$.

O ile zainteresowane mocarstwa mogły wpływać na działania banków należących do konsorcjum, nie miały takiej władzy wobec innych banków, a Chiny, pozbawione możliwości wzięcia pożyczki od konsorcjum, zwróciły się do nich. W tej kwestii Waszyngton uważał, że mocarstwa powinny odwodzić swych obywateli od dawania pożyczek, chyba że spełniałyby one warunki neutralności i umiędzynarodowienia ${ }^{43}$. Toteż Departament Stanu był nieprzychylnie nastawiony do negocjacji pożyczkowych między japońskimi i chińskimi firmami (część pieniędzy z pożyczek miała ostatecznie trafić do rewolucjonistów) ${ }^{44}$, jak i między Salomon \& Co. z Nowego Jorku a rządem pekińskim. W drugim przypadku Knox nie tylko odmówil jakiejkolwiek pomocy, ale również osobiście interweniowal, aby zablokować umowę ${ }^{45}$.

Oprócz zasady neutralności kilka innych powodów przemawiało przeciwko udzieleniu pożyczki. Przede wszystkim Stany Zjednoczone obawiały się, że mogło to doprowadzić do komplikacji międzynarodowych oraz narazić na niebezpieczeństwo cudzoziemców znajdujących się na terenach kontrolowanych przez rewolucjonistów ${ }^{46}$. Istniało też ryzyko, że Chińczycy wezmą odwet ekonomiczny,

State to the British Ambassador, December 18, 1911, [w: ] ibidem, s. 107. Cytat pochodzi z ostatniego dokumentu. E.W. Edwards, China and Japan, 1911-1914, [w:] F.H. Hinsley (red.), British Foreign Policy under Sir Edward Grey, Cambridge 1977, s. 369.

42 Bacon to the Secretary of State, December 22, 1911, KP, container 32; Leishman to the Secretary of State, December 22, 1911, ibidem; Bacon to the Secretary of State, December 23, 1911, ibidem; Knox to the American Embassy at Tokyo, December 27, 1911, ibidem; Calhoun to the Secretary of State, December 27, 1911, ibidem; Document written by Miller, January 3, 1912, ibidem.

43 The Assistant Secretary of State to the British Ambassador, December 18, 1911, [w: ] PRFRUS 1912, s. 107; Knox to the American Embassy at London, January 24, 1912, KP, container 32; The Secretary of State to the German Ambassador, February 3, 1912 [w: ] PRFRUS 1912, s. 63-64.

44 Rewolucjoniści uzyskali trzy pożyczki od japońskich firm i jedną od Hongkong and Shanghai Bank, który był brytyjskim reprezentantem w konsorcjum mocarstw. Japońskie pożyczki były nieoficjalnie popierane przez rząd, z kolei lokalny oddział Hongkong and Shanghai Bank przekazał pieniądze bez informowania Foreign Office. Knox to the American Embassy at London, January 24, 1912, KP, container 32; Bryan to the Secretary of State, January 31, 1912, ibidem; Phillips to the Secretary of State, January 31, 1912, ibidem; Calhoun to the Secretary of State, February 7, 1912, ibidem; M.B. Jansen, The Japanese and Sun Yat-sen..., s. 145-148; H.Z. Schiffrin, The Enigma of..., s. 471; P. Lowe, Great Britain and Japan ..., s. 84.

45 Knox to the American Legation at Peking, December 16, 1911, TP, series 6: case files, 397, reel 383; D.M. Crane, T.A. Breslin, An Ordinary Relationship ..., s. 66.

46 The Secretary of State to the American Minister, December 7, 1911, [w:] PRFRUS 1912, s. 103. Patrz także opinia Calhouna: Calhoun to the Secretary of State, December 11, 
rozpoczynając bojkot amerykańskich produktów, co z pewnymi sukcesami uczynili kilka lat wcześniej ${ }^{47} .27$ listopada poselstwo otrzymało anonim grożący takim działaniem, jeśli Mandżurom pożyczono by pieniądze ${ }^{48}$.

Mimo że USA prowadziły raczej konsekwentną politykę, nie wszystkie osoby zaangażowane w jej kształtowanie podzielały opinię, że ścisła neutralność to najlepszy wybór. Niektórzy Amerykanie w Chinach, zwłaszcza Calhoun, Williams i Willard Straight, w owym czasie pekiński reprezentant amerykańskiej grupy w konsorcjum, starali się przekonać swoich przełożonych do odejścia od polityki nieingerencji i poparcia władz centralnych, a przede wszystkim Yuana ${ }^{49}$. Argumentowali, że Yuan, w przeciwieństwie do rewolucjonistów, potrafil utrzymać porządek, ale jego pozycję poważnie osłabiał brak funduszy. Rząd, którym kierował, był bliski niewypłacalności i mógł upaść w każdej chwili50. Calhoun przewidywał, że gdyby tak się stało, miałoby to ujemny wpływ na Chiny i międzynarodowe stosunki. Poseł ujął to następująco:

1911, TP, series 6: case files, 397, reel 383. 13 października rewolucjoniści ostrzegli, że "obce mocarstwa pomagające rządowi cesarskiemu będą uważane za wrogów”. W grudniu oświadczyli, że jakąkolwiek pożyczkę dla dynastii będą traktowali jako „skierowaną przeciwko nim w ich walce o wolność". Williams to the Secretary of State, October 14, 1911, KP, container 32; The Minister for Foreign Affairs of the Revolutionary Government to the Secretary of State, undated, received December 13, 1911, [w:] PRFRUS 1912, s. 106.

${ }^{47}$ Antyamerykański bojkot rozpoczął się w 1905 roku z powodu polityki imigracyjnej USA. Trzy lata później Chińczycy zaczęli bojkotować towary z Japonii ze względu na jej reakcję na incydent „Tatsu Maru”. M.C. Wright, Introduction: The Rising Tide of Change ..., s. 10.

${ }_{48}$ Calhoun to the Secretary of State, November 27, 1911, TP, series 6: case files, 397, reel 383 .

${ }^{49}$ Copy of a personal telegram from Mr. Straight to Mr. Davison, October 16, 1911, KP, container 32; Williams to the Secretary of State, October 19, 1911, ibidem; The American Minister to the Secretary of State, December 6, 1911, [w:] PRFRUS 1912, s. 102; Calhoun to the Secretary of State, December 11, 1911, TP, series 6: case files, 397, reel 383; H. Croly, Willard Straight..., s. 416-418, 422-423; D.M. Crane, T.A. Breslin, An Ordinary Relationship..., s. 65-66; Ch. Vevier, The United States and China ..., s. 193196; W. Scholes, M. Scholes, The Foreign Policies of the Taft Administration, Columbia 1970, s. 222-225; D.D. Lazo, An Enduring Encounter ..., s. 205-207.

so Zagraniczni dyplomaci w Pekinie obawiali się również o życie Yuana. Jak się okazało słusznie - w połowie stycznia 1912 roku miała miejsce próba zamachu, z której jednak wyszedł on bez szwanku. Zgładzić chcieli go ponadto różni japońscy oficerowie i awanturnicy, lecz ich plany zostały udaremnione. Calhoun to the Secretary of State, November 25, 1911, TP, series 6: case files, 397, reel 383; J. Ch'ên, Yuan Shih-k'ai, 18591916: Brutus Assumes the Purple, London 1961, s. 125-126; H. Croly, Willard Straight ..., s. 431-433; M.B. Jansen, The Japanese and Sun Yat-sen ..., s. 139. 
Doceniam zalety neutralności, ale jeśli porozumienie nie zostanie w najbliższej przyszłości zawarte, nie będzie jej można długo kontynuować. [...] Jeśli pokój nie zostanie wkrótce wynegocjowany, rebelianckie [oddziały - J.P.] rozpadną się na bandy rozbójników. Cudzoziemcy raczej [...] nie unikną wówczas ataków. [... J Jeśli [Yuan - J.P.] nie opłaci wojsk, one również zaczną plądrować. Nastąpi generalne pandemonium i cudzoziemcy wszędzie będą zagrożeni. Tak więc kontynuowanie neutralności oznacza czekanie, aż warunki staną się tak złe, że zbrojna interwencja, niosąca za sobą najprawdopodobniej poważne międzynarodowe komplikacje, będzie niezbędna. W grę mogą wchodzić los Chin i pokój na świecie ${ }^{51}$.

Williams podawał dwa kolejne powody, dla których należało poprzeć władze pekińskie. Uważał, że cztery mocarstwa reprezentowane w konsorcjum miały „moralny obowiązek”, aby pomóc Pekinowi przezwyciężyć kryzys, wywołany m.in. przez umowę z bankierami. Ponadto, jeśli by tego nie zrobiły, mogłaby interweniować Japonia ${ }^{52}$. Williams, Calhoun i Straight zalecali więc, aby wspomóc finansowo Yuana, ale Departament Stanu pozostał wierny swej polityce ścisłej neutralności ${ }^{53}$.

W znakomitej większości wspomnianych wyżej spraw, a także różnych innych, USA konsultowały swoje decyzje z pozostałymi mocarstwami, gdyż jednym z podstawowych celów amerykańskiej dyplomacji było „utrzymanie w każdy sposób [... pełnej jedności działań wśród mocarstw" ${ }^{54}$. Zastosowanie się do tej wytycznej mogło przynieść dwie korzyści. Nie tylko mogło wywrzeć większy nacisk na Chiny, ale również pohamować inne mocarstwa przed próbą wykorzystania turbulentnego okresu ${ }^{55}$. Druga korzyść była istotna, ponieważ nie wszystkie państwa w pełni przestrzegały polityki neutralności.

51 Calhoun to the Secretary of State, December 11, 1911, TP, series 6: case files, 397, reel 383. Calhoun twierdził ponadto, że pożyczka o szerokim międzynarodowym charakterze mogłaby skłonić rewolucjonistów do zmniejszenia żądań i zawarcia rozsądnego porozumienia $\mathrm{z}$ Yuanem.

52 Williams to the Secretary of State, October 14, 1911, KP, container 32; Williams to the Secretary of State, October 19, 1911, ibidem.

53 E.P. Young, Yuan Shih-k'ai's Rise..., s. 430; Ch. Vevier, The United States and China..., s. 193-196. Straight zaproponowal, aby konsorcjum pożyczyło pieniądze rządowi pekińskiemu, pod warunkiem że Chiny staną się monarchią konstytucyjną z Yuanem na czele. Ibidem, s. 195-196.

54 The Secretary of State to the American Minister, January 5, 1912, [w:] PRFRUS 1912, s. 169; The Secretary of State to the German Ambassador, February 3, 1912, [w:] ibidem, s. 63-64. Cytat pochodzi z pierwszego dokumentu.

55 W. Scholes i M. Scholes twierdzą, że Knox dążył do osiągnięcia nawet bardziej dalekosiężnego celu - chciał ustanowić „wzorzec współpracy między mocarstwami 
Szczególnie niepokojące były pod tym względem działania i enuncjacje Japonii ${ }^{56}$. Od początku rewolucji spekulowano, że przygotowuje się ona do interwencji. Paradoksalnie nie wiadomo było tylko, na czyją rzecz. 15 października amerykański chargé d'affaires w Tokio wyraził opinię, że oczekiwała ona prośby ze strony Qingów, aby stłumić rebelię. Osiem dni później „Pacific Commercial Advertiser" opublikował wiadomość, że prośba została wystosowana i Japonia czeka jedynie na międzynarodową aprobatę swoich działań ${ }^{57}$. Tymczasem władze pekińskie, mające rzekomo zabiegać o japońską pomoc, niepokoily się zamiarami Tokio i poprosity Stany Zjednoczone o dopilnowanie, aby żadne z mocarstw nie podjęło samodzielnych działań, odnosząc się nie wprost do Japonii oraz być może, chociaż w mniejszym stopniu, do Wielkiej Brytanii i Rosji ${ }^{58}$. Inne doniesienia potwierdzały, że Japonia pomagała rewolucjonistom ${ }^{59} .7$ grudnia oświadczyła ona expressis verbis, że jeśli walki w Chinach będą kontynuowane, rozważy możliwość interwencji. Ciągle nie określiła jednak przeciwko komu. Cztery dni później Departament Stanu otrzymał telegram mówiący, że „zawarte zostało porozumienie między brytyjskimi i japońskimi dowódcami, aby interweniować w Chinach, używając japońskich żołnierzy" ${ }^{\circ 0}$. Okazało się to nieprawdą

w sprawach chińskich", utrudniając prowadzenie przez nie samodzielnej polityki. W. Scholes, M. Scholes, The Foreign Policies ..., s. 221-222.

${ }^{56}$ Według Francuzów neutralność naruszały także Niemcy, które miały militarnie pomagać rządowi pekińskiemu i wyrazić gotowość do interwencji na jego rzecz. Clausse à Selves, 2 décembre 1911, [w:] DDF, $3^{\mathrm{e}}$ série, t. 1, s. 258-260; Note pour le Président de la République, 13 janvier 1912, [w:] ibidem, s. 481-482; Poincaréaux Ambassadeurs de France à Londres, Berlin, Pétersbourg, Washington, 27 janvier 1912, [w:] ibidem, s. 555-557.

${ }^{57}$ The American Chargé d'Affaires at Tokyo to the Secretary of State, October 15, 1911, [w:] PRFRUS 1912, s. 50; The Chinese Residents of Honolulu to the Secretary of State, undated, received October 24, 1911, [w:] ibidem, s. 51.

58 Williams to the Secretary of State, October 15, 1911, KP, container 32; The American Ambassador to Germany to the Secretary of State, October 24, 1911, [w:] PRFRUS 1912, s. 51. Rosja chciała wykorzystać powstanie do rozszerzenia wplywów w Mongolii (przede wszystkim w Mongolii Zewnętrznej). Wielka Brytania była z kolei zainteresowana ugruntowaniem swej pozycji w Tybecie.

${ }^{59}$ Calhoun to the Secretary of State, November 27, 1911, TP, series 6: case files, 397, reel 383; Williams (American Consul at Swatow) to Calhoun, January 26, 1912, RDSRIACh, roll 10. W lutym 1912 roku pojawiła się informacja, że według Sun Yat-sena członkowie genrō zaproponowali rewolucjonistom sojusz zaczepno-odporny w zamian za uznanie ich władz i pomoc przy organizowaniu armii i floty. Calhoun to the Secretary of State, February 8, 1912, KP, container 32; The Chinese Secretary of the Legation to Minister Calhoun, February 10, 1912, KP, container 43.

${ }^{60}$ The American Ambassador to Japan to the Secretary of State, December 7, 1911, [w: PRFRUS 1912, s. 55; The Naval Attaché at Tokyo to the Secretary of the Navy, telegram transmitted to the Secretary of State on December 11, 1911, [w:] ibidem. 
i ostatecznie do żadnej interwencji nie doszło ${ }^{61}$. Chociaż USA mogły odegrać pewną rolę w przekonaniu Japonii do zaniechania jej planów, ich wplyw trudno uznać za decydujący ${ }^{62}$. W tym przypadku kluczowe było stanowisko sojusznika Japonii - Wielkiej Brytanii, która dominowała handlowo w Chinach i posiadała tam znaczne wplywy polityczne. Przyjęła ona pozycję wyczekującą i powstrzymywała próby interwencji militarnej ${ }^{63}$. Z istoty brytyjskich koneksji międzynarodowych w pełni zdawali sobie zresztą sprawę Amerykanie. Już 14 października Wydział ds. Dalekiego Wschodu w Departamencie Stanu radził skontaktować się nieoficjalne z Rządem Jego Królewskiej Mości, aby mógł on wykorzystać swoje wpływy na Japonię, Francję i Rosję $e^{64}$.

Ogólnie rzecz biorąc, polityka wspólpracy okazała się skuteczna. Jedność między mocarstwami została zachowana, mimo że każde z nich miało własne, nierzadko sprzeczne interesy. Wielka Brytania, Japonia, Francja, Rosja, Niemcy i Stany Zjednoczone działały wspólnie, aby pchnąć walczące strony do zawarcia kompromisu. Wiedząc, że przedłużający się konflikt mógł tylko pogorszyć sytuację w Chinach i narazić cudzoziemców, zdecydowały się wywrzeć „presję moralną" i wręczyć jednakowe noty negocjatorom, którzy 18 grudnia rozpoczęli rozmowy pokojowe w Szanghaju ${ }^{65}$. W mediacji inicjatywę przejęła Wielka Brytania,

${ }^{61}$ Polityka Japonii podczas rewolucji była zawiła i przeszła kilka poważnych zmian. Poza tym japońscy politycy, dyplomaci, wojskowi i awanturnicy mieli często odmienne opinie i plany. Na temat polityki japońskiej patrz: M. Ikei, Japan's Response ...; M.B. Jansen, The Japanese and Sun Yat-sen ..., s. 131-153; P. Lowe, Great Britain and Japan..., s. 58-88.

${ }^{62}$ The American Chargé d'Affaires at Tokyo to the Secretary of State, October 15, 1911, [w: ] PRFRUS 1912, s. 50; M. Ikei, Japan's Response ..., s. 225.

${ }^{63}$ J. Polit, Mocarstwa..., s. 91-92, 97, 99; P. Lowe, Great Britain and Japan..., s. 58-88; L. Pomerantz-Zhang, Wu Tingfang ..., s. 215, 221; H. Croly, Willard Straight ..., s. 429-431; E.P. Young, Yuan Shih-k'ai's Rise ..., s. 430-431. Zob. też: Minutes attached to MacDonald to Grey, April 24, 1911, [w:] British Documents on the Origins of the War 1898-1914 (dalej BDOW), (opr.) G.P. Gooch, H. Temperley, t. 8: Arbitration, Neutrality and Security, London 1932, s. 518-520.

${ }^{64}$ The Division of Far Eastern Affairs to the Secretary of State, October 14, 1911, KP, container 32. Zob. też: Straight to Davison, December 18, 1911, Willard Dickerman Straight Papers (dalej SP), Division of Rare and Manuscript Collections, Cornell University Library, Cornell University, Ithaca, reel 5, segment 1, online: http://ecommons.cornell. edu/handle/1813/22053 (dostęp: 10.02.2018).

${ }_{65}$ Identyczne noty wręczono 20 grudnia negocjatorom pokojowym, którzy nie udzielili żadnej odpowiedzi. Wymowa not została podobno wzmocniona ostrzeżeniem, że jeśli porozumienie nie zostanie szybko zawarte, mocarstwa mogą interweniować w Chinach. Calhoun to the Secretary of State, December 15, 1911, TP, series 6: case files, 397, reel 383; The Secretary of State to the Japanese Chargé d'Affaires, December 21, 1911, [w:] PRFRUS 1912, s. 57-58; The Secretary of State to the German Ambassador, February 3, 
ponieważ miała najlepsze kontakty zarówno z rewolucjonistami, jak i z Yuanem. Brytyjscy dyplomaci od początku rewolucji działali jako pośrednicy, a w grudniu, gdy rozpoczęły się poważne negocjacje, zaproponowali Japonii przyłączenie się. Wówczas Waszyngton, zapewne trochę niezadowolony, że nie znalazł się w tym gronie, zacząl podejrzewać, iż Londyn i Tokio chciały wyłamać się z koncertu mocarstw. Whitehall zapewnił, że tak nie było, i wyjaśnil, iż pozostałe państwa nie zostały zaproszone do pomocy w negocjacjach tylko z powodu niepraktyczności takiego rozwiązania. Sir John Jordan miał być zaś w stałym kontakcie z Calhounem i innymi członkami korpusu dyplomatycznego ${ }^{66}$.

Amerykańskie wpływy podczas rewolucji można ocenić jako istotne, choć nie kluczowe. Bezsprzecznie to Wielka Brytania miała najsilniejszą pozycję, zarówno w Chinach, jak i wśród mocarstw ${ }^{67}$. Głos Ameryki był jednak również słyszalny, mimo że jej możliwości oddziaływania były ograniczone z kilku powodów. Pierwsza trudność wynikała z braku sojuszników, podczas gdy pozostałe mocarstwa ich miały. Wartość sojuszów zaś stale rosła, gdyż zwiększało się prawdopodobieństwo wybuchu wojny w Europie. Skłaniało to zwłaszcza Londyn i Paryż do większego przyzwolenia na politykę swych aliantów na Dalekim Wschodzie. Petersburg i Tokio zdawały sobie z tego sprawę i chciały to wykorzystać - np. w listopadzie 1911 roku Rosja oznajmiła, że w zamian za poparcie podczas kryzysu agadirskiego oczekuje od Francji zgody na „swobodę działania” m.in. w Mandżurii, Mongolii i Turkiestanie Wschodnim ${ }^{68}$. Mocarstwa były także podejrzliwe wobec ostatnich aktywnych poczynań Waszyngtonu w Chinach, uważając, że dążył on do uzyskania wyłącznych przywilejów ${ }^{69}$.

Kolejne ograniczenie amerykańskiej polityki wypływało z faktu, że miała ona jedynie dyplomatyczny charakter. $\mathrm{Z}$ nieco przesadnym pesymizmem i goryczą wyrazil to Calhoun:

1912, [w: ibidem, s. 63-64; L. Pomerantz-Zhang, Wu Tingfang ..., s. 212; D.M. Crane, T.A. Breslin, An Ordinary Relationship..., s. 55.

${ }^{66}$ PRFRUS 1912, s. 58-60; J. Polit, Mocarstwa ..., s. 94, 97-100.

${ }^{67}$ J. Reed, The Missionary Mind..., s. 114; E.P. Young, Yuan Shih-k'ai's Rise..., s. 430; D.M. Crane, T.A. Breslin, An Ordinary Relationship..., s. 48, 50-51; P. Lowe, Great Britain and Japan..., s. 86; J. Polit, Mocarstwa ..., s. 90-91, 103; The Cambridge History of China ..., t. 11, s. 531.

${ }^{68}$ Isvolsky à Selves, 4 novembre 1911, [w: ] DDF, $3^{\text {e }}$ série, t. 1, s. 14-16.

${ }^{69}$ Calhoun to the Secretary of State, December 5, 1911, KP, container 32; Straight to Davison, December 18, 1911, SP, reel 5, segment 1; Straight to Davison, January 16, 1912, ibidem; Straight to Morgan, Grenfell and Co., January 16, 1912, KP, container 32; Calhoun to the Secretary of State, January 17, 1912, ibidem; Straight to J.P. Morgan and Co., January 28,1912 , SP, reel 5, segment 1. 
Gdybyśmy mieli flotę pancerników przecinających wody Pacyfiku; gdybyśmy mieli politykę zagraniczną [...] konsekwentną [...] i wspartą "grubą pałką”; gdyby Amerykanie zrozumieli kiedyś potrzeby [...] rynku w taki sposób, aby poparli politykę państwową na Dalekim Wschodzie, która zapewniała „otwarte drzwi” i równe szanse, nastawienie innych państw do nas mogłoby być zdecydowanie inne. W obecnej sytuacji jesteśmy stosunkowo bezsilni. Dyplomacja, jakkolwiek zręczna, jakkolwiek dobroczynna i altruistyczna mogłaby być, jeśli nie jest wsparta przez siłę, która nie tylko wzbudza, ale żąda respektu $[\ldots]$, na niewiele się $\mathrm{zda}^{70}$.

Mimo wszystkich tych ograniczeń USA prowadziły aktywną politykę podczas rewolucji 1911 roku i odegrały ważną rolę wśród mocarstw. Knox był wręcz przekonany, że jego kraj niemal przewodził mocarstwom w Chinach ${ }^{71}$.

Pod brytyjskimi auspicjami Yuan i rewolucjoniści osiągnęli porozumienie kosztem Mandżurów. Negocjacje nie były jednak łatwe, ponieważ obie strony miały różne poglądy, brakowało im funduszy i ogólnie znajdowały się w delikatnym położeniu ${ }^{72}$. Polityczny pat wydawał się prawdopodobny. W sylwestra 1911 roku Yuan poprosił mocarstwa, aby pomogły przedłużyć rozejm na kilka miesięcy lub nawet na rok według zasady uti possidetis ${ }^{73}$. Tymczasem rewolucjoniści, chcąc wzmocnić swoją pozycję, ustanowili w Nankinie Republikę Chińską i wybrali Sun Yat-sena na tymczasowego prezydenta. Stworzyło to nową sytuację i trzeba było przedyskutować rozmaite kwestie dotyczące ustroju, nominacji politycznych i szczegółów przekazania władzy. W tym czasie Yuan wstrzymał się z atakowaniem przeciwników, licząc, że ulegną oni rozbiciu ${ }^{74}$. Kompromis zaczął się zarysowywać w drugiej połowie stycznia, gdy dwór, naciskany przez Yuana, wiernych mu generałów, a także rewolucjonistów i cudzoziemców, zgodził się oddać władzę. 12 lutego regentka Longyu (wdowa po cesarzu Guangxu, od początku grudnia nowa regentka po ustąpieniu księcia Chuna) ogłosiła abdykację sześcioletniego cesarza Puyi i scedowała władzę na rzecz Yuana. W ciągu następnych dni parlament w Nankinie przyjął rezygnację Suna z urzędu tymczasowego prezydenta i wybrał w jego miejsce Yuana. Wydarzenia te wyznaczały koniec rewolucji Xinhai ${ }^{75}$.

70 Minister Calhoun to the Secretary of State, February 12, 1912, KP, container 43. Zob. też dość podobną opinię Straighta: Straight to Davison, December 18, 1911, SP, reel 5 , segment 1 .

${ }^{71}$ Knox to the President, October 27, 1911, KP, container 32. Niektórzy badacze uważają, że USA prowadziły raczej pasywną politykę podczas rewolucji Xinhai. J. Reed, The Missionary Mind ..., s. 115; J. Polit, Mocarstwa..., s. 92.

72 Calhoun to the Secretary of State, December 11, 1911, TP, series 6: case files, 397, reel 383; Calhoun to the Secretary of State, January 13, 1912, TP, series 6: case files, 443, reel 385; L. Pomerantz-Zhang, Wu Tingfang..., s. 221; H. Croly, Willard Straight..., s. 425-428. Na temat przebiegu negocjacji patrz: L. Pomerantz-Zhang, Wu Tingfang..., s. 211-223.

73 Calhoun to the Secretary of State, December 31, 1911, KP, container 32.

74 Calhoun to the Secretary of State, January 5, 1912, KP, container 32.

75 PRFRUS 1912, s. 62-66. 


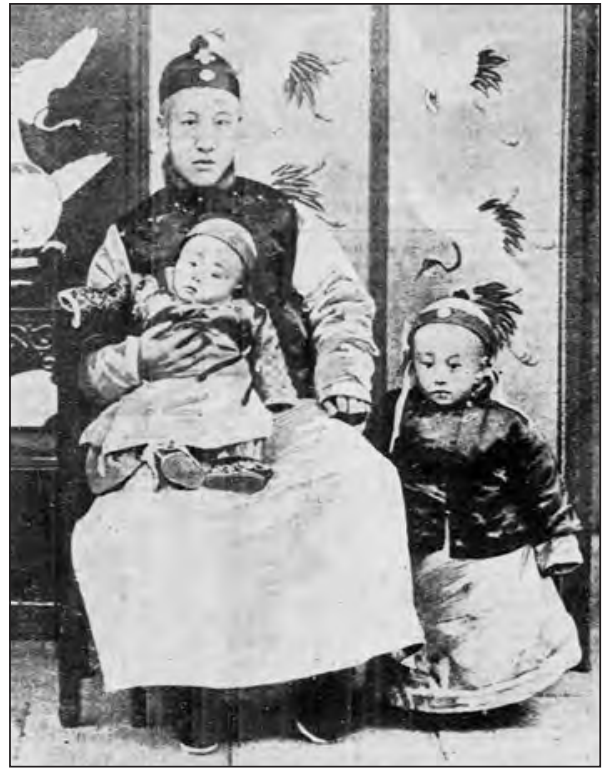

13. Puyi z ojcem (Zaifengiem) i młodszym bratem

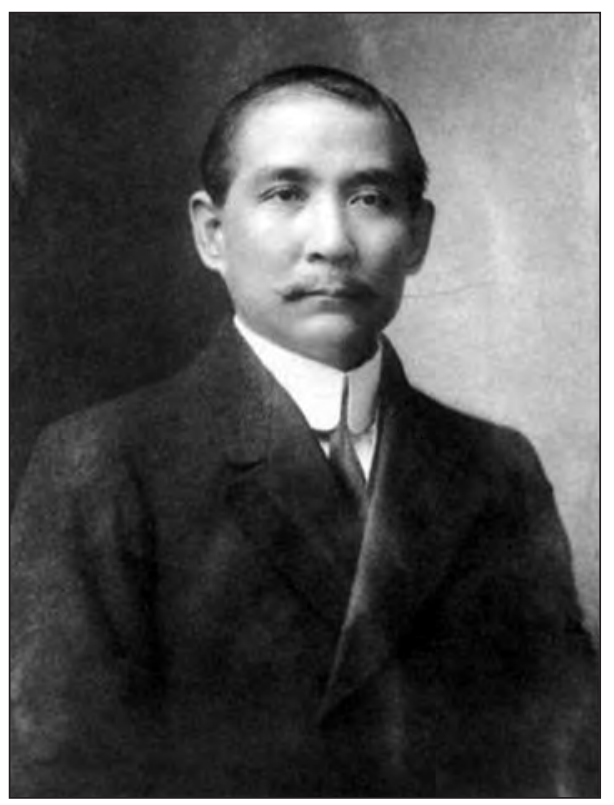

15. Sun Yat-sen

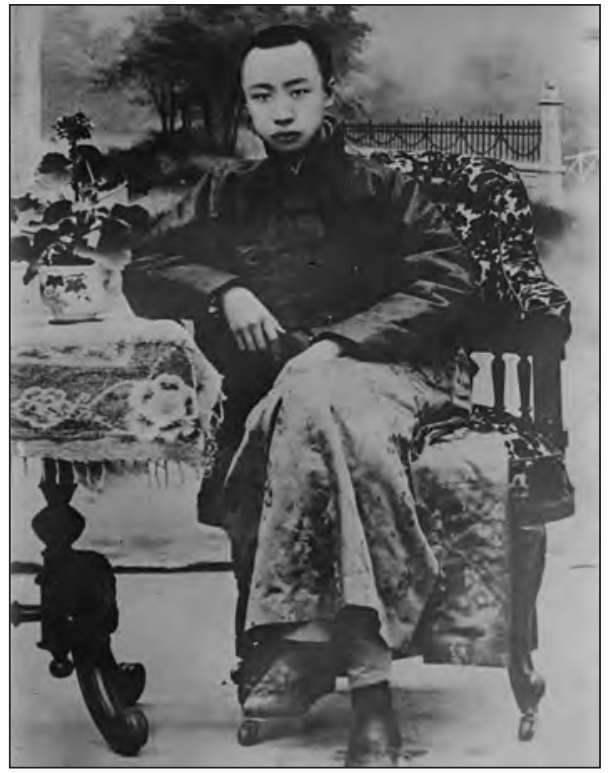

14. Puyi

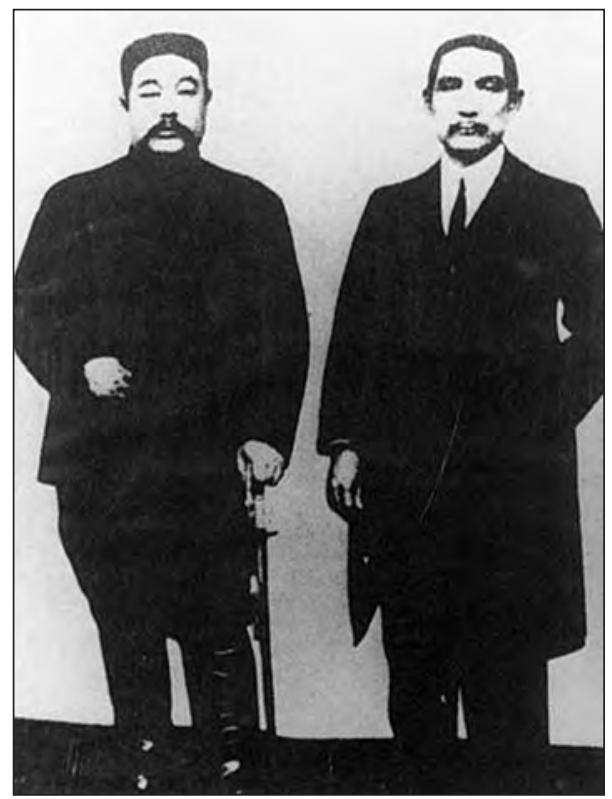

16. Li Yuanhong i Sun Yat-sen 
64 Chiny w polityce zagranicznej Stanów Zjednoczonych w latach 1911-1918

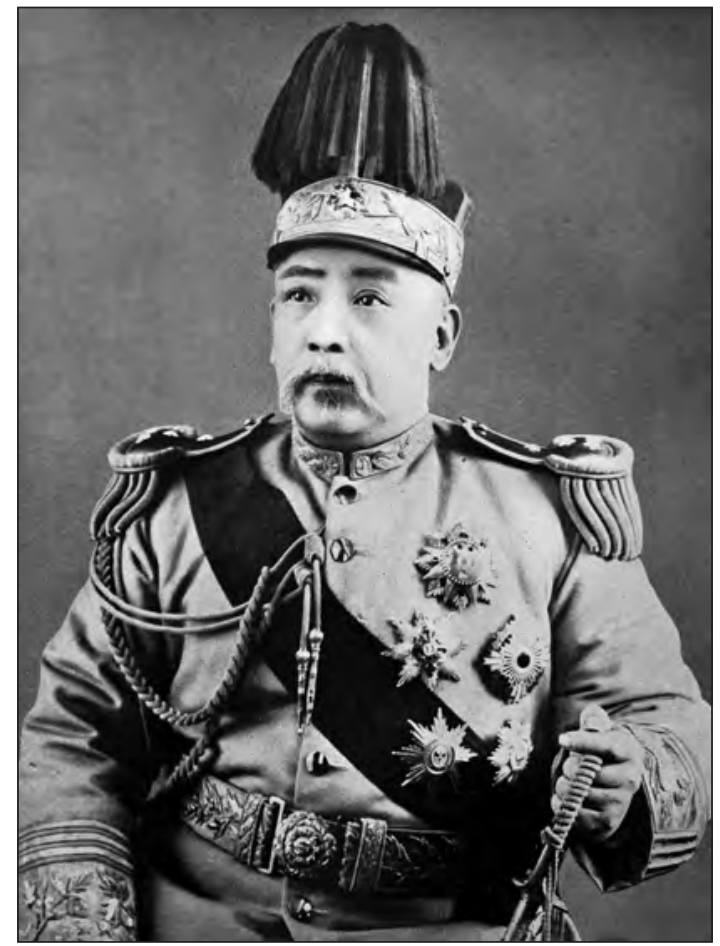

17. Yuan Shikai

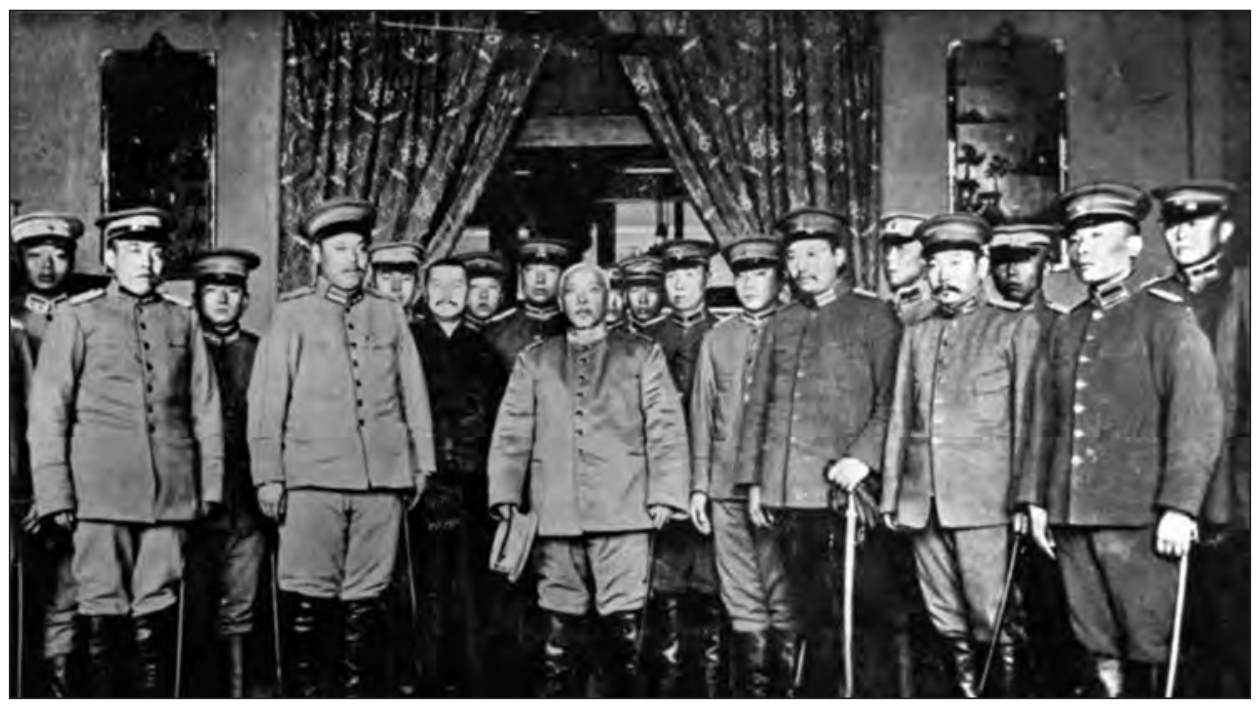

18. Yuan Shikai podczas zaprzysiężenia na urząd tymczasowego prezydenta Republiki Chińskiej (10 marca 1912 roku) 
Stany Zjednoczone pozostały raczej bierne podczas negocjacji, ale pozytywnie oceniły ich wynik ${ }^{76}$. Cieszyły się, że wojna domowa, stanowiąca bądź co bądź zagrożenie dla cudzoziemców i amerykańskiej polityki w Chinach, zakończyła się, i to, przynajmniej do jakiegoś stopnia, w pojednawczym duchu, co wzmacniało nadzieję, że pokój będzie trwały. W dodatku władzę przejął Yuan, z którym USA - podobnie jak prawie wszystkie inne mocarstwa - sympatyzowały ${ }^{77}$.

Od początku rewolucji amerykańscy dyplomaci postrzegali Yuana jako najbardziej odpowiednią osobę do rządzenia Chinami ${ }^{78}$. Już 26 października Williams przewidywał, że tylko jeśli generał obejmie przywództwo i zdoła pozyskać rewolucjonistów dzięki reorganizacji rządu, dynastia utrzyma się u władzy ${ }^{79}$. Również Calhoun wysoko cenił Yuana, aczkolwiek czasami, intencjonalnie lub przez naiwność, przypisywał mu zbyt duże zasługi i przymioty, np. gdy napisał: „Nie mam wątpliwości, że przybył on tutaj w dobrej wierze, zamierzając wspomóc mandżurską dynastię", co było nieprawdą, gdyż Yuana bardziej interesowało przejęcie władzy niż resuscytacja walącego się imperium Qingów ${ }^{80}$. Dla Straighta generał był po prostu właściwym „koniem, na którego należy postawič"

Yuan był powszechnie postrzegany przez cudzoziemców jako „najzdolniejszy człowiek, jakiego mają obecnie Chiny” i „nadzieja” kraju ${ }^{82}$. Opinia ta wynikała

${ }^{76}$ Oprócz tego, że Amerykanie nie mieli tak dobrych kontaktów z walczącymi stronami jak Brytyjczycy, mogli chcieć oddać inicjatywę dyplomatyczną państwu, które miało największe interesy $\mathrm{w}$ Chinach, tak jak zrobili to w przypadku proponowanej pożyczki dla Yuana. The Secretary of State to the American Minister, November 18, 1911, [w:] PRFRUS 1912, s. 102; Calhoun to the Secretary of State, December 11, 1911, TP, series 6: case files, 397, reel 383; H. Croly, Willard Straight ..., s. 422, 429-430.

77 Jedyny wyjątek stanowiła Japonia, której stosunek do Yuana można określić jako ambiwalentny. Tokio głównie ze względu na różne historyczne zaszłości oceniało go nieprzychylnie lub wręcz całkiem negatywnie, lecz jednocześnie widziało w nim jedynego gwaranta stabilizacji w Chinach. M. Ikei, Japan's Response ..., s. 217; J. Polit, Mocarstwa ..., s. 96; E.P. Young, Yuan Shih-k'ai's Rise..., s. 428; P. Lowe, Great Britain and Japan ..., s. 70 .

${ }^{78}$ M.H. Hunt, The Making of a Special Relationship ..., s. 271-272; D.M. Crane, T.A. Breslin, An Ordinary Relationship ..., s. 28.

79 The American Chargé d'Affaires to the Secretary of State, October 26, 1911, [w:] PRFRUS 1912, s. 52.

${ }^{80}$ Minister Calhoun to the Secretary of State, January 16, 1912, KP, container 43; J. Ch'ên, Yuan Shih-k'ai ..., s. 117, 123-124.

${ }^{81}$ Straight to Davison, December 18, 1911, SP, reel 5, segment 1.

${ }_{82}$ Reeves to McCoy, October 23, 1911, KP, container 32; Minister Calhoun to the Secretary of State, January 16, 1912, KP, container 43; Calhoun to the Secretary of State, January 17, 1912, KP, container 32; Margerie à Poincaré, 17 janvier 1912, [w:] DDF, $3^{\mathrm{e}}$ série, t. 1, s. 492-493; Poincaré aux Ambassadeurs de France à Londres, Berlin, Pétersbourg, 
z kilku powodów. Przede wszystkim wierzono, że Yuan, mający duże wpływy i bardzo dobrą reputację wśród żołnierzy, mógł przywrócić porządek. Według Calhouna dysponował on „najlepszą armią, najlepiej wyszkoloną, wyekwipowaną i zdyscyplinowaną" ${ }^{83}$. Miał ponadto duże doświadczenie w rządzeniu, a jako gubernator prowincji Zhili okazal się kompetentny i umiejętnie przeprowadzał reformy. Równie istotne było, że nie przejawiał antycudzoziemskiego nastawienia. Pomimo rozkazów nie atakował cudzoziemców podczas powstania „bokserów”, miał zagranicznych doradców i dobre kontakty z obcymi dyplomatami, zwłaszcza z brytyjskim posłem Jordanem ${ }^{84}$.

Yuan sytuował się gdzieś pomiędzy rządzącą dynastią a rewolucjonistami. Był związany z Mandżurami, ale żywił do nich urazę, gdyż swego czasu prawie doprowadzili do jego egzekucji ${ }^{85}$. Jednocześnie respektowali go insurgenci, mimo że nie podzielał większości ich poglądów. 12 listopada, miesiąc po rozpoczęciu walk, zaproponowali mu nawet objęcie urzędu prezydenta państwa, pod warunkiem że przestanie popierać Qingów i ustrój monarchiczny ${ }^{86}$. Specjalna pozycja

Washington, 27 janvier 1912, [w:] ibidem, s. 555-557. Cytaty pochodzą odpowiednio z dokumentów z 16 stycznia i 23 października. Zob. też: Knox to the President, October 17, 1911, TP, series 6: case files, 397, reel 383; Aide-memoire from the British Embassy, October 24, 1911, KP, container 32; Calhoun to the Secretary of State, November 17, 1911, ibidem.

${ }^{83}$ Calhoun to the Secretary of State, December 11, 1911, TP, series 6: case files, 397, reel 383; Minister Calhoun to the Secretary of State, January 16, 1912, KP, container 43. Cytat pochodzi z drugiego dokumentu. Trzeba zaznaczyć, że Yuan nie mógł być całkowicie pewien lojalności swojej armii i nie miał przewagi militarnej nad przeciwnikami. E.P. Young, Yuan Shih-k'ai's Rise ..., s. 423-428; J. Polit, Mocarstwa ..., s. 102-103.

${ }^{84}$ The Japanese Chargé d'Affaires to the Secretary of State, undated, handed on December 21, 1911, [w:] PRFRUS 1912, s. 58; The American Ambassador to Great Britain to the Secretary of State, December 27, 1911, [w:] ibidem, s. 59-60. Na temat wcześniejszej politycznej i wojskowej kariery Yuana patrz: J. Ch'ên, Yuan Shih-k'ai ..., s. 13-114; S.R. MacKinnon, Power and Politics in Late Imperial China: Yuan Shi-kai in Beijing and Tianjin, 1901-1908, Berkeley 1980; M. Nowikiewicz, Yuan Shikai jako reformator armii chińskiej u schytku panowania dynastii Qing (1895-1908), [w:] J. Jędrysiak, D. Koreś, G. Strauchold, K. Widziński (red.), Kadry decyduja o wszystkim. Studia z zakresu biografistyki wojskowej, Wrocław 2015, s. 423-448.

${ }^{85}$ W 1908 roku po śmierci cesarzowej wdowy Cixi nowy regent książę Chun chciał pomścić swego brata cesarza Guangxu, którego Yuan zdradził podczas tzw. stu dni reform. Ostatecznie Yuan nie został stracony, ale musiał wycofać się z życia politycznego.

${ }^{86}$ H.Z. Schiffrin, The Enigma of ..., s. 472; E.P. Young, Yuan Shih-k'ai's Rise..., s. 421-422. Według Calhouna Yuan rozważał zmianę stron i przystąpienie do rewolucjonistów. Miał on „słuchać wszelkich rad” i „po prostu dryfować z prądem”. Calhoun to the Secretary of State, December 11, 1911, TP, series 6: case files, 397, reel 383; Minister Calhoun to the Secretary of State, January 16, 1912, KP, container 43. 
Yuana niejako predysponowała go do negocjowania porozumienia między walczącymi. Zdaniem Calhouna Yuan chciał dać pierwszeństwo negocjacjom, wznawiając walki, tylko gdyby rozmowy okazały się bezowocne ${ }^{87}$. Przewidywano, że generał, kiedy będzie już kontrolował państwo, podąży umiarkowaną ścieżką, wprowadzi pewne reformy, lecz zaniecha podejmowania radykalnych kroków. Był on też, co niezmiernie istotne, popierany przez społeczeństwo. Wszystkie te uwarunkowania i cechy czyniły go w oczach mocarstw dobrym kandydatem do rządzenia Państwem Środka ${ }^{88}$. Dla Stanów Zjednoczonych miał jeszcze jedną zaletę - chciał wcześniej z nimi współpracować, można było zatem podejrzewać, że gdyby obecnie znalazł się u steru władzy, kontakty amerykańsko-chińskie by na tym zyskały.

Stosunek Waszyngtonu do rewolucjonistów był bardziej skomplikowany. Calhoun, którego opinie były nieco tendencyjne, przedstawiał ich jako przeciwieństwo Yuana. Podzieleni, słabi, pozbawieni prawdziwego dowództwa, nieprzygotowani do administrowania Chinami nie stanowili konkurencji dla generała. Calhoun najbardziej obawiał się, że gdy tylko Mandżurowie zostaną zdetronizowani, rewolucjoniści wystąpią przeciwko sobie i zapanuje anarchia. Powątpiewał, aby takiemu scenariuszowi mógł zapobiec Sun Yat-sen, którego w liście z 16 stycznia 1912 roku sportretował następująco:

Jakikolwiek mógłby być jego charakter i zdolności, nie jest tutaj postrzegany jako reprezentant [narodu - J.P.]. Urodził się na wybrzeżu. Kształcił się i większość życia spędził za granicą. Nie wie nic o wnętrzu Chin ani o życiu, charakterze, tradycjach i zwyczajach Chińczyków. Jest dużo zazdrości i wiele antagonizmów między prowincjami, zwłaszcza między prowincjami wewnętrznymi a nadbrzeżnymi. Jest dlatego wielce wątpliwe, czy Sun Yat-sen będzie potrafił zapanować nad sytuacją lub sprawować dowództwo nad różnymi i sprzecznymi wpływami, które staną się aktywne, gdy wplywy mandżurskie zostaną usunięte ${ }^{89}$.

${ }^{87}$ Calhoun to the Secretary of State, December 11, 1911, TP, series 6: case files, 397, reel 383. Być może był to kolejny przykład naiwności Calhouna.

${ }_{88}$ E.P. Young, Yuan Shih-k'ai's Rise ..., s. 419-433; H.Z. Schiffrin, The Enigma of..., s. 472; M.H. Hunt, The Making of a Special Relationship ..., s. 271-272, 392; J. Polit, Mocarstwa..., s. 94-96, 98; P. Lowe, Great Britain and Japan ..., s. 59, 65, 68-69, 82, $85-86$.

89 The American Minister to the Secretary of State, November 22, 1911, [w:] PRFRUS 1912, s. 53; Calhoun to the Secretary of State, December 11, 1911, TP, series 6: case files, 397, reel 383; Calhoun to the Secretary of State, January 5, 1912, KP, container 32; Minister Calhoun to the Secretary of State, January 16, 1912, KP, container 43. Francja uważała, że gdyby Yuan zmarł lub wycofał się z życia politycznego, doszłoby do poważnych niepokojów wewnętrznych i rozpadu Chin, gdyż rząd nankiński nie miał wystarczającej władzy, aby temu zapobiec. Poincaré aux Ambassadeurs de France à Londres, Berlin, Pétersbourg, Washington, 27 janvier 1912, [w: ] DDF, 3 série, t. 1, s. 555-557. 
Jeszcze bardziej krytyczną i dosadną opinię na temat ruchu rewolucyjnego i kolejnego z jego przywódców Wu Tingfanga miał Straight: „Rebelianci są o wiele gorsi. Kiedy przyszłoby do wyboru między najbardziej reakcyjnym Mandżurem a tą pierdołą [that ass] Wu Tingfangiem, wolałbym Mandżura za każdym razem"90. Generalnie, spece od Chin postrzegali rewolucjonistów negatywnie, bardziej jako marzycieli niż poważnych polityków ${ }^{91}$.

Nie we wszystkich jednak doniesieniach, jakie docierały do Waszyngtonu, rewolucjoniści byli odmalowywani w podobnie posępnych barwach. Na przykład James Reeves, wojskowy attaché amerykańskiego poselstwa, wysoko cenił Li Yuanhonga ${ }^{92}$. Z kolei kontradmirał Joseph Murdock, dowódca Floty Azjatyckiej, pisal, że cudzoziemcy w Szanghaju byli pod wrażeniem „zdolności i siły” Suna, a inni rewolucyjni przywódcy, choć niedoświadczeni, byli kompetentni ${ }^{93}$. W styczniu 1912 roku Murdock i Charles Tenney, pracownik poselstwa, zostali wysłani do Nankinu, aby ocenić sytuację rewolucjonistów i ich poparcie wśród ludności. Amerykanie odnieśli pozytywne wrażenia - rząd republikański cieszył się szerokim uznaniem i reprezentował wolę społeczeństwa. Porządek był utrzymany, a żołnierze, mimo swej liczebności, zachowywali się dobrze. Rewolucyjni przywódcy wydawali się raczej wykwalifikowani, rozważni i szczerzy. Na przykład Suna amerykańscy wysłannicy opisali w taki oto sposób: „Jest on spokojny i dostojny, wydaje się stanowczy i zdecydowany. Jest wyraźnie wielce szanowany przez swych zwolenników wśród młodych postępowców" ".

Dla Departamentu Stanu sytuacja była nawet bardziej złożona, niż wynikałoby to z korespondencji dyplomatycznej. Rewolucjoniści nie tylko nie prezentowali się w rzeczywistości tak zatrważająco źle jak w raportach Calhouna, ale udało im się również zaskarbić przychylność opinii publicznej w Stanach Zjednoczonych. Większość Amerykanów w kraju i przebywających w Chinach sympatyzowała z rewolucją, odbierając ją jako postępowy ruch walczący z despotyczną,

90 Straight to McKnight, December 22, 1911, SP, reel 5, segment 1. Zob. też opinię Straighta na temat Sun Yat-sena: Straight to Grenfell, December 12, 1911, ibidem.

91 J. Reed, The Missionary Mind ..., s. 121-124; J. Polit, Mocarstwa ..., s. 89, 101.

92 Reeves to McCoy, October 23, 1911, KP, container 32.

93 Knox to the American Legation at Peking, December 29, 1911, KP, container 32; Murdock to the Secretary of the Navy, January 26, 1912, ibidem.

94 Knox to the American Legation at Peking, January 23, 1912, KP, container 32; The Chinese Secretary of the Legation to Minister Calhoun, February 3, 1912, KP, container 43; The Chinese Secretary of the Legation to Minister Calhoun, February 8, 1912, ibidem; The Chinese Secretary of the Legation to Minister Calhoun, February 10, 1912, ibidem; Minister Calhoun to the Secretary of State, February 12, 1912, ibidem; Murdock to the Secretary of the Navy, February 12, 1912, RDSRIACh, roll 10. Cytat pochodzi z dokumentu z 10 lutego. J. Reed, The Missionary Mind..., s. 116-117; R.D. Challener, Admirals, Generals..., s. 74-77. 
skorumpowaną i odrętwiałą władzą qingowską ${ }^{95}$. Fakt, że rewolucjoniści zamierzali wprowadzić republikańską formę rządów, wzmacniał ich pozytywny wizerunek, ponieważ wielu Amerykanów wierzyło, że misją dziejową ich kraju było promowanie demokracji na świecie. Powszechność poparcia dla rewolucjonistów najlepiej chyba obrazowały dwa przykłady. Pierwszym były wyniki ankiety opublikowane w sylwestrowym wydaniu „The New York Timesa”. Dziennikarze poprosili prawie trzydzieści osobistości z Europy i Stanów Zjednoczonych, aby wskazały „pięć największych osiągnięć, jakich dokonała ludzka rasa” w mijającym roku. Spośród szesnastu amerykańskich respondentów dziewięciu podało rewolucję Xinhai w swoich odpowiedziach ${ }^{96}$. Jednak nie tylko elity były zainteresowane sytuacją w Państwie Środka. W lutym 1912 roku Departament Stanu otrzymał esej nastolatki z Oregonu, w którym uzasadniała, dlaczego Ameryka powinna być pierwszym państwem, które uzna Republikę Chińską. Kongresman Walter Lafferty, pośredniczący w przekazaniu eseju, stwierdzil, że wiele osób z jego stanu podzielało opinię wyrażoną przez młodą autorkę ${ }^{97}$.

Administracja Tafta nie mogła całkowicie zignorować nastrojów społecznych, zwłaszcza w perspektywie nadchodzących wyborów prezydenckich, które miały się odbyć w listopadzie 1912 roku. Co gorsza, jej polityczni rywale, demokraci, chcieli wykorzystać te niemal powszechne odczucia. „Partia Demokratyczna - pisze James Reed - uczepiła się amerykańskiej polityki wobec Chin jako środka do postawienia w trudnym położeniu i dalszego osłabienia republikańskiej administracji”"98. 29 lutego 1912 roku Izba Reprezentantów przyjęła wspólną rezolucję (później stała się ona rezolucją całego Kongresu), w której pogratulowano Chińczykom tego, co osiągnęli ${ }^{99}$. Rezolucję przygotował Departament Stanu jako kontrpropozycję wobec projektu autorstwa Williama Sulzera, demokratycznego kongresmana z Nowego Jorku i przewodniczącego Komisji Spraw Zagranicznych, który w swoim dokumencie zaapelował również do prezydenta o uznanie Republiki Chińskiej ${ }^{100}$. W tych okolicznościach administracja Tafta musiała działać ostrożnie, mimo że sympatyzowała z Yuanem.

95 J. Reed, The Missionary Mind ..., s. 120-135; K.R. Chong, Americans and Chinese Reform ..., s. 143, 153; D.M. Crane, T.A. Breslin, An Ordinary Relationship ..., s. 41-43; Yat-sen Sun, Memoirs of a Chinese Revolutionary ..., s. 220.

96 „The New York Times”, December 31, 1911. Warto dodać, że prezydent Taft, który również został zapytany przez dziennikarzy, wybrał inne wydarzenia.

97 J. Reed, The Missionary Mind ..., s. 132.

98 Ibidem, s. 136.

99 Congressional Records..., t. 48, s. 2489, 2587, 2645, 2652, 4702-4704, 4868, 4906; The Acting Secretary of State to the American Minister, March 2, 1912, [w: ] PRFRUS 1912, s. 71.

100 Huntington Wilson to the President, February 26, 1912, TP, series 6: case files, 272, reel 378; J. Reed, The Missionary Mind ..., s. 136-139; W. Scholes, M. Scholes, The Foreign Policies ..., s. 226-227. 
W swoich rachubach Waszyngton zapewne uwzględniał również fakt, że rewolucjoniści byli zdecydowani, aby przeprowadzić reformy, do czego USA chciały od dawna przekonać Chiny ${ }^{101}$. Wielu rewolucjonistów było ponadto w jakiś sposób związanych z Ameryką, gdzie przez pewien czas mieszkali, studiowali lub pracowali. Niektórzy zaś zostali ochrzczeni przez amerykańskich misjonarzy albo uczęszczali do szkól przez nich prowadzonych ${ }^{102}$. Nawet jeden z najbliższych wojskowych i politycznych doradców Sun Yat-sena - samozwańczy generał Homer Lea - był Amerykaninem ${ }^{103}$. W tej sytuacji Stany Zjednoczone mogły liczyć na wzrost swoich wpływów w Chinach, gdyby rewolucja zakończyła się sukcesem. Potwierdził to osobiście Sun, który w listopadzie 1911 roku, podczas swej misji w Europie mającej na celu uzyskanie poparcia dla sprawy rewolucyjnej, zaproponował w Londynie zawarcie sojuszu z Wielką Brytanią i Stanami Zjednoczonymi i przyznanie obu mocarstwom specjalnych przywilejów ${ }^{104}$. W dodatku większość Chińczyków, w kraju i za granicą, opowiedziało się za insurekcją, Amerykanie mogli zatem zyskać lub stracić ich uznanie zależnie od tego, jak by postąpili ${ }^{105}$. Wszystkie te pozytywy nie równoważyły jednak najistotniejszego atutu, jaki

101 L. Pomerantz-Zhang, Wu Tingfang..., s. 202-203; D.M. Crane, T.A. Breslin, An Ordinary Relationship..., s. 42.

102 Także czołowe postaci rewolucji były często związane z Ameryką. Na przykład Sun Yat-sen został ochrzczony przez amerykańskiego misjonarza, Wu Tingfang był dwukrotnie posłem w USA, a Wang Chonghui otrzymał doktorat z prawa na Yale University. J. Polit, Mocarstwa ..., s. 90; J. Reed, The Missionary Mind..., s. 141-142; M.V. Metallo, American Missionaries, Sun Yat-sen, and the Chinese Revolution, „Pacific Historical Review” 1978, t. 47, nr 2, s. 265-267; L. Pomerantz-Zhang, Wu Tingfang ..., s. 217; ChingChun Wang, The Effect of the Revolution upon the Relations between China and the United States, dołączone do: Napier to Bryan, March 12, 1913, Records of the Department of State Relating to Political Relations of the United States with China, 1910-1929 (dalej RDSRPRUSCh), The National Archives at College Park, College Park, (mikrofilm), roll 1.

103 Homer Lea pomagał Sun Yat-senowi zorganizować wojska, zebrać fundusze i uzyskać poparcie amerykańskich, europejskich i australijskich polityków, urzędników i przedsiębiorców. Reprezentował stronę rewolucyjną podczas konferencji konsorcjum mocarstw i towarzyszył Sunowi w Paryżu i Londynie, gdzie obaj starali się pozyskać gospodarzy do pomocy. Na temat życia Lei, jego zaangażowania w ruch rewolucyjny i roli podczas rewolucji 1911 roku patrz: L. Kaplan, Homer Lea: American Soldier of Fortune, Lexington 2010; K.R. Chong, Americans and Chinese Reform ..., passim.

104 H.Z. Schiffrin, The Enigma of ..., s. 471.

105 Gdy wybuchła rewolucja, pojawiły się głosy przekonujące Biały Dom do pokrycia wydatków chińskich studentów kształcących się w Stanach Zjednoczonych, nim sytuacja w Państwie Środka się unormuje. Przywoływano m.in. argument, że miałoby to bardzo pozytywny wpływ na przyszłe kontakty handlowe między oboma państwami. Jenks to Taft, November 19, 1911, TP, series 6: case files, 397, reel 383. 
przypisywano Yuanowi - zdolności utrzymania porządku. Mocarstwa uważały, że Yuan mógł go utrzymać, a rewolucjoniści nie.

Jeśli chodzi o trzecią stronę konfliktu w Chinach - Qingów, stosunek rządu waszyngtońskiego był bardziej oczywisty. Przed październikiem 1911 roku nie był on zainteresowany odsunięciem Mandżurów od władzy ${ }^{106}$. Dopóki potrafili utrzymać porządek, mocarstwa ich popierały, lecz gdy rewolucja Xinhai obnażyła ich znaczną słabość, tylko Japonia i w mniejszym stopniu Rosja myślały o pozostawieniu ich na Tronie Smoka (chociaż nawet Japonia miała poważne wątpliwości ${ }^{107}$. Ostatecznie Qingowie, dysponujący wyłącznie nominalną władzą, zostali zmuszeni do abdykacji, co nie zmartwiło dyplomacji amerykańskiej i było antycypowane od jakiegoś czasu' ${ }^{108}$.

Stany Zjednoczone interesowały się również ustrojem, jaki miał zostać wprowadzony w Państwie Środka. Amerykańscy dyplomaci odnosili się sceptycznie do pomysłu zastąpienia cesarstwa republiką. Uważali, że dla kraju z największą populacją na świecie, niezwykle wysokim odsetkiem analfabetów i ogólnie nieprzyzwyczajonego do samodzielnego rządzenia i demokracji był to krok przedwczesny. Dodatkowym problemem była narastająca rywalizacja między prowincjami. Konieczny był długi okres przejściowy, nie zaś raptowne zakończenie istnienia jednej z najstarszych monarchii na świecie ${ }^{109}$. Podobną opinię, przynajmniej do

106 J. Polit, Mocarstwa ..., s. 87.

107 The American Chargé d'Affaires to the Secretary of State, October 26, 1911, [w:] PRFRUS 1912, s. 52; Calhoun to the Secretary of State, December 11, 1911, TP, series 6: case files, 397, reel 383; Translation of the substance of the telegram received by the Japanese Chargé d'Affaires from his Government, undated, handed on December 18, 1911, KP, container 32; Guild to the Secretary of State, December 23, 1911, ibidem; Minister Calhoun to the Secretary of State, January 16, 1912, KP, container 43.

108 Reeves to McCoy, October 23, 1911, KP, container 32; The American Chargé d'Affaires to the Secretary of State, October 26, 1911, [w:] PRFRUS 1912, s. 52; The American Minister to the Secretary of State, November 22, 1911, [w:] ibidem, s. 53; Calhoun to the Secretary of State, November 25, 1911, TP, series 6: case files, 397, reel 383; Calhoun to the Secretary of State, December 11, 1911, ibidem; Calhoun to the Secretary of State, January 13, 1912, TP, series 6: case files, 443, reel 385; Minister Calhoun to the Secretary of State, January 16, 1912, KP, container 43; The American Minister to the Secretary of State, January 19, 1912, [w:] PRFRUS 1912, s. 62; The American Minister to the Secretary of State, January 20, 1912, [w:] ibidem, s. 63.

109 The American Minister to the Secretary of State, November 22, 1911, [w: ] PRFRUS 1912, s. 53; Extracts from a personal letter received from Mr. Williams at Peking, December 8, 1911, KP, container 16; The Chinese Secretary of the Legation to Minister Calhoun, February 3, 1912, KP, container 43; Calhoun to the Secretary of State, February 6, 1912, RDSRIACh, roll 10; H. Croly, Willard Straight..., s. 417-418; M.H. Hunt, The Making of a Special Relationship ..., s. 271-272; D.M. Crane, T.A. Breslin, An Ordinary Relationship ..., s. 5152, 55; D.D. Lazo, An Enduring Encounter ..., s. 209; M. Ikei, Japan's Response ..., s. 219. 
pewnego stopnia, wyrazily prawie wszystkie pozostałe mocarstwa, które opowiedziały się za jakąś formą monarchii konstytucyjnej przede wszystkim dlatego, że pozwalałaby reformować Chiny odgórnie i nie angażować aż tak bardzo obywateli $^{110}$. Rewolucjoniści zdecydowali jednak inaczej, gdyż byli zdeterminowani, aby zlikwidować wszelkie pozostałości starego systemu ${ }^{111}$. Równie zasadnicze znaczenie miało to, że republikańskie rozwiązanie zyskało ostatecznie aprobatę Wielkiej Brytanii ${ }^{112}$.

Był jeszcze jeden fundament, na którym Waszyngton oparł swą politykę podczas całego wydarzenia - doktryna „otwartych drzwi”. Rewolucja zagrażała obu jej zasadom. Jak można się było spodziewać, walki i ogólne zamieszanie utrudniały prowadzenie handlu i innych przedsięwzięć biznesowych. Stany Zjednoczone bardziej jednak obawiały się, że wojna domowa może doprowadzić do rozłamu Chin. Williams kilkakrotnie ostrzegał, że było to prawdopodobne ${ }^{113}$. Podobnie przewidywali niektórzy amerykańscy dziennikarze ${ }^{114}$. Na przełomie lat, gdy Yuan ugruntował swą pozycję na północy, a rewolucjoniści na południu, impas militarny i polityczny nie był odległy. Przez cały czas działali też zakulisowo japońscy awanturnicy i oficerowie, którzy próbowali utworzyć marionetkowe państwo w Mandżurii i części Chin Północnych pod nominalną

110 Translation of the substance of the telegram received by the Japanese Chargé d'Affaires from his Government, undated, handed on December 18, 1911, KP, container 32; Guild to the Secretary of State, December 23, 1911, ibidem; Calhoun to the Secretary of State, December 24, 1911, ibidem; Buchanan to Grey, February 24, 1912, [w:] BDOW, t. 9: The Balkan Wars, cz. 1: The Prelude; The Tripoli War, London 1933, s. 546-549; D.M. Crane, T.A. Breslin, An Ordinary Relationship..., s. 49-50; J. Polit, Mocarstwa..., s. 97, 101102; M. Ikei, Japan's Response..., s. 218-219, 221; W. Rodziński, Historia Chin..., s. 613. Oprócz mocarstw za monarchią konstytucyjną opowiadał się Yuan. J. Chên, Yuan Shih-k'ai..., s. 118-120; E.P. Young, Yuan Shih-k'ai's Rise ..., s. 422.

111 Calhoun to the Secretary of State, December 17, 1911, TP, series 6: case files, 397, reel 383; Document written by the Division of Far Eastern Affairs, January 20, 1912, KP, container 16.

112 Stanowisko Londynu w tej sprawie zmieniło się podczas rewolucji - ostatecznie porzucił on pomysł wprowadzenia monarchii konstytucyjnej i poparł republikańskie rozwiązanie. M. Ikei, Japan's Response ..., s. 220-223; J. Polit, Mocarstwa ..., s. 101-102; E.P. Young, Yuan Shih-k'ai's Rise..., s. 430, 432; P. Lowe, Great Britain and Japan..., s. 58-88.

113 The American Chargé d'Affaires to the Secretary of State, October 26, 1911, [w: ] PRFRUS 1912, s. 52; Chargé Williams to the Secretary of State, November 12, 1911, KP, container 43; Extracts from a personal letter received from $\mathrm{Mr}$. Williams at Peking, December 8, 1911, KP, container 16. Zob. też: Reeves to McCoy, October 23, 1911, KP, container 32.

114 D.M. Crane, T.A. Breslin, An Ordinary Relationship ..., s. 48. Zob. również: Calhoun to the Secretary of State, January 30, 1912, KP, container 32. 
władzą Mandżurów, zakładając, że reszta kraju znajdzie się pod kontrolą Sun Yat-sena ${ }^{115}$.

Integralność terytorialna Chin mogła również zostać naruszona przez mocarstwa europejskie i Japonię. Przedłużające się walki i zamieszanie dawały im pretekst do interwencji i podbicia części Państwa Środka, a nawet dokonania jego podziału. Takie informacje i spekulacje pojawiały się co pewien czas $\mathrm{w}$ amerykańskiej korespondencji dyplomatycznej ${ }^{116}$. Chcąc zapobiec temu zagrożeniu, Stany Zjednoczone próbowały uzyskać ponowne zapewnienie o respektowaniu polityki „otwartych drzwi”. Mocarstwa odniosły się jednak do tego niechętnie, ale przyrzekły, że jeśli zajdzie konieczność interweniowania w Chinach, będą się konsultować i współdziałać ${ }^{117}$. Ta obietnica w połączeniu z naleganiem na zachowanie wspólnego frontu mocarstw i zakończenie wojny domowej tak szybko, jak to możliwe, okazała się wystarczająca. Chiny nie uległy rozbiciu wewnętrznemu ani podziałowi, chociaż dwa regiony - Tybet i Mongolia Zewnętrzna - nie uznały nowych władz centralnych i stopniowo popadły w obcą zależność, odpowiednio brytyjską i rosyjską ${ }^{118}$.

115 P. Lowe, Great Britain and Japan ..., s. 81; M.B. Jansen, The Japanese and Sun Yat-sen ..., s. 137-140.

116 Reeves to McCoy, October 23, 1911, KP, container 32; Guild to the Secretary of State, January 16, 1912, ibidem; Guild to the Secretary of State, January 17, 1912, ibidem.

117 Leishman to the Secretary of State, January 25, 1912, KP, container 32; The Secretary of State to the German Ambassador, February 3, 1912, [w:] PRFRUS 1912, s. 6364; Huntington Wilson to the President, February 21, 1912, TP, series 6: case files, 272, reel 378; Charles Lee Swem's Summary of a Letter from James Whitford Bashford, January 10, 1913, [w: ] The Papers of Woodrow Wilson (dalej PWW), (opr.) A.S. Link, t. 27, Princeton 1978, s. 27-28; D.M. Crane, T.A. Breslin, An Ordinary Relationship ..., s. 52. Zob. też: Note pour le Président de la République, 13 janvier 1912, [w: ] DDF, 3 érie, t. 1, s. 481-482; Poincaré aux Ambassadeurs de France à Berlin, Londres, St-Pétersbourg, Washington, Tokio, 4 février 1912, [w: ] ibidem, s. 607. Reed sugeruje, że ta próba potwierdzenia doktryny „otwartych drzwi” wynikała bardziej z wymogów polityki wewnętrznej, miała na celu odzyskać poparcie opinii publicznej i odparować ataki demokratów. J. Reed, The Missionary Mind..., s. 137-138. Podczas rewolucji do Departamentu Stanu napłynęły prośby o podjęcie działań gwarantujących przestrzeganie obu zasad polityki „otwartych drzwi". Laughlin and Vail to Knox, November 14, 1911, RDSRPRUSCh, roll 1; Aiken to the Secretary of State, February 22, 1912, ibidem.

118 J. Polit, Chiny, Warszawa 2004, s. 69-70; T. Dmochowski, Walka polityczna mocarstw o dominację w dorzeczu Amuru, Toruń 1999, s. 202-204; L. Bazylow, Historia Mongolii, Wrocław 1981, s. 239-247. Straight widział w tym logiczną konsekwencję dziejową, że Mongolia, Tybet i Mandżuria, które stały się dependencjami dzięki Qingom i im były wierne, zaczęły odpadać od Chin, gdy dynastia została pozbawiona władzy. Straight to Brown, February 18, 1913, RDSRIACh, roll 12. 
W odniesieniu do Tybetu i Mongolii Waszyngton nie protestował bezpośrednio, starał się jedynie przypomnieć wszystkim o zasadach „otwartych drzwi”. Przynajmniej dwa powody zaważyły na tym - pierwszym było ciche porozumienie między Wielką Brytanią, Francją, Rosją i zapewne Japonią, które byłoby trudne do przezwyciężenia, drugim zaś fakt, że Amerykanie przejawiali małe zainteresowanie oboma regionami ${ }^{119}$. Calhoun tak skomentował sytuację mongolską: „Nie ma nic do powiedzenia ani zrobienia. [... ] Jeśli jedynym celem Rosji jest stworzenie państwa buforowego, nie może być specjalnych zastrzeżeń”. Poseł bardziej martwił się, jak wpłynie to na sytuację międzynarodową, a konkretnie, czy Japonia nie wykona kontrposunięcia i nie zajmie Mandżurii, gdzie amerykańskie interesy były znacznie większe ${ }^{120}$.

Polityce „otwartych drzwi” mogły zagrażać nie tylko działania innych państw, ale i plany powstające w USA. Podczas rewolucji Departament Marynarki nalegal, jak czynił to w przeszłości, aby naruszyć integralność terytorialną Chin i uzyskać bazę w okolicach Ningbo. Zalecał poza tym, aby w razie cudzoziemskiej interwencji Amerykanie samodzielnie okupowali Szanghaj. Oba pomysły oprotestował Departament Stanu, a prezydent Taft je odrzuci1 ${ }^{121}$.

Ponieważ Stany Zjednoczone były uważane przez Chińczyków za państwo przyjazne, wszystkie trzy strony konfliktu zwróciły się do nich o pomoc. Część z tych zabiegów została już opisana, dlatego tylko przypadki, o których nie wspomniano, zostaną tutaj poruszone. Podczas rewolucji Departament Stanu otrzymał co najmniej trzy wspierające buntowników petycje od Chińczyków przebywających poza ojczyzną. Pierwsza, sygnowana przez Chinese National Association, prosiła „rząd USA o użycie swych wpływów, aby utrzymać i zachować neutralność mocarstw wobec rewolucyjnej walki dziejącej się obecnie w Chinach, aby ich [Chin - J.P.] integralność mogła być zachowana i stabilny rząd utworzony”. W dwóch pozostałych rezolucjach Chińczycy mieszkający na Hawajach prosili, aby Stany Zjednoczone nadały ton w koncercie mocarstw poprzez „przyjęcie postawy ścisłej neutralności” oraz starały się powstrzymać inne mocarstwa przed interwencją przeciwko wprowadzeniu republikańskiego ustroju w Chinach ${ }^{122}$.

119 Calhoun to the Secretary of State, January 10, 1912, KP, container 32; Straight to Morgan, Grenfell and Co., January 16, 1912, ibidem; Guild to the Secretary of State, January 16, 1912, ibidem; Guild to the Secretary of State, January 17, 1912, ibidem.

120 Calhoun to the Secretary of State, January 10, 1912, KP, container 32. Zob. też: Minister Calhoun to the Secretary of State, January 22, 1912, KP, container 43.

121 The Division of Far Eastern Affairs to the Secretary of State, November 14, 1911, KP, container 32; Memorandum for the Secretary of the Navy, November 15, 1911, ibidem; The Division of Far Eastern Affairs to the Secretary of State, November 16, 1911, ibidem; D.M. Crane, T.A. Breslin, An Ordinary Relationship ..., s. 52.

122 The Chinese National Association to the Secretary of State, October 16, 1911, [w: ] PRFRUS 1912, s. 50; The Chinese Residents of Honolulu to the Secretary of State, undated, 
W listopadzie 1911 roku Homer Lea bezskutecznie starał się przekonać byłego sekretarza stanu Elihu Roota (w tym czasie senatora i członka Komisji Spraw Zagranicznych), aby został doradcą rządu rewolucyjnego i pomógł mu wystarać się o pożyczkę. Niezrażony brakiem powodzenia Lea poprosił następnie, aby Knox nalegał na abdykację dynastii i zarekomendował jakiegoś amerykańskiego jurystę, który mógłby uczestniczyć w opracowaniu chińskiej konstytucji ${ }^{123}$.

Tymczasem w listopadzie Longyu w imieniu swoim i cesarza zapytała w ścisłej tajemnicy o możliwość schronienia w amerykańskim poselstwie. Wyjaśniła, że chciała tylko zawczasu znaleźć bezpieczne miejsce, ale nie miała zamiaru uciekać. Przeczyły temu jednak wcześniejsze sygnały. Williams gorąco poparl jej prośbę, a i Knox odpowiedział pozytywnie, choć nieco wymijająco ${ }^{124}$. Niemal w tym samym czasie o schronienie poprosili również członkowie lokalnych władz w Nankinie. Kontradmirał Murdock rozkazał ich przyjąć i przetransportować w bezpieczne miejsce, gdyby się pojawili ${ }^{125}$. Niedługo później chińscy parlamentarzyści zwrócili się do Calhouna po radę na temat federalnej formy rządów. Konsultowali się z nim w pierwszej kolejności, ponieważ ufali mu oraz państwu, które reprezentowal, a na którym chcieli się wzorować $\mathrm{w}$ kwestiach ustrojowych $^{126}$. Z kolei w styczniu 1912 roku rząd republikański szukał międzynarodowego uznania, zapewniając, że był stabilny i solidnie umocowany ${ }^{127}$. Waszyngton nie odpowiedział, gdyż wolał rozstrzygnąć tę sprawę wspólnie z innymi mocarstwami, nie zaś samodzielnie.

received October 24, 1911, [w:] ibidem, s. 51; The Representatives of the Chinese in Hawaii to the Secretary of State, undated, received December 24, 1911, KP, container 32. Cytaty pochodzą odpowiednio z pierwszego i drugiego dokumentu.

${ }^{123}$ Anderson to the Secretary of State, December 21, 1911, KP, container 32. Zob. także: The Division of Far Eastern Affairs to the Secretary of State, November 14, 1911, ibidem; K.R. Chong, Americans and Chinese Reform ..., s. 151-152, 156.

${ }^{124}$ Chargé Williams to the Secretary of State, November 9, 1911, KP, container 43; Chargé Williams to the Secretary of State, November 10, 1911, ibidem; Chargé Williams to the Secretary of State, undated, received November 10, 1911, ibidem; The Secretary of State to Chargé Williams, November 10, 1911, ibidem; Chargé Williams to the Secretary of State, November 12, 1911, ibidem.

${ }_{125}$ Murdock to the Secretary of the Navy, November 12, 1911, KP, container 32.

126 The American Minister to the Secretary of State, November 22, 1911, [w: ] PRFRUS 1912, s. 53. Według biskupa Jamesa Whitforda Bashforda Chińczycy od jakiegoś już czasu przychodzili do Calhouna po radę. Bashford to Knox, June 20, 1911, TP, series 6: case files, 443, reel 385 .

127 The Chinese Republican Minister for Foreign Affairs to the Secretary of State, undated, received January 17, 1912, [w:] PRFRUS 1912, s. 62; The Chinese Republican Minister for Foreign Affairs to the Secretary of State, January 19, 1912, [w:] ibidem. W grudniu 1911 roku także Lea prosił o uznanie władz rewolucyjnych. Lea to Knox, undated, received December 29, 1911, KP, container 32. 
Podsumowując dotychczasowe rozważania, można stwierdzić, że Stany Zjednoczone były zaskoczone wybuchem rewolucji 1911 roku, ale szybko zdały sobie sprawę z jej powagi. Gdy upewniły się, że nie była skierowana przeciwko cudzoziemcom, a Amerykanie w Chinach byli bezpieczni, wyrzekły się możliwości interwencji i przyjęły neutralne stanowisko. Kolejny priorytet ich polityki stanowiło zachowanie jedności wśród mocarstw i ograniczenie tym samym niebezpieczeństwa, że któreś $\mathrm{z}$ nich interweniuje militarnie lub poprze finansowo jedną ze stron konfliktu. Zapobieżenie takim próbom było istotne ze względu na politykę „otwartych drzwi” - filar chińskiej polityki USA. Większość z tych celów udało się Departamentowi Stanu zrealizować. Chociaż nie odgrywał tak zasadniczej roli, jak podczas powstania „bokserów”, nadal wpływał na stanowiska pozostałych mocarstw.

Jeśli chodzi o strony konfliktu, to dyplomacja amerykańska widziała w Yuanie najbardziej odpowiednią osobę do przejęcia władzy, gdyż wierzyła, że gwarantował zaprowadzenie porządku. Jej stosunek do rewolucjonistów był bardziej ambiwalentny. Wszystkie ich zalety nikły wobec powszechnej opinii, że pod ich rządami nie dojdzie do uspokojenia sytuacji. Trzecią stronę konfliktu, Qingów, uznawano za nieudolną i pozbawioną realnej władzy.

$\mathrm{Z}$ amerykańskiego punktu widzenia wynik rewolucji przedstawiał się raczej pozytywnie. Mandżurowie abdykowali, Yuan zdobył dominującą pozycję w kraju, a wojna domowa zakończyła się kompromisem w stosunkowo krótkim czasie. Jedyną rzeczą, jaka mogła niepokoić Waszyngton, było natychmiastowe ustanowienie republiki, lecz skoro Yuan został jej prezydentem, negatywnych konsekwencji obawiano się mniej.

Po abdykacji Qingów Chiny wkroczyły w okres formowania nowych władz. 10 marca Yuan został zaprzysiężony w Pekinie jako tymczasowy prezydent Republiki. Przyjął ułożoną w Nankinie Konstytucję Tymczasową, co było jednym z warunków stawianych przez rewolucjonistów. Nie zgodził się natomiast na inny ich warunek, aby przenieść stolicę na południe. Pekin pozostał centrum życia politycznego kraju - tam zebrał się parlament (zgromadzenie nankińskie uzupełnione o nowych przedstawicieli), tam znajdowały się siedziby prezydenta i premiera. Tym ostatnim został Tang Shaoyi, zaufany Yuana, ale mający też pewne związki z rewolucjonistami. Skład nowego rządu był kompromisowy, cztery z dziesięciu ministerstw objęli członkowie Chińskiej Ligi Związkowej. Udało się dzięki temu doprowadzić do unifikacji władz chińskich na najwyższym szczeblu i zakończyć groźny dla kraju okres dwuwładzy. Przez następny rok, do wybuchu „drugiej rewolucji" w polowie 1913 roku, między rewolucjonistami a Yuanem i jego adherentami trwała w miarę pokojowa kohabitacja, podczas której obie strony starały się wzmocnić swoją pozycję, nie ufając politycznym rywalom. W sierpniu 1912 roku członkowie Chińskiej Ligi Związkowej razem z przedstawicielami czterech małych partii powołali do życia Partię Narodową (Kuomintang), która miała 
wystartować w wyborach parlamentarnych zaplanowanych na koniec roku. Szykowało się do nich również stronnictwo Yuana, chociaż bynajmniej nie pokładało ono wszystkich nadziei w demokratycznym rozwiązaniu.

Rywalizacja i napięcia na szczycie władzy były jedną z przyczyn słabości nowo powstałej Republiki. Słabość ta wynikała ponadto z samodzielności prowincji, które uzyskawszy szeroką autonomię podczas rewolucji, często nie chciały podporządkować się decyzjom Pekinu ${ }^{128}$. Ograniczało to polityczne, finansowe i militarne możliwości władz centralnych, a dodatkowo podważało ich autorytet, nadwątlony już przez samą zmianę ustroju. Obalenie bowiem instytucji cesarza, która mając wielowiekową tradycję i sakralne podstawy, była ostoją ładu, osłabiało pozycję rządzących. Miało to tym istotniejsze znaczenie, że wprowadzona w zamian koncepcja republiki była dla szerokich mas chińskich całkowitą abstrakcją ${ }^{129}$.

Osłabiona władza centralna miała problemy z utrzymaniem porządku, zwłaszcza że panowało ogólne rozprężenie i niepewność. Kłopoty sprawiali nieopłaceni żołnierze, licznie powołani podczas rewolucji, których należało teraz zdemobilizować ze względu na wysokie koszty utrzymania. W ciągu 1912 roku doszło do wielu bandyckich napadów, buntów i rozruchów. Jedno z najpoważniejszych wystąpień miało miejsce na przełomie lutego i marca, kiedy to zbuntowane wojska zniszczyły i ograbiły centrum Pekinu ${ }^{130}$. Chociaż buntownicy nie byli wrogo nastawieni do cudzoziemców, ci zdecydowali się wzmocnić straż dzielnicy poselstw, licząc, że sam widok obcych wojsk podziała mitygująco. Zagrożenie udało się opanować, ale cudzoziemcy poważnie obawiali się o przyszłość Chin ${ }^{131}$.

Do pesymistów należeli też amerykańscy dyplomaci. W korespondencji Calhouna i Williamsa często pojawiały się takie słowa jak: „chaos”, „anarchia”,

128 Young pisze, że w początkowym okresie Republika Chińska stanowiła faktycznie konfederację prowincji. The Cambridge History of China, t. 12: Republican China, 1912-1949, cz. 1, (red.) J.K. Fairbank, Cambridge 1983, s. 213.

129 Fragment dotyczący przemian w Chinach na podstawie: W. Rodziński, Historia Chin ..., s. 610-612, 615-618; J. Ch'ên, Yuan Shih-k'ai..., s. 134-160; The Cambridge History of China ..., t. 12, s. 208-228.

130 Niektórzy historycy podejrzewają, że Yuan sam zaaranżował rozruchy, aby mieć argument przeciwko żądaniu przeniesienia stolicy do Nankinu. Por. J. Ch'ên, Yuan Shih-k'ai ..., s. 135-138; W. Rodziński, Historia Chin ..., s. 610-611. Odmiennego zdania jest Young. E.P. Young, Yuan Shih-k'ai's Rise ..., s. 436-441.

131 The American Minister to the Secretary of State, March 1, 1912, [w:] PRFRUS 1912, s. 70-71; Calhoun to the Secretary of State, March 3, 1912, TP, series 6: case files, 397, reel 383; Calhoun to the Secretary of State, March 4, 1912, ibidem; Murdock to the Secretary of the Navy, March 4, 1912, ibidem; Huntington Wilson to the American Legation at Peking, March 4, 1912, ibidem; Calhoun to the Secretary of State, March 6, 1912, TP, series 6: case files, 443, reel 385; The American Minister to the Secretary of State, March 8, 1912, [w:] PRFRUS 1912, s. 72-74; H. Croly, Willard Straight ..., s. 436-441. 
„zamieszki”. Rząd był ich zdaniem słaby i miał znaczne problemy z utrzymaniem porządku i egzekwowaniem swoich decyzji. Calhoun posunął się nawet do stwierdzenia, że gdyby wśród Mandżurów znalazł się w miarę odważny przywódca, mogliby oni z łatwością odzyskać władzę na północy kraju. Obaj dyplomaci wskazywali na zagrożenie, jakie stanowili niezdyscyplinowani, pozbawieni patriotyzmu i nastawieni na plądrowanie żołnierze. Williams pisał, że rewolucjoniści niczym doktor Frankenstein stworzyli monstrum, którego nie byli w stanie kontrolować. Nie szczędził też krytyki nowym elitom politycznym. Wytykał im małostkowość, egotyzm i brak zaangażowania. Podejrzewał - jak pokazały przyszłe wydarzenia całkiem słusznie - że ze zgiełku rewolucyjnego wyłoni się chiński Napoleon, który założy cesarskie szaty ${ }^{132}$. Williams wszelkie nadzieje pokładał w Yuanie, który choć niepozbawiony wad, był jako jedyny zdolny zaprowadzić porządek. Podobnie myślał Calhoun, później jednak donosił, że nastąpiła pewna poprawa sytuacji ${ }^{133}$.

Chaos w Państwie Środka ułatwiał mocarstwom utrwalanie stref wpływów, mógł doprowadzić do wewnętrznego rozbicia lub obcej interwencji. Niebezpieczeństwa te były całkiem realne. Wielka Brytania, Rosja i Japonia zaciskały swój uścisk wokół Tybetu, Mongolii i Mandżurii. Rosja ponadto otwarcie zapowiedziała, że nie dopuści do powstania silnych Chin, które by jej zagrażały ${ }^{134}$. Możliwość obcej interwencji wielokrotnie sygnalizowali amerykańscy dyplomaci w ciągu 1912 roku. „Bez znacznych pieniędzy nowy rząd - alarmował na przykład Calhoun w listopadzie - nie stanie na nogi. [...] Jeśli nie zostanie wsparty, upadnie, dojdzie do anarchii i zbrojna interwencja cudzoziemska ze wszystkimi swoimi komplikacjami i nieprzewidzianymi konsekwencjami na

132 Podobnie przypuszczali Rosjanie. Buchanan to Grey, July 18, 1912, [w:] BDOW, t. 9, cz. 1, s. 591-592.

133 The American Minister to the Secretary of State, February 13, 1912, [w:] PRFRUS 1912, s. 65; The American Minister to the Secretary of State, March 1, 1912, [w:] ibidem, s. 70-71; Calhoun to the Secretary of State, March 3, 1912, TP, series 6: case files, 397, reel 383; Calhoun to the Secretary of State, March 4, 1912, ibidem; The American Minister to the Secretary of State, March 8, 1912, [w:] PRFRUS 1912, s. 72-74; The American Minister to the Secretary of State, March 21, 1912, [w: ] ibidem, s. 117-119; The American Minister to the Secretary of State, May 2, 1912, [w:] ibidem, s. 77-78; Calhoun to the Secretary of State, May 7, 1912, KP, container 17; The American Minister to the Secretary of State, August 3, 1912, [w: ] PRFRUS 1912, s. 84-85; The American Minister to the Secretary of State, November 12, 1912, [w:] PRFRUS 1913, Washington 1920, s. 87-88; D.D. Lazo, An Enduring Encounter ..., s. 208-216.

134 The American Ambassador to Russia to the Secretary of State, March 12, 1912, [w: ] PRFRUS 1912, s. 75; The American Ambassador to Russia to the Secretary of State, March 13, 1912, [w: ] ibidem; O'Beirne to Grey, July 8, 1912, [w:] BDOW, t. 9, cz. 1, s. 580-582. 
pewno nastąpi”135. W Waszyngtonie traktowano te ostrzeżenia poważnie. Lewis Einstein, pracownik Departamentu Stanu, w memorandum z maja brał pod uwagę możliwość, że w Chinach zapanuje anarchia i konieczne będzie przejęcie nad nimi zarządu przez mocarstwa. Przekonywał, że gdyby tak się stało, wówczas najlepiej, aby mocarstwa działały razem, ponieważ osobna interwencja sprzyjałaby rozwijaniu stref wpływów. Einstein konkludował, że jeśli zasada współpracy zostanie utrzymana, „nie ma powodu do obaw”, niezależnie od tego, jak potoczą się losy Chin ${ }^{136}$.

W zaistniałej sytuacji Stany Zjednoczone chciały finansowo i politycznie pomóc Państwu Środka oraz kontynuować politykę współpracy z innymi mocarstwami, wierząc, że uchroni ona Chiny przed jednostronną agresją i zabezpieczy amerykańskie interesy, również gdyby zapanował w nich jednak nieporządek i niezbędna okazała się międzynarodowa interwencja. Oba priorytety (pomocy i współpracy) wpłynęły na stanowisko amerykańskiej dyplomacji w dwóch kluczowych kwestiach - udzielenia pożyczki reorganizacyjnej i uznania Republiki Chińskiej.

\section{Stany Zjednoczone a pożyczka reorganizacyjna i kwestia uznania Republiki Chińskiej}

Problem oficjalnego uznania nowych władz republikańskich pojawił się jeszcze w trakcie rewolucji, przy czym dla Waszyngtonu występował on na dwóch płaszczyznach: w polityce wewnętrznej i zagranicznej. Co zrozumiałe, o uznanie zabiegali rewolucjoniści, ale i Kongres na nie nalegał. Administracja Tafta postanowiła wstrzymać się z jakąkolwiek decyzją i spokojnie obserwować rozwój wydarzeń. Sytuacja w Chinach była wszak zagmatwana i trudno było przewidzieć $\mathrm{z}$ dużą dozą pewności, co wyłoni się z rewolucyjnej nawałnicy. Nawet po uformowaniu się jednolitych władz Chinom - jak pokazywały doniesienia Calhouna i Williamsa - daleko było do elementarnej stabilizacji. Waszyngton nie podejmował żadnych działań nie tylko dlatego, że czekał na wykrystalizowanie się sytuacji, ale także, a chyba nawet przede wszystkim dlatego, że chciał w tej sprawie kontynuować współpracę z mocarstwami. Okazję, aby jasno to zakomunikować, stworzyło japońskie memorandum przekazane 23 lutego 1912 roku. Japonia również popierała utrzymanie wspólnego frontu mocarstw, lecz cel, jaki zamierzała dzięki

135 The American Minister to the Secretary of State, November 12, 1912, [w: ] PRFRUS 1913, s. 87-88.

136 The Chinese Revolution and American Policy, May, 1912 [brak daty dziennej], KP, container 18; Einstein to the Secretary of State, May 23, 1912, ibidem; Miller to the Secretary of State, June 13, 1912, ibidem. 
temu osiągnąć, był już z amerykańskiej perspektywy mało korzystny. Liczyła ona bowiem, że wspólny front zmusi nowe władze chińskie do potwierdzenia praw przysługujących cudzoziemcom i akceptacji swych międzynarodowych zobowiązań finansowych. Od spełnienia tych warunków miano uzależnić uznanie Republiki. Wydawały się one z pozoru zasadne, ale Tokio chciało potwierdzić wszystkie prawa, zarówno wynikające z traktatów, jak i ze zwyczajów, co oznaczałoby usankcjonowanie nieformalnych wpływów i uprzednio bezprawnych działan ${ }^{137}$. Mocarstwa, które w zasadzie zgodziły się na japońską propozycję, mogły także wykorzystać wspólny nacisk, aby domagać się nowych przywilejów ${ }^{138}$. Tak na przykład zrobiły Wielka Brytania i Rosja. Pierwsza oświadczyła, że nie uzna Republiki, dopóki ta nie przyjmie jej warunków dotyczących Tybetu, druga uzależniła uznanie od pomyślnego dla niej uregulowania kwestii mongolskiej ${ }^{139}$.

Stany Zjednoczone znalazły się $\mathrm{w}$ delikatnym położeniu. Polityka współpracy, mająca chronić Chiny i amerykańskie interesy, mogła, jak na ironię, stać się środkiem do umacniania stref wpływów i wymuszania nowych ustępstw. Departament Stanu zdecydował jednak, że wspólpraca w kwestii uznania była pożądana, ponieważ - jak dowodził asystent sekretarza stanu Huntington Wilson - utrwalała samą zasadę współpracy mocarstw w Chinach, gwarantowała, że żadne państwo nie uprzedzi USA, oraz mogła uświadomić Pekinowi, że powinien postępować odpowiedzialnie. $Z$ tych też powodów Waszyngton ustosunkował się pozytywnie do japońskiego memorandum, ale zastrzegł, że współpraca będzie wiążąca, o ile nie doprowadzi do opóźnienia w uznaniu. Huntington Wilson wyjaśnił Taftowi, że specjalnie pozostawiono tę furtkę, na wypadek gdyby presja Kongresu zmusiła administrację do samodzielnego działania. Departament Stanu starał się również utemperować japońskie zapędy, odnosząc się tylko do „ustalonych zobowiązań" jako automatycznie przechodzących na nowe władze Chin, co kwestionowało zasadność domagania się praw niewynikających z oficjalnych porozumien ${ }^{140}$. Pomyślano zarazem o stronie chińskiej, która oczekiwała szybkiego uznania przez Amerykę. Huntington Wilson stwierdzil, że gdyby, przy dochowaniu wierności polityce współpracy, udało się jednocześnie okazać przychylność

137 Memorandum from the Japanese Embassy, handed on February 23, 1912, TP, series 6: case files, 272 , reel 378 .

138 M.E. Cameron, American Recognition Policy toward the Republic of China, 19121913, „Pacific Historical Review” 1933, t. 2, nr 2, s. 216.

139 The American Minister to the Secretary of State, August 31, 1912, [w:] PRFRUS 1912, s. 86; Annotation du Département joint à Gérard à Pichon, 4 avril 1913, [w:] DDF, $3^{\text {e }}$ série, t. 6, Paris 1933, s. 234.

${ }_{140}$ Huntington Wilson to the President, February 26, 1912, TP, series 6: case files, 272, reel 378; Draft Reply to Japanese Government, undated, ibidem; The Department of State to the Japanese Embassy, February 27, 1912, [w:] PRFRUS 1912, s. 69. Cytaty zaczerpnięto odpowiednio z pierwszego i trzeciego dokumentu. 
Chinom, można by, jak obrazowo przedstawiają to historycy, „zjeść ciastko i mieć ciastko" ${ }^{141}$. Wyrazem sympatii miała być opracowana przez Departament Stanu rezolucja Izby Reprezentantów z 29 lutego gratulująca ustanowienia Republiki. Dokument przesłano do amerykańskich konsulów celem rozpowszechnienia, wyraźnie zaznaczając jednak, że nie oznaczał on uznania ${ }^{142}$. Dzięki tym działaniom amerykańskiej dyplomacji udało się, przynajmniej na razie, zgrabnie wybrnąć z niełatwego położenia i zyskać na czasie. Usatysfakcjonowała ona choć trochę opinię publiczną w kraju i w Chinach, podtrzymała współpracę z mocarstwami, pozostawiając sobie swobodę decyzji, gdyby zaszła taka konieczność. Teraz można było śledzić rozwój wydarzeń w Chinach. Pozostałe mocarstwa też nie śpieszyły się z uznaniem, czekając na to, jak rozwinie się sytuacja, oraz licząc, że uzyskają najpierw potwierdzenie swoich praw oraz będą miały dodatkowy atut podczas negocjacji dotyczących pożyczki reorganizacyjnej ${ }^{143}$.

Sprawa pożyczki, odroczona podczas rewolucji, powróciła, gdy tylko Qingowie zostali pozbawieni władzy. Nowy rząd Tanga potrzebował pieniędzy na bieżące wydatki i przeprowadzenie reform. Jego sytuacja finansowa była trudna, gdyż prowincje niechętnie przekazywały dochody z podatków, monopole rządowe były albo źle zarządzane, albo kontrolowane przez cudzoziemców, a próby wyemitowania pożyczki wewnętrznej skończyły się fiaskiem ${ }^{144}$. W lutym 1912 roku Chiny zwróciły się do konsorcjum czterech mocarstw o co miesięczne zaliczki i rozpoczęły negocjacje na temat pożyczki reorganizacyjnej. Jej pierwotne warunki zakładały pożyczkę w wysokości 60 milionów funtów szterlingów (ok. 292 milionów dol., ok. 449 milionów taeli) ${ }^{145}$, wydaną $\mathrm{w}$ ciągu pięciu lat $\mathrm{w}$ równych transzach po 12 milionów rocznie i zabezpieczoną dochodami z podatku solnego ${ }^{146}$. Uzyskane $w$ ten sposób fundusze miały być spożytkowane na spłatę zaliczek i innych zagranicznych zobowiązań

141 W. Scholes, M. Scholes, The Foreign Policies ..., s. 227.

142 Huntington Wilson to the President, February 26, 1912, TP, series 6: case files, 272, reel 378; The Acting Secretary of State to the American Minister, March 2, 1912, [w:] PRFRUS 1912, s. 71.

143 The Japanese Ambassador to the Secretary of State, March 24, 1913, [w: ] PRFRUS 1913, s. 173-174; Annotation du Département joint à Gérard à Pichon, 4 avril 1913, [w: ] DDF, $3^{\text {e }}$ série, t. 6, s. 234.

144 K.C. Chan, British Policy in the Reorganization Loan to China 1912-1913, „Modern Asian Studies” 1971, t. 5, nr 4, s. 361.

${ }_{145}$ W 1912 roku funt szterling wart był 4,87 dolara amerykańskiego, a tael równał się około 0,65 dolara. D.D. Lazo, An Enduring Encounter ..., s. 240. Historyczne kursy można sprawdzić również online: http://www.measuringworth.com/datasets/exchangepound/result.php (dostęp: 10.02.2018).

146 The American Minister to the Secretary of State, March 21, 1912, [w:] PRFRUS 1912, s. $117-119$. 
finansowych, rozpuszczenie zbędnych wojsk, modernizację administracji i rozwój kraju.

Konsorcjum było zainteresowane udzieleniem zaliczek i pożyczki, ponieważ pozwalały one osiągnąć ekonomiczne i polityczne cele - prowadzić intratny interes i wesprzeć nowe władze chińskie, tak aby mogły utrzymać porządek (jak stwierdzili Brytyjczycy, zaliczki miały wzmocnić rząd pekiński przeciwko „siłom nieładu” ${ }^{147}$. Dla Stanów Zjednoczonych pożyczka reorganizacyjna wydawała się nawet jeszcze bardziej korzystna. Stanowiła bowiem szansę na dalsze rozwijanie „dyplomacji dolarowej” i miała dostarczyć środków na wprowadzenie reform w Chinach, na czym zależało Waszyngtonowi. Wzmocnienie Chin i przeprowadzenie ich przez okres zawieruchy konweniowało też z polityką „otwartych drzwi”. Co więcej, pożyczka mogła w rzeczywistości stanowić narzędzie do dalszego rozszerzania owej polityki o kwestie inwestycyjne, gdyż wszyscy członkowie konsorcjum mieli otrzymać równy udział w pożyczce. Last but not least, działanie $\mathrm{w}$ ramach konsorcjum stanowiło kontynuację polityki wspólpracy ${ }^{148}$.

$\mathrm{Z}$ tych powodów Stany Zjednoczone i pozostali członkowie konsorcjum zgodzili się udzielić zaliczek i negocjować pożyczkę reorganizacyjną. Domagali się jednak wyłączności na obie transakcje. Kiedy tylko Yuan przyznał im ją 9 marca, zaczęli dyskutować nad kolejnymi warunkami. Chcieli mianowicie nadzorować wydatki i uzyskać gwarancję, że dopóki pożyczka reorganizacyjna nie zostanie w całości wypłacona, czyli co najmniej przez pięć lat, Chiny będą mogły pożyczać pieniądze tylko od nich. Drugi warunek był dla niektórych bankierów i polityków kontrowersyjny, ponieważ de facto ustanawiał monopol. USA uważały, że chociaż bankom należało zapewnić dogodne warunki, wrażenia monopolu należało uniknąć. Razem z pozostałymi mocarstwami próbowały zatem znaleźć formułę pozwalającą pogodzić oba interesy ${ }^{149}$.

Tymczasem 14 marca Pekin podpisał z belgijskim syndykatem umowę dotyczącą pożyczki w wysokości miliona funtów szterlingów i dającą pierwszeństwo przy następnej pożyczce na 10 milionów ${ }^{150}$. Konsorcjum uznało to

147 The Ambassador of Great Britain to the Acting Secretary of State, March 22, 1912, [w:] PRFRUS 1912, s. 122. Zdaniem Francji czynnik polityczny miał być istotniejszy niż ekonomiczny - o pożyczce reorganizacyjnej nie mieli decydować bankierzy, lecz politycy. The American Ambassador to France to the Secretary of State, June 3, 1912, [w:] ibidem, s. 135-136.

${ }^{148}$ W. Straight, China's Loan Negotiations, „The Journal of Race Development” 1913 , t. 3, nr 4, s. 370, 404-405.

149 PRFRUS 1912, s. 110-120.

${ }_{150}$ Wstępne porozumienie podpisano 20 lutego. Doc. no. 1912/4: Belgium (Banque Sino-Belge) and China. Agreement for the Chinese Government five per cent Gold Loan of 1912, March 14, 1912, [w:] Treaties and Agreements with and Concerning China, 
za rażące złamanie zobowiązań zaciągniętych przez Yuana i stanowczo zaprotestowało $^{151}$.

Amerykańska grupa bankowa i Departament Stanu podzielali tę opinię. Ich zaniepokojenie wynikało $\mathrm{z}$ jeszcze jednego powodu. Belgijski kontrakt nie przewidywał bowiem żadnej kontroli wydatków, którą Amerykanie uważali za niezbędną, ponieważ ich zdaniem republikańskie Chiny miały skłonność do rozrzutności ${ }^{152}$. „Jeśli Chiny mają zostać uratowane - pisal Calhoun - muszą być chronione przed brakiem przezorności finansowej. Powinno się zapobiec niczym nieograniczonemu pożyczaniu i lekkomyślnej konkurencji między bankierami”"153. Młoda Republika, znajdująca się na krawędzi chaosu, mogła według Calhouna zostać ustabilizowana tylko dzięki pomocy finansowej z zewnątrz. Gdyby jednak pozwolono jej „wszędzie pożyczać pieniądze bez ograniczeń i kontroli, skutek mógł być tylko jeden, i to szybki - narodowe bankructwo". Doprowadzenie do niego mogło stanowić ukryty cel niektórych mocarstw, jako że dałoby im powód do interwencji. Calhoun konkludował, że było to sprzeczne z polityką prowadzoną przez Stany Zjednoczone, ustawicznie dążące do „powzięcia kroków, które [...] uratują chiński rząd przed nim samym, zapobiegną bezmyślnemu pożyczaniu i lekkomyślnemu wydawaniu, pomogą mu utrzymać wiarygodność kredytową i zbudować dobrobyt na solidnych fundamentach" 154 .

Kolejnym aspektem belgijskiej umowy budzącym obawy w Waszyngtonie były implikacje polityczne. Administracja Tafta opowiadała się za szerokim umiędzynarodowieniem pożyczek dla Chin, aby nie dopuścić do pożyczek o wybitnie politycznym charakterze. Chociaż belgijskiej pożyczki udzielił syndykat złożony

1894-1919, zebrał i opracował J.V.A. MacMurray, t. 2: Republican Period (1912-1919), New York 1921, s. 947-950; The American Minister to the Secretary of State, March 16, 1912, [w:] PRFRUS 1912, s. 113; The American Minister to the Secretary of State, March 21, 1912, [w: ] ibidem, s. 117-119. Według zagranicznych dyplomatów po ich proteście Pekin podpisał jeszcze jedną umowę z belgijskim syndykatem. Straight twierdzil, że Tang próbował ponownie pożyczyć pieniądze od belgijskiej grupy, ale mu się to nie udało. The Ministers of the four Powers to the Foreign Office, April 18, 1912, [w: ] ibidem, s. 125; W. Straight, China's Loan Negotiations ..., s. 391.

151 PRFRUS 1912, s. 114-119, 121-123.

152 Doc. no. 1912/4: Belgium (Banque Sino-Belge) and China. Agreement for the Chinese Government five per cent Gold Loan of 1912, March 14, 1912, [w:] Treaties and Agreements..., s. 947-950; The American Minister to the Secretary of State, March 29, 1912, [w: ] PRFRUS 1912, s. 122-123.

153 The American Minister to the Secretary of State, March 30, 1912, [w:] PRFRUS 1912, s. 123.

154 The American Minister to the Secretary of State, March 21, 1912, [w:] PRFRUS 1912, s. 117-119. 
z brytyjskich, francuskich, belgijskich i rosyjskich firm, to głównym inspiratorem była Rosja, która chciała się przeciwstawić konsorcjum ${ }^{155}$.

W odpowiedzi na protest konsorcjum chińskie władze stwierdziły, że po prostu potrzebowały pieniędzy i skorzystały z okazji ${ }^{156}$. Ich decyzja miała oczywiście skłonić konsorcjum do poczynienia ustępstw, zwłaszcza do rezygnacji z pomysłu ustanowienia monopolu finansowego ${ }^{157}$. Takie postępowanie było zgodne ze starą chińską strategią wykorzystywania jednych barbarzyńców przeciwko dru$\operatorname{gim}^{158}$. Tym razem jednak nie przyniosło ono większego efektu.

15 marca konsorcjum zerwało negocjacje, a rządy Wielkiej Brytanii i Francji poinformowały swoich obywateli w belgijskim syndykacie, że nie będą mogli liczyć na oficjalne poparcie ${ }^{159}$. Ponieważ także Rosja chwilowo się wycofała, syndykat nie był w stanie udzielić kolejnych zaliczek ${ }^{160}$. W tej sytuacji Tang spotkał się z posłami czterech mocarstw, aby dowiedzieć się, co musiałby zrobić, żeby negocjacje zostały wznowione. Dyplomaci, zwłaszcza brytyjski i francuski, stwierdzili, że niezbędne byłoby anulowanie belgijskiego kontraktu. Chiny, ciągle desperacko potrzebujące funduszy, musiały udobruchać konsorcjum i 27 kwietnia unieważniły klauzule umowy dotyczące większej pożyczki, deklarując jednocześnie, że nie będą spłacać belgijskich zaliczek z pieniędzy konsorcjum. Usatysfakcjonowało to konsorcjum, które dwa dni później ponownie

155 The Acting Secretary of State to the American Minister, March 19, 1912, [w: ] PRFRUS 1912, s. 115-116; The American Minister to the Secretary of State, March 29, 1912, [w: ] ibidem, s. 122-123; W. Scholes, M. Scholes, The Foreign Policies ..., s. 233.

156 The American Minister to the Secretary of State, March 29, 1912, [w:] PRFRUS 1912, s. 122-123. Później Chińczycy przedstawili jeszcze dwa wytłumaczenia. Twierdzili, że podczas rozruchów na przełomie lutego i marca konsorcjum odmówiło natychmiastowego udzielenia zaliczki, zmuszając ich do szukania innego pożyczkodawcy. Innym razem wyjaśniali, że zaszło „nieporozumienie”. The Ministers of the four Powers to the Foreign Office, April 18, 1912, [w:] ibidem, s. 125; The Chinese Minister to the Secretary of State, May 27, 1912, [w:] ibidem, s. 134-135; W. Straight, China's Loan Negotiations ..., s. 388-391.

157 Ch. Vevier, The United States and China..., s. 197.

158 M.B. Young, The Rhetoric of Empire: American China Policy, 1895-1901, Cambridge 1968, s. 217.

159 The Ambassador of Great Britain to the Acting Secretary of State, March 21, 1912, [w: ] PRFRUS 1912, s. 121-122; Poincaré à Margerie, 15 avril 1912, [w: ] DDF, 3e série, t. 2, Paris 1931, s. 346-347; The American Minister to the Secretary of State, May 7, 1912, [w: ] PRFRUS 1912, s. 126-127; W. Scholes, M. Scholes, The Foreign Policies ..., s. 235. Niemcy zapewne podejrzewały, że mające z nimi napięte stosunki Francja i Wielka Brytania wspierały swoich bankierów spoza konsorcjum. The American Ambassador to Germany to the Secretary of State, March 21, 1912, [w:] PRFRUS 1912, s. 121.

160 Ch. Vevier The United States and China..., s. 197. 
podjęło negocjacje, aczkolwiek od tej pory z większą rezerwą podchodziło do władz chińskich ${ }^{161}$.

Przez następnych kilka tygodni konsorcjum i Chiny debatowały na temat nadzorowania wydatków. Podczas spotkania 30 kwietnia Tang powiedział bankierom, że będzie potrzebował więcej pieniędzy na bieżące płatności, niż wcześniej przewidywał. Chciał otrzymać 35 milionów taeli w ciągu najbliższych pięciu tygodni, a potem 10 milionów co miesiąc, do połowy października. Bankierzy wyrazili zgodę, ale nalegali na kontrolę wydatków. Tang szybko jednak odrzucił taką możliwość. Konsorcjum stanęło wówczas przed zasadniczym dylematem. Odmowa udzielenia pożyczki mogła mieć poważne reperkusje (zdaniem Calhouna „spokój kraju był zagrożony”), jej przyznanie bez odpowiednich zabezpieczeń mogło natomiast pogorszyć sytuację, którą już oceniano jako „krytyczną”162. Stany Zjednoczone zajęły raczej pojednawcze stanowisko, uważając, że:

bycie zbyt surowym w kwestii kontroli zaliczek byłoby błędem i że jest najważniejsze, aby fundusze $[\ldots]$ na najpilniejsze potrzeby zostały natychmiast przekazane, tak by rząd tymczasowy mógł jak najszybciej zacząć działać na bardziej stabilnych podstawach. [...] Pełna dyskusja na temat warunków kontroli dużej pożyczki reorganizacyjnej, chociaż tocząca się jednocześnie, nie powinna zbytnio opóźniać [udzielania - J.P.] zaliczek $[\ldots]^{163}$.

Ugodowe nastawienie zwyciężyło i 16 maja Chiny zawarły porozumienie z konsorcjum, a nazajutrz bankierzy przekazali kolejną zaliczkę. Kompromis zakładał utworzenie departamentu audytu $\mathrm{z}$ dwoma audytorami na czele - jednym cudzoziemcem (wybranym i opłacanym przez grupy) i jednym Chińczykiem (zatrudnionym i opłacanym przez rząd pekiński). Uzgodniono, że departament zostanie rozwiązany, gdy zaliczki zostaną wypłacone, a na potrzeby większej pożyczki opracowane zostaną inne procedury audytu. Kolejną sprawę sporną rozstrzygnięto po myśli Chin. Miały one - wbrew postulatom bankierów - samodzielnie zajmować się opłacaniem żołnierzy i demobilizacją niepotrzebnych wojsk, bez udziału cudzoziemskich oficerów. Ustalono również, że rząd centralny nie zezwoli, aby władze lokalne pożyczały pieniądze od innych podmiotów niż grupy, o ile najpierw nie zwróciły się do nich. Chociaż porozumienie zostało

${ }_{161}$ The American Minister to the Secretary of State, April 27, 1912, [w:] PRFRUS 1912, s. 124; The Premier, The Acting Minister for Foreign Affairs, and the Acting Minister for Finance to the Ministers of the four Powers, April 27, 1912, [w:] ibidem, s. 126; The American Minister to the Secretary of State, May 7, 1912, [w:] ibidem, s. 126-127.

162 The American Minister to the Secretary of State, May 7, 1912, [w: PRFRUS 1912, s. $126-127$.

163 The Acting Secretary of State to the American Minister, April 29, 1912, [w:] PRFRUS 1912, s. 124-125. 
zawarte, obie strony nie były w pełni usatysfakcjonowane i próbowały je zmienić $^{164}$. Tymczasem inny problem wysunął się na plan pierwszy.

Kwestia, która skomplikowała i wydłużyła negocjacje, dotyczyła przystąpienia Rosji i Japonii do konsorcjum. Po raz pierwszy pojawiła się ona wiosną 1911 roku, gdy oba mocarstwa zaczęły się obawiać, że zawarcie pożyczki walutowej i na rozwój przemysłu zagrozi ich pozycjom w Mandżurii i Mongolii. Aby oddalić niebezpieczeństwo, mogły albo walczyć z konsorcjum, albo starać się zadbać o własne interesy od wewnątrz. Także członkowie konsorcjum, przede wszystkim Francja i Wielka Brytania, nabierali przekonania, że Rosja i Japonia powinny zostać do niego dopuszczone ${ }^{165}$.

W USA opinie byly podzielone. Podczas gdy Departament Stanu raczej popierał takie rozwiązanie, bankierzy byli mu przeciwni. Uważali, że Rosja i Japonia w największym stopniu naruszały politykę „otwartych drzwi” i przeszkadzały $\mathrm{w}$ rozszerzaniu amerykańskich interesów $\mathrm{w}$ Chinach. $\mathrm{Z}$ czasem jednak zmienili nastawienie, akceptując, że kontrola Tokio i Petersburga nad Mandżurią była mocno ustanowiona. Nawet Straight, uprzednio jeden z najbardziej zagorzałych zwolenników polityki „otwartych drzwi” i inwestycji w Mandżurii, stwierdził na początku 1912 roku, że w odniesieniu do Północnego-Wschodu Stany Zjednoczone powinny „dojść do jakiegoś porozumienia z Rosją i Japonią, które pozwoliłoby czterem grupom prowadzić interesy w swoich strefach wpływów”166.

Departament Stanu był od początku bardziej przychylny udziałowi Rosji i Japonii w konsorcjum ${ }^{167}$. Gdyby oba państwa do niego przystąpiły, wszystkie mocarstwa mające swoje interesy w Państwie Środka byłyby obecne. Mogłoby

164 The American Minister to the Secretary of State, May 7, 1912, [w:] PRFRUS 1912, s. 126-127; Draft regulations for the supervision of expenditure of provisional advances, May 12, 1912, [w: ] ibidem, s. 132-133; The American Minister to the Secretary of State, May 16, 1912, [w: ] ibidem, s. 128; The American Minister to the Secretary of State, May 21, 1912, [w: ] ibidem, s. 130-132.

165 Selves à Louis, 9 janvier 1912, [w:] DDF, $3^{\text {e }}$ série, t. 1, s. 456-464; Cambon à Poincaré, 5 février 1912, [w: ] ibidem, s. 612; Note du Département, 31 mars 1912, [w: ] ibidem, t. 2, s. 283-285; Note relative aux emprunts chinois, 12 avril 1912, [w:] ibidem, s. 339-341.

166 Straight to Davison, January 16, 1912, SP, reel 5, segment 1. Zob. też: Straight to Davison, December 18, 1911, ibidem; Straight to ffrench, January 16, 1912, ibidem; Straight to J.P. Morgan and Co., January 20, 1912, ibidem; Straight to J.P. Morgan and Co., January 28, 1912, ibidem; Ch. Vevier, The United States and China ..., s. 197-199; W. Scholes, M. Scholes, The Foreign Policies ..., s. 227-232; H. Croly, Willard Straight ..., s. 443-445; D.M. Crane, T.A. Breslin, An Ordinary Relationship ..., s. 69.

167 Knox to the American Embassy at London, January 24, 1912, KP, container 32; W. Scholes, M. Scholes, The Foreign Policies..., s. 229; D.M. Crane, T.A. Breslin, An Ordinary Relationship..., s. 70. 
to ograniczyć międzynarodową konkurencję na rynku chińskim, dając każdemu członkowi równy udział w pożyczkach, a może i w przedsięwzięciach przemysłowych. Jeśli udałoby się to osiągnąć, duża część przewagi wynikającej z posiadania stref wpływów zostałaby zniwelowana, co byłoby bardzo korzystne dla USA, które jako jedyne w tym gronie nie miały swojej strefy. Poza tym mocarstwa zacieśniłyby współpracę, a to ułatwiłoby powstrzymanie wrogich zamiarów wobec młodej Republiki i oddaliłoby groźbę udzielenia przez jedno mocarstwo pożyczki o wyłącznie politycznym charakterze. Tak więc powiększone konsorcjum mogło stanowić jeszcze lepszy instrument do rozwijania zarówno „dyplomacji dolarowej”, jak i polityki „otwartych drzwi”.

Jak już zostało wspomniane, podczas rewolucji 1911 roku amerykańska dyplomacja optowała za pożyczkami mającymi szeroki międzynarodowy charakter. Potwierdziła to 1 lutego 1912 roku, deklarując, że: „gdyby rząd chiński zawarł odtąd pożyczkę z czterema grupami, byłaby skłonna poprzeć przyjęcie innych zainteresowanych mocarstw, zwłaszcza Japonii i Rosji”. Później powtórzyła tę opinię jeszcze parokrotnie ${ }^{168}$. Ponieważ inne rządy i bankierzy również popierali ten pomysł, w marcu oficjalnie zaproszono do rozmów Rosję i Japonię $e^{169}$.

Odpowiedzi obu mocarstw wskazywały, że negocjacje nie będą łatwe. Siergiej Sazonow, carski minister spraw zagranicznych, zgodził się, aby jego kraj partycypował w zaliczkach, ale wyraził niezadowolenie, że konsorcjum udzieliło ich bez konsultacji z Rosją. Podkreślił też, że zgoda nie oznaczała aprobaty innych pożyczek dla Pekinu, które miały zostać przyznane w przyszłości ${ }^{170}$. Powściągliwa reakcja Rosji nie była zaskakująca, skoro generalnie była ona przeciwna konsorcjum i starała się nakłonić Francję i Japonię do stworzenia odrębnego zrzeszenia finansowego ${ }^{171}$.

168 The Secretary of State to the American Ambassador to Great Britain, February 1, 1912, [w:] PRFRUS 1912, s. 109; The Acting Secretary of State to the American Minister, February 24, 1912, [w:] ibidem, s. 109-110; The Acting Secretary of State to the Ambassador of Great Britain, February 27, 1912, [w: ] ibidem, s. 111; The Acting Secretary of State to the American Ambassador to France, March 19, 1912, [w:] ibidem, s. 116; The Secretary of State to the American Ambassador to France, May 18, 1912, [w:] ibidem, s. 129.

169 The Ambassador of Great Britain to the Acting Secretary of State, February 24, 1912, [w: PRFRUS 1912, s. 110; The American Ambassador to Germany to the Secretary of State, February 28, 1912, [w: ] ibidem, s. 111; The Acting Secretary of State to the American Ambassador to Russia, March 11, 1912, [w:] ibidem, s. 111-112; The Ambassador of Great Britain to the Acting Secretary of State, March 12, 1912, [w:] ibidem, s. 112; H. Croly, Willard Straight ..., s. 445.

170 The American Ambassador to Russia to the Secretary of State, March 15, 1912, [w:] PRFRUS 1912, s. 112-113.

171 Straight to Morgan, Grenfell and Co., January 16, 1912, KP, container 32; Note du Département, 31 mars 1912, [w:] DDF, $3^{\text {e }}$ série, t. 2, s. 283-285; Note relative aux 
Odpowiedź Tokio zasygnalizowała inny problem. Rząd cesarski przyjął zaproszenie, ale oczekiwał, że planowana pożyczka w niczym nie naruszy specjalnych praw i interesów Japonii w południowej Mandżurii i wschodniej części Mongolii Wewnętrznej ${ }^{172}$. Także Sazonow, który niedługo później był już chętny do udziału w pożyczce reorganizacyjnej, postawił podobny warunek w odniesieniu do północnej Mandżurii, Mongolii i zachodnich Chin (Turkiestanu) ${ }^{173}$. Jak powiedział francuskiemu dyplomacie, miało to zapobiec powtórzeniu się takich inicjatyw jak plan neutralizacji Knoxa ${ }^{174}$.

Akceptacja rosyjskich i japońskich zastrzeżeń równałaby się jawnemu przyznaniu, że wymienione obszary były wyłączone spod działania polityki „otwartych drzwi”. Chociaż Waszyngton sam właśnie doszedł do podobnego wniosku, to oficjalne uznanie tego stanowiło odrębną kwestię $e^{175}$. Dlatego też rząd Tafta przyjął kompromisowe rozwiązanie zaproponowane przez Wielką Brytanię, aby uznać tylko te prawa i przywileje, które były potwierdzone przez traktaty z Chinami, wiedząc, że część z nich potwierdzona nie była ${ }^{176}$.

Sprawę rozszerzenia konsorcjum poruszono następnie podczas majowej konferencji bankierów w Londynie. Rozmowy szybko jednak utknęły w martwym punkcie ze względu na nowe żądania Rosji i Japonii, na które nie wyrazily zgody pozostałe mocarstwa. Państwa ubiegające się o przyjęcie chciały mieć możliwość wyemitowania swojej części pożyczki na rynkach zagranicznych przez jakiegokolwiek przedstawiciela, nie zaś obligatoryjnie przez pozostałe grupy. Pozwoliłoby im to konkurować na brytyjskim i francuskim rynku z bankami należącymi do konsorcjum. Japonia i Rosja domagały się również

emprunts chinois, 12 avril 1912, [w: ibidem, s. 339-341; W. Scholes, M. Scholes, The Foreign Policies..., s. 227-230; T. Dmochowski, Walka polityczna mocarstw ..., s. 198.

172 The American Ambassador to Japan to the Secretary of State, March 18, 1912, [w:] PRFRUS 1912, s. 114-115; The German Ambassador to the Acting Secretary of State, May 5, 1912, [w:] ibidem, s. 78; Memorandum of a conversation between the Acting Secretary of State and the Japanese Ambassador, May 16, 1912, [w:] ibidem, s. 79; The American Ambassador to France to the Secretary of State, June 13, 1912, [w: ] ibidem, s. 137.

173 The Acting Secretary of State to the American Minister, April 8, 1912, [w: ] PRFRUS

1912, s. 124. Zob. też: The Ambassador of Russia to the Acting Secretary of State, March 8, 1912, [w:] ibidem, s. 74; The American Ambassador to Russia to the Secretary of State, March 12, 1912, [w:] ibidem, s. 75.

174 Vieugué à Poincaré, 12 mars 1912, [w: ] DDF, 3e série, t. 2, s. 181.

175 W. Scholes, M. Scholes, The Foreign Policies..., s. 227-231; Ch. Vevier, The United States and China..., s. 199-200.

176 The Ambassador of Great Britain to the Acting Secretary of State, March 22, 1912, [w: ] PRFRUS 1912, s. 122; The Acting Secretary of State to the American Minister, April 8, 1912, [w: ] ibidem, s. 124. 
zapewnienia, że środki z pożyczki nie zostaną wydane w Mandżurii, Mongolii i Turkiestanie ${ }^{177}$.

Porozumienie, które okazało się niemożliwe w maju, zostało osiągnięte miesiąc później podczas kolejnego spotkania konsorcjum w Paryżu. Tym razem bankierzy i politycy wykazali większą determinację w dążeniu do kompromisu. Rząd carski wywarł nacisk na swych sojuszników, tak że Francja nieoficjalne zagroziła wycofaniem z konsorcjum, jeśli Rosja nie zostanie przyjęta, a Wielka Brytania złagodziła swoje stanowisko, pomijając warunek, że tylko prawa wynikające $\mathrm{z}$ traktatów będą uznane. W zamian Foreign Office zaproponowało, aby ponownie potwierdzić politykę „otwartych drzwi”, lecz ostatecznie do tego nie doszło ${ }^{178}$. Także USA bezskutecznie starały się wprowadzić do porozumienia klauzulę, która ograniczyłaby prawa i interesy Rosji i Japonii tylko do tych „rozsądnie związanych $\mathrm{z}$ istniejącymi traktatami i konwencjami z Chinami i kompatybilnych z uznaną zasadą równości szans i „otwartych drzwi” ${ }^{179}$.

Ostatecznie Rosja i Japonia otrzymały niemal wszystko, na czym im zależało. Ich szczególna pozycja w Mandżurii, Mongolii i Turkiestanie została potwierdzona, one same miały zaś wziąć udział w pożyczce reorganizacyjnej, pod warunkiem, że nie naruszy ona ich praw na rzeczonych obszarach. Oba mocarstwa uzyskały ponadto gwarancję, że grupy nie będą rozważały przedsięwzięć biznesowych, którym rządy mogły się sprzeciwić, a Chiny, zanim otrzymają pieniądze, miały poinformować banki, na co chcą je wydać. Rosja i Japonia, podobnie jak pozostała czwórka, miały prawo wycofać się z porozumienia, jeśli pożyczka, której się sprzeciwiły, zostałaby mimo wszystko przyznana przez pozostałych członków ${ }^{180}$.

Departament Stanu zgodził się na warunki Rosji i Japonii mimo sugestii posła Calhouna, który wątpiąc w dobre intencje obu mocarstw, uważał, że USA powinny raczej wycofać się z konsorcjum. Jednakże - o czym jednoznacznie świadczy adnotacja na jego komunikacie - przełożeni w Waszyngtonie byli innego zdania. Komentarz brzmiał: „Jeśli nie możesz dostać tego, czego chcesz, nic nie

177 The American Ambassador to Great Britain to the Secretary of State, May 20, 1912, [w:] PRFRUS 1912, s. 130; Poincaré à Louis, 22 mai 1912, [w: ] DDF, 3 érérie, t. 3, Paris 1931, s. 36-40; Poincaré à Louis, 31 mai 1912, [w: ibidem, s. 80-81; W. Scholes, M. Scholes, The Foreign Policies ..., s. 235-236.

178 The American Ambassador to Great Britain to the Secretary of State, June 10, 1912, [w: ] PRFRUS 1912, s. 136; W. Scholes, M. Scholes, The Foreign Policies ..., s. 236-237.

179 Cytat za: W. Scholes, M. Scholes, The Foreign Policies ..., s. 237.

180 PRFRUS 1912, s. 137, 140-141; Doc. no. 1913/5: Note 1: Excerpt from minutes of the Second Day, June 19, 1912, [w:] Treaties and Agreements ..., s. 1024; Doc. no. 1913/5: Note 1: Excerpt from minutes of third day, June 20, 1912, [w: ] ibidem; Doc. no. 1913/5: Note 1: Minutes of Meeting held at the Banque de l'Indo-Chine, June 20, 1912, [w: ibidem; Poincaré aux Représentants diplomatiques de France à Saint-Pétersbourg, Londres, Berlin, Pékin, Tokio, Washington, Vienne, 24 juin 1912, [w: ] DDF, 3 ${ }^{\text {e }}$ série, t. 3, s. 168-171. 
weźmiesz?”181. Departament Stanu zdecydowal, że lepiej było dokooptować Tokio i Petersburg i starać się je kontrolować, niż pozwolić im działać poza konsorcjum, nawet jeśli „cena” przystąpienia - uznanie, że polityka „otwartych drzwi” ograniczała się do osiemnastu prowincji Chin właściwych - była wysoka ${ }^{182}$. Knox uważał, że dalsze zwlekanie z przyjęciem obu mocarstw sprawiłoby tylko, że ich żądania byłyby większe. Także Straight, który wyjechał z Pekinu i prowadził w Europie negocjacje w imieniu amerykańskiej grupy, ocenił porozumienie raczej pozytywnie. Widział w nim jedynie akceptację stanu faktycznego, co mogło mieć nawet dobre skutki, ponieważ mocarstwa, które w rzeczywistości kontrolowały sytuację na Dalekim Wschodzie, przystąpiły do konsorcjum ${ }^{183}$.

Oprócz Rosji i Japonii rozważano także przyjęcie Austro-Węgier, Włoch, Belgii i Holandii. Stany Zjednoczone każdorazowo popierały aplikacje, pozostając

181 Cytat za: Ch. Vevier, The United States and China ..., s. 201.

182 We wrześniu Japończycy chcieli ponownie uzyskać amerykańskie gwarancje w odniesieniu do południowej Mandżurii i wschodniej części Mongolii Wewnętrznej. Przybyłemu na pogrzeb cesarza Meiji Knoxowi przekazali memorandum, w którym zadeklarowali chęć przestrzegania tam zasady „otwartych drzwi” w handlu, oczekując w zamian uznania ich specjalnej pozycji i specjalnych praw. Podkreślili, że wobec ograniczonej możliwości osadnictwa w Stanach Zjednoczonych musieli skierować się w inne miejsca. Wskazali również na paralelę między amerykańskim zainteresowaniem Zatoką Magdaleny (o czym poniżej) a ich zainteresowaniem Mandżurią i Mongolią. Knox nie odniósł się do memorandum, co wzbudziło podejrzenia gospodarzy. Do sprawy powrócono na początku 1915 roku, kiedy Waszyngton zastanawiał się, jak zareagować na japońskie żądania wobec Chin. Będzie o tym mowa w rozdziale IV. Confidential Minute. Document written by the Gaimusho, September 1912 [brak daty dziennej], $K P$, container 18. Wspomniana $\mathrm{w}$ memorandum kontrowersja wokó Zatoki Magdaleny doprowadziła w 1912 roku do wzrostu w Stanach Zjednoczonych antyjapońskich nastrojów podsycanych przez prasę brukową i niektórych polityków. Pojawily się wówczas, jak się okazało raczej bezzasadne, doniesienia o groźbie nabycia przez japońską firmę meksykańskiej zatoki znajdującej się na południu Półwyspu Kalifornijskiego. Na początku sierpnia Senat przyjął nawet rezolucję, której promotorem był wpływowy polityk republikański Henry Cabot Lodge (stąd niektórzy historycy piszą o Lodge'owskim uzupełnieniu doktryny Monroego), stwierdzającą, że USA byłyby poważnie zaniepokojone, gdyby jakiś port lub inne miejsce o strategicznym znaczeniu na kontynencie amerykańskim znalazło się w posiadaniu obcego przedsiębiorstwa. Więcej na ten temat patrz: T.A. Bailey, The Lodge Corollary to the Monroe Doctrine, „Political Science Quarterly” 1933, t. 48, nr 2, s. 220-239; R.D. Challener, Admirals, Generals ..., s. $272-275$.

${ }^{183}$ The Chinese Revolution and American Policy, May, 1912 [brak daty dziennej], KP, container 18; D.M. Crane, T.A. Breslin, An Ordinary Relationship ..., s. 77; H. Croly, Willard Straight ..., s. 449-452; F.M. Huntington Wilson, Memoirs of an Ex-Diplomat, Boston 1945, s. 217. 
zwolennikami szerokiego umiędzynarodowienia pożyczek dla Chin. Pozostali członkowie konsorcjum z różnych przyczyn ekonomicznych i politycznych odrzucili jednak wszystkie kandydatury ${ }^{184}$.

Przystąpienie Rosji i Japonii wzmocniło pozycję negocjacyjną konsorcjum, gdyż Chiny nie mogły się już zwrócić do żadnego mocarstwa jako przeciwwagi wobec jego wpływów. Dotychczas taką rolę odgrywała Rosja, która stała za belgijską pożyczką, a w czerwcu, tuż przed dołączeniem do konsorcjum, miała według różnych doniesień negocjować z Tangiem kolejną pożyczkę na 10 milionów funtów szterlingów. Calhoun podejrzewał, że celem planu ułożonego w Petersburgu było, aby to Chiny zerwały z konsorcjum, oszczędzając Rosji konieczności doprowadzenia do fiaska konferencji w Paryżu ${ }^{185}$. Ostatecznie jednak rząd carski zdecydował się przystąpić do konsorcjum.

Niedługo później konsorcjum, mimo wcześniejszego porozumienia z połowy maja, próbowało zmusić Chiny do akceptacji twardszych warunków. Obejmowały one m.in.: wyszczególnienie celów dla zaliczek i pożyczki reorganizacyjnej; nadzór wydatków; pierwszeństwo w udzieleniu pożyczki reorganizacyjnej; klauzulę o sile wyższej (która w niepewnej sytuacji Chin była więcej niż zrozumiała); ustanowienie grup finansowymi przedstawicielami Chin na pięć lat; zobowiązanie strony chińskiej, że nie zaciągnie pożyczek spoza konsorcjum, dopóki pożyczka reorganizacyjna nie zostanie wyemitowana. Warunki, które opracowano wstępnie 15 maja podczas konferencji w Londynie, zostały przedstawione Chinom 24 czerwca $^{186}$.

Waszyngton szybko się zorientowat, że mogą one być trudne do zaakceptowania przez Chiny i już 17 maja zaapelował do europejskich rządów i bankierów o większą wyrozumiałość, aby nie dopuścić do zerwania negocjacji. Nad Potomakiem uważano, że porozumienie powinno opierać się na uzgodnieniach

184 Vieugué à Poincaré, 9 mars 1912, [w:] DDF, 3e série, t. 2, s. 169-170; Poincaré à Vieugué, 11 mars 1912, [w:] ibidem, s. 176-177; The Acting Secretary of State to the American Ambassador to France, March 19, 1912, [w:] PRFRUS 1912, s. 116; The American Ambassador to Germany to the Secretary of State, March 21, 1912, [w: ] ibidem, s. 121; Poincaré à Louis, 13 mai 1912, [w: ] DDF, $3^{\text {e }}$ série, t. 3, s. 5; The Secretary of State to the American Ambassador to France, May 18, 1912, [w:] PRFRUS 1912, s. 129; Poincaré à Vieugué, 23 mai 1912, [w: ] DDF, 3érie, t. 3, s. 40; The American Ambassador to France to the Secretary of State, June 3, 1912, [w:] PRFRUS 1912, s. 135-136; The American Ambassador to Germany to the Secretary of State, June 6, 1912, [w: ] ibidem, s. 136.

185 The American Minister to the Secretary of State, June 14, 1912, [w: ] PRFRUS 1912, s. 137-138; The American Minister to the Secretary of State, June 15, 1912, [w: ] ibidem, s. 138.

186 Draft telegram of Inter-bank London Conference of May 15, 1912, as amended and adopted June 20, 1912, [w:] PRFRUS 1912, s. 141-142; The American Minister to the Secretary of State, June 24, 1912, [w: ] ibidem, s. 142. 
poczynionych w Pekinie, a nowe warunki należało złagodzić. Jeśli chodzi o szczegóły, to Stany Zjednoczone nie sprzeciwiały się finansowemu przedstawicielstwu, o ile Pekin wyraziłby zgodę, ale równie dobrze mogły z tego zrezygnować. Naciskały za to bardziej na zapewnienie solidnej ochrony inwestycjom bankierów, lecz bez przyznawania im monopolu ${ }^{187}$.

$\mathrm{Z}$ oczywistych względów zaniepokojone nowymi warunkami były również Chiny, które musiały o nich wiedzieć, zanim oficjalnie im je przedstawiono. Pod koniec maja Pekin poprosił bowiem rząd amerykański o pomoc w przekonaniu pozostałych państw do porzucenia wygórowanych warunków. Celowo wspomniał o sprzeciwie opinii publicznej, możliwości buntu wśród nieopłaconych żołnierzy oraz o tradycyjnej przyjaźni łączącej oba narody. Wszystko to miało skłonić Waszyngton do poparcia prośby. Nie wiadomo, czy dyplomacja chińska wiedziała o raczej koncyliacyjnym nastawieniu USA, czy zwróciła się do nich ze względu na tradycję, czy też z obu powodów. Niezależnie od motywacji jej prośba nie przyniosła jednak większego efektu ${ }^{188}$.

Zanim Chinom przedstawiono w końcu nowe warunki, miał miejsce jeszcze jeden mały kryzys w negocjacjach z konsorcjum. 14 czerwca rząd Tanga poprosił o niezwłoczną zaliczkę w kwocie 19 milionów taeli (potem sumę zwiększył o 2 miliony) do 19 tegoż miesiąca, kiedy to przypadało święto, podczas którego należało uregulować należności. Prośba przybrała właściwie formę ultimatum, ponieważ Pekin zagrozil, że zwróci się do innych banków, gdyby grupy nie dostarczyły pieniędzy. Chińczycy ponownie wzmocnili swój przekaz, odmalowując mroczny pejzaż konsekwencji - z buntującymi się wojskami i ogólnym chaosem.

Amerykańska dyplomacja szczerze starała się zaaranżować wypłatę, ostrzegając jednocześnie Chiny, aby nie czyniły żadnych pochopnych ruchów, które mogłyby narazić negocjacje na temat pożyczki reorganizacyjnej. Sytuacja była napięta ze względu na presję czasu, możliwe reperkusje, informacje, że Rosja przygotowuje się do udzielenia pożyczki, oraz cały czas niepewny wynik rozmów z nią podczas konferencji w Paryżu. Kryzys udało się zażegnać dzięki temu, że Tang i Yuan zgodzili się obniżyć sumę potrzebną niezwłocznie do 6 milionów taeli, z której połowa została przekazana 18 czerwca przez pekińskich reprezentantów konsorcjum, najwyraźniej bez zgody przełożonych, gdyż posłowie wzięli osobistą odpowiedzialność za transakcję ${ }^{189}$.

187 The Secretary of State to the American Ambassador to France, May 17, 1912, [w: ] PRFRUS 1912, s. 128-129; The Secretary of State to the American Ambassador to France, May 18, 1912, [w: ] ibidem, s. 129.

188 The Chinese Minister to the Secretary of State, May 25, 1912, [w:] PRFRUS 1912, s. 133-134; The Chinese Minister to the Secretary of State, May 27, 1912, [w: ] ibidem, s. 134-135; The Secretary of State to the Chinese Minister, May 29, 1912, [w:] ibidem, s. 135. 189 PRFRUS 1912, s. 137-140. 
24 czerwca konsorcjum przedstawiło swoje warunki, które Chiny odrzuciły. Calhoun suponowal, że w tej sytuacji grupy przynajmniej na jakiś czas będą musiały wycofać się z rozmów ${ }^{190}$. Chiny zaproponowały obniżenie wysokości pożyczki do 10 milionów funtów szterlingów, licząc na uzyskanie w zamian mniej restrykcyjnych warunków nadzoru ${ }^{191}$. Pokrywało się to częściowo ze stanowiskiem Wielkiej Brytanii, która postrzegała pożyczkę 60 milionów jako „wyłącznie teoretyczną propozycję" i uważała, że należało pożyczyć pieniądze tylko na utrzymanie porządku, nie zaś na przeprowadzenie reform. Ale nawet mniejsza pożyczka powinna zawierać takie same warunki nadzoru ${ }^{192}$. Brytyjczycy naciskali na kontrolę wydatków, lecz nie na finansowe pośrednictwo, jeśli jego cel mógł zostać osiągnięty w inny sposób. Aby wywrzeć nacisk na Chiny, chcieli poinformować je, że mocarstwa nie zaakceptują żadnych pożyczek swoich obywateli, które nie będą spełniały warunków ustalonych przez konsorcjum 15 maja. Niemcy proponowali inne rozwiązanie - zawiesić udzielanie zaliczek, aż Chiny ustąpią ${ }^{193}$. Oba pomysły zastosowano, ale Yuan i nowy premier Lu Zhengxiang nie zmienili zdania. W obliczu powszechnej opozycji, zarówno społecznej, jak i ze strony parlamentu, pozostali nieugięci, nie chcieli bowiem powtórzyć fatalnego błędu, jaki książę Qing popełnił rok wcześniej, rozniecając rewolucję. Władze pekińskie bezskutecznie starały się wbić klin między rządy sześciu mocarstw a grupy, prosząc pierwsze o zaprzestanie popierania prób ustanowienia monopolu finansowego przez banki ${ }^{194}$.

190 The American Minister to the Secretary of State, June 24, 1912, [w:] PRFRUS 1912, s. 142.

191 The American Minister to the Secretary of State, July 1, 1912, [w:] PRFRUS 1912, s. 143; The American Minister to the Secretary of State, July 15, 1912, [w:] ibidem, s. 146-147. Pożyczka w wysokości 10 milionów funtów szterlingów była zdecydowanie niewystarczająca, absolutne minimum szacowano na 25 milionów. W. Straight, China's Loan Negotiations..., s. 401-404.

192 Cytat pochodzi z pierwszego dokumentu. The American Ambassador to Great Britain to the Secretary of State, June 27, 1912, [w:] PRFRUS 1912, s. 142-143; The American Minister to the Secretary of State, July 1, 1912, [w:] ibidem, s. 143; The American Ambassador to Great Britain to the Secretary of State, July 12, 1912, [w: ] ibidem, s. 145146. Także Francja była przeciwna rozluźnieniu warunków. The American Minister to the Secretary of State, July 1, 1912, [w:] ibidem, s. 143.

193 The British Chargé d'Affaires to the Secretary of State, June 30, 1912, [w: ] PRFRUS 1912, s. 143; The American Ambassador to Germany to the Secretary of State, June 29, 1912, [w:] ibidem. Francja i Wielka Brytania poparly niemiecką propozycję. The British Chargé d'Affaires to the Secretary of State, July 7, 1912, [w: ] ibidem, s. 145.

${ }_{194}$ The American Minister to the Secretary of State, July 2, 1912, [w: ] PRFRUS 1912, s. 144; The American Minister to the Secretary of State, July 9, 1912, [w:] ibidem, s. 145; The Chinese Minister to the Secretary of State, July 15, 1912, [w: ] ibidem, s. 146; The American Minister to the Secretary of State, July 15, 1912, [w:] ibidem, s. 146-147. 
Reakcja Waszyngtonu na czerwcowo-lipcowy kryzys była z początku dość umiarkowana. Calhoun trafnie przewidział przebieg wydarzeń. Zerwanie negocjacji było nieuniknione, skoro politycy chińscy nie mieli ani wystarczających wpływów, ani woli, aby podjąć decyzję wbrew opinii publicznej. Poseł nie był jednak zupełnym pesymistą, gdyż jak wyjaśnił: „dopóki francuski rynek pozostaje zamknięty, można śmiało powiedzieć, że żadna duża pożyczka nie może być wyemitowana”. Amerykańska dyplomacja raczej opowiadała się za kontynuacją dawania zaliczek, zapewne $\mathrm{z}$ obawy przed załamaniem się kruchego porządku. Zgadzała się także z Londynem, że wszystkie pożyczki dla Chin powinny zawierać gwarancje nadzoru wydatków, choć niekoniecznie finansowe pośrednictwo. Podczas rozmowy z chińskim ministrem finansów Calhoun podsumował stanowisko swojego kraju następującymi słowami: „Pragniemy tylko, aby środki z pożyczek były dokładnie pilnowane, mądrze wykorzystane i uczciwie rozliczone, tak żeby pieniądze mogły raczej pomóc Chinom, niż nałożyć na nie wysoki dług bez jakichkolwiek odpowiednich korzyści"195.

Jeśli dotychczas Stany Zjednoczone nie odgrywały czołowej roli podczas czerwcowo-lipcowego kryzysu, to zmieniło się to wraz z nieoczekiwaną deklaracją Knoxa. 18 lipca oświadczył on, że mocarstwa powinny obstawać przy swoim stanowisku, ale jeśli Pekin pozostałby niewzruszony, powinien mieć swobodę działania, aby sprostać naglącym potrzebom ${ }^{196}$. Co najmniej cztery powody legły u źródeł ruchu Knoxa. Dwa z nich zostały już wspomniane - silny opór Chin oraz obawa Stanów Zjednoczonych, że mogą wybuchnąć zamieszki, gdyby rząd pekiński nie otrzymał pieniędzy na bieżące wydatki. Rolę odgrywał też słabnący entuzjazm amerykańskiej grupy, zniechęconej przedłużającymi się pertraktacjami i rozważającej wycofanie się z konsorcjum ${ }^{197}$. Poza tym administracja Tafta była ostro krytykowana w kraju za swą chińską politykę. Opinia publiczna, napędzana przez misjonarzy, domagała się jeśli nie bezpośredniej pomocy dla nowo powstałej Republiki, to przynajmniej oficjalnego jej uznania. Amerykanie podejrzewali, że jedną z głównych przeszkód stanowiła pożyczka reorganizacyjna, ponieważ konsorcjum chciało poprzez sprawę uznania wywierać nacisk na Chiny podczas negocjacji. W rzeczywistości było w tym rozumowaniu więcej niż ziarno prawdy (kiedy w styczniu 1913 roku pojawiła się groźba rozpadu konsorcjum, Calhoun radził, że jeśliby się spełniła, należało od

195 The Acting Secretary of State to the American Ambassador to Great Britain, June 26, 1912, [w: ] PRFRUS 1912, s. 142; The American Minister to the Secretary of State, July 2, 1912, [w: ] ibidem, s. 144; The Secretary of State to the American Minister, July 2, 1912, [w: ] ibidem, s. 145. Oba cytaty pochodzą z listu amerykańskiego posła z 2 lipca.

196 The Secretary of State to American Ambassador to France, July 18, 1912, [w:] PRFRUS 1912, s. 147.

197 W. Scholes, M. Scholes, The Foreign Policies ..., s. 239. 
razu uznać władze chińskie $\left.{ }^{198}\right)$. Następstwem takiego myślenia była narastająca niechęć wobec Wall Street i pożyczki reorganizacyjnej. Gdy wzrosła presja społeczna i polityczna, gabinet Tafta stał się bardziej skłonny do zrewidowania swej postawy, zwłaszcza mając na uwadze zbliżające się wybory prezydenckie ${ }^{199}$.

Propozycja Knoxa nie spotkała się z przychylnym odzewem mocarstw ${ }^{200}$. Podobny los spotkał inną jego inicjatywę w tym czasie - uznania Republiki. Niezadowolenie społeczne i kolejne naciski w Kongresie pod koniec kwietnia skłoniły Departament Stanu do rozważenia możliwości uznania władz chińskich ${ }^{201}$. 6 maja Calhoun został poproszony o ocenienie, czy można już było to zrobić. Poseł miał wiele wątpliwości, ale ostatecznie stwierdził, że obecny rząd był „jedynym w zasięgu wzroku" i uznanie wzmocniłoby go, zwłaszcza jeśli mocarstwa uczyniłyby to wspólnie ${ }^{202}$. Taka opinia dawała dwa kolejne argumenty za tym krokiem - rząd był już na tyle stabilny, że uznanie go wydawało się zasadne, a zarazem na tyle słaby, że należało go wspomóc. Stany Zjednoczone poczekały na zakończenie sprawy z przystąpieniem Rosji i Japonii do konsorcjum (ich przyjęcie mogło zwiększyć szanse powodzenia inicjatywy) i 20 lipca zwróciły się do Francji, Niemiec, Wielkiej Brytanii, Rosji, Japonii, Włoch i Austro-Węgier z zapytaniem, czy można by już uznać Republikę Chińską. Znamienne było, że amerykańscy dyplomaci mieli w zaufaniu powiedzieć, iż ze względu na nastroje społeczne w USA Kongres będzie się najprawdopodobniej stanowczo domagać uznania, jeśli prezydent będzie z tym nadal zwlekać. Wszyscy adresaci odpowiedzieli odmownie, uzasadniając, że było jeszcze za wcześnie na taki krok ${ }^{203}$. W tej sytuacji Waszyngton, ciągle ufając w zasadność polityki współpracy, stwierdził, że trzeba przeprowadzić rodzaj testu demokratycznego, a więc poczekać, aż parlament wyłoniony w wyborach uchwali stałą konstytucję, zgodnie z którą dokonana zostanie elekcja stałego prezydenta, a rząd przestanie być tymczasowy ${ }^{204}$. Wówczas także pozostałe mocarstwa powinny zgodzić się na uznanie. Była to jednak odleglejsza perspektywa, na razie uwaga ponownie skupiła się na pożyczce reorganizacyjnej.

198 The American Minister to the Secretary of State, January 23, 1913, [w:] PRFRUS 1913, s. 147. Zob. też: Moore to Wilson, May 15, 1913, [w: ] PWW, t. 27, s. 437-440.

199 J. Reed, The Missionary Mind..., s. 131-140.

200 The American Ambassador to Germany to the Secretary of State, July 23, 1912, [w: ] PRFRUS 1912, s. 148.

201 Congressional Records ..., t. 48, s. 4868.

202 Huntington Wilson to the American Legation at Peking, May 6, 1912, KP, container 17; Calhoun to the Secretary of State, May 7, 1912, ibidem. Zob. tez: The American Minister to the Secretary of State, August 3, 1912, [w: ] PRFRUS 1912, s. 84-85.

${ }^{203}$ PRFRUS 1912, s. 81-86.

204 The Secretary of State to the American Minister, September 20, 1912, [w:] PRFRUS 1912 , s. 86. 
W negocjacjach na jej temat nadal nie było postępu, gdyż Pekin i konsorcjum nie zmieniły nastawienia. Konsorcjum raczej czekało na rozwój wydarzeń, Chiny natomiast usiłowały pożyczyć pieniądze od podmiotów z nim niezwiązanych. Początkowe efekty ich starań były mało imponujące ${ }^{205}$, ale 30 sierpnia udało im się podpisać umowę pożyczki na 10 milionów funtów szterlingów z brytyjskim syndykatem bankowym, na czele którego stał Charles Birch Crisp (tzw. pożyczka Crispa). Warunki pożyczki były mniej restrykcyjne niż te zaproponowane przez konsorcjum. Umowa zawierała również klauzulę pierwszeństwa ważną do momentu całkowitego wypłacenia pożyczki ${ }^{206}$.

Konsorcjum, jak w przypadku belgijskiej pożyczki, wystąpiło z protestem, ale według brytyjskiego posła Jordana nie miało zbytnio do tego podstaw. Whitehall, zaambarasowany całą sytuacją, próbował zablokować pożyczkę i zgodnie z wcześniejszym postanowieniem mocarstw odmówił oficjalnego jej uznania. Nie przyniosło to jednak żadnego skutku, oprócz rozpoczęcia antybrytyjskiej kampanii w prasie chińskiej ${ }^{207}$.

We wrześniu Chiny podpisały dwa inne kontrakty: $\mathrm{z}$ amerykańską firmą na 5 milionów dol. i z belgijskim przedsiębiorstwem na 250 milionów franków na budowę linii kolejowej ${ }^{208}$. Druga z umów wywołała niepokój konsorcjum, gdyż wskazywała na powrót do polityki, którą uważano za zarzuconą - przyznawania

${ }^{205}$ W lipcu Chiny pożyczyły 3 miliony taeli od niemieckiej firmy, która później otrzymała również koncesję na budowę linii tramwajowych $\mathrm{w}$ Pekinie $\mathrm{w}$ zamian za zaliczkę w wysokości 8 milionów marek. Przeciwko temu protestowały Paryż i Waszyngton. Departament Stanu odmówił też poparcia amerykańskich firm, które chciały udzielić pożyczek Chinom. The American Minister to the Secretary of State, July 22, 1912, [w:] PRFRUS 1912, s. 147; The American Minister to the Secretary of State, July 24, 1912, [w:] ibidem, s. 148; The Secretary of State to the American Minister, July 25, 1912, [w:] ibidem; The French Chargé d'Affaires to the Secretary of State, September 4, 1912, [w: ] ibidem, s. 149-150; The Acting Secretary of State to the American Ambassador to Germany, September 11, 1912, [w:] ibidem, s. 150.

${ }^{206}$ Doc. no. 1912/9: Great Britain (G. Birch Crisp \& Company) and China. Agreement for the Chinese Government five per cent Gold Loan of 1912, August 30, 1912, [w:] Treaties and Agreements ..., s. 967-972.

207 The American Minister to the Secretary of State, August 10, 1912, [w:] PRFRUS 1912, s. 149; The American Ambassador to Great Britain to the Secretary of State, September 19, 1912, [w:] ibidem, s. 152; The American Minister to the Secretary of State, September 25, 1912, [w: ] ibidem; W. Scholes, M. Scholes, The Foreign Policies ..., s. 240; Ch. Vevier, The United States and China ..., s. 203.

${ }^{208}$ Doc. no. 1912/11: Belgium (Compagnie Générale de Chemins de Fer et de Tramways en Chine) and China. Contract for a loan for the construction of a railway from Lanchow to Haichow, September 24, 1912, [w:] Treaties and Agreements ..., s. 976-991; The American Minister to the Secretary of State, September 27, 1912, [w:] PRFRUS 1912, s. 153; The American Minister to the Secretary of State, October 5, 1912, [w:] ibidem, s. 157. 
koncesji zamiast brania pożyczek wprost. Bankierzy obawiali się, że może to zwiastować nowy etap walk o koncesje $\mathrm{e}^{209}$.

Konsorcjum starało się przeciwdziałać tym umowom, korzystając z różnych dostępnych ścieżek. Najpierw protestowało, domagając się anulowania pożyczki Crispa. Brytyjczycy zwrócili się w tej sprawie do Yuana, wykorzystując swoje bardzo dobre z nim kontakty, lecz nic nie zdziałali, ponieważ był nieustępliwy, po części z powodu nadchodzących wyborów parlamentarnych ${ }^{210}$. Pojawiła się także propozycja, aby wywrzeć nacisk poprzez żądanie zwrotu zaliczek dotychczas udzielonych lub przypomnienie Pekinowi o wcześniejszych pożyczkach i międzynarodowych zobowiązaniach ${ }^{211}$. Rozważano również przeciwne rozwiązanie. Brytyjska grupa nalegała na wznowienie negocjacji i postawienie tym razem łagodniejszych warunków. Negocjacje rzeczywiście wznowiono, lecz szybko znalazły się w ślepym zaułku. 21 września Chiny przedstawiły swoją propozycję, która została odrzucona i nastąpiło kolejne zerwanie rozmów ${ }^{212}$.

Pożyczka Crispa oraz upór Chin wywołały niepokój i pośpiech wśród brytyjskich polityków i bankierów ${ }^{213}$, którzy opowiedzieli się za uczynieniem jeszcze jednego wysiłku, aby osiągnąć porozumienie. Odeszli oni od stanowiska wyrażonego w lipcu, twierdząc obecnie, że zmniejszenie sumy pożyczki usprawiedliwiałoby złagodzenie warunków. Postrzegali ostatnią chińską propozycję jako dość

209 The American Minister to the Secretary of State, October 22, 1912, [w:] PRFRUS 1912, s. $157-159$.

210 The American Ambassador to Great Britain to the Secretary of State, September 26, 1912, [w:] PRFRUS 1912, s. 153; The British Chargé d'Affaires to the Secretary of State, September 28, 1912, TP, series 6: case files, 102, reel 366; K.C. Chan, British Policy..., s. 367.

211 The American Minister to the Secretary of State, September 25, 1912, [w: ] PRFRUS 1912, s. 152; The Acting Secretary of State to the American Minister, September 26, 1912, [w: ] ibidem, s. 152-153; D.M. Crane, T.A. Breslin, An Ordinary Relationship ..., s. 95. Również Yuan chciał wywrzeć nacisk na konsorcjum i groził, że zrezygnuje, jeśli nie otrzyma pieniędzy. K.C. Chan, British Policy..., s. 367.

212 The Acting Secretary of State to the American Ambassador to France, September 17, 1912, [w:] PRFRUS 1912, s. 151; The British Chargé d'Affaires to the Secretary of State, September 28, 1912, TP, series 6: case files, 102, reel 366; W. Scholes, M. Scholes, The Foreign Policies ..., s. 241. Straight twierdzil, że Chiny przedstawiły swoje warunki 23 września. W. Straight, China's Loan Negotiations ..., s. 397.

213 Takie nastawienie wynikało m.in. z faktu, że różne brytyjskie banki naciskały na Foreign Office, aby dopuściło je do brytyjskiej grupy, w której był tylko Hongkong and Shanghai Bank. Ten ostatni, świadomy żądań konkurentów, skłonny był złagodzić warunki i kontynuować negocjacje. The American Minister to the Secretary of State, September 25, 1912, [w:] PRFRUS 1912, s. 152; The Acting Secretary of State to the Ambassador of Great Britain, October 4, 1912, [w:] ibidem, s. 154-157; W. Scholes, M. Scholes, The Foreign Policies ..., s. 240-241. 
sensowną i żałowali, że została odrzucona bez gruntownego namysłu. Konsorcjum powinno ich zdaniem jeszcze raz przemyśleć decyzję i podjąć ostatnią próbę porozumienia się z Pekinem. Jeśli kompromis okazałby się niemożliwy, negocjacje należało całkowicie zakończyć, a wówczas Chiny powinny móc swobodnie czynić inne ustalenia finansowe ${ }^{214}$. Ta ostatnia sugestia była zbieżna $\mathrm{z}$ lipcową propozycją Knoxa.

Niepokój i pośpiech Brytyjczyków nie znalazł zrozumienia nad Potomakiem. Huntington Wilson spokojnie wyjaśnił, że na tym właśnie polegają negocjacje, iż odrzuca się pewne propozycje i formułuje inne. Nie widział powodu do uderzania w tak dramatyczny ton i wzywania do ostatniego wysiłku, aby „uratować sytuację". Nie uważał za zasadne rozluźnienie warunków lub zarzucenie dotychczasowej polityki. Ostatnia chińska propozycja, choć nie idealna, stanowiła znaczący krok naprzód i mogła się stać punktem wyjścia do wznowienia negocjacji. Huntington Wilson był raczej optymistą co do ich wyniku, lecz uważał, że suma pożyczki nie powinna wpływać na podstawowe zasady i szczegółowe rozwiązania, które konsorcjum zaakceptowało. W jego przekonaniu można było rozważyć każdą propozycję, która przewidywała odpowiedni nadzór wydatków ${ }^{215}$.

Odmienną optykę, zwłaszcza po zawarciu belgijskiego kontraktu, prezentował Calhoun. Chiny były jego zdaniem niechętne do współpracy, chciały pieniędzy, ale bez jakiejkolwiek kontroli. Bankierzy spoza konsorcjum mogli im udzielić pożyczek bez odpowiednich zabezpieczeń, ale była to polityka krótkowzroczna. Gdyby były one wystarczająco duże, aby zaspokoić potrzeby Chin, nie byłoby według posła powodu do narzekania. Ale nie były, i w końcu Chiny będą musiały się zgodzić na warunki grup. Niestety, do tego czasu będą poważnie zadłużone i „zdemoralizowane” przez zbyt łagodne warunki. Co gorsza, ten scenariusz mógł się nawet nie ziścić, gdyż konsorcjum mogło się wcześniej rozpaść. Calhoun ostrzegał, że: „Jeśli obecny impas będzie trwał znacznie dłużej, jeśli inne koncesje - jak ta dana Belgom - zostaną przyznane, i jeśli inne pożyczki - jak ta udzielona przez londyński syndykat - dojdą do skutku, więź, która trzyma grupy razem, pęknie i nastąpi ich rozwiązanie"216. Chociaż przypuszczenia Huntingtona Wilsona i Calhouna wydawały się wykluczające, oba zaczęły się z czasem spełniać.

214 The British Chargé d'Affaires to the Secretary of State, September 28, 1912, TP, series 6: case files, 102, reel 366 .

215 The Acting Secretary of State to the Ambassador of Great Britain, October 4, 1912, [w:] PRFRUS 1912, s. 154-157; Huntington Wilson to the President, October 5, 1912, TP, series 6: case files, 102, reel 366. Cytat pochodzi z pierwszego dokumentu.

216 The American Minister to the Secretary of State, October 22, 1912, [w:] PRFRUS 1912, s. 157-159. Calhoun przewidywał wcześniej, że konsorcjum zostanie rozwiązane, ponieważ Chiny wszystkie swoje dochody dadzą jako zabezpieczenie pożyczek od innych banków. The American Minister to the Secretary of State, September 25, 1912, [w:] ibidem, s. 152. 
Podczas gdy konsorcjum robiło postępy w negocjacjach, niektórzy z jego członków poważnie zastanawiali się nad wycofaniem.

Pod koniec października Pekin poinformował konsorcjum, że był gotowy wypowiedzieć umowę z Crispem i przystąpić do negocjacji z grupami. Zmiana polityki wynikała przede wszystkim z faktu, że syndykat Crispa nie był w stanie dostarczyć obiecanych funduszy. Swoją rolę odegrała też presja wywierana przez grupy i mocarstwa. Konsorcjum przyjęło inicjatywę Chin pozytywnie i w listopadzie powróciło do negocjacji ${ }^{217}$. Na wstępie trzeba było uregulować dwie sprawy. Po pierwsze, anulować pożyczkę Crispa, co uczyniono ostatecznie 23 grudnia ${ }^{218}$. Po drugie, konsorcjum chciało otrzymać zapewnienie, że sytuacja się nie powtórzy. We wspólnym liście z 11 listopada premier, minister spraw zagranicznych i minister finansów Chin zobowiązali się negocjować wyłącznie z konsorcjum ${ }^{219}$. Można było wówczas przejść do najtrudniejszego zadania - wypracowania porozumienia akceptowalnego dla obu stron. 21 grudnia konsorcjum przedstawiło swoje warunki. Pożyczka reorganizacyjna miała opiewać na 25 milionów funtów szterlingów i być zabezpieczona dochodami z podatku solnego. Nadzór byłby zapewniony przez centralną administrację podatku solnego, biuro audytu, departament długów państwowych (dla wszystkich zagranicznych pożyczek) i departament pożyczki (tylko dla pożyczki reorganizacyjnej), w których zatrudnieni zostaliby cudzoziemscy doradcy ${ }^{220}$. Chiny i niektóre z grup nie były jednak usatysfakcjonowane warunkami i nastąpiła kolejna przerwa w negocjacjach.

Dla rządu amerykańskiego kwestie te miały mniejsze znaczenie, ponieważ zajmowały go wydarzenia krajowe. W listopadzie Taft przegrał w wyborach z kandydatem Partii Demokratycznej Thomasem Woodrowem Wilsonem. Przez pozostałe kilka miesięcy urzędowania jego administracja była $\mathrm{w}$ polityce zagranicznej mniej aktywna. W odniesieniu do Chin dążyła do sfinalizowania pożyczki przed końcem swej kadencji, upływającej 4 marca 1913 roku. Okazało się to jednak trudne, nie tylko ze względu na ciągłe klincze w negocjacjach, ale również ze względu na wzrastającą chęć amerykańskiej grupy do wycofania się z konsorcjum. Jej rozczarowanie wyraził Straight pod koniec grudnia: „Do chwili obecnej rezultaty ograniczały się $\mathrm{w}$ dużej mierze do słowa pisanego i oracji. Wierzę, że

217 Introductory Note, [w:] PRFRUS 1913, s. 143-144; W. Scholes, M. Scholes, The Foreign Policies..., s. 243.

${ }_{218}$ Doc. no. 1912/9: Great Britain (G. Birch Crisp \& Company) and China. Agreement for the Chinese Government five per cent Gold Loan of 1912, August 30, 1912, [w:] Treaties and Agreements ..., s. 967-972; Doc. no. 1913/5: Note 3: Letter from Mr. Chou Hsueh Hsi to Mr. Hillier (handed to Mr. Hillier personally by Minister of Finance at signing of Loan Agreement), April 26, 1913, [w:] ibidem, s. 1034-1035. Za anulowanie umowy Chiny zapłacily odszkodowanie w wysokości 150 tysięcy funtów szterlingów.

219 Introductory Note, [w: ] PRFRUS 1913, s. 143-144.

220 Ibidem; K.C. Chan, British Policy..., s. 368. 
pewnego dnia będziemy mieli coś do zaproponowania oprócz pustosłowia i nadziei”. Departamentowi Stanu udało się na razie przekonać bankierów do pozostania, ale ich entuzjazm zdecydowanie gasł ${ }^{221}$.

Na przełomie 1912 i 1913 roku dwie kolejne przeszkody opóźniały negocjacje. Pierwszą przezwyciężono stosunkowo szybko. Francja domagała się, aby z pożyczki reorganizacyjnej zrekompensowane zostały straty poniesione przez cudzoziemców podczas rewolucji Xinhai. Posłowie w Pekinie odradzili to, twierdząc, że nie znano jeszcze wysokości roszczeń, wiele z nich było wyolbrzymionych lub bezzasadnych, nie w każdym przypadku ustalono odpowiedzialność, a w ogóle rozważana pożyczka nie wystarczyłaby na pokrycie pierwotnych celów i nowych zobowiązań. Zdecydowano, że francuscy i japońscy dyplomaci porozmawiają na ten temat z ministrem spraw zagranicznych Chin. Chociaż Calhoun miał wątpliwości, czy przyniesie to skutek, rząd pekiński uznał swoją odpowiedzialność za straty, ale ograniczyl je do poniesionych na obszarze operacji wojskowych ${ }^{222}$.

Drugą kwestią, która przedłużała negocjacje i zagroziła nawet istnieniu konsorcjum, był wybór zagranicznych doradców. Pekin niechętnie zgodził się ich zatrudnić, ale sam chciał ich wyznaczyć. 4 lutego poinformował nieoficjalnie mocarstwa, że zamierzał mianować Duńczyka głównym inspektorem centralnej administracji podatku solnego, Niemca dyrektorem biura długu państwowego oraz Włocha doradcą $\mathrm{w}$ departamencie audytu ${ }^{223}$. Liczba stanowisk i narodowość kandydatów zostały szybko zakwestionowane przez niektóre mocarstwa, głównie Francję i Rosję. Od jakiegoś już czasu Francuzi optowali za sześcioma doradcami, po jednym dla każdego z mocarstw pożyczkodawców. Pomysł poparła Rosja, ale sprzeciwiły mu się Wielka Brytania i w pewnym stopniu Stany Zjednoczone ${ }^{224}$.

${ }^{221}$ Straight to the President, December 26, 1912, TP, series 6: case files, 102, reel 366. Zob. też: Straight to Knox, December 26, 1912, KP, container 20; Straight to Knox, January 9, 1913, ibidem; Ch. Vevier, The United States and China ..., s. 204-205; D.M. Crane, T.A. Breslin, An Ordinary Relationship ..., s. 106-107.

222 The American Minister to the Secretary of State, December 30, 1912, [w:] PRFRUS 1913, s. 144-145; The American Minister to the Secretary of State, January 21, 1913, [w: ] ibidem, s. 147.

${ }^{223}$ The American Minister to the Secretary of State, December 30, 1912, [w: ] PRFRUS 1913, s. 144-145; The American Minister to the Secretary of State, January 21, 1913, [w:] ibidem, s. 147; The American Minister to the Secretary of State, February 4, 1913, [w:] ibidem, s. 151.

${ }^{224}$ The American Minister to the Secretary of State, January 21, 1913, [w: ] PRFRUS 1913, s. 147; The American Minister to the Secretary of State, January 29, 1913, [w:] ibidem, s. 149; The American Ambassador to France to the Secretary of State, January 30, 1913, [w:] ibidem, s. 149-150; The American Minister to the Secretary of State, February 10, 1913, [w:] ibidem, s. 154-155; The American Ambassador to France to the Secretary of State, February 14, 1913, [w:] ibidem, s. 157-158. 
Kiedy Pekin ujawnił swoje nominacje, Waszyngton zasugerował, aby obywateli państw nienależących do konsorcjum zastąpić przedstawicielami Wielkiej Brytanii i Francji. Co zrozumiałe, Quai d'Orsay i Foreign Office odebrały to przychylnie, lecz wkrótce chciały dołączyć rosyjskiego doradcę, który razem z francuskim kierowałby departamentem audytu i rachunkowości, brytyjski z kolei stałby na czele administracji podatku solnego, a niemiecki zgodnie z pierwotnym planem zarządzałby biurem długu państwowego. Podział stanowisk oprotestowały Niemcy, Stany Zjednoczone i Chiny. Jednakże w obliczu niesłabnących nalegań członków trójporozumienia i w mniejszym stopniu Japonii, jego nieco zmodyfikowana wersja, w której Niemcy zyskały urząd zastępcy inspektora generalnego podatku solnego, została ostatecznie zaakceptowana w marcu ${ }^{225}$.

W sprawie doradców USA zajęły ugodowe stanowisko. Najważniejsze było dla nich jak najszybsze znalezienie kompromisu i niepozwolenie, aby doszło do nadmiernego przedłużenia czy zerwania negocjacji. Dlatego naciskały na zawarcie niezwłocznego porozumienia, a same odrzuciły propozycję, by Amerykanin zostałjednym z doradców, przynajmniej dopóki miało być ich trzech. Chociaż Waszyngton uważał, że kwalifikacje doradców były istotniejsze niż ich narodowość, zgodził się na zastąpienie kandydatów z państw neutralnych przedstawicielami pożyczkodawców. Popierał różne konfiguracje z trzema doradcami (Duńczyk, Niemiec, Włoch; Niemiec, Francuz, Brytyjczyk; Duńczyk, Niemiec, Francuz) i oponował przeciwko dodaniu czwartego (Rosjanina), widząc w tym niepokojącą intruzję czynnika politycznego. Zorientowawszy się, że wszystkie mocarstwa, z wyjątkiem Niemiec, zdecydowanie wolały to ostatnie rozwiązanie, zaakceptował je bez entuzjazmu ${ }^{226}$.

Dojście do porozumienia wewnątrz konsorcjum stanowiło tylko połowę sukcesu, trzeba było następnie sprawić, aby Chiny je przyjęły. Pekin sprzeciwiał się zaś zwiększeniu liczby doradców. Był również niezadowolony, że grupy odmówiły udzielenia kolejnej zaliczki, która była mu niezbędna do spłacenia należności przed chińskim Nowym Rokiem, przypadającym 6 lutego. Bankierzy nie spełnili jednak jego prośby o przekazanie w styczniu 2 milionów funtów szterlingów, zamierzając najpierw ułożyć inne sprawy. Skłoniło to Chiny do zerwania $\mathrm{z}$ konsorcjum i szukania pieniędzy z innych źródeł ${ }^{227}$. W celu

225 PRFRUS 1913, s. 151-170. Niemcy chciały się wymienić stanowiskami z Wielką Brytanią, ale ta odmówiła. Aby jednak zaspokoić Berlin, Londyn zaproponowal stworzenie kolejnego urzędu - zastępcy inspektora w Szanghaju, który przypadłby Niemcom. W tej sprawie Stany Zjednoczone stwierdziły, że zaakceptują zmiany, jeśli pozostałe mocarstwa i Chiny zrobią tak samo.

226 PRFRUS 1913, s. 151-167.

227 The American Minister to the Secretary of State, January 21, 1913, [w:] PRFRUS 1913, s. 146-147; The American Minister to the Secretary of State, January 23, 1913, [w: ] ibidem, s. 147; The British Ambassador to the Secretary of State, February 5, 1913, [w: ] ibidem, s. 151-152; The Minister of Finance of China to the Sextuple Group, March 11, 1913, [w: ] ibidem, s. 169-170. 


\section{Chiny w polityce zagranicznej Stanów Zjednoczonych w latach 1911-1918}

zablokowania takiej transakcji i zmuszenia Chin do wyrażenia zgody na czterech doradców Rosja chciała domagać się, aby wszelkie pieniądze otrzymane spoza konsorcjum zostały w pierwszej kolejności przeznaczone na spłatę kontrybucji „bokserskiej”, którą w tym czasie odroczono ${ }^{228}$. Waszyngton odrzucił tę propozycję, twierdząc, że podniesienie nowego wątku mogłoby jeszcze bardziej opóźnić zawarcie umowy na pożyczkę reorganizacyjną ${ }^{229}$. W instrukcji dla poselstwa w Pekinie Knox wyjaśnił również, że on i Wall Street zawsze uważali, iż Chiny powinny móc swobodnie decydować, czy chciały podpisać umowę. Sekretarz stanu polecił, aby poselstwo jasno zakomunikowało przedstawicielom innych państw, że Stany Zjednoczone nie przyłączą się do żadnych „kroków represyjnych” obliczonych na przymuszenie Chin do zaakceptowania warunków pożyczki ${ }^{230}$.

Wspomniana prośba Chin o zaliczkę doprowadziła do rozdźwięku wewnątrz konsorcjum. Wielka Brytania i Niemcy wyraziły gotowość do przekazania pieniędzy i podpisania kontraktu pożyczkowego, niezależnie nawet od stanowiska pozostałych państw. Konsorcjum znalazło się na skraju rozłamu, ale kryzys został zażegnany, gdy Wielka Brytania pod naciskiem swoich sojuszników porzuciła Niemcy i przyłączyła się do Francji, Rosji i Japonii. Amerykańscy politycy i bankierzy nie widzieli powodu do alarmu, ponieważ wszystkie sześć grup mogło partycypować w zaliczce, nawet jeśli dałyby ją dwie z nich ${ }^{231}$.

Na początku 1913 roku amerykańscy dyplomaci kilkakrotnie sygnalizowali możliwość rozpadu konsorcjum ${ }^{232}$. Calhoun niepokoił się wzrostem wpływu europejskich konfliktów i aliansów na sytuację dalekowschodnią. „Wiele wskazuje na to, że toczy się wielka dyplomatyczna gra, która może [...] mieć odzwierciedlenie tutaj” - skomentował 9 lutego. Nieco później dodał: „Moim zdaniem nie jest to już kwestia przyjaznej międzynarodowej współpracy, aby pomóc Chinom, ale połączenie mocarstw ze wspólnymi interesami, aby osiągnąć samolubne cele polityczne”. Calhoun chciał wesprzeć Państwo Środka i ciągle wierzył, że dzięki pożyczce reorganizacyjnej można było ustabilizować panującą tam niepewną sytuację. To z kolei mogło zapobiec obcej interwencji, która stawała się zdaniem

228 The American Ambassador to Russia to the Secretary of State, February 15, 1913, [w:] PRFRUS 1913, s. 158-159; The Russian Ambassador to the Secretary of State, February 19, 1913, [w: ibidem, s. 162-163. Zob. także: Scott to Wilson, May 31, 1913, [w: ] PWW, t. 27, s. 488-490.

229 The Secretary of State to the Russian Ambassador, February 26, 1913, [w: ] PRFRUS 1913, s. 165.

230 The Secretary of State to the American Chargé d'Affaires, February 27, 1913, [w: ] PRFRUS 1913, s. 166-167.

231 PRFRUS 1913, s. 147-148, 151-153, 156, 159-160, 163-164.

232 PRFRUS 1913, s. 147, 149-151, 154-156, 159-160. 
posła coraz bardziej prawdopodobna ${ }^{233}$. Wątpliwości Amerykanów co do losu konsorcjum wzmogli Niemcy, którzy podejrzewali, że Rosja (główny winowajca) i Francja rozmyślnie starały się doprowadzić do jego upadku, aby stworzyć nowe zrzeszenie, tym razem już bez udziału Niemiec i Stanów Zjednoczonych ${ }^{234}$.

Pesymistycznej wizji nie podzielał Knox, który pod koniec lutego napisał, że:

trudności w negocjacjach na temat pożyczki nie muszą być tak poważne, jak wskazywałyby na to niektóre raporty rozpatrywane pojedynczo. [...] Sugestia ukrytych motywów i celowych starań, by utrudnić negocjacje, o jakich wspominają pewne raporty, nie wydaje się być potwierdzona przez bezstronną analizę całej korespondencji. Przeciwnie, $[\ldots]$ stanowisko rządów $[. .$.$] wydaje się wyjątkowo praktycz-$ ne, szczere i przekonujące ${ }^{235}$.

Odmienność ocen mogła wynikać z faktu, że Knox miał szerszą, bardziej obiektywną perspektywę, a dyplomaci w Pekinie byli bezpośrednio zaangażowani w negocjacje i naocznie widzieli, jak Chiny zmagały się z problemami podczas burzliwego okresu.

Wydaje się, że na początku 1913 roku Waszyngton przyjął konsensową postawę, ponieważ chciał jak najszybciej zakończyć negocjacje ${ }^{236}$. Kadencja gabinetu Tafta dobiegała końca, a przeszkody ciągle się piętrzyły - niepokoje w Chinach, dyplomatyczne przepychanki między mocarstwami oraz rosnąca determinacja amerykańskiej grupy, aby wycofać się z konsorcjum. Przeciągające się negocjacje, niekorzystne warunki na rynku krajowym i ostatnia wyraźniejsza ingerencja czynnika politycznego coraz bardziej zniecierpliwiły i rozczarowały bankierów, ale Knox przekonał ich do wstrzymania się z jakąkolwiek decyzją do momentu objęcia władzy przez nową administrację, aby nie wprawić ustępującej w zakłopotanie ${ }^{237}$. Starania, by podpisać umowę na pożyczkę reorganizacyjną przed

${ }^{233}$ The American Minister to the Secretary of State, January 21, 1913, [w: ] PRFRUS 1913, s. 146-147; The American Minister to the Secretary of State, February 9, 1913, [w:] ibidem, s. 152-153; The American Minister to the Secretary of State, February 10, 1913, [w:] ibidem, s. 154-155; The American Minister to the Secretary of State, February 17, 1913, [w:] ibidem, s. 159-160; The American Minister to the Secretary of State, February 21, 1913, [w: ibidem, s. 163-164. Cytaty pochodzą z dokumentów z 9 i 21 lutego.

${ }^{234}$ The American Minister to the Secretary of State, February 9, 1913, [w:] PRFRUS 1913 , s. $152-153$.

${ }^{235}$ The Secretary of State to the American Chargé d'Affaires, February 27, 1913, [w: ] PRFRUS 1913, s. 166-167.

${ }^{236}$ Amerykańscy bankierzy stawiali z kolei w tym czasie raczej twarde warunki. D.M. Crane, T.A. Breslin, An Ordinary Relationship ..., s. 99-108.

237 The Secretary of State to the American Minister, February 20, 1913, [w:] PRFRUS 1913, s. 163; Ch. Vevier, The United States and China ..., s. 204-207; D.M. Crane, T.A. Breslin, An Ordinary Relationship ..., s. 106-107; W. Scholes, M. Scholes, The Foreign 
zmianą w Białym Domu, okazały się daremne i sprawą zajęła się już administracja Wilsona. To samo stało się z kwestią uznania Republiki Chińskiej, którą na początku 1913 roku Departament Stanu, mimo niemal nieustających nacisków społecznych i politycznych, nie chciał się już zajmować238.

Trwanie Waszyngtonu przy wspólpracy z mocarstwami w sprawie uznania i pożyczki reorganizacyjnej rozczarowało część Chińczyków, którzy liczyli na większą życzliwość. USA starały się podtrzymać wizerunek „przyjaciela” Chin na innych polach, wspierając różne inicjatywy edukacyjne i dobroczynne swoich obywateli w Chinach, na przykład walkę z głodem i powodziami ${ }^{239}$.

Amerykańska dyplomacja kontynuowała również swe zaangażowanie w kampanię przeciwko opium. Między innymi dzięki jej wysiłkom doszło do zwołania I Międzynarodowej Konferencji Opiumowej, która obradowała w Hadze na przełomie lat 1911 i 1912. Dotychczasowy wkład Stanów Zjednoczonych w całą sprawę został symbolicznie doceniony, gdyż przewodniczącym konferencji wybrano ich delegata - biskupa Charlesa Brenta, który wcześniej stał na czele komisji szanghajskiej. Sama konferencja, w znacznej mierze w wyniku starań amerykańskiej delegacji, zakończyła się przyjęciem przez dwanaście uczestniczących państw Międzynarodowej Konwencji Opiumowej, która nakładała różne zakazy i ograniczenia dotyczące wytwarzania, handlu i używania opium, jak i - choć mniej restrykcyjne - dotyczące morfiny, heroiny i kokainy. Sygnatariusze zobowiązali się pomóc Chinom w walce z narkotykami i zwalczać je w cudzoziemskich settlementach, koncesjach i dzierżawach. Mniej korzystnie wyglądała natomiast kwestia ratyfikacji porozumienia. Zdecydowano, że zanim do niej dojdzie, wszystkie państwa europejskie i amerykańskie (w sumie 34), które nie uczestniczyły w konferencji, zostaną zaproszone do podpisania konwencji. Jeśli nie udałoby się uzyskać ich zgody do końca 1912 roku, kolejne spotkanie miało

Policies..., s. 245; Tien-yi Li, Woodrow Wilson's China Policy, 1913-1917, Kansas City 1952, s. 32-33. Niektóre z pozostałych grup także rozważały wycofanie się z konsorcjum podczas negocjacji. K.C. Chan, British Policy ..., s. 366, 369-370; W. Scholes, M. Scholes, The Foreign Policies ... , s. 236-237.

238 Memorandum on the recognition of the "Republican Government of China", undated, [w: ] PRFRUS 1913, s. 88-92; Congressional Records, 62 Cong., 3 sess., t. 49, Washington 1913, s. 914-915; M.E. Cameron, American Recognition Policy ..., s. 221-225.

239 Halford to Hilles, January 22, 1912, TP, series 6: case files, 397, reel 383; Jusserand à Poincaré, 30 janvier 1912, [w: ] DDF, $3^{\mathrm{e}}$ série, t. 1, s. 573-574; Mooser to the President, February 11, 1912, TP, series 6: case files, 2720, reel 435; Mooser to the President, February 13, 1912, ibidem; Hilles to Mooser, February 13, 1912, ibidem; Mooser to the President, February 16, 1912, ibidem; Mages to Forster, February 17, 1912, ibidem; Boardman to Hilles, February 26, 1912, ibidem; Boardman to the President, October 14, 1912, TP, series 6: case files, 397, reel 383; Huntington Wilson to the President, October 25, 1912, ibidem; Davis to the President, December 16, 1912, TP, series 6: case files, 2720, reel 435. 
zostać zwołane w Hadze, aby ustalić, jak dalej postępować z ratyfikacją. Waszyngton był początkowo przeciwny temu rozwiązaniu, obawiając się, że skomplikuje ono proces zatwierdzania konwencji, ale później uznał, że może pomóc skonsolidować międzynarodową współpracę.

Po zakończeniu konferencji Stany Zjednoczone nie przestały być jednym z głównych motorów napędowych ruchu przeciwko opium. Chociaż to rząd holenderski miał wystąpić do 34 państw z prośbą o podpisanie konwencji, amerykańska dyplomacja uzgodniła z nim, że wystara się o zgody państw Ameryki Łacińskiej. Jej działania okazały się skuteczne, ponieważ oprócz Peru, które w ogóle nie odpowiedziało na apel, pozostałe kraje amerykańskie zgodziły się lub zobowiązały się to zrobić w najbliższej przyszłości. Jednak brak akceptacji konwencji przez wszystkie założone państwa (głównie europejskie) w wyznaczonym czasie sprawił, że zwołana została II Międzynarodowa Konferencja Opiumowa, która odbyła się już za prezydentury Woodrowa Wilsona ${ }^{240}$.

W latach 1911-1913 Chiny pozostawały ważnym państwem dla Stanów Zjednoczonych. Podczas rewolucji Xinhai i w pierwszym roku funkcjonowania Republiki Chińskiej administracja Tafta prowadziła aktywną politykę w Chinach, bacznie obserwując dziejowe przemiany oraz podejmując szereg działań i inicjatyw dyplomatycznych. Dopiero porażka w wyborach prezydenckich zmniejszyła jej zaangażowanie. Rozwój sytuacji w Chinach zaczął się też cieszyć stosunkowo dużym zainteresowaniem opinii publicznej w USA, zapewne największym od czasu powstania „bokserów”. Większość Amerykanów krytykowała jednak postępowanie swojego rządu wobec Chin, dlatego też przeciwnicy z Partii Demokratycznej atakowali go właśnie na tym polu, licząc, że przysporzy im to zwolenników.

Pod koniec urzędowania i niedługo po opuszczeniu Białego Domu Taft i Knox z pełnym przekonaniem bronili swej polityki wobec Chin. Używali przy tym nierzadko górnolotnych stwierdzeń - Taft pisał na przykład, że „pomagając Chinom, mogliśmy pomóc cywilizacji świata”, Knox z kolei nie zawahał się skonstatować, że dolary wypełniały na Dalekim Wschodzie „szlachetne obowiązki moralne"241. Czy rzeczywiście przyjęta przez nich strategia była słuszna i, co może istotniejsze, czy była skuteczna? Wydaje się, że w obu przypadkach można odpowiedzieć twierdząco. Trzeba jednak zaznaczyć, że chińska polityka administracji Tafta nie była cały czas taka sama, lecz podlegała zmianom, między innymi w wyniku zmieniających się uwarunkowań w samych Chinach i na arenie międzynarodowej. Te zaś od drugiej połowy 1911 roku zaczęły kształtować

240 Fragment na podstawie: PRFRUS 1912, s. 182-224; PRFRUS 1913, s. 215-283.

241 Interview with the Honorable Philander C. Knox, Secretary of State, 1912 [brak daty dziennej], KP, container 29; Taft to the Membership Committee of the University Club, September 7, 1913, TP, series 8, reel 519. 
się mniej pomyślnie. Wcześniej Departament Stanu dążył do rozwijania wpływów politycznych i ekonomicznych poprzez zwiększenie zaangażowania amerykańskich inwestorów, osłabienie pozycji innych mocarstw i wzmocnienie Chin. Dwa czynniki były wtedy w miarę pewne - zainteresowanie biznesmenów oraz sytuacja wewnętrzna Chin, a ponadto można było liczyć na większą przychylność niektórych mocarstw. Rewolucja Xinhai i inne wydarzenia z lat 1911-1913 zmieniły ten układ. Okres samej rewolucji stanowil przerwę w „dyplomacji dolarowej”, która znalazła się wówczas w zawieszeniu. Trzeba było podejmować inne, doraźne działania, aby chronić swoje interesy i osłonić Chiny przed ingerencją z zewnątrz w oczekiwaniu na rozstrzygnięcie wojny domowej.

Po ustaniu walk perspektywy nadal nie przedstawiały się szczególnie obiecująco. Brak stabilizacji osłabiał Chiny, mógł ośmielić mocarstwa do agresji oraz zniechęcał amerykańskich inwestorów, którzy w dodatku, podobnie zresztą jak sam rząd, byli coraz ostrzej krytykowani w kraju. Co gorsza, narastające napięcie między mocarstwami europejskimi (np. kryzys agadirski, I wojna bałkańska) sprawiało, że jeszcze istotniejszego znaczenia nabierały powiązania sojusznicze, co w przypadku Dalekiego Wschodu oznaczało większe przyzwolenie Wielkiej Brytanii i Francji na działania bardziej agresywnie usposobionych Rosji i Japonii. Z tych powodów chińska polityka administracji Tafta nie mogła być już tak ofensywna jak wcześniej, musiała przybrać bardziej defensywny charakter. Nastąpiło przewartościowanie podstawowych założeń - należało skoncentrować się na bronieniu swojego stanu posiadania i wzmocnieniu Chin, nie zaś na atakowaniu pozycji innych mocarstw.

W ogólnym rozrachunku Departamentowi Stanu udało się nawet całkiem zręcznie wyjść z trudnego położenia. Nierzadko odgrywał on rolę moderującą, przekonał amerykańską grupę do pozostania w konsorcjum oraz przynajmniej próbował skłonić inne mocarstwa do przyśpieszenia uznania nowych władz pekińskich. Chiny, wspierane przez konsorcjum, nie pogrążyły się w chaosie, a na ich czele nadal stał popierany przez USA Yuan. Mocarstwa utrzymały wspólny front, zacieśniając nawet współpracę w wyniku przyjęcia Rosji i Japonii do konsorcjum. To ostatnie nie rozpadło się i mimo różnych komplikacji kontynuowało negocjacje na temat pożyczki reorganizacyjnej, które zbliżały się do końca. Również sprawa uznania nie wydawała się aż tak odległa, skoro w Chinach odbyły się już wybory i lada moment miał się zebrać stały parlament. Zasadnicze kwestie układały się zatem dla Waszyngtonu w miarę przychylnie, a on sam zachował możliwość manewru. Pozostaje jeszcze pytanie: czy idąc inną drogą, można było osiągnąć więcej? Odmienna ścieżka, jak pokazał rząd Wilsona, istniała, ale efekty podążania nią były mniej korzystne.

Cztery lata prowadzenia „dyplomacji dolarowej” w Chinach kończyły się jednak bez spektakularnych sukcesów. W połowie 1912 roku Stany Zjednoczone zaakceptowały nawet, że Mandżuria, o którą wcześniej tak chciały walczyć, 
znajdowała się właściwie poza zasięgiem ich gospodarczej penetracji. Mimo tego niepowodzenia nie poniosły one porażki - wywalczyły sobie miejsce wśród mocarstw prowadzących interesy w Chinach właściwych i - co może nawet ważniejsze - pokazały zainteresowanie rynkiem chińskim, próbując częściowo zasypać przepaść między głoszonymi hasłami a faktycznym zaangażowaniem. Jak pisał Knox: „nasza dalekowschodnia polityka została «sprowadzona na ziemię»"242. Za sprawą administracji Wilsona szybko miała się ponownie znaleźć w obłokach.

242 Interview with the Honorable Philander C. Knox, Secretary of State, 1912 [brak daty dziennej], KP, container 29. 



\section{ROZDZIAE III}

\section{CHIŃSKA POLITYKA ADMINISTRACJI THOMASA WOODROWA WILSONA DO WYBUCHU I WOJNY ŚWIATOWEJ (MARZEC 1913 ROKU - SIERPIEŃ 1914 ROKU)}

W polityce Stanów Zjednoczonych wobec Chin nastąpity znaczące zmiany, gdy 4 marca 1913 roku na urząd prezydenta został zaprzysiężony Thomas Woodrow Wilson. W tym przypadku zmiany nie wynikały tylko z tego, że starą administrację zastąpiła nowa ani że miejsce republikanów po ponad piętnastu latach zajęli demokraci ${ }^{1}$, ale także, a może przede wszystkim, z tego, że w wielu kwestiach Wilson chciał prowadzić politykę diametralnie inną niż jego poprzednik. Znalazło to swój wyraz również w nastawieniu i działaniach amerykańskiej dyplomacji wobec Chin.

„Byłoby ironią losu, jeśli moja administracja miałaby się przede wszystkim zajmować sprawami zagranicznymi" - powiedział Wilson kilka dni przed wyjazdem do Waszyngtonu ${ }^{2}$. Los okazał się dlań przewrotny, gdyż osiem lat jego urzędowania w Białym Domu obfitowało w przełomowe lub istotne wydarzenia na świecie, w które USA się zaangażowały. W wyznaczaniu zrębu polityki zagranicznej, a często i podejmowaniu konkretnych decyzji, Wilson zajmował centralne miejsce. Uważał, że prezydent powinien bacznie ją nadzorować, jeśli nie wręcz osobiście prowadzić. Jak zauważył sekretarz rolnictwa David Houston, przynajmniej na początku Wilson sam kierował amerykańską dyplomacją ${ }^{3}$. Toteż jego trzej sekretarze stanu musieli się pogodzić z ograniczeniem swobody działania ${ }^{4}$. Stosunkowo najsilniejszą pozycję wyjściową miał pierwszy z nich - William Jennings Bryan ${ }^{5}$. Czołowy polityk Partii Demokratycznej i jej trzykrotny kandydat

1 Gdyby pominąć dwie prezydentury Grovera Clevelanda, to demokraci nie zasiadali w Białym Domu od 1869 roku.

2 Cytat za: R.S. Baker, Woodrow Wilson. Life and Letters, t. 4: President, 1913-1914, Garden City 1931, s. 55.

3 D.F. Houston, Eight Years with Wilson's Cabinet, 1913 to 1920, t. 1, New York 1926, s. 44.

4 R.W. Curry, Woodrow Wilson and Far Eastern Policy, 1913-1921, New York 1968, s. 17; A.S. Link, Wilson: The New Freedom, Princeton 1956, s. 279.

5 Na temat życia i kariery politycznej Bryana patrz np.: M. Kazin, A Godly Hero: The Life of William Jennings Bryan, New York 2007; P. Coletta, William Jennings Bryan, t. 1-3, 
na prezydenta poparł w wyborach Wilsona, a ten odwdzięczył się, mianując Bryana szefem Departamentu Stanu. Nominacja miała podłoże czysto polityczne, niemniej Bryan, przynajmniej na początku, dobrze współpracował z Wilsonem i akceptował jego sposób zarządzania ${ }^{6}$. Chociaż Wilson miał podejmować wiele decyzji osobiście, to postawienie na czele amerykańskiej dyplomacji nawet bardziej od niego idealistycznie i moralizatorsko nastawionego Bryana było istotne, gdyż wzmacniało te cechy u prezydenta i w jego otoczeniu.

Wizja polityki zagranicznej Wilsona i Bryana odzwierciedlała ich światopogląd. Gdy wkraczali do Białego Domu, byli - jak pisze Arthur Link - „zdeterminowani, aby zainaugurować nową erę w amerykańskich stosunkach zagranicznych. [... ] Obiecali Nową Wolność [... ], opartą na altruizmie [i przyjaźni - J.P.] raczej niż na zwykłym myśleniu o narodowych i materialnych interesach" ${ }^{\prime}$. I rzeczywiście w ciągu kilku miesięcy Wilson i Bryan zmienili lub nawet odwrócili politykę prowadzoną przez poprzedników wobec różnych państw, w tym i wobec Chin. Chcieli zerwać z „dyplomacją dolarową” i wyznaczyć nowy zbiór pryncypiów.

Wilson i Bryan byli gorliwymi prezbiterianami i wyrazicielami amerykańskiego mesjanizmu. Wierzyli, że ich kraj miał do wypełnienia na świecie specjalne posłannictwo polegające na propagowaniu chrześcijańskich i typowo amerykańskich wartości. Machtpolitik i Realpolitik powinny ich zdaniem zostać zastąpione przez chrześcijańską moralność i altruizm. Należało odejść od rozwiązań siłowych na rzecz moralnej perswazji, miłowania pokoju i sprawiedliwości oraz zacieśniania współpracy międzynarodowej. Równie ważne było szerzenie demokracji i wolności. Obaj politycy przeciwni byli imperializmowi i deklarowali, że pod ich rządami Stany Zjednoczone wyrzekną się ekspansji terytorialnej. Uważali, że państwa stojące na wyższym poziome cywilizacyjnym powinny przyczyniać się do postępu państw nierozwiniętych, a nie je wykorzystywać. Była to, jak nazywają ją niektórzy historycy, swoista „dyplomacja misjonarska”.

Nie tylko główne założenia nowej polityki zagranicznej USA, ale także sposób jej realizacji przywodził na myśl postępowanie i mentalność misjonarzy. Wilson i Bryan przejawiali bowiem skłonność do paternalizmu i kaznodziejstwa. Chcieli czynić dobro i naprawiać świat, ale wyłącznie według własnych wyobrażeń, nierzadko nawet wbrew woli najbardziej zainteresowanych. Dobrze obrazuje to

Lincoln 1964 -1969. O następcy Bryana Robercie Lansingu będzie mowa w kolejnych rozdziałach. Trzecim i ostatnim sekretarzem stanu u Wilsona był Bainbridge Colby. Na jego temat patrz: D.M. Smith, Aftermath of War: Bainbridge Colby and Wilsonian Diplomacy, 1920-1921, Philadelphia 1970.

${ }^{6}$ December 19, 1912, January 8, 1913, [w:] The Intimate Papers of Colonel House, (opr.) Ch. Seymour, t. 1: Behind the Political Curtain, 1912-1915, Boston-New York 1926, s. 97-98, 100.

${ }^{7}$ A.S. Link, Wilson: The New ..., s. 277. 
wypowiedź prezydenta, który stwierdzil, że musi nauczyć społeczeństwa Ameryki Łacińskiej wybierać na przywódców odpowiednie osoby. Na zachodniej półkuli jego nauki często wspierane były przez interweniujące wojska amerykańskie ${ }^{8}$.

Taką właśnie politykę zagraniczną, opartą na idealistycznych przekonaniach, które zwłaszcza w perspektywie nadciągającego kataklizmu I wojny światowej wydawały się naiwne, zamierzali prowadzić Wilson i Bryan. Nie byli oni całkowicie oderwani od ówczesnych realiów dyplomatycznych oraz brali pod uwagę amerykańskie interesy ekonomiczne i polityczne, ale przynajmniej na początku częściej podejmowali decyzje dlatego, że ich zdaniem były moralnie słuszne, a nie konieczne lub korzystne. Bardziej realistyczne spojrzenie prezentował „pułkownik” Edward M. House - nieoficjalny doradca polityczny Wilsona, który zajmował się głównie sprawami zagranicznymi, lecz akurat rzadziej dotyczącymi Dalekiego Wschodu. Przynajmniej na początku mniejszą niż wcześniej rolę w kształtowaniu polityki zagranicznej odgrywali za to wysocy urzędnicy Departamentu Stanu, których Wilson traktował z rezerwą i pewną nieufnością jako zaangażowanych $\mathrm{w}$ działania poprzednich administracji. Wkrótce część z nich została zresztą zwolniona, przeniesiona lub sama zrezygnowała, co w połączeniu ze zmianami personalnymi w zagranicznej służbie dyplomatycznej skutkowało obniżeniem poziomu amerykańskiej dyplomacji. Owo obniżenie wynikało też z faktu, że Wilson i Bryan mieli pobieżne pojęcie o stosunkach międzynarodowych oraz nikłe doświadczenie w dyplomacji?

Ich wiedzę na temat Dalekiego Wschodu także należy uznać za powierzchowną. Bryan co prawda kilka lat wcześniej odwiedził kraje Orientu, ale jak uszczypliwie skomentował sir John Jordan, prawdziwy znawca Państwa Środka,

8 A.S. Link, Wilson the Diplomatist: A Look at His Major Foreign Policies, Baltimore 1957, s. 3-29; idem, Wilson: The New ..., s. 277-280; H. Notter, The Origins of the Foreign Policy of Woodrow Wilson, New York 1965; Tien-yi Li, Woodrow Wilson's China Policy, 1913-1917, Kansas City 1952, s. 5, 11-19, 23-24, 33-34, 46, 51; R.W. Curry, Woodrow Wilson and Far Eastern Policy ..., s. 13-18, 31, 40-41; W.A. Williams, The Tragedy of American Diplomacy, New York 1962, s. 61-64; J. Reed, The Missionary Mind and American East Asia Policy, 1911-1915, Cambridge 1983, s. 141-142.

9 A.S. Link, Wilson: The New ..., s. 278-279; idem, Wilson the Diplomatist ..., s. 4-9; R.S. Baker, Woodrow Wilson ..., s. 36, 60; Tien-yi Li, Woodrow Wilson's China Policy..., s. 23, 33-35, 46, 52; R.W. Curry, Woodrow Wilson and Far Eastern Policy..., s. 15, 18. Nawet w 1919 roku podczas konferencji pokojowej w Paryżu Wilson - według relacji Roberta Lansinga, którego opinię trzeba jednak traktować ostrożnie - nie był zręcznym negocjatorem i brakowało mu wiedzy w pewnych kwestiach międzynarodowych. R. Lansing, The Big Four and Others of the Peace Conference, Boston-New York 1921, s. 72. Jeszcze gorzej o kompetencjach Wilsona wypowiadał się John Bassett Moore, ekspert w dziedzinie prawa międzynarodowego. R.W. Curry, Woodrow Wilson and Far Eastern Policy..., s. 51. 


\section{Chiny w polityce zagranicznej Stanów Zjednoczonych w latach 1911-1918}

„Podróżowałem z nim kiedyś przez cztery dni i powiedział mi wiele rzeczy o Chinach, których wcześniej nie wiedziałem"10. Wilson interesował się Chinami szczególnie pod kątem prowadzonej tam ewangelizacji. Utrzymywał kontakty z amerykańskimi misjonarzami (m.in. ze swoim kuzynem Samuelem I. Woodbridgem, Charlesem E. Scottem i biskupem Jamesem W. Bashfordem), od których dowiadywał się o politycznej i społecznej sytuacji Chin ${ }^{11}$. Doceniał też działalność Chrześcijańskiego Stowarzyszenia Młodzieży Męskiej (YMCA), które jego zdaniem „przekształcało oblicze” Chin ${ }^{12}$. Wilson widział w Chinach kraj o znacznym potencjale, kraj budzący się właśnie z letargu i zaczynający się zmieniać. Zmiany te należało kontynuować i wspierać poprzez szerzenie chrześcijaństwa, demokracji oraz rozwijanie kontaktów handlowych, które w opinii Wilsona również stymulowały rozprzestrzenianie się wspomnianych idei. Dlatego też Wilson był zwolennikiem polityki „otwartych drzwi”, przynoszącej korzyści stronie chińskiej i amerykańskiej.

Prezydent popierał ekspansję ekonomiczną swojego państwa, uznając, że nie tylko wspomoże ona rozwój terenów zacofanych, ale jednocześnie zapewni Stanom Zjednoczonym kontynuację rozkwitu i zapobiegnie upadkowi ducha narodu amerykańskiego. Szczególne miejsce w jego wizji zajmowała Azja, a zwłaszcza Chiny $\mathrm{z}$ ich potencjalnie olbrzymim rynkiem zbytu i możliwościami inwestycyjnymi ${ }^{13}$.

Można podejrzewać, że Wilson postrzegał Republikę Chińską jako ważną $\mathrm{i}$ interesującą, ponieważ można w niej było realizować wiele $\mathrm{z}$ istotnych dla niego zadań - wprowadzać postępowe zmiany, głosić Słowo Boże, szerzyć demokrację, nawiązywać perspektywiczne kontakty biznesowe, organizować pomoc charytatywną i osłaniać przed zaborczością mocarstw. Nie dziwi zatem, że w styczniu 1913 roku Wilson stwierdził nawet, iż wydarzenia rozgrywające się na Dalekim Wschodzie, którego centralny punkt stanowiły przecież Chiny, w największym stopniu wpłyną na „przyszły rozwój świata” i dlatego powinny się dokonywać pod najlepszym możliwym przewodnictwem, w domyśle amerykańskim ${ }^{14}$.

10 Cytat za: J. Reed, The Missionary Mind ..., s. 144. Zob. też: F.M. Huntington Wilson, Memoirs of an Ex-Diplomat, Boston 1945, s. 246-247.

11 E.P. Trani, Woodrow Wilson, China, and the Missionaries, 1913-1921, „Journal of Presbyterian History” 1971, t. 49, nr 4, s. 329-332; Tien-yi Li, Woodrow Wilson's China Policy..., s. 14-15.

12 A News Report of Remarks in Columbia, June 2, 1911, [w: ] The Papers of Woodrow Wilson (dalej PWW), (opr.) A.S. Link, t. 23, Princeton 1977, s. 113-114. Uniwersytet Princeton, Alma Mater Wilsona, wspierał pracę YMCA w Pekinie.

13 Tien-yi Li, Woodrow Wilson's China Policy..., s. 12-13; R.W. Curry, Woodrow Wilson and Far Eastern Policy..., s. 15; S. Pash, The Currents of War: A New History of American-Japanese Relations, 1899-1941, Lexington 2014, s. 34; A. Iriye, Pacific Estrangement: Japanese and American Expansion, 1897-1911, Chicago 1994, s. 67-68.

14 Wilson to Eliot, January 20, 1913, [w: ] PWW, t. 27, Princeton 1978, s. 65. 
Rozdziat III. Chińska polityka administracji Thomasa Woodrowa Wilsona ... 113

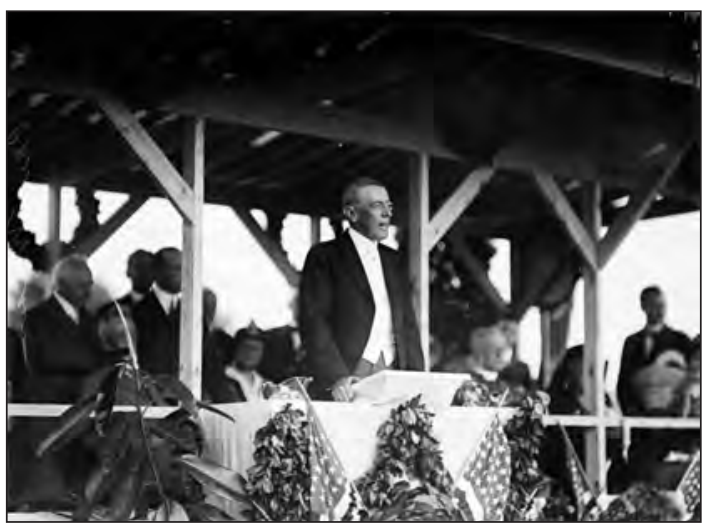

19. Woodrow Wilson

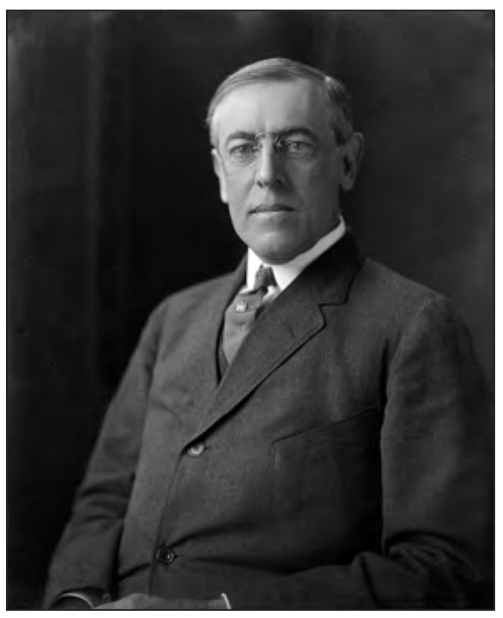

20. Woodrow Wilson

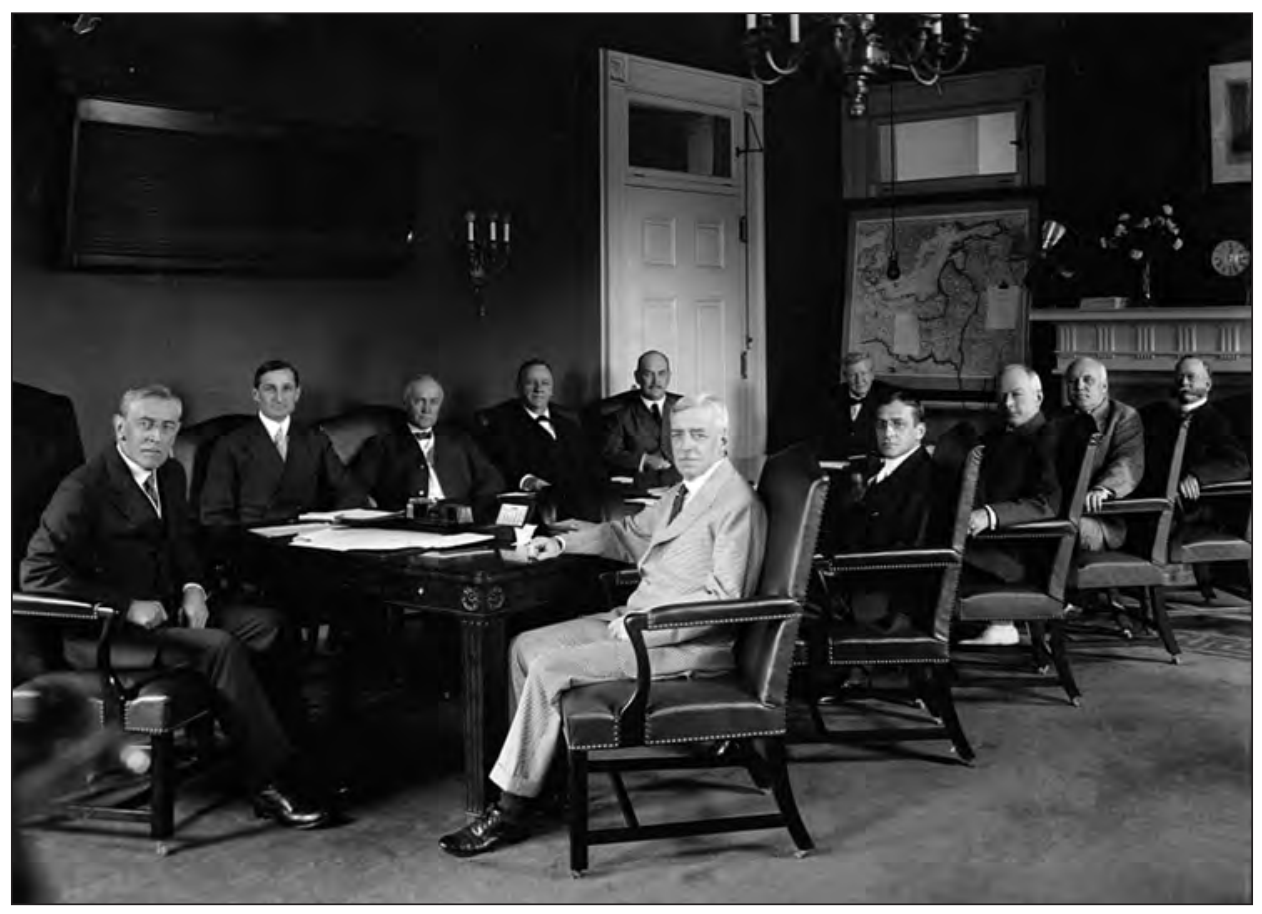

21. Rząd Woodrowa Wilsona 
114 Chiny w polityce zagranicznej Stanów Zjednoczonych w latach 1911-1918

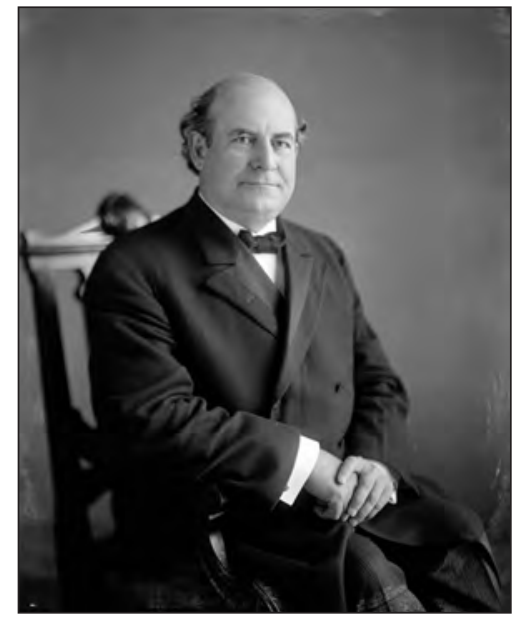

22. William J. Bryan

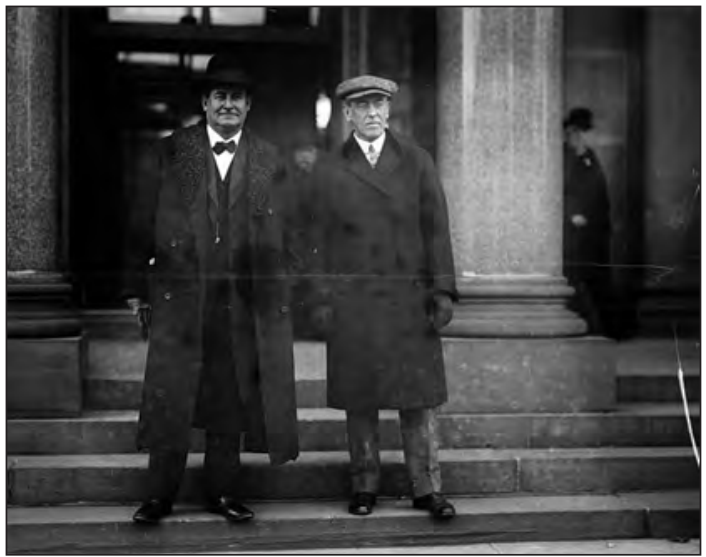

23. William J. Bryan i Woodrow Wilson

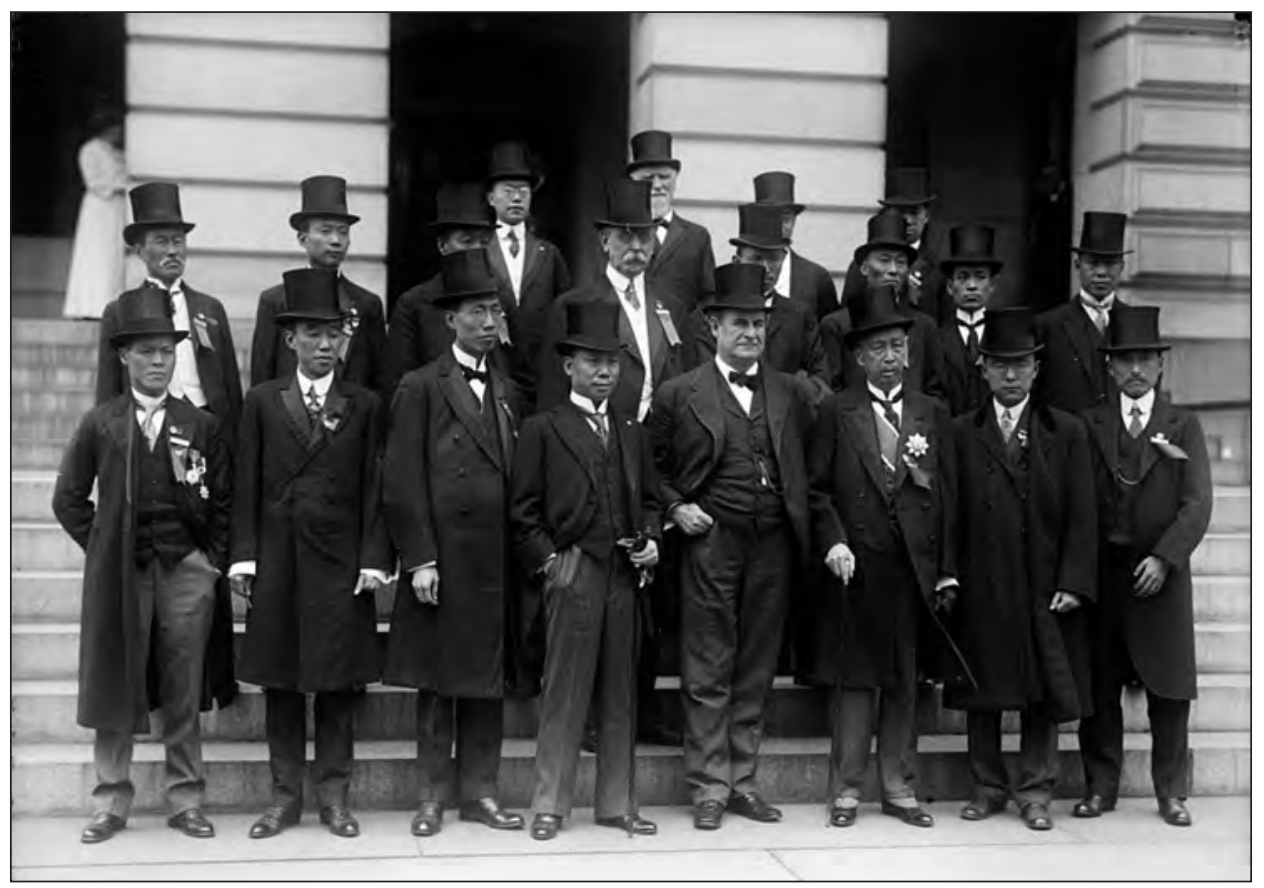

24. William J. Bryan w otoczeniu przedstawicieli Chinese Chamber of Commerce 
Od momentu zwycięstwa w wyborach Wilson zaczął baczniej przyglądać się związanym z Chinami kwestiom, które narosły za rządów ustępującej administracji. Potwierdził chęć działania dla dobra nowo powstałej Republiki i z sympatią patrzył na zachodzące w niej przemiany ${ }^{15}$. Polityka wobec Chin znalazła się wśród najważniejszych wyzwań dyplomatycznych podczas pierwszych miesięcy funkcjonowania nowej administracji, która musiała zająć stanowisko w sprawie pożyczki reorganizacyjnej, uznania Republiki Chińskiej, „drugiej rewolucji” i wzrostu dążeń autorytarnych Yuan Shikaia oraz dokonać wyboru nowego posła w Pekinie.

\section{Wycofanie się USA z konsorcjum mocarstw}

18 marca 1913 roku, dwa tygodnie po inauguracji, Wilson ogłosił w oświadczeniu przekazanym prasie, że nie poprosi amerykańskiej grupy o kontynuowanie udziału w pożyczce reorganizacyjnej. Bankierzy byli gotowi nadal w niej partycypować, ale domagali się deklaracji poparcia ze strony nowego rządu ${ }^{16}$. Cofnięcie politycznej akceptacji skłoniło ich do opuszczenia konsorcjum, co uczynili nazajutrz ${ }^{17}$.

Jakie były motywy decyzji Wilsona? W oświadczeniu prezydent wyjaśnil, że warunki pożyczki „dotyczą bardzo blisko administracyjnej niepodległości Chin” i jego rząd nie chce nawet pośrednio być stroną układu zawierającego te warunki. W pewnych okolicznościach mogłoby bowiem dojść do „przymusowej ingerencji w finansowe, a nawet polityczne sprawy" Chin.

Oprócz oficjalnych argumentów rolę odgrywały różne inne czynniki. Po pierwsze, jedna z naczelnych zasad amerykańskiej dyplomacji - niezawierania sojuszów, ponieważ mogły one wplątać kraj w niepożądane kontrowersje międzynarodowe. Bryan potwierdził to, zauważając, że „jeśli USA przystąpiłyby do porozumienia $\mathrm{z}$ innymi mocarstwami, byłyby zmuszone współpracować z nimi we wszystkich sprawach dotyczących Chin i to mogłoby postawić je w sytuacji, w której zostałyby zobowiązane do zrobienia rzeczy, których nie powinny

15 Wilson to Sun, December 3, 1912, [w: ] PWW, t. 25, Princeton 1978, s. 576; Wilson to Bryan, January 16, 1913, [w: ] PWW, t. 27, s. 57-58; Wilson to Mott, February 24, 1913, [w: ] ibidem, s. 131; H. Notter, The Origins ..., s. 202.

16 A Statement on the Pending Chinese Loan, March 18, 1913, [w:] PWW, t. 27, s. $192-194$.

17 The American Group to the Secretary of State, March 19, 1913, [w: ] Papers Relating to the Foreign Relations of the United States (dalej PRFRUS) 1913, Washington 1920, s. 171-172; The American Group to Morgan, Grenfell and Company, March 19, 1913, [w: ] ibidem, s. 172-173; Announcement handed to the press by the American group, March 19, 1913, [w: ] W. Straight, China's Loan Negotiations, „The Journal of Race Development” 1913, t. 3, nr 4, s. 410-411. 
zrobić" ${ }^{18}$. Podobnie David Starr Jordan, rektor Uniwersytetu Stanforda, skomentował z satysfakcją w liście gratulacyjnym do Wilsona, że „dyplomacja dolarowa” została porzucona, ponieważ mogła nie tylko zaszkodzić autorytetowi państwa, ale również doprowadzić do użycia sily ${ }^{19}$.

Nie mniej istotne było, aby odciąć się od innych mocarstw, podkreślając jednocześnie ich wrogie zamiary, okazując własną sympatię i utrwalając przekonanie o specjalnych relacjach łączących USA i Chiny. Zaledwie pięć dni po opublikowaniu oświadczenia Wilsona Bryan był pewien, że Ameryka „zyskała trwałą wdzięczność Chin” i po takiej manifestacji dobrej woli nikt nie zmusi ich do przyjęcia niesprawiedliwych warunków. Sekretarz konkludowal, że od teraz państwa będą konkurować o przyjaźń Pekinu ${ }^{20}$. Wilson sądzil, że Stany Zjednoczone osiągną o wiele więcej, działając samodzielnie niż w obrębie koncertu mocarstw. Mogłyby wówczas pomóc Chinom poprzez zapobieżenie wrogim planom Europejczyków i Japończyków ${ }^{21}$. Wycofanie się z konsorcjum, w połączeniu z uznaniem Republiki Chińskiej, przywróciłoby również pozytywny wizerunek Waszyngtonu w Chinach, poniekąd nadszarpnięty przez poprzednią administrację $^{22}$. "Jeśli udzielilibyśmy pożyczki z innymi mocarstwami - zauważył prezydent - nic byśmy nie zyskali, oprócz zwykłych wpływów w Chinach, a stracilibyśmy zaszczytną pozycję, którą Ameryka zdobyła, gdy sekretarz Hay opowiedział się za «otwartymi drzwiami» w Chinach po powstaniu «bokserów»"23.

Jednakże te cnoty moralne i międzynarodowa reputacja nie musiały stanowić celu samego w sobie. Zapewniwszy sobie wdzięczność Chin, można było oczekiwać otrzymania od nich większej liczby kontraktów komercyjnych. Tym samym wystąpienie z konsorcjum mogło mieć na celu poprawę ekonomicznej,

18 April 1, 1913, [w:] The Cabinet Diaries of Josephus Daniels, (opr.) E.D. Cronon, Lincoln 1963, s. 19-21.

19 Jordan to Wilson, March 19, 1913, [w: ] PWW, t. 27, s. 195.

20 Bryan to Wilson, March 23, 1913, [w: $]$ PWW, t. 27, s. 218. Zob. też: Executive Joint Conference of the Senate and Assembly of the State of California at Sacramento, April 28, 1913, William Jennings Bryan Papers (dalej BP), Manuscript Division, Library of Congress, Washington, container 29; Bryan Tells of State Problems, August 12, 1913, ibidem. 8 marca Myron Herrick, amerykański ambasador w Paryżu, zasugerował, że Stany Zjednoczone mogły zyskać wdzięczność Chin, gdyby ogłosiły, że albo umowa dotycząca pożyczki reorganizacyjnej zostanie niezwłocznie podpisana, albo wycofają się z konsorcjum i same spróbują pomóc finansowo Chinom. The American Ambassador to France to the Secretary of State, March 8, 1913, [w: ] PRFRUS 1913, s. 168.

21 March 28, 1913, [w:] The Cabinet Diaries ..., s. 15-19.

22 Zobacz opinię zawartą w: Walker to Wilson, March 20, 1913, Woodrow Wilson Papers (dalej WWP), Manuscript Division, Library of Congress, Washington, (mikrofilm), series 4: case files, 227, reel 242.

23 March 28, 1913, [w:] The Cabinet Diaries ..., s. 15-19. 
a może i politycznej pozycji w Chinach. Skoro współpraca w ramach konsorcjum była skomplikowana i w przypadku pożyczki reorganizacyjnej nie przynosiła jak dotychczas większych korzyści, być może samodzielna polityka byłaby bardziej owocna ${ }^{24}$. Wilson zaś wydawał się chętny, aby rozwijać amerykańskie interesy biznesowe w Chinach. Przyrzekł, aczkolwiek dość mgliście, że wesprze przedsiębiorców i kupców, zapewniając im „bankowe i inne finansowe ułatwienia, których obecnie im brakuje"25. William Appleman Williams twierdzi, że Wilson chciał pomóc biznesmenom $\mathrm{w}$ walce o rynki zagraniczne, ale nie popierał koncepcji międzynarodowego konsorcjum, ponieważ Amerykanie nie mogli go kontrolować. Williams nie postrzega cofnięcia akceptacji dla pożyczki reorganizacyjnej jako zmiany zasadniczej polityki rządu (zagranicznej ekspansji ekonomicznej), tylko jako zmianę taktyki, aby osiągnąć ten $\mathrm{cel}^{26}$.

Wyjaśniając wczesne posunięcia Wilsona wobec Chin, należy wspomnieć o kontekście polityki wewnętrznej. Historycy wskazują, że różnorakie jej czynniki mogły wpłynąć na woltę prezydenta. Po pierwsze, Wilson i Bryan byli czołowymi osobami ruchu progresywnego (Progressive Movement), który dążył m.in. do przeprowadzania reform i promowania demokracji. Postępowcy postrzegali Republikę Chińską powstałą po rewolucji Xinhai jako spełnienie tych ideałów i chcieli jej pomóc w rozwoju. Sprzeciwiali się również imperializmowi i przejawiali nieufność wobec świata finansjery, zwłaszcza Wall Street. Wszystko to czyniło dla nich pożyczkę reorganizacyjną idealnym „wrogiem”, nawet pomimo tego, że miano z niej sfinansować pewne reformy.

Ponadto podczas kampanii wyborczej Wilson krytykował podejście urzędującej administracji i atakował świat wielkiego biznesu ${ }^{27}$. Zamierzał zerwać $\mathrm{z}$ „dyplomacją dolarową" i politykę wobec Chin prowadzić na wyżej opisanych zasadach. Jego „dyplomacja misjonarska” miała w tym przypadku dodatkowy wymiar, gdyż protestanccy misjonarze byli w USA najbardziej zagorzałymi zwolennikami pomocy Republice Chińskiej ${ }^{28}$. Wielu Amerykanów podzielało ich opinię i sprzeciwiało się polityce gabinetu Tafta, dlatego też Wilson mógł zyskać

${ }^{24}$ Dowiedziawszy się, że amerykańska firma sprzedała Chinom sześć nowoczesnych lokomotyw, sekretarz handlu William Redfield skomentował naiwnie, że „Ameryka przewodzi w Chinach". Ibidem.

${ }_{25}$ A Statement on the Pending Chinese Loan, March 18, 1913, [w:] PWW, t. 27, s. 192-194.

${ }^{26}$ W.A. Williams, The Tragedy of ..., s. 67-78.

${ }^{27}$ Dodatkowo w 1912 roku wszyscy czterej członkowie amerykańskiej grupy w konsorcjum zostali prześwietleni przez kontrolowany przez demokratów Pujo Committee, który badał monopol finansowy na Wall Street. Ch. Vevier, The United States and China, 1906-1913: A Study in Finance and Diplomacy, New York 1968, s. 207-208; R.W. Curry, Woodrow Wilson and Far Eastern Policy..., s. 24.

${ }^{28} \mathrm{~J}$. Reed, The Missionary Mind ..., s. 124-127, 131-134, 140-148. 
(i w istocie zyskał) poparcie społeczne dzięki swej decyzji. Był to niebagatelny powód, tym bardziej, że Wilson został wybrany przez mniej niż połowę głosujących ${ }^{29}$ i szykował się właśnie do rozmów z Kongresem na temat reform wewnętrznych. Samo wycofanie się z konsorcjum, jak i późniejsze uznanie władz chińskich stanowily politycznie bezpieczne ruchy, ponieważ Kongres był do nich pozytywnie nastawiony ${ }^{30}$. Co więcej, Wilson miał okazję wypełnić obietnice z kampanii, pokazać swoje zdecydowanie i skonsolidować bazę polityczną, atakując kilku „przeciwników” naraz ${ }^{31}$. W swoim oświadczeniu jednym pociągnięciem pióra zdyskredytował działania poprzedniej administracji, Wall Street $\mathrm{i}$ innych mocarstw poprzez powiązanie ich $\mathrm{z}$ wrogimi zamiarami wobec Chin. Napisał, że proponowana pożyczka była „wstrętnym [obnoxious] [zaprzeczeniem - J.P.] zasad, na których opiera się nasze państwo", co stanowiło dosadne stwierdzenie.

Wśród innych czynników, które mogły rzutować na decyzję Wilsona, wypada jeszcze wymienić nie najlepsze przygotowanie prezydenta i jego sekretarza stanu do prowadzenia polityki zagranicznej. Akurat posiadanie wiedzy i doświadczenia dyplomatycznego było kluczowe, aby zajmować się sprawami chińskimi generalnie, a pożyczką reorganizacyjną w szczególności. Zważywszy na zaangażowanie niemal wszystkich ówczesnych mocarstw, finansowe niuanse i polityczne implikacje (nie wspominając o specyfice Dalekiego Wschodu i zmiennej sytuacji w Chinach), negocjacje na temat pożyczki reorganizacyjnej były jedną z najbardziej skomplikowanych spraw dyplomatycznych w swoim czasie ${ }^{32}$. Wobec tego niektórzy Amerykanie, zagraniczni politycy i późniejsi badacze odebrali oświadczenie z 18 marca jako pośpieszne i amatorskie ${ }^{33}$.

29 Ponieważ w wyborach prezydenckich w 1912 roku startowało trzech liczących się kandydatów, głosy były bardziej podzielone niż zazwyczaj i w głosowaniu powszechnym Wilson otrzymał niespełna $42 \%$.

30 R.S. Baker, Woodrow Wilson ..., s. 76; J. Reed, The Missionary Mind ..., s. 143.

31 R.S. Baker, Woodrow Wilson..., s. 76; J. Reed, The Missionary Mind ..., s. 143; J. Daniels, The Wilson Era: Years of Peace, 1910-1917, Chapel Hill 1946, s. 160. Wilson powiedział kiedyś: „Osoba zarządzająca [an executive] to człowiek czynu [...]. Moja decyzja może być dobra, może być błędna. Nieważne. Zaryzykuję i zrobię - cokolwiek”. Cytat za: R.W. Curry, Woodrow Wilson and Far Eastern Policy..., s. 14.

32 Zobacz np. opinię Gardnera. L.C. Gardner, Safe for Democracy. The AngloAmerican Response to Revolution, 1913-1923, New York 1984, s. 71.

33 Zob. Huntington Wilson to Wilson, March 19, 1913, [w: ] PWW, t. 27, s. 195-197; Taft to Straight, July 6, 1913, William H. Taft Papers (dalej TP), Manuscript Division, Library of Congress, Washington, (mikrofilm), series 8, reel 519; D.F. Houston, Eight Years..., s. 49; R.S. Baker, Woodrow Wilson..., s. 72, 74, 76; J. Reed, The Missionary Mind ..., s. 141; A.S. Link, Wilson: The New ..., s. 285-286. Przeciwnego zdania jest Williams. W.A. Williams, The Tragedy of ..., s. 74. 
Tak właśnie kształtowały się motywy, które legły u podstaw oświadczenia z 18 marca. Próbując wskazać najważniejsze z nich, należy zgodzić się z autorami, którzy twierdzą, że Wilson szczerze wierzył w to, co napisał, i jego decyzja wypływała przede wszystkim z przekonań moralnych ${ }^{34}$. Można zarazem dodać, że była obliczona na zajęcie niezależnej pozycji w Chinach i zyskanie ich wdzięczności.

Sytuacja była nawet bardziej złożona, gdyż w istocie inicjatywa przedyskutowania kwestii pożyczki dla Chin wyszła od bankierów, którzy byli rozczarowani i zniechęceni przedłużającymi się negocjacjami i zastanawiali się nad wycofaniem z konsorcjum. Już 5 marca, zaledwie dzień po inauguracji nowych władz, poprosili oni Bryana, aby określił swoje stanowisko ${ }^{35}$. Pięć dni później ${ }^{36}$ Bryan przyjął reprezentantów amerykańskiej grupy (Willarda Straighta, Henry'ego P. Davidsona i Paula Warburga). W spotkaniu uczestniczyli również prokurator generalny James McReynolds i wysocy rangą urzędnicy Departamentu Stanu - Huntington Wilson (asystent sekretarza stanu), Chandler P. Anderson (counselor - radca) i Ransford Miller (szef Wydziału ds. Dalekiego Wschodu), których wezwano, bo Bryan mało wiedział o dotychczasowych negocjacjach. Bankierzy przedstawili warunki pożyczki i poprosili o potwierdzenie rządowego poparcia. Chcieli, aby żaden inny amerykański bank nie został dopuszczony do pożyczki reorganizacyjnej. Poinformowali również, że konsorcjum zamierzało kontrolować przyszłe pożyczki dla Chin. Ich ostatni warunek zakładał, że jeśli Chiny nie wywiązałyby się ze swoich zobowiązań, amerykańska armia pomogłaby wyegzekwować spłatę należności. Bryan wysłuchał ich, ale nie udzielił żadnej wiążącej odpowiedzi, mimo nalegań Huntingtona Wilsona i Andersona, aby się zgodzi1 ${ }^{37}$.

34 A.S. Link, Wilson: The New..., s. 286; Tien-yi Li, Woodrow Wilson's China Policy..., s. 46-48.

35 The American Group to the Secretary of State, March 5, 1913, [w:] PRFRUS 1913, s. $167-168$.

36 The Secretary of State to the Ambassador of Great Britain, April 1, 1913, [w: ] PRFRUS 1913, s. 177-178; A.S. Link, Wilson: The New ..., s. 284; Ch. Vevier, The United States and China ..., s. 208. Daniels i Baker twierdzą, że spotkanie miało miejsce 9 marca. J. Daniels, The Wilson Era ..., s. 158; R.S. Baker, Woodrow Wilson ..., s. 60, 70.

37 F.M. Huntington Wilson, Memoirs of an Ex-Diplomat..., s. 246; D.F. Houston, Eight Years ..., s. 44; R.S. Baker, Woodrow Wilson ..., s. 70; Ch. Vevier, The United States and China..., s. 208-209; A.S. Link, Wilson: The New..., s. 284; Tien-yi Li, Woodrow Wilson's China Policy..., s. 35-36, 52; W.J. Bryan, M.B. Bryan, The Memoirs of William Jennings Bryan, Chicago 1925, s. 362. Anderson, Huntington Wilson lub obaj napisali memorandum do prezydenta, w którym zalecali kontynuowanie udziału w konsorcjum. Huntington Wilson wyraził tę opinię również podczas spotkania w Białym Domu, na które zabrał go Bryan. R.S. Baker, Woodrow Wilson ..., s. 70; F.M. Huntington Wilson, Memoirs of an Ex-Diplomat..., s. 248-249. 
Sprawę poruszono następnie na posiedzeniu rządu ${ }^{38}$. Niemal wszyscy członkowie opowiedzieli się za cofnięciem oficjalnego poparcia. Wątpliwości miał jedynie sekretarz handlu William Redfield, który obawiał się, że jeśli Stany Zjednoczone porzucą negocjacje i inaczej nie pomogą Chinom, pozostałe państwa należące do konsorcjum i tak udzielą pożyczki, co utrudni rozszerzanie amerykańskich interesów. Wilson bez wahania odparl, że był skłonny „pomóc Chinom w jakiś lepszy sposób”. Zdecydowano ostatecznie, że prezydent sam napisze oświadczenie w sprawie pożyczki ${ }^{39}$. Gdy przedstawił je na kolejnym posiedzeniu 18 marca, kilku członków gabinetu chciało stonować dokument, tak aby uczynić go mniej oskarżycielskim wobec innych mocarstw. Wilson przystał na to niechętnie, wprowadził poprawki i przekazał oświadczenie prasie ${ }^{40}$.

Podsumowując, obie strony - rząd i bankierzy - wzajemnie utwierdziły się w przekonaniu, że opuszczenie konsorcjum było zasadne, a przynajmniej konieczne. Żądania Wall Street wzmocniły opozycję administracji do pożyczki, anulowanie zaś oficjalnego poparcia ostatecznie przekonało bankierów do wycofania się z konsorcjum. Niektórzy badacze twierdzą, że bankierzy i tak byli zdeterminowani, aby się wycofać, i tylko szukali pretekstu ${ }^{41}$. Wydaje się jednak, że to zbyt daleko idąca opinia, gdyż bankierzy jedynie skłaniali się ku wycofaniu, ale nie byli zdecydowani ${ }^{42}$.

Jak można się było spodziewać, znakomita większość Amerykanów z aplauzem przyjęła decyzję administracji. Pięć dni po wydaniu oświadczenia Bryan pisał

38 Autorzy podają różne daty pierwszego posiedzenia rządu, na którym rozpatrywano sprawę konsorcjum. Niektórzy uważają, że odbyło się ono 12 marca, inni, że dwa dni później. Por. March 12, 1913, [w: ] The Cabinet Diaries ..., s. 7-8; A.S. Link, Wilson: The New ..., s. 284; R.S. Baker, Woodrow Wilson ..., s. 70; D.F. Houston, Eight Years ..., s. 44; Ch. Vevier, The United States and China ..., s. 209; H. Notter, The Origins ..., s. 232. Zob. też: Tien-yi Li, Woodrow Wilson's China Policy..., s. 36-37, 52-53.

${ }^{39}$ March 12, 1913, [w:] The Cabinet Diaries ..., s. 7-8; W.J. Bryan, M.B. Bryan, The Memoirs of William Jennings Bryan..., s. 362-363. Wilson napisał wstępną wersję oświadczenia 13 marca. A Statement on the Pending Chinese Loan, March 18, 1913, [w:] $P W W$, t. 27, s. 192-194. Cichym przeciwnikiem wydawania oświadczenia był podobno sekretarz skarbu William McAdoo, który bezskutecznie starał się uzyskać w tej sprawie poparcie House'a. R.W. Curry, Woodrow Wilson and Far Eastern Policy ..., s. 21-22.

40 D.F. Houston, Eight Years ..., s. 45; R.S. Baker, Woodrow Wilson ... , s. 70-71. Pierwotnie Wilson chciał opublikować oświadczenie dopiero po uprzednim powiadomieniu zainteresowanych mocarstw, ale w wyniku przecieku zdecydował się niezwłocznie przekazać je prasie. Tien-yi Li, Woodrow Wilson's China Policy..., s. 37; R.W. Curry, Woodrow Wilson and Far Eastern Policy..., s. 22.

${ }^{41}$ Zobacz np.: D.M. Crane, T.A. Breslin, An Ordinary Relationship: American Opposition to Republican Revolution in China, Gainesville 1986, s. 107-108.

42 Podobną opinię ma Williams. W.A. Williams, The Tragedy of ..., s. 74. 
do Wilsona z satysfakcją: „Nie spotkałem jeszcze ani jednej osoby, która sprzeciwiałaby się Twojemu stanowisku na temat chińskiej pożyczki”33. I rzeczywiście różni ludzie i instytucje z całego kraju chwalili decyzję, nawet jeśli nie wszyscy zdawali sobie sprawę z jej znaczenia i konsekwencji ${ }^{44}$.

Naturalnie niektóre osoby, zwłaszcza zaangażowane w „dyplomację dolarową”, były niezadowolone. Taft, Knox i Straight po cichu wyrazili swój sprzeciw ${ }^{45}$, podczas gdy Huntington Wilson złożył rezygnację, którą przyjęto. Był on zły nie tylko dlatego, że porzucono politykę, którą uważał za słuszną, ale także dlatego, że nie powiadomiono go o tym zamiarze, i to mimo że zastępował wówczas Bryana na czele Departamentu Stanu ${ }^{46}$. Podobnie banki należące do amerykańskiej grupy czuły się dotknięte oskarżeniami oraz sposobem oznajmienia decyzji, gdyż wcześniej prosiły, aby w przypadku odmowy rząd dał im czas na poinformowanie partnerów biznesowych ${ }^{47}$. Niektóre gazety przewidywały, że decyzja spowoduje zmniejszenie amerykańskich wpływów ekonomicznych w Chinach $^{48}$. Na inną ujemną stronę wskazywał pekiński korespondent „The New York Timesa” - Chińczycy mieli łudzić się nadzieją, że USA były gotowe udzielić pożyczek bez zabezpieczeń ${ }^{49}$.

${ }^{43}$ Bryan to Wilson, March 23, 1913, [w:] PWW, t. 27, s. 218.

${ }^{44}$ W kolekcji Wilsona znajduje się kilkadziesiąt listów z gratulacjami od różnych osób i instytucji. WWP, series 4: case files, 227, reel 242; A.S. Link, Wilson: The New..., s. 286; R.S. Baker, Woodrow Wilson ..., s. 72; J. Reed, The Missionary Mind ..., s. 143144; R.W. Curry, Woodrow Wilson and Far Eastern Policy..., s. 24-25, 326; Tien-yi Li, Woodrow Wilson's China Policy..., s. 43-44.

45 Sleicher to Knox, March 21, 1913, Philander C. Knox Papers, Manuscript Division, Library of Congress, Washington, container 20; Taft to Straight, July 6, 1913, TP, series 8, reel 519; Straight to Taft, July 10, 1913, TP, series 3, reel 129; Taft to the Membership Committee of the University Club, September 7, 1913, TP, series 8, reel 519; F.M. Huntington Wilson, Memoirs of an Ex-Diplomat ..., s. 220-221; H. Croly, Willard Straight, New York 1924, s. 453; Tien-yi Li, Woodrow Wilson's China Policy ..., s. 41-42. Taft w liście do Straighta z 6 lipca napisał, że przynajmniej w polityce zagranicznej administracji Wilsona „trudno będzie $[\ldots]$ zrobić coś $[\ldots]$ bardziej szkodliwego, niż zrobiła w odniesieniu do tej pożyczki”.

${ }^{46}$ Huntington Wilson to Wilson, March 19, 1913, [w: $P W W$, t. 27, s. 195-197; Wilson to Bryan, March 20, 1913, [w:] ibidem, s. 197-198; Wilson to Huntington Wilson, March 20, 1913, [w:] ibidem, s. 198; From the Diary of Colonel House, March 20, 1913, [w:] ibidem, s. 198-201; March 21, 1913, [w:] The Cabinet Diaries..., s. 12; F.M. Huntington Wilson, Memoirs of an Ex-Diplomat ..., s. 218-222, 248-250; Tien-yi Li, Woodrow Wilson's China Policy..., s. 39-40.

${ }^{47}$ Tien-yi Li, Woodrow Wilson's China Policy ..., s. 36, 40-41.

${ }^{48}$ Ibidem, s. 43.

49 „The New York Times”, March 22, 1913. 


\section{Chiny w polityce zagranicznej Stanów Zjednoczonych w latach 1911-1918}

W przeciwieństwie do raczej entuzjastycznej reakcji w Stanach Zjednoczonych, w innych krajach, przynajmniej w oficjalnych kręgach, dominowały gorzkie odczucia. Mocarstwa były nie tylko rozczarowane samym oświadczeniem Wilsona, ale i źle odebrały zawarte w nim insynuacje. Negatywny odbiór potęgował nadto fakt, że dowiedziały się o nim z prasy, co stanowiło naruszenie dyplomatycznego savoir-vivre' $u^{50}$. Wilson i Bryan przyznali później, że był to błąd ${ }^{51}$. Jedynym państwem szczerze zadowolonym z wycofania się Amerykanów były Chiny. Zarówno opinia publiczna, jak i politycy podzielali to zdanie. Prezydent Yuan Shikai poinstruował swojego posła w Waszyngtonie, aby podziękował gospodarzom, a sam podczas spotkania z amerykańskim chargé d'affaires Edwardem T. Williamsem powiedział: „Jestem bardzo wdzięczny amerykańskiemu rządowi za jego działanie sprzed kilku dni. Będzie ono nam wielce pomocne" 52 . Słowa Yuana nie powinny dziwić, bo chociaż zależało mu na jak najszybszym uzyskaniu pieniędzy, to mógł od teraz ubiegać się o nie z dwóch źródeł (od konsorcjum i z USA) i liczyć na korzystną dla siebie konkurencję na tym polu. Wycofanie się Amerykanów przyśpieszyło zresztą negocjacje w sprawie pożyczki reorganizacyjnej, które zakończyły się ostatecznie podpisaniem umowy pod koniec kwietnia ${ }^{53}$.

Należy się zastanowić, czy również dla Stanów Zjednoczonych wycofanie się było korzystnym ruchem. Patrząc wyłącznie przez pryzmat ich interesów w Chinach, wydaje się, że nie. Mogłaby to być w miarę dobra strategia, choć i tak nie jest pewne, czy byłaby wystarczająco efektywna, aby zerwać więzi z konsorcjum i samodzielnie ubiegać się o kontrakty, wykorzystując przychylność

50 March 28, 1913, [w:] The Cabinet Diaries..., s. 15-19; L.C. Gardner, Safe for Democracy..., s. 71, 74; A.S. Link, Wilson: The New..., s. 285-286; Tien-yi Li, Woodrow Wilson's China Policy..., s. 44-45; J. Reed, The Missionary Mind..., s. 144. W kwietniu, nieco ponad miesiąc od zaprzysiężenia, Wilson zauważył z rozbawieniem: „Zrywam $\mathrm{z}$ tradycją niemal codziennie, od kiedy tu przybyłem”. Wilson to Hulbert, April 8, 1913, [w: ] PWW, t. 27, s. 273.

${ }_{51}$ March 28, 1913, [w:] The Cabinet Diaries..., s. 15-19; D.F. Houston, Eight Years..., s. 45.

52 The American Chargé d'Affaires to the Secretary of State, March 25, 1913, [w: ] PRFRUS 1913, s. 174-175; The Acting Secretary of State to the President, March 25, 1913, [w: ] ibidem, s. 175; Scott to Wilson, May 31, 1913, [w: ] PWW, t. 27, s. 488-490. Cytat pochodzi z pierwszego dokumentu.

53 Pożyczka reorganizacyjna opiewała na 25 milionów funtów szterlingów. Doc. no. 1913/5: France (Banque de l'Indo-Chine), Germany (Deutsch-Asiatische Bank), Great Britain (Hongkong of Shanghai Banking Corporation), Japan (Yokohama Specie Bank), Russia (Russo-Asiatic Bank) and China. Chinese Government five per cent Reorganization Gold Loan Agreement (with Agreement for advances, and annexes), April 26, 1913, [w:] Treaties and Agreements with and Concerning China, 1894-1919, zebrał i opracował J.V.A. MacMurray, t. 2: Republican Period (1912-1919), New York 1921, s. 1007-1038. 
Pekinu. Wymagałoby to jednak zdecydowanego poparcia politycznego ze strony Waszyngtonu dla amerykańskich przedsiębiorców, aby skuteczniej przekonać ich do inwestowania w Chinach oraz by zrównoważyć lub przynajmniej zminimalizować przewagę konkurentów z innych państw, wynikającą z systemu stref wplywów ${ }^{54}$. Nic takiego nie nastąpiło, wręcz odwrotnie - we wrześniu 1913 roku Bryan poinstruował poselstwo w Pekinie, że przedsiębiorcy nie będą mogli liczyć na szczególne wsparcie ${ }^{55}$. Wobec takiego nastawienia rządu, ciągle niestabilnej sytuacji w Chinach, możliwości prowadzenia bezpieczniejszych i równie dochodowych interesów w innych miejscach (przede wszystkim we własnym kraju), a także wobec problemów ze zgromadzeniem kapitału potrzebnego do udzielania dużych pożyczek zagranicznych, amerykańscy inwestorzy nie wkroczyli entuzjastycznie na rynek chiński, w którym ich udział pozostał stosunkowo niewielki ${ }^{56}$.

Ponadto wycofanie się oznaczało, że Amerykanie nie będą uczestniczyć w innych pożyczkach dotychczas lub w przyszłości wynegocjowanych przez konsorcjum (mieli się też wycofać z pożyczki huguangskiej i na reformę walutową ${ }^{57}$ ), tracąc tym samym wpływy polityczne i ekonomiczne, jako że obie dziedziny były ze sobą powiązane.

Być może nawet większe zagrożenie dla chińskiej polityki Stanów Zjednoczonych wynikało $\mathrm{z}$ wyłamania się z frontu mocarstw. Jeśli wycofanie się Waszyngtonu spowodowałoby rozpad konsorcjum, jego byli członkowie najpewniej skoncentrowaliby się wówczas na umacnianiu stref wpływów, utrudniając jeszcze bardziej utrzymanie zasad „otwartych drzwi”. Paradoksalnie odwrotny scenariusz był równie pesymistyczny. Gdyby pozostałe pięć mocarstw zacieśniło współpracę, Stany Zjednoczone, prowadzące samodzielną politykę, miałyby małe szanse, aby z nimi konkurować. A zatem niezależnie od rozwoju międzynarodowej sytuacji Chin należało się spodziewać, że polityczna i ekonomiczna pozycja USA ulegnie tam pogorszeniu.

${ }^{54}$ Zobacz opinię: R.W. Curry, Woodrow Wilson and Far Eastern Policy ..., s. 26-27.

55 The Secretary of State to the American Chargé d'Affaires, September 11, 1913, [w:] PRFRUS 1913, s. 186-187. Zob. też: Bryan to Wilson, June 4, 1913, [w:] PWW, t. 27, s. 494-495.

56 The American Chargé d'Affaires to the Secretary of State, October 21, 1913, [w: ] PRFRUS 1913, s. 189-191; Moore to Wilson, October 28, 1913, [w: ] PWW, t. 28, Princeton 1978, s. 458-463; W. Scholes, M. Scholes, The Foreign Policies of the Taft Administration, Columbia 1970, s. 247-248; The Cambridge History of China, t. 12: Republican China, 1912-1949, cz. 1, (red.) J.K. Fairbank, Cambridge 1983, s. 116-119; A.W. Griswold, The Far Eastern Policy of the United States, New York 1938, s. 174.

57 The American Group to the Secretary of State, March 19, 1913, [w: ] PRFRUS 1913, s. 171-172; The American Group to Morgan, Grenfell and Company, March 19, 1913, [w:] ibidem, s. 172-173. 


\section{Chiny w polityce zagranicznej Stanów Zjednoczonych w latach 1911-1918}

Równie niekorzystne mogło się okazać to, że po odejściu Amerykanów, którzy dotychczas starali się tonować zapędy innych członków, w konsorcjum wzrosną wpływy państw chcących wykorzystać słabość Chin i stanie się ono narzędziem ich polityki.

Był jeszcze jeden negatywny aspekt całej sprawy. Wilson poniekąd oskarżył inne mocarstwa i - na co zwraca uwagę Lloyd Gardner - zaczął zyskiwać niezbyt dobrą dla polityka „donkiszotowską reputację"58.

\section{Uznanie przez Stany Zjednoczone Republiki Chińskiej}

Wiedząc już, że nowy rząd amerykański miał zupełnie inną wizję polityki zagranicznej i działał „impulsywnie”, mocarstwa zaczęły obawiać się, że może on samodzielnie uznać Republikę Chińską. Pod koniec marca Wielka Brytania, Japonia i Niemcy przypomniały, że w 1912 roku Stany Zjednoczone zgodziły się w tej kwestii zachować jedność z pozostałymi mocarstwami ${ }^{59}$. Obawy okazały się jak najbardziej uzasadnione, bo właśnie w tym czasie Wilson zdecydował się uznać de iure władze pekińskie.

Z problemem mierzyła się wcześniej administracja Tafta, która chociaż momentami skłaniała się ku uznaniu, to ze względu na politykę współpracy i toczące się negocjacje na temat pożyczki reorganizacyjnej nie wyłamała się z koncertu mocarstw. Sytuacja Wilsona prezentowała się zgoła odmiennie - po wycofaniu się z konsorcjum i postawieniu na indywidualny kurs uznanie stanowiło dla niego logiczne następstwo wcześniejszego działania. Większość powodów wyjścia z konsorcjum odegrała też rolę w tym przypadku: chęć zerwania z „dyplomacją dolarową", odcięcia się od polityki poprzedników oraz innych mocarstw, podniesienia prestiżu w Chinach i ugruntowania przyjacielskich relacji między oboma państwami, zaznaczenia moralnego przewodnictwa na arenie międzynarodowej i zdecydowania nowego rządu. Ponownie była to decyzja politycznie bezpieczna i mogąca przysporzyć zwolenników, jako że większość rodaków ją popierała, w tym zwłaszcza środowiska misjonarskie i postępowe. Wreszcie kluczowy powód stanowiło wewnętrzne przekonanie Wilsona, że tak należało postąpić.

Pojawiły się też nowe czynniki. Oficjalna akceptacja Republiki Chińskiej wpisywałaby się w tradycyjną politykę Stanów Zjednoczonych, które jako kolebka nowożytnego republikanizmu („matka republik”, używając określenia chargé

58 L.C. Gardner, Safe for Democracy ..., s. 74.

59 The Japanese Ambassador to the Secretary of State, March 24, 1913, [w:] PRFRUS 1913, s. 173-174; The Ambassador of Great Britain to the Secretary of State, March 31, 1913, [w: ] ibidem, s. 105; Memorandum by the Division of Far Eastern Affairs of the Department of State, March 31, 1913, [w: ] ibidem, s. 105-106. 
d'affaires Williamsa ${ }^{60}$ ) uważały za swą powinność dziejową propagowanie tej idei. Niezwłoczne uznanie zmazałoby nieprzychylne wrażenie, jakie powstało w Chinach wskutek tego, że USA mimo głoszonych przez siebie zasad zwlekały dotychczas z podjęciem działań ${ }^{61}$. Było to tym istotniejsze, że zdaniem wielu osób ostatnie przemiany w Chinach dokonały się dzięki amerykańskim wpływom, a Chińczycy, postrzegający Amerykanów jako swoich mentorów i przyjaciół, szczególnie liczyli na ich wsparcie w okresie formatywnym. Brak uznania miał też według misjonarzy utrudniać wykorzystanie dogodnej szansy na ewangelizację, jaka pojawiła się po triumfie rewolucji $1911 \mathrm{roku}^{62}$.

Kolejny argument był co najmniej równie istotny, jeśli nie ważniejszy - sądzono, że uznanie wzmocniłoby młode władze chińskie, tym samym przyczyniając się do stabilizacji kraju. Stabilizacja stanowiła zaś nieodzowny warunek dalszego rozwoju, wprowadzenia reform, szerzenia demokracji i chrześcijaństwa, jak i zmniejszała ryzyko imperialistycznej ingerencji. Podkreślał to Williams, który chociaż nie szczędził cierpkich słów Republice, w marcu i kwietniu zalecił jej uznanie, szczególnie że na jej czele stał pozytywnie oceniany przez niego Yuan. Dyplomata wskazywał, że uznanie zapobiegłoby wysuwaniu przez inne mocarstwa żądań w zamian za akceptację władz pekińskich, jak czyniła to na przykład Wielka Brytania w odniesieniu do Tybetu ${ }^{63}$.

O uznanie zabiegała oczywiście strona chińska, dostrzegająca zmianę nastawienia amerykańskiej dyplomacji ${ }^{64}$. W Waszyngtonie zaczęto jednak podejrzewać, zapewne słusznie, że Yuanowi, który popadł w konflikt z opozycją, bardziej zależało na wzmocnieniu własnej pozycji aniżeli pozycji Chin ${ }^{65} .28$ marca Alvey Adee, drugi asystent sekretarza stanu, sporządzil na prośbę Bryana memorandum, w którym przedstawił różne procedury uznania obcego rządu. Ostatecznie zasugerował dwie, zależnie od efektu, jaki planowano uzyskać. Jeśli intencją było

${ }^{60}$ The American Chargé d'Affaires to the Secretary of State, March 18, 1913, [w: ] PRFRUS 1913, s. 96-98.

${ }^{61}$ Mott to Dodge, March 1, 1913, [w:] PWW, t. 27, s. 144-145; The American Chargé d'Affaires to the Secretary of State, March 18, 1913, [w:] PRFRUS 1913, s. 96-98.

${ }^{62}$ Scott to Wilson, March 1, 1913, WWP, series 4: case files, 226, reel 242; Moriarty to O'Shaunessy, April 24, 1913, WWP, series 4: case files, 227, reel 242.

${ }^{63}$ The American Chargé d'Affaires to the Secretary of State, March 18, 1913, [w:] PRFRUS 1913, s. 96-98; The American Chargé d'Affaires to the Secretary of State, March 28, 1913, [w: ] ibidem, s. 100; The American Chargé d'Affaires to the Secretary of State, April 1, 1913, [w:] ibidem, s. 106-108.

${ }^{64}$ The Chinese Minister for Foreign Affairs to the Secretary of State, March 25, 1913, [w:] PRFRUS 1913, s. 98-99; The American Chargé d'Affaires to the Secretary of State, March 28, 1913, [w:] ibidem, s. 100.

${ }_{65}$ The Second Assistant Secretary to the Secretary of State, March 28, 1913, [w:] PRFRUS 1913, s. 100-103. 
potwierdzenie władzy Yuana, Wilson mógł przyjąć chińskiego posła, który wręczyłby list gratulacyjny od przywódcy Chin. Jeśli natomiast chciano podkreślić akceptację zmiany ustroju, amerykańskie poselstwo powinno wydać stosowne oświadczenie, gdy zbierze się nowy parlament w Pekinie ${ }^{66}$. Przełożeni Adee'ego zdecydowali się na drugi wariant, zapewne właśnie dlatego, że oznaczał uznanie systemu politycznego, a nie rządów Yuana, przeciwko któremu zaczęto wysuwać różne oskarżenia. Drugi wariant miał jeszcze jedną zaletę - pozwalał po części spełnić wymóg testu demokratycznego, który podnosiła administracja Tafta. Ukonstytuowanie się parlamentu wyłonionego w wyborach ogólnokrajowych przynajmniej częściowo spełniało stawiany przez nią warunek.

1 kwietnia podczas posiedzenia rządu Wilson oznajmil, że zamierza uznać Republikę Chińską 8 kwietnia, kiedy miała się odbyć inauguracyjna sesja parlamentu w Pekinie. Członkowie gabinetu zaczęli jednak wyrażać różne wątpliwości. Poruszyli na przykład kwestię współpracy z innymi mocarstwami. Wilson zgodził się poinformować je o swoim zamiarze i zaprosić do przyłączenia się, ale stanowczo zaznaczyl, że nie dopuści, aby sprawa uznania stała się przedmiotem międzynarodowej konferencji, podczas której wszyscy mieliby jednakowy głos, a Stany Zjednoczone byłyby związane wolą większości. Decyzja Wilsona o uznaniu Republiki Chińskiej była nieodwołalna, pozostali mogli jedynie pójść jego śladem ${ }^{67}$.

Był to zręczny manewr dyplomatyczny, gdyż pozwalał uniknąć ponownych oskarżeń o nieinformowanie zainteresowanych mocarstw ${ }^{68}$, a zarazem krótki termin dany do namysłu sprawiał, że ich odmowa była właściwie przesądzona ${ }^{69}$. Atut manewru polegał również na tym, że niezależnie od decyzji mocarstw Stany Zjednoczone i tak odniosłyby korzyść. Gdyby mocarstwa przyłączyły się, uznałyby przywództwo Ameryki, podkreślając jej rolę na arenie międzynarodowej, i same przyznałyby się do prowadzenia błędnej polityki. Pekin byłyby ponadto niezwykle wdzięczny Waszyngtonowi. W skrócie - Stany Zjednoczone zyskałyby wszystko, co było do zyskania, pozostałe mocarstwa nie zyskałyby nic. Gdyby mocarstwa pozostały zaś przy dotychczasowym stanowisku, Chiny byłyby USA równie wdzięczne, że przynajmniej one zdecydowały się na oficjalne uznanie.

Zgodnie z ustaleniami 2 kwietnia Bryan zwrócił się do państw, które nawiązały relacje z Chinami, z propozycją wspólnego uznania Republiki ${ }^{70}$. Tylko Brazylia,

${ }^{66}$ Ibidem.

${ }^{67}$ April 1, 1913, [w:] The Cabinet Diaries ..., s. 19-21.

${ }^{68}$ Pomni ostatnich doświadczeń członkowie rządu zastanawiali się także, kiedy poinformować o całej sprawie prasę. Ibidem.

${ }^{69}$ Zob. odpowiedź Wielkiej Brytanii z 7 kwietnia. Note, [w:] PRFRUS 1913, s. 110-111.

70 Aide Mémoire handed by the Secretary of State to the representatives in Washington of countries having treaty relations with China, as follows: Austria-Hungary, Belgium, Brazil, Cuba, Denmark, France, Germany, Great Britain, Italy, Japan, Mexico, Netherlands, Norway (mailed), Peru, Portugal, Russia, Spain and Sweden, April 2, 1913, [w:] PRFRUS 1913, s. 108. 
Meksyk, Peru i Kuba odpowiedziały pozytywnie, pozostali adresaci, w tym najbardziej liczące się państwa, odmówili przyłączenia się. Londyn i Tokio prosiły nawet o odroczenie zaplanowanego działania, ale Waszyngton nie chciał się wycofać ${ }^{71}$.

Oprócz kwestii współpracy członkowie rządu Wilsona wskazywali też na inne problematyczne aspekty całej sytuacji. Sekretarz rolnictwa David Houston uważal, że informacje z Chin były niewystarczające. Nie wiedziano nic chociażby na temat potencjalnych działań i nastawienia parlamentu, dlatego Houston doradzał czekać na rozwój wydarzeń. Inni członkowie rządu zastanawiali się, czy Chiny będą w stanie funkcjonować jako republika i czy Yuan nie miał inklinacji dyktatorskich, zwłaszcza że - o czym ku zaskoczeniu pozostałych poinformował Bryan - oskarżono go właśnie o zlecenie morderstwa jednego z głównych przeciwników politycznych (będzie o tym mowa w dalszej części rozdziału). Wątpliwości nie odwiodły Wilsona od już powziętej decyzji. Stwierdził on, że uznanie pomoże utworzyć w Chinach stabilny rząd i osłonić je przed wrogimi zakusami mocarstw. Na obiekcje dotyczące możliwości utrzymania przez Chiny systemu republikańskiego odparł dosyć zaskakująco, że po latach badań doszedł do przekonania, że „ten sam typ rządów nie jest odpowiedni dla wszystkich państw”72.

6 kwietnia Williams otrzymał instrukcje, aby uznać Republikę Chińską, gdy tylko zbierze się parlament, dokona elekcji władz i będzie gotowy do podjęcia pracy $^{73}$. Dwa dni później podczas połączonych obrad obu izb odbyła się ceremonia otwarcia parlamentu, ale czynności organizacyjne, głównie ze względu na narastający konflikt wewnętrzny, trwały aż do początku maja ${ }^{74}$. Do tego czasu Stany Zjednoczone wstrzymały się z ogłoszeniem uznania, wyrażając zdziwienie i nawet pewne rozczarowanie opieszałością Chińczyków ${ }^{75}$.

${ }^{71}$ Japonia uważała, że uznanie Chin w momencie, gdy narastał tam kryzys polityczny, oznaczałoby ingerencję w wewnętrzne sprawy tego państwa i opowiedzenie się po stronie Yuana. Rosja była zdania, że USA powinny się podporządkować jej przywództwu w odniesieniu do Chin, a ona uczyni to samo wobec amerykańskiego rządu w kwestii Meksyku. Wilson stanowczo odrzucił taką możliwość. PRFRUS 1913, s. 109-115; April 1, 1913, April 4, 1913, [w:] The Cabinet Diaries ..., s. 19-23; D.F. Houston, Eight Years ..., s. 49.

72 D.F. Houston, Eight Years ..., s. 49; April 4, 1913, [w:] The Cabinet Diaries ..., s. 21-23. Cytat zaczerpnięty został z pierwszej książki.

73 The Secretary of State to the American Chargé d'Affaires, April 6, 1913, [w:] PRFRUS 1913, s. 109-110.

${ }^{74}$ Zdaniem Williamsa gdyby nie informacja, że USA zamierzają uznać Republikę Chińską, parlament pewnie w ogóle by się wówczas nie zebrał. The American Chargé d'Affaires to the Secretary of State, April 11, 1913, [w:] PRFRUS 1913, s. 112-114.

75 Zdziwienie wynikało poniekąd z faktu, że politycy w Waszyngtonie byli słabo poinformowani o sytuacji w Chinach. April 4, 1913, April 18, 1913, [w:] The Cabinet Diaries..., s. 21-23, 40-46; Remarks at a Press Conference, April 11, 1913, [w: ] PWW, 


\section{Chiny w polityce zagranicznej Stanów Zjednoczonych w latach 1911-1918}

Pekin, chcąc zdopingować Waszyngton do działania, wpadł na osobliwy, acz do pewnego stopnia skuteczny pomysł. 17 kwietnia zaapelował, aby za dziesięć dni w chrześcijańskich kościołach odprawiono modły za pomyślność Republiki, w tym m.in. za uznanie jej na arenie międzynarodowej. Wilson i Bryan byli zachwyceni, poczytali to za dowód na duchowe przeobrażenie Chin zapoczątkowane przez rewolucję Xinhai. Bryan stwierdził nawet, że to „najbardziej niezwykły oficjalny dokument, jaki został wydany w ciągu pokolenia”. Więcej sceptycyzmu wykazał Redfield, który kwestionował szlachetność intencji Chińczyków, dopatrując się w ich apelu wyrachowanej próby zyskania poparcia społeczności chrześcijańskiej. Uważał, że cała inicjatywa mogła się nawet okazać szkodliwa dla Republiki Chińskiej, gdyż mogła dać asumpt do oskarżeń, że nowe władze były faktycznie kontrolowane przez cudzoziemskich chrześcijan, zwłaszcza że chrześcijanie w Chinach stanowili zdecydowaną mniejszość. Wilson, chociaż nie wykluczał, że Redfield mógł mieć trochę racji, stwierdził, że należało przyjąć inicjatywę jako szczerą, wypływającą z potrzeby serca i przyłączyć się do modlitwy. Opowiedział się też za niezwłocznym uznaniem władz pekińskich. Wcześniej jednak Bryan miał się dowiedzieć, co działo się w Chinach i dlaczego doszło do opóźnienia $^{76}$. Ostatecznie nie przyśpieszono momentu uznania, który nastąpił 2 maja 1913 roku, po tym jak parlament w Pekinie w pełni się ukonstytuował. Stany Zjednoczone były pierwszym mocarstwem, które formalnie zaakceptowało Republikę Chińską ${ }^{77}$.

Uznanie Republiki spotkało się w znacznej mierze z podobną reakcją jak decyzja o wycofaniu się z konsorcjum. Tak jak poprzednio większość Amerykanów popierała działanie rządu. Z kolei Wilson i Bryan nie kryli ukontentowania. Bryan z typową dla siebie przesadą pisał o „epokowym” wydarzeniu. Jeszcze większy entuzjazm panował w Chinach. Pomijając część członków Kuomintangu, którzy obawiali się, że uznanie umocni pozycję Yuana, ludzie w całym kraju cieszyli się i dawali temu wyraz (np. 8 maja zorganizowano w Pekinie paradę na cześć USA, w której uczestniczyli przedstawiciele różnych środowisk). Negatywnie uznanie odebrały mocarstwa, choć tym razem nie były urażone ani zaskoczone ${ }^{78}$.

t. 27, s. 284-289; Remarks at a Press Conference, April 21, 1913, [w: ibidem, s. 337-341. Zob. też: Remarks at a Press Conference, April 7, 1913, [w: ] PWW, t. 50, Princeton 1985, s. 5-13.

${ }^{76}$ April 18, 1913, [w: ] The Cabinet Diaries ..., s. 40-46.

77 The American Chargé d'Affaires to the Secretary of State, May 2, 1913, [w:] PRFRUS 1913, s. 115; The American Chargé d'Affaires to the Secretary of State, May 6, 1913, [w: ibidem, s. 116-118. Wcześniej, zdaniem Williamsa w wyniku nieporozumienia, Republikę Chińską uznały Brazylia i Peru. The American Chargé d'Affaires to the Secretary of State, April 11, 1913, [w: ] ibidem, s. 112-114.

78 The President of China to the President of the United States, May 2, 1913, [w: ] PRFRUS 1913, s. 116; The American Chargé d'Affaires to the Secretary of State, May 6, 
Uznanie Republiki stanowiło logiczne uzupełnienie wcześniejszych działań - wzmocniło wydźwięk wycofania się z konsorcjum i potwierdziło, że nastąpił nowy etap w amerykańskiej polityce wobec Chin. W tym sensie należy ocenić je pozytywnie. Waszyngton starał się tym razem działać $\mathrm{z}$ większą rozwagą. Poinformował o swoim zamiarze inne mocarstwa, aby przynajmniej zachować pozory współpracy. Nie czekał, co prawda, na pełne ukonstytuowanie się nowego syste$\mathrm{mu}$ (np. przyjęcie ustawy zasadniczej czy wybór stałego prezydenta), ale uznanie nie było bezwarunkowe, nastąpiło dopiero po zebraniu się parlamentu. Stany Zjednoczone próbowały odnieść się tylko do ustroju i uniknąć bezpośredniego wsparcia Yuana, chociaż niektórzy inaczej to odebrali, a i sam Yuan poczuł się pewniej. Całkowicie zawiodły zaś amerykańskie rachuby dotyczące ustabilizowania się sytuacji w Chinach. Jeszcze kilka dni po formalnym uznaniu Williams przekonywat, że będzie ono miało kojący wpływ na wewnętrzne konflikty oraz ugruntuje poparcie dla Republiki ${ }^{79}$. Nic bardziej mylnego. Dwa miesiące później wybuchła w Chinach kolejna rewolucja, w wyniku której pełnię władzy przejął Yuan, zmierzający do wprowadzenia jednowładztwa, a w dalszej perspektywie do obalenia ustroju republikańskiego i restauracji cesarstwa.

\section{Waszyngton wobec „drugiej rewolucji” w Chinach i wzrostu dążeń autorytarnych Yuan Shikaia ${ }^{80}$}

Gdy następowała reorientacja amerykańskiej polityki wobec Chin, w Państwie Środka narastał konflikt wewnętrzny, który doprowadził ostatecznie do wybuchu wojny domowej, zwanej „drugą rewolucją”. Na przełomie lat 1912 i 1913 stosunki między Yuan Shikaiem i jego stronnikami a Kuomintangiem i częścią urzędników prowincjonalnych stopniowo się pogarszaty. Kilka przyczyn legło u źródeł wzrastających animozji. Pierwszym kluczowym wydarzeniem były wybory do parlamentu ogólnonarodowego, trwające od grudnia 1912 roku.

1913, [w:] ibidem, s. 116-119; The American Chargé d'Affaires to the Secretary of State, May 9, 1913, [w:] ibidem, s. 119; Adee to Tumulty, May 9, 1913, WWP, series 4: case files, 226, reel 242; The Chinese Minister to the Secretary of State, May 12, 1913, [w:] PRFRUS 1913, s. 120; The American Chargé d'Affaires to the Secretary of State, May 13, 1913, [w: ] ibidem, s. 120-121; Moore to Tumulty, May 14, 1913, WWP, series 4: case files, 226, reel 242; Moore to Tumulty, May 16, 1913, ibidem; R.W. Curry, Woodrow Wilson and Far Eastern Policy ..., s. 30-32; Tien-yi Li, Woodrow Wilson's China Policy ..., s. 78-81.

79 The American Chargé d'Affaires to the Secretary of State, May 6, 1913, [w:] PRFRUS 1913, s. 116-119.

${ }^{80}$ Niniejszy podrozdział z drobnymi zmianami opublikowałem jako artykuł w: „Dzieje Najnowsze” 2014, R. 46, nr 4, s. 55-72. Dziękuję redakcji „Dziejów Najnowszych" za zgodę na ponowne opublikowanie tekstu. 
Zwycięstwo odniósł w nich Kuomintang, kierowany przez młodego i energicznego Song Jiaorena. Partia Narodowa uzyskała przewagę w obu izbach, mając tym samym dogodną pozycję do sformowania swojego gabinetu i odsunięcia od władzy rządu kontrolowanego przez Yuana. Naturalnym kandydatem na premiera wydawał się Song, który od momentu poznania wyników wyborów zaczął się coraz ostrzej wypowiadać przeciwko Yuanowi, czego unikał podczas kampanii. W przemówieniach optował za wzmocnieniem parlamentu kosztem władzy wykonawczej. Rozważał nawet usunięcie Yuana $\mathrm{z}$ fotela prezydenckiego, i to wbrew stanowisku Sun Yat-sena. Wzrost znaczenia Kuomintangu i coraz bardziejkonfrontacyjna postawa Songa na tyle zaniepokoiły Yuana, że najprawdopodobniej zlecił on zabicie niewygodnego rywala. W zamachu dokonanym 20 marca 1913 roku w Szanghaju Song został ciężko ranny i dwa dni później zmarł. Zamordowanie go wywołało powszechne oburzenie i wzmogło wojenne nastroje wśród członków Kuomintangu, którzy jednoznacznie uznali Yuana za mocodawcę skrytobójców ${ }^{81}$.

Kolejnym wydarzeniem, które zaogniło sytuację w Chinach, było podpisanie pożyczki reorganizacyjnej bez akceptacji parlamentu, a więc niezgodnie z Konstytucją Tymczasową. Yuan, świadomy negatywnego nastawienia Kuomintangu, zdecydował się na takie rozwiązanie, aby tylko otrzymać pieniądze potrzebne mu do sfinansowania funkcjonowania administracji, wprowadzenia reform, jak i do rozprawy z opozycją w coraz bardziej realnym starciu wewnętrznym. Parlamentarzyści próbowali nie dopuścić do zawarcia kontraktu, ale ich protesty okazały się daremne, gdyż zarówno Yuan, jak i konsorcjum byli zdeterminowani, aby sfinalizować negocjacje, nawet $\mathrm{z}$ naruszeniem konstytucyjnych procedur ${ }^{82}$.

Trzecia płaszczyzna konfliktu dotyczyła organizacji państwa. W Chinach ścierały się naówczas dwie tendencje - centralistyczna i decentralistyczna. Rewolucja 1911 roku doprowadziła do osłabienia rządu w Pekinie i wzmocnienia struktur lokalnych. Większość prowincji uzyskała znaczną niezależność militarną,

81 The Cambridge History of China..., s. 222-224, 226-228; J. Ch'ên, Yuan Shih-k'ai, 1859-1916. Brutus Assumes the Purple, London 1961, s. 160-163; W. Rodziński, Historia Chin, Wrocław 1992, s. 618; K.S. Liew, Struggle for Democracy: Sung Chiao-jen and the 1911 Chinese Revolution, Berkeley 1971, s. 182-192.

82 The American Chargé d'Affaires to the Secretary of State, April 27, 1913, [w: ] PRFRUS 1913, s. 179; The American Chargé d'Affaires to the Secretary of State, May 6, 1913, [w: ] ibidem, s. 180-182; Manifesto of Doctor Sun Yat Sen, undated, issued on May 6, 1913, [w:] ibidem, s. 123; The American Chargé d'Affaires to the Secretary of State, May 16, 1913, [w:] ibidem, s. 121-122; J. Ch'ên, Yuan Shih-k'ai..., s. 157-159; The Cambridge History of China ..., s. 231-232. Sir John Jordan, brytyjski poseł w Pekinie, uznał, że udzielając pożyczki, mocarstwa właściwie opowiedziały się po stronie Yuana. K.C. Chan, British Policy in the Reorganization Loan to China 1912-1913, „Modern Asian Studies” 1971, t. 5, nr 4, s. 372. 
polityczną i finansową - dysponowała własną armią, własnym parlamentem, ściągała podatki, których następnie często nie przesyłała do stolicy. Na tym tle również zarysował się spór między przywódcami Kuomintangu, zwłaszcza Songiem, a Yuanem. Ci pierwsi chcieli utrzymać autonomię prowincji, zamysły prezydenta szły z kolei w przeciwnym kierunku. Dążył on do centralizacji państwa i właściwie od początku urzędowania próbował realizować swoje zamiary. Początkowo efekty jego działań były niezbyt zadowalające, ale z czasem zdołał podporządkować sobie część prowincji, wiele jednak pozostawało poza jego kontrolą. Na początku 1913 roku Yuan zaczął szykować się do rozprawy z opozycją. Po uzyskaniu funduszy od konsorcjum i zakończeniu przygotowań militarnych nakazał w czerwcu ustąpienie trzem wrogim mu gubernatorom kuomintangowskim, przystępując jednocześnie do pacyfikacji kraju. Obie decyzje stały się bezpośrednimi przyczynami wybuchu „drugiej rewolucji”, czyli zbrojnego oporu części Kuomintangu wobec działań Yuana ${ }^{83}$.

Omawiając genezę wojny domowej w Chinach, należy także wspomnieć o chęci przejęcia władzy przez Partię Narodową. Część osób zaangażowanych w rewolucję Xinhai uważała, że kompromis wypracowany na początku 1912 roku był niekorzystny, gdyż zanadto faworyzował Yuana, który okazał się politykiem konserwatywnym. Ich rozgoryczenie potęgował fakt, że różne ważne stanowiska w państwie obsadzone zostały przez dostojników i wojskowych związanych z dawnym systemem. „Fasada się zmieniła, ale istota funkcjonowania państwa i ludzie pozostali ci sami” - zdawali się sądzić niektórzy rewolucjoniści. Od jakiegoś czasu proponowali oni, aby dokonać secesji i utworzyć własny rząd w Nankinie. Koncyliacyjne nastawienie reszty zwyciężyło, ale po zabójstwie Songa i podpisaniu pożyczki reorganizacyjnej ich głosy stały się ponownie wyraźnie słyszalne ${ }^{84}$.

Informacje o narastającym kryzysie w Chinach docierały do Waszyngtonu w miarę regularnie. Autorem najważniejszych wiadomości był chargé d'affaires Edward Williams, który od końca lutego do listopada 1913 roku stał na czele amerykańskiego poselstwa w Pekinie ${ }^{85}$. Spowodowane to było różnymi komplikacjami, jakie administracja Wilsona napotkała przy wyborze nowego posła, co zostanie szerzej poruszone $\mathrm{w}$ dalszej części tego rozdziału.

Williams miał wyraźnie sprecyzowane poglądy na temat sytuacji w Chinach i polityki, jaką Stany Zjednoczone powinny prowadzić w tym państwie. Głównym

83 J. Ch'ên, Yuan Shih-k'ai..., s. 163-165; The Cambridge History of China..., s. 214-216, 227-230, 232-233.

84 The American Chargé d'Affaires to the Secretary of State, May 16, 1913, [w: ] PRFRUS 1913, s. 121-122.

85 D.D. Lazo, An Enduring Encounter: E.T. Williams, China, and the United States, nieopublikowany doktorat, University of Illinois at Urbana-Champaign, Urbana 1977, s. 199, 220; R.W. Curry, Woodrow Wilson and Far Eastern Policy ..., s. 39. 


\section{Chiny w polityce zagranicznej Stanów Zjednoczonych w latach 1911-1918}

założeniem jego rozumowania było przekonanie, że w dłuższej perspektywie jedynie Chiny mogły zagwarantować przestrzeganie obu zasad „otwartych drzwi”, na czym zależało Amerykanom. By tak się stało, Chiny musiały zostać wzmocnione. Republika, która wyłoniła się po rewolucji Xinhai, była tworem wątłym, pozbawionym wewnętrznej spójności. Chaos, bezprawie, konflikty wewnętrzne i presja mocarstw uniemożliwiały zbudowanie stabilnego państwa. Zdaniem Williamsa jedynym rozwiązaniem było stworzenie silnego rządu centralnego, zdolnego zapanować nad sytuacją, zaprowadzić porządek i zainicjować program modernizacji kraju. To z kolei oddaliłoby niebezpieczeństwo interwencji mocarstw i podziału Chin. Williams uważał, że demokracja i parlamentaryzm stanowiły właściwy kierunek rozwoju, ale zmiany należało wprowadzać powoli, zważywszy na zacofanie cywilizacyjne społeczeństwa chińskiego (m.in. bardzo wysoki odsetek analfabetów) i jego nieprzystosowanie do takich rozwiązań ustrojowych. Niezbędny był długi okres przejściowy, podczas którego nadzór nad państwem sprawować powinien silny rząd centralny, czerpiący wzorce z władców oświeconych. Jeśli chodzi o najlepszą strategię działania dyplomacji amerykańskiej, to - według Williamsa - aby osiągnąć priorytetowy cel, a więc wzmocnienie Chin, należało zależnie od okoliczności manewrować między współpracą z innymi mocarstwami a samodzielnym kursem. Proponowana przez Williamsa metoda sytuowała się zatem między podejściem Tafta a Wilsona ${ }^{86}$.

Poglądy Williamsa znalazły odzwierciedlenie w jego raportach przesyłanych do Waszyngtonu. Właściwie niemal wszystkie wydarzenia w Chinach oceniał on przez pryzmat swoich przeświadczeń, stąd można mówić o pewnej jego tendencyjności, jeśli nie o stronniczości. Miało to spore znaczenie, gdyż o ile w latach 1911-1912 doniesienia Williamsa były uzupełnieniem raportów posła Williama Calhouna, o tyle przez większość 1913 roku, po wyjeździe tego drugiego z Pekinu, stanowiły już najistotniejsze źródło wiadomości Departamentu Stanu. Departament dysponował również częścią raportów od amerykańskich konsulów, które przesyłali albo oni sami, albo Williams, lecz ich perspektywa była ograniczona, a ranga znacznie niższa. Należy jeszcze wspomnieć o komunikatach kontradmirała Reginalda Nicholsona, dowódcy Floty Azjatyckiej, co pewien czas docierających do Departamentu Stanu z Departamentu Marynarki. Bezsprzecznie jednak to Williams miał największe możliwości, aby wpływać na obraz „drugiej rewolucji”, jaki kształtował się w Waszyngtonie.

Williams dość regularnie informował swoich przełożonych o narastającym konflikcie w Chinach. W marcu pisał, że chociaż wybory z przełomu roku przebiegły spokojnie, to atmosfera w kraju była napięta. Już od kilku miesięcy Yuan nie mógł porozumieć się z tymczasowym parlamentem, który blokował wszystkie jego inicjatywy. Prezydent próbował różnymi metodami (perswazją,

86 D.D. Lazo, An Enduring Encounter ..., s. 208-222. 
przekupstwem, groźbami) przezwyciężyć to obstrukcyjne nastawienie parlamentarzystów, ale od pewnego czasu byli oni nieugięci. Sprzeciwili się m.in. rządowemu projektowi powołania komisji mającej opracować Stałą Konstytucję, uznając, że dopiero parlament wyłoniony w wyborach ogólnokrajowych może to zrobić. Williams bardzo krytycznie wypowiadał się o parlamencie, stwierdził nawet, że jego rozwiązanie nie byłoby wielką stratą ${ }^{87}$.

Drugi z poważnych sporów przebiegał na linii Pekin-prowincje i dotyczył zakresu autonomii tych ostatnich. Uzyskawszy znaczną niezależność podczas rewolucji 1911 roku, były one niechętne przywróceniu status quo ante bellum. Niektórzy gubernatorzy jawnie przeciwstawiali się poleceniom płynącym ze stolicy. Williams przewidywal, że minie wiele miesięcy, nim ta kwestia zostanie ostatecznie unormowana. Wzajemna wrogość i zawiść prowincji oraz ich niechęć wobec rządu centralnego były bowiem równie wyraźne, jak wśród Amerykanów w okresie, gdy walczyli o swoją niepodległość ${ }^{88}$.

Zamieszanie w Chinach pogłębiały jeszcze liczne wystąpienia żołnierzy, rozruchy i spiski, w tym ostatni z początku lutego 1913 roku skierowany przeciwko wiceprezydentowi Li Yuanhongowi. W wielu rejonach kraju szerzyły się bandytyzm i grabieże, których władze lokalne nie potrafily wyplenić. Ponadto Republika ponosiła porażki w wojnie z Tybetem oraz musiała odpierać ataki Mongołów, inspirowane przez Rosję, która liczyła, że przygraniczne potyczki dadzą jej pretekst do interwencji zbrojnej. Negatywny pejzaż dopełniały jeszcze działania mandżurskich konspiratorów, dążących do restytucji swojej władzy ${ }^{89}$.

Williams uważal, że w zaistniałych okolicznościach najlepszym rozwiązaniem było wsparcie Yuana i jego rządu, dlatego zalecił formalne ich uznanie, o czym była już mowa. Starając się nakłonić przełożonych do podjęcia takiej decyzji, złagodził nieco wydźwięk swoich doniesień, czasem wręcz im przecząc. Stwierdził między innymi, że prowincjonalizm, jakkolwiek nadal silny, „powoli zanika” dzięki różnym reformom i działaniom misjonarzy. Także agresywne poczynania mocarstw

87 The American Chargé d'Affaires to the Secretary of State, March 11, 1913, [w:] PRFRUS 1913, s. 94-95; The American Chargé d'Affaires to the Secretary of State, March 18, 1913, [w: ] ibidem, s. 96; Williams to the Secretary of State, July 18, 1913, Records of the Department of State Relating to Internal Affairs of China, 1910-1929 (dalej RDSRIACh), The National Archives at College Park, College Park, (mikrofilm), roll 12.

${ }^{88}$ The American Chargé d'Affaires to the Secretary of State, March 11, 1913, [w:] PRFRUS 1913, s. 94-95; The American Chargé d'Affaires to the Secretary of State, March 18, 1913, [w:] ibidem, s. 96-98.

89 The American Chargé d'Affaires to the Secretary of State, March 11, 1913, [w: ] PRFRUS 1913, s. 94-95; The American Chargé d'Affaires to the Secretary of State, March 18, 1913, [w: ] ibidem, s. 96; The American Chargé d'Affaires to the Secretary of State, March 18, 1913, [w: ibidem, s. 96-98; Williams to Bryan, April 30, 1913, WWP, series 4: case files, 227, reel 242. 


\section{Chiny w polityce zagranicznej Stanów Zjednoczonych w latach 1911-1918}

stały się katalizatorem dla kiełkującego chińskiego patriotyzmu. Zasługi na tym polu miał ponadto Yuan, który z „wyjątkowym taktem” łagodził wszelkie spory między prowincjami i wzmacniał jedność państwa. Williams zrewidował też po części swoją opinię na temat niepokojów i rozruchów społecznych, odnotowując, że summa summarum obecne wystąpienia nie były gorsze niż za czasów Qingów. „Kiedy zrozumie się, jak wielka rewolucja miała miejsce - przekonywał - wyda się zadziwiające, że porządek jest tak dobrze utrzymany" 90 .

Można przypuszczać, że zmiana postrzegania niektórych spraw przez Williamsa nie była szczera, a raczej podyktowana względami taktycznymi. Jedno przekonanie pozostawało jednak u niego stałe - niesłabnące poparcie dla Yuana. Chociaż generał nie był „idealnym prezydentem czy znakomitym mężem stanu”, to i tak stanowił jedyny możliwy wybór wobec chaosu. Wyłącznie on mógł utrzymać porządek, dając czas republikańskim instytucjom na okrzepnięcie, a społeczeństwu na wyłonienie może i wybitniejszego przywódcy. Zdaniem Williamsa największe niebezpieczeństwo ówczesnej sytuacji Chin polegało na tym, że los państwa zależał wyłącznie od jednego człowieka. Gdyby Yuan zmarł lub został zabity, a ta druga ewentualność była całkiem realna, skutki okazałyby się katastrofalne ${ }^{91}$. Williams tak bardzo wierzył w Yuana, że bronił go przed oskarżeniami o zlecenie zamordowania Songa czy nawet ciche na to przyzwolenie. Argumentem świadczącym o niewinności prezydenta miało być jego duże doświadczenie polityczne, dzięki któremu musiał zdawać sobie sprawę, że w przypadku zamachu na przywódcę opozycji automatycznie stałby się głównym podejrzanym, co osłabiłoby jego wpływy w państwie. Yuan był zresztą tak wytrawnym politykiem, że z pewnością wymanewrowałby Songa bez konieczności uciekania się do jego fizycznej likwidacji. Williams nie wyłączał jednak możliwości, że zamachu dokonał jakiś nadgorliwy zwolennik Yuana ${ }^{92}$.

Wyższość Yuana wynikała nie tylko z jego zalet per se, ale także ze słabości politycznych przeciwników. Zdaniem Williamsa nikt nie był nawet „wart wzmiankowania" jako potencjalny kontrkandydat do fotela prezydenckiego.

90 The American Chargé d'Affaires to the Secretary of State, March 18, 1913, [w:] PRFRUS 1913, s. 96-98.

91 Williams pisał, że od czasu inauguracji Yuan tylko dwa lub trzy razy opuścił swoją rezydencję, przedsiębiorąc przy każdej z tych okazji wzmożone środki ostrożności. Minister spraw zagranicznych Lu Zhengxiang miał z kolei codziennie otrzymywać listy z pogróżkami. The American Chargé d'Affaires to the Secretary of State, April 1, 1913, [w:] PRFRUS 1913, s. 106-108. W kolejnych latach Yuan nadal niesłychanie rzadko wyjeżdżał ze swego pałacu, co wynikało z groźby zamachu, jak i chęci odseparowania się od społeczeństwa, aby wytworzyć wokół siebie aurę niedostępności, nawiązującą do czasów cesarskich. P. Reinsch, An American Diplomat in China, Garden City 1922, s. 6.

92 The American Chargé d'Affaires to the Secretary of State, April 1, 1913, [w:] PRFRUS 1913, s. 106-108. 
Kuomintang podobno nie miał w swoich szeregach osoby o ogólnopaństwowej renomie, zdolnej rywalizować z urzędującym prezydentem. Williams w swej deprecjacji Partii Narodowej posunął się jeszcze dalej, imputując, że to najprawdopodobniej któryś z jej członków odpowiadał za morderstwo Songa. Twierdził, że przywódcy mniejszych partii wchodzących w skład Kuomintangu zazdrościli Songowi kariery oraz nie zgadzali się z jego polityką, i z tych powodów zlecili jego zabójstwo. Nie było to zaskakujące - przekonywał dyplomata - wszak rewolucjoniści od dawna głosili i stosowali terror indywidualny. „Muszą się spodziewać, że zbiorą to, co sieją" - brzmiała jego nieco poetycka konkluzja ${ }^{93}$.

Jaki był oddźwięk tych doniesień w Waszyngtonie, trudno jednoznacznie stwierdzić. Wydaje się, że w początkowym okresie administracja Wilsona i tak prowadziła wcześniej już ustaloną przez siebie politykę, bez oglądania się na opinie innych, nawet własnych dyplomatów. Akurat spostrzeżenia Williamsa raczej współgrały z jej stanowiskiem, zwłaszcza w kwestii uznania nowych władz chińskich, i dlatego zapewne utwierdzały ją w przekonaniu o słuszności obranego kierunku, nawet jeśli owego kierunku nie wyznaczały.

O tym, że w Waszyngtonie podzielano punkt widzenia Williamsa, może świadczyć odpowiedź, jakiej prezydent Wilson udzielił podczas konferencji prasowej. Zapytany, czy w Chinach dojdzie do kolejnych zabójstw politycznych, stwierdził: „Ależ, miało miejsce tylko jedno, czyż nie?"94, świadomie umniejszając wagę zamordowania Songa. Sekretarz marynarki Josephus Daniels wydawał się z kolei sądzić, że Yuan był niewinny i tylko próbowano go wplątać w zgładzenie „prominentnego Chińczyka”, którego nazwiska Amerykanin w swoim dzienniku nigdy nawet nie wymieni195. Ogólnie rzecz biorąc, członkowie gabinetu Wilsona mimo komunikatów Williamsa sprawiali wrażenie słabo zorientowanych w zawikłanej sytuacji Chin. Część wydarzeń przeinaczali, o pewnych dowiadywali się z opóźnieniem, co wynikało poniekąd z o wiele mniejszego niż w 1911 roku zainteresowania opinii publicznej rozwojem wypadków w Państwie Środka ${ }^{96}$.

Po podjęciu dwóch kluczowych decyzji w sprawie Chin - wycofaniu z konsorcjum mocarstw i uznaniu Republiki - Stany Zjednoczone spokojne obserwowały rozwój wydarzeń w tym kraju, ciągle popierając Yuana. Ani zarzuty o współudział w zabójstwie Songa, ani okoliczności podpisania pożyczki reorganizacyjnej nie nadszarpnęły ich wiary w niego ${ }^{97}$. Oczywiście wybuch nowej wojny byłby dla Amerykanów niekorzystny, gdyż postawiłby ich przed niemal tymi samymi

93 Ibidem.

94 Remarks at a Press Conference, April 11, 1913, [w: ] PWW, t. 27, s. 284-289.

95 April 4, 1913, April 8, 1913, April 18, 1913, [w: ] The Cabinet Diaries ..., s. 21-23, $25-28,40-46$.

96 Ibidem.

97 D.M. Crane, T.A. Breslin, An Ordinary Relationship ..., s. 130. 
wyzwaniami i dylematami, co rewolucja Xinhai, ale sądzili oni, że do wojny nie dojdzie ${ }^{98}$.

W tym duchu wypowiadał się Williams, który donosił, że przywódcy Kuomintangu spotkali się w Szanghaju i dyskutowali nad wszczęciem zbrojnego powstania. Podjęli też próby uzyskania pożyczki i zakupu broni ${ }^{99}$. Grono spiskowców i potencjalnych buntowników było jednak ograniczone do zwolenników Sun Yatsena, gdyż zwykli ludzie generalnie odnieśli się do pomysłu kolejnego powstania obojętnie, a kupcy byli mu przeciwni. Świadomość tego utemperowała nieco zapał rewolucjonistów, którzy chwilowo wycofali się ze swoich planów, ale ponieważ Yuan kontynuował bezkompromisowy kurs, nastąpił wybuch wojny domowej. Williams ciągle sądził, że tak się nie stanie. Wierzył, że dopóki środowiska kupieckie pozostawały negatywnie nastawione do prób przejęcia władzy, dopóty jakiekolwiek tego typu działanie było skazane na niepowodzenie. W maju i czerwcu kilkakrotnie informował Departament Stanu, że sytuacja się poprawiła ${ }^{100}$. Zaproponował nawet wówczas, aby wycofać amerykańskich żołnierzy wysłanych podczas rewolucji 1911 roku do ochrony linii kolejowej łączącej Pekin z morzem ${ }^{101}$.

Mimo zapewnień Williamsa rząd amerykański wolał działać ostrożnie. W maju - wbrew zaleceniom wojskowych - nie zezwolił na wycofanie trzech okrętów z Chin. I choć główna przyczyna tej decyzji tkwiła w chęci uniknięcia pogorszenia stosunków z Japonią ${ }^{102}$, to kolejny z argumentów stanowiła niepewna sytuacja w $\mathrm{Chinach}^{103}$. Bez entuzjazmu odniesiono się również w Waszyngtonie do pomysłu odwołania oddziałów broniących linii kolejowej, godząc się ewentualnie na redukcję ich liczebności, ale nie na całkowitą ewakuację ${ }^{104}$.

98 Ibidem; April 18, 1913, [w:] The Cabinet Diaries..., s. 40-46.

99 The American Chargé d'Affaires to the Secretary of State, May 6, 1913, [w:] PRFRUS 1913, s. 116-118.

100 The American Chargé d'Affaires to the Secretary of State, May 16, 1913, [w: ] PRFRUS 1913, s. 121-122; Note, [w: ] ibidem, s. 123; Williams to the Secretary of State, June 20, 1913, RDSRIACh, roll 12.

101 Williams to the Secretary of State, undated, received May 12, 1913, RDSRIACh, roll 11; Williams to the Secretary of State, May 16, 1913, ibidem.

${ }^{102} \mathrm{~W}$ tym czasie doszło do kolejnego poważnego kryzysu amerykańsko-japońskiego, który mógł doprowadzić do wybuchu wojny między oboma państwami. Był on spowodowany przyjęciem przez Kalifornię ustawy zabraniającej posiadania ziemi osobom „niekwalifikującym się do obywatelstwa amerykańskiego”, co uderzało w japońskich imigrantów licznie zamieszkujących ten stan. Więcej na ten temat patrz np.: R.W. Curry, Woodrow Wilson and Far Eastern Policy..., s. 43-63; P. Coletta, William Jennings Bryan ..., t. 2: Progressive Politician and Moral Statesman, 1909-1915, s. 214-222.

103 May 15, 1913, May 16, 1913, May 17, 1913, [w:] The Cabinet Diaries..., s. 59, 64-68.

104 Moore to the Secretary of War, June 12, 1913, RDSRIACh, roll 11. 
Narastający konflikt w Państwie Środka spowodował ostatecznie, że w lipcu 1913 roku doszło do wybuchu wojny domowej. Była ona stosunkowo krótka i miała raczej jednostronny przebieg. Mimo że dysproporcja sił między walczącymi nie była aż tak znaczna, to jednak Kuomintang stał na gorszej pozycji, ustępując finansowo i militarnie stronie rządowej. Jego siły były ponadto rozproszone i gorzej dowodzone, a część żołnierzy i przywódców nie wierzyła w możliwość zwycięstwa. Nie udało mu się również pozyskać innych sojuszników. Przed końcem lata armia Yuana niemal całkowicie rozprawiła się z przeciwnikiem. 1 września zdobyła Nankin, co praktycznie rozstrzygnęło wynik konfrontacji, chociaż walki trwały jeszcze jakiś czas. Rząd stopniowo rozciągał swoje zwierzchnictwo nad całymi Chinami. Kuomintang został wyparty, a jego przywódcy udali się na emigrację, głównie do Japonii ${ }^{105}$.

Podobnie jak podczas rewolucji Xinhai Stany Zjednoczone zachowały neutralność wobec całego konfliktu ${ }^{106}$. Identycznie postąpiły też pozostałe mocarstwa, ponieważ było to najbezpieczniejsze i najrozsądniejsze posunięcie. Sprzyjało ono protegowanemu mocarstw Yuanowi, który będąc u władzy, miał większe możliwości manewru niż opozycja. Co istotniejsze, neutralność zmniejszała ryzyko, że cudzoziemcy przebywający w Chinach zostaną zaatakowani, interesy mocarstw naruszone, a one same wplątane w wojnę. Warto zaznaczyć, że neutralność USA, w odróżnieniu od innych mocarstw, była nie tylko nominalna, ale i faktyczna ${ }^{107}$, zważywszy na wycofanie się Amerykanów z pożyczki reorganizacyjnej, której środki Yuan wykorzystywał do zdławienia powstania ${ }^{108}$.

105 The Cambridge History of China ..., s. 228-236; W. Rodziński, Historia Chin ..., s. 620; J. Ch'ên, Yuan Shih-k'ai..., s. 166-168.

106 Bryan to the American Legation at Peking, July 20, 1913, RDSRIACh, roll 12; Williams to the Secretary of State, July 26, 1913, ibidem; Bryan to the American Legation at Peking, July 28, 1913, ibidem. Zob. też: Remarks at a Press Conference, July 21, 1913, [w: PWW, t. 50, s. 156-162; Remarks at a Press Conference, July 24, 1913, [w:] ibidem, s. $162-168$.

107 Innego zdania są Crane i Breslin, którzy twierdzą, że USA pozostały neutralne tylko „w teorii”. D.M. Crane, T.A. Breslin, An Ordinary Relationship ..., s. 132-133. Podane przez nich przykłady nie przekonują mnie jednak, świadczą raczej o tym, że Stany Zjednoczone sympatyzowały z Yuanem, a nie że naruszyły zasady neutralności.

108 Spośród mocarstw do zwycięstwa Yuana najbardziej przyczyniła się Wielka Brytania, która czuwała, aby środki z pożyczki reorganizacyjnej trafiły bezpośrednio do niego, a chińska marynarka nie została przejęta przez rebeliantów. The Cambridge History of China ..., s. 235; D.M. Crane, T.A. Breslin, An Ordinary Relationship ..., s. 134. Niemcy miały z kolei dostarczać wojskom rządowym uzbrojenie. Conty à Pichon, 29 juillet 1913, [w: Documents Diplomatiques Français, 1871-1914 (dalej DDF), 3érie: 1911-1914, t. 7, Paris 1934, s. 532-533. 
Stany Zjednoczone ściśle przestrzegały polityki nieingerencji. Chargé d’affaires Williams zalecał m.in., aby żadna z wojujących stron nie mogła używać międzynarodowego settlementu w Szanghaju jako bazy dla swej działalności ${ }^{109}$. Nie chciał również wywierać nacisku na walczących ani zostać mediatorem w konflikcie, co zyskało aprobatę jego przełożonych ${ }^{110}$. Ostatecznie Waszyngton, mimo próśb obu stron, nie zdecydowal się pośredniczyć w rozmowach pokojowych. Polecił też, aby wszyscy Amerykanie przebywający w Chinach zachowali pełną neutralność, a konsulowie powstrzymali się przed uznaniem władz rewolucyjnych. Ponadto $\mathrm{w}$ porozumieniu $\mathrm{z}$ innymi państwami odmówił rządowi pekińskiemu prawa do sądzenia cudzoziemców pomagających rebeliantom, jak i nie zezwolił mu na przeszukiwanie cudzoziemskich statków i domów w celu znalezienia wojennej kontrabandy i ukrywających się rebeliantów ${ }^{111}$.

Oprócz już wymienionych przesłanek dwa inne czynniki zdawały się utwierdzać amerykańską dyplomację w przekonaniu o słuszności pozostania neutralną. Po pierwsze, nic nie wskazywało, aby cudzoziemcom mogło cokolwiek grozić, oczywiście, o ile jawnie nie opowiedzieliby się po którejś ze stron. W odróżnieniu od niedawnych wystąpień w Chinach, „druga rewolucja” miała wybitnie wewnętrzny charakter. Nie była ani otwarcie skierowana przeciwko cudzoziemcom, jak insurekcja „bokserów”, ani nawet nie stanowiła pośredniego zagrożenia, jak rewolucja Xinhai, gdy nastawienie buntowników było początkowo niepewne, a załamanie się dotychczasowego systemu politycznego mogło mieć nieprzewidziane konsekwencje. Cudzoziemcy mogli się co prawda stać przypadkowymi ofiarami walk, ale takie ryzyko było mniejsze niż w przypadku chińskich cywilów, gdyż wojujące strony wiedziały, że jakiekolwiek zagrożenie dla cudzoziemców mogło doprowadzić do interwencji mocarstw.

109 Ta decyzja skierowana była przeciwko przywódcom rewolucjonistów, których wydalono z międzynarodowej koncesji w Szanghaju.

110 Williams to the Secretary of State, July 14, 1913, RDSRIACh, roll 12; Williams to the Secretary of State, July 16, 1913, ibidem; Williams to the Secretary of State, July 26, 1913, ibidem; Bryan to the American Legation at Peking, July 28, 1913, ibidem. Williams udzielił też reprymendy Amosowi Wilderowi, konsulowi w Szanghaju, który miał sympatyzować z rebeliantami i zbyt krytycznie wypowiadać się o rządzie centralnym. Wilder to Williams, August 5, 1913, ibidem; Williams to Wilder, August 13, 1913, ibidem; Williams to the Secretary of State, August 13, 1913, ibidem; Williams to Wilder, September 30, 1913, ibidem.

111 Cheshire to the Secretary of State, July 23, 1913, RDSRIACh, roll 12; Moore to the American Legation at Peking, July 23, 1913, ibidem; Williams to the Secretary of State, July 24, 1913, ibidem; Williams to the Secretary of State, July 25, 1913, ibidem; Greene to Williams, July 25, 1913, ibidem; Gilbert to Williams, August 18, 1913, ibidem; Gilbert to Williams, August 28, 1913, ibidem; R.W. Curry, Woodrow Wilson and Far Eastern Policy..., s. 33. 
Niemal wszystkie docierające do Waszyngtonu doniesienia potwierdzały, że powstanie nie miało antycudzoziemskiego charakteru, a Amerykanie byli bezpieczni. W tym duchu wypowiadali się Williams, kontradmirał Nicholson i konsulowie $\mathrm{z}$ różnych miejsc $\mathrm{w}$ Chinach ${ }^{112}$. Właściwie jedynie John Fowler, konsul w Fuzhou, pisał o atakach na chińskich chrześcijan, które traktował jako wymierzone przeciwko cudzoziemcom. Także zbyt jawne proyuanowskie sympatie mocarstw mogły jego zdaniem wywołać wrogą reakcję ${ }^{113}$.

Powszechny niepokój budziły natomiast działania rozbójników i piratów, którzy wykorzystywali ogólny zamęt w kraju. Szeregi bandytów zasilali maruderzy z obu walczących armii. Szczególnie zagrożeni byli amerykańscy misjonarze, rozsiani na rozległym terytorium Chin, często daleko od skupisk cudzoziemców $^{114}$. Zagraniczni przedstawiciele i dyplomaci obawiali się również o bezpieczeństwo rodaków przebywających w wakacyjnym kurorcie - Gulingu. Na początku powstania Williams przychylił się do prośby, aby wysłać tam żołnierzy do ochrony, ale kontradmirał Nicholson miał odmienne zdanie ${ }^{115}$.

Mimo że cudzoziemcy nie znajdowali się w szczególnym zagrożeniu, to sytuacja była na tyle niepewna, że Stany Zjednoczone nie zdecydowały się wycofać czy nawet zmniejszyć liczebności swoich wojsk stacjonujących na północy Chin. Decyzję o ewakuacji oddziałów ze stołecznej prowincji Zhili, właściwie już po wygaśnięciu powstania, podjęła Rosja, ale pozostałe mocarstwa uznały jej posunięcie za przedwczesne ${ }^{116}$.

112 Williams to the Secretary of State, July 14, 1913, RDSRIACh, roll 12; Greene to Williams, July 14, 1913, ibidem; Nicholson to the Secretary of the Navy, July 17, 1913, ibidem; Wilder to Secretary of State, July 23, 1913, ibidem; Nicholson to the Secretary of the Navy, July 26, 1913, ibidem; Baker to Williams, July 28, 1913, ibidem; Baker to Williams, August 5, 1913, ibidem; Nicholson to the Secretary of the Navy, August 9, 1913, ibidem; Nicholson to the Secretary of the Navy, August 12, 1913, ibidem; Gilbert to Williams, August 18, 1913, ibidem; Moore to North, August 26, 1913, ibidem.

${ }_{113}$ Fowler to Williams, June 14, 1913, RDSRIACh, roll 12; Fowler to Williams, June 16, 1913, ibidem; Fowler to Williams, July 25, 1913, ibidem.

114 Cheshire to Williams, June 10, 1913, RDSRIACh, roll 12; Fowler to Williams, June 14, 1913, ibidem; Cheshire to Williams, July 5, 1913, ibidem; Cheshire to Williams, August 2, 1913, ibidem; Fowler to Williams, August 25, 1913, ibidem; Cheshire to Williams, September 8, 1913, ibidem; Baker to Williams, September 9, 1913, ibidem; Jameson to Williams, September 29, 1913, ibidem; Williams to the Secretary of State, November 2, 1913, ibidem.

115 Williams to the Secretary of State, July 20, 1913, RDSRIACh, roll 12; Williams to the Secretary of State, July 21, 1913, ibidem; Williams to the Secretary of State, July 23, 1913, ibidem; Williams to the Secretary of State, July 24, 1913, ibidem; Williams to the Secretary of State, July 29, 1913, ibidem; Greene to Williams, August 4, 1913, ibidem.

116 Reinsch to the Secretary of State, December 12, 1913, RDSRIACh, roll 13; Reinsch to the Secretary of State, December 16, 1913, ibidem; The Secretary of State to the American Minister, December 17, 1913, [w:] PRFRUS 1913, s. 140. Rosyjska decyzja 
Drugim czynnikiem potwierdzającym zasadność przyjętej polityki neutralności był przebieg rewolucji - szybkie i niekwestionowane zwycięstwo popieranego przez USA Yuana. Chociaż takie rozważania sytuują się w obrębie historii alternatywnej, można przypuszczać, że gdyby wygrywały siły Kuomintangu albo doszło do klinczu militarnego grożącego rozbiciem Chin lub interwencją mocarstw, wówczas Departament Stanu mógłby zrewidować swoje nastawienie, choć trudno wyobrazić sobie zbrojną ingerencję, a prędzej innego typu wsparcie. Nie było jednak takiej potrzeby. Wiele raportów Williamsa zaczynało się od stwierdzenia, że od uprzedniego komunikatu rząd odniósł znaczące sukcesy w walce z rebeliantami. Już 26 lipca Williams przewidywał, że powstanie pozbawione poparcia środowisk kupieckich „musi niedługo upaść" i dlatego odmówił podjęcia się mediacji. Trzy dni później donosił, że nie ziściły się oczekiwania rewolucjonistów, liczących, że więcej prowincji wypowie posłuszeństwo Pekinowi. Gdyby odnieśli oni jakieś spektakularne zwycięstwo, może rzeczywiście tak by się stało, ale w obecnych okolicznościach ich koniec wydawał się bliski. Na początku sierpnia Williams właściwie obwieścił zakończenie zorganizowanego oporu, uznając, że ucieczka przywódców Kuomintangu przekreśliła szansę na inne rozstrzygnięcie. Pod koniec miesiąca stwierdził, że „całkowite stłumienie insurekcji jest w zasięgu ręki” ${ }^{117}$. Otrzymując takie relacje, Departament Stanu nie wątpił w zwycięstwo Yuana i nie widział najmniejszej potrzeby modyfikowania przyjętego kursu $^{118}$.

W trakcie „drugiej rewolucji” Williams nadal usilnie starał się kształtować pozytywny wizerunek Yuana i zarazem dyskredytować liderów Kuomintangu. Temu służyło przypomnienie dokonań obu stron z czasów rewolucji 1911 roku. Jedna z głównych przyczyn jej sukcesu miała tkwić w postępowaniu Yuana, który pragnąc „oszczędzić rodakom potworności wojny domowej", świadomie nie wyzyskał swoich sukcesów militarnych i doprowadził

była prawdopodobnie obliczona na zyskanie przychylności chińskiej w kwestii uznania autonomii Mongolii. Podobnie postąpił rząd carski w sierpniu 1900 roku podczas powstania „bokserów”. P. Reinsch, An American Diplomat ..., s. 76-78; Adee to Herdliska, August 29, 1900, [w: ] PRFRUS 1900, Washington 1902, s. 304-305.

117 Williams to the Secretary of State, July 26, 1913, RDSRIACh, roll 12; Williams to the Secretary of State, July 29, 1913, ibidem; Williams to the Secretary of State, July 30, 1913, ibidem; Williams to the Secretary of State, August 8, 1913, ibidem; Williams to the Secretary of State, August 22, 1913, ibidem. Cytaty pochodzą z dokumentów z 26 lipca i 22 sierpnia. Zobacz też: Cheshire to Williams, August 11, 1913, ibidem; Cheshire to Williams, August 19, 1913, ibidem; Wilder to Williams, August 23, 1913, ibidem; Nicholson to the Secretary of the Navy, September 1, 1913, ibidem.

118 Moore to North, August 26, 1913, RDSRIACh, roll 12. 
do zjednoczenia kraju. Był on - w oczach Williamsa - „prawdziwym twórcą Republiki" 119 .

Zasługi rewolucjonistów zostały z kolei wyraźnie umniejszone. Williams sugerowal, że nie przyczynili się oni do zwycięstwa. Właściwie to nawet podejrzana reputacja części z nich i niepraktyczność innych sprawily, że Chińczycy z pewną rezerwą przyłączali się do antyqingowskiego wystąpienia. Niemal wyłącznie głęboka niechęć do mandżurskiej dynastii zdecydowała wówczas o poparciu społecznym. Obecnie, gdy przeciwnikiem był Yuan, powstanie spotkało się ze znikomym odzewem, zwłaszcza środowisk biznesowych. Williams zarzucał przywódcom Kuomintangu, że ich jedynym celem było usunięcie Yuana i przejęcie władzy. Mieli oni być rozgoryczeni utratą kontroli nad wydarzeniami w państwie i próbować przeszkadzać Yuanowi w rządzeniu, a gdy to nie dało efektów, wystąpili zbrojnie. Williams starał się podważyć ich argument, jakoby „druga rewolucja” stanowiła jedynie reakcję na wysłanie przez prezydenta oddziałów na południe, przypominając, że o wiele wcześniej mówili oni o możliwości wszczęcia powstania. Próbował również zakwestionować drugi z rzekomych powodów - chęć pomszczenia morderstwa Songa. Nie mogło to być prawdą - uznał Amerykanin - skoro doprowadzili oni do uwolnienia jednego ze spiskowców. Z raportów Williamsa wyłaniał się zatem typowy zamach stanu, za wywołanie którego pełną odpowiedzialność ponosił Kuomintang ${ }^{120}$.

Inni amerykańscy przedstawiciele też raczej nieprzychylnie wypowiadali się o powstaniu i jego przywódcach, chociaż zazwyczaj nie aż tak krytycznie jak Williams ${ }^{121}$. Jedynym, który odmiennie postrzegał sytuację, był konsul w Szanghaju Amos Wilder. Jego zdaniem Yuan wraz ze swymi stronnikami hołdowali dawnemu stylowi rządzenia, w którym dominowały „korupcja, przemoc i ultrakonserwatyzm”, i dlatego nie można w nich było upatrywać „zbawców Chin”. Rewolucjoniści, mimo że niedoświadczeni, byli za to zdolni do przeprowadzenia reform i stanowili przyszłość kraju. Ich wystąpienie było wyrazem sprzeciwu wobec metod stosowanych przez Yuana. Wilder przestrzegał przed zbyt ewidentnym okazywaniem sympatii politycznych, gdyż „przegrani dzisiaj mogą łatwo zostać

119 The American Chargé d'Affaires to the Secretary of State, August 22, 1913, [w: ] PRFRUS 1913, s. 128-129.

120 Williams to the Secretary of State, July 18, 1913, RDSRIACh, roll 12; Williams to the Secretary of State, July 26, 1913, ibidem; Williams to the Secretary of State, August 15, 1913, ibidem; The American Chargé d'Affaires to the Secretary of State, August 22, 1913, [w:] PRFRUS 1913, s. 128-129. Wzmiankowany przez Williamsa spiskowiec został uwolniony przez szanghajskich gangsterów. J. Ch'ên, Yuan Shih-k'ai ..., s. 161-163.

121 Cheshire to Williams, June 11, 1913, RDSRIACh, roll 12; Cheshire to Williams, June 23, 1913, ibidem; Gilbert to Williams, July 16, 1913, ibidem; Fowler to Williams, August 6, 1913, ibidem; Cheshire to Williams, August 11, 1913, ibidem. 


\section{Chiny w polityce zagranicznej Stanów Zjednoczonych w latach 1911-1918}

zwycięzcami jutro"122. Raport Wildera został kategorycznie odrzucony przez Williamsa, a sam konsul posądzony o stronniczość i ignorancję. Williams dowodził, że rząd pekiński składał się z ludzi kompetentnych, wykształconych według nowoczesnych wzorców, obeznanych w świecie i nastawionych reformatorsko ${ }^{123}$. Dyplomata starał się też usprawiedliwić rząd za wejście w porozumienie z generałem Zhang Xunem, którego wojska spustoszyły Nankin. Z opisu Williamsa wynikało, że to właściwie działania rewolucjonistów, którzy sami chcieli pozyskać generała do współpracy, zmusiły rząd do takiego mariażu. Oddziały rewolucjonistów miały się zresztą dopuścić równie bestialskich czynów, co ich przeciwni$\mathrm{cy}^{124}$. Czarny obraz powstańców uzupełnił jeszcze kontradmirał Nicholson, który zarzucił ich głównemu dowódcy Huang Xingowi tchórzostwo, a przede wszystkim zlecenie zamordowania niezgadzających się z nim członków Kuomintangu. Nicholson wskazywał na okrutną ironię - metody przypisywane Yuanowi i będące jedną z przyczyn powstania zostały przejęte przez jego adwersarzy ${ }^{125}$.

Wszystkie te opinie zapewne uspakajały Departament Stanu, że mimo trwającej wojny wydarzenia w Chinach rozwijały się pomyślnie dla Amerykanów - przywódca, z którym sympatyzowali, stanowił dobrywybór i sprawnie zwyciężał przeciwników. Kształtując swoją politykę podczas „drugiej rewolucji”, administracja Wilsona miała łatwiejsze zadanie niż ekipa Tafta w czasie rewolucji 1911 roku. Tym razem nie doszło bowiem do rozdźwięku między Białym Domem a społeczeństwem. Opinia publiczna w USA także generalnie popierała Yuana, postrzegając rewolucjonistów już nie jako szermierzy postępu i demokracji, lecz jako wichrzycieli porządku występujących przeciwko legalnej władzy ${ }^{126}$. Dobrze obrazuje to artykuł opublikowany 6 sierpnia w „The New York Timesie”, w którym całkowicie przyjęto optykę Yuana (tego samego dnia zamieszczono zresztą jego oświadczenie na temat wydarzeń w Chinach), uznając powstanie nie za wyraz buntu społeczeństwa przeciwko rządowi, tylko za próbę przejęcia władzy przez zawiedzionych polityków. Przewidywano szybkie stłumienie powstania, dzięki czemu pozycja Yuana zostałaby wzmocniona - rezultat, który cały świat miał powitać $\mathrm{z}$ radością ${ }^{127}$.

122 Wilder to Williams, August 5, 1913, RDSRIACh, roll 12.

123 Williams to Wilder, August 13, 1913, RDSRIACh, roll 12.

124 Williams to the Secretary of State, September 12, 1913, RDSRIACh, roll 12.

125 Nicholson to the Secretary of the Navy, August 12, 1913, RDSRIACh, roll 12.

126 Tym razem także amerykańscy misjonarze podzielali tę opinię, uznając, że buntownicy to niepraktyczni marzyciele, a nawet bezbożni socjaliści lub anarchiści. M.V. Metallo, The United States and Sun Yat-sen, 1911-1925, nieopublikowany doktorat, New York University, New York 1974, s. 94-111; D.M. Crane, T.A. Breslin, An Ordinary Relationship..., s. 126-136.

127 „The New York Times”, August 6, 1913. Należy w tym kontekście wspomnieć, że według Ch'êna Yuan zatrudnił amerykańskich dziennikarzy, aby zaskarbić sobie przychylność prasy w USA. J. Ch'ên, Yuan Shih-k'ai..., s. 173. 


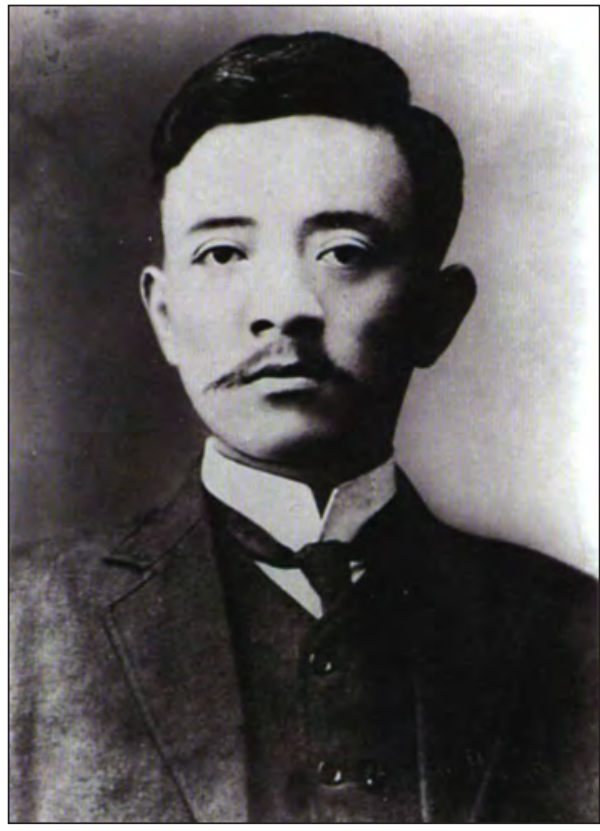

25. Song Jiaoren

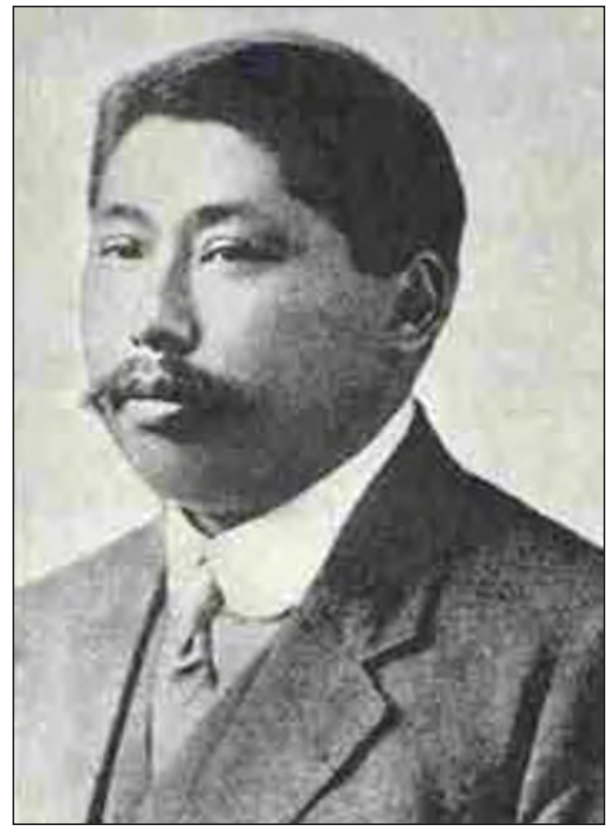

26. Huang Xing

Jeśli wydarzenia w Chinach zaczynały się kształtować w miarę korzystnie dla USA, to także dlatego, że „druga rewolucja” poważnie nie zagroziła funkcjonowaniu polityki „otwartych drzwi”. Jak przy każdym tego typu konflikcie istniało ryzyko chaosu wewnętrznego oraz ingerencji z zewnątrz. Zostało ono jednak znacząco zminimalizowane przez szybkie zwycięstwo Yuana oraz dość zgodne proyuanowskie nastawienie większości mocarstw. Pewne obawy w Waszyngtonie budziły jedynie poczynania Japończyków, którzy pomagali rewolucjonistom ${ }^{128}$.

128 Podobnie jak podczas rewolucji 1911 roku polityka Japonii była niejednolita. Rząd starał się przynajmniej oficjalnie zachować neutralność, która działała na korzyść Yuana, natomiast opinia publiczna chciała zwycięstwa rebeliantów. Część japońskich oficerów, dyplomatów, urzędników i biznesmenów pomagała im finansowo i militarnie (doradcy wojskowi oraz dostawy broni). Nadto Tokio udzieliło schronienia przywódcom Kuomintangu, którzy uciekli z Chin na początku sierpnia. Fowler to the Secretary of State, May 23, 1913, RDSRIACh, roll 12; Williams to the Secretary of State, July 14, 1913, ibidem; Greene to Williams, July 14, 1913, ibidem; Greene to Williams, July 16, 1913, ibidem; Cheshire to Williams, July 18, 1913, ibidem; Williams to the Secretary of State, July 18, 1913, ibidem; Nicholson to the Secretary of the Navy, July 20, 1913, ibidem; Nicholson to the Secretary of the Navy, July 24, 1913, ibidem; Cheshire to Williams, July 25, 1913, ibidem; Bailly-Blanchard to the Secretary of State, August 6, 1913, ibidem; Fowler to Williams, August 6, 1913, ibidem; Williams to the Secretary of State, August 15, 1913, ibidem; Williams 


\section{Chiny w polityce zagranicznej Stanów Zjednoczonych w latach 1911-1918}

Ponadto wysłali oni kilkuset swoich żołnierzy do Nankinu, wykorzystując fakt zabicia trzech ich rodaków przez wojska rządowe. Krążyły też pogłoski, że gdyby Chiny nie zgodziły się na pierwotne warunki zadośćuczynienia wobec wydarzenia w Nankinie oraz dwóch innych incydentów, Tokio mogło zażądać przedłużenia dzierżawy Port Artur, prawdopodobnie dając tym samym początek kolejnemu etapowi walk o koncesje $\mathrm{e}^{129}$.

Wybuch „drugiej rewolucji” na tyle zmienił sytuację w Chinach, że administracja Wilsona, chociaż nie ogłosiła tego wprost, powróciła do polityki współpracy z innymi mocarstwami, której zaniechała na początku swojej kadencji ${ }^{130}$. W zaistniałych okolicznościach było to bezpieczniejsze rozwiązanie, dające więcej możliwości i większy wpływ na przebieg konfrontacji, a zarazem pozwalające lepiej kontrolować poczynania innych mocarstw.

Kiedy trwały jeszcze walki, lecz ich wynik był już niemal przesądzony, zaczęto się zastanawiać na dalszymi losami Chin. Williams uznał, że „wszystko zależy od mądrości, z jaką prezydent wykorzysta swoją wygraną”. Ale nawet jego przewidywania były niejednoznaczne. Raz utyskiwał, że dotychczasowy konflikt na linii Pekin-prowincje oraz nienawiść do Yuana będą nadal istniały, a bankructwo państwa, mogące doprowadzić do obcej interwencji, okaże się „bliższe niż kiedykolwiek”. Innym razem stwierdził, że zwycięstwo pozwoli rządowi kontrolować wszystkie prowincje i ich finanse, dzięki czemu Republika będzie „silniejsza niż kiedykolwiek przedtem"131.

„Mądrość” Yuana okazała się aż nazbyt pragmatyczna, przejawiając się wzrostem tendencji autorytarnych. Yuan, zwolennik jednowładztwa, zaczął powoli rugować wszelkie przejawy demokracji, centralizować państwo

to the Secretary of State, August 22, 1913, ibidem; Jameson to Williams, September 25, 1913, ibidem; PRFRUS 1913, s. 129-131; P. Lowe, Great Britain and Japan 1911-1915: A Study of British Far Eastern Policy, London 1969, s. 99-117; M.B. Jansen, The Japanese and Sun Yat-sen, Cambridge 1954, s. 158-169; R.P.S. Chan, The Great Powers and the Chinese Revolution, 1911-1913, nieopublikowany doktorat, Fordham University, New York 1971, s. 236-240.

129 The American Chargé d'Affaires to the Secretary of State, September 12, 1913, [w:] PRFRUS 1913, s. 130-131; The American Chargé d'Affaires to the Secretary of State, September 25, 1913, [w:] ibidem, s. 187-189. Najprawdopodobniej zabójstwo Japończyków w Nankinie miał też na myśli Bryan w liście do Wilsona. Bryan to Wilson, September 9, 1913, [w:] PWW, t. 28, s. 268. Żądania japońskie patrz: P. Lowe, Great Britain ..., s. 117-119.

130 J. Ch'ên, Yuan Shih-k'ai ..., s. 166-167.

131 Williams to the Secretary of State, July 29, 1913, RDSRIACh, roll 12; Williams to the Secretary of State, July 30, 1913, ibidem; The American Chargé d'Affaires to the Secretary of State, August 22, 1913, [w: ] PRFRUS 1913, s. 128-129. Cytaty pochodzą z dokumentów z 29 lipca i 22 sierpnia. 
i ugruntowywać swoją dyktaturę. Pierwszym jego posunięciem było zapewnienie sobie wyboru na urząd stałego prezydenta Republiki. Udało mu się to osiągnąć 6 października, chociaż jego kandydatura, mimo gróźb wobec parlamentarzystów i wręczonych im łapówek, dopiero w trzecim głosowaniu uzyskała wymaganą większośćc 132 . Zmiana charakteru władzy i jej stabilizacja skłonily różne państwa, w tym mocarstwa europejskie i Japonię, do oficjalnego uznania Republiki ${ }^{133}$. Nim to jednak nastąpiło, Yuan musiał przystać na warunki mocarstw. Przede wszystkim zadeklarował, że międzynarodowe "traktaty, konwencje i inne zobowiązania” dotychczas zaciągnięte, zarówno przed rewolucją 1911 roku, jak i po niej, będą ściśle przestrzegane. Potwierdził ponadto wszystkie „prawa, przywileje i immunitety przysługujące cudzoziemcom w Chinach” oraz ważność kontraktów podpisanych z zagranicznymi firmami ${ }^{134}$. Konieczne okazało się także poczynienie ustępstw na rzecz konkretnych mocarstw. Yuan uznał więc autonomię Tybetu i Mongolii Zewnętrznej, co usatysfakcjonowało Wielką Brytanię i Rosję, przychylność Japonii zaskarbił sobie zaś dzięki przyrzeczeniu zaciągnięcia u niej pożyczki na budowę pięciu linii kolejowych w Mandżurii i Mongolii Wewnętrznej ${ }^{135}$.

Uzyskawszy wewnętrzne i zewnętrzne potwierdzenie swojej władzy, Yuan przystąpił do bardziej zdecydowanych działań przeciwko opozycji. Na początku listopada zdelegalizował Kuomintang, oskarżając go o wywołanie ostatniego powstania i knucie kolejnych spisków. Członkowie partii zostali usunięci z parlamentu, a część z nich aresztowano. Dzięki temu Yuan nie tylko znacząco osłabił swoich przeciwników politycznych, ale również sparaliżował funkcjonowanie parlamentu, który pozbawiony kworum, nie mógł kontynuować prac

132 Wiceprezydentem pozostał Li Yuanhong. The Chinese Chargé d'Affaires to the Secretary of State, October 6, 1913, [w: ] PRFRUS 1913, s. 131; The Chinese Chargé d'Affaires to the Secretary of State, October 8, 1913, [w:] ibidem; W. Rodziński, Historia Chin..., s. 620-621; The Cambridge History of China ..., s. 242; J. Ch'ên, Yuan Shih-k'ai ..., s. 171.

133 The American Chargé d'Affaires to the Secretary of State, October 8, 1913, [w: ] PRFRUS 1913, s. 132; The American Minister to Switzerland to the Secretary of State, October 8, 1913, [w:] ibidem; The American Chargé d'Affaires to the Secretary of State, October 10, 1913, [w: ] ibidem, s. 134; The American Chargé d'Affaires to the Secretary of State, October 11, 1913, [w: ] ibidem.

134 Inaugural Address of the President, Yuan Shih K'ai, delivered October 10, 1913, [w: ] PRFRUS 1913, s. 82-86; Williams to the Secretary of State, October 13, 1913, RDSRIACh, roll 13.

135 Doc. no. 1913/9: Japan and China. Exchange of Notes in regard to the construction of certain railways in Manchuria, October 5, 1913, [w: ] Treaties and Agreements..., t. 2, s. 1054; Doc. no. 1913/11: Russia and China. Declaration, and accompanying Exchange of Notes, in regard to Outer Mongolia, November 5, 1913, [w: ] ibidem, s. 1066-1067; J. Ch'ên, Yuan Shih-k'ai ..., s. 174-177; W. Rodziński, Historia Chin ..., s. 621. 
legislacyjnych. Druga z tych korzyści była dla Yuana o tyle istotna, że udało mu się tym samym zablokować przyjęcie Stałej Konstytucji, która ograniczyłaby jego władzę prezydencką. Kolejny etap utrwalania dyktatury nastąpił na początku 1914 roku, kiedy to ostatecznie rozwiązane zostały parlament oraz zgromadzenia prowincjonalne. Od jakiegoś już czasu trwały też represje, pacyfikacja i centralizacja kraju oraz wprowadzanie rozwiązań typowych dla państwa policyjnego ${ }^{136}$.

Wzrost dążeń autorytarnych wpłynął na postrzeganie Yuana przez Waszyngton. O ile do tej pory było ono jednoznacznie pozytywne, to na przełomie lat 1913 i 1914 zaczęly kiełkować bardziej ambiwalentne odczucia. Jeszcze na początku października Bryan wyraził zadowolenie z rozwoju wydarzeń w Chinach i wyboru nowego prezydenta ${ }^{137}$, ale miesiąc później wyraźnie zmienił ton. W liście do Wilsona pisal, że wiadomości z Chin były alarmujące. Yuan rozwiązał Kuomintang i zaczął stosować podobne metody co Victoriano Huertaa ${ }^{138}$, podając zresztą te same powody. Chociaż sytuacja w Meksyku i Chinach nie była tożsama, należało - zdaniem Bryana - powściągnąć oczekiwania co do „szybkiego postępu w krajach Orientu"139.

Już samo porównanie Yuana do Huerty, naówczas bête noire Wilsona w polityce zagranicznej, stanowiło poważny zarzut ${ }^{140}$. Oznaczało podważenie legalności dojścia do władzy i oskarżenie o stosowanie antydemokratycznych metod. Jak dużą zbieżność między Yuanem a meksykańskim generałem widział Bryan (czy np. dostrzegał podobieństwo między zabójstwem Songa a Francisca Madery $\left.{ }^{141}\right)$, trudno jednoznacznie stwierdzić. Bezsprzecznie jednak nad Potomakiem

136 Wilder to Williams, October 4, 1913, RDSRIACh, roll 13; Williams to the Secretary of State, October 13, 1913, ibidem; The American Chargé d'Affaires to the Secretary of State, November 5, 1913, [w: ] PRFRUS 1913, s. 139; Williams to the Secretary of State, November 5 (4 a.m.), 1913, RDSRIACh, roll 13; Williams to the Secretary of State, November 5 (12 midnight), 1913, ibidem; Williams to the Secretary of State, November 11, 1913, ibidem; Reinsch to the Secretary of State, July 2, 1914, ibidem; The Cambridge History of China..., s. 237-243; W. Rodziński, Historia Chin ..., s. 620-621.

137 Bryan to Wilson, October 6, 1913, WWP, series 4: case files, 226, reel 242.

138 Victoriano Huerta (1850-1916) - meksykański generał i polityk, od lutego 1913 roku do lipca 1914 roku prezydent Meksyku, który to urząd objął dzięki zamachowi stanu. Zrezygnował w wyniku przegranej w zbrojnym starciu z opozycją.

139 Bryan to Wilson, November 5, 1913, [w: ] PWW, t. 28, s. 490.

140 Notabene, w listopadzie 1914 roku Sun wysłał telegram do Wilsona, w którym określił Yuana jako „chińskiego Huertę”, chcąc zapewne wykorzystać antypatię Wilsona do Huerty. Sun to Wilson, November 30, 1914, WWP, series 4: case files, 227, reel 242.

141 Francisco Madero (1873-1913) - meksykański polityk, prezydent Meksyku w latach 1911-1913. Doprowadził do obalenia władzy Porfiria Díaza, sam zaś został pozbawiony urzędu przez spisek Huerty, na którego rozkaz został zamordowany. 
nastąpiło pewne rozczarowanie działaniami Yuana ${ }^{142}$. Świadczyło o tym nie tylko porównanie do Huerty, ale i komentarz o konieczności zmniejszenia oczekiwań w stosunku do Chin, co miało niebagatelne znaczenie, zwłaszcza gdy pamięta się, jaką wagę administracja Wilsona przywiązywała do wprowadzenia tam postępowych reform. Decyzje Yuana pogorszyły też jego notowania u amerykańskich przedstawicieli w Państwie Środka. Williams, dotychczas niemal apologeta generała, stał się wobec niego bardziej krytyczny ${ }^{143}$. Nadal negatywną opinię o nim miał Amos Wilder ${ }^{144}$. Willys Peck, pracownik poselstwa, pisał wprost o „dyktatorskich aspiracjach” Yuana, chociaż zarazem wspominał, że wiele osób uznawało je raczej za przejaw patriotyzmu, gdyż ich zdaniem tylko silna władza centralna była w stanie przezwyciężyć tendencje odśrodkowe i sprawnie administrować krajem ${ }^{145}$.

Autorytarne dążenia Yuana postawily USA przed niełatwym wyborem. Bryan nie wiedział, czy ma zareagować, i ostatecznie uchylił się od podjęcia jakichkolwiek działań ${ }^{146}$. Rozpatrując tę decyzję, warto zestawić ją z bardzo stanowczym wystąpieniem Stanów Zjednoczonych przeciwko uzurpacji Huerty, wobec której Wilson oświadczył, że nie uzna „rządu rzeźników” ${ }^{147}$. Skąd zatem taka asymetria w podejściu do obu reżimów - względna pobłażliwość wobec jednego, a niesłabnący sprzeciw wobec drugiego? Wydaje się, że kilka było powodów tej pozornej lub faktycznej niekonsekwencji. Najbardziej prozaiczny stanowiło następstwo położenia geograficznego obu państw. Czym innym byłbowiem dyktator po drugiej stronie Pacyfiku, czym innym po drugiej stronie Rio Grande. Wynikało to z założeń doktryny Monroego, jak i z faktu, że z punktu widzenia amerykańskiego bezpieczeństwa i amerykańskiej ekonomii Meksyk miał nieporównywalnie większe znaczenie niż Chiny ${ }^{148}$. Następnym powodem było już wcześniejsze uznanie Republiki i pośrednio przywództwa Yuana. W pewnym sensie Waszyngton stał się „zakładnikiem” swojej majowej decyzji. Skoro pół roku wcześniej jako jeden z pierwszych uznał władze pekińskie, to obecnie trudniej mu było przeciwko nim wystąpić, zwłaszcza że również inne mocarstwa dopiero co rozciągnęły swoje

142 Yuan chyba zdawał sobie sprawę z częściowej utraty przychylności Waszyngtonu.

P. Reinsch, An American Diplomat..., s. 2.

143 Williams to the Secretary of State, November 11, 1913, RDSRIACh, roll 13;

D.D. Lazo, An Enduring Encounter ..., s. 228-233.

144 Wilder to Williams, October 4, 1913, RDSRIACh, roll 13.

145 Memorandum on the political situation, December 19, 1913, [w:] PRFRUS 1913, s. $141-143$.

146 Bryan to Wilson, November 5, 1913, [w: $]$ PWW, t. 28, s. 490.

147 L. Pastusiak, Prezydenci Stanów Zjednoczonych Ameryki, Warszawa 2002, s. 571.

148 Wystarczy wspomnieć, że Amerykanie zainwestowali w Meksyku ok. miliarda dol., podczas gdy w Chinach niecałe 50 milionów. Ibidem; W. Rodziński, Historia Chin ..., s. 530; C.F. Remer, Foreign Investments in China, New York 1968, s. 76, 262-274, 338. 
uznania. Międzynarodowe zagmatwanie sytuacji w Chinach stanowiło kolejny problem. Podczas gdy w przypadku Meksyku USA były jedynym mocarstwem mającym realny wpływ na jego sytuację wewnętrzną, to w przypadku Chin tylko jednym z sześciu. Pozostała piątka czekała zaś na dalszy rozwój wydarzeń i popierała Yuana ${ }^{149}$.

Istotny wpływ na decyzję administracji Wilsona miało również przekonanie, że condicio sine qua non do przeprowadzenia reform było ustabilizowanie sytuacji w Chinach, a tylko silny, scentralizowany rząd mógł tego dokonać. Dopiero po zaprowadzeniu porządku i zorganizowaniu państwa można było przystąpić do jego modernizacji i przygotowywania społeczeństwa do demokratycznych rozwiązań ${ }^{150}$. Wewnętrzna sprzeczność takiego myślenia polegała na tym, że rzadko który dyktator dobrowolnie zrzeka się władzy lub inicjuje zmiany mogące w dłuższej perspektywie osłabić jego pozycję. Ale walka $\mathrm{z}$ chaosem w Chinach miała dla Waszyngtonu jeszcze inne uzasadnienia. Jeśli Amerykanie i w pewniejszych czasach w nikłym stopniu zagospodarowali rynek chiński, to szansa, że zwiększą swój udział w okresie perturbacji wewnętrznych, była cokolwiek wątpliwa. Ponadto brak rudymentarnej stabilizacji zwiększał niebezpieczeństwo interwencji $\mathrm{z}$ zewnątrz. Na tym tle uwidaczniała się kolejna różnica między sytuacją w Chinach i Meksyku. Chaos w Meksyku mógł wywołać właściwie tylko amerykańską interwencję, chaos w Chinach o wiele szybciej interwencję innych mocarstw niż USA. Warto jeszcze wspomnieć o osobistej niechęci Wilsona i Bryana do niepokojów i chaosu jako zjawisk podważających ład stworzony przez Boga ${ }^{151}$. Wreszcie, przedłużający się okres destabilizacji zagrażał bezpieczeństwu cudzoziemców, zwłaszcza przebywających w odległych miejscach misjonarzy. Z tych powodów zaprowadzenie porządku po „drugiej rewolucji” stanowiło priorytet dla Departamentu Stanu. Doniesienia Williamsa potwierdzały zaś, że Yuan miał realne szanse, aby tego dokonać ${ }^{152}$.

Fakt, że formalnie zagwarantował on prawa, przywileje i kontrakty cudzoziemców, działał dodatkowo na jego korzyść. Stany Zjednoczone były oczywiście zadowolone z takiego oświadczenia. Pewien niepokój mogło jedynie budzić oficjalne uznanie osłabienia zwierzchności chińskiej nad Tybetem i Mongolią. Było to jednak raczej potwierdzenie stanu faktycznego niż nowe ustępstwo.

149 Memorandum on the political situation, December 19, 1913, [w: ] PRFRUS 1913, s. $141-143$.

${ }_{150}$ D.M. Crane, T.A. Breslin, An Ordinary Relationship ..., s. 135-136, 194; Tien-yi Li, Woodrow Wilson's China Policy..., s. 139-140, 143; R.W. Curry, Woodrow Wilson and Far Eastern Policy ..., s. 31. Podobnie rozumowali amerykańscy misjonarze w Chinach. M.V. Metallo, American Missionaries, Sun Yat-sen, and the Chinese Revolution, „Pacific Historical Review" 1978, t. 47, nr 2, s. 277, 281.

151 S. Pash, The Currents of War ..., s. 30.

152 Williams to the Secretary of State, October 13, 1913, RDSRIACh, roll 13. 
Departament Stanu nie protestował, chyba pogodzony z takim rozwiązaniem, zwłaszcza że Amerykanie przejawiali raczej nikłe zainteresowanie tymi regionami. Istniało co prawda ryzyko wywołania efektu domina, ale w tym przypadku do tego nie doszło.

Jeszcze innymi atutami Yuana, odróżniającymi go od Huerty, były pozytywne nastawienie do Stanów Zjednoczonych oraz otaczanie się zagranicznymi doradcami, wśród których niepoślednią rolę odgrywali Amerykanie. Oprócz wzmiankowanych już dziennikarzy dbających o dobry wizerunek Yuana w prasie amerykańskiej należy również wspomnieć o przynajmniej dwóch innych osobach. W maju 1913 roku przyjechał do Pekinu Frank Goodnow - profesor prawa z Columbia University, naukowiec o uznanej renomie. Był on pierwszym przewodniczącym American Political Science Association (1903-1905), później także rektorem Uniwersytetu Johna Hopkinsa (1914-1929). Dobrze znał się z prezydentem Wilsonem oraz Paulem Reinschem, amerykańskim posłem w Chinach ${ }^{153}$. Zadanie Goodnowa, zatrudnionego przez Carnegie Endowment for International Peace ${ }^{154}$, polegało na udzieleniu pomocy przy opracowaniu projektu chińskiej konstytucji. Na początku 1914 roku Yuan pozyskał innego znakomitego doradcę - Williama Rockhilla, czołowego amerykańskiego znawcę Państwa Środka i Tybetu, jednego z architektów doktryny „otwartych drzwi”, w latach 1905-1909 posła w Pekinie. Zarówno Goodnow, jak i Rockhill byli negatywnie nastawieni do - przynajmniej natychmiastowego i bezrefleksyjnego - przeszczepiania republikańskich rozwiązań na grunt chiński i przychylnie odnosili się do koncentracji władzy przez Yuana ${ }^{155}$.

Splot wszystkich tych czynników sprawil, że Stany Zjednoczone nie wycofały swego poparcia dla Yuana mimo jego coraz wyraźniejszych autorytarnych dążeń. Niedługo po wyborze na stałego prezydenta Wilson, za radą Bryana, przesłał

153 Warto dodać, że Wilson i Reinsch również byli przewodniczącymi American Political Science Association, pierwszy w latach 1909-1910, drugi od 1919 do 1920 roku. Informacja za: https://www.apsanet.org/apsapresidents (dostęp: 27.08.2018).

${ }_{154}$ Carnegie Endowment for International Peace to pozarządowa organizacja założona w 1910 roku w celu szerzenia współpracy międzynarodowej oraz wspierania międzynarodowego zaangażowania Stanów Zjednoczonych. Informacja za: http:// carnegieendowment.org/about/? $\mathrm{fa}=$ centennial (dostęp: 27.08.2018).

155 Sammons to Reinsch, April 14, 1914, RDSRIACh, roll 13; Sammons to Reinsch, May 14, 1914, ibidem; N. Pugach, Embarrassed Monarchist: Frank J. Goodnow and Constitutional Development in China, 1913-1915, „Pacific Historical Review” 1973, t. 42, nr 4, s. 499-517; P.A. Varg, Open Door Diplomat. The Life of W.W. Rockhill, Urbana 1952, s. 119-123; P. Reinsch, An American Diplomat ..., s. 30-32, 47, 68; D.M. Crane, T.A. Breslin, An Ordinary Relationship ..., s. 127-129. W chińskiej administracji zatrudnieni byli jeszcze inni Amerykanie, np. ekonomista prof. Henry Adams. P. Reinsch, An American Diplomat ..., s. 68-69. 
Yuanowi gratulacje $\mathrm{e}^{156}$. I choć była to standardowa procedura dyplomatyczna, to już sam fakt wysłania listu świadczył o akceptacji jego władzy ${ }^{157}$. Waszyngton planował współpracować z przywódcą Chin, czego dowodem był chociażby pomysł z połowy października, aby zaoferować mu pomoc amerykańskich doradców wojskowych przy szkoleniu armii ${ }^{158}$.

\section{Nominacja Paula Reinscha na posła w Chinach (15 sierpnia 1913 roku)}

Pierwsze miesiące urzędowania Wilsona w Białym Domu obfitowały w liczne istotne decyzje dotyczące Chin, poważnie zmieniające wcześniejszą politykę Stanów Zjednoczonych wobec tego państwa. W tym czasie nowa administracja nie miała swojego posła $\mathrm{w}$ Pekinie, ponieważ z różnych powodów wydłużył się proces jego wyłaniania.

Niedługo po wygraniu wyborów prezydent elekt przystąpił do kompletowania swojego gabinetu i wyznaczania przedstawicieli dyplomatycznych. Znalezienie nowego posła w Pekinie okazało się jednak zadaniem skomplikowanym i długotrwałym. Wynikało to częściowo z oczekiwań, jakie wiązano z potencjalnym kandydatem. Wilson chciał, aby amerykańscy dyplomaci

156 The President to the President of China, October 9, 1913, [w:] PRFRUS 1913, s. 132-133; Tien-yi Li, Woodrow Wilson's China Policy ..., s. 141. Wilson wyraził nadzieję, że Yuan będzie działał praworządnie, sprawiedliwie oraz zgodnie z ideałami republikańskimi. Jeśli nie była to wyłącznie konwencjonalna frazeologia, a w przypadku Wilsona można podejrzewać, że tak nie było, to oczekiwania wyraźnie rozminęły się z rzeczywistością.

157 Yuan nie tylko podziękował Wilsonowi za gratulacje, ale przesłał mu również swoje zdjęcie z autografem, co z kolei skłoniło amerykańskiego przywódcę do podobnego gestu. The President of China to the President, October 13, 1913, [w:] PRFRUS 1913, s. 135; Yuan to Wilson, December 2, 1913, Records of the Department of State Relating to Political Relations of the United States with China, 1910-1929 (dalej RDSRPRUSCh), The National Archives at College Park, College Park, (mikrofilm), roll 1; Tumulty to Bryan, February 6, 1914, ibidem; Bryan to Tumulty, February 11, 1914, ibidem; Draft reply from Wilson to Yuan, undated, ibidem.

158 Stany Zjednoczone nie chciały, aby szkolenie armii chińskiej zostało zmonopolizowane przez niemieckich oficerów. Pekin nie zaakceptował jednak ich propozycji, gdyż planował redukcję wojsk i nie miał zamiaru zatrudniać zagranicznych doradców militarnych. Garrison to Wilson, October 11, 1913, WWP, series 4: case files, 227, reel 242; Wilson to Bryan, October 14, 1913, ibidem; Bryan to Wilson, October 15, 1913, ibidem; Bryan to Wilson, October 20, 1913, ibidem; Williams to Bryan, October 20, 1913, ibidem. Zob. też: Conty à Pichon, 29 juillet 1913, [w: ] DDF, $3^{\text {e }}$ série, t. 7, s. 532-533. 
w Chinach i Japonii wywodzili się spośród najlepszych ludzi w kraju. Sądził bowiem, jak już zostało wspomniane, że na przyszłości świata w największym stopniu zaważą wydarzenia na Dalekim Wschodzie, które powinny rozegrać się pod egidą Amerykanów ${ }^{159}$.

Znamienne było, jakie kwalifikacje zdaniem Wilsona i Bryana czyniły daną osobę najlepiej przygotowaną do służby w Chinach czy Japonii. Zamiast wydawałoby się bardziej naturalnych wymogów, takich jak: doświadczenie w dyplomacji, znajomość lokalnego języka, wiedza na temat danego państwa, regionu i stosunków międzynarodowych, uznali oni, że kluczowymi „kompetencjami” będą ugruntowana religijność oraz dobre relacje z misjonarzami ${ }^{160}$. Selekcję kandydatów pod takim właśnie kątem zasugerował Bryan, argumentując, że Chiny i Japonia przedstawiały najlepsze perspektywy dla pracy misjonarskiej, a „nowa chińska cywilizacja została ufundowana na ruchu chrześcijańskim"161. Wilson zdecydowanie poparł takie rozwiązanie, uznając, że amerykańskie interesy w Chinach przybierały „w znacznym stopniu postać działalności misjonarskiej” i osoby o „wyraźnie chrześcijańskim charakterze” najlepiej sprawdzą się we wdrażaniu polityki, jaką zamyślał tam prowadzićc ${ }^{162}$. Szybko się jednak okazało, że pojęcie „chrześcijański” nie obejmowało nawet wszystkich protestanckich odłamów. Gdy Bryan dowiedział się, że jeden z kandydatów to unitarianin, zdecydowanie zaprotestował, uzasadniając, że unitarianie nie wierzą w boskość Chrystusa. Szanse innych zniweczył fakt, że albo nie mieli sprecyzowanych poglądów religijnych, albo nie należeli do żadnego Kościoła ${ }^{163}$.

Przyjęte kryteria konkretnej religii i współpracy z misjonarzami odnosiły się wyłącznie do Chin (w mniejszym stopniu do Japonii), w przypadku innych państw nie miały zastosowania ${ }^{164}$. Na przykład wyznający judaizm Henry Morgenthau senior nie został posłem w Pekinie, o którą to posadę zabiegal, ale

159 Wilson to Eliot, January 20, 1913, [w:] PWW, t. 27, s. 65; Wilson to Mott, February 24, 1913, ibidem, s. 131.

${ }^{160} \mathrm{Na}$ temat braku profesjonalizmu w amerykańskiej służbie dyplomatycznej w Chinach patrz: J. Polit, Dyplomacja brytyjska, japońska i amerykańska w Chinach, 1895-1949, „Dzieje Najnowsze” 2010, R. 42, nr 1, s. 31-39.

${ }^{161}$ Bryan to Wilson, January 5, 1913, [w: ] PWW, t. 27, s. 14; January 31, 1913, [w: ] The Intimate Papers of Colonel House ..., s. 105. Cytat pochodzi z drugiego dokumentu.

162 Wilson to Bryan, January 16, 1913, BP, container 29; R.W. Curry, Woodrow Wilson and Far Eastern Policy..., s. 38. Zobacz też: Mead to Wilson, March 27, 1913, $W W P$, series 4: case files, 227, reel 242. Pierwszy cytat pochodzi z książki Curry'ego, drugi z listu Wilsona do Bryana.

163 January 31, 1913, [w:] The Intimate Papers of Colonel House..., s. 105; From the Diary of Colonel House, April 4, 1913, [w:] PWW, t. 27, s. 262-263; N. Pugach, Paul S. Reinsch: Open Door Diplomat in Action, Millwood 1979, s. 56.

164 From the Diary of Colonel House, April 4, 1913, [w: ] PWW, t. 27, s. 262-263. 


\section{Chiny w polityce zagranicznej Stanów Zjednoczonych w latach 1911-1918}

ambasadorem USA w Turcji już tak ${ }^{165}$. Można zatem uznać, że w odniesieniu do Państwa Środka nastąpiło utożsamienie interesu narodowego z interesem misjonarzy, co dobitnie pokazywało, jaką politykę zamierzała prowadzić administracja Wilsona ${ }^{166}$. Oddalało to zarazem sterników amerykańskiej dyplomacji od profesjonalnego podejścia.

Mimo upływających tygodni i niepowodzeń w poszukiwaniach, Wilson i Bryan obstawali przy swoich warunkach, chociaż z czasem zaczęli wykazywać pewne zniecierpliwienie przedłużającym się impasem ${ }^{167}$. Od początku odrzucano możliwość pozostawienia dotychczasowego posła Williama Calhouna ${ }^{168}$. Zresztą Wilson, rozpoczynając urzędowanie w Białym Domu, postanowił wymienić większość szefów zagranicznych placówek dyplomatycznych. Spowodowane to było chęcią obsadzenia stanowisk zaufanymi członkami partii lub osobami zasłużonymi w trakcie kampanii (tzw. system łupów), jak i przekonaniem, że dyplomaci mianowani przez poprzednią administrację tak bardzo przyzwyczaili się do dawnych wytycznych i odmiennego sposobu myślenia, że nie będą potrafili się przestawić i prowadzić innej polityki. Zarzucano im przedkładanie interesu materialnego i jednostkowego nad dobro moralne i publiczne ${ }^{169}$. W przekonaniu o słuszności zmiany Calhouna utwierdziła Wilsona także opinia biskupa Jamesa Bashforda. Duchowny, który wcześniej wypowiadal się bardzo przychylnie o Calhunie, na początku 1913 roku zasugerowal, że należałoby go zastąpić kimś innym, ponieważ „nie był w Chinach wystarczająco długo" ${ }^{170}$. Trudno traktować ten zarzut jako coś więcej niźli pretekst, zważywszy że Calhoun spędził w Chinach chyba najwięcej czasu spośród wszystkich osób branych pod uwagę przy obsadzaniu poselstwa w Pekinie.

Sam biskup Bashford stał się głównym rzecznikiem pomysłu, aby to Bryan został nowym przedstawicielem USA w Chinach, a poselstwo zostało podniesione do rangi ambasady, o co biskup zabiegał już wcześniej. Bryan z zadowoleniem przyjął całą inicjatywę, ale nie zamierzał się zgodzić. Jego

165 N. Pugach, Paul S. Reinsch ..., s. 56.

166 Dodge to Wilson, April 1, 1913, [w: ] PWW, t. 27, s. 247-248.

${ }^{167}$ From the Diary of Colonel House, April 4, 1913, [w: $P W W$, t. 27, s. 262-263; Bryan to Wilson, June 2, 1913, BP, container 59.

168 Sam Calhoun też nie czuł się najlepiej w Chinach i chwilami żałowal, że zgodził się zostać posłem. Calhoun to Favill, August 31, 1910, TP, series 6: case files, 443, reel 385; W. Scholes, M. Scholes, The Foreign Policies ..., s. 23.

169 Wilson to Eliot, September 17, 1913, [w: ] R.S. Baker, Woodrow Wilson ..., s. 42.

170 Bashford to Knox, June 20, 1911, TP, series 6: case files, 443, reel 385; Charles Lee Swem's Summary of a Letter from James Whitford Bashford, January 10, 1913, [w:] PWW, t. 27, s. 27-28. Cytat pochodzi z drugiego dokumentu. 
nominacja na sekretarza stanu położyła kres wszelkim tego typu spekulacjom $^{171}$.

Pierwszy poważny wybór Wilsona stanowił profesor Charles Eliot, były wieloletni rektor Harvardu (1869-1909), który jednak odmówił z powodów rodzinnych, co zapewne uspokoiło Bryana, mocno zaniepokojonego unitarianizmem naukowca ${ }^{172}$. Następny z liczących się kandydatów John Mott miał już poparcie zarówno Wilsona, jak i Bryana. Mott, czołowy działacz YMCA i późniejszy laureat Pokojowej Nagrody Nobla (1946), również odrzucił proponowane mu stanowisko, i to mimo usilnych nalegań prezydenta ${ }^{173}$. Tymczasem zaczęli się pojawiać inni pretendenci: profesor Ernest Burton, syn byłego prezydenta Ulyssesa Granta - Jesse, jeden z przywódców środowiska misjonarskiego - Samuel B. Capen, dziennikarze William Ellis i Norman Hapgood, profesor Jeremiah Jenks, profesor Edward Ross, byly gubernator Missouri Joseph Folk oraz biznesmen i adwokat Henry Morgenthau senior ${ }^{174}$. Wszyscy oni okazali się jednak z różnych powodów nieodpowiedni. Widać wyraźnie, że znalazło się w tym gronie wiele osób wywodzących się ze środowisk najlepiej znanych Wilsonowi - świata nauki i polityki ${ }^{175}$. Może to zaskakiwać, zważywszy na wcześniejsze deklaracje o misjonarskich priorytetach pracy w Chinach.

${ }_{171}$ Bashford to Knox, June 20, 1911, TP, series 6: case files, 443, reel 385; Charles Lee Swem's Summary of a Letter from James Whitford Bashford, January 10, 1913, [w:] PWW, t. 27, s. 27-28; R.W. Curry, Woodrow Wilson and Far Eastern Policy..., s. 35-36; Tien-yi Li, Woodrow Wilson's China Policy..., s. 16-17.

172 From the Diary of Colonel House, January 17, 1913, [w: $P W W$, t. 27, s. 61-63; From the Diary of Colonel House, January 24, 1913, [w:] ibidem, s. 69-72; From the Diary of Colonel House, February 13, 1913, [w:] ibidem, s. 109-111; Wilson to Bryan, February 21, 1913 [dokument najprawdopodobniej blędnie datowany, pochodzi raczej z 5 lutego], $B P$, container 29.

173 Wilson to Bryan, February 14, 1913, BP, container 29; Wilson to Bryan, February 17, 1913, ibidem; Wilson to Bryan, February 21, 1913 [dokument najprawdopodobniej blędnie datowany, pochodzi raczej z 5 lutego], ibidem; $P W W$, t. 27, s. 109-111, 131, 167, $175,179,190,202,214-215,247-248$.

174 Charles Lee Swem's Summary of a Letter from James Whitford Bashford, January 10, 1913, [w:] PWW, t. 27, s. 27-28; From the Diary of Colonel House, January 17, 1913, [w:] ibidem, s. 61-63; Mead to Wilson, March 27, 1913, WWP, series 4: case files, 227, reel 242; Dodge to Wilson, April 1, 1913, [w: $P W W$, t. 27, s. 247-248; From the Diary of Colonel House, April 3, 1913, [w:] ibidem, s. 259; From the Diary of Colonel House, April 4, 1913, [w:] ibidem, s. 262-263; Dodge to Wilson, April 8, 1913, [w:] ibidem, s. 274275; Wilson to Dodge, April 10, 1913, [w:] ibidem, s. 283; Bryan to Wilson, June 2, 1913, BP, container 59; Mott to Wilson, July 3, 1913, [w:] PWW, t. 28, s. 22-23; R.W. Curry, Woodrow Wilson and Far Eastern Policy..., s. 38; N. Pugach, Paul S. Reinsch ..., s. 56.

175 Nie sprawdziły się obawy późniejszego sekretarza spraw wewnętrznych Franklina K. Lane’a, który podejrzewał, że Wilson, sam będąc profesorem, nie będzie chciał 
Przedstawicielem społeczności akademickiej był również Paul Reinsch, profesor politologii z Uniwersytetu Wisconsin, który z czasem stał się faworytem do objęcia poselstwa w Pekinie. Jako pierwszy wspomniał o nim Charles Crane, lecz nie w odniesieniu do Chin, a w kontekście Ameryki Południowej ${ }^{176}$. Ostatecznie na przełomie czerwca i lipca Wilson zdecydował się powierzyć prowadzenie polityki w Chinach Reinschowi, który ofertę z radością przyjąl, ponieważ już od ponad dziesięciu lat zabiegał o stanowisko w amerykańskiej dyplomacji, zwłaszcza na Dalekim Wschodzie ${ }^{177}$.

Kilka czynników wpłynęło na ten wybór. Niebagatelne znaczenie miał fakt, że Wilson znał osobiście Reinscha, wiedział o jego dokonaniach naukowych i zmyśle organizacyjnym (obaj współzakładali American Political Science Association). Świadomy był też jego reputacji znawcy bieżących wydarzeń na świecie, sytuacji w Chinach i Japonii oraz prawa międzynarodowego ${ }^{178}$. Dodatkowy atut stanowiło zaangażowanie Reinscha w ruch reformatorski, zarówno na terenie własnego stanu, jak i w skali ogólnokrajowej. Nie mniej istotne, a może wręcz kluczowe, okazało się poparcie, jakiego udzielił mu Charles Crane, wpływowy biznesmen z Chicago, jeden z głównych sponsorów kampanii Wilsona, który nowemu prezydentowi nieformalnie doradzał przy obsadzaniu placówek dyplomatycznych ${ }^{179}$.

Zastanawiające jest, że wśród czynników i cech, które przyczyniły się do sukcesu Reinscha, nie pojawiła się kwestia religijności. Właściwie nie był on bardzo wierzący, tylko czasami chodził do kościoła, nie utożsamiał się z konkretnym wyznaniem, ze zrozumieniem odnosił się do innych religii i na pewno

angażować innych członków akademii. Lane to Wheeler, December 23, 1912, [w: ] The Letters of Franklin K. Lane: Personal and Political, (opr.) A.W. Lane, L.H. Wall, Boston-New York 1922, s. 119-120.

176 Crane to Wilson, March 21, 1913, [w: ] PWW, t. 27, s. 203.

177 Wilson to Bryan, June 25, 1913, [w: ] PWW, t. 28, s. 4; Bryan to Wilson, June 25, 1913, [w: ] ibidem, s. 4-5; Wilson to Reinsch, June 30, 1913, [w:] ibidem, s. 15. Na temat życia i kariery naukowej Reinscha do momentu zostania posłem w Pekinie patrz: N. Pugach, Paul S. Reinsch ..., s. 3-59; P.J. Scanlan, No Longer a Treaty Port: Paul S. Reinsch and China 1913-1919, nieopublikowany doktorat, University of Wisconsin, Madison 1973, s. $2-17$.

178 Reinsch opublikował dwie dość dobrze przyjęte książki na temat Dalekiego Wschodu: World Politics at the End of the Nineteenth Century as Influenced by the Oriental Situation (1900) i Intellectual and Political Currents in the Far East (1911).

179 N. Pugach, Paul S. Reinsch..., s. 54-57; P.J. Scanlan, No Longer a Treaty..., s. 12-15. Crane zobowiązał się uzupełnić pensję Reinscha, który nie był na tyle dobrze sytuowany, aby wobec niewystarczającego uposażenia poselskiego samemu pokryć wszystkie wydatki związane z nową posadą. 
nie przejawiał zacięcia misjonarskiego ${ }^{180}$. Dlaczego zatem został wybrany, skoro najważniejszą rolę miał odgrywać zdecydowanie przychylny stosunek do religii? Czyżby Wilson i Bryan zmienili priorytety lub zapomnieli o nich? Biografowie Reinscha milczą na ten temat, ale być może prezydent uznał, że wspieranie misjonarzy nie mogło stanowić jedynego kryterium, zwłaszcza że w tym czasie zaczął słabnąć ich entuzjazm co do perspektyw ewangelizacji w Chinach $^{181}$. Wycofanie się $\mathrm{z}$ konsorcjum mocarstw sprawiło $\mathrm{z}$ kolei, że należało w inny sposób zadbać o ekonomiczne interesy w Państwie Środka, a do tego Reinsch był już lepiej przygotowany. Nie natrafilem na żadne bezpośrednie dowody potwierdzające taki domysł, ale sądzę, że do wysunięcia podobnych wniosków może uprawniać zestawienie portretu pożądanego kandydata $\mathrm{z}$ ostatecznie wybranym. Należy wykluczyć z całą pewnością, że był to nieświadomy wybór. Wilson znał przecież poglądy Reinscha na temat ekspansji zagranicznej oraz wiedział, że jednym $\mathrm{z}$ jego mentorów (i zarazem promotorem dysertacji doktorskiej) był prof. Frederick Jackson Turner, postulujący odtworzenie pogranicza m.in. na Dalekim Wschodzie. Wydaje się, że na początku Wilson rzeczywiście chciał wybrać posła o nastawieniu misjonarskim, ale potem, zapewne w wyniku pierwszych niepowodzeń i presji czasu, własnych posunięć dyplomatycznych oraz rozwoju sytuacji w Chinach, zdecydował się na osobę o innej charakterystyce. Zresztą fakt, że Reinsch był postępowcem, pozwalał liczyć, że wesprze on misjonarzy w ich dążeniu do moralnej i cywilizacyjnej przebudowy Chin, nawet jeśli nie będzie to sednem jego działań. Podczas rozmowy z Reinschem Wilson wyraził swoje poparcie dla konstruktywnych przedsięwzięć w Chinach, przy czym - ku pewnemu zawodowi swojego rozmówcy - szerzej rozwodził się nad edukacją, moralnym i politycznym patronatem niż nad kwestiami gospodarczymi ${ }^{182}$. Reinsch odwrotnie rozłożył akcenty, dając pierwszeństwo ekonomii przed innymi obszarami aktywności, co wynikało z jego przekonań o nadrzędnej roli handlu i inwestycji zagranicznych.

Dyplomata upatrywał w ekspansji ekonomicznej gwarancji dobrobytu i stabilności wewnętrznej Stanów Zjednoczonych. Ale handel i inwestycje ${ }^{183}$ miały jego zdaniem nie tylko wartość samą w sobie, były także nośnikami postępu, zarówno w wymiarze ogólnoświatowym, jak i w odniesieniu do państw słabo

180 Rodzice Reinscha byli bardzo religijni. Ojciec był luterańskim pastorem, a matka osobą gorliwie wierzącą. W młodości Paul uczęszczał do szkół luterańskich i sądzono nawet, że zostanie duchownym. Później jednak jego światopogląd, zainteresowania i plany życiowe uległy zmianie. N. Pugach, Paul S. Reinsch ..., s. 4-5. Trochę inne zdanie na temat religijności Reinscha ma Trani. E.P. Trani, Woodrow Wilson ..., s. 339.

${ }_{181}$ M.V. Metallo, American Missionaries ..., s. 275, 280-281.

182 P. Reinsch, An American Diplomat ..., s. 63.

${ }_{183}$ Dla Reinscha ważniejsze były inwestycje, bo stymulowały handel. N. Pugach, Paul S. Reinsch ..., s. 32. 
rozwiniętych. Przyczyniały się bowiem do wzrostu powiązań między krajami i zacieśniania współpracy, co miało łagodzić nastroje nacjonalistyczne i zmniejszać ryzyko wojny. W przypadku państw zacofanych lub pogrążonych w stagnacji pobudzały rozwój gospodarczy, który następnie promieniowal na inne dziedziny, stając się impulsem do zmian. W ten sposób postęp cywilizacyjny dokonywał się za sprawą aktywności ekonomicznej.

Reinsch uważał, że państwa rozwinięte, takie jak USA, miały niemal powinność moralną, aby dokonywać ekspansji ekonomicznej na terenach zacofanych, gdyż - w przeciwieństwie do podboju terytorialnego, któremu Reinsch był zdecydowanie przeciwny - wspierało to stabilizację i postęp. Zarazem przestrzegał on przed ingerencją w innych obszarach. Próby przeszczepienia okcydentalnych wartości, rozwiązań politycznych lub społecznych mogły zaburzyć dotychczasowy porządek i doprowadzić do wyzwolenia sił reakcyjnych, czego przykładem był ruch „bokserów”. Państwa słabiej rozwinięte, w tym Chiny, miały własne tempo ewolucji i jedyny bezpieczny sposób jej przyśpieszenia stanowiły handel i inwestycje. Reinsch wierzył, że zmiany ustroju i życia społecznego powinny zachodzić dobrowolnie, a nie być wymuszone przez mocarstwa. Liczyl, że gdy państwa zacofane dostrzegą przewagę Zachodu, same zdecydują się na zaadoptowanie do swoich warunków dorobku cudzoziemców.

Reinsch podkreślał znaczenie Orientu, uznając, że w przyszłości właśnie tam będzie się znajdować centrum światowych wydarzeń. Amerykanie powinni zatem jak najszybciej przystąpić do wzmożonej penetracji ekonomicznej Chin, gwarantując sobie możliwość korzystania z ich zasobów. Dotychczasowe starania w tym kierunku były zdaniem Reinscha ewidentnie niewystarczające. Źródeł niepowodzenia upatrywał on w nikłym zainteresowaniu biznesmenów, wynikającym zapewne z braku wiedzy na temat potencjału rynku chińskiego. By zmienić tę niekorzystną sytuację, należało przeprowadzić kampanię informacyjną. Niezbędne było również większe zaangażowanie ze strony Departamentu Stanu, który do tej pory nie wspierał należycie rodaków. To nie kupcy i przedsiębiorcy mieli podążać za flagą, przekonywał profesor z Wisconsin, lecz to rząd miał chronić ich inwestycje.

Reinsch był zwolennikiem polityki „otwartych drzwi”, którą uznawał za dogodny instrument do rozszerzania ekonomicznych wpływów. Pozwalała ona na swobodną konkurencję na rynku chińskim, zmniejszając jednocześnie ryzyko odrzucanej przez Reinscha ekspansji terytorialnej. Postulował on zresztą uniwersalizację doktryny, tak aby mogła być stosowana w skali światowej oraz obejmowała nieskrępowany przepływ „towarów, kapitału i idei” ${ }^{84}$.

184 Fragment dotyczący poglądów Reinscha na podstawie: P.J. Scanlan, No Longer a Treaty ..., s. 4-12; N. Pugach, Paul S. Reinsch ..., s. 8-42, 58-59. 


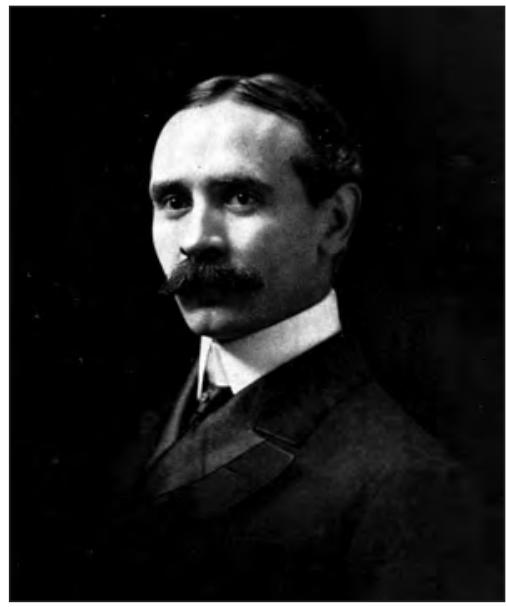

27. Paul Reinsch

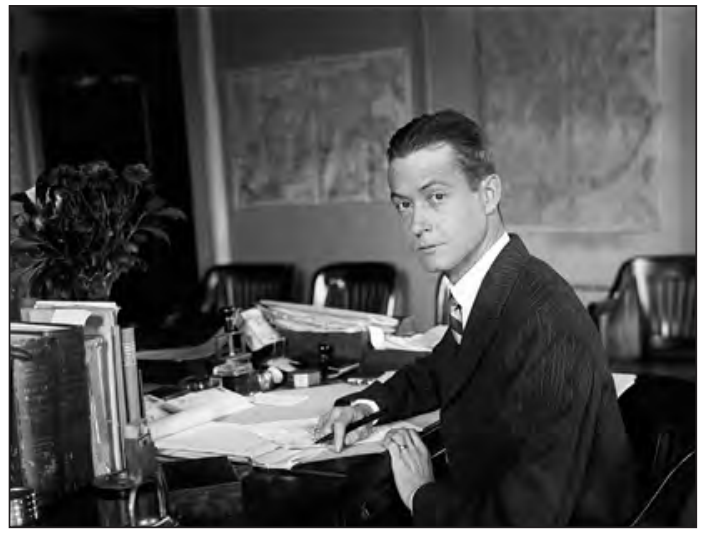

28. John V.A. MacMurray

Poglądy Reinscha, łączące postulaty ekspansjonizmu i ruchu postępowego, wydawały się zbyt idealistyczne. Chyba nadmierną moc przypisywał on ekonomii, a zwłaszcza jej zdolności przekształcania innych dziedzin życia. Wizja świata, w którym swobodna konkurencja gospodarcza nie wywołuje konfliktów, ale przeciwnie, zmniejsza ich prawdopodobieństwo, wypiera ekspansję terytorialną i stępia nacjonalizm, także przypominała bardziej wyabstrahowaną z rzeczywistości koncepcję akademicką, niż przystawała do realiów międzynarodowych w przededniu wybuchu I wojny światowej. Reinsch sądzil, że większe zaangażowanie USA w Chinach raczej nie spotka się z negatywną reakcją innych mocarstw, co sprzeczne było $\mathrm{z}$ wieloma dotychczasowymi przypadkami ${ }^{185}$.

O to, że Reinsch miał idealistyczne wyobrażenie o Chinach, obawiał się John V.A. MacMurray, który poznał Reinscha w Waszyngtonie, kiedy obaj przygotowywali się do wyjazdu do Chin. MacMurray, były student Wilsona, miał zostać pierwszym sekretarzem poselstwa ${ }^{186}$. Jego obawy zostały jednak szybko rozwiane, a perspektywa współpracy z przyszłym szefem wyglądała obiecująco. Reinsch ujął go w szczególności zamiarem naocznego poznania Kraju Smoka podczas licznych podróży ${ }^{187}$.

\section{P.J. Scanlan, No Longer a Treaty ..., s. 9.}

186 Wilson chciał mianować MacMurraya posłem w Syjamie, ale ten wolał zostać sekretarzem poselstwa w Chinach. Bryan to Wilson, August 13, 1913 [dokument jest najprawdopodobniej błędnie datowany], BP, container 45; Wilson to Bryan, August 14, 1913, ibidem. Warto dodać, że w 1916 roku MacMurray poślubił córkę profesora Goodnowa - Lois.

${ }_{187}$ N. Pugach, Paul S. Reinsch ..., s. 58. 
Zanim Reinsch udał się do Chin, spotkał się z Charlesem Cranem, który przedstawił go kilku dalekowschodnim specjalistom. Znajdowali się wśród nich John W. Foster - były sekretarz stanu (1892-1893), który pomagał wynegocjować pokój po wojnie japońsko-chińskiej - oraz John Mott, niedoszły poseł w Pekinie. Następnie Reinsch nawiązał kontakty z bankierami i przedsiębiorcami z Nowego Jorku i San Francisco, m.in. zadzierzgnął znajomość z Willardem Straightem ${ }^{188}$.

\section{Nieudane próby zwiększenia amerykańskiej aktywności w Chinach (listopad 1913 roku - sierpień 1914 roku)}

Reinsch przybył do Chin na początku listopada 1913 roku. Niedługo później w przeciwnym kierunku pojechał Edward Williams, którego mianowano szefem Wydziału ds. Dalekiego Wschodu. Stał się on głównym chińskim specjalistą w Departamencie Stanu, gdyż zarówno asystent sekretarza stanu John Osborne, jak i radca John Bassett Moore mieli nieporównywalnie mniejszą wiedzę na ten temat. Williams wypełnił lukę, jaka powstała po rezygnacji Huntingtona Wilsona i wyjeździe Ransforda Millera na placówkę w Seulu ${ }^{189}$. W kolejnych latach wspólpracował on z Reinschem, próbując rozszerzyć amerykańskie wpływy w Chinach.

Po dotarciu do Chin Reinsch stanął przed dwoma wyzwaniami - ekonomicznym i politycznym. Pierwsze wynikało z zadania, jakie sam sobie wyznaczył, a mianowicie zwiększenia amerykańskich wpływów na rynku chińskim ${ }^{190}$. Chińczycy ze swej strony również o to zabiegali. Ich sytuacja finansowa była trudna rosły deficyt i zadłużenie zagraniczne, rozprzestrzeniała się korupcja, ściągalność podatków była poważnie zakłócona, a wydatki ciągle się zwiększały ${ }^{191}$.

Jeszcze przed wybuchem „drugiej rewolucji” do USA przybył wysłannik Sun Yat-sena Amerykanin George Bronson Rea, który raczej bezskutecznie starał się nakłonić polityków i przedsiębiorców do inwestowania w budowę kolei w Chinach ${ }^{192}$. Wiosną i latem 1913 roku Chińczycy kilkakrotnie zwracali

188 Ibidem, s. 57-59.

189 D.D. Lazo, An Enduring Encounter..., s. 187. Kiedy było wiadome, że Williams ma zostać przeniesiony do Waszyngtonu, bardzo pochlebnie o jego kompetencjach wypowiadali się Yuan i biskup Bashford. Bashford to Bryan, October 10, 1913, RDSRPRUSCh, roll 1; Yuan to Wilson, December 2, 1913, ibidem.

190 P. Reinsch, An American Diplomat..., s. 64.

191 The American Chargé d'Affaires to the Secretary of State, July 11, 1913, [w: ] PRFRUS 1913, s. 183-186; The American Chargé d'Affaires to the Secretary of State, September 25, 1913, [w: ] ibidem, s. 187-189; P. Reinsch, An American Diplomat..., s. 55.

192 March 28, 1913, [w:] The Cabinet Diaries..., s. 15-19; Memorandum, March 28, 1913, WWP, series 4: case files, 227, reel 242; The American Chargé d'Affaires to the Secretary of State, July 11, 1913, [w:] PRFRUS 1913, s. 183-186. 
się do Williamsa $\mathrm{z}$ ofertami zaciągnięcia pożyczek na różne cele administracyjne i przemysłowe (m.in. konstrukcję linii kolejowych, odbudowę Hankou, oddłużenie i reorganizację kopalni i walcowni, pokrycie wydatków prowincjonalnych). Williams nastawiony był pozytywnie, ale w świetle marcowego oświadczenia Wilsona miał wątpliwości co do tego, jak powinien się zachować i które inicjatywy zyskają aprobatę przełożonych. Sądzil, że oficjalnego poparcia nie otrzymają pożyczki zabezpieczone dochodami z podatków, inne natomiast mogły na takowe liczyćc ${ }^{193}$.

Przypuszczenia Williamsa rozminęły się z instrukcjami płynącymi z Waszyngtonu. We wrześniu Bryan jednoznacznie stwierdzil, że rola dyplomacji miała polegać wyłącznie na czuwaniu, aby amerykańskie firmy nie były dyskryminowane, w żadnym wypadku nie na lobbowaniu na ich rzecz czy na pośredniczeniu w transakcjach. Rząd nie był stroną kontraktów i nie zaciągał w ich wyniku zobowiązań. Rodakom należało zaś nieustannie przypominać, że „przy ubieganiu się, rozwijaniu i chronieniu okazji biznesowych w Chinach muszą liczyć przede wszystkim na własny wysiłek, oczekując od tego rządu tylko takiej pomocy i ochrony, jakie są zazwyczaj udzielane $[. .$.$] amerykańskim przedsięwzięciom$ w obcych krajach"194.

Takie stanowisko stawiało Amerykanów w niekorzystnym położeniu. Ich konkurenci mieli wszak poparcie rządowe i mogli bazować na strefach wpływów. Kontrakty w Chinach były zaś przeważnie przyznawane nie według kryteriów ekonomicznych, ale z uwzględnieniem czynnika politycznego. Tylko zdecydowane poparcie Waszyngtonu mogło zrównoważyć szanse Amerykanów, którzy nie mieli przecież oparcia w strefie wpływów. Co więcej, niepewna sytuacja w Państwie Środka czyniła wszelkie inwestycje mało atrakcyjnymi, a bez oficjalnego wsparcia ryzykownymi. Stanowisko Bryana musiało zatem wpływać zniechęcająco na przedsiębiorców w USA, ale i pośrednio na chińskich oficjeli z nadzieją patrzących na możliwość współpracy.

Ci ostatni, zwłaszcza nowy premier Xiong Xiling i jeden z jego ministrów Zhang Jian, nie ustawali w swych wysiłkach przyciągnięcia amerykańskiego kapitału. Stałe problemy finansowe przy niemal całkowitym wyczerpaniu środków z pożyczki reorganizacyjnej zmuszały ich do szukania kolejnej dużej pożyczki zagranicznej. Podejrzewając, że konsorcjum mocarstw będzie chciało narzucić

193 The American Chargé d'Affaires to the Secretary of State, July 11, 1913, [w:] PRFRUS 1913, s. 183-186.

194 The Secretary of State to the American Chargé d'Affaires, September 11, 1913, [w: ] PRFRUS 1913, s. 186-187. Na początku 1915 roku jeden z przedsiębiorców stwierdził, że Bryan nie interesował się sprawami biznesowymi i nie rozumiał, jakie szanse mieli pod tym względem Amerykanie w Chinach. Scott to Montague, February 13, 1915, Robert Lansing Papers, Manuscript Division, Library of Congress, Washington, box 7. 
jeszcze cięższe warunki niż ostatnio, zwrócili się do Amerykanów ${ }^{195}$. Oczekiwali pożyczki opiewającej na 5 do 10 milionów funtów szterlingów, potrzebnej do przeprowadzenia reformy walutowej, w której Stany Zjednoczone chciały wcześniej uczestniczyć. Wiedząc, że amerykańscy biznesmeni mogli być umiarkowanie zainteresowani, zwłaszcza po marcowym oświadczeniu prezydenta Wilsona, byli gotowi przyznać im wyższe oprocentowanie, aby tylko uniknąć monopolu konsorcjum. Dążyli również do uzyskania wsparcia amerykańskiego rządu, aby przekonał on swoich bankierów do wznowienia akcji pożyczkowej. Jeden z argumentów stanowiło przypuszczenie, że gdyby Pekin musiał się ponownie zwrócić do konsorcjum, interesy USA znacznie by na tym ucierpiały. Zdaniem Williamsa należało się spodziewać, że pozostałe mocarstwa narzuciłyby wówczas warunki pozwalające im właściwie kontrolować finanse Chin, a dzięki sieci doradców i inspektorów ulokowanych w rozmaitych chińskich instytucjach byłyby w uprzywilejowanej pozycji podczas ubiegania się o koncesje gospodarcze i pożyczki o charakterze przemysłowym. Williams podkreślił ponadto, że finanse Chin były w tak złym stanie, że ingerencja z zewnątrz wydawała się nieunikniona, co powinno zostać wzięte pod uwagę przy rozpatrywaniu prośby o pożyczkę. Nie miał on chyba jednak większej nadziei na pozytywny odzew Departamentu Stanu, zwłaszcza że jak sam zaznaczył, prawdziwe motywacje strony chińskiej były też zapewne inne. Miała ona liczyć przede wszystkim na doprowadzenie do konkurencji między Amerykanami a konsorcjum, co skłoniłoby konsorcjum do złagodzenia warunków ${ }^{196}$. Jak można się było spodziewać, Departament Stanu nie zmienił nastawienia i za właściwą uznał zachowawczą odpowiedź, jakiej Williams udzielił Xiongowi: że USA zasadniczo popierały amerykańskie inwestycje w Chinach, ale nie zamierzały uczestniczyć w negocjacjach biznesowych ${ }^{197}$.

Nowa sytuacja zaistniała, gdy do Chin przybył Reinsch, który z animuszem przystąpił do wspierania kupców i inwestorów. Przekonany, że to właśnie oni byli prawdziwymi ambasadorami amerykańskiego interesu w Chinach, skoro ów interes w tym państwie splatał sprawy polityczne $\mathrm{z}$,handlem, finansami i przemysłem”, uznał rozwijanie kontaktów gospodarczych za główny cel swoich działań $^{198}$. Wydatnie pomagali mu w tym Chińczycy, którzy ciągle starali się pozyskać

195 Zgodnie z warunkami pożyczki reorganizacyjnej Chiny nie mogły zaciągać nowych pożyczek przez sześć miesięcy od momentu wypłacenia całej sumy przez konsorcjum. Karencja upływała w lutym 1914 roku. The American Chargé d'Affaires to the Secretary of State, October 21, 1913, [w: ] PRFRUS 1913, s. 189-191.

196 The American Chargé d'Affaires to the Secretary of State, September 25, 1913, [w: ] PRFRUS 1913, s. 187-189; The American Chargé d'Affaires to the Secretary of State, October 21, 1913, [w: ] ibidem, s. 189-191.

197 The Secretary of State to Minister Reinsch, December 2, 1913, [w:] PRFRUS 1914, Washington 1922, s. 61-62.

198 P. Reinsch, An American Diplomat..., s. 60, 64. 
Amerykanów do współpracy, oferując dogodne warunki. Wynikało to z ich przekonania, że Stany Zjednoczone nie tylko nie miały ambicji politycznej kurateli i terytorialnej ekspansji, ale i mogły stanowić przeciwwagę dla takich właśnie wrogich dążeń innych mocarstw, zwłaszcza Rosji i Japonii ${ }^{199}$. Reinsch podzielał ten punkt widzenia, sugerował nawet, że każdy amerykański biznes w Chinach wspierał niepodległość tego państwa ${ }^{200}$.

Entuzjazm Reinscha i Chińczyków musiał się zmierzyć z różnymi trudnościami. O powściągliwym nastawieniu Departamentu Stanu była już mowa. Reinsch nie przejmował się tym zbytnio i realizował powzięty przez siebie cel. Jego działania nie skutkowały reprymendą od przełożonych ${ }^{201}$, spotkały się za to z negatywną reakcją niektórych mocarstw. Najbardziej zaniepokojona była Japonia, której nie podobała się zwłaszcza perspektywa budowy przez amerykańskie przedsiębiorstwo bazy morskiej w Fujianie, prowincji znajdującej się w japońskiej strefie wpływów. Japonia starała się zablokować tę inwestycję, wyrażając swoje niezadowolenie w Waszyngtonie i Pekinie. Reinsch uważał jej pretensje za bezzasadne i zalecił ich nie uznawać, gdyż w przeciwnym przypadku oznaczałoby to przyznanie prawa weta wobec układów dwustronnych państwu trzeciemu. A to z kolei naruszyłoby suwerenność Chin i amerykańskie interesy w tym kraju ${ }^{202}$.

Jeszcze inny, wręcz zasadniczy problem stanowiło niewielkie faktyczne zainteresowanie Amerykanów rynkiem chińskim. Reinsch obawiał się, że mianowanie go posłem zapewne wzmocniło jeszcze negatywne nastawienie rodaków, gdyż wybór intelektualisty o akademickiej proweniencji mógł zostać opacznie odczytany jako sygnał świadczący o innych niż komercyjne priorytetach nowej administracji. Nic wszakże bardziej mylnego, skoro przedkładał on gospodarkę nad pozostałe pola działań ${ }^{203}$. Reinsch wiedzial, że ostatnie decyzje gabinetu Wilsona zniechęciły część inwestorów i dlatego postanowił angażować się w te przedsięwzięcia, które wynikały z wcześniejszych kontaktów lub stanowiły rozwinięcie dotychczasowej działalności ${ }^{204}$. Z czasem zwrócił się też do bankierów z Wall Street, ale ci nadal byli rozżaleni tym, jak zostali potraktowani, i uzależnili swój udział od wydania przez rząd zdecydowanej deklaracji poparcia dla inwestycji

199 Ibidem, s. 65, 70, 73, 75, 81, 89-90, 106; Interview. The American Minister and the Secretary of Legation with the President, November 24, 1913, RDSRIACh, roll 13; Reinsch to the Secretary of State, December 2, 1913, ibidem.

200 P. Reinsch, An American Diplomat..., s. 106.

201 Reinsch twierdził, że Departament Stanu zawsze wspierał jego wysiłki na rzecz rozwijania amerykańskich interesów w Chinach. Ibidem, s. 102.

202 Ibidem, s. 82-84, 87-88, 99-100.

203 Ibidem, s. 64.

204 Ibidem, s. 80-81. 
w Chinach lub w inny sposób jasnego zasygnalizowania takiej woli. Przed wybuchem I wojny światowej nic takiego nie nastąpiło ${ }^{205}$.

Starania Reinscha zaowocowały dwoma kontraktami podpisanymi na początku 1914 roku. Pierwszy otrzymał amerykański Czerwony Krzyż, któremu zawierzono pieczę nad pracami regulującymi bieg rzeki Huai He, drugi przyznano Standard Oil na poszukiwanie i eksploatację złóż ropy w prowincjach Zhili i Shaanxi ${ }^{206}$. Renegocjowano również umowę z Bethlehem Steel, zawartą jeszcze przez rząd qingowski. Amerykańska firma miała dostarczyć statki handlowe dające się łatwo przekształcić w okręty wojenne oraz zbudować stocznię i bazę morskąa ${ }^{207}$. Chińczycy byli skłonni poprzeć i inne projekty czy przyznać dalsze koncesje (m.in.: monopol tytoniowy dla British-American Tobacco Company; budowę sieci tramwajowej w Pekinie; udział w banku, który inwestowałby w Państwie Środka; zatrudnienie amerykańskich instruktorów w marynarce wojennej; utworzenie linii żeglugowej między oboma państwami; zaciągnięcie pożyczek na spłatę zadłużenia, przeprowadzenie reformy walutowej i reorganizację systemu bankowego), ale próby te zakończyły się niepowodzeniem ${ }^{208}$.

Inny ciekawy pomysł, który również nie doszedł do skutku, zakładał utworzenie międzynarodowego syndykatu mającego sfinansować i zbudować linie kolejowe w Chinach. Inicjatorami byli Chińczycy, którzy chcieli pozyskać do współpracy wybrane firmy konstrukcyjne z Wielkiej Brytanii, Francji, Stanów Zjednoczonych i Niemiec. Stanowiło to poniekąd próbę reaktywacji porozumienia czterech mocarstw, przy czym tym razem kontrahentami mieli być

205 Straight to Reinsch, April 29, 1914, [w:] ibidem, s. 91-94. W czerwcu 1914 roku Departament Stanu oświadczył co prawda, że popiera pożyczki dla Chin, ale zrobił to w sposób bardzo ogólnikowy i bez większego przekonania. Ibidem, s. 101-102.

206 Doc. no. 1916/6: United States (American International Corporation) and China. Note: Huai River Conservancy Memorandum addressed by the Government of the Republic of China to the American National Red Cross, or its Representatives, or Successors, January 30, 1914, [w: ] Treaties and Agreements..., t. 2, s. 1310-1312; Doc. no. 1914/3: United States (Standard Oil Company of New York) and China. Agreement for the exploration and operation of petroleum oil fields in Chihli and Shensi Provinces, February 10, 1914, [w:] ibidem, s. 1109-1111.

207 P.J. Scanlan, No Longer a Treaty ... , s. 65-67; P. Reinsch, An American Diplomat ..., s. 74, 82-84, 99-100.

208 Reinsch to the Secretary of State, December 2, 1913, RDSRIACh, roll 13; Minister Reinsch to the Secretary of State, February 6, 1914, [w:] PRFRUS 1914, s. 62-63; P. Reinsch, An American Diplomat ... s. s2-75, 89-91, 105; P.J. Scanlan, No Longer a Treaty ..., s. 53, 63-64, 71. Chińczycy chcieli też wysłać do USA misję handlową, która miała przede wszystkim zbadać, jak zwiększyć amerykański eksport do ich kraju. Lansing to Tumulty, June 8, 1914, WWP, series 4: case files, 227, reel 242; Memorandum, June 1, 1914, ibidem. 
wykonawcy, a dostarczający fundusze bankierzy pozostać na drugim planie. Pamiętając o niechęci administracji Wilsona do konsorcjum mocarstw, Chińczycy i pomagający im George Bronson Rea zapewnili, że nowe zrzeszenie nie będzie miało monopolu, a jedynie pierwszeństwo przy ubieganiu się o koncesje. Gdyby inne przedsiębiorstwo zaproponowało korzystniejsze warunki, Chiny zastrzegały sobie prawo wyboru tejże oferty. Rząd w Waszyngtonie rzeczywiście był przeciwny, chociaż bardziej obstrukcyjna okazała się postawa Wielkiej Brytanii i Francji, które domagały się respektowania ich wyłącznych praw w strefach wpływów. Brytyjczycy chcieli na przykład gwarancji, że wszystkie linie biegnące przez dolinę Jangcy oraz dochodzące do Hongkongu będą budowane przez ich przedstawiciela w syndykacie. Stanowiło to sygnał, że wśród mocarstw europejskich ponownie przewagę zyskiwała koncepcja stref wpływów. Początek wojny na Starym Kontynencie ostatecznie pogrzebał cały projekt ${ }^{209}$.

Niestety, także wszystkie kontrakty zawarte lub wskrzeszone dzięki pośrednictwu Reinscha spotkał podobny los. Brak zainteresowania lub opieszałość amerykańskich inwestorów, niemrawe poparcie Białego Domu ${ }^{210}$, opór innych mocarstw, zmiany w pekińskim rządzie ${ }^{211}$ czy w końcu wybuch I wojny światowej przyczyniły się do ich anulowania lub odroczenia. Reinsch, podobnie zresztą jak Chińczycy, był rozczarowany, ale nie tracił zapału, cały czas przekonując o konieczności zwiększenia zaangażowania gospodarczego w Chinach. Jedynym wymiernym efektem jego działań w tym czasie było mianowanie przez Departament Stanu attaché handlowego, co jednak też trudno uznać za jego osobisty sukces, skoro ogółem dziesięciu attachés handlowych miało się pojawić przy amerykańskich placówkach dyplomatycznych na świecie ${ }^{212}$.

Drugim problemem, z którym musiał się zmierzyć Reinsch, była sytuacja polityczna w Chinach. Po stłumieniu „drugiej rewolucji” Yuan kontynuował umacnianie swojej dyktatury. Chociaż co pewien czas pojawiały się pogłoski o próbach

209 Memorandum, May 13, 1914, WWP, series 4: case files, 226, reel 242; Rea to Redfield, June 3, 1914, BP, container 30; Rea to Redfield, June 3, 1914, ibidem; Redfield to Bryan, June 11, 1914, ibidem; Reinsch to the Secretary of State, June 29, 1914, RDSRIACh, roll 13; P. Reinsch, An American Diplomat..., s. 100-101.

${ }^{210}$ Administracja Wilsona zgodziła się ostatecznie poprzeć projekt dotyczący rzeki Huai He. Moore to Wilson, February 4, 1914, WWP, series 4: case files, 227, reel 242; Wilson to Moore, February 6, 1914, ibidem; Boardman to Wilson, February 11, 1914, ibidem; Moore to Wilson, February 11, 1914, ibidem.

$211 \mathrm{Na}$ początku 1914 roku Xiong Xiling zrezygnował z premierostwa. Z rządu odszedł też m.in. Zhang Jian.

212 P. Reinsch, An American Diplomat..., s. 103; P.J. Scanlan, No Longer a Treaty..., s. 75; N. Pugach, Paul S. Reinsch..., s. 169. 
zorganizowania kolejnego powstania, to nic nie zagrażało pozycji prezydenta ${ }^{213}$. $\mathrm{Na}$ początku 1914 roku rozwiązał on parlament, na miejsce którego powołał całkowicie przez siebie kontrolowaną Radę Polityczną. 1 maja ogłoszono zmienioną Konstytucję Tymczasową, dającą prezydentowi bardzo szerokie prerogatywy ${ }^{214}$. Spekulowano, że Yuan chce zapewnić sobie dożywotnie sprawowanie urzędu prezydenta lub dąży wręcz do restauracji monarchii ${ }^{215}$. Krokiem w tym kierunku miało być ponowne oparcie władzy na konfucjanizmie, nadające mu niemal status religii państwowej. 23 grudnia Yuan odprawił ceremonię w Świątyni Nieba, co wcześniej czynili wyłącznie cesarze - Synowie Nieba. Kilka dni później zmieniono zasady dotyczące prezydentury - kadencję wydłużono z pięciu do dziesięciu lat, zniesiono ograniczenia dotyczące możliwości reelekcji, głowie państwa przyznano też prawo do nominowania następcy ${ }^{216}$.

Dyktatorskie posunięcia Yuana Reinsch ocenił w sposób umiarkowany, a przynajmniej z wyrozumiałością. Uznał, że chociaż kompetencje prezydenta były „nadzwyczaj duże”, a ostatnie decyzje rzeczywiście oddalały Chiny od parlamentaryzmu, to cała sytuacja nie powinna być postrzegana jako „definitywna reakcja przeciw demokracji”, ale raczej jako przejęcie przez rząd centralny władzy koniecznej do stworzenia warunków, w których demokracja mogła się rozwijać, czyli „warunków narodowej spójności i wewnętrznego spokoju”217. Reinsch podkreślał złożoność i ważkość problemów, z jakimi musieli się zmierzyć rządzący w Pekinie. Niestabilna sytuacja w kraju, jego ogromna populacja i skomplikowana tkanka społeczna, różne spiski i intrygi polityczne, niekorzystne położenie międzynarodowe oraz zakłócenie przez wydarzenia ostatnich lat ewolucyjnego wprowadzania zmian ustrojowych - wszystko to sprawiało, że rząd musiał działać powoli i ostrożnie ${ }^{218}$.

213 Gilbert to Williams, October 4, 1913, RDSRIACh, roll 13; Greene to Reinsch, November 20, 1913, ibidem; Fisher to Reinsch, December 19, 1913, ibidem; Myers to Reinsch, April 20, 1914, ibidem; Myers to Reinsch, May 2, 1914, ibidem; Myers to Reinsch, May 13, 1914, ibidem. Zob. też: Gilbert to Reinsch, June 4, 1914, ibidem.

${ }^{214}$ Tekst zmienionej Konstytucji Tymczasowej - patrz załącznik do: Memorandum by the Chinese Secretary, May 30, 1914, [w:] PRFRUS 1914, s. 54-60.

215 Williams to the Secretary of State, November 11, 1913, RDSRIACh, roll 13; Reinsch to the Secretary of State, March 16, 1914, ibidem; Reinsch to the Secretary of State, April 14, 1914, ibidem; Memorandum written by the Chinese Secretary, April 13, 1914, ibidem.

${ }^{216}$ Reinsch to the Secretary of State, March 16, 1914, RDSRIACh, roll 13; J. Chên, Yuan Shih-k'ai ..., s. 200-202; W. Rodziński, Historia Chin ..., s. 622; P. Reinsch, An American Diplomat..., s. 23-27.

${ }^{217}$ Minister Reinsch to the Secretary of State, May 5, 1914, [w:] PRFRUS 1914, s. 51-52.

${ }^{218}$ Reinsch to the Secretary of State, March 16, 1914, RDSRIACh, roll 13; Reinsch to the Secretary of State, July 2, 1914, ibidem. 
Reinsch przychylnie wypowiadał się o stworzonym przez profesora Goodnowa projekcie konstytucji, który stał się podstawą zmian wprowadzonych przez Yuana. Zgadzał się, że w realiach Państwa Środka rozwiązanie z silną pozycją prezydenta było wyraźnie lepsze. Chyba trochę naiwnie ufał zapewnieniom Yuana, że nie dąży on do całkowitego wyeliminowania parlamentu z życia politycznego, tylko do jego reorganizacji. Amerykański poseł doceniał też osobowość samego Yuana - jego bystrość, życzliwość, przenikliwość, energię oraz autorytet, jakim się cieszy1219.

Reinsch nie był jednak bezkrytyczny wobec działań nowego reżimu. Uważał, że poważnym błędem było rozwiązanie parlamentów, które chociaż rzeczywiście bywały „nastawione na własne korzyści [self-seeking], frakcyjne i niepraktyczne”, to jednak dawały możliwość pozyskania do wspólpracy bogatszej i lepiej wykształconej części społeczeństwa. Tak natomiast władza rządu centralnego opierała się tylko na armii i miała wątlejsze podstawy. Reinsch zarzucał Yuanowi, że nie rozumiał demokracji i mylił opozycję polityczną z wrogim działaniem, a nawet zdradą stanu ${ }^{220}$.

Ponadto armia, mająca stanowić fundament, nie dość, że była droga w utrzymaniu, to jeszcze nieskuteczna, gdyż nie potrafiła sobie poradzić ani z wrogiem zewnętrznym (Mongołami), ani wewnętrznym (bandytami). Dyskredytowało to rząd i zmniejszało społeczną akceptację dla wprowadzenia dyktatury wojskowej, skoro nie gwarantowała ona bezpieczeństwa i porząaku ${ }^{221}$. Autorytet rządzących szczególnie podważały działania bandytów, cały czas nękających większość prowincji $^{222}$. Sytuacja była na tyle niestabilna, że jeszcze w marcu 1914 roku Reinsch sprzeciwił się wycofaniu amerykańskich oddziałów z Chin, twierdząc, że były bardziej potrzebne niż „kiedykolwiek w ciągu ostatnich dwóch lat”223.

219 Interview. The American Minister and the Secretary of Legation with the President, November 24, 1913, RDSRIACh, roll 13; Reinsch to the Secretary of State, December 1, 1913, ibidem; Minister Reinsch to the Secretary of State, January 16, 1914, [w: ] PRFRUS 1914, s. 42-44; P. Reinsch, An American Diplomat..., s. 1, 5.

220 Reinsch to the Secretary of State, December 1, 1913, RDSRIACh, roll 13; Reinsch to the Secretary of State, March 16, 1914, ibidem; Reinsch to the Secretary of State, July 2, 1914, ibidem. Cytat pochodzi z drugiego z dokumentów. P. Reinsch, An American Diplomat..., s. $1-7,53-58$.

221 Reinsch to the Secretary of State, March 16, 1914, RDSRIACh, roll 13; Memorandum written by the Chinese Secretary, April 13, 1914, ibidem.

222 Greene to Reinsch, November 18, 1913, RDSRIACh, roll 13; Greene to Reinsch, November 20, 1913, ibidem; Pontius to Reinsch, February 26, 1914, ibidem; Reinsch to the Secretary of State, March 16, 1914, ibidem; Baker to Reinsch, March 19, 1914, ibidem; Memorandum written by the Chinese Secretary, April 13, 1914, ibidem.

223 Reinsch to the Secretary of State, March 18, 1914, RDSRIACh, roll 13. 
Drugi obok armii typowy filar dyktatury, administracja, również wydawał się Reinschowi wadliwy. Urzędy były źle zorganizowane i zarządzane, pełne ludzi niekompetentnych, przekupnych i nieodpowiedzialnych. Sytuację pogarszały jeszcze spory i rywalizacja polityczna między najważniejszymi członkami obozu rządzącego (między gen. Duan Qiruiem a gen. Feng Guozhangiem; między Liang Shiyiem a Liang Dunyanem i Duanem; między Xiong Xilingiem, Zhang Jianem i Liang Qichao a Yuanem) ${ }^{224}$. Samego Yuana podejrzewano o otrucie jednego z zaufanych współpracowników - Zhao Bingjuna, wcześniej premiera, uwikłanego z kolei w morderstwo Song Jiaorena ${ }^{225}$.

Na te wszystkie problemy nakładały się również poważne trudności finansowe. Szczególnie niska była ściągalność podatków i właściwie - zdaniem Reinscha - tylko dzięki wpływom z ceł i monopolu soli, kontrolowanych przez cudzoziemców, Chiny uniknęly bankructwa. Kolejne niepokojące zjawiska stanowity wzrost zadłużenia państwa i coraz większe uzależnienie od pożyczek zagranicznych ${ }^{226}$.

Ponadto Reinsch krytycznie odnosił się do wznowienia publicznego kultu konfucjańskiego, dostrzegając w tym zagrożenie dla swobody wyznania. Podobne obawy wyrażali amerykańscy misjonarze ${ }^{227}$.

Reinsch nie opowiedział się jednoznacznie, czy popiera działania Yuana, czy je odrzuca. Na pewno utrwalanie militarnej dyktatury i reakcyjne zmiany były mu obce, ale zarazem wydawał się je rozumieć jako po części wymuszone koniecznością chwili. Nie ustosunkował się też do kwestii wskrzeszenia cesarstwa (w dawnej formie lub jako monarchii parlamentarnej). Sygnalizował jedynie, że takie rozwiązanie było coraz częściej dyskutowane w Pekinie i należało opracować amerykańskie stanowisko na taką ewentualnośćc28.

$\mathrm{Z}$ czasem Reinsch połączył w swych doniesieniach wątek polityczny z ekonomicznym. Starał się przekonać, że Chiny zamierzały rozwijać demokrację,

224 Williams to the Secretary of State, November 11, 1913, RDSRIACh, roll 13; Reinsch to the Secretary of State, March 16, 1914, ibidem; Memorandum written by the Chinese Secretary, April 13, 1914, ibidem; Reinsch to the Secretary of the State, April 14, 1914, ibidem; Reinsch to the Secretary of State, July 2, 1914, ibidem.

225 Reinsch to the Secretary of State, March 3, 1914, RDSRIACh, roll 13; Reinsch to the Secretary of State, March 16, 1914, ibidem; W. Rodziński, Historia Chin ..., s. 618; K.S. Liew, Struggle for Democracy..., s. 192; J. Ch'ên, Yuan Shih-k'ai..., s. 160-163.

226 Reinsch to the Secretary of State, March 16, 1914, RDSRIACh, roll 13.

227 A Christmas Message to the Home Friends from Mr. and Mrs. C.E. Scott, December 25, 1913, WWP, series 4: case files, 227, reel 242; Minister Reinsch to the Secretary of State, January 16, 1914, [w: PRFRUS 1914, s. 42-44; P. Reinsch, An American Diplomat..., s. 23. Niektórzy amerykańscy misjonarze uważali, że powrót do konfucjanizmu to reakcja na fakt, że Sun Yat-sen i inni przywódcy „drugiej rewolucji” byli blisko związani z chrześcijaństwem. M.V. Metallo, The United States ..., s. 108-109.

228 Reinsch to the Secretary of State, March 16, 1914, RDSRIACh, roll 13. 
naśladując w największym stopniu model amerykański. Podczas wprowadzania zmian napotkały jednak różne trudności. Najbardziej hamującą okazał się opór mocarstw, których wplyw wynikał w znacznej mierze z faktu, że Chiny były od nich uzależnione finansowo, ponieważ potrzebowały pieniędzy na przeprowadzenie reform. Stąd też wniosek, że gdyby pozyskały pieniądze bez politycznego uwikłania, mogłyby kontynuować przemiany ustrojowe. Reinsch pisał wprost, że „dalszy rozwój republikanizmu w Chinach zależy od tego, jak dalece Chiny można uczynić niezależnymi od politycznej presji z zewnątrz, wywieranej za pomocą środków finansowych". Innym razem stwierdzil, że to, skąd Chiny otrzymają pomoc, w znacznej mierze wpłynie na kierunek przemian w tym państwie ${ }^{229}$.

Pekin od jakiegoś czasu prowadził rozmowy z konsorcjum na temat nowej pożyczki (na ok. 20 milionów funtów szterlingów), ale zostały one zawieszone, gdyż bankierzy domagali się m.in. przyznania opcji na pożyczkę walutową oraz dalszych uprawnień kontrolnych ${ }^{230}$. Stwarzało to szansę dla amerykańskich inwestorów. Aby jednak chcieli oni rozpocząć negocjacje, potrzebne było zapewnienie o przychylności ze strony rządu. Reinsch opowiadał się za takim rozwiązaniem. Przekonywał, że amerykańskie wpływy muszą się opierać na realnym zaangażowaniu w handel, finanse i politykę Chin. W kwestii pożyczki argumentował, że niezbędna suma była stosunkowo niewielka (50 milionów dol.), a korzyści dla obu państw znaczne. Oprócz już wspomnianych Stany Zjednoczone mogły udowodnić, że ich chińska polityka to konkretne działania, a nie wyłącznie „czcze gadanie", co zarzucali im niektórzy. Poza tym udzielenie pożyczki bez ingerowania w finanse Chin zaskarbiłoby wdzięczność Chińczyków, ułatwiając tym samym pracę amerykańskim misjonarzom, nauczycielom i lekarzom. Uchylenie się od pomocy finansowej groziło odwrotną reakcją̨231.

Przewidując zapewne, że ktoś może mu wytknąć nielogiczność, Reinsch przygotował nawet wyjaśnienie, dlaczego mimo niestabilnej sytuacji politycznej należało przekonywać Amerykanów do większej aktywności na rynku chińskim. Udowadniał, że albo Chiny wyjdą z tarapatów, zaczną się rozwijać i nastąpi okres

229 Reinsch to the Secretary of State, March 16, 1914, RDSRIACh, roll 13; Reinsch to the Secretary of State, July 2, 1914, ibidem; Reinsch to the Secretary of State, July 3, 1914, RDSRIACh, roll 14; Reinsch to the President, October 5, 1914, [w: PWW, t. 31, Princeton 1979, s. 284-288. Cytat pochodzi z ostatniego z wymienionych dokumentów.

${ }^{230}$ Minister Reinsch to the Secretary of State, February 6, 1914, [w: ] PRFRUS 1914, s. 62-63; Reinsch to the Secretary of State, July 2, 1914, RDSRIACh, roll 13; Chargé MacMurray to the Secretary of State, July 18, 1914, [w:] PRFRUS 1914, s. 63; T. Dmochowski, Walka polityczna mocarstw o dominacje w dorzeczu Amuru, Toruń 1999, s. 209.

231 Reinsch to the Secretary of State, March 16, 1914, RDSRIACh, roll 13; Reinsch to the Secretary of State, July 3, 1914, RDSRIACh, roll 14; Reinsch to the President, October 5, 1914, [w: $P W W$, t. 31, s. 284-288. Cytat zaczerpnięto z ostatniego dokumentu. 
prosperity, albo zbankrutują, a wtedy administrowanie krajem przejmą mocarstwa, które zagwarantują wywiązanie się z zobowiązań. W obu przypadkach amerykańskie inwestycje miały być bezpieczne ${ }^{232}$.

Wydaje się, że Reinsch był tak zdeterminowany, aby przekonać polityków nad Potomakiem do swoich racji, że dopuścil się nadużycia. Jego rozumowanie zasadzało się na wątpliwych, jeśli nie błędnych przesłankach. Oczywiście, międzynarodowe położenie Państwa Środka było skrajnie niekorzystne, ale odejście od demokracji wynikało akurat przede wszystkim z wydarzeń wewnętrznych, a nie z nacisków zewnętrznych. To ambicje Yuana, a nie presja mocarstw sprawiły, że wprowadzono dyktaturę. Co więcej, pomoc finansowa raczej nie doprowadziłaby do demokratyzacji rządów, prędzej już należało się spodziewać utrwalenia ich autorytarnego charakteru. Reinsch wiedział doskonale, jaką wagę przywiązywali Wilson i Bryan do szerzenia demokracji na świecie, i zapewne liczyl, że wizja przeobrażeń w Chinach skłoni ich do energiczniejszego poparcia amerykańskich inicjatyw ekonomicznych w tym państwie.

Wilson rzeczywiście wykazał pewne zainteresowanie całą sprawą. Listy od Reinscha, który wykorzystał osobiste kontakty i napisał bezpośrednio do prezydenta, przesłał sekretarzowi skarbu Williamowi McAdoo z informacją, że poruszały ważną kwestię $e^{233}$. Reinschowi odpisał, że zamierza porozmawiać z kilkoma osobami i ma nadzieję, iż uda się znaleźć jakieś rozwiązanie ${ }^{234}$. Nic takiego jednak nie nastąpiło, przynajmniej nie na przełomie lat 1914 i 1915. W tym czasie zdanie na temat pomocy finansowej dla Chin zaczął również zmieniać Bryan. Gdy dowiedział się, że dwaj chińscy wysłannicy negocjowali pożyczkę na Wall Street, skomentował, iż taka pożyczka, o ile zawarta na uczciwych warunkach, byłaby „korzystna nie tylko dla Chin, ale i dla Stanów Zjednoczonych”. Wątpił zarazem, aby w ówczesnych okolicznościach (trwała już I wojna światowa) naprawdę do niej doszło ${ }^{235}$.

Nie zmieniło się natomiast nastawienie Bryana do rozwoju wypadków w Chinach. Nadal był on rozczarowany postępowaniem Yuana, ale chyba pogodził się $\mathrm{z}$ tym, a nawet zdawał się je usprawiedliwiać. Stwierdzil, że Yuanowi zapewne blisko było do dyktatora, ale zastrzegł, że „nie należy ferować wyroków, nie znając wszystkich okoliczności", co nie wystawiało mu najlepszego świadectwa jako szefowi dyplomacji. Bryan podkreślił, że w ostatnim czasie sytuacja w Chinach uległa poprawie, społeczeństwo popierało Yuana i nie zamierzało się buntować, do czego dążyli Sun Yat-sen i Huang Xing ${ }^{236}$.

232 Reinsch to the Secretary of State, March 16, 1914, RDSRIACh, roll 13.

233 Wilson to McAdoo, November 9, 1914, [w: ] PWW, t. 31, s. 283.

234 Wilson to Reinsch, November 9, 1914, [w: ] PWW, t. 31, s. 289.

235 Bryan to Tumulty, December 2, 1914, [w: ] PWW, t. 31, s. 381-382.

236 Ibidem. 
Wzmiankowani rewolucjoniści rzeczywiście próbowali wzniecić kolejne powstanie, ale z niewielkim skutkiem. Władze amerykańskie starały się współpracować z Pekinem, aby temu zapobiec lub przynajmniej utrudnić zadanie konspiratorom przebywającym na ich terytorium. Kiedy upadła „druga rewolucja”, jej główni przywódcy schronili się w Japonii, skąd część chciała wyjechać do Stanów Zjednoczonych ${ }^{237}$. Taki kierunek obrał m.in. generał Huang. Amerykanie początkowo nie zgadzali się na jego wjazd z pominięciem normalnych procedur ${ }^{238}$. Ostatecznie generał został wpuszczony, ale bacznie przyglądano się poczynaniom jego i osób z nim związanych ${ }^{239}$. W październiku 1914 roku Bryan negatywnie zaopiniował prośbę Huanga o spotkanie z Wilsonem, czego oczywiście nie życzyło sobie chińskie poselstwo w Waszyngtonie. Amerykanie nie ulegli jednak namowom strony chińskiej, aby generała aresztować ${ }^{240}$. Zobligowali się za to informować o wszystkich transportach broni ze Stanów Zjednoczonych do Chin lub portów znajdujących się w ich pobliżu i z tego zobowiązania się wywiązywali ${ }^{241}$.

237 The American Ambassador to Japan to the Secretary of State, August 25, 1913, [w: ] PRFRUS 1913, s. 129-130. Yuan wyznaczył nagrody za głowy przywódców rewolty i do Japonii mieli ich śladem przyjechać zabójcy.

${ }^{238}$ Svony to Guthrie, September 2, 1913, RDSRIACh, roll 12; Guthrie to the Secretary of State, September 7, 1913, ibidem; Moore to the Secretary of Labor, October 25, 1913, ibidem. Co zrozumiałe, przeciwko udzieleniu Huangowi pozwolenia na wjazd protestowała strona chińska. Note, July 6, 1914, RDSRIACh, roll 13. W sierpniu 1913 roku konsul Fowler wyraził z kolei nadzieję, że do Stanów Zjednoczonych nie zostanie wpuszczony Sun Yat-sen. Fowler to Williams, August 6, 1913, RDSRIACh, roll 12.

${ }_{239}$ Memorandum from the Chinese Legation left at the Department of State, July 28, 1914, RDSRIACh, roll 13; Assistant Attorney General to the Secretary of State, July 29, 1914, ibidem; Bryan to Shah, July 31, 1914, ibidem; Raport made by Rathbun, August 7, 1914, ibidem; Raport made by Rathbun, August 16, 1914, ibidem; Shah to Bryan, August 27, 1914, RDSRIACh, roll 14; Bryan to Shah, August 31, 1914, ibidem; Assistant Attorney General to the Secretary of State, September 3, 1914, ibidem; Bryan to Shah, September 9, 1914, ibidem. Władze amerykańskie przyglądały się także innym Chińczykom, którzy w USA mieli agitować przeciwko Yuanowi i zbierać fundusze na zorganizowanie kolejnego powstania. Paraphrase of a cablegram received from the Chinese Foreign Office by the Legation, January 16, 1914, RDSRIACh, roll 13; Moore to the Attorney-General, January 19, 1914, ibidem.

${ }^{240}$ Mullowney to Bryan, August 2, 1914, RDSRIACh, roll 14; Shah to Bryan, October 1, 1914, ibidem; Bryan to Shah, October 6, 1914, ibidem; Mullowney to Tumulty, October 6, 1914, WWP, series 4: case files, 227, reel 242; Bryan to Tumulty, October 7, 1914, ibidem; Memorandum, December 3, 1914, RDSRIACh, roll 14.

${ }^{241}$ Waichiao Pu to the Chinese Minister at Washington, June 3, 1914, RDSRIACh, roll 13; Shah to Williams, June 4, 1914, ibidem; Lansing to Shah, June 9, 1914, ibidem; Copy of telegram received from San Francisco, June 30, 1914, ibidem; Phillips to the Secretary of the 
Administracja Wilsona przynajmniej w ograniczonym stopniu wspierała zatem Yuana, licząc, że ustabilizuje on sytuację i wzmocni młodą Republikę, dzięki czemu zmaleje niebezpieczeństwo zawirowań wewnętrznych i ingerencji z zewnątrz. To ostatnie było co prawda w przededniu wybuchu I wojny światowej trochę mniejsze niż wcześniej, ale mocarstwa cały czas umacniały swoje strefy wpływów. Wielka Brytania, Rosja i Japonia kontynuowały też zabiegi o mniej lub bardziej formalne oderwanie Tybetu, Mongolii i Mandżurii, co mogło doprowadzić do całkowitej dezintegracji Chin ${ }^{242}$.

Na początku swojej prezydentury Woodrow Wilson wyraźnie zademonstrowal, że zamierza prowadzić niezależną od innych państw politykę w Chinach. To podejście uległo pewnej zmianie w trakcie „drugiej rewolucji”, ale później USA nadal raczej same dążyły do realizacji celów politycznych i ekonomicznych. Były natomiast obszary, w których wspólpracowały z innymi państwami, starając się nawet nadać ton tej współpracy. Przykładem takich działań może być zaangażowanie $\mathrm{w}$ walkę $\mathrm{z}$ opium, $\mathrm{w}$ której administracja Wilsona kontynuowała starania rozpoczęte przez poprzedników. Amerykańscy delegaci odegrali aktywną rolę podczas II Międzynarodowej Konferencji Opiumowej, która odbyła się w Hadze w lipcu 1913 roku. Zwołano ją, ponieważ nie wszystkie z przewidzianych państw podpisały konwencję antyopiumową uchwaloną podczas pierwszej konferencji. Stany Zjednoczone razem z pięcioma europejskimi krajami przeforsowały propozycję, aby nie dyskutować o ratyfikacji porozumienia, ale podjąć kolejną próbę nakłonienia państw, które jeszcze go nie podpisały lub odmówiły zrobienia tego. Uważano, że należy ponowić starania, gdyż niewiele brakowało do osiągnięcia powszechnej akceptacji. Po konferencji Amerykanie wspierali zabiegi holenderskiej dyplomacji w tej kwestii, ale sukces okazał się połowiczny.

W tych okolicznościach w czerwcu 1914 roku zebrała się III Międzynarodowa Konferencja Opiumowa. Tym razem między uczestnikami wystąpiły poważne kontrowersje w kwestii ratyfikacji konwencji. Stany Zjednoczone chciały odroczyć obrady, dając sobie i Holandii czas na przekonanie wahających się i negatywnie nastawionych, ale amerykańscy delegaci wyperswadowali przełożonym

Treasury, July 3, 1914, ibidem; Bryan to Shah, July 15, 1914, ibidem; Shah to Bryan, July 16, 1914, ibidem; Assistant Secretary of the Treasury to the Secretary of State, August 6, 1914, RDSRIACh, roll 14; Bryan to Shah, August 10, 1914, ibidem; Assistant Secretary of the Treasury to the Secretary of State, September 4, 1914, ibidem; Lansing to Shah, September 10, 1914, ibidem.

${ }^{242}$ Reinsch to the Secretary of State, November 28, 1913, RDSRIACh, roll 13; Reinsch to the Secretary of State, June 29, 1914, ibidem; Doc. no. 1906/2: Note 1: Great Britain and Tibet. Agreement in regard to Tibet (Summary, only), July 3, 1914, [w:] Treaties and Agreements..., t. 1: Manchu Period (1894-1911), s. 581-582; T. Dmochowski, Walka polityczna mocarstw ..., s. 206-208; L. Bazylow, Historia Mongolii, Wrocław 1981, s. 248253. 
takie rozwiązanie, uważając je za jałowe. Waszyngton poparł więc odwrotną propozycję, aby konwencję zatwierdzić i wprowadzić w życie, niezależnie od tego, że nie wszyscy ją podpisali. Wprowadzenie regulacji uznano za istotniejsze niż dążenie do osiągnięcia jednomyślności. Ostatecznie konferencja tak też zdecydowała, ale proces wdrażania okazał się długotrwały i trudny, zwłaszcza że podczas I wojny światowej, która niebawem wybuchła, wzrosło zapotrzebowanie na opium i inne narkotyki ${ }^{243}$.

Administracja Wilsona czyniła także inne starania na rzecz poprawy sytuacji Chińczyków, wspierając działalność charytatywną, edukacyjną i misjonarską. To $\mathrm{w}$ połączeniu z prowadzeniem polityki odbieranej w Chinach jako im przyjaznej stworzyło pozytywny wizerunek Stanów Zjednoczonych. Jak pisał Edward Carleton Baker, konsul w Chongqingu, parafrazując słynne określenie użyte przez Tafta, „dobra wola zastąpiła dolary”. Miała to być jego zdaniem najskuteczniejsza metoda, przekładająca się na wymierne efekty handlowe (gdy produkty różnego pochodzenia były podobne, Chińczycy mieli preferować amerykańskie) i ułatwiająca pracę amerykańskim nauczycielom ${ }^{244}$. Patrząc jednak obiektywnie, ani polityczne, ani ekonomiczne wplywy USA w Chinach nie wzrosły w tym czasie, przeciwnie - raczej zmalały. Polityka „dobrej woli” była zbyt mglista, nieskoordynowana, oddziaływała w sposób zanadto pośredni i długofalowy, aby, przynajmniej w krótkim okresie, spełnić pokładane w niej nadzieje. W zderzeniu z konkretnymi działaniami innych mocarstw, ich pozycją, ograniczeniami amerykańskiej dyplomacji, sytuacją międzynarodową i realiami chińskimi okazała się ona niewystarczająca.

W pierwszym roku swojego urzędowania administracja Wilsona w istotny sposób zmieniła politykę Stanów Zjednoczonych wobec Chin. Działając według nowych założeń, zdecydowała się wycofać poparcie dla międzynarodowego konsorcjum bankowego oraz uznać Republikę Chińską, co oznaczało wyłamanie się $\mathrm{z}$ frontu mocarstw i zerwanie $\mathrm{z}$ „dyplomacją dolarową”. Amerykańska polityka nabrała wówczas bardziej reformatorskiego i misjonarskiego rysu. Jej aspekt ekonomiczny starali się za to ciągle podkreślać - $\mathrm{z}$ umiarkowanym jednakże skutkiem - amerykańscy dyplomaci przebywający w Chinach.

Chociaż nad Potomakiem nastąpiła rewizja sposobów postępowania i częściowo celów, miejsce Chin w polityce zagranicznej USA pozostało ważne. Oprócz poszczególnych działań potwierdzały to wypowiedzi Wilsona i Bryana, wyrażające duże oczekiwania względem Państwa Środka. W porównaniu z okresem rządów Tafta zainteresowanie Chinami ze strony nowej administracji podlegało jednak większym wahaniom. O ile na początku jej kadencji było ono znaczne, to na przełomie lat 1913 i 1914 zmalało w wyniku rozwoju sytuacji w Chinach

${ }^{243}$ Fragment na podstawie: PRFRUS 1913, s. 215-283; PRFRUS 1914, s. 924-939.

${ }^{244}$ Baker to the Secretary of State, February 2, 1914, RDSRPRUSCh, roll 1. 
172 Chiny w polityce zagranicznej Stanów Zjednoczonych w latach 1911-1918

i na świecie. Pierwotny entuzjazm osłabł ze względu na zaprowadzenie rządów autorytarnych przez Yuana, którego Waszyngton mimo wszystko niezmiennie popierał. Niebagatelne znaczenie miał także proces narastania antagonizmów w Europie, który coraz bardziej skupiał uwagę amerykańskiej dyplomacji, odciągając ją od spraw toczących się na innych kontynentach. Wybuch I wojny światowej w połowie 1914 roku pogłębił tę tendencję, ale zarazem sprawil, że przed amerykańską polityką w Chinach pojawiły się nowe szanse i perspektywy. 


\section{ROZDZIAE IV}

\section{POLITYKA STANÓW ZJEDNOCZONYCH WOBEC CHIN W PIERWSZYCH LATACH WIELKIEJ WOJNY (1914-1916)}

Wybuch I wojny światowej istotnie zmienił międzynarodowe położenie Chin. Istniejąca od kilkunastu lat równowaga między mocarstwami została zaburzona. Państwa europejskie, uwikłane w długotrwały i wyniszczający konflikt na swoim kontynencie, $\mathrm{w}$ większości przestały interesować się sprawami Dalekiego Wschodu i wycofały stamtąd znaczną część wojsk. Stworzyło to szansę dla Japonii i Stanów Zjednoczonych na rozszerzenie interesów politycznych, gospodarczych, militarnych i kulturalnych. Oba państwa uzyskały możliwość wyparcia i zastąpienia wpływów Europejczyków, zwłaszcza że dosyć szybko okazało się, iż wbrew optymistycznym przypuszczeniom wojna nie będzie krótka i nawet zwycięzcy wyjdą z niej poważnie osłabieni. Na kilka lat USA stały się jednym z dwóch państw (lub jednym z trzech, jeśli doliczyć do tego grona Wielką Brytanię) mogących realnie wpływać na wydarzenia w Chinach, co w porównaniu z sytuacją sprzed wojny, gdy konkurentów miały aż pięciu, stanowiło wyraźny wzrost ich pozycji. Wycofanie Europejczyków mogło też pomóc urzeczywistnić wizję amerykańskiego posła w Pekinie Paula Reinscha, który, jak już zostało wspomniane w poprzednim rozdziale, twierdził, że Chiny zaczną się rozwijać, także pod względem politycznym, gdy zelżeje presja z zewnątrz.

Oprócz pozytywów wybuch wojny przyniósł amerykańskiej polityce w Chinach nowe wyzwania, zagrożenia i komplikacje. Wraz ze wzrostem znaczenia wzrosła też odpowiedzialność za pilnowanie bezpieczeństwa, interesów i przywilejów cudzoziemców, a przecież Chinom ciągle daleko było do pełnej stabilizacji. Ponadto Japonia, trzymana dotychczas w ryzach, mogła teraz o wiele śmielej przystąpić do umacniania swojej pozycji kosztem słabszego sąsiada. Chcąc temu zapobiec, USA musiały aktywniej przeciwstawić się japońskim ambicjom i momentalnie stały się głównym „obrońcą” Chin. Kolejnym niekorzystnym czynnikiem był fakt, że podczas wojny większego znaczenia nabierały powiązania sojusznicze, co przy jednoczesnym spadku zainteresowania Dalekim Wschodem mogło skutkować różnego rodzaju układami godzącymi w Chiny. Stanom Zjednoczonym, niezwiązanym aliansem z żadnym z państw, mogło być jeszcze trudniej przeciwdziałać tego typu porozumieniom. Amerykańska dyplomacja musiała też pilnować, aby Chiny nie zostały wciągnięte do wojny oraz by na ich terytorium nie prowadzono działań zbrojnych, gdyż zagrażałoby to ich 
suwerenności i integralności, a poza tym mogłoby przyczynić się do pogłębienia fermentu wewnętrznego, destabilizacji i kolejnej rewolucji. Wybuch wojny miał z punktu widzenia amerykańskiej polityki w Chinach jeszcze jedną negatywną konsekwencję - stawiał sprawy europejskie w centrum uwagi, czyniąc pozostałe kwestie dyplomatyczne mniej istotnymi ${ }^{1}$.

Początek I wojny światowej nie był jedynym wydarzeniem, dzięki któremu USA zyskały większe pole manewru w Kraju Środka. Niemal w tym samym czasie, gdy w Europie rozgorzały walki, na półkuli zachodniej ukończono budowę Kanału Panamskiego, co stanowiło ukoronowanie wieloletnich dążeń Amerykanów. Jeszcze w 1909 roku Theodore Roosevelt, ustępując z Białego Domu, radził swojemu następcy, żeby nie dzielił floty i wszystkie okręty skoncentrował albo na Pacyfiku, albo na Oceanie Atlantyckim². W połowie 1914 roku ta sugestia stała się nieaktualna, a amerykańskie okręty i statki handlowe uzyskały łatwiejszy dostęp także do azjatyckich wybrzeży.

\section{Stany Zjednoczone wobec wybuchu wojny na Dalekim Wschodzie i zajęcia przez Japonię Jiaozhou}

Gdy tylko rozpoczęła się wojna, Chiny ogłosiły neutralność i zwróciły się do Stanów Zjednoczonych i Japonii z prośbą o uzyskanie od walczących stron gwarancji, że działania wojenne nie zostaną rozciągnięte na Daleki Wschód ${ }^{3}$. Wiedziały, że inicjatywa miała większą szansę powodzenia, jeśli przedstawi ją dyplomacja amerykańska, która zresztą w przeszłości występowała już z podobnymi propozycjami (np. podczas wojny rosyjsko-japońskiej). W kolejnych dniach o poparcie Departamentu Stanu zabiegaty Holandia i Belgia, chcące odpowiednio neutralizacji zachodniej części Pacyfiku i zachowania status quo w Chinach. Z kolei zagraniczni dyplomaci w Pekinie rozważali możliwość wyłączenia spod działań wojennych cudzoziemskich koncesji (oprócz dzierżaw), ale ostatecznie uchylili się od podjęcia

${ }^{1}$ P. Reinsch, An American Diplomat in China, Garden City 1922, s. 102.

${ }^{2}$ Roosevelt to Taft, March 3, 1909, William H. Taft Papers, Manuscript Division, Library of Congress, Washington, (mikrofilm), series 4a, reel 322.

3 The Chinese Legation to the Department of State, August 3, 1914, [w:] Papers Relating to the Foreign Relations of the United States (dalej PRFRUS), The Lansing Papers, 1914-1920, t. 1, Washington 1939, s. 1; The Chargé d'Affaires in China (MacMurray) to the Secretary of State, August 6, 1914, [w:] PRFRUS 1914, Supplement: The World War, Washington 1928, s. 162-163; Memorandum by the Counselor for the Department of State (Lansing) on Course to Be Pursued To Preserve the "Status Quo" in China, August 7, 1914, [w: ] PRFRUS, The Lansing Papers, 1914-1920, t. 1, s. 1-3; The Chargé d'Affaires in China (MacMurray) to the Secretary of State, August 13, 1914, [w:] PRFRUS 1914, Supplement: The World War, s. 169. 
jakichkolwiek decyzji. Amerykański chargé d’affaires John V.A. MacMurray, stojący na czele poselstwa pod nieobecność przebywającego w Europie Reinscha, sugerowal, że w takim razie Stany Zjednoczone mogłyby chociaż podnieść na forum międzynarodowym kwestię respektowania neutralności Chin ${ }^{4}$.

Do tych propozycji odniósł się w swoich memorandach Robert Lansing, nowy radca w Departamencie Stanu, który w marcu 1914 roku zastąpił na tym stanowisku Johna Bassetta Moore’a. Lansing uważał, że wszelkie próby neutralizacji części Oceanu Spokojnego zostałyby odrzucone przez niektórych walczących, dlatego nie należało się o to staraćs. Za zasadne uznał natomiast działanie na rzecz neutralizacji cudzoziemskich posiadłości z wyłączeniem dzierżaw, stanowiących właściwie bazy morskie ${ }^{6}$, szanowania przez strony konfliktu neutralności Chin oraz - co najważniejsze - zachowania tam praw i interesów cudzoziemców w przedwojennym kształcie. Dążenie do uzyskania znaczniejszych zobowiązań byłoby nierozsądne i mogłoby zniweczyć zawarcie takiego porozumienia lub poważnie je odroczyć. Lansing zalecił działać niezwłocznie, ale po namyśle zasugerował, aby najpierw wysondować stanowisko Japonii, zgodnie z porozumieniem Root-Takahira. Później jeszcze raz zmienił zdanie i postulował, aby nie podejmować żadnych działań i czekać na rozwój wydarzeń7. O ambitniejszym porozumieniu myślał sekretarz stanu William Jennings Bryan, proponujący wystąpienie z inicjatywą wyłączenia spod działań wojennych całego Dalekiego Wschodu.

${ }^{4}$ The Chargé d'Affaires in China (MacMurray) to the Secretary of State, August 3, 1914, [w: ] PRFRUS 1914, Supplement: The World War, s. 161-162; The Chargé d'Affaires in China (MacMurray) to the Secretary of State, August 6, 1914, [w: ibidem, s. 162-163; Memorandum by the Counselor for the Department of State (Lansing) on Course to Be Pursued To Preserve the "Status Quo" in China, August 7, 1914, [w:] PRFRUS, The Lansing Papers, 1914-1920, t. 1, s. 1-3.

${ }^{5}$ Przeciwna neutralizacji Pacyfiku była m.in. Wielka Brytania, wobec której Stany Zjednoczone wystąpily z taką propozycją 8 sierpnia. The Ambassador in Great Britain (Page) to the Secretary of State, August 11, 1914, [w:] PRFRUS 1914, Supplement: The World War, s. 165-166; J. Polit, Odwrót znad Pacyfiku? Wielka Brytania wobec Dalekiego Wschodu (1914-1922), Kraków 1999, s. 43.

${ }^{6}$ Pekin chciał neutralizacji obu kategorii. The Chargé d'Affaires in China (MacMurray) to the Secretary of State, August 3, 1914, [w:] PRFRUS 1914, Supplement: The World War, s. 162.

${ }^{7}$ Memorandum by the Counselor for the Department of State (Lansing) on Course to Be Pursued To Preserve the "Status Quo" in China, August 7, 1914, [w:] PRFRUS, The Lansing Papers, 1914-1920, t. 1, s. 1-3; The Counselor for the Department of State (Lansing) to the Secretary of State, August 14, 1914, [w:] ibidem, s. 3-4; M. Chi, China Diplomacy, 1914-1918, Cambridge 1970, s. 4.

${ }^{8}$ A.S. Link, Wilson: The Struggle for Neutrality, 1914-1915, Princeton 1960, s. 193; E.R. May, American Policy and Japan's Entrance into World War I, „Mississippi Valley Historical Review" 1953, t. 40, nr 2, s. 284. 
Opinie te przedstawiono Woodrowowi Wilsonowi, który tak jak na początku swojej kadencji miał osobiście nakreślić główne wytyczne chińskiej polityki Stanów Zjednoczonych. Niestety, w tym czasie był on pogrążony w żałobie po śmierci żony Ellen Axson Wilson, zmarłej 6 sierpnia. Oprócz tego zajmowała go oczywiście kwestia wybuchu wojny w Europie. Zanim podjął jakąś decyzję w odniesieniu do Dalekiego Wschodu, sytuacja uległa tam zmianie 9

15 sierpnia 1914 roku $^{10}$ Japonia wystosowała ultimatum, w którym „radziła” Rzeszy wycofać żołnierzy i okręty z Dalekiego Wschodu oraz przekazać bez kompensaty Jiaozhou, które miało zostać ostatecznie oddane Chinom ${ }^{11}$. Niemcy miały czas do 23 sierpnia, aby bezwarunkowo przyjąć oba żądania, w przeciwnym wypadku Japonia zastrzegła sobie prawo „podjęcia takich działań, jakie uzna za konieczne, by sprostać sytuacji”, co niechybnie oznaczało wypowiedzenie przez nią wojny. Nie otrzymawszy odpowiedzi w wyznaczonym terminie, 23 sierpnia cesarz Yoshihito wydał reskrypt oznajmiający początek wojny między oboma państwami $^{12}$. Niedługo potem Japonia zerwała stosunki z Austro-Węgrami, które postanowiły poprzeć swojego sojusznika. Konflikt miał w tym przypadku wymiar niemal wyłącznie symboliczny, zważywszy że Austro-Węgry nie miały prawie żadnych wojsk (oprócz krążownika „Kaiserin Elisabeth”) ani posiadłości na Dalekim Wschodzie ${ }^{13}$.

Niemcy próbowały uniknąć starcia z Japonią. W tym celu szukały pomocy Waszyngtonu oraz porozumienia $\mathrm{z}$ Londynem i Tokio ${ }^{14}$. Zdecydowały się

9 Bryan to Wilson, August 8, 1914, William Jennings Bryan Papers (dalej BP), Manuscript Division, Library of Congress, Washington, container 59; The Counselor for the Department of State (Lansing) to the Secretary of State, August 14, 1914, [w:] PRFRUS, The Lansing Papers, 1914-1920, t. 1, s. 3-4; President Wilson to the Secretary of State, August 17, 1914, [w: ibidem, s. 5.

${ }^{10}$ Zdaniem Rodzińskiego przekazanie ultimatum nastąpiło 14 sierpnia. W. Rodziński, Historia Chin, Wrocław 1992, s. 623.

${ }^{11}$ Pojawiający się w polskiej historiografii przekład ultimatum z języka angielskiego wydaje się mylący. $\mathrm{W}$ angielskiej wersji występuje sformułowanie: „deliver [...] Kiaochow, with a view to eventual restoration of the same to China". Slowo eventual oznacza „ostateczny”, „końcowy”, natomiast w części polskich prac tłumaczone jest ono jako „ewentualny”, co może prowadzić do nieporozumień.

12 The Ambassador in Japan (Guthrie) to the Secretary of State, August 15, 1914, [w:] PRFRUS 1914, Supplement: The World War, s. 170-171; The Imperial rescript issued at Tokyo, August 23, 1914, [w:] ibidem, s. 175.

13 The Austro-Hungarian Ambassador (Dumba) to the Secretary of State, August 26, 1914, [w:] PRFRUS 1914, Supplement: The World War, s. 177; The Ambassador in Japan (Guthrie) to the Secretary of State, August 29, 1914, [w:] ibidem, s. 180.

${ }_{14}$ The Ambassador in Japan (Guthrie) to the Secretary of State, August 10, 1914, [w:] PRFRUS 1914, Supplement: The World War, s. 165; The Ambassador in Germany (Gerard) to the Secretary of State, August 13, 1914, [w:] ibidem, s. 169-170. 
nawet rozpocząć negocjacje z Chinami na temat retrocesji Jiaozhou, ale nic to nie dało ${ }^{15}$. Japonia była bowiem zdeterminowana, aby przystąpić do wojny, upatrując $\mathrm{w}$ tym szansy na rozszerzenie swoich wpływów ${ }^{16}$. W tym dążeniu wspierała ją Wielka Brytania, choć nie bez obaw o reakcję pacyficznych dominiów i USA oraz zamiary swojego sojusznika m.in. w odniesieniu do Chin. Toteż nad Tamizą starano się wyznaczyć pewne ramy dla japońskiej interwencji, niestety z przeciętnym skutkiem ${ }^{17}$.

Działania Japonii niepokoiły jeszcze bardziej Chińczyków i Amerykanów. Ci pierwsi uważali, że ewentualna okupacja Jiaozhou przez wojska japońskie będzie zagrażać ich niepodległości. Podejrzewali ponadto, że Japonia ma większe ambicje i oprócz niemieckiej dzierżawy będzie chciała zająć południową Mandżurię, Fujian i Zhili. Jej zaczepna postawa miała być obliczona na sprowokowanie Chińczyków, których reakcja stałaby się pretekstem do kolejnej agresji ${ }^{18}$. Japonia

15 The Chargé d'Affaires in China (MacMurray) to the Secretary of State, August 19, 1914, [w: ] PRFRUS 1914, Supplement: The World War, s. 172-173; The Chargé d'Affaires in China (MacMurray) to the Secretary of State, August 20, 1914, [w:] ibidem, s. 173174. Niemcy liczyły, że po zakończeniu wojny odzyskają Jiaozhou albo otrzymają inną dzierżawę. Tien-yi Li, Woodrow Wilson's China Policy, 1913-1917, Kansas City 1952, s. 95 .

16 The Chargé d'Affaires in China (MacMurray) to the Secretary of State, August 7, 1914, [w:] PRFRUS 1914, Supplement: The World War, s. 164; The Ambassador in Japan (Guthrie) to the Secretary of State, August 10, 1914, [w:] ibidem, s. 165; The Chargé d'Affaires in China (MacMurray) to the Secretary of State, August 11, 1914, [w: ibidem, s. 166; The Chargé d'Affaires in China (MacMurray) to the Secretary of State, August 13, 1914, [w: ibidem, s. 169. Japoński rząd uważał I wojnę światową za „szansę jedną na tysiąc lat". Cytuję za: D.D. Lazo, An Enduring Encounter: E.T. Williams, China, and the United States, nieopublikowany doktorat, University of Illinois at Urbana-Champaign, Urbana 1977, s. 251.

17 Grey to Greene, August 1, 1914, [w: British Documents on the Origins of the War 1898-1914, (opr.) G.P. Gooch, H. Temperley, t. 11: The Outbreak of War, London 1926, s. 256; Greene to Grey, August 2, 1914, [w: ] ibidem, s. 279; Grey to Greene, August 3, 1914, [w:] ibidem, s. 298; Greene to Grey, August 3, 1914, [w:] ibidem, s. 305; Greene to Grey, August 4, 1914, [w:] ibidem, s. 327-328; Grey to Greene, August 4, 1914, [w:] ibidem, s. 329; E. Grey, Twenty-five Years 1892-1916, t. 2, New York 1925, s. 103-105, 234; M. Kajima, The Diplomacy of Japan 1894-1922, t. 3: The First World War, Paris Peace Conference, Washington Conference, Tokyo 1980, s. 35-53, 55-57; J. Polit, Odwrót znad Pacyfiku..., s. 39-46.

${ }_{18}$ Chargé d'Affaires in China (MacMurray) to the Secretary of State, August 13, 1914, [w:] PRFRUS 1914, Supplement: The World War, s. 169; MacMurray to the Secretary of State, September 29, 1914, Records of the Department of State Relating to Internal Affairs of China, 1910-1929 (dalej RDSRIACh), The National Archives at College Park, College Park, (mikrofilm), roll 14; M. Chi, China Diplomacy ..., s. 2-3. 
wyraziła niezadowolenie, że Pekin zwrócił się o pomoc do USA, oraz ostrzegła przed kontynuowaniem rozmów z Niemcami. Groziła przy tym, że wspólnie z Wielką Brytanią stłumią wszelkie wystąpienia w Państwie Środka ${ }^{19}$.

W tej sytuacji Chiny w największym stopniu liczyły na amerykańską pomoc. Oprócz wspomnianej uprzednio prośby dotyczącej neutralizacji wystąpiły również z tyleż niedorzeczną, co desperacką propozycją, aby Waszyngton wystarał się o zgodę Wielkiej Brytanii i Niemiec na przejęcie Jiaozhou, które następnie niezwłocznie przekazałby Pekinowi ${ }^{20}$. Chińczycy co jakiś czas wypytywali się o prawdziwość pogłosek rozsiewanych przez prasę japońską, jakoby amerykańska Flota Atlantycka zmierzała na Daleki Wschód celem ochrony Chin ${ }^{21}$. 5 sierpnia sam Yuan Shikai oświadczył w pełnej tajemnicy, że z satysfakcją powitałby zwiększenie sił amerykańskich, aby tylko Japonia w pojedynkę nie chroniła cudzoziem ców ${ }^{22}$. W podobnym tonie wypowiadali się też różni urzędnicy, na przykład specjalny wysłannik Ministerstwa Spraw Zagranicznych (Waijiao bu) wyraził nadzieję, że odpowiednio liczne amerykańskie wojska będą mogły „pomóc w utrzymaniu neutralności ogłoszonej przez Chiny, jak i w ochronie życia i mienia, jeśli zajdzie taka konieczność”23.

19 The Chargé d'Affaires in China (MacMurray) to the Secretary of State, August 13, 1914, [w: ] PRFRUS 1914, Supplement: The World War, s. 169; MacMurray to the Secretary of State, August 18, 1914, RDSRIACh, roll 14; The Chargé d'Affaires in China (MacMurray) to the Secretary of State, August 19, 1914, [w:] PRFRUS 1914, Supplement: The World War, s. 172-173; The Chargé d'Affaires in China (MacMurray) to the Secretary of State, August 20, 1914, [w:] ibidem, s. 173-174. Wielka Brytania, zapewne w porozumieniu z Japonią, kategorycznie odrzuciła pomysł rozważany w Pekinie, aby Chiny wypowiedziały wojnę Niemcom i przyłączyly się do ataku na Jiaozhou. R.H. Fifield, Woodrow Wilson and the Far East. The Diplomacy of the Shantung Question, Hamden 1965, s. 15; Guoqi Xu, China and the Great War. China's Pursuit of a New National Identity and Internationalization, Cambridge 2005, s. 90-91.

20 The Chargé d'Affaires in China (MacMurray) to the Secretary of State, August 20, 1914, [w:] PRFRUS 1914, Supplement: The World War, s. 173-174.

${ }^{21}$ The Ambassador in Japan (Guthrie) to the Secretary of State, August 10, 1914, [w:] PRFRUS 1914, Supplement: The World War, s. 165; Fisher to MacMurray, August 10, 1914, RDSRIACh, roll 14; The Chargé d'Affaires in China (MacMurray) to the Secretary of State, August 12, 1914, [w:] PRFRUS 1914, Supplement: The World War, s. 168; MacMurray to the Secretary of State, August 18, 1914, RDSRIACh, roll 14; M. Chi, China Diplomacy..., s. 3. Co ciekawe, gdy pojawiły się pogłoski, że amerykańskie wojska miały pomagać w chronieniu chińskich portów, to Japończycy dopytywali się Chińczyków o prawdziwość tych informacji. Tien-yi Li, Woodrow Wilson's..., s. 93.

${ }_{22}$ M. Chi, China Diplomacy ..., s. 2-3.

${ }_{23}$ Williams to MacMurray, August 7, 1914, RDSRIACh, roll 14; Sammons to MacMurray, August 20, 1914, ibidem. Cytat pochodzi z drugiego dokumentu. 
Podobnie jak Chiny zaniepokojone rozwojem wydarzeń były Stany Zjednoczone. Już w 1912 roku przewidywały one, że wybuch wojny europejskiej pozostawi je sam na sam z bardzo silną Japonią, a ich flota wojenna będzie musiała podołać dwóm zadaniom - utrzymaniu status quo na Dalekim Wschodzie i ochronie neutralności Karaibów ${ }^{24}$. Dwa lata później, gdy wojna rzeczywiście nadeszła, Waszyngton podjął pewne działania. Rozpoczął konsultacje z najbardziej zainteresowanymi mocarstwami na temat możliwości neutralizacji, ale japońskie ultimatum unieważniło te starania. Udało się przynajmniej uzyskać ogólnikowe potwierdzenie, że Tokio i Londyn uszanują niepodległość, integralność i neutralność $\mathrm{Chin}^{25}$. Amerykanie nie zamierzali się jednak mocniej wikłać w międzynarodową rozgrywkę, dlatego odrzucili chiński pomysł dotyczący Jiaozhou. Zdementowali również pogłoski o przesunięciu okrętów z Atlantyku ${ }^{26}$. Zwiększyli natomiast nieco swoje siły w Chinach, o co apelowali Reinsch, MacMurray i różni konsulowie, lecz było to podyktowane bardziej koniecznością ochrony interesów cudzoziemskich po wycofaniu innych wojsk aniżeli chęcią wsparcia suwerenności Państwa Środka ${ }^{27}$.

${ }^{24}$ The Anglo German Rivalry and the United States, 1912 [brak daty dziennej], Philander C. Knox Papers (dalej KP), Manuscript Division, Library of Congress, Washington, container 17.

${ }^{25}$ PRFRUS 1914, Supplement: The World War, s. 165-171; R.H. Fifield, Woodrow Wilson and the Far East..., s. 21; B. Elleman, Wilson and China. A Revised History of the Shandong Question, Armonk 2002, s. 12.

${ }^{26}$ The Ambassador in Japan (Guthrie) to the Secretary of State, August 10, 1914, [w: ] PRFRUS 1914, Supplement: The World War, s. 165; The Secretary of State to the Chargé d'Affaires in China (MacMurray), August 12, 1914, [w: ibidem, s. 168; MacMurray to the Secretary of State, August 18, 1914, RDSRIACh, roll 14; The Secretary of State to the Chargé d'Affaires in China (MacMurray), August 20, 1914, [w:] PRFRUS 1914, Supplement: The World War, s. 174.

${ }^{27}$ W RDSRIACh i PRFRUS znajduje się kilkadziesiąt dokumentów na ten temat, ale ze względu na przejrzystość wywodu podaję tutaj odniesienia tylko do niektórych. Sammons to MacMurray, August 4, 1914, RDSRIACh, roll 14; Williams to MacMurray, August 7, 1914, ibidem; Reinsch to the Secretary of State, August 27, 1914, Records of the Department of State Relating to Political Relations Between China and Other States, 19101929 (dalej RDSRPRBChOS), The National Archives at College Park, College Park, (mikrofilm), roll 24; The American Legation at Peking to the Department of State, September 9, 1914, RDSRIACh, roll 14; Bryan to the American Legation at Peking, September 9, 1914, ibidem; MacMurray to the Secretary of State, September 10, 1914, ibidem; Bryan to the American Legation at Peking, September 11, 1914, ibidem; Sammons to Cowles, October 2, 1914, ibidem; Reinsch to the Secretary of State, October 3, 1914, ibidem; Lansing to the Secretary of War, October 3, 1914, ibidem; Lansing to Reinsch, October 10, 1914, ibidem; PRFRUS 1914, Supplement: The World War, s. 161-162, 164, 186-190. 
Tymczasem na Dalekim Wschodzie wydarzenia nabierały coraz większego rozpędu. Na początku września oddziały japońskie wspierane przez Brytyjczyków rozpoczęły operację w celu zdobycia Qingdao, głównej twierdzy na terenie niemieckiej dzierżawy. Chiny, wiedząc, że protesty przeciwko naruszeniu ich neutralności będą daremne, 3 września uznały półwysep Shandong za strefę wojenną ${ }^{28}$. Powtórzyła się tym samym sytuacja z wojny rosyjsko-japońskiej, kiedy to Chiny, mimo ogłoszenia neutralności, również musiały się zgodzić, że na części ich terytorium będą się toczyły walki. Japończycy nie zamierzali wszelako trzymać się wytyczonych ram. Pod koniec września zajęli znajdującą się już poza strefą wojenną miejscowość Weixian oraz linię kolejową do stolicy Shandongu Jinanu (ponad trzysta kilometrów w głąb prowincji, licząc od Qingdao), tłumacząc to koniecznością militarną. Protesty chińskie w obliczu nieugiętej postawy Tokio, które oświadczyło arogancko, że nie uzna żadnych argumentów, oraz cichego przyzwolenia Londynu okazały się próżne ${ }^{29}$.

Japonia kontynuowała umacnianie swojej pozycji na Dalekim Wschodzie. W październiku zajęła niemieckie wyspy na Pacyfiku, a 7 listopada zdobyła ostatecznie Qingdao. Niedługo potem baron Katō Takaaki, stojący na czele Ministerstwa Spraw Zagranicznych (Gaimushō), kilkakrotnie stwierdził, że do zakończenia wojny w Europie jego kraj zatrzyma Jiaozhou, a kwestia zwrócenia go Chinom pozostanie otwarta i będzie przedmiotem negocjacji ${ }^{30}$. Wypowiedzi

${ }^{28}$ Note from the Ministry of Foreign Affairs to the diplomatic representatives at Peking respecting declaration of war zone, September 3, 1914, [w:] V.K. Wellington Koo's Foreign Policy. Some Selected Documents, zebrał W. King, Shanghai 1931, s. 74-75; M. Kajima, The Diplomacy of Japan ..., s. 111-135. Japonia nalegała na wyznaczenie większej strefy wojennej, na co nie zgodzily się Chiny. Tien-yi Li, Woodrow Wilson's..., s. 96-97. Chiny przerzucały co prawda wojska w pobliże przewidywanego rejonu walk, ale nie zdecydowały się na żadną kontrakcję, zdając sobie sprawę, że próba militarnego przeciwstawienia się Japonii zakończyłaby się katastrofą. Remillard to MacMurray, August 27, 1914, RDSRIACh, roll 14; One of the American Consuls to MacMurray, August 28, 1914, ibidem.

${ }_{29}$ PRFRUS 1914, Supplement: The World War, s. 181-183, 191-194; V.K. Wellington Koo's..., s. 75-83; M. Kajima, The Diplomacy of Japan ..., s. 136-163; J. Polit, Odwrót znad Pacyfiku ..., s. 49-50. Griswold twierdzi, że również Niemcy naruszyli neutralność Chin, chociaż nie tak znacznie jak Japończycy. A.W. Griswold, The Far Eastern Policy of the United States, New York 1938, s. 184.

${ }^{30}$ The Ambassador in Japan (Guthrie) to the Secretary of State, November 23, 1914, [w:] PRFRUS 1914, Supplement: The World War, s. 203-204; The Ambassador in Japan (Guthrie) to the Secretary of State, December 12, 1914, [w:] ibidem, s. 206-207; The Ambassador in Japan (Guthrie) to the Secretary of State, December 18, 1914, [w:] ibidem, s. 207-209; Reinsch to the Secretary of State, December 22, 1914, Woodrow Wilson Papers (dalej WWP), Manuscript Division, Library of Congress, Washington, (mikrofilm), series 2, reel 66; The Ambassador in Japan (Guthrie) to the Secretary of State, December 31, 1914, [w:] PRFRUS 1914, Supplement: The World War, s. 210. 
ministra wspierała brukowa i ekspansjonistycznie nastawiona prasa, dowodząca, że niespełnienie przez Niemcy ultimatum anulowało punkt dotyczący oddania dzierżawy, która powinna stanowić „zdobycz wojenną”31. Japończycy rzeczywiście zaczęli tak ją traktować i szybko przystąpili do zaprowadzania swoich porządków. W grudniu na przykład zażądali od Chin prawa do mianowania swoich urzędników celnych w Qingdao, na co nie chciała zezwolić strona chińska, a na co i Brytyjczycy patrzyli niechętnie, gdyż godziło to w jedność Zarządu Ceł Morskich, którym kierował ich rodak sir Francis Aglen ${ }^{32}$. Zgodnie z zapowiedziami barona Katō Japonia zaczęła równolegle wzmacniać swoją pozycję w Mandżurii i Mongolii, m.in. wysyłając wojska do Mukdenu ${ }^{33}$. Należy dodać, że jej żołnierze często zachowywali się prowokacyjnie lub brutalnie wobec chińskich cywilów, czym potęgowali ich nienawiśćs ${ }^{4}$.

Działania i enuncjacje Japonii wywołały zaniepokojenie Chin, Stanów Zjednoczonych i brytyjskich dominiów - Australii i Nowej Zelandii. Te ostatnie bardzo nieprzychylnie i podejrzliwie odnosiły się do japońskiej ekspansji na Pacyfiku. Dla polityków i wojskowych w metropolii, patrzących na interesy Imperium z perspektywy europejskiej, sprawa było bardziej skomplikowana, zwłaszcza że żywili oni nadzieję na przekonanie Japonii do zaangażowania się w wojnę na Starym Kontynencie. Co było zrozumiałe, wszystko

31 The Ambassador in Japan (Guthrie) to the Secretary of State, November 23, 1914, [w: ] PRFRUS 1914, Supplement: The World War, s. 202-203.

32 The Minister in China (Reinsch) to the Secretary of State, December 18, 1914, [w: ] PRFRUS 1914, Supplement: The World War, s. 204; Reinsch to the Secretary of State, December 22, 1914, WWP, series 2, reel 66; The Minister in China (Reinsch) to the Secretary of State, December 23, 1914, [w:] PRFRUS 1914, Supplement: The World War, s. 204; The Secretary of State to the Minister in China (Reinsch), December 30, 1914, [w: ibidem; The Minister in China (Reinsch) to the Secretary of State, January 2, 1915, [w:] ibidem, s. 205. Japończycy dyskutowali też nad możliwością przejęcia z rąk Brytyjczyków stanowiska Inspektora Generalnego Zarządu Ceł Morskich. W 1898 roku władze qingowskie zgodziły się, aby dopóki Wielka Brytania dominowała w handlu z Chinami, na czele tego urzędu stał Brytyjczyk. Doc. no. 1898/2: Great Britain and China. Declaration that the Inspector-General of Maritime Customs shall be a British subject while British trade predominates, February 13, 1898, [w: ] Treaties and Agreements with and Concerning China, 18941919, zebrał i opracował J.V.A. MacMurray, t. 1: Manchu Period (1894-1911), New York 1921, s. 105-106.

33 The Ambassador in Japan (Guthrie) to the Secretary of State, December 12, 1914, [w:] PRFRUS 1914, Supplement: The World War, s. 206-207; The Minister in China (Reinsch) to the Secretary of State, December 18, 1914, [w: ibidem, s. 204.

34 Davis to MacMurray, September 7, 1914, RDSRIACh, roll 14; Ayers to the American Consul at Chefoo, September 15, 1914, ibidem; Davis to MacMurray, September 18, 1914, ibidem; Williams to Lansing, November 25, 1914, ibidem. Inaczej sprawę widzi Polit, powołujący się na źródła brytyjskie. J. Polit, Odwrót znad Pacyfiku..., s. 54. 


\section{Chiny w polityce zagranicznej Stanów Zjednoczonych w latach 1911-1918}

podporządkowali wysiłkowi wojennemu, stąd też większa ich wyrozumiałość dla postępowania sojusznika ${ }^{35}$.

Wobec takiego nastawienia Wielkiej Brytanii i własnej bezsilności militarnej, która sprawiała, że próba oporu przeciwko Japonii równałaby się narodowemu samobójstwu ${ }^{36}$, Chiny ciągle prosiły USA o pomoc i interwencję dyplomatyczną, także wespół z Londynem ${ }^{37} .27$ sierpnia z MacMurrayem spotkał się Wellington Koo (Gu Weijun), pracownik Ministerstwa Spraw Zagranicznych, późniejszy poseł w Waszyngtonie ${ }^{38}$. Koo zainteresowany był układem Root-Takahira, który Departament Stanu przywołał w odpowiedzi na japońskie ultimatum wobec Niemiec ${ }^{39}$. Koo uważał, że układ zobowiązywał Japonię do konsultowania ze Stanami Zjednoczonymi wszelkich zamierzonych kroków w Chinach, a nawet uzyskania dla nich zgody. Kontekstem rozmowy było przewidywane lądowanie sił japońskich w Shandongu i rozszerzenie strefy walk poza obszar niemieckiej dzierżawy ${ }^{40}$.

Reakcja Waszyngtonu okazała się mocno powściągliwa, jeśli nie odmowna. Już MacMurray tłumaczył Koo, że ten mylnie interpretował porozumienie Root-Takahira, które - wbrew swej potocznej nazwie - nie stanowiło międzynarodowego zobowiązania, lecz jedynie wymianę not wyrażających zbieżne intencje sygnatariuszy. Ponadto przewidywało ono konsultacje wyłącznie w przypadku wystąpienia wewnętrznych niepokojów w Chinach ${ }^{41}$. Eksplikację MacMurraya pochwalił Lansing, dodając, że powołano się na ten układ z obawy przed tym, iż

35 J. Polit, Odwrót znad Pacyfiku..., s. 50-56.

36 Zobacz opinie ministra wojny gen. Duan Qiruia i gen. Cai E: S.G. Craft, Angling for an Invitation to Paris: China's Entry into the First World War, „The International History Review” 1994, t. 16, nr 1, s. 4; The Minister in China (Reinsch) to the Secretary of State, October 12, 1914, [w: ] PRFRUS 1914, Supplement: The World War, s. 191-201.

37 The Minister in China (Reinsch) to the Secretary of State, October 2, 1914, [w:] PRFRUS 1914, Supplement: The World War, s. 183; P. Reinsch, An American Diplomat ..., s. $124-125$.

38 Mimo młodego wieku Koo, urodzony najprawdopodobniej w 1888 roku, był jedną z ważniejszych i najlepiej wykształconych osób w ministerstwie. W 1912 roku obronił doktorat na Columbia University napisany pod opieką prof. Johna Bassetta Moore'a. W tym samym roku wrócił do Chin i rozpoczął pracę w dyplomacji. Na temat jego życia i długoletniej kariery patrz: S.G. Craft, V.K. Wellington Koo and the Emergence of Modern China, Lexington 2004; J. Clements, Wellington Koo: China, London 2008; Pao-chin Chu, V.K. Wellington Koo. A Case Study of China's Diplomat and Diplomacy of Nationalism, 1912-1966, Hong Kong 1981.

39 The Secretary of State to the Ambassador in Japan (Guthrie), August 19, 1914, [w: ] PRFRUS 1914, Supplement: The World War, s. 172.

40 The Chargé d'Affaires in China (MacMurray) to the Secretary of State, September 10, 1914, [w: ] PRFRUS 1914, Supplement: The World War, s. 186-188.

41 Ibidem. 
atak na Jiaozhou mógł zostać wykorzystany przez rewolucjonistów do wszczęcia rozruchów. W konsekwencji nieodzowna mogła się okazać obca interwencja, i na taką właśnie ewentualność chciano się zabezpieczyć. Lansing wyraził też dobitnie nadrzędne założenie chińskiej polityki swojego kraju.

Stany Zjednoczone - pisał w liście do Reinscha z 4 listopada - pragną, by Chiny czuly, że amerykańska przyjaźń jest szczera, i by były pewne, że ten rząd z chęcią użyje wszystkich wpływów, jakie posiada, by metodami pokojowymi zadbać o dobro Chińczyków, ale Departament [Stanu - J.P.] ma świadomość, że byłoby skrajną donkiszoterią pozwolić, by kwestia integralności terytorialnej Chin wplątała Stany Zjednoczone w trudności międzynarodowe ${ }^{42}$.

Zdanie Lansinga podzielał Bryan, który gdy dowiedział się, że Japonia zdecydowała się przejąć kolej w Shandongu, stwierdził, że nie widzi niczego, co Chiny mogłyby, a USA powinny by uczynić ${ }^{43}$. Pod koniec grudnia, po konsultacji z Lansingiem i z aprobatą Wilsona, odrzucił też sugestię Edwarda Williamsa, szefa Wydziału ds. Dalekiego Wschodu w Departamencie Stanu, zalecającego zwrócenie się do Wielkiej Brytanii, aby ta wplynęła na Japonię w kwestii urzędników celnych w Qingdao. Bryan uważał, że takie działanie, a także bezpośrednie wystąpienie do Japonii, zostałoby źle odebrane i mogłoby pogorszyć napięte stosunki bilateralne. Powoływał się przy tym na opinię amerykańskiego ambasadora w Tokio George’a Guthriego, który donosil, że zła prasa Stanów Zjednoczonych w Japonii wynikała z przekonania, iż sprzeciwiają się one chińskiej polityce Nipponu ${ }^{44}$. Podobnie myślał zapewne Wilson, który popierał działania Bryana, a sam podczas konferencji prasowych we wrześniu i październiku uchylił się od komentarza na temat naruszenia chińskiej neutralności, wykroczenia przez Japonię poza ustaloną strefę wojenną i zajęcia przez nią kolei ${ }^{45}$.

Nie wszyscy w amerykańskiej dyplomacji zgadzali się z tak łagodnym podejściem wobec Japonii. Bardziej zdecydowany kurs postulowali Williams i Reinsch. O stanowisku tego pierwszego była już mowa, Reinsch twierdził zaś, że dotychczasowa polityka „wyrozumiałości i dobrej woli” nie była doceniana przez Japonię, która postrzegała Stany Zjednoczone jako umyślnie sprzeciwiające się jej

42 The Acting Secretary of State to the Minister in China (Reinsch), November 4, 1914, [w: ] PRFRUS 1914, Supplement: The World War, s. 189-190.

43 Bryan to Wilson, October 2, 1914, BP, container 45.

44 Bryan to Wilson, December 26, 1914, [w: The Papers of Woodrow Wilson (dalej PWW), (opr.) A.S. Link, t. 31, Princeton 1979, s. 546-547; Wilson to Bryan, December 29, 1914, [w: ] ibidem, s. 546.

45 Remarks at a Press Conference, September 3, 1914, [w: $P W W$, t. 30, Princeton 1979, s. 469-471; Remarks at a Press Conference, October 8, 1914, [w: ] PWW, t. 50, Princeton 1985, s. 594-599. 


\section{Chiny w polityce zagranicznej Stanów Zjednoczonych w latach 1911-1918}

planom w Chinach. Była ona negatywnie nastawiona do amerykańskich przedsięwzięć biznesowych w Chinach, w prasie japońskiej trwała nagonka na USA, a czołowi japońscy politycy, w tym baron Katō i premier Ōkuma Shigenobu, wypowiadali mniej lub bardziej zawoalowane groźby pod adresem Waszyngtonu. Należało się zatem spodziewać - uważał Reinsch - że amerykańskie interesy w Państwie Środka zamiast się rozszerzać, wyzyskując dogodną okazję, ulegną ograniczeniu. Aby temu zapobiec, trzeba było zachęcać rodaków do zwiększenia aktywności i zbudowania takiej pozycji ekonomicznej, której nie mogliby łatwo zignorować rywale, dążący do zdobycia rynku chińskiego za pomocą wpływów politycznych. Konieczne było ponadto przeciwstawienie się „mandżuryzacji Shandongu” oraz jakiemukolwiek naruszeniu polityki „otwartych drzwi” czy umów międzynarodowych. W tym celu można było stworzyć wspólny front z innymi państwami zaniepokojonymi wzrostem znaczenia Japonii na Dalekim Wschodzie: Chinami, Rosją ${ }^{46}$, Wielką Brytanią oraz jej dominiami - Australią i Kanadą ${ }^{47}$. Zdaniem Reinscha najważniejsi członkowie ententy byli niezadowoleni, że Japonia wykorzystywała ich wysiłek wojenny, bezproblemowo zajęła niemieckie posiadłości i umacniała swoją pozycję, co nie byłoby możliwe w innych okolicznościach. Poseł podkreślał zwłaszcza szkodliwy wpływ japońskich działań na brytyjskie interesy, ale nie miał złudzeń, że póki wojna trwała, utrzymanie sojuszu stanowiło priorytet ${ }^{48}$.

Reinsch uważał, że dotychczasowe łatwe zwycięstwa Japonii rozpaliły jej ambicje, utrudniając stronnictwu umiarkowanemu poskromienie ekspansjonistycznych zapędów. Po pokonaniu Niemiec głównym przeciwnikiem stała się Ameryka ze względu na jej politykę w Chinach, pozycję na Pacyfiku oraz traktowanie japońskich imigrantów. Japonia, uznająca się za równą innym mocarstwom i przeświadczona o trwałości aliansu z Wielką Brytanią, gotowa była nawet, zdaniem Reinscha, wystąpić zbrojnie przeciwko Stanom Zjednoczonym. Na razie zamierzała zatrzymać Qingdao oraz kontynuować rozszerzanie

${ }^{46}$ Rosyjski poseł w Pekinie stwierdził ironicznie, że „sytuacja [wewnętrzna Chin - J.P.] sama w sobie nie wydaje mi się poważna, jedyne, co jest w niej poważne, to fakt, że Japończycy mówią, że jest poważna”. Reinsch to the Secretary of State, November 28, 1914, RDSRPRBChOS, roll 23.

47 Przed wojną Reinsch uważał, że głównymi stronnikami Stanów Zjednoczonych w obronie polityki „otwartych drzwi” mogły być Wielka Brytania i Niemcy. Reinsch to the Secretary of State, November 28, 1913, RDSRIACh, roll 13; Reinsch to the Secretary of State, June 29, 1914, ibidem.

48 Reinsch to the Secretary of State, August 27, 1914, RDSRPRBChOS, roll 24; Reinsch to the Secretary of State, November 28, 1914, RDSRPRBChOS, roll 23; Reinsch to the Secretary of State, December 22, 1914, WWP, series 2, reel 66. Cytaty pochodzą z ostatniego dokumentu. 
wpływów w Shandongu i innych prowincjach. Jej plan zakładał również wywołanie niepokojów w Chinach, aby zyskać pretekst do interwencji ${ }^{49}$.

Opinie Williamsa i Reinscha nie przyczyniły się do zmiany kursu amerykańskiej dyplomacji, która przez cały 1914 rok dość spokojnie podchodziła do japońskich działań. Nad Potomakiem uznano, że jeśli już wojna dosięgła Dalekiego Wschodu, to walk w dzierżawach nie dało się uniknąć. A skoro ograniczyły się głównie do niemieckiej posiadłości i tylko nieznacznie poza nią wykroczyły, łamiąc neutralność Chin, nie widziano większych powodów do zmartwień. Podobnie inne naruszenia suwerenności Państwa Środka wydawały się stosunkowo mało istotne, przynajmniej z punktu widzenia amerykańskich interesów. Uspokajać musiał poza tym fakt, że działania wojenne szybko się zakończyły i perspektywy ich wznowienia były znikome. W tych okolicznościach nadrzędnym celem Waszyngtonu - jak jednoznacznie ujął to Lansing - pozostawała chęć uniknięcia poważniejszych zatargów międzynarodowych. Na pewno nie dążono do dalszego zaognienia relacji z Tokio. Amerykanie musieli być też świadomi, jakie znaczenie na tym etapie wojny miała dla Londynu Japonia i że niezmiernie trudno byłoby go nakłonić do bardziej stanowczego wystąpienia przeciwko cennemu sojusznikowi. Być może, chociaż jest to bardziej przypuszczenie niż pewność, administracja Wilsona reagowała z większą wyrozumiałością także dlatego, że nie udało jej się zapobiec przyjęciu antyjapońskiego ustawodawstwa na poziomie stanowym. Wówczas większe przyzwolenie na działania w Chinach byłoby swoistą „rekompensatą” za dyskryminacyjne traktowanie Japończyków u siebie. Że nie jest to rozumowanie całkowicie pozbawione podstaw, świadczy fakt, iż od jakiegoś już czasu obie kwestie zaczęto ze sobą łączyćs ${ }^{50}$.

Nastawienie Departamentu Stanu zmieniło się na początku 1915 roku, gdy Japonia wystosowała 21 żądań, poważnie godzących w chińską suwerenność i amerykańskie interesy.

49 Reinsch to the Secretary of State, November 28, 1914, RDSRPRBChOS, roll 23; Reinsch to the Secretary of State, December 22, 1914, WWP, series 2, reel 66.

so Document written by Division of Far Eastern Affairs, January 20, 1912, KP, container 16; Confidential Minute. Document written by the Gaimusho, September 1912 [brak daty dziennej], KP, container 18; Reinsch to the Secretary of State, August 27, 1914, RDSRPRBChOS, roll 24; Reinsch to the Secretary of State, November 28, 1914, RDSRPRBChOS, roll 23; P. Reinsch, An American Diplomat ..., s. 126; L.C. Gardner, Safe for Democracy. The Anglo-American Response to Revolution, 1913-1923, New York 1984, s. 80 . 


\section{Reakcja USA na japońskie 21 żądań}

Stosunkowo łatwe wyparcie Niemiec z Dalekiego Wschodu i regionu Pacyfiku ośmieliło Japonię do podjęcia próby podporządkowania Chin. Sprzyjała temu sytuacja w Europie, gdzie walki na zachodzie przybrały już charakter pozycyjny, a na froncie wschodnim zaczynała się zarysowywać przewaga państw centralnych. Jeszcze bardziej odciągało to członków ententy od spraw azjatyckich, pozostawiając Japonii dużą swobodę działania. Oprócz korzystnych uwarunkowań międzynarodowych ważnym czynnikiem była perspektywa wyborów parlamentarnych, zaplanowanych na marzec 1915 roku. Rząd Ōkumy, krytykowany w ojczyźnie m.in. za zbyt powściągliwą politykę zagraniczną, potrzebował sukcesu, a zwasalizowanie Chin, okraszone dodatkowo upokorzeniem nielubianego Yuana, nadawało się do tego idealnie ${ }^{51}$.

Na początku grudnia 1914 roku cesarski poseł w Pekinie Hioki Eki otrzymał od barona Katō instrukcje zawierające żądania wobec $\mathrm{Chin}^{52}$. Z ich wysunięciem poczekano do kolejnego sporu między oboma państwami, który nastąpił niedługo potem. 7 stycznia, dwa miesiące po upadku Qingdao, Chiny uznały, że nadszedł czas na anulowanie strefy wojennej, na którą wcześniej nolens volens musiały się zgodzić. Japonia odebrała to jako działanie niestosowne i odmówiła akceptacji. 16 stycznia Waijiao bu zaprotestowało, wyrażając nadzieję, że Tokio zmieni zdanie, aby zachować pokój na Dalekim Wschodzie i przyjazne stosunki bilateralne ${ }^{53}$. W jaki sposób Japonia rozumiała te pojęcia, okazało się dwa dni później ${ }^{54}$.

${ }^{51}$ Reinsch pisał, że Chińczycy i cudzoziemcy w Pekinie łączyli wystosowanie żądań $\mathrm{z}$ kwestią wyborów. Już po ich przeprowadzeniu rząd Ōkumy nalegał na przyznanie praw buddyjskim mnichom w Chinach, argumentując, że przyczynili się do jego zwycięstwa. Reinsch to Bryan, January 26, 1915, [w:] PWW, t. 32, Princeton 1980, s. 137-138; Reinsch to Bryan, March 31, 1915, [w:] ibidem, s. 461.

${ }_{52}$ Instructions given by Baron Kato to Mr. Hioki, December 3, 1914, [w:] The SinoJapanese Negotiations of 1915. Japanese and Chinese Documents and Chinese Official Statement, Washington 1921, s. 1-2.

${ }_{53}$ First note from the Ministry of Foreign Affairs to the British and Japanese ministers at Peking, notifying the cancellation of the war zone, January 7, 1915, [w:] V.K. Wellington Koo's..., s. 83; Note from the Japanese minister at Peking to the Ministry of Foreign Affairs refusing to recognize the cancellation of the war zone, January 9, 1915, [w: ] ibidem, s. 84-85; Second note from the Ministry of Foreign Affairs to the Japanese minister at Peking respecting the cancellation of the war zone, January 16, 1915, [w:] ibidem, s. 85-87; M. Kajima, The Diplomacy of Japan ..., s. 164-176.

${ }^{54} \mathrm{Na}$ marginesie można odnotować, że Japończycy - nie po raz pierwszy zresztą w swojej historii - wykazali się perfidią, umieszczając w preambule do 21 żądań sformułowanie nawiązujące do chińskiej noty, oznajmili mianowicie, że chcą „utrzymać powszechny pokój w Azji Wschodniej oraz osiągnąć dalsze wzmocnienie przyjacielskich 
18 stycznia Hioki przekazał Yuanowi 21 żądań, spisanych dla wzmocnienia ich wymowy na papierze z wytłoczonymi wizerunkami pancerników i karabinów maszynowych. Żądania podzielone były na pięć grup. Pierwsza dotyczyła Shandongu, druga - potwierdzenia i dalszego umocnienia specjalnej pozycji Japonii w południowej Mandżurii i we wschodniej części Mongolii Wewnętrznej. Kolejne żądania miały na celu przejęcie przez Japonię kontroli nad ważnym kompleksem metalurgicznym Hanyeping. Ta znajdująca się w dolinie Jangcy spółka miała ponadto otrzymać monopol kopalniany na okolicznym terenie. W dalszej części Chiny miały się zobowiązać, że nie odstąpią ani nie wydzierżawią żadnego fragmentu swojego wybrzeża państwu trzeciemu, co oznaczało domyślnie, że zakaz ten nie odnosił się do Japonii. Najbardziej daleko idące żądania ujęte zostały w grupie piątej, w której Japonia domagała się, aby rząd pekiński m.in.: zatrudnił jej doradców politycznych, finansowych i wojskowych; zgodził się na powolanie $\mathrm{w}$ wybranych miejscowościach policji mieszanej; zobowiązał się kupować od niej co najmniej połowę swojego uzbrojenia oraz przyznał jej prawo weta wobec przedsięwzięć przemysłowych powierzonych zagranicznemu kapitałowi w Fujianie ${ }^{55}$.

Przyjęcie powyższych żądań, zwłaszcza zawartych w grupie piątej, przekształciłoby Chiny w państwo podległe Japonii, a później zapewne w jej protektorat na modłę koreańską. Istotne było, że Japonia zyskałaby przywileje, prawa i koncesje zarówno na szczeblu centralnym, jak i lokalnym, a strefa jej bezpośrednich wpływów obejmowałaby tereny w różnych częściach Chin - Mandżurię, Mongolię Wewnętrzną i Shandong na północy, fragment doliny Jangcy w środkowych Chinach i Fujian na poludniu.

Ponieważ żądania naruszały interesy pozostałych mocarstw, Japonia zakazała ich ujawniania, grożąc „poważnymi konsekwencjami”" ${ }^{6}$. W trakcie negocjacji wywierała presję militarną oraz wystosowała dwa ultimata. Oprócz kija stosowała także metodę marchewki. W zamian za akceptację żądań oferowała m.in. spokój ze strony chińskich rewolucjonistów przebywających na jej terytorium, zwrot Jiaozhou (chociaż nie bez konieczności kolejnych ustępstw Pekinu) i przyzwolenie na monarsze plany Yuana ${ }^{57}$.

i dobrosąsiedzkich stosunków" z Chinami. Podczas negocjacji Hioki - wyjaśniając, jaka szansa rysowała się przed Japonią $\mathrm{w}$ wyniku I wojny światowej - miał z kolei stwierdzić cynicznie, że niepodobna „oczekiwać, że sąsiad pomagający w gaszeniu ognia w sklepie jubilerskim powinien wrócić z pustymi rękami". Reinsch to the Secretary of State, May 4, 1915, RDSRPRBChOS, roll 24.

${ }_{55}$ Tekst 21 żądań znajduje się w załączniku 2.

${ }_{56}$ Minister Reinsch to the Secretary of State, January 23, 1915, [w:] PRFRUS 1915, Washington 1924, s. 79.

${ }_{57}$ Reinsch to Bryan, January 26, 1915, [w:] PWW, t. 32, s. 137-138; M. Chi, China Diplomacy..., s. 30, 153. 
Yuan znalazł się w skrajnie trudnym położeniu. Z oczywistych względów nie chciał się godzić na żądania, ale zapewnienie sobie przychylności czy choćby neutralności potężnego sąsiada miało dla niego znaczenie, szczególnie w perspektywie przygotowań do wprowadzenia cesarstwa ${ }^{58}$. Nie mógł zarazem uczynić zbyt dużych ustępstw, gdyż zdyskredytowałoby go to w oczach rodaków, a wówczas mogło dojść do wybuchu kolejnej rewolucji. Konieczne było też kontrolowanie i tonowanie antyjapońskich nastrojów, aby nie przerodzily się w rozruchy, które Japonia mogłaby wykorzystać jako powód do interwencji. Wobec niemożności stawienia jej skutecznego oporu militarnego i z uwagi na wspomniane komplikacje Chinom pozostało tylko jedno wyjście - przedłużać rozmowy i zwracać się o pomoc do Wielkiej Brytanii i USA. Podobną taktykę stosowały w przeszłości, np. podczas negocjacji z Rosją, która na początku XX wieku próbowała wymusić układ dotyczący Mandżurii.

Mimo japońskiego zakazu ujawniania żądań informacje o nich zaczęły po kilku dniach docierać do zagranicznych dyplomatów w Pekinie. Reinsch miał się o nich dowiedzieć 22 stycznia podczas rozmowy z chińskim ministrem ${ }^{59}$. Na początku nie znał szczegółów, a jedynie ogólny zarys niektórych punktów, choć stopniowo ukazywał się przed nim pełen obraz żądań. Jednak nawet dysponując tylko częścią informacji, Reinsch zaczął alarmować o poważnym naruszeniu chińskiej niepodległości i polityki „otwartych drzwi”. Stwierdził wręcz, że rozpoczął się najpoważniejszy kryzys w dziejach Państwa Środka ${ }^{60}$.

W miarę jak napływały kolejne wiadomości od Reinscha, Departament Stanu wykazywał coraz większe zainteresowanie całą sprawą, ale zanim zajął jakieś stanowisko, chciał poznać pełnię żądań. W tym celu zwrócił się do Wielkiej Brytanii i Japonii, lecz pierwsza nie uważała sytuacji za poważną i odpowiedziała bez żadnych konkretów z dużym opóźnieniem, a druga z wyrachowaniem stosowała taktykę dezinformacji. Kilka razy zaprzeczyła, aby żądania naruszały integralność terytorialną Chin lub prawa cudzoziemców. 6 lutego premier Ōkuma osobiście zapewnił ambasadora Guthriego o swoim przywiązaniu do polityki „otwartych drzwi” oraz integralności terytorialnej Chin ${ }^{61}$.

58 J. Polit, Odwrót znad Pacyfiku..., s. 79; J. Ch’ên, Yuan Shih-k'ai, 1859-1916. Brutus Assumes the Purple, London 1961, s. 186.

59 P. Reinsch, An American Diplomat..., s. 131.

60 Minister Reinsch to the Secretary of State, January 23, 1915, [w:] PRFRUS 1915, s. 79; Reinsch to the Secretary of State, January 24, 1915, RDSRPRBChOS, roll 23; Reinsch to Bryan, January 26, 1915, [w:] PWW, t. 32, s. 137-138; Reinsch to the Secretary of State, January 27, 1915, RDSRPRBChOS, roll 23; Reinsch to the Secretary of State, February 1, 1915, WWP, series 2, reel 68; Minister Reinsch to the Secretary of State, February 10, 1915, [w:] PRFRUS 1915, s. 85-87.

${ }_{61}$ Ambassador Guthrie to the Secretary of State, February 1, 1915, [w:] PRFRUS 1915, s. 82; The Secretary of State to Ambassador Page, February 2, 1915, [w: ibidem; 
Apogeum obłudy miało miejsce 8 lutego, gdy Japonia przekazała listę żądań, na której pominęła jednak najbardziej kontrowersyjną grupę piątą, a część pozostałych żądań złagodziła lub nadała im bardziej ogólnikowe brzmienie. Dzięki doniesieniom Reinscha i Guthriego politycy w Waszyngtonie wiedzieli, że przekazany dokument był niekompletny. Bryan zwrócił się zatem do japońskiego ambasadora Chindy Sutemiego z prośbą o wyjaśnienia, ale ten zarzekał się, że wszystkie żądania zostały ujęte ${ }^{62}$.

Tymczasem Chiny, dowiedziawszy się o dwulicowości i manipulacjach Japonii, postanowiły przekazać $\mathrm{w}$ tajemnicy zainteresowanym mocarstwom pełen tekst żądań ${ }^{63}$. W tej sytuacji Bryan ponownie zwrócił się do Japonii, wyrażając zadowolenie, że zaprzeczyła pogłoskom o istnieniu dodatkowych żądań, czym postawił ją w kłopotliwym położeniu i skłonił do wyjawienia prawdy ${ }^{64}$. Sam starał się jeszcze znaleźć jakieś inne wytłumaczenie. Sugerował, że być może oryginalna nota Hiokiego zawierała grupę piątą, ale w toku negocjacji Tokio z niej zrezygnowało i dlatego obecnie ją pominięto ${ }^{65}$. Reinsch szybko rozwiał wszystkie złudzenia ${ }^{66}$.

Ostatecznie 21 lutego baron Katō przyznał, że japońska nota zawierała również grupę piątą, jednakże - i tu minister wykazał się nie lada inwencją i tupetem - nie znajdowały się w niej żądania, a jedynie życzenia (w angielskiej wersji dokumentu mowa jest o requests albo wishes, w przeciwieństwie do demands) ${ }^{67}$. Chociaż w instrukcjach dla Hiokiego z grudnia 1914 roku rzeczywiście uczyniono

Ambassador Guthrie to the Secretary of State, February 3, 1915, [w:] ibidem; Ambassador Guthrie to the Secretary of State, February 6, 1915, [w:] ibidem, s. 83; Ambassador Page to the Secretary of State, February 13, 1915, [w:] ibidem, s. 88; J. Polit, Odwrót znad Pacyfi$k u \ldots$, s. $65-66,68$.

${ }^{62}$ PRFRUS 1915, s. 83-92.

${ }^{63}$ Reinsch to the Secretary of State, February 17, 1915, RDSRPRBChOS, roll 23; The Chinese Minister to the Secretary of State, undated, [w: ] PRFRUS 1915, s. 93-95.

${ }^{64}$ Bryan to the American Embassy at Tokyo, February 18, 1915, [w: ] PWW, t. 32, s. 247; Bryan to the American Embassy at Tokyo, February 18, 1915, [w:] ibidem, s. 248. Link podejrzewa, że pomysłodawcą tego posunięcia był Wilson, a nie Bryan, który nie wykazywał się podobnym sprytem. A.S. Link, Wilson: The Struggle ..., s. 280.

${ }^{65}$ Bryan to the American Legation at Peking, February 18, 1915, [w: $P W W$, t. 32, s. 246-247; Bryan to the American Embassy at Tokyo, February 18, 1915, [w:] ibidem, s. 247.

${ }^{66}$ Minister Reinsch to the Secretary of State, February 20, 1915, [w:] PRFRUS 1915, s. 95-96. Zobacz też: Reinsch to the Secretary of State, February 17, 1915, RDSRPRBChOS, roll 23.

${ }^{67}$ Ambassador Guthrie to the Secretary of State, February 21, 1915, [w:] PRFRUS 1915, s. 96; The Japanese Embassy to the Department of State, undated, handed on February 22, 1915, [w:] ibidem, s. 97. Podobnych wyjaśnień Katō udzielił Brytyjczykom już 10 lutego. J. Polit, Odwrót znad Pacyfiku..., s. 70-71. 
podobne rozróżnienie, to ponieważ opublikowano je już po zakończeniu całego konfliktu, można podejrzewać, że zostały odpowiednio zmienione post factum. Bez względu nawet na te wątpliwości, istotne było, że zdaniem Reinscha Japonia, przedstawiając Chinom swoje żądania, nie dzieliła ich na różne kategorie i faktycznie wszystkie traktowała jednakowo ${ }^{68}$.

$\mathrm{W}$ drugiej połowie lutego Waszyngton miał już w miarę pełne rozeznanie w sytuacji. Zakończył się tym samym pierwszy etap ustalania faktów i przyszła pora na sformułowanie planu działania. Okazało się to nie takie proste, gdyż główni architekci chińskiej polityki Stanów Zjednoczonych - Reinsch, Williams, Lansing, Bryan i Wilson - mieli różne pomysły, jak należało zareagować.

Wystąpienie przez Japonię z żądaniami było dla Waszyngtonu poważnym problemem $^{69}$. Żądania same w sobie łamały politykę „otwartych drzwi”, zarówno w kwestii równości szans, jak i suwerenności i terytorialnej integralności Chin. Poza tym ich wystosowanie stwarzało sytuację groźną dla amerykańskiej polityki. Potencjalnie niepożądanych scenariuszy - jak trafnie analizował Reinsch - było kilka. Przyjęcie żądań równało się umniejszeniu władzy Pekinu i mogło doprowadzić do destabilizacji kraju i wybuchu kolejnego powstania. Odrzucenie oznaczałoby zapewne bezpośredni atak Japonii lub próbę wzniecenia przez nią rewolucji. Ale nawet niezależnie do przebiegu rokowań resentymenty antyjapońskie szerzące się w społeczeństwie chińskim mogły przerodzić się w antyjapońskie wystąpienia, a te nabrać ogólniejszego rysu antycudzoziemskiego. I jedne, i drugie mogły zaś stanowić dla Japonii podstawę do interwencji, tak samo zresztą jak rewolucja przez nią wywołana ${ }^{70}$.

W Waszyngtonie zaczęto się w tym czasie obawiać jeszcze jednego negatywnego scenariusza. Podejrzewano, że podporządkowanie Chin przez Japonię zagroziłoby nie tylko amerykańskiej polityce w Państwie Środka, ale na domiar złego fundamentowi całej amerykańskiej polityki zagranicznej - doktrynie Monroego. Gdyby Japonia istotnie ograniczyła lub zamknęła dostęp do rynku chińskiego dla innych cudzoziemców, wyrugowane z niego państwa europejskie szukałyby po zakończeniu wojny rekompensaty na innych obszarach i zapewne zwrócilyby się ku Ameryce Łacińskiej, stwarzając tym samym zagrożenie dla interesów i bezpieczeństwa Stanów Zjednoczonych ${ }^{71}$. Nie będzie więc przesadą

68 Minister Reinsch to the Secretary of State, April 2, 1915, [w:] PRFRUS 1915, s. 118; Minister Reinsch to the Secretary of State, April 5, 1915, [w: ] ibidem, s. 119-122.

69 Tien-yi Li pisze z pewną przesadą, że żądania „stanowiły wyzwanie dla Stanów Zjednoczonych jako światowego mocarstwa”. Tien-yi Li, Woodrow Wilson's ..., s. 100.

70 Minister Reinsch to the Secretary of State, January 23, 1915, [w: ] PRFRUS 1915, s. 79; Reinsch to Bryan, January 26, 1915, [w: ] PWW, t. 32, s. 137-138.

71 S. Hornbeck, Contemporary Politics in the Far East, New York-London 1916, s. 347 . 
stwierdzenie, że w następstwie japońskich żądań mogło się pojawić wiele problemów i niebezpieczeństw.

Wśród osób decydujących o kształcie chińskiej polityki USA najbardziej nieprzejednane stanowisko wobec 21 żądań prezentował Reinsch ${ }^{72}$. Uważał on, że akceptacja narzuconych warunków przekształciłaby Chiny w protektorat i pozbawiłaby je kontroli nad zasobami naturalnymi. Spośród cudzoziemców najbardziej uderzyłoby to w Brytyjczyków, ale pozycja Amerykanów także znacząco by na tym ucierpiała. Reinsch alarmował o największym kryzysie w dziejach Państwa Środka i chciał, aby amerykańska dyplomacja próbowała powstrzymać agresję. Sam zaproponował dwa uzupełniające się działania - zwrócenie się zarówno do Pekinu, jak i do Londynu. W tym pierwszym, sformułowanym jeszcze na etapie ustalania kontekstu i podstawowych faktów, chodziło o skłonienie Chin, aby nie bacząc na nakaz dyskrecji, ujawniły treść żądań. Uniemożliwiłoby to Japonii dalsze mataczenie w tej sprawie. Według Reinscha istniała duża szansa, że Chiny zgodzą się na upublicznienie, o ile Stany Zjednoczone wezmą za to „moralną i [...] polityczną odpowiedzialność”. Inny wariant zakładał uzyskanie potrzebnych informacji via Londyn lub wysłanie oficjalnego zapytania do Tokio. Dysponując pełną wiedzą o żądaniach, należało starać się je zablokować lub przynajmniej złagodzić. I tutaj ponownie główną rolę miała odegrać Wielka Brytania. „Wszystkie aspekty kryzysu - pisał poseł 1 lutego - wskazują, że rząd brytyjski trzyma klucz do całej sytuacji”. Reinsch przekonywał, że Wielka Brytania, która doceniała „przyjacielski charakter amerykańskiej neutralności” oraz fakt, że USA stanowiły nieocenioną bazę zaopatrzeniową, nie zignoruje ich woli politycznej i stanowczo wpłynie na swojego alianta. To zaś niemal na pewno sprawi, że Japonia zrezygnuje z żądań, bo w przeciwnym razie ryzykowałaby osłabienie sojuszniczych więzów lub nawet ich zerwanie ${ }^{73}$. Rozumowanie Reinscha miało jedną

${ }^{72}$ Podczas całego kryzysu Reinsch nieoficjalnie doradzał też Pekinowi, co momentami stawiało go w kłopotliwym położeniu. P. Reinsch, An American Diplomat ..., s. 130, 132, 134, 143-144; Minister Reinsch to the Secretary of State, April 5, 1915, [w: ] PRFRUS 1915, s. 119-122; Tien-yi Li, Woodrow Wilson's..., s. 105-106; A.W. Griswold, The Far Eastern ..., s. 191.

${ }^{73}$ Reinsch to the Secretary of State, January 24, 1915, RDSRPRBChOS, roll 23; Reinsch to Bryan, January 26, 1915, [w:] PWW, t. 32, s. 137-138; Reinsch to the Secretary of State, January 27, 1915, RDSRPRBChOS, roll 23; Reinsch to the Secretary of State, January 29, 1915, ibidem; Reinsch to the Secretary of State, February 1, 1915, WWP, series 2, reel 68; Minister Reinsch to the Secretary of State, February 10, 1915, [w:] PRFRUS 1915, s. 85-87; P. Reinsch, An American Diplomat ..., s. 129-149. Wszystkie cytaty pochodzą z dokumentu z 1 lutego. Curry zauważa, że pomysł, aby liczyć na współpracę z Wielką Brytanią przeciwko Japonii, pojawiał się podczas każdego kryzysu w Azji za prezydentury Wilsona. R.W. Curry, Woodrow Wilson and Far Eastern Policy, 1913-1921, New York 1968, s. 115. Przynajmniej w trakcie wojny Londyn raczej nie zamierzał jednak współpracować 


\section{Chiny w polityce zagranicznej Stanów Zjednoczonych w latach 1911-1918}

poważną wadę, zapomniał on, że podczas wojny to Wielka Brytania bardziej potrzebowała Japonii niż vice versa.

Stronnikiem Reinscha w Departamencie Stanu był Williams. W serii memorandów skierowanych do Bryana na przełomie stycznia i lutego, a więc gdy treść żądań i kulisy ich przedstawienia były ciągle przedmiotem niepotwierdzonych doniesień i spekulacji, pisał on o „poważnym kryzysie [...] grożącym nie tylko pokojowi Chin, ale również interesom Ameryki”. Dowodził, że żądania łamały szereg międzynarodowych zobowiązań i oświadczeń Japonii, wobec czego Stany Zjednoczone, jako „strażnik” polityki „otwartych drzwi”, miały „moralny obowiązek” domagać się wyjaśnień i nalegać na przestrzeganie przysługujących im praw. Wszelka pobłażliwość tylko ośmieliłaby do dalszego ograniczania praw innych państw i naruszania polityki „otwartych drzwi”, istotnej dla przedsięwzięć komercyjnych, edukacyjnych i misjonarskich. Williams wskazywał, że co prawda z gospodarczego punktu widzenia Japonia miała dla Stanów Zjednoczonych obecnie większe znaczenie niż Chiny, to w amerykańskim interesie leżało utrzymanie niepodległych i silnych Chin, a nie zdominowanie ich przez Japonię. Co więcej, uchylenie się od pomocy Chinom, które na ową pomoc z Waszyngtonu szczególnie liczyły, skutkowałoby zapewne utratą wpływów na Dalekim Wschodzie. Intencje rządu tokijskiego były dla Williamsa jasne - stopniowe powielanie schematu koreańskiego. Nie ufał on zapewnieniom Japonii, gdyż wielokrotnie już je łamała. Obawiał się też, że po opanowaniu Państwa Środka stanie się ona poważnym zagrożeniem dla USA.

Williams miał trochę inne niż Reinsch sugestie, co należało zrobić w zaistniałym kryzysie. Mniejszą wagę przykładał do współpracy z Wielką Brytanią, którą podejrzewał o ignorowanie alarmujących sygnałów i „przymykanie oka” na działania sojusznika. Jednakowoż sądził, że gdy upubliczni się żądania, Whitehall pomoże w ich ograniczeniu. Należało w takim razie dążyć do ujawnienia całej sprawy i w tym celu, podobnie jak Reinsch, Williams proponował zwrócić się do Chińczyków. Uzupełnieniem tego miał być stanowczy protest przeciwko przyznawaniu koncesji naruszających amerykańskie prawa. Williams miał nawet bardziej dalekosiężną wizję. "Jeśli udałoby nam się zredukować żądania - pisał 2 lutego - wydaje mi się, że powinniśmy nalegać na Chiny, aby zaprowadziły u siebie

z Waszyngtonem w Chinach, postrzegając go, podobnie jak Tokio, jako zagrożenie dla swych interesów. C.B. Davis, Limits of Effacement: Britain and the Problem of American Cooperation and Competition in China, 1915-1917, „Pacific Historical Review” 1979, t. 48, nr 1, s. 47-63. Podczas kryzysu wywołanego przez 21 żądań Wielka Brytania nie chciała konsultować swoich działań z innymi mocarstwami i wolała samodzielnie rozmawiać z Japonią. Nie doszło wówczas do współpracy amerykańsko-brytyjskiej, na którą USA też zresztą nie nalegały. R.J. Gowen, Great Britain and the Twenty-One Demands of 1915: Cooperation versus Effacement, „The Journal of Modern History” 1971, t. 43, nr 1, s. 90-91, 94. 
porządek i stały się zdolne do obrony. Możemy i powinniśmy im w tym pomóc, a poprzez to zbudujemy silną obronę dla siebie"74. Takie stanowisko oznaczało znaczne zbliżenie amerykańsko-chińskie, a zdaniem A.S. Linka niosło nawet ze sobą ryzyko wojny ${ }^{75}$.

Wyraźnie sprecyzowana opinia Williamsa z przełomu stycznia i lutego uległa kilka tygodni później głębokiej zmianie. 26 lutego wystosował on kolejne memorandum do Bryana, w którym zgadzał się na żądania w odniesieniu do Mandżurii i Shandongu w zamian za uregulowanie sprawy japońskiej imigracji do USA. I chociaż Williams obwarował to pewnymi warunkami, takimi jak potwierdzenie przez Japonię polityki „otwartych drzwi” i zaprzestanie pobierania przez nią dyskryminujących opłat frachtowych w Mandżurii ${ }^{76}$, to pomysł polegał na klasycznej wymianie quid pro quo. Ciekawe jest, że sam Williams zdawał sobie sprawę, jak ryzykowne byłoby to posunięcie. Na początku memorandum wspomniał, że naruszałoby to amerykańskie prawa traktatowe oraz stanowiłoby „niebezpieczny precedens", który niemal na pewno zapoczątkowałby lawinę żądań innych mocarstw, mogącą doprowadzić do rozpadu Chin lub w wariancie mniej pesymistycznym - do ugruntowania stref wpływów ${ }^{77}$.

Historycy różnie starali się wytłumaczyć woltę Williamsa, ale ich próby wydają się nie do końca satysfakcjonujące ${ }^{78}$. Dostępne mi materiały nie pozwalają wyrokować na temat motywacji szefa Wydziału ds. Dalekiego Wschodu, można zatem jedynie wskazać na pewne tropy. Nie ulega wątpliwości, że sytuacja pod

74 Williams to Bryan, January 25, 1915, RDSRPRBChOS, roll 25; Williams to Bryan, January 27, 1915, [w: ] PWW, t. 32, s. 135-137; A Memorandum by Williams, January 28, 1915, [w:] ibidem, s. 148-149; Williams to Bryan, February 2, 1915, [w:] ibidem, s. 177-178. Cytaty pochodzą ze wszystkich trzech dokumentów. D.D. Lazo, An Enduring Encounter ..., s. 257-260. Zob. też: Williams to the Secretary of State, February 15, 1915, RDSRPRBChOS, roll 23.

75 A.S. Link, Wilson: The Struggle ..., s. 277.

${ }^{76} \mathrm{Na}$ ten temat patrz: PRFRUS 1915, s. 594-625; PRFRUS 1916, Washington 1925 , s. 446-450.

77 Williams to Bryan, February 26, 1915, BP, container 45. Williams godził się na żądania z grup pierwszej, drugiej i może czwartej. Trzecią chciał wyjaśnić, a piątej w ogóle nie rozważał. Potem okazało się, że i wobec trzeciej miał poważne zastrzeżenia. Williams to Bryan, March 12, 1915, BP, container 59.

78 Curry i Tien-yi Li ograniczają się do stwierdzenia, że było to „dziwne”. Beers sugeruje, że Williams dał się przekonać Lansingowi i tak naprawdę zaprezentował jego stanowisko. Lazo uznaje z kolei, że Williams nie porzucił sprawy chińskiej, zmienił tylko taktykę. Zaakceptował faktyczny stan rzeczy w Chinach i chciał je uchronić przed większymi stratami. Zob. R.W. Curry, Woodrow Wilson and Far Eastern Policy ..., s. 116; Tien-yi Li, Woodrow Wilson's..., s. 113; B. Beers, Vain Endeavor. Robert Lansing's Attempts to End the American-Japanese Rivalry, Durham 1962, s. 38; D.D. Lazo An Enduring Encounter ..., s. 264-265, 275. 


\section{Chiny w polityce zagranicznej Stanów Zjednoczonych w latach 1911-1918}

koniec lutego była inna niż na początku miesiąca. Williams wiedział, że jego poprzednie memoranda nie odniosły większego efektu. Ostry antyjapoński ton nie zyskał aprobaty przełożonych, zmiana podejścia mogła być więc zrozumiała. Ponadto Bryan, dysponując już przekazaną przez Japonię pełną listą żądań, skupił się na analizowaniu grupy piątej. Williams obawiał się, że zostanie to odebrane jako zgoda na pozostałe grupy, wśród których jego zdaniem również znajdowały się warunki nie do zaakceptowania ${ }^{79}$. Jego memorandum miało na to zwrócić uwagę, o czym świadczy pierwsze zdanie dokumentu: „Zanim Departament zdecyduje się ostatecznie nie zgłaszać żadnych zastrzeżeń wobec «żądań» jako różnych od «życzeń», [...] sugeruję [...] uzyskanie quid pro quo, skoro będziemy się zrzekać cennych praw traktatowych”.

Odejście od oporu wobec Japonii na rzecz wzajemnych ustępstw miało dla Williamsa pewne korzyści, aczkolwiek trzeba pamiętać, że jednocześnie przedstawił on argumenty przeciw, przez co jego stanowisko nie było w pełni jednoznaczne. Na pewno porozumienie się pozwalało rozwiązać problem japońskiej imigracji, który ponownie mógł się stać bardzo poważny, bo Idaho i Oregon debatowały właśnie nad przyjęciem ustaw antyjapońskich ${ }^{80}$. Williams odwołał się do memorandum, które Japończycy wręczyli Philanderowi Knoxowi we wrześniu 1912 roku (gdy ten przybył na pogrzeb cesarza Meiji), a które pozostało bez odpowiedzi ${ }^{81}$. Łączyło ono kwestię emigracji do USA z możliwością osadnictwa w Korei, Mandżurii i Mongolii Wewnętrznej. Skierowanie żywiołu japońskiego na te tereny pozwalało wygasić migrację przez Pacyfik. Williams przyjął ten argument, uważając, że Stany Zjednoczone powinny uznać specjalną pozycję Japonii w Mandżurii, co właściwie już wcześniej uczyniły. Poza tym, jak zauważa Dimitri D. Lazo, Williams chciał w ten sposób związać oba państwa porozumieniem pozwalającym ograniczyć i lepiej kontrolować poczynania Japonii ${ }^{82}$. Wreszcie Waszyngton uzyskałby większy wpływ na negocjacje japońsko-chińskie.

Lista negatywów była co najmniej równie długa. Oprócz tych wskazanych przez samego Williamsa należy zauważyć, że USA otwarcie godziłyby się na naruszenie chińskiej suwerenności i integralności terytorialnej, tym samym podważając obie zasady polityki „otwartych drzwi”, także i pierwszą. Trudno było bowiem oczekiwać, że Japonia rzeczywiście równo traktowałaby

79 D.D. Lazo, An Enduring Encounter ..., s. 260, 263.

80 R. Lansing, War Memoirs of Robert Lansing, Secretary of State, Westport 1970, s. 283 .

81 Guthrie pisał, że zignorowanie memorandum pogłębiało nieufność Japonii wobec Stanów Zjednoczonych. Guthrie to Bryan, November 7, 1914, BP, container 30.

82 D.D. Lazo, An Enduring Encounter ..., s. 264. Williams poparł później pomysł porozumienia japońsko-amerykańskiego na temat Fujianu, o którym będzie mowa w dalszej części rozdziału. Williams to Bryan, March 22, 1915, BP, container 59. 
wszystkich kupców i przedsiębiorców, nawet jeśli ponownie by się do tego zobowiązała.

O ile Williams zdawał się nie do końca przekonany do pomysłu porozumienia z Japonią, wątpliwości nie miał Lansing, najbardziej konsekwentny zwolennik takiego rozwiązania.

Jeśli udałoby się zawrzeć układ według tych wytycznych - pisał 1 marca, odnosząc się do memorandum Williamsa - uwolniłoby to nas od dokuczliwej kontrowersji dotyczącej ziemi w Kalifornii i zapobiegłoby w znacznej mierze przyszłym sporom, które wydają się prawie nieuniknione, jeśli pozwoli się obecnie, aby „żądania” Japonii przeszły bez sprzeciwu.

Lansing pytał się retorycznie: „Czy może być coś złego w próbie osiągnięcia dwustronnego porozumienia $[\ldots]$ ?.” i odpowiadał:

Na pewno nie będziemy w gorszej sytuacji, niż byliśmy przedtem; sądzę, że nawet jeśli nasza propozycja zostanie odrzucona, będziemy w o wiele lepszej pozycji do omawiania zachowania Japonii, kiedy nadejdzie bardziej sprzyjający czas na podjęcie z innymi zainteresowanymi mocarstwami kwestii „otwartych drzwi” $[\ldots]^{83}$.

Lansing, mający wykształcenie prawnicze i długoletnią praktykę w zawodzie, w mniejszym stopniu niż inne osoby współtworzące politykę zagraniczną kierował się sentymentem czy idealistycznymi przesłankami. Nie miał poczucia misji, nie był też emocjonalnie związany z Chinami. Bardziej koncentrował się na obronie amerykańskich praw i interesów, realnie kalkulując korzyści i straty. Zdecydowanie przedkładał pierwszą zasadę polityki „otwartych drzwi” nad drugą, i to w jej najbardziej sprecyzowanym brzmieniu z $1899 \mathrm{roku}^{84}$. Stąd jego wcześniejsza uwaga, aby nie zachowywać się jak rycerz z La Manchy, oraz popieranie koncepcji ułożenia stosunków z Japonią kosztem Chin. Chociaż Wilson i Bryan na początku marca odrzucili taką możliwość, Lansing nie zrezygnował z niej ani do końca kryzysu spowodowanego japońskimi żądaniami, ani w późniejszym czasie, gdy został sekretarzem stanu ${ }^{85}$.

Tak przedstawiały się najistotniejsze opinie docierające do Wilsona i Bryana, którzy mieli zdecydować o reakcji Waszyngtonu. Dosyć ogólnikowo głos w całej sprawie zabrał jeszcze Edward House, najbardziej wpływowy doradca prezydenta $\mathrm{w}$ polityce zagranicznej, ale raczej w aspektach innych niż

83 Lansing to Bryan, March 1, 1915, BP, container 45.

84 B. Beers, Vain Endeavor ..., s. 3-16, 19-23, 27-35. W późniejszym czasie Lansing przyjął wykładnię polityki „otwartych drzwi” zaproponowaną przez Johna Haya w lutym 1902 roku.

${ }^{85}$ Przypis nr $1 \mathrm{w} P W W$, t. 32, s. 323-324; B. Beers, Vain Endeavor ..., s. 36-51. 
dalekowschodni. 25 stycznia $\mathrm{w}$ rozmowie $\mathrm{z}$ Wilsonem i Lansingiem zalecił on dużą ostrożność, aby nie doszło do wojny z Japonią z powodu Chin ${ }^{86}$.

Bryan i Wilson w największym stopniu zdecydowali o kursie amerykańskiej dyplomacji podczas kryzysu wywołanego przez 21 żądań ${ }^{87}$. Początkowo aktywniejszy był Bryan, choć i na tym etapie wszystkie posunięcia konsultował z prezydentem, później natomiast stery bardziej zdecydowanie przejął Wilson. Pierwszym celem obu było uzyskanie pełnej informacji o japońskich żądaniach. Trwało to ponad miesiąc ze względu na wspomnianą już chęć zachowania przez Japonię negocjacji w tajemnicy i jej dwulicowość, ale także dlatego, że Bryan aż do 22 lutego, kiedy to ambasador Chinda wręczył mu listę wszystkich żądań, nie dowierzał istnieniu grupy piątej i skłonny był przyjąć zapewnienia Tokio, nawet wbrew opiniom swoich doradców i dyplomatów. 23 stycznia, tego samego dnia, gdy Reinsch po raz pierwszy zawiadomił o żądaniach, Bryan napisał do prezydenta $\mathrm{z}$ pytaniem, jak planuje załagodzić konflikt wynikający z antyjapońskich ustaw. Wilson odpowiedział, że owszem chce coś zrobić w tej kwestii, ale najpierw należy się zorientować, jakie są zamiary Japonii wobec Chin i czy będzie ona przestrzegać polityki „otwartych drzwi” ${ }^{88}$. Bryan zaczął bacznie przyglądać się rozwojowi wydarzeń, czekając na informacje od Brytyjczyków i wyjaśnienia $z$ Tokio. Nie dawał do końca wiary alarmującym doniesieniom Reinscha, memorandom Williamsa oraz - jak sam stwierdził „zapewne przesadzonym” - artykułom prasowym ${ }^{89}$. Wyczekującą pozycję zająl także Wilson, który 8 lutego napisał do Reinscha, że stara się działać zakulisowo na rzecz Chin, gdyż obawia się, że bezpośrednia ingerencja rozzłościłaby Japonię, mogącą wyładować swój gniew na Chinach. Wilson widział się w roli „rozważnego przyjaciela”, który dba o to, aby Wielka Brytania uzmysłowiła sobie „powage sytuacji”. „Na razie obserwuję sytuację naprawdę bardzo uważnie, gotów wkroczyć w każdym momencie, kiedy będzie rozsądne, aby to zrobić” - zapewnił ogólnikowo prezydent ${ }^{90}$.

86 From the Diary of Colonel House, January 25, 1915, [w: ] PWW, t. 32, s. 119-122.

87 Wilson i Bryan nie byli bynajmniej oddani tylko tej sprawie. Zajmowali się ciągle niestabilną sytuacją w Meksyku oraz kontynuowali pokojowe starania o zakończenie wojny (z misją do Europy udał się House). Przede wszystkim jednak absorbował ich narastający konflikt z Niemcami, gdy te 4 lutego ogłosiły, że będą atakować statki na wodach wokół Wysp Brytyjskich, a pod koniec marca zatopiły brytyjski liniowiec „Falaba”, w wyniku czego zginął Amerykanin. Wstęp do PWW, t. 32, s. vii-viii.

${ }_{88}$ The Secretary of State to President Wilson, January 23, 1915, [w:] PRFRUS, The Lansing Papers, 1914-1920, t. 2, Washington 1940, s. 399-400; President Wilson to the Secretary of State, January 27, 1915, [w: ] ibidem, s. 400.

89 The Secretary of State to Ambassador Page, February 2, 1915, [w:] PRFRUS 1915, s. 82 .

90 Wilson to Reinsch, February 8, 1915, WWP, series 2, reel 68. 
W przeciwieństwie do Wilsona, który wiedział już, że kryzys był poważny, Bryan ciągle uważał doniesienia prasowe za wyolbrzymione, co powtórzył 13 lutego $\mathrm{w}$ rozmowie $\mathrm{z}$ niemieckim ambasadorem Johannem Heinrichem von Bernstorffem $^{91}$. Reinsch, Guthrie i Williams daremnie próbowali wyprowadzić go z błędu i przekonać, że japońskie żądania obejmowały pięć grup, a nie cztery, znajdujące się na liście przekazanej przez Chindę 8 lutego. Bryan nie zmienił zdania. Memorandum z 15 lutego, w którym Williams nazwał działania Japonii „celowo zwodniczymi”, opatrzył komentarzem: „Uważam, że [Reinsch i inni - J.P.] się mylą. Wierzę japońskiemu ambasadorowi”" ${ }^{2}$. Następnego dnia rozmawiał z Chindą, który zdementował pogłoski i potwierdził swoją wersję. Bryan dociekał następnie źródła owych pogłosek, sugerując, że inspirowali je Niemcy, chcący zantagonizować Japonię z innymi mocarstwami. Chinda odparl, że to możliwe, lecz nie ma na to dowodów ${ }^{93}$. Sytuacja była doprawdy niecodzienna, jeśli nie kuriozalna: to Bryan podpowiedział wytłumaczenie ambasadorowi, a ten zareagował na nie w sposób umiarkowany.

Dopiero w ciągu kolejnych kilku dni, po tym jak 21 i 22 lutego Katō i Chinda przyznali się do żądań z grupy piątej, Bryan i Wilson zmienili nastawienie. Zaczęła w nich dojrzewać myśl o wystosowaniu formalnego protestu, chociaż jeszcze 23 lutego prezydent podczas konferencji prasowej wahał się, czy było to konieczne ${ }^{94}$. Dwa dni później nie miał już wątpliwości, być może w wyniku doniesień Reinscha, który pisał, że Chiny liczyły na amerykańską pomoc, a Japonia cały czas naciskała na wszystkie żądania ${ }^{95}$. Wilson popierał w miarę zdecydowaną notę, przynajmniej w stosunku do żądań z grupy piątej, przewidując, że będzie to najważniejszy dokument jego rządów ${ }^{96}$. O démarche myślał też Bryan, który jednak cały czas pozostawał pod niezrozumiałym w świetle wydarzeń ostatnich tygodni „urokiem” Japonii. W memorandum z 22 lutego w pełni przyjął on niesłychanie naciągane wyjaśnienie o podziale żądań na te sensu stricto i życzenia oraz nie wspomniał nawet o zwodniczości Japonii. Nieprzystawalność Bryana do świata dyplomacji uwidoczniła się jeszcze wyraźniej, gdy na podstawie telegramu

${ }^{91}$ Bryan's note, February 13, 1915, RDSRPRBChOS, roll 25.

92 Williams to the Secretary of State, February 15, 1915, RDSRPRBChOS, roll 23.

${ }_{93}$ Department Memorandum, February 16, 1915, [w:] PRFRUS 1915, s. 92. Wcześniej rzeczywiście pojawiły się pogłoski, że wystosowanie żądań stanowiło reakcję Japonii na szukanie przez Chiny zbliżenia z Niemcami. Reinsch zdecydowanie jednak odrzucił taką możliwość. Reinsch to Bryan, January 26, 1915, [w:] PWW, t. 32, s. 137-138; Reinsch to the Secretary of State, February 17, 1915, RDSRPRBChOS, roll 23; J. Polit, Odwrót znad Pacyfiku..., s. 68.

${ }_{94}$ Remarks at a Press Conference, February 23, 1915, [w:] PWW, t. 32, s. 273-274.

${ }_{95}$ Minister Reinsch to the Secretary of State, February 23, 1915, [w:] PRFRUS 1915, s. 97; A.S. Link, Wilson: The Struggle ..., s. 281.

${ }_{96}$ Wilson to Bryan, February 25, 1915, [w: ] PWW, t. 32, s. 287. 


\section{Chiny w polityce zagranicznej Stanów Zjednoczonych w latach 1911-1918}

dotyczącego potwierdzenia przez Katō żądań z grupy piątej wysnuł przypuszczenie, że Japonia zrezygnuje z nich m.in. na skutek amerykańskich działań. Co ciekawe, w dalszej części memorandum sekretarz stanu odniósł się wyłącznie do ostatniej grupy żądań, akceptując tym samym pozostałe. Jego zastrzeżenia budziły punkty dotyczące doradców, zakupu uzbrojenia, wspólnych sił policyjnych, koncesji kolejowych i Fujianu. Ale nawet obiekcje wyraził on w sposób umiarkowany, a przy okazji zasugerował, że Chiny mogłyby przekazać całą Mandżurię Japonii, o ile zapewniłoby to suwerenność reszcie kraju ${ }^{97}$.

Kwestię Mandżurii poruszyli następnie Williams i Lansing, którzy zaproponowali wspominane już porozumienie $z$ Tokio. Wilson i Bryan odrzucili je jednak, gdyż uznali to za załatwianie własnych problemów kosztem państwa trzeciego ${ }^{98}$. Rozpoczęto zatem przygotowanie noty, która odnosiłaby się tylko do japońskich żądań.

Kiedy trwały jeszcze prace nad jej tekstem, sytuacja na Dalekim Wschodzie uległa pogorszeniu. Powolny postęp negocjacji i konsekwentna odmowa Pekinu, aby rozmawiać o żądaniach z grupy piątej, w połączeniu ze zbliżającymi się wyborami, jak i obawą przed ewentualną ingerencją mocarstw sprawiły, że Japonia wystosowała ultimatum. 6 marca Hioki oświadczył, że jeśli do 12 marca Chiny „nie przyznają istotnych koncesji, środki pozadyplomatyczne” mogą zostać przedsięwzięte. Groźbę poparto wysłaniem dodatkowych wojsk do Chin ${ }^{99}$.

Rozwój wydarzeń mocno zaniepokoił Wilsona, który zaczął nalegać na przyśpieszenie prac nad notą, tak aby wręczyć ją przed upływem terminu wyznaczonego w ultimatum ${ }^{100}$. Ostatecznie się to nie udało i dopiero 13 marca notę przekazano Chindzie.

97 Bryan to Wilson, February 22, 1915, BP, container 45. 23 lutego, odpowiadając na list jednego z kongresmenów, Bryan napisał, że nie sądzi, aby negocjacje dotyczące 21 żądań mogły wpłynąć znacząco na status quo w Chinach. Hobson to Bryan, February 18, 1915, RDSRPRBChOS, roll 23; Bryan to Hobson, February 23, 1915, ibidem.

98 Wilson to Bryan, March 4, 1915, BP, container 59. Na początku maja pojawiła się w Pekinie informacja, że Bryan i Chinda doszli do porozumienia na temat Chin i Japończyków w Kalifornii. Sekretarz stanu kazał Reinschowi nieoficjalnie kategorycznie zaprzeczyć tym pogłoskom. Reinsch to the Secretary of State, May 3, 1915, RDSRPRBChOS, roll 24; Bryan to the American Legation at Peking, May 3, 1915, ibidem.

99 Minister Reinsch to the Secretary of State, March 8, 1915, [w:] PRFRUS 1915, s. 103-104; Ambassador Guthrie to the Secretary of State, March 11, 1915, [w: ibidem, s. 104; Minister Reinsch to the Secretary of State, March 12, 1915, [w: ] ibidem; Williams to Bryan, March 12, 1915, BP, container 59; Minister Reinsch to the Secretary of State, March 13, 1915, [w: ] PRFRUS 1915, s. 104. Cytat pochodzi z najwcześniejszego dokumentu. M. Chi, China Diplomacy..., s. 42-43.

100 Wilson to Bryan, March 10, 1915, [w:] PWW, t. 32, s. 353; Wilson to Bryan, March 12, 1915, [w:] ibidem, s. 367; Wilson to Bryan, March 12, 1915, BP, container 59. Napisanie noty zajęło trochę czasu, ponieważ była długa i pracowało nad nią kilka osób - Lansing, Williams i Bryan, a ostatnie poprawki naniósł Wilson. 
Miała ona niejednoznaczny wydźwięk, gdyż próbowała łączyć różne podejścia. Skrupulatnie wyliczono w niej zobowiązania międzynarodowe rządu tokijskiego względem Chin, jak i amerykańskie prawa wynikające z traktatów z tymiż. Stwierdzono, że część japońskich żądań narusza jedną z tych kategorii lub obie. Punkty dotyczące uzbrojenia i Fujianu były mianowicie sprzeczne z zasadą równego traktowania, a te mówiące o doradcach, policji, uzbrojeniu i nieodstępowaniu żadnej części wybrzeża godziły w suwerenność Państwa Środka. Waszyngton, który nie mógł „patrzeć z obojętnością”, gdy jakieś mocarstwo zdobywało „polityczną, militarną lub ekonomiczną dominację nad Chinami”, sugerował, aby z nich zrezygnować i przestrzegał przed próbą przymuszenia Pekinu do ich akceptacji, gdyż spotkałoby się to z negatywną reakcją Chińczyków i opozycją ze strony innych mocarstw.

Jednocześnie nota zawierała fragmenty przychylne Japonii. Amerykanie zgodzili się na wszystkie żądania z grup pierwszej i drugiej oraz na mniej istotne z grupy piątej (dotyczące nabywania gruntów, koncesji kolejowych i działalności misjonarskiej). Ważniejsza okazała się nawet nie sama zgoda, a jej uzasadnienie. Chociaż, jak zaznaczono, Stany Zjednoczone miały podstawy prawne, aby oponować przeciwko żądaniom w odniesieniu do Mandżurii, Mongolii Wewnętrznej i Shandongu, to uznając, że „przyległość terytorialna stwarza specjalne stosunki” między Japonią a tymi obszarami, wycofały wszelkie zastrzeżenia ${ }^{101}$.

Nota wyraźnie zaznaczała amerykański sprzeciw wobec konkretnych żądań i działań oraz przyzwolenie na inne. Potwierdzała przywiązanie do obu zasad polityki „otwartych drzwi” i chęć starania się o ich przestrzeganie. Nie do zaakceptowania były najbardziej rażąco sprzeczne z nimi żądania z grup czwartej i piątej. W zamian zdecydowano się uznać żądania dotyczące Shandongu, Mandżurii i Mongolii Wewnętrznej. Miało to skłonić Japonię do wycofania pozostałych żądań oraz rezygnacji z metod zastraszania. Dokument prezentował więc nie tylko amerykańskie stanowisko, ale sygnalizował też możliwość porozumienia w wyznaczonych ramach. Kluczowe sformułowanie całej noty było jednak niefortunne. Sugerowało, że sam fakt bliskości geograficznej stwarzał specjalne relacje, a nie - co mieli na myśli Williams i Lansing - że specjalna pozycja wynikała $\mathrm{z}$ zainwestowanych środków i kolonizacji ${ }^{102}$. Tak nieostre sformułowanie mogło zostać w przyszłości wykorzystane przez Japonię w stosunku do innych części Chin.

${ }^{101}$ The Secretary of State to the Japanese Ambassador, March 13, 1915, [w: ] PRFRUS 1915 , s. $105-111$.

${ }_{102}$ Zwraca na to uwagę Link. A.S. Link, Wilson: The Struggle ..., s. 285. Nie wiadomo, kto był autorem sformułowania „przyległość terytorialna”. Według Williamsa wymyślił je Bryan. D.D. Lazo, An Enduring Encounter ..., s. 275. 
Kolejna wada noty polegała na pominięciu trzeciej grupy żądań. Jaki był tego powód - zwykłe przeoczenie czy celowe działanie - nie sposób rozstrzygnąćco W każdym razie brak odniesienia sprawiał wrażenie, że Waszyngton albo nie interesował się tymi żądaniami, albo milcząco na nie przyzwalał.

Jeszcze poważniejszym problemem był brak spójności - powołanie się na politykę „otwartych drzwi” i prawa traktatowe przy pewnych żądaniach i kompletne się ich zrzeczenie w stosunku do Shandongu, Mandżurii i Mongolii Wewnętrznej. Amerykanie byli gotowi pójść na takie ustępstwo, aby zapobiec całkowitej wasalizacji Chin. Niemniej jednak stanowiło to niebezpieczny precedens.

Można zauważyć, że Wilson i Bryan, którzy odrzucili wcześniej propozycję uznania specjalnej pozycji Japonii w Mandżurii i Shandongu w zamian za uregulowanie kwestii japońskich imigrantów, nie wzbraniali się przed „przehandlowaniem” tych obszarów, jeśli Japonia zrezygnowałaby z większości żądań dotyczących całych Chin. Nawiązywało to do pomysłu Bryana, który uważał, że Chiny mogłyby oddać Mandżurię, gdyby ocaliły dzięki temu resztę kraju.

Nota z 13 marca jest w historiografii oceniana różnie - od niemal genialnego posunięcia poprzez umiarkowane osiągnięcie po wewnętrznie sprzeczny dokument, niezgodny z dotychczasową polityką i przyzwalający Japonii na dalszą ekspansję ${ }^{104}$. Skrajne opinie wydają się w tym przypadku nieuzasadnione. Noty nie należy postrzegać ani w kategoriach triumfu, ani porażki, a raczej jako wybrnięcie z sytuacji przy w miarę realnej ocenie układu sił, swoich możliwości i środków. Udało się klarownie wyłożyć amerykańskie stanowisko i doprowadzić do rozpoczęcia rozmów z Tokio, co pozwoliło uzyskać wpływ na negocjacje prowadzone w Pekinie. Cena manewru była znaczna - uznanie japońskiej dominacji na trzech obszarach, jednak wobec właściwie wykluczenia możliwości użycia siły, niechęci do eskalacji konfliktu z Tokio i niemrawej reakcji Londynu na próby współdziałania Waszyngtonowi nie pozostawało lepsze rozwiązanie. Oczywiście można było w całości potępić żądania, ale wówczas efekt byłby jeszcze gorszy, skoro także wariant z ustępstwami Japończycy, o czym będzie mowa, traktowali nie do końca poważnie.

Wręczenie noty 13 marca zwieńczyło drugi etap poświęcony formowaniu zrębu amerykańskiego stanowiska i rozpoczęło etap trzeci, podczas którego prowadzono rozmowy z Japonią na temat konkretnych żądań. Tego samego dnia

103 Lazo uważa, że mogło to być niedopatrzenie, co potwierdzałoby jego opinię, że cała nota stanowiła dyplomatyczny blamaż. D.D. Lazo, An Enduring Encounter..., s. 275. Beers twierdzi z kolei, że notę musiał napisać wytrawny dyplomata. B. Beers, Vain Endeavor..., s. 45.

104 Por. D.D. Lazo, An Enduring Encounter ..., s. 266, 275; B. Beers, Vain Endeavor ..., s. 44-45; A.S. Link, Wilson: The Struggle ..., s. 285; W. Rodziński, Historia Chin ..., s. 625; Tien-yi Li, Woodrow Wilson's ..., s. 115-116; A.W. Griswold, The Far Eastern ... , s. 192-193. 
streszczenie noty przesłano Guthriemu, aby mógł poinformować o niej Gaimusho $^{105}$. Katō zareagował podejrzliwie. Indagował ambasadora, czy notę napisano $\mathrm{z}$ inspiracji innego mocarstwa (w domyśle Wielkiej Brytanii) lub Chin. Guthrie zaprzeczyl, choć bardziej z obowiązku niż z przekonania, ponieważ nie znał szczegółów ${ }^{106}$. W rozmowie z brytyjskim ambasadorem Conynghamem Greene'em Katō z kolei wydrwił barokowe epistoły Bryana, ale z całej wymiany korespondencji z władzami amerykańskimi odniósł generalnie mylne wrażenie, że nie będą one protestować przeciwko żądaniom z grupy piątej. Utwierdziło to ministra w przekonaniu, że należy kontynuować naciski na Chiny, aby zaakceptowały wszystkie żądania ${ }^{107}$.

22 marca Japonia wyraziła zadowolenie, że jej specjalna pozycja w Shandongu, Mandżurii i Mongolii Wewnętrznej nie budziła zastrzeżeń Waszyngtonu. Następnie odniosła się do głównych zarzutów na temat doradców, uzbrojenia, policji i Fujianu. W pierwszej kwestii zaprzeczyła, jakoby chciała zmusić Chiny do wyrażenia zgody. Miała nadzieję, że dobrowolnie zatrudnią one japońskich doradców. Jeśli chodzi o uzbrojenie, to Japończycy tłumaczyli się, że ilość broni i amunicji, jaką Chiny miały nabyć, nie była sprecyzowana, a dążenie do wcześniejszego jej oszacowania wynikało wyłącznie z chęci lepszego przygotowania się do transakcji. Japonia nie mogła też zignorować faktu, że dotychczas znaczną część uzbrojenia dostarczały Chinom Niemcy i Austro-Węgry. Wspólna policja miała zaś działać tylko w Mandżurii i Mongolii, a więc na obszarach, na których specjalne uprawnienia Japonii nie były kwestionowane.

${ }^{105}$ Streszczenie noty otrzymał także Reinsch. Wilson chciał ją poza tym wysłać do Wielkiej Brytanii, Francji i Holandii, jeśli udałoby się uniknąć przecieku do prasy. Nie wiadomo, czy nota została ostatecznie wysłana do tych państw. Link podejrzewa, że nie, Lansing twierdzi, że do Wielkiej Brytanii i Francji tak. The Secretary of State to Minister Reinsch, March 13, 1915, [w:] PRFRUS 1915, s. 111; Wilson to Bryan, March 16, 1915, [w:] PWW, t. 32, s. 391; A.S. Link, Wilson: The Struggle ..., s. 283; R. Lansing, War Memoirs of Robert Lansing..., s. 283. Na przecieki do prasy i wścibstwo dziennikarzy skarżył się wcześniej Bryan, a później również Japonia, która sugerowała, że przecieki miały źródło w Pekinie, być może w amerykańskim poselstwie. Bryan to Wilson, February 18, 1918 [ewidentna pomyłka przy dacie rocznej], BP, container 45; Ambassador Guthrie to the Secretary of State, March 21, 1915, [w:] PRFRUS 1915, s. 113-115; Bryan to Wilson, April 9, 1915, [w:] PWW, t. 32, s. 499-500; Bryan to the American Legation at Peking, April 9, 1915, RDSRPRBChOS, roll 24; Reinsch to the Secretary of State, April 12, 1915, RDSRPRBChOS, roll 23.

106 Ambassador Guthrie to the Secretary of State, March 17, 1915, [w:] PRFRUS 1915, s. 112.

107 J. Polit, Odwrót znad Pacyfiku..., s. 75; R.J. Gowen, Great Britain ..., s. 103; N. Kawamura, Turbulence in the Pacific: Japanese-U.S. Relations during World War I, Westport 2000, s. 47. 
Najwięcej miejsca poświęcono wyjaśnieniom dotyczącym Fujianu. Japończycy podkreślili, że ich żądanie nie było ewenementem, a podobne prawa pierwszeństwa przysługiwały Wielkiej Brytanii, Francji i Niemcom w innych prowincjach. Istotniejsze było jednak, że Fujian znajdował się naprzeciwko Tajwanu i z tego powodu Japonia nie mogła tam tolerować żadnych innych wpływów cudzoziemskich. Otrzymała już co prawda deklarację o nieodstępowaniu tej prowincji, ale ponieważ w Chinach koncesje ekonomiczne splatały się nierozerwalnie z pozycją polityczną, potrzebowała dodatkowych gwarancji. Z satysfakcją przypomniała też Amerykanom o kontrakcie Bethlehem Steel oraz o epizodzie z 1900 roku, kiedy to sekretarz stanu John Hay, ten sam, który zainicjował politykę „otwartych drzwi”, podjął starania o dzierżawę bazy morskiej w Fujianie. Japończycy mogli jednak przemyśleć żądanie, jeśli rząd amerykański przyrzekłby, że obywatele USA nie zaangażują się w żadne przedsięwzięcia w tej prowincji ${ }^{108}$.

Japońskie tłumaczenia bardzo pozytywnie przyjął Bryan, który właściwie skłonny był w całości w nie uwierzyć. Podchwycił pomysł porozumienia w sprawie Fujianu i chciał, aby stało się ono bardziej uniwersalne. Chiny miałyby zawrzeć odpowiedni układ z Japonią, który potwierdziłyby Stany Zjednoczone ${ }^{109}$.

Ze zdecydowanie większym sceptycyzmem zareagował na tłumaczenia Wilson, już wcześniej prezentujący bardziej stanowcze nastawienie niż Bryan. Być może nota z 13 marca, mimo że ją zatwierdził, nie do końca odzwierciedlała jego poglądy, ale zależało mu na jak najszybszym przedstawieniu jej Tokio ze względu na upływające ultimatum. Obecnie, gdy presja czasu była mniejsza, ponownie zasygnalizował swoje wątpliwości. Chociaż zgodził się na rozwiązanie dotyczące Fujianu, to pozostałe sprawy nadal uważał za problematyczne.

Szczerze mówiąc, nie uważam, że wyjaśnienia pozostałych «życzeń» zawarte w nocie ambasadora Chindy są przekonujące $[. .$.$] . Całkowicie rozumiem przedstawio-$ ne motywy. [...] Ale uważam, że rozwiązania i zabezpieczenia zaproponowane $\mathrm{w}$ «życzeniach» idą za daleko. Bez względu na intencję, stanowią one faktycznie poważne ograniczenie swobody działania Chin oraz dają Japonii bardzo wyraźne pierwszeństwo przed innymi narodami, dla których drzwi miały być otwarte ${ }^{110}$.

108 Unofficial Memorandum left by Ambassador Chinda, March 22, 1915, [w: ] PWW, t. 32, s. 416-421. Zobacz też: Ambassador Guthrie to the Secretary of State, March 17, 1915, [w: ] PRFRUS 1915, s. 112; Ambassador Guthrie to the Secretary of State, March 21, 1915, [w: ibidem, s. 113-115.

109 Bryan to Wilson, March 22, 1915, BP, container 45; Bryan to Wilson, March 25, 1915, BP, container 59.

110 Wilson to Bryan, March 24, 1915, [w: ] PWW, t. 32, s. 426. 
Bryan nie podzielał tych obaw i nadal był nastawiony projapońsko. Jego dwa listy do Wilsona pokazują, jak mocno trzymał się swojego kursu. Widać to zarówno po szczegółowych rozwiązaniach, w których co prawda starał się znaleźć formułę pozwalającą złagodzić żądania z grupy piątej, ale generalnie ich nie odrzucal, jak i po bardziej ogólnych komentarzach.

Ponieważ Japonia i Chiny muszą pozostać sąsiadami - pisał 25 marca - jest ogromnie ważne, żeby byli dobrosąsiedzcy, a ducha dobrosąsiedztwa nie można oczekiwać, jeśli Japonia zażąda zbyt wiele lub jeśli Chiny przyznają zbyt mało. Jest całkiem oczywiste, że każde z państw jest podejrzliwe wobec drugiego ${ }^{111}$.

Wątki podejrzliwości i stosunków dobrosąsiedzkich pojawily się też w drugim liście z 6 kwietnia.

To, co najbardziej niepokoi mnie w tym konflikcie wschodnim, to atmosfera podejrzliwości po obu stronach - atmosfera, która nie daje gwarancji pokoju. Te dwa narody muszą pozostać sąsiadami, i o ile nie będą postępowały względem siebie $\mathrm{w}$ duchu przyjaźni, nie ma mowy, aby uniknąć silnego antagonizmu ${ }^{12}$.

Zdumiewające jest, jak opacznie Bryan odczytywał całą sytuację. Podchodził do obu państw jednakowo, a przecież role agresora i atakowanego były jasno sprecyzowane. Pisał o wzajemnej podejrzliwości, na równi traktując uzasadnione obawy strony chińskiej i naciągane japońskiej, która rzekomo miała z niepokojem patrzeć na niemieckie intrygi w Chinach. Uznawał, że władze pekińskie powinny przyjąć część żądań i przyjaźnie ułożyć stosunki z Tokio. Zdawał się naprawdę wierzyć, że było to słuszne rozwiązanie, które pozwoliłoby zachować pokój na Dalekim Wschodzie. Twierdził tak w prywatnej korespondencji do prezydenta, w której mógł sobie pozwolić na szczerość. Co innego, gdyby uznał, że Japonia była agresorem, ale w obecnych okolicznościach nie można jej było powstrzymać - dlatego, aby uchronić pokój, Chiny musiałyby się zgodzić na część jej żądań. Byłaby to w miarę realistyczna ocena, a tak wyglądało to na kompletne niezrozumienie sytuacji.

Opinie Bryana i Wilsona zaczęły się coraz poważniej rozmijać, m.in. w wyniku kolejnych informacji od Reinscha na temat przebiegu negocjacji. Powolne ustępstwa Chin sprawiły, że Japonia wycofała się z ultimatum i kontynuowała rozmowy, chociaż nie satysfakcjonowało jej ich tempo. Nie zrezygnowała więc $\mathrm{z}$ wywierania presji, przerzucając kolejne oddziały wojska do Chin. W Pekinie obawiano się, że Japonia prowadzi negocjacje już tylko pro forma, a zdecydowała

111 Bryan to Wilson, March 25, 1915, BP, container 59.

112 Bryan to Wilson, April 6, 1915, BP, container 45. 
się na rozwiązanie siłowe. Reinsch spodziewał się, że wkrótce wystosowane zostanie kolejne ultimatum ${ }^{113}$.

Niepokojących wieści było więcej. Japonia zniechęcała Chińczyków do oporu, twierdząc, że nie mają co liczyć na pomoc Stanów Zjednoczonych, bo te zapewniły, że nie będą protestowały przeciwko jej działaniom. Ponadto w relacjach z Pekinem Japonia podobno nigdy nie rozróżniała żądań od życzeń i ciągle naciskała na przyjęcie grupy piątej. Reinsch zwracał uwagę, że część żądań ma ogólny charakter i nie uda się ich zaspokoić konkretnymi koncesjami. Podkreślał szkodliwość żądań z grupy trzeciej, zapewne pamiętając, że Bryan nie odniósł się do nich w swojej nocie ${ }^{114}$.

Całą sytuację komplikował nasilający się bojkot japońskich towarów, rozpoczęty przez Chińczyków w geście protestu. Władze pekińskie starały się go tłumić i mimo japońskich prowokacji unikać innych zatargów, nie chcąc dać pretekstu do interwencji zbrojnej ${ }^{115}$. Reinsch pisał o delikatnym położeniu reżimu Yuana, któremu groziła z jednej strony agresja z zewnątrz, z drugiej - rewolucja wewnętrzna. Reinsch, podobnie jak wielu innych cudzoziemców w Państwie Środka, ostrzegał, że jeśli Japonii udałoby się podporządkować Chiny, zagrażałoby to pokojowi na Dalekim Wschodzie, a nawet na całym świecie ${ }^{116}$.

Reinsch wyraził również opinię na temat amerykańskich działań. W osobistym liście do prezydenta z 22 marca przekonywał, że obrona Chin nie tylko wpisywała się w tradycyjną politykę USA, ale mogła także zniechęcić do „wszelkich prób kształtowania przeznaczenia wielkich narodów za pomocą tajnej

113 Ambassador Guthrie to the Secretary of State, March 17, 1915, [w:] PRFRUS 1915, s. 112; Minister Reinsch to the Secretary of State, March 22, 1915, [w: ibidem, s. 115; Reinsch to Bryan, March 24, 1915, BP, container 59; Reinsch to the Secretary of State, March 25, 1915, RDSRPRBChOS, roll 23; Reinsch to Bryan, March 31, 1915, [w:] $P W W$, t. 32, s. 461.

114 Reinsch to Bryan, March 24, 1915, BP, container 59; Reinsch to Bryan, March 31, 1915, [w:] PWW, t. 32, s. 461; Reinsch to the Secretary of State, April 12, 1915, RDSRPRBChOS, roll 23; PRFRUS 1915, s. 118-122, 124-126.

115 Reinsch to the Secretary of State, March 27, 1915, RDSRPRBChOS, roll 23; Minister Reinsch to the Secretary of State, March 30, 1915, [w: ] PRFRUS 1915, s. 117-118. Na temat bojkotu i działań władz chińskich zobacz też np.: Heintzleman to Reinsch, March 18, 1915, RDSRIACh, roll 14; Heintzleman to Reinsch, March 25, 1915, ibidem; Cheshire to Reinsch, April 2, 1915, ibidem; Heintzleman to Reinsch, April 10, 1915, ibidem; Cheshire to Reinsch, April 15, 1915, ibidem; Peck to the Secretary of State, A pril 20, 1915, ibidem; Cheshire to Reinsch, April 26, 1915, ibidem; Pontius to Reinsch, June 19, 1915, ibidem; Z. Luo, National Humiliation and National Assertion: The Chinese Response to the Twenty-One Demands, „Modern Asian Studies" 1993, t. 27, nr 2, s. 300-305.

116 Minister Reinsch to the Secretary of State, April 5, 1915, [w:] PRFRUS 1915, s. 119-122. 
dyplomacji popartej siłą"117. Takie odniesienie, które Reinsch uczynił świadomie, wiedząc o ambicjach prezydenta, mogło przekonać Wilsona, zainteresowanego wyznaczeniem nowych standardów w stosunkach międzynarodowych.

Duże wrażenie wywarł na pewno kolejny list Reinscha z 30 marca $^{118}$, w którym zakwestionował on podejście Bryana i jego ostatnie instrukcje dla Guthriego, zawierające kompromisową odpowiedź na żądania z grupy piątej ${ }^{119}$. Chińczycy byli tak wrogo nastawieni do żądań, przekonywał Reinsch, że gdyby dowiedzieli się o amerykańskiej odpowiedzi, najprawdopodobniej uznaliby ją za zdradę ich interesu. Reinsch chciał, aby instrukcje zostały cofnięte także dlatego, że wpłynęłyby na zaostrzenie stanowiska Japonii. Radzil, że jeśli Departament Stanu nie zamierza przeciwstawić się Japonii, to niech lepiej prowadzi politykę „biernego przyzwolenia", aniżeli angażuje się w taki sposób, który wywoła oburzenie w Chinach ${ }^{120}$. Bezczynność i nieprzyjście z pomocą mogły jednak sprawić, ostrzegał poseł 8 kwietnia, że Chiny ulegną namowom Japonii, która kusiła wizją połączenia sił obu państw azjatyckich w celu usunięcia z Państwa Środka wpływów ludzi rasy białej ${ }^{121}$.

Wilson i Bryan zareagowali odmiennie na listy Reinscha. O ile prezydent wydawał się zmartwiony i chciał coś zrobić, to szef dyplomacji bronił swoich dotychczasowych działań i starał się podważyć trafność doniesień z Pekinu. 25 marca Wilson poprosił Bryana, aby powiedział Chindzie o amerykańskich obawach i spytał, czy negocjacje rzeczywiście zostaną przerwane i dojdzie do interwencji zbrojnej ${ }^{122}$. Po przeczytaniu listu z 30 marca ponownie wyraził zaniepokojenie i poparł wyjaśnienia napisane przez Bryana, mając nadzieję, że naprawią one złe wrażenie $^{123}$.

117 Reinsch to Wilson, March 22, 1915, WWP, series 2, reel 69. Reinsch już wcześniej dzielił się z Wilsonem swoimi przemyśleniami na temat możliwości zakończenia wojny i ułożenia ładu światowego. Reinsch to Wilson, January 4, 1915, [w:] PWW, t. 32, s. 11-12.

118 Tego samego dnia Reinsch przesłał do Departamentu Stanu wiadomość od Juleana Arnolda, attaché handlowego, który alarmował, że jeśli żądania japońskie zostaną przyjęte, amerykańskie interesy handlowe w Chinach poważnie na tym ucierpią. Reinsch to the Secretary of State, March 30, 1915, RDSRPRBChOS, roll 23.

119 Bryan to the American Embassy at Tokyo, March 25, 1915, BP, container 59. Instrukcje zaakceptował Wilson. Bryan to Wilson, March 25, 1915, ibidem.

120 Reinsch to Bryan, March 30, 1915, [w: ] PWW, t. 32, s. 459-460. W sierpniu 1914 roku Reinsch ostrzegał, że jeśli Waszyngton pozostawi Chiny same wobec japońskich prób zdominowania, podziw Chińczyków dla Stanów Zjednoczonych może się bardzo szybko przekształcić w nienawiść. Reinsch to the Secretary of State, August 27, 1914, RDSRPRBChOS, roll 24.

${ }_{121}$ Reinsch to the Secretary of State, April 8, 1915, RDSRPRBChOS, roll 23.

${ }^{122}$ Wilson to Bryan, March 25, 1915, BP, container 59.

123 Wilson to Bryan, March 31, 1915, [w: $P W W$, t. 32, s. 461. 
Zarzuty Reinscha musiały poważnie skonfundować dotychczas pewnego siebie Bryana, bo jego wyjaśnienia były wymijające i napisane z pozycji defensywnej. „Jest nam bardzo przykro - konkludował rozgoryczony - jeśli rada, jaką daliśmy obu narodom w duchu życzliwości, miałaby się okazać nie do zaakceptowania, ale ponieważ została dana jako rada, nie jest bardziej wiążąca dla Chin niż dla Japonii” ${ }^{124}$. Wycofanie instrukcji dla Guthriego nie było możliwe, gdyż o ich treści poinformowano już Japonię ${ }^{125}$.

Niedługo później Bryan przeszedł z pozycji obronnej do bardziej ofensywnej. Zaczął dociekać, jak wyglądała sprawa żądań dotyczących Hanyepingu. Po uzyskaniu zapewnień od Katō, że koncesja miała obejmować niewielki obszar, chyba z pewną satysfakcją napisał do Wilsona, że „stawia to japońskie żądanie w zupełnie innym świetle" niż w liście Reinscha, według którego Japonia miała zawładnąć całą doliną Jangcy ${ }^{126}$. Bryan ponownie, jakby w ogóle nie pamiętając o wcześniejszych doświadczeniach, przyjął w pełni wyjaśnienia z Tokio, choć tym razem usprawiedliwiać go może fakt, że taką samą interpretację Katō przedstawił Brytyjczykom ${ }^{127}$.

W połowie kwietnia dotarly do Waszyngtonu kolejne informacje od Reinscha, które ostatecznie wpłynęły na zmianę amerykańskiej polityki i odejście od łagodnego kursu Bryana na rzecz bardziej zdecydowanych działań. 14 kwietnia w ściśle tajnym liście Reinsch alarmowal, że Japonia po raz kolejny wmawiała Chinom, że nie mają co liczyć na pomoc Waszyngtonu, gdyż zaakceptował on jej żądania. Takie sądy wypowiadane były nie tylko w gabinetach dyplomatów, pojawiały się również $\mathrm{w}$ prasie kształtującej opinię publiczną. Reinsch podawał jako przykład artykul, w którym z ubolewaniem stwierdzono, że Stany Zjednoczone wyrzekły się polityki „otwartych drzwi”, a Bryan - według przytoczonej opinii jednego z prominentnych Japończyków - znajdował się pod tak przemożnym wpływem Chindy, że w żaden sposób mu się nie sprzeciwial. W tych okolicznościach Reinsch nalegal, aby nieoficjalnie, acz zdecydowanie odciąć się od tego typu oskarżeń i potwierdzić, że Stany Zjednoczone nie zrezygnowały ani

124 Bryan to the American Legation at Peking, March 31, 1915, [w:] PWW, t. 32, s. 460-461; A.S. Link, Wilson: The Struggle ..., s. 289.

125 Bryan to Chinda, March 30, 1915, BP, container 45; A.S. Link, Wilson: The Struggle..., s. 290.

126 Bryan to Wilson, April 2, 1915, [w: ] PWW, t. 32, s. 466-467; Bryan to the American Embassy at Tokyo, April 2, 1915, [w: ibidem, s. 467; Bryan to the American Legation at Peking, April 2, 1915, [w: ] ibidem; Bryan to Wilson, April 6, 1915, BP, container 45; The Ambassador in Japan (Guthrie) to the Secretary of State, April 6, 1915, [w:] PRFRUS, The Lansing Papers, 1914-1920, t. 2, s. 415-416. Cytat pochodzi z czwartego z wymienionych dokumentów.

127 The Ambassador in Japan (Guthrie) to the Secretary of State, April 6, 1915, [w:] PRFRUS, The Lansing Papers, 1914-1920, t. 2, s. 415-416. 
ze swoich praw, ani z „zobowiązań moralnych” wobec Chin. Chcial, aby dodano, że w razie naruszenia tychże praw i zobowiązań jego państwo zastrzegało sobie możliwość podjęcia odpowiednich działań ${ }^{128}$.

Dzień wcześniej dotarł do Departamentu Stanu inny list Reinscha, wysłany przez niego zwykłą pocztą 6 marca. Zestawiono w nim dwie listy japońskich żądań - oryginalną, którą Hioki przekazał Yuanowi, z tą, którą wręczył Reinschowi 14 lutego. Oczywiście druga była okrojoną wersją pierwszej. Nie mogło to wywołać wielkiego poruszenia w Waszyngtonie, bo sprawa była już dobrze znana, niemniej list przypomniał o japońskiej nieszczerości ${ }^{129}$.

Antyjapońskie nastroje podsycał również list otrzymany przez Wilsona około 12 kwietnia od amerykańskich misjonarzy i nauczycieli przebywających w Chinach. Prosili oni, aby Stany Zjednoczone doprowadziły do zwołania konferencji międzynarodowej, na której zajęto by się sprawą 21 żądań. Podkreślali z jednej strony pokojowe usposobienie Chin i ich zdolność do samodzielnego rządzenia się, z drugiej japoński imperializm i militaryzm, które tak samo jak w przypadku państw europejskich powinny zostać powstrzymane ${ }^{130}$. Podobnie oskarżycielskie w tonie i wzywające do działania były listy biskupa Jamesa Bashforda, który osobiście napisał do Wilsona i Bryana ${ }^{131}$.

Czas na tego typu petycje był w Waszyngtonie odpowiedni. Akurat w kwietniu pojawiły się w amerykańskiej prasie niepokojące artykuły na temat aktywności

128 Reinsch to Bryan, April 14, 1915, [w: ] PWW, t. 32, s. 519-520.

129 Minister Reinsch to the Secretary of State, March 6, 1915, [w:] PRFRUS 1915, s. 98-103; Bryan to Wilson, A pril 16, 1915, [w: ] PWW, t. 32, s. 529-530; A.S. Link, Wilson: The Struggle..., s. 291. Williams skomentował, że Japonia cały czas świadomie zwodziła Stany Zjednoczone. Williams to the Secretary of State, April 13, 1915, RDSRPRBChOS, roll 23.

130 Wilson to Bryan, April 12, 1915, [w: ] PWW, t. 32, s. 508-509 (przypis nr 1). Później okazało się, że rząd chiński pokrył koszty przesłania tego listu telegraficznie do Stanów Zjednoczonych. R.W. Curry, Woodrow Wilson and Far Eastern Policy..., s. 122.

131 Bashford to Wilson, March 12, 1915, [w:] PWW, t. 33, Princeton 1980, s. 23-26; Bashford to Bryan, March 12, 1915, [w: ] ibidem, s. 31-37. Zobacz też: Bryan to Wilson, April 27, 1915, [w: ] ibidem, s. 80. Bardzo krytycznie o Japonii wyraził się też MacMurray w liście do Wilsona z początku kwietnia. Od rozpoczęcia kryzysu przeciwko 21 żądaniom wypowiadali się niektórzy misjonarze, biznesmeni oraz amerykańska prasa. Sammons to Reinsch, February 25, 1915, RDSRPRBChOS, roll 23; Reinsch to the Secretary of State, March 6, 1915, ibidem; Reinsch to the Secretary of State, March 7, 1915, ibidem; R.W. Curry, Woodrow Wilson and Far Eastern Policy..., s. 121; J. Ch'ên, Yuan Shih-k'ai..., s. 191; D.M. Crane, T.A. Breslin, An Ordinary Relationship: American Opposition to Republican Revolution in China, Gainesville 1986, s. 143-144; E.P. Trani, Woodrow Wilson, China, and the Missionaries, 1913-1921, „Journal of Presbiterian History" 1971, t. 49, nr 4, s. 343-345. 
Japończyków w meksykańskiej Zatoce Żółwiej ${ }^{132}$. Administracja Wilsona nie bagatelizowała tych doniesień, pamiętając niedawne japońskie próby skaperowania Pancho Villi ${ }^{133}$.

W połowie kwietnia pączkująca w Wilsonie od jakiegoś już czasu idea przeciwstawienia się Japonii środkami dyplomatycznymi zaczęła przybierać bardziej realne ksztalty. 13 kwietnia podczas konferencji prasowej prezydent zaprzeczył informacjom rozgłaszanym przez japońskich negocjatorów, jakoby USA powiedziały Chinom, że nie mogą liczyć na amerykańską pomoc ${ }^{134}$. Następnego dnia Wilson pisał zaś do Bryana:

Jestem bardzo zaniepokojony tym, co - jak donosi Pan Reinsch - się dzieje, i muszę szczerze przyznać, że nie wierzę zapewnieniom, które Japończycy starają się nam dać. [...] Krótko mówiąc, uważam, że powinniśmy tak aktywnie, jak okoliczności na to pozwalają, pokazywać, że obecnie, jak zawsze, jesteśmy orędownikami suwerennych praw Chin, lecz bez zamiaru ubiegania się o jakąkolwiek specjalną korzyść czy przywilej dla siebie.

Dwa dni później prezydent dodawał:

Jestem przekonany, że powinniśmy próbować bronić Chin w każdy wykonalny sposób. [...] Musimy być odtąd bardzo ostrożni, gdy wydajemy się uznawać zasadność jakichkolwiek żądań czy też życzeń Japonii, zanim [...] nie usłyszymy z Pekinu, jak i z Tokio.

Szczególnie niepokoiły Wilsona naciski Japonii na przyjęcie grupy piątej oraz oświadczenia premiera Ōkumy, który powiedział, że Amerykanie zaakceptowali żądania ${ }^{135}$.

132 Obecność Japończyków w Zatoce Żółwiej spowodowana była koniecznością oswobodzenia krążownika „Asama”, który w grudniu 1914 roku wpadł tam na skały. W kwietniu następnego roku prasa w Los Angeles podniosła larum, że Japończycy utworzyli bazę morską i zaminowali zatokę. Doniesienia okazały się nieprawdziwe. Bryan to Wilson, April 15, 1915, [w: $P W W$, t. 32, s. 524-525; Wilson to Bryan, April 16, 1915, [w: ] ibidem, s. 528-529; Bryan to Wilson, April 16, 1915, [w: ibidem, s. 529-530; Chinda to Bryan, April 19, 1915, BP, container 59; Kato to Chinda, April 19, 1915, ibidem; Bryan to Wilson, April 19, 1915, ibidem.

${ }_{133}$ R.W. Curry, Woodrow Wilson and Far Eastern Policy ..., s. 132.

${ }_{134}$ Remarks at a Press Conference, April 13, 1915, [w: $P W W$, t. 50, s. 717-719.

135 Wilson to Bryan, April 14, 1915, BP, container 45; Wilson to Bryan, April 16, 1915, [w: ] PWW, t. 32, s. 531. Zob. też: Guthrie to the Secretary of State, March 19, 1915, RDSRPRBChOS, roll 23. 
Tym razem także Bryan, być może z powodu niepochlebnej wzmianki o nim, był bardziej skory do przyjęcia prezydenckiego punktu widzenia ${ }^{136}$. Obaj zdecydowali się wysłać instrukcje dla Reinscha zbieżne z tymi, które poseł postulowal, z pominięciem jedynie zastrzeżenia o możliwości podjęcia odpowiednich działań. Reinsch miał nieoficjalnie poinformować, że Stany Zjednoczone nie zrzekły się żadnych swoich praw ani nie przestały interesować się „przemysłowym i politycznym dobrem Chin”. W świetle noty z 13 marca rozmijało się to z prawdą, o czym wiedział Bryan, a o czym zdaje się zapomniał Wilson. Prezydent chciał nawet iść dalej i powiadomić Reinscha, że nie przystano na żadne żądania. Bryan, zdając sobie sprawę, że przeczyłoby to wcześniejszym deklaracjom, znalazł kompromisowe rozwiązanie - dodał taki ustęp, ale tylko do wiedzy Reinscha ${ }^{137} .16$ kwietnia amerykański poseł przekazał stanowisko swojego rządu władzom pekińskim, które odczytały je jako wsparcie i stały się - przynajmniej w ocenie japońskich i rosyjskich dyplomatów - mniej skłonne do ustępstw w negocjacjach ${ }^{138}$.

Oprócz wysłania instrukcji Bryan uznał za konieczne przeciwdziałanie sytuacjom, w których Japonia wypowiadała się w imieniu Amerykanów. W tym celu poradził Chińczykom, aby zwracali się bezpośrednio do USA po potwierdzenie stanowiska, gdy Japonia się na nie powoła ${ }^{139}$. Sekretarz stanu dostrzegł też w końcu niebezpieczeństwo wynikające z żądań dotyczących Hanyepingu i przy poparciu Wilsona zamierzał o tym porozmawiać $\mathrm{z}$ Chindą ${ }^{140}$.

Sprzeciw wobec żądań z grupy trzeciej zawarł Bryan w nocie przekazanej japońskiemu ambasadorowi pod koniec kwietnia. Wyraził ponadto obawy związane ze wzrostem liczby japońskich żołnierzy w Chinach oraz przekonanie, że podział na żądania i życzenia, o którym poinformowano różne mocarstwa, nie został „dostatecznie jasno” wyłożony Chinom, przez co doszło do nieporozumień i kontrowersji. Bryan zasygnalizował również, że w najbliższym czasie upubliczni amerykańskie stanowisko, aby uciąć spekulacje ${ }^{141}$.

Za ujawnieniem opowiedział się wcześniej Wilson, który uważał, że piętą achillesową dotychczasowych wystąpień był właśnie ich tajny charakter. Chciał

${ }^{136}$ Nie jest wykluczone, że Reinsch specjalnie przytoczył artykuł dotyczący akurat Bryana, licząc, że poruszy w nim czułą strunę.

${ }_{137}$ Wilson to Bryan, April 14, 1915, BP, container 45; Bryan to the American Legation at Peking, April 15, 1915, [w:] $P W W$, t. 32, s. 520. Cytat pochodzi z drugiego dokumentu. A.S. Link, Wilson: The Struggle ..., s. 294-295.

${ }_{138}$ N. Kawamura, Turbulence in the Pacific ..., s. 26-27, 29, 52.

139 Bryan to Wilson, April 15, 1915, BP, container 45; Bryan to the American Legation at Peking, April 16, 1915, [w:] PWW, t. 32, s. 528.

140 Bryan to Wilson, April 16, 1915, [w:] PWW, t. 32, s. 529-530; Wilson to Bryan, April 16, 1915, [w:] ibidem, s. 531.

${ }^{141}$ Bryan to Chinda, April 27, 1915, [w: ] PWW, t. 33, s. 82-84. 
jednocześnie zapewnić Chiny, że popiera ich sprzeciw wobec wygórowanych żądań. Za radą Reinscha proponował, aby zachęcić inne mocarstwa do wyrażenia opinii. Bryan był bardziej wstrzemięźliwy, obawiał się, że członkowie ententy nie zdecydują się na taki krok, a zwrócenie się do Niemiec było z oczywistych powodów wykluczone. Ostatecznie ustalono, że wręczając notę, Bryan powie Chindzie, iż planowane oświadczenie może przybrać formę noty cyrkularnej, której adresaci zostaną poproszeni o komentarz ${ }^{142}$.

Nim Departament Stanu wydał swoje oświadczenie, negocjacje japońsko-chińskie wkroczyły w ostateczną fazę. 26 kwietnia Hioki przedstawił zmienioną wersję żądań, w której z pewnych punktów zrezygnowano lub je zmodyfikowano. Japonia wycofała się z prawa weta dla Hanyepingu oraz z pomysłu wspólnej policji. Złagodziła wymowę żądań dotyczących doradców, uzbrojenia i koncesji kolejowych z grupy piątej, a dyskusję na temat praw misjonarzy odłożyła na później. Przyrzekła poza tym zwrot Jiaozhou, obwarowany co prawda koniecznością kolejnych ustępstw ${ }^{143}$.

1 maja rząd pekiński przedstawił kontrpropozycję, która jednak nie zadowoliła Japonii. Przedłużające się negocjacje i coraz większe zaangażowanie innych mocarstw sprawiły, że zdecydowała się ona szybko załatwić sprawę i 7 maja przedstawiła kolejne ultimatum. Chinom dano czas do 9 maja na przyjęcie warunków zaproponowanych 26 kwietnia, ale z wyłączeniem żądań z grupy piątej, mającej być przedmiotem przyszłych rozmów. Jedynie kwestia Fujianu miała zostać obecnie uregulowana ${ }^{144}$.

Te wydarzenia pobudzily amerykańską dyplomację do jeszcze energiczniejszych działań. Otrzymawszy tekst propozycji z 26 kwietnia, Bryan wydawał się zadowolony z ustępstw poczynionych przez Japonię, zwłaszcza że przypisywał je swoim sugestiom. Nadal miał różne zastrzeżenia wobec grupy piątej, lecz dotyczyły one głównie sformułowań i właściwie tylko w przypadku punktu

142 Reinsch to the Secretary of State, April 24, 1915, RDSRPRBChOS, roll 23; Bryan to Wilson, April 27, 1915, [w:] PWW, t. 33, s. 80; Wilson to Bryan, April 27, 1915, [w: ] ibidem, s. 81; Bryan to Wilson, April 28, 1915, [w:] ibidem, s. 82; Wilson to Bryan, April 28, 1915, [w: ] ibidem, s. 85; R.W. Curry, Woodrow Wilson and Far Eastern Policy..., s. 123-124. Link twierdzi, choć nie powołuje się na żadne dokumenty, że Bryan zapomniał jednak o tym powiedzieć Chindzie. A.S. Link, Wilson: The Struggle ..., s. 297-298.

143 The Amended Japanese Proposals, April 26, 1915, [w: ] The Sino-Japanese ..., s. 1019. Tekst propozycji przekazany Amerykanom był trochę inny. The Japanese Embassy to the Department of State, undated, handed on April 30, 1915, [w: ] PRFRUS 1915, s. 128-130.

144 The Final Amended Project of the Chinese Government, May 1, 1915, [w: ] The Sino-Japanese..., s. 23-31; The Japanese Foreign Office to the Japanese Ambassador, May 6, 1915, [w:] PRFRUS 1915, s. 141-142; Minister Reinsch to the Secretary of State, May 6, 1915, [w: ] ibidem, s. 144; Minister Reinsch to the Secretary of State, May 7, 1915, [w:] ibidem; Minister Reinsch to the Secretary of State, May 17, 1915, [w: ibidem, s. 148-150. 
o uzbrojeniu były poważniejsze. Ponieważ zmodyfikowana propozycja zawierała nowe żądania w innych grupach, Bryan wyraził też sprzeciw wobec pewnych kwestii dotyczących Mandżurii, mimo że wcześniej uznał specjalną pozycję Japonii na tym terenie. Był więc $\mathrm{z}$ jednej strony ciągle w miarę przychylny Japonii, z drugiej, podobnie jak Wilson, wykazywał chęć do kwestionowania jej żądań, nawet wbrew swoim wcześniejszym deklaracjom ${ }^{145}$.

Nieustępliwą politykę wobec Tokio podsycał Reinsch, który konsekwentnie przedstawiał Chiny w pozytywnym, a Japonię negatywnym świetle (m.in. przesłał do Departamentu Stanu dokumenty świadczące o jej agresywnych i ekspansyjnych planach). Przewidywał wystosowanie ultimatum, lecz gdy to nastąpiło, zaskoczony byl, podobnie jak Chińczycy, brakiem żądań z grupy piątej ${ }^{146}$. Reinsch nie wykluczał możliwości, że ultimatum zostało wręczone z inicjatywy Yuana, który chciał mieć alibi, że godzi się na żądania. Amerykanin odrzucał natomiast oskarżenie sformułowane przez Sun Yat-sena, twierdzącego, że to Yuan tak naprawdę wymyślił 21 żądań, aby zyskać akceptację Japonii dla swych cesarskich planów ${ }^{147}$.

Groźba postawienia ultimatum i wybuchu wojny zaniepokoiła polityków nad Potomakiem i przyśpieszyła ich działania. 5 maja Bryan przekazał Chindzie notę, w której odniósł się do propozycji z 26 kwietnia. W rozmowie z ambasadorem mial też poruszyć sprawę ultimatum ${ }^{148}$. Nazajutrz wydał zapowiadane już od jakiegoś czasu oświadczenie dla prasy, w którym kategorycznie zaprzeczył, aby USA zrzekły się jakichkolwiek praw w Chinach $^{149}$. Tego samego

145 Bryan to Wilson, May 3, 1915, BP, container 45; A.S. Link, Wilson: The Struggle ..., s. 299.

146 Pekin tak bardzo obawiał się ultimatum, że tuż przed jego otrzymaniem zgodził się nawet rozważyć żądania z grupy piątej. Uratował go fakt, że Japonia o treści ultimatum poinformowała już mocarstwa i nie mogła się z niego wycofać. M. Chi, China Diplomacy..., s. 55 .

147 Reinsch to the Secretary of State, April 27, 1915, RDSRPRBChOS, roll 24; Reinsch to the Secretary of State, May 4, 1915, ibidem; Minister Reinsch to the Secretary of State, May 4, 1915, [w:] PRFRUS 1915, s. 137-140; Reinsch to Bryan, May 4, 1915, [w: ] PWW, t. 33, s. 104-105; Minister Reinsch to the Secretary of State, May 6, 1915, [w: ] PRFRUS 1915, s. 143; Reinsch to the Secretary of State, May 6, 1915, RDSRPRBChOS, roll 24; Reinsch to the Secretary of State, May 7, 1915, ibidem; Minister Reinsch to the Secretary of State, May 17, 1915, [w:] PRFRUS 1915, s. 148-150; Brown to Wilson, July 13, 1915, RDSRPRBChOS, roll 25; P. Reinsch, An American Diplomat ..., s. 146-147; B. Elleman, Wilson and China..., s. 16-17.

148 Bryan to Wilson, May 4, 1915, [w: ] PWW, t. 33, s. 101; Bryan to Chinda, May 5, 1915, [w: ] ibidem, s. 102-104; Wilson to Bryan, May 5, 1915, [w: ] ibidem, s. 105.

149 The Secretary of State to Minister Reinsch, May 6, 1915, [w:] PRFRUS 1915, s. 143. 
dnia po konsultacji z Wilsonem wysłał komunikaty do Pekinu (w imieniu prezydenta) i Tokio (osobisty list do Ōkumy), nalegając na kontynuowanie negocjacji i niedopuszczenie do wybuchu wojny ${ }^{150}$. Chcąc wzmocnić presję międzynarodową, zwrócił się do Wielkiej Brytanii, Rosji i Francji o przyłączenie się do amerykańskich zabiegów ${ }^{151}$. Szef Foreign Office sir Edward Grey odpowiedział, że poczynił już starania w tym kierunku. Zżymał się na postępowanie Chin, które mimo wycofania piątej grupy żądań nie chciały się zgodzić na porozumienie ${ }^{152}$. Carski minister spraw zagranicznych Siergiej Sazonow odrzucił możliwość przyłączenia się do jakiegokolwiek protestu, argumentując, że Rosja otrzymywała od Japonii znaczną pomoc i liczyła na jej zwiększenie ${ }^{153}$. Théophile Delcassé, stojący na czele Quai d’Orsay, też nie zamierzał reagować, skoro grupa piąta została wycofana ${ }^{154}$.

Amerykańskie działania poważnie zaniepokoiły Tokio. Ōkuma i Katō obawiali się presji mocarstw oraz oporu Pekinu, który wiedząc o wsparciu z zewnątrz, mógł usztywnić stanowisko. Katō zaapelował nawet do Wielkiej Brytanii, aby spróbowała odwieść Stany Zjednoczone od planowanego wspólnego wystąpienia, a przynajmniej się do niego nie przyłączała. Prosił też, aby jej poseł w Pekinie sir John Jordan doradził Chińczykom zaakceptowanie żądań. Z kolei w Waszyngtonie Chinda starał się wyperswadować gospodarzom pomysł zwracania się do mocarstw, a gdy okazało się to niemożliwe, złożył formalny protest ${ }^{155}$.

150 Bryan to Wilson, May 6, 1915, [w: ] PWW, t. 33, s. 113; Bryan to the American Embassy at Tokyo, May 6, 1915, [w: ] ibidem; Bryan to the American Embassy at Tokyo, May 6, 1915, [w: ] ibidem, s. 114; Bryan to the American Legation at Peking, May 6, 1915, [w: ] ibidem; Wilson to Bryan, May 6, 1915, [w: ] ibidem, s. 115.

151 Bryan to Wilson, May 6, 1915, [w: ] PWW, t. 33, s. 113; Bryan to the American Embassy at London, Paris, Petrograd, May 6, 1915, [w:] ibidem, s. 114-115; Wilson to Bryan, May 6, 1915, [w: ] ibidem, s. 115.

152 House to Wilson, May 7, 1915, [w: ] PWW, t. 33, s. 121-123; The American Ambassador at London to the Secretary of State, May 7, 1915, [w: ibidem, s. 131-132; J. Polit, Odwrót znad Pacyfiku ..., s. 78-80; M. Chi, China Diplomacy ..., s. 56-57.

153 Marye to the Secretary of State, May 9, 1915, RDSRPRBChOS, roll 24; Marye to the Secretary of State, May 9, 1915, ibidem; R.H. Fifield, Woodrow Wilson and the Far East..., s. 44-45.

154 Sharp to the Secretary of State, May 8, 1915, RDSRPRBChOS, roll 24.

155 M. Chi, China Diplomacy..., s. 57-58; N. Kawamura, Turbulence in the Pacific ..., s. 54-55. Według Reinscha 5 maja posłowie Wielkiej Brytanii, Francji i Rosji poinformowali Waijiao bu, że Chiny nie powinny próbować przeciwstawić się militarnie Japonii. Minister Reinsch to the Secretary of State, May 17, 1915, [w: ] PRFRUS 1915, s. 148-150. Gdy ultimatum zostało już wystosowane, Brytyjczycy, niezależnie od prośby Tokio, naciskali na Pekin, aby zaakceptował warunki. J. Polit, Odwrót znad Pacyfiku..., s. 79-80, 82; A.S. Link, Wilson: The Struggle ..., s. 305; M. Chi, China Diplomacy..., s. 58. 
Ostatecznie 9 maja Chiny przyjęły japońskie warunki ${ }^{156}$. Niemożność stawienia skutecznego oporu militarnego, rezygnacja z piątej grupy żądań i naciski mocarstw skłoniły je do podjęcia takiej decyzji ${ }^{157} .25$ maja zawarto oficjalnie różne traktaty kończące kryzys 21 żądań, chociaż Japonia wyraźnie zaznaczyła, że sprawa grupy piątej będzie przedmiotem przyszłych negocjacji ${ }^{158}$.

Jeszcze zanim wiadome było, jak rozwinęła się sytuacja w Pekinie, Lansing, przewidując, że państwa europejskie nie przyłączą się do protestu, zaproponował 7 maja, aby wystosować notę, która chroniłaby amerykańskie i chińskie prawa. Nie miał złudzeń, że nie powstrzyma ona Japonii przed narzuceniem swojej woli, ale sądził, że będzie stanowiła zastrzeżenie pozwalające powrócić do całej sprawy w bardziej sprzyjających okolicznościach ${ }^{159}$. Chwilowo wstrzymano się z wystosowaniem noty, ale gdy okazało się, że Japonia nie wykluczała w przyszłości powrotu do negocjacji, Wilson poparł jej wysłanie. Liczył, że skłoni ona tokijskie władze do porzucenia na bardzo długo żądań z grupy piątej ${ }^{160}$.

Notę przedstawiono Japonii i Chinom 11 maja. Stany Zjednoczone zadeklarowały, że nie uznają żadnych porozumień, które naruszały ich prawa, politykę „otwartych drzwi” oraz polityczną lub terytorialną integralność Chin ${ }^{161}$.

156 Minister Reinsch to the Secretary of State, May 9, 1915, [w:] PRFRUS 1915, s. 145; Chargé Wheeler to the Secretary of State, May 9, 1915, [w: ] ibidem; Tien-yi Li, Woodrow Wilson's..., s. 137.

157 Niektórzy chińscy politycy i wojskowi chcieli walczyć z Japonią, ale uznano, że wycofanie żądań z grupy piątej uratowało kraj. Minister Reinsch to the Secretary of State, May 17, 1915, [w:] PRFRUS 1915, s. 148-150; J. Polit, Odwrót znad Pacyfiku..., s. 79-80; M. Chi, China Diplomacy ..., s. 58. Zdaniem Ellemana Chiny chętnie zgodzily się na żądania, chcąc zrównoważyć wpływy Rosji w Mongolii Zewnętrznej. Elleman stara się też, w moim odczuciu nieprzekonująco, udowodnić hipotezę, że to właśnie działania rządu carskiego pchnęły Japonię do wystosowania żądań. B. Elleman, Wilson and China ..., s. 13-21.

158 Doc. no. 1915/7: China. Presidential mandate concerning the non-alienation of the coasts of China, May 13, 1915, [w:] Treaties and Agreements..., t. 2: Republican Period (1912-1919), s. 1215; Treaties Signed and Notes Exchanged between Japan and China on May 25, 1915, [w:] The Sino-Japanese Negotiations..., s. 39-63; Minister Reinsch to the Secretary of State, May 9, 1915, [w:] PRFRUS 1915, s. 145; Minister Reinsch to the Secretary of State, May 17, 1915, [w: ] ibidem, s. 148-150.

${ }_{159}$ Bryan to Wilson, May 7, 1915, [w:] PWW, t. 33, s. 120; Lansing to Bryan, May 7, 1915, [w:] ibidem, s. 140; Draft of notice to be sent to the Governments of Japan and China in case the Allied Powers fail to unite in a joint representation, undated, [w:] ibidem, s. 141.

${ }^{160}$ Wilson to Bryan, May 10, 1915, [w: ] PWW, t. 33, s. 140.

161 The Secretary of State to Ambassador Guthrie, May 11, 1915, [w:] PRFRUS 1915, s. 146. Nota z 11 maja stanowiła podstawę dla doktryny Stimsona z 1932 roku. R.W. Curry, Woodrow Wilson and Far Eastern Policy..., s. 128; A.W. Griswold, The Far Eastern ..., s. 195. 
Nota była zaskakująca, wyglądało na to, że Waszyngton wystąpił z najostrzejszym protestem, gdy konflikt wydawał się już zakończony. Takie wrażenie wynikało poniekąd z faktu, że notę wysłano w kształcie, w jakim ją sporządzono 7 maja. A wówczas nie wiedziano jeszcze, co zawierało ultimatum i czy Chiny je przyjmą, czy też dojdzie do wojny. Chociaż Wilson wyraźnie stwierdził, że nota ma skłonić Japonię do rezygnacji z grupy piątej, to można było wywnioskować, że Amerykanie sprzeciwiali się wszystkim żądaniom, także uprzednio zaakceptowanym. Nota potwierdzała, że w ostatnich kilku tygodniach w amerykańskiej polityce zwyciężyło stanowisko Wilsona, a nie Bryana. Sekretarz stanu próbował nawet osłabić wydźwięk noty i podczas rozmowy ze zdezorientowanym i zaniepokojonym Chindą powiedzial, że nie należy jej interpretować jako kwestionującej porozumienie japońsko-chińskie, lecz jedynie jako „zabezpieczenie" 162 .

Generalnie Wilson i Bryan byli zadowoleni, że cały kryzys minął, przynajmniej na jakiś czas ${ }^{163}$. Nie doszło do wybuchu wojny, najdrastyczniejsze żądania zostały wycofane, a przyjęcie pozostałych, mimo że wywołało silne niezadowolenie społeczeństwa (wielu Chińczyków nazywało 9 maja „Dniem Narodowego Upokorzenia"), to - według Reinscha - nie doprowadzi do wszczęcia powstania ${ }^{164}$. Dobre samopoczucie Wilsona i Bryana wynikało też z przeświadczenia, że to ich działania wraz z interwencją Greya przyczyniły się do pomyślnego zakończenia kryzysu ${ }^{165}$.

Czy samozadowolenie polityków w Waszyngtonie było uzasadnione? Czy ich zabiegi rzeczywiście wpłynęły na przebieg i ostateczny rezultat negocjacji japońsko-chińskich? Historycy różnie oceniają działania amerykańskiej dyplomacji. Część uznaje je za decydujące dla uratowania Chin i pokoju ${ }^{166}$, w innych

162 A.S. Link, Wilson: The Struggle ..., s. 308. Jak można się było spodziewać, Japonia zareagowała nieprzychylnie na amerykańską notę. Tien-yi Li, Woodrow Wilson's..., s. 127; R.H. Fifield, Woodrow Wilson and the Far East ..., s. 48.

${ }_{163}$ Bryan to Wilson, May 8, 1915, [w: ] PWW, t. 33, s. 131; Wilson to Bryan, May 10, 1915, [w: ibidem, s. 139-140. W tym samym czasie rozpoczął się poważniejszy kryzys -7 maja zatonęła „Lusitania”.

${ }^{164}$ Minister Reinsch to the Secretary of State, May 17, 1915, [w:] PRFRUS 1915, s. 148-150; W. Rodziński, Historia Chin ..., s. 625; Z. Luo, National Humiliation..., s. 309-312.

165 Bryan to Wilson, May 8, 1915, [w:] PWW, t. 33, s. 131; Wilson to Bryan, May 10, 1915, [w: ibidem, s. 139-140; A.S. Link, Wilson: The Struggle ..., s. 305-306.

166 Zob. P. Coletta, William Jennings Bryan, t. 2: Progressive Politician and Moral Statesman, 1909-1915, Lincoln 1969, s. 235, 238; G. Hudson, The Far East at the End of the First World War, "Journal of Contemporary History” 1969, t. 4, nr 2, s. 166-167; R.W. Curry, Woodrow Wilson and Far Eastern Policy..., s. 129. 
pracach dominuje punkt widzenia deprecjonujący osiągnięcia Waszyngtonu i podkreślający zasługi Londynu ${ }^{167}$.

Aby dokonać właściwej oceny, należy ustalić, kiedy, dlaczego i w jakich okolicznościach Japonia podjęła kluczową decyzję o rezygnacji z żądań z grupy piątej. Nastąpiło to 4 i 5 maja podczas spotkań rządu z członkami genrō, zwołanych, aby uzyskać aprobatę tych ostatnich dla wysłania ultimatum. Członkowie genrō ostro skrytykowali politykę barona Katō, zwłaszcza sposób postępowania z mocarstwami. W toku dyskusji powołali się na dwa ostrzeżenia od Greya (z 29 kwietnia i 3 maja) oraz list od japońskiego ambasadora w Londynie (z 4 maja), który przewidywał problemy ze Stanami Zjednoczonymi, jeśli Japonia będzie zbyt mocno naciskać na Chiny. Stanowczy sprzeciw genrō zmusił rząd do wycofania grupy piątej z pierwotnej wersji ultimatum ${ }^{168}$.

W tym kontekście widać, że amerykańskie działania z 5 i 6 maja nie miały większego wpływu (podobnie zresztą jak interwencje Greya z 5, 6 i 7 maja), decyzja zapadła bowiem wcześniej. Widać też jednak, że podjęto ją właśnie w wyniku uprzednich nacisków Wielkiej Brytanii i Stanów Zjednoczonych i w obawie przed zniechęceniem obu mocarstw. Najpewniej dla Japonii większe znaczenie miały opinie docierające znad Tamizy niż znad Potomaku, co nie zmienia faktu, że i amerykańskie zdanie brano pod uwagę, a przynajmniej brali je członkowie genrō, nawet jeśli Katō je wyszydzał. Zresztą nieco rozpaczliwa reakcja szefa Gaimushō na działania podjęte przez Waszyngton 6 maja pokazała, że i on nie był obojętny na amerykańskie stanowisko.

Podsumowując cały kryzys wywołany przez japońskie żądania, można stwierdzić, że z amerykańskiej perspektywy zakończył się on pomyślnie. Uniknięto wojny i ujarzmienia Chin. Stany Zjednoczone ponownie pokazały się jako obrońca Państwa Środka, nie doprowadzając zarazem do zbytniego

167 Zob. R.J. Gowen, Great Britain ..., s. 77, 100-106; J. Polit, Odwrót znad Pacyfiku..., s. 81-83; C.B. Davis, Limits of Effacement..., s. 54-55; A.W. Griswold, The Far Eastern ..., s. 190, 196; R.H. Fifield, Woodrow Wilson and the Far East ... s. 44-47. Tien-yi Li twierdzi, że amerykańska dyplomacja próbowała ratować Chiny, ale osiągnęła niewiele. Większy był za to efekt działań Londynu. Tien-yi Li, Woodrow Wilson's ..., s. 123-125, 128-129. Lansing pisał, że trudno jest ocenić, jaki był wpływ amerykańskich i brytyjskich zabiegów. R. Lansing, War Memoirs of Robert Lansing ..., s. 283. Część Chińczyków wierzyła, że porozumienie z Japonią zostało zawarte głównie dzięki staraniom sir Johna Jordana. Za pomoc jemu i Foreign Office podziękowali przedstawiciele zarówno rządu chińskiego, jak i japońskiego. Cheshire to Reinsch, May 12, 1915, RDSRIACh, roll 14; M. Chi, China Diplomacy..., s. 59.

168 A.S. Link, Wilson: The Struggle..., s. 301-304; M. Chi, China Diplomacy..., s. 53-55; N. Kawamura, Turbulence in the Pacific..., s. 27-28. Yuan podobno wysła do Japonii emisariuszy, aby rozmawiali z członkami genrō o żądaniach. J. Ch'ên, Yuan Shih-k'ai..., s. 192. 
popsucia stosunków z Japonią, chociaż po obu stronach Pacyfiku pogłębiła się wzajemna nieufność. Kryzys potwierdził wzrost pozycji USA na Dalekim Wschodzie i ich gotowość do wywiązania się z nowych obowiązków. Pokazał, że Waszyngton był zdecydowany, aby dyplomatycznymi metodami upomnieć się o swoje interesy i dobro Chin, nawet kosztem pogorszenia relacji z Japonią. Dowodzi to po raz kolejny, że Chiny odgrywały ważną rolę w amerykańskiej polityce zagranicznej.

Podczas kryzysu ujawniła się znaczna rozbieżność zdań w amerykańskiej dyplomacji, nawet na najwyższym szczeblu. Bryan i Wilson od początku trochę inaczej postrzegali sytuację, z czasem ich poglądy coraz wyraźniej się rozmijały. Jako że większy wpływ na politykę swojego kraju miał najpierw pierwszy $\mathrm{z}$ nich, a potem drugi, była ona niespójna. Jeśli za punkt wyjścia przyjąć notę z 13 marca, a za punkt końcowy oświadczenie z 11 maja, to widać ewolucję amerykańskiego stanowiska wobec żądań - od umiarkowanego do stanowczego. Podejście to okazało się skuteczne, mimo że stanowiło odwrotność powszechnej taktyki negocjacyjnej, zakładającej ustępstwa, a nie usztywnienie stanowiska wraz z upływem czasu. Za negatywną konsekwencję można uważać to, że amerykańska dyplomacja musiała się teraz zdecydować, którą deklarację uznać za wiążącą.

\section{Waszyngton wobec amerykańskich inwestycji w Chinach (1914-1915)}

Wybuch wojny i działania Japonii sprawiły, że w Stanach Zjednoczonych znów zaczęto mówić o inwestycjach i pożyczkach dla Chin. Okoliczności sprzyjały Amerykanom, którzy nie musieli się obawiać konkurencji ze strony Europejczyków i mieli większe możliwości rozszerzania wpływów gospodarczych. Dodatkowo, w porównaniu z ogarniętą walkami Europą, Azja wydawała się bezpiecznym miejscem do lokowania kapitału. W Waszyngtonie zdawano sobie też sprawę, że pozostawienie bez pomocy finansowej rządu pekińskiego, który nie mógł liczyć na pożyczki z Europy, a którego dochody zostały jeszcze uszczuplone przez spadek wymiany handlowej, mogło doprowadzić do niepokojów w kraju ${ }^{169}$. Inwestycje sprzyjały z kolei stabilizacji i rozwojowi oraz osłabiały strefy wpływów mocarstw. Z czasem pojawił się jeszcze jeden motyw - chęć przeciwstawienia się za pomocą amerykańskich pieniędzy japońskim próbom zdominowania $\mathrm{Chin}^{170}$.

169 MacMurray to the Secretary of State, September 9, 1914, RDSRIACh, roll 14; Cunningham to Reinsch, April 29, 1915, ibidem.

170 Bryan to Wilson, May 3, 1915, BP, container 45. 
Trudności w wykorzystaniu nadarzającej się „wielkiej szansy”, jak określił ją pewien biznesman $\mathrm{z}$ Richmond, było jednak niemało ${ }^{171}$. Przeciwko amerykańskim przedsięwzięciom z oczywistych względów działała Japonia ${ }^{172}$. Swój sprzeciw wyraził również Sun Yat-sen, obawiający się, że pieniądze z Wall Street posłużą Yuanowi do realizacji osobistych ambicji i celów ${ }^{173}$. Poważniejszy problem stanowiło bardzo umiarkowane zainteresowanie amerykańskich firm, które nadal wolały inwestować w swoim kraju, a wojenna pożoga nie skłaniała do odwrócenia tej tendencji, choć co jakiś czas pojawiali się przedsiębiorcy gotowi wkroczyć na rynek chiński ${ }^{174}$. Niewielkie zainteresowanie wynikało poniekąd z dotychczasowego zniechęcającego nastawienia administracji Wilsona, które, jak zostało wspomniane w poprzednim rozdziale, zaczynało jednak ewoluować w kierunku większego poparcia.

Gdy rząd chiński ogłosił 8 sierpnia 1914 roku moratorium na swoje krótkoterminowe zobowiązania zagraniczne, Waszyngton od razu to zaakceptowal. Zgodził się też na opóźnienia w splacie odszkodowania przyznanego po powstaniu „bokserów" ${ }^{175}$. W ciągu 1914 roku Bryan i Lansing wyrażali się przychylnie o chińskich próbach zaciągnięcia pożyczek w USA, chociaż obaj przewidywali, że zawirowania na rynkach finansowych wywołane przez wojnę uniemożliwią pożyczenie pieniędzy ${ }^{176}$.

Cały czas na zwiększenie aktywności nalegał Reinsch. W marcu 1915 roku napisał osobisty list do Wilsona, w którym przekonywał o zasadności utworzenia organizacji zapewniającej finansowanie amerykańskich przedsięwzięć biznesowych. Bankierzy z grupy należącej niegdyś do konsorcjum mocarstw (zwłaszcza J.P. Morgan and Company) nie tylko nie chcieli obecnie angażować się w Chinach, obwiniając rząd o zaprzepaszczenie ich wysiłków, ale rozgłaszali również, że prowadzenie interesów w Państwie Środka jest nieopłacalne. Nie wszyscy podzielali ten pesymizm i przy zachęcie ze strony Białego Domu byli gotowi do sformowania nowego zrzeszenia. Tym razem nie miałoby ono monopolistycznego charakteru, przeciwnie - byłoby otwarte dla wielu podmiotów. Jego powstanie mogłoby też skłonić bankierów z dawnej amerykańskiej grupy do wznowienia działalności na rynku chińskim ${ }^{177}$.

171 Scott to Montague, February 13, 1915, Robert Lansing Papers (dalej LP), Manuscript Division, Library of Congress, Washington, box 7; Montague to Lansing, February 15, 1915, ibidem. Cytat pochodzi z pierwszego listu.

172 Scott to Montague, February 13, 1915, LP, box 7.

173 Sun to Wilson, November 30, 1914, WWP, series 4: case files, 227, reel 242; Brown to Wilson, July 13, 1915, RDSRPRBChOS, roll 25.

174 R.W. Curry, Woodrow Wilson and Far Eastern Policy..., s. 144.

175 PRFRUS 1914, Washington 1922, s. 67-68, 76-79.

176 Lansing to MacMurray, August 5, 1914, RDSRIACh, roll 14; Bryan to Tumulty, December 2, 1914, [w:] PWW, t. 31, s. 381-382.

177 Reinsch to Wilson, March 5, 1915, WWP, series 2, reel 69. 
Wilson bardzo szybko miał okazję pokazać, czy zgadza się z Reinschem. W kwietniu 1915 roku napisał do niego Benjamin Howell Griswold jr., bankier z Baltimore, zainteresowany udziałem $\mathrm{w}$ pożyczce dla Chin. Te ostatnie chciały pożyczyć w Stanach Zjednoczonych kwotę między 100 a 200 milionów dol. na reformy walutową, bankową i podatku gruntowego. W nawiązaniu kontaktów pomagał im prof. William F. Willoughby, który zastąpil prof. Franka Goodnowa jako konstytucyjny doradca władz pekińskich. Skontaktował się on właśnie z Goodnowem, a ten z Griswoldem, który wykazał zainteresowanie sprawą, ale wolał upewnić się co do nastawienia administracji Wilsona, zanim rozpoczął negocjacje mogące postawić ją w kłopotliwym położeniu ${ }^{178}$.

Wilson spotkał się z Griswoldem i Goodnowem w połowie kwietnia. Zdecydowano, że bankier zredaguje wyrażający poparcie list, który prezydent następnie przejrzy i podpisze. Ostatecznie w czerwcu tak też się stało. List był istotny, gdyż wyraźnie pokazywał, że Wilson popierał pożyczki dla Chin, aczkolwiek nie bezwarunkowo - chcial, aby jak najwięcej podmiotów mogło w nich uczestniczyć, oraz zastrzegł, że nie będzie "egzekutorem długu” i na pewno nie użyje siły, aby ściągnąć należności zagraniczne ${ }^{179}$.

Podobne zapewnienia Wilson i Lansing powtórzyli podczas spotkań z Reinschem w lipcu i sierpniu ${ }^{180}$. Zdanie Lansinga było o tyle ważne, że w czerwcu został on nowym sekretarzem stanu. Nastąpiło to po rezygnacji z urzędu Bryana, który nie zgadzal się ze stanowczą polityką Wilsona wobec Niemiec. Na jego miejsce Wilson chciał wyznaczyć kogoś o silnej osobowości i własnych pomysłach, ale odwiódł go od tego House, który obawiał się o swoją pozycję nieoficjalnego doradcy w sprawach zagranicznych. To właśnie House nakłonił prezydenta do nominowania Lansinga, ponieważ miał on kompetentnie spełniać polecenia przełożonych ${ }^{181}$.

Zmiana sternika Departamentu Stanu wpłynęła na całokształt polityki zagranicznej USA, w tym także na politykę wobec Chin. Nowy szef amerykańskiej dyplomacji miał lepsze kwalifikacje i inne priorytety niż jego poprzednik, dbał przede wszystkim o kwestie prawne i ekonomiczne. Nie zapominając, że Wilson w znacznej mierze nadal pozostawał własnym sekretarzem stanu, można uznać, że zastąpienie Bryana Lansingiem wzmocniło w otoczeniu prezydenta realistyczne, a osłabiło idealistyczne podejście do spraw zagranicznych. W odniesieniu do

178 Griswold to Wilson, April 10, 1915, [w: ] PWW, t. 32, s. 502.

179 Ibidem, s. 503 (przypis nr 3); Bryan to Wilson, May 3, 1915, [w: ] PWW, t. 33, s. 99-100; Bryan to Wilson, June 4, 1915, BP, container 59; Wilson to Bryan, June 7, 1915, [w: ] PWW, t. 33, s. 349; Wilson to Griswold, June 8, 1915, WWP, series 4: case files, 227, reel 242.

180 N. Pugach, Paul S. Reinsch: Open Door Diplomat in Action, Millwood 1979, s. $174-175$.

181 B. Beers, Vain Endeavor ..., s. 52-56. 
Chin m.in. umocniło to przekonanie o potrzebie energiczniejszego wspierania amerykańskich inwestycji. Lansing wiele przekonań na temat Dalekiego Wschodu miał zaczerpnąć od swojego teścia Johna W. Fostera, sekretarza stanu w latach 1892-1893, a później doradcy rządu pekińskiego. Foster uważał, że zainteresowanie Amerykanów Chinami w XX wieku będzie miało przede wszystkim wymiar ekonomiczny, a nie moralny i dobroczynny, będzie polegało na szukaniu rynku zbytu, a nie pomocy w rozwoju cywilizacyjnym. W związku z tym nadrzędnym zadaniem rządu federalnego powinno być wspieranie rodzimych przedsiębiorców w walce o rynek chiński ${ }^{182}$.

Niektórzy historycy twierdzą, że w 1915 roku administracja Wilsona powróciła do „dyplomacji dolarowej” 183 . Jest to pogląd częściowo uzasadniony, ale trzeba zastrzec, że wówczas ten proces dopiero się rozpoczął a i w późniejszym okresie nie wrócono w pełni do wariantu Taftowskiego - zaangażowanie rządu było tym razem mniejsze, negatywnie patrzył on na ingerencję w wewnętrzne sprawy Chin oraz praktyki monopolistyczne, a bardziej podkreślał fakt, że inwestycje miały nie tylko rozszerzać amerykańskie interesy i osłabiać wpływy innych mocarstw, ale również rozwijać Chiny.

Ze zmiany nastawienia zadowolony był Reinsch, który latem 1915 roku przyjechał do ojczyzny, aby osobiście przedstawić swoje pomysły przełożonym oraz aby przekonać środowiska biznesowe do prowadzenia interesów w Chinach. Starania Reinscha, wspierane i kontynuowane po jego wyjeździe przez Departament Stanu i Departament Handlu, dały pewne efekty. W listopadzie 1915 roku sformowano American International Corporation (AIC), która miała wyszukiwać, finansować i prowadzić inwestycje zagraniczne. Jej prezesem został Frank Vanderlip, od 1909 roku stojący na czele The National City Bank of New York, banku wchodzącego w skład amerykańskiej grupy należącej wcześniej do konsorcjum mocarstw. Trzecim wiceprezesem AIC mianowano Willarda Straighta, co wskazywało, że Chiny będą jednym z głównych obszarów jej działalności. Powołano też spółki skoncentrowane na rynku chińskim: China Corporation oraz Siems-Carey Railway and Canal Company. Do rywalizacji aktywnie włączyli się ponadto Griswold i bank z Bostonu - Lee, Higginson \& Co. ${ }^{184}$ Rozpoczęły się negocjacje z rządem pekińskim na temat pożyczek i różnych inwestycji rzecznych i kolejowych, które zaowocowały pierwszymi kontraktami wiosną 1916 roku. Amerykanie działali jednak nadal powoli i ostrożnie, między innymi dlatego, że na przełomie lat 1915-1916 sytuacja w Chinach uległa pogorszeniu. rozdziału)

182 Ibidem, s. 7-8, 72-73.

183 Zob. N. Pugach, Paul S. Reinsch ..., s. 177; B. Beers, Vain Endeavor ..., s. 72 (tytuł

${ }^{184}$ N. Pugach, Paul S. Reinsch..., s. 172-177; B. Beers, Vain Endeavor ..., s. 73-75. 
220 Chiny w polityce zagranicznej Stanów Zjednoczonych w latach 1911-1918

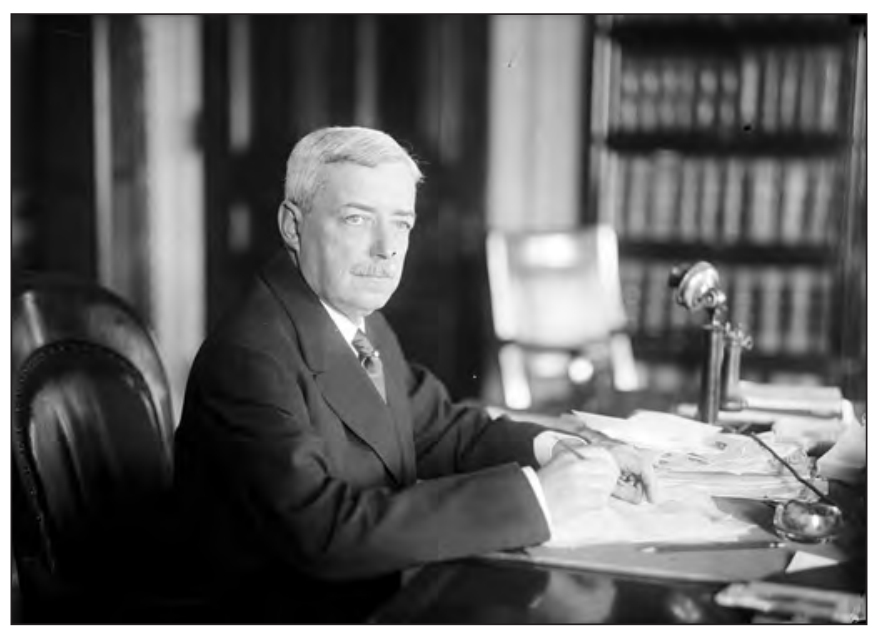

29. Robert Lansing

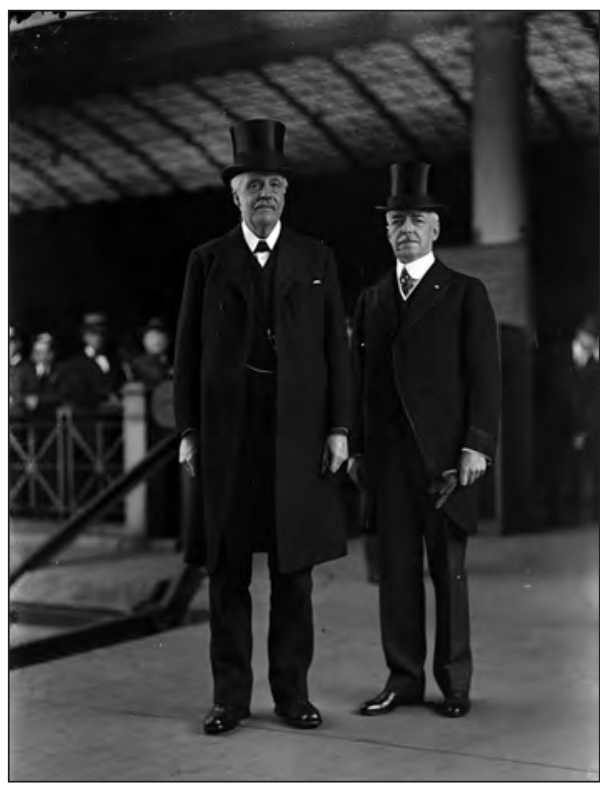

30. Arthur Balfour i Robert Lansing

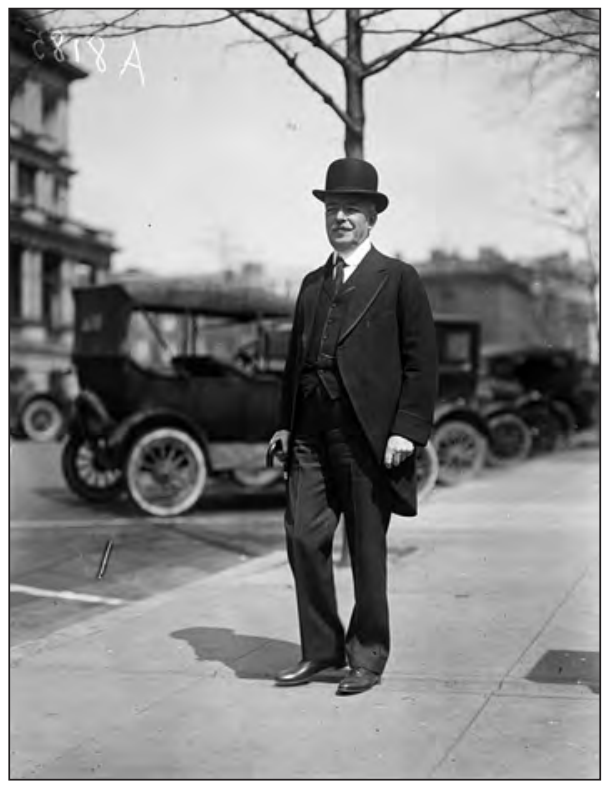

31. Robert Lansing 
Rozdział IV. Polityka Stanów Zjednoczonych wobec Chin w pierwszych latach ... 221

\section{Waszyngton wobec ruchu na rzecz restauracji cesarstwa i „trzeciej rewolucji” w Chinach (połowa 1915 roku - czerwiec 1916 roku)}

Wybuch wojny światowej, japońsko-brytyjska kampania w Shandongu oraz niepewność finansowa mogły przyczynić się do osłabienia władzy centralnej i wzmożenia działalności rewolucjonistów, i chociaż z różnych stron Chin docierały takie sygnały, to przeważała opinia, że rząd raczej kontroluje sytuację ${ }^{185}$. Także zagrożenie ze strony bandytów stało się mniejsze, właśnie w sierpniu 1914 roku zmarł Bai Lang zwany Białym Wilkiem, herszt bandy, która przez ponad dwa lata pustoszyła i terroryzowała różne prowincje ${ }^{186}$.

Yuanowi udało się przetrwać epizod 21 żądań i uniknąć - mimo antyjapońskich nastrojów szerzących się w społeczeństwie oraz japońskich prowokacji - poważniejszych incydentów czy rozruchów, które mogły dać agresywnemu sąsiadowi pretekst do interwencji. Oczywiście przyjęcie żądań rozsierdziło część Chińczyków, ale ich gniew skierowany był bardziej przeciwko Tokio niż Pekinowi $^{187}$. Wydawało się zatem, że przynajmniej przez jakiś czas reżim Yuana będzie mógł spokojnie funkcjonować, niezagrożony ani wewnętrznie, ani zewnętrznie. Tak się jednak nie stało, a prezydent w znacznej mierze sam doprowadził do swojego upadku, próbując przywrócić monarchię.

185 MacMurray to the Secretary of State, September 9, 1914, RDSRIACh, roll 14; Arnold to MacMurray, September 29, 1914, ibidem; Arnold to the Secretary of State, October 28, 1914, ibidem; Cheshire to Reinsch, October 29, 1914, ibidem; Arnold to the Secretary of State, November 2, 1914, ibidem; Cheshire to Reinsch, November 5, 1914, ibidem; Cheshire to Reinsch, November 11, 1914, ibidem; Cheshire to Reinsch, November 13, 1914, ibidem; Arnold to Reinsch, November 16, 1914, ibidem; Reinsch to the Secretary of State, November 25, 1914, ibidem; Cheshire to Reinsch, November 30, 1914, ibidem; Arnold to the Secretary of State, December 9, 1914, ibidem. Podczas kryzysu wywołanego przez 21 żądań Yuan zaproponował amnestię dla swych przeciwników. Wielu z nich, z Huang Xingiem na czele, opowiedziało się za zaprzestaniem walk wewnętrznych i narodowym zjednoczeniem. Nie zgodził się na to jednak Sun Yat-sen i jego zwolennicy. Z. Luo, National Humiliation ..., s. 299.

186 MacMurray to the Secretary of State, September 9, 1914, RDSRIACh, roll 14; The Cambridge History of China, t. 12: Republican China, 1912-1949, cz. 1, (red.) J.K. Fairbank, Cambridge 1983, s. 240-241.

$187 \mathrm{~W}$ wielu miejscach kontynuowano bojkot japońskich towarów i zbieranie funduszy dla rządu, aby mógł przeciwstawić się kolejnej agresji. Cheshire to Reinsch, May 12, 1915, RDSRIACh, roll 14; Heintzleman to Reinsch, June 5, 1915, RDSRPRBChOS, roll 24; Fisher to Reinsch, June 8, 1915, ibidem; Pontius to Reinsch, June 19, 1915, RDSRIACh, roll 14; Maynard to the Secretary of State, July 17, 1915, ibidem; Z. Luo, National Humiliation..., s. 305-309. 
O objęciu Tronu Smoka Yuan myślał już podobno podczas rewolucji 1911 roku $^{188}$. Wówczas okazało się to niemożliwe, ale Yuan nie wyrzekł się cesarskich ambicji. Po stłumieniu „drugiej rewolucji” i ugruntowaniu rządów autorytarnych pojawiało się coraz więcej sygnałów, że dąży on do restauracji monarchii. W obliczu japońskich żądań plany te odroczono, ale powrócono do nich ze zdwojonym animuszem w połowie 1915 roku, gdy kryzys został zażegnany, zwłaszcza że Yuan mógł wtedy sądzić, iż dysponuje poparciem Tokio.

W sierpniu rozpoczęła się energiczna kampania propagandowa, która miała pokazać, że pragnienie zmiany ustroju było powszechne i oddolne. $Z$ inicjatywy kierującego nią Stowarzyszenia Planowania Pokoju różne środowiska słały do Pekinu kolejne petycje z prośbą o przywrócenie monarchii. W agitacji wykorzystano memorandum, które prof. Goodnow sporządził na życzenie Yuana podczas pobytu w Chinach latem 1915 roku. Konkluzja memorandum, któremu nadano znaczny rozgłos, zakładała, że „monarchia jest odpowiedniejsza dla Chin”, albowiem ludzie przyzwyczajeni są do autokracji, brakuje im należytego wykształcenia oraz „kompetencji politycznych”. I chociaż Goodnow nie przesądzał, czy moment był właściwy do zmiany ustroju, to jego opinia została zgrabnie wyzyskana propagandowo, w równym stopniu ze względu na jej treść, jak i narodowość autora - obywatela najważniejszej przecież republiki na świecie ${ }^{189}$.

Ponieważ Yuanowi i kantońskiej frakcji w rządzie (nazywanej też komunikacyjną, na czele z Liang Shiyiem, ministrem komunikacji), która przejęła przygotowania do wprowadzenia cesarstwa od frakcji Anhui (przewodzonej przez Duan Qiruia, uprzednio ministra wojny), zależało na zachowaniu pozorów legalności i pokazaniu, że realizują tylko wolę ludu, postanowiono zorganizować swoiste referendum ${ }^{190}$. Przy okazji wyborów parlamentarnych wyłoniono w prowincjach przedstawicieli, którzy następnie jednomyślnie zdecydowali o przywróceniu Cesarstwa Chińskiego i wskazali na Yuana jako nowego władcę. 10 grudnia książę

188 D.M. Crane, T.A. Breslin, An Ordinary Relationship ..., s. 147.

189 Dr. Goodnow's Memorandum to the President, undated, published in the 'Peking Daily News' on August 20, 1915, [w:] PRFRUS 1915, s. 53-58; Chargé MacMurray to the Secretary of State, August 25, 1915, [w: ] ibidem, s. 46-47; Chargé MacMurray to the Secretary of State, September 2, 1915, [w: ibidem, s. 47; Chargé MacMurray to the Secretary of State, September 7, 1915, [w: ] ibidem, s. 48-53. Trudno się zgodzić z nad wyraz surową oceną Rodzińskiego, który całkowicie dyskredytuje zarówno intencje Goodnowa, jak i poziom merytoryczny jego memorandum. W. Rodziński, Historia Chin ..., s. 626. Warto dodać, że częściowo podobne obserwacje do Goodnowa miał przyszły prezydent USA Herbert Hoover, który spędził kilka lat w Chinach. H. Hoover, The Memoirs of Herbert Hoover, t. 1: Years of Adventure, 1874-1920, New York 1952, s. 66-67, 71-72.

190 Bardziej reakcyjna frakcja Anhui była przeciwna referendum, uważając, że jest to metoda zbyt demokratyczna. Minister Reinsch to the Secretary of State, October 2, 1915, [w: ] PRFRUS 1915, s. 65. 
Pulun w imieniu dynastii mandżurskiej poparł ten wybór. Zgodnie z tradycją tego typu politycznych „przedstawień” Yuan najpierw odmówil, by dopiero za drugim razem zgodzić się zadośćuczynić prośbie ${ }^{191}$.

Współcześni i potomni upatrywali różnych przyczyn jego decyzji, w jednym natomiast byli zgodni - czas wprowadzenia zmian zostal fatalnie wybrany ${ }^{192}$. Planom przywrócenia monarchii sprzeciwily się mocarstwa i opozycja wewnętrzna, co doprowadziło ostatecznie do upadku Yuana.

Sprawą zmiany ustroju interesowały się Stany Zjednoczone, i to na dwóch płaszczyznach. O ile pozostałe mocarstwa miały tylko na uwadze, czy nie wywoła to jakichś rozruchów lub innych komplikacji, w przypadku Amerykanów dochodził jeszcze jeden czynnik o kapitalnym znaczeniu - ich nadzieje związane z rozwojem demokracji w Państwie Środka. Jeszcze pod koniec maja 1915 roku Bryan i Wilson chwalili Chiny za przejęcie amerykańskich wzorców ustrojowych ${ }^{193}$. Szybko jednak musieli wyzbyć się złudzeń.

Od końca sierpnia MacMurray, zastępujący Reinscha na czele placówki w Pekinie, coraz częściej informował o narastającej agitacji procesarskiej. Początkowo nie był pewien, czy władza wysyłała jedynie ballon d'essai, aby przetestować nastroje społeczne i zadowolić konserwatywne środowiska, czy rzeczywiście przygotowywała się do wprowadzenia cesarstwa. MacMurray powątpiewał, aby Yuan, wielce przecież doświadczony polityk, zdecydował się na ten drugi wariant $\mathrm{w}$ tak niesprzyjającym momencie, ale kolejne petycje, wypowiedzi oficjeli i inne sygnały przekonały dyplomatę, że się mylił. MacMurray i amerykańscy konsulowie nie dali się natomiast zwieść propagandzie i wiedzieli, że cały

191 Chargé MacMurray to the Secretary of State, September 24, 1915, [w:] PRFRUS 1915, s. 61-64; Minister Reinsch to the Secretary of State, October 2, 1915, [w: ibidem, s. 65; Minister Reinsch to the Secretary of State, October 11, 1915, [w:] ibidem, s. 65-67; Minister Reinsch to the Secretary of State, November 12, 1915, [w:] ibidem, s. 77-78; Reinsch to the Secretary of State, December 11, 1915, WWP, series 2, reel 75; W. Rodziński, Historia Chin ..., s. 626-627.

${ }^{192}$ Wśród czynników, które miały skłonić Yuana do odbudowy cesarstwa, wymienia się: jego próżność oraz dążenie do realizacji niepohamowanych ambicji i osobistej nobilitacji; zamiar potrzebnego do przeprowadzenia reform wzmocnienia władzy centralnej, gdyż do cesarza Chińczycy byli przyzwyczajeni i darzyli go autorytetem, a republikanizm był im obcy; próbę odwrócenia uwagi od problemów wewnętrznych i niepowodzeń w polityce zagranicznej; chęć ochrony kraju przed zakusami Japonii, której miałoby być trudniej atakować Chiny, gdyby oba państwa miały ten sam ustrój. Zob. Minister Reinsch to the Secretary of State, October 11, 1915, [w:] PRFRUS 1915, s. 65-67; D.M. Crane, T.A. Breslin, An Ordinary Relationship ..., s. 146-149; W. Rodziński, Historia Chin ..., s. 625-627; The Cambridge History of China ..., s. 246-249; J. Polit, Odwrót znad Pacyfiku ..., s. 85, 89, 91, 98-99; G. Hudson, The Far East ..., s. 173.

193 P. Coletta, William Jennings Bryan ..., s. 236. 
ruch poparcia nie był spontaniczny, tylko w pełni sterowany z Pekinu. Przywrócenie monarchii miało co prawda swoich zwolenników, część osób zaś konformistycznie opowiadała się za rozwiązaniem, które według nich zostanie wprowadzone, lecz zdecydowana większość społeczeństwa w ogóle nie interesowała się tą kwestią. Stąd też zapewne wynikało przekonanie, że proponowane zmiany nie wywołają powszechnej rebelii, a co najwyżej lokalne wystąpienia, z którymi rząd sobie poradzi. Jak ujął to Reinsch w liście z 2 października: „żaden otwarty opór nie jest spodziewany, chociaż mogą być jakieś zamachy”. Jedyne niebezpieczeństwo, zdaniem zagranicznych i rodzimych obserwatorów, mogło pojawić się, gdyby Japonia, cały czas próbująca osłabić Chiny, wsparła buntowników. Przewidywanie okazało się trafne, zakulisowa ingerencja Japonii przyczyniła się bowiem do ich zwycięstwa. Amerykańskie poselstwo nie doceniło za to potencjału samej opozycji, która narastała w Państwie Środka. Nie do końca właściwie odczytało również nastawienie mocarstw, uważając, że spokojnie przyjmą one wprowadzenie cesarstwa, o ile oczywiście nie dojdzie do rozruchów zagrażających cudzoziemskim interesom ${ }^{194}$.

Mocarstwa nie zamierzały jednak przyglądać się biernie rozwojowi wydarzeń i wystąpiły z protestem, którego spiritus movens była Japonia. Początkowo udawała ona, że popiera dążenia Yuana, chcąc go najpewniej zachęcić, po czym od połowy października zaczęła nakłaniać europejskich sojuszników i Stany Zjednoczone do wspólnej interwencji dyplomatycznej. Mocarstwa miały dać Chinom „przyjacielską radę", aby odroczyły wprowadzenie cesarstwa. Do protestu, wystosowanego ostatecznie 28 października, przyłączyły się Wielka Brytania i Rosja, a później także Francja i Włochy, przede wszystkim dlatego, aby nie pozwolić Japonii na samodzielne działanie ${ }^{195}$.

Wystąpienie Japonii zmusiło także Waszyngton do zajęcia stanowiska. Odmiennie niż podczas kryzysu 21 żądań nad Potomakiem od początku przyjęto punkt widzenia amerykańskich dyplomatów w Pekinie, choć i tym razem wśród osób decydujących o polityce wobec Chin nie było pełnej jednomyślności. We wrześniu Lansing zgodził się z sugestią MacMurraya, aby w przypadku pytań gospodarzy o stosunek USA do wprowadzenia monarchii odpowiedzieć wymijająco, że zostanie on ustalony po jej inauguracji zależnie od takich czynników jak poparcie społeczne, możliwość utrzymania porządku oraz reakcja

194 PRFRUS 1915, s. 46-53, 61-67, 71, 77-78.

195 The Japanese Embassy to the Department of State, undated, handed on October 27, 1915, [w:] PRFRUS 1915, s. 69-70; The British Embassy to the Department of State, undated, handed on October 27, 1915, [w: ] ibidem, s. 70; Minister Reinsch to the Secretary of State, October 29, 1915, [w:] ibidem, s. 71; Minister Reinsch to the Secretary of State, November 1, 1915, [w:] ibidem, s. 72; Minister Reinsch to the Secretary of State, November 3, 1915, [w:] ibidem, s. 72-73; J. Polit, Odwrót znad Pacyfiku ..., s. 87-90. 
Amerykanów i innych mocarstw ${ }^{196}$. Gdy jakiś czas później Chińczycy zapytali Reinscha o zdanie, usłyszeli, że zmiana ustroju to ich wewnętrzna sprawa, chociaż nie mogą oczekiwać, że Stany Zjednoczone powitają ją z radością. Opinia ta stała się następnie oficjalnym stanowiskiem rządu amerykańskiego, zakomunikowanym Japonii 4 listopada ${ }^{197}$. Zdecydował o tym Wilson, który uznał, że co prawda czas był wyjątkowo „nieodpowiedni” na tego typu zmianę i najlepiej, gdyby ją odroczono, ale leżała ona wyłącznie w gestii Chińczyków i obce mocarstwa nie powinny ingerować, gdyż poważnie naruszało to suwerenność Chin ${ }^{198}$.

Inne zdanie miał na ten temat Lansing, uważający, że nie powinno się protestować przeciwko interwencji. Nie trzeba się było do niej od razu przyłączać, lecz jeśli osiągnęłaby zamierzony cel, byłoby to korzystne. Yuan miał już pełnię władzy i nie było uzasadnienia dla restauracji monarchii. Na domiar złego, według Lansinga, większość amerykańskich doniesień z Chin potwierdzała, że jej wprowadzenie wywołałoby powstanie ${ }^{199}$. Zastanawiające jest, skąd Lansing miał takie informacje, skoro gros raportów sugerowało coś odwrotnego ${ }^{200}$. Być może nie dowierzał on swojej służbie dyplomatycznej w Chinach. W tym kontekście warto wspomnieć o odpowiedzi, jakiej udzielił w czerwcu 1915 roku, gdy prof. Westel W. Willoughby (brat Williama), udający się razem z Goodnowem do Chin, spytał, czy mógłby się jakoś przydać Departamentowi Stanu. Lansing poprosił wówczas o opisanie wrażeń z Dalekiego Wschodu, a zwłaszcza tego, jak Chiny radziły sobie z utworzeniem sprawnego rządu, gdyż wiele raportów stamtąd było tendencyjnych i przez to niewiele wartych ${ }^{201}$. Lansing nie do końca orientował się też w intencjach Japonii, co sam stwierdził w liście do Wilsona: „Przyznam, że nie rozumiem celu Japonii w działaniu, które zostało przedsięwzięte. Być może jestem bardzo podejrzliwy i miało ono [wyłącznie - J.P.] na celu zachowanie pokoju na Dalekim

196 Chargé MacMurray to the Secretary of State, September 4, 1915, [w:] PRFRUS 1915, s. 47; The Secretary of State to Chargé MacMurray, September 7, 1915, [w: ] ibidem, s. 60 .

197 Minister Reinsch to the Secretary of State, October 11, 1915, [w:] PRFRUS 1915, s. 65-67; The Department of State to the Japanese Embassy, November 4, 1915, [w: ibidem, s. 76 .

198 Wilson to Lansing, October 31, 1915, [w:] PWW, t. 35, Princeton 1980, s. 143-144. Wilson chciał jednocześnie ostrzec Chiny, by działały ostrożnie.

199 Lansing to Wilson, October 27, 1915, [w: ] PWW, t. 35, s. 115.

200 Kilka dni później podczas rozmowy z japońskim ambasadorem Lansing stwierdził, że w Chinach nie ma poważnej opozycji wobec wprowadzenia cesarstwa. Nie wiadomo jednak, na ile była to szczera opinia. A Memorandum by Robert Lansing, November 3, 1915, [w: ] PWW, t. 35, s. 163-164.

201 Willoughby to Lansing, June 5, 1915, LP, box 10; Lansing to Willoughby, June 7, 1915, ibidem. 
Wschodzie"202. Wątpliwości te mogły dziwić w świetle nie tak przecież dawnego kryzysu 21 żądań, jak i poglądów samego Lansinga, który w memorandum z 11 lipca pisal, że Rosja i Japonia są niemal równie „wrogie demokracji” i ekspansjonistycznie nastawione co Niemcy, a potencjalny sojusz tych trzech państw i ich zwycięstwo oznaczałyby „cofnięcie ludzkiego rozwoju o dwa wieki”203.

Ostatecznie to nie „zagubiony” Lansing, lecz - jak już nie raz bywało - Wilson zdecydował o stanowisku USA. Warto się w tym miejscu zastanowić, co skłoniło go do obrania innego kursu niż reszta mocarstw i zarazem innego, niż sugerował Lansing. Ważne znaczenie miało zdanie Reinscha, któremu prezydent ufał. Reinsch nie krył rozczarowania z planu przywrócenia monarchii, ale wydawał się też wierzyć zapewnieniom Yuana i Liang Shiyia, że równocześnie przeprowadzone zostaną różne reformy, nastąpi rozwój oświaty, zwołany zostanie prawdziwie reprezentatywny parlament, a wiedza i doświadczenie zagranicznych doradców będą lepiej wykorzystywane. Reinsch doceniał też fakt, że zmianę przeprowadzano z zachowaniem przynajmniej pozorów legalności, a nie na drodze zamachu stanu. Argumenty te zapewne przemawiały do Wilsona, choć i tak największe znaczenie miało to, że w opinii Reinscha Chińczycy bardzo sprawnie dokonywali transformacji ustrojowej, nie było większej opozycji i nie zanosiło się na poważniejsze niepokoje wewnętrzne ${ }^{204}$. Utrzymanie porządku stanowiło zaś nadal nadrzędny cel Stanów Zjednoczonych i póki było zagwarantowane, mogły one przystać, aczkolwiek niechętnie, na restaurację monarchii. Wpisywało się to $\mathrm{w}$ ich dotychczasową politykę popierania Yuana, którego uznawały za zdolnego do ustabilizowania sytuacji. Zaakceptowanie zmiany ustroju mogło być dla administracji Wilsona o tyle łatwiejsze, że amerykańska prasa straciła już w tym czasie zainteresowanie republikanizmem w $\mathrm{Chinach}^{205}$. Wśród potencjalnych przyczyn odżegnania się od interwencji można jeszcze wymienić: wyjaśnienia Chin (poniżej); stanowisko Goodnowa ${ }^{206}$; chęć odróżnienia się po raz kolejny od reszty mocarstw ${ }^{207}$ oraz nieufność wobec Japonii, spotęgowaną przez kryzys 21 żądań

${ }^{202}$ Lansing to Wilson, October 27, 1915, [w:] PWW, t. 35, s. 115.

${ }^{203}$ Memorandum "Consideration and Outline of Policies", July 11, 1915, LP, box 64.

${ }^{204}$ Minister Reinsch to the Secretary of State, October 2, 1915, [w:] PRFRUS 1915, s. 65; Minister Reinsch to the Secretary of State, October 11, 1915, [w:] ibidem, s. 65-67; Wilson to Lansing, October 31, 1915, [w: ] PWW, t. 35, s. 143-144; Minister Reinsch to the Secretary of State, November 12, 1915, [w: PRFRUS 1915, s. 77-78; Minister Reinsch to the Secretary of State, December 18, 1915, [w:] ibidem, s. 78-79.

${ }^{205}$ D.M. Crane, T.A. Breslin, An Ordinary Relationship ..., s. 149-150.

${ }^{206}$ Wilson znał Goodnowa i chyba cenil sobie jego zdanie. Na pewno brał je pod uwage poprzedni sekretarz stanu - Bryan. Bryan to Tumulty, December 2, 1914, [w:] $P W W$, t. 31, s. 381-382.

${ }^{207}$ Chiny byly wdzięczne Stanom Zjednoczonym za odmowę udziału w proteście. Minister Reinsch to the Secretary of State, November 19, 1915, [w: ] PRFRUS 1915, s. 78. 
i kolejne doniesienia, które wskazywały, że dąży ona do uzyskania od sojuszników prawa do nadzorowania wydarzeń w Chinach w zamian za chronienie tam wszystkich cudzoziemskich interesów ${ }^{208}$. Nie sposób pominąć również przekonania Wilsona, że narody mają prawo do samookreślenia.

Protest mocarstw nie przyniósł większego rezultatu. Pekin zręcznie odpowiedział, że nie może zatrzymać ani opóźnić rozpoczętego procesu, gdyż ma on charakter oddolny i wszelka ingerencja mogłaby dopiero wywołać niepożądane reperkusje. Powszechna akceptacja gwarantowała nadto zachowanie porządku. Zdecydowano jedynie, że inauguracja cesarstwa nie nastąpi w $1915 \mathrm{roku}^{209}$.

Taka odpowiedź oczywiście nie usatysfakcjonowała Japonii, która kontynuowała wywieranie nacisków na Chiny (np. oznajmiając, że wyśle siedem okrętów do portów chińskich) i europejkkich sojuszników ${ }^{210}$. Te ostatnie zabiegi zaowocowały kolejnym wspólnym démarche, wystosowanym w połowie grudnia ${ }^{211}$, już po wyrażeniu przez Yuana zgody na tytuł cesarski. Tak jak i za pierwszym razem Stany Zjednoczone nie przyłączyły się do wystąpienia. Nie zamierzały zmieniać swojego stanowiska, szczególnie że coraz bardziej niepokoiły je poczynania Japonii. 21 grudnia Lansing polecił uznać cesarstwo, gdy zostanie ogłoszone, jeśli tylko nie pojawi się zorganizowana opozycja. Za uznaniem był Reinsch, który dodawał, że inni cudzoziemscy posłowie w Pekinie mieli takie samo zdanie ${ }^{212}$.

Pod koniec roku Yuan stanął według Reinscha przed dylematem, czy przyjąć ostrzeżenia mocarstw, wyrzekając się ambicji i nadwątlając swoją pozycję w kraju, czy zignorować je, narażając się tym samym na obcą interwencję ${ }^{213}$. Postanowił nie przerywać przygotowań, które nabierały coraz większego tempa (m.in.

208 The Minister in China (Reinsch) to the Secretary of State, October 28, 1915, [w: ] PRFRUS, The Lansing Papers, 1914-1920, t. 2, s. 427-428. Reinsch sugerował, że jeśli już Departament Stanu uzna za stosowne zaprotestować przeciwko restauracji monarchii, to niech zrobi to osobno, a nie razem $\mathrm{z}$ Japonią, która chciała osiągnąć cele sprzeczne $\mathrm{z}$ amerykańskimi interesami.

209 Minister Reinsch to the Secretary of State, October 29, 1915, [w:] PRFRUS 1915, s. 71; The Chinese Legation to the Department of State, undated, read to the Secretary of State on October 29, 1915, [w:] ibidem, s. 71-72; A translation of the answer of the Chinese Government to the Chargé d'Affaires of Japan and the Minister of Great Britain and Russia, November 2, 1915, [w: ] ibidem, s. 74-75; Reinsch to Lansing, November 9, 1915, [w:] $P W W$, t. 35, s. 203-204.

210 Reinsch to Lansing, November 9, 1915, [w: ] PWW, t. 35, s. 203-204; J. Polit, Odwrót znad Pacyfiku..., s. 91-93.

211 Rodziński pisze, że protest złożono 15 grudnia, a Polit, że dwa dni później. Por. W. Rodziński, Historia Chin ..., s. 628; J. Polit, Odwrót znad Pacyfiku ..., s. 93.

212 Minister Reinsch to the Secretary of State, December 18, 1915, [w:] PRFRUS 1915, s. 78-79; The Secretary of State to Minister Reinsch, December 21, 1915, [w: ] ibidem, s. 79.

213 Reinsch to Lansing, November 9, 1915, [w:] PWW, t. 35, s. 203-204. 
ogłoszono już datę intronizacji). Mogły na to wpłynąć stanowisko Waszyngtonu oraz postawa mocarstw europejskich należących do ententy, które co prawda protestowały, ale głównie ze względu na Japonię, a same akurat w tym czasie chciały pozyskać Chiny do współpracy przeciwko państwom centralnym.

W Pekinie myślano o tym samym. Od wybuchu konfliktu światowego rozważano możliwość wypowiedzenia wojny Niemcom, ale blokowała to Japonia, wspierana przez Wielką Brytanię. W listopadzie 1915 roku powrócono do pomysłu, licząc, że jego realizacja uchroniłaby Chiny przed japońską agresją, przyznałaby im prawo uczestnictwa w konferencji pokojowej rozstrzygającej o przyszłości Jiaozhou, wzmocniłaby pozycję Yuana i pozwoliłaby mu uzyskać międzynarodową akceptację dla cesarskiego tytułu ${ }^{214}$. Wielka Brytania, Francja i Rosja wykazały zainteresowanie przystąpieniem Pekinu do wojny, szukały bowiem możliwości dozbrojenia Rosji i usunięcia Niemców z Chin. Kluczowy okazał się jednak kategoryczny sprzeciw Japonii, której zależało na dalszym osłabianiu sąsiada, a już na pewno nie na jego wzmacnianiu ${ }^{215}$.

Zawetowawszy niebezpieczny pomysł, Japonia przystąpiła do kontrakcji. Jak donosił Reinsch 4 grudnia, chciała, aby przyznano jej swobodę działania w Chinach, oznaczającą uznanie jej dominacji. Amerykański poseł obawiał się, że Wielka Brytania, pochłonięta wojną i nieotrzymująca dostatecznego poparcia od Rosji w sprawach dalekowschodnich, będzie musiała na to przystać. Sugerował zatem wsparcie jej wysiłków na rzecz utrzymania status quo w Chinach ${ }^{216} .11$ grudnia przedstawił jeszcze inny pomysł - wciągnięcie Chin do grona państw neutralnych, które - o ile byłoby to w ogóle planowane - miały się podjąć mediacji między stronami wojny. Udział Chin w takiej akcji wzmocniłby ich bezpieczeństwo na arenie międzynarodowej. Gdyby zaś Japonia, korzystając z rozruchów, interweniowała w Chinach, USA powinny w opinii Reinscha współuczestniczyć w zagwarantowaniu porządku. Interwencja nie była jedynym szkodliwym działaniem,

214 Reinsch to Lansing, November 9, 1915, [w:] PWW, t. 35, s. 203; J. Polit, Odwrót znad Pacyfiku..., s. 95; S.G. Craft, Angling for an Invitation ..., s. 12.

215 Reinsch to Lansing, November 9, 1915, [w: ] PWW, t. 35, s. 203; Reinsch to Lansing, November 13, 1915, [w: ] ibidem, s. 204-205; Reinsch to the Secretary of State, November 16, 1915, RDSRPRBChOS, roll 25; Reinsch to the Secretary of State, November 27, 1915, ibidem; J. Polit, Odwrót znad Pacyfiku..., s. 94-98. W drugiej połowie listopada prasa w USA poinformowała o rozmowach na temat przystąpienia Chin do wojny, co rozzłościło Reinscha, który uznał, że przedwczesne ujawnienie tej informacji może zaszkodzić Chinom, jak i dyskredytuje amerykańską dyplomację, gdyż krąg wtajemniczonych był wąski. Lansing zapewnił, że przeciek nie nastąpił w Departamencie Stanu. Reinsch to the Secretary of State, November 20, 1915, RDSRPRBChOS, roll 25; Lansing to the American Legation at Peking, November 20, 1915, ibidem; Reinsch to the Secretary of State, November 22, 1915, ibidem.

216 Reinsch to Lansing, December 4, 1915, [w: ] PWW, t. 35, s. 289-290. 
które Japonia mogła podjąć. Inne potencjalnie negatywne scenariusze zakładały rozszerzenie jej wplywów poprzez tajne negocjacje z Yuanem lub wystosowanie nowych żądań. W każdym razie Japonia miała być zdecydowana na „maksymalne wykorzystanie sytuacji”"17.

$\mathrm{Na}$ te doniesienia zareagował niezwłocznie Wilson. Nazajutrz po otrzymaniu pierwszego listu od Reinscha polecił Lansingowi wyraźnie zakomunikować ambasadorowi Chindzie, że Stany Zjednoczone negatywnie ocenią próby dalszego umacniania pozycji Japonii w Chinach ${ }^{218}$.

Tymczasem sytuacja w Państwie Środka jeszcze mocniej się skomplikowała. Pod koniec grudnia 1915 roku w odległym Yunnanie wybuchła rebelia, nazywana też „trzecią rewolucją”. Na jej czele stanął gen. Cai E, onegdaj gubernator tej prowincji, były uczeń przywódcy Partii Postępowej ${ }^{219}$ Liang Qichao, który również ostro wystąpił przeciwko Yuanowi. Buntownicy żądali zaprzestania przygotowań do wprowadzenia cesarstwa i ukarania czołowych orędowników ruchu monarchicznego. Ponieważ Yuan zignorował ich ultimatum, Yunnan, a niedługo później Guizhou wypowiedziały mu posłuszeństwo. Rozpoczęła się wojna domowa, w której powstańcy, mimo początkowo niekorzystnego dla nich układu sił, zaczęli odnosić znaczne sukcesy. Coraz więcej prowincji przyłączało się do nich lub deklarowało zachowanie neutralności. Armia, dotychczas fundament dyktatury Yuana, przestała być mu całkowicie wierna i na przykład oddziały w Sichuanie przeszły na stronę przeciwników. Do ruchu antyyuanowskiego przystąpili członkowie zorganizowanej przez Sun Yat-sena Chińskiej Partii Rewolucyjnejej ${ }^{220}$ choć tym razem nie odgrywali w nim głównej roli. Yuana zaczęli też opuszczać jego niegdyś najwierniejsi poplecznicy. Jeszcze w maju 1915 roku z rządu odszedł gen. Duan. Teraz pozycję wyczekującą zajął drugi z najważniejszych generałów - Feng Guozhang, a pozostali dowódcy albo postąpili podobnie, albo otwarcie sprzeciwili się niedoszłemu cesarzowi. Wobec Yuana zdystansował się nawet Liang Shiyi, nie godząc się na dalsze jego kredytowanie ${ }^{221}$.

217 Reinsch to the Secretary of State, December 11, 1915, WWP, series 2, reel 75.

218 Wilson to Lansing, December 5, 1915, [w: ] PWW, t. 35, s. 289.

219 Partia Postępowa została utworzona wiosną 1913 roku z połączenia trzech partii o konserwatywnym charakterze, aby rywalizować z Kuomintangiem o wpływy w parlamencie. Na początku popierała Yuana, ale gdy postanowił on przywrócić monarchię, większość jej członków, z Liangiem na czele, przeszła do zdecydowanej opozycji.

220 Chińska Partia Rewolucyjna została powołana w lipcu 1914 roku w Japonii przez przebywającego tam na emigracji Sun Yat-sena. Po niepowodzeniu „drugiej rewolucji” Sun uznał, że konieczne było stworzenie partii bardziej zdyscyplinowanej i bezpośrednio mu wiernej (członkowie składali mu przysięgę). Ten nowy rys zniechęcił do przystąpienia część jego dawnych towarzyszy broni.

${ }_{221}$ W. Rodziński, Historia Chin ..., s. 627-631; The Cambridge History of China ..., s. 250-253. 
Powody „trzeciej rewolucji” były różne, bo i sam ruch był amalgamatem różnych środowisk. Niektórzy sprzeciwiali się tylko odtworzeniu monarchii, uważając ją za przeżytek i krok wstecz lub - jak zapewne w przypadku Duana i Fenga - obawiając się, że jej wprowadzenie i ustanowienie nowej dynastii pogrzebie ich szanse na sukcesję po Yuanie. Inni rozczarowani byli całokształtem rządów Yuana, jeszcze inni od dawna byli mu wrodzy ${ }^{222}$. Nie sposób wykluczyć, że część osób przyłączyła się do powstania z przyczyn pragmatycznych - poparli stronę, która osiągnęła przewagę i która, zdawało się, że zwycięży. Należy także pamiętać o pomocy, jakiej „trzeciej rewolucji” udzieliło Tokio, upatrujące w niej sposobności do rozszerzenia wpływów i pozbycia się Yuana.

Wybuch "trzeciej rewolucji” i jej przebieg zaskoczył Amerykanów. W przeważającej większości doniesień z 1915 roku konsulowie i poselstwo w Pekinie relacjonowali, że sytuacja w Chinach się poprawia i skłaniali się ku przewidywaniu, że do poważnego powstania nie dojdzie ${ }^{223}$. Pod koniec roku pojawily się co prawda sygnały świadczące o wzmożonej aktywności rewolucjonistów (np. 5 grudnia przejęli oni w Szanghaju na kilkanaście godzin krążownik „Zhao He” i ostrzelali arsenał oraz inne okręty), ale nie przejęto się tym za bardzo, być może uznając, że spiski stały się już normalnym elementem politycznego krajobrazu Chin ${ }^{224}$. Nie sądzono bynajmniej, aby wszystko było w najlepszym porządku. W połowie grudnia Reinsch i Clarence Gauss z konsulatu w Szanghaju (przyszły ambasador w Chinach) stanowczo zaprotestowali przeciwko decyzji o wycofaniu części amerykańskich okrętów z chińskich wód. Argumentowali, że nadal istniała groźba rozruchów oraz japońskiej interwencji ${ }^{225}$.

Gdy wybuchła „trzecia rewolucja”, Reinsch pozostał przy zdaniu, że nie stanowiła ona poważnego kryzysu. W większości swoich wczesnych doniesień przekonywał, że perspektywy były w miarę pomyślne, powstanie ograniczało się do Yunnanu i nie rozprzestrzeniło się na inne prowincje. Miało to świadczyć o braku zorganizowanej opozycji, która nie wyszła poza stadium „osobistej rewolty” kilku

${ }^{222}$ W. Rodziński, Historia Chin ..., s. 627-631; The Cambridge History of China ..., s. 249-250; D.M. Crane, T.A. Breslin, An Ordinary Relationship ..., s. 155.

223 Patrz przypis nr 194 oraz np. Pontius to Reinsch, April 22, 1915, RDSRIACh, roll 14; Pontius to Reinsch, June 19, 1915, ibidem; Hanson to Reinsch, June 28, 1915, ibidem; Pontius to MacMurray, August 18, 1915, ibidem; Pontius to MacMurray, September 13, 1915, ibidem; Cheshire to the Secretary of State, September 22, 1915, ibidem; Pontius to MacMurray, October 4, 1915, ibidem; Heintzleman to Reinsch, December 20, 1915, ibidem.

224 Gauss to Reinsch, December 7, 1915, RDSRIACh, roll 14; Reinsch to the Secretary of State, December 11, 1915, WWP, series 2, reel 75.

225 Gauss to Reinsch, December 17, 1915, RDSRIACh, roll 14; Reinsch to the Secretary of State, December 17, 1915, ibidem; Lansing to the Secretary of the Navy, December 18, 1915, ibidem; Daniels to Lansing, December 23, 1915, ibidem; Reinsch to the Secretary of State, December 23, 1915, ibidem. W wyniku protestu decyzja została częściowo zmieniona. 
dowódców wojskowych przeciw Yuanowi. Sytuacja tego ostatniego przedstawiała się dosyć korzystnie - dysponował większymi funduszami niż przeciwnicy, armia i gubernatorzy byli mu posłuszni, a ludzie wykształceni i przedsiębiorcy, chociaż rozczarowani dotychczasowymi rządami, nie zamierzali przeciwko niemu występować. 11 stycznia 1916 roku Reinsch stwierdził nawet, że „istnieją powody, aby sądzić, że ruch rewolucyjny się zakończył"226.

Jednocześnie Reinsch, być może asekurując się, wspominał, że kryzys mógł się jednak okazać groźny. Yunnan był prowincją trudną do zdobycia, przez co buntownicy mogli się tam długo utrzymywać, a to z kolei mogło ośmielić wystąpienia w innych miejscach. Yuan był niepopularny w społeczeństwie i gdyby rewolucjonistom udało się opanować południowe i centralne prowincje, musiałby on poważnie ograniczyć swoją władzę lub doszłoby do podziału państwa ${ }^{227}$.

Reinsch pozostawał jednak optymistycznie nastawiony. 19 stycznia poinformował Departament Stanu, że zgodnie z grudniowymi instrukcjami zamierza uznać cesarstwo, kiedy zostanie ogłoszone. Odroczenie uznania dałoby tylko impuls do dalszych wystąpień, które nie przyniosłyby niczego konstruktywnego, a jedynie „rozlew krwi i niepokoje”. Im dłużej trwał zaś okres niestabilności, tym bardziej rosło prawdopodobieństwo japońskiej ingerencji. Niebagatelne znaczenie, przynajmniej w oczach Reinscha, miał ponadto fakt, że rząd kontrolowała frakcja postępowa, chcąca przeprowadzić światłe reformy ${ }^{228}$. Rebelianci nie stanowili dla niej konkurencji. Chociaż powszechnie doceniano zalety Cai E, to amerykańscy przedstawiciele charakteryzowali rebeliantów jako powodowanych wyłącznie osobistymi pobudkami i podkreślali, że na scenie politycznej nie istnieli żadni inni „zdolni i odpowiedzialni” ludzie, którym można by powierzyć władzę 229 .

226 Reinsch to the Secretary of State, December 29, 1915, WWP, series 2, reel 76; Reinsch to the Secretary of State, December 30, 1915, ibidem; Minister Reinsch to the Secretary of State, January 3, 1916, [w: ] PRFRUS 1916, s. 51-53; Minister Reinsch to the Secretary of State, January 11, 1916, [w: ] ibidem, s. 53; Minister Reinsch to the Secretary of State, January 15, 1916, [w: ] ibidem, s. 53-55; Minister Reinsch to the Secretary of State, January 19, 1916, [w:] ibidem, s. 55.

227 Minister Reinsch to the Secretary of State, January 3, 1916, [w:] PRFRUS 1916, s. 51; Minister Reinsch to the Secretary of State, January 3, 1916, [w:] ibidem, s. 51-53. Podczas „trzeciej rewolucji” Reinsch kilkakrotnie zmieniał zdanie i chwilami pisał niespójne lub sprzeczne doniesienia. N. Pugach, Paul S. Reinsch ..., s. 190, 193.

228 Minister Reinsch to the Secretary of State, January 19, 1916, [w:] PRFRUS 1916, s. 55; Minister Reinsch to the Secretary of State, February 24, 1916, [w:] ibidem, s. 62-63.

${ }^{229}$ Minister Reinsch to the Secretary of State, January 3, 1916, [w:] PRFRUS 1916, s. 51-53; Minister Reinsch to the Secretary of State, January 15, 1916, [w: ] ibidem, s. 53-55; Minister Reinsch to the Secretary of State, January 19, 1916, [w:] ibidem, s. 55. Cytat pochodzi z listu z 15 stycznia. D.M. Crane, T.A. Breslin, An Ordinary Relationship ..., s. 150. 
Nie wiadomo, jaki był odzew na te doniesienia w Waszyngtonie. Problem ze zrekonstruowaniem stanowiska wynika z braku materiałów, ponieważ ani archiwalia, ani opublikowane zbiory dokumentów nie pozwalają naświetlić chińskiej polityki administracji Wilsona w pierwszych miesiącach $1916 \mathrm{roku}^{230}$. Jest to tym bardziej zaskakujące, że listów i telegramów adresowanych do Departamentu Stanu jest bardzo wiele ${ }^{231}$. Także historycy zajmujący się tą problematyką pomijają ten wątek. Być może politycy w Waszyngtonie tak pochłonięci byli w tym czasie innymi sprawami międzynarodowymi, że tylko pobieżnie śledzili wydarzenia w Chinach ${ }^{232}$. Sugeruje to na przykład list z początku kwietnia, w którym Wilson wyznał Lansingowi, że nie miał czasu dogłębnie przestudiować depesz z Pekinu ${ }^{233}$.

Reinsch tymczasem zaczął zmieniać swoje zdanie. 29 stycznia stwierdził, że na razie nie uzna cesarstwa, gdy zostanie ogłoszone. Postanowił dać rebeliantom więcej czasu na wykazanie, że są zdolni do rządzenia. Polecił attachés wojskowym udać się do doliny Jangcy i Kantonu w celu wybadania sytuacji ${ }^{234}$. Od konsulów i zwykłych Amerykanów docierały informacje, że w wielu miejscach panował spokój, a tam, gdzie toczyły się walki, wojska Południa zachowywały się wzorowo

230 Wyjątek może stanowić list z 28 grudnia 1915 roku, w którym Lansing wyraził zaniepokojenie sytuacją polityczną na Dalekim Wschodzie (referował on co prawda stanowisko amerykańskich bankierów, ale być może je podzielał). Wydaje się jednak, że źródłem niepokoju nie była w tym przypadku sytuacja wewnętrzna Chin, tylko sytuacja międzynarodowa. The Secretary of State to Minister Reinsch, December 28, 1915, [w: ] PRFRUS 1915, s. 215.

231 Na przykład w PRFRUS z 1916 roku w części poświęconej „trzeciej rewolucji” (kilkadziesiąt stron) nie ma ani jednego dokumentu napisanego przez prezydenta, sekretarza stanu lub innego wysokiego rangą pracownika Departamentu Stanu.

232 Przełom lat 1915 i 1916 obfitował w ważne dla USA wydarzenia międzynarodowe. Z kolejną misją pokojową gościł w Europie House. Relacje z Niemcami pozostawały napięte, zwłaszcza po storpedowaniu przez nie nieuzbrojonego statku „Sussex” w marcu 1916 roku. Miesiąc wcześniej rozpoczęło się najkrwawsze starcie wojny - bitwa pod Verdun. Mniej więcej w tym samym czasie doszło do poważnego kryzysu amerykańsko-meksykańskiego. 9 marca oddziały Pancho Villi najechały przygraniczne miasto Columbus w Nowym Meksyku. W odpowiedzi Stany Zjednoczone zorganizowały dowodzoną przez gen. Johna J. Pershinga ekspedycję karną, która przez prawie rok bezskutecznie próbowała schwytać Villę, doprowadzając jednocześnie do pogorszenia stosunków z południowym sąsiadem. Wstępy do: $P W W$, t. 35, s. vii-viii; $P W W$, t. 36, Princeton 1981, s. vii-viii.

233 Wilson to Lansing, April 7, 1916, [w: ] PWW, t. 36, s. 428. Zob. też R.S. Baker, Woodrow Wilson. Life and Letters, t. 7: War Leader, 1917-1918, New York 1946, s. 25.

234 Minister Reinsch to the Secretary of State, January 29, 1916, [w: ] PRFRUS 1916, s. 55-56. 
i nie były nastawione antycudzoziemsko ${ }^{235}$. Co ważniejsze, już na samym początku rebelianci, podobnie jak podczas rewolucji Xinhai, zadeklarowali, że będą chronić cudzoziemców i ich dobytek oraz respektować uprzednio zawarte traktaty ${ }^{236}$. Słowa dotrzymali. To, że Yuan nie zwróci się przeciwko cudzoziemcom, było jasne. Przynajmniej na początku powstania sytuacja wydawała się więc na tyle bezpieczna, że Reinsch i konsulowie nie zalecili rodakom opuszczenia miejsc zamieszkania ani nie podjęli innych zdecydowanych kroków ${ }^{237}$.

„Trzecia rewolucja” nie niosła za sobą bezpośredniego ryzyka dla interesów mocarstw, niosła za to ryzyko pośrednie - okres zawieruchy, ogólnej niestabilności i potencjalnego wzrostu wpływów Japonii. Wobec konfliktu w Chinach mocarstwa pozostały neutralne, chociaż bardziej sympatyzowały z Yuanem, którego dotychczas popierały ${ }^{238}$. Wyjątek stanowiła Japonia, pomagająca nieoficjalnie - lecz z taką intensywnością, że niemal jawnie - rebeliantom.

Stany Zjednoczone otrzymywały wiele sygnałów świadczących o japońskim zaangażowaniu w powstanie ${ }^{239}$. Równie mocno niepokoił je fakt, że

${ }^{235}$ Jamson to Reinsch, January 3, 1916, RDSRIACh, roll 14; Minister Reinsch to the Secretary of State, January 11, 1916, [w:] PRFRUS 1916, s. 53; Heintzleman to Reinsch, January 18, 1916, RDSRIACh, roll 14; Josselyn to Reinsch, January 31, 1916, ibidem; Cunningham to Reinsch, February 9, 1916, ibidem; Hockman to unknown person, February 12, 1916, ibidem; Hockman to friends, February 22, 1916, ibidem; Winterhalter to the Secretary of the Navy, March 2, 1916, RDSRIACh, roll 16; Johnson to Reinsch, March 21, 1916, RDSRIACh, roll 14; Winterhalter to the Secretary of the Navy, April 7, 1916, RDSRIACh, roll 16; Hanson to Reinsch, April 18, 1916, RDSRIACh, roll 14.

${ }^{236}$ Reinsch to the Secretary of State, December 29, 1915, WWP, series 2, reel 76; The Leaders of the Rebellion to Reinsch, December 31, 1915, RDSRIACh, roll 14; Chew Han Man to the Consul General for United States of America, January 1, 1916, ibidem.

${ }^{237}$ Cunningham to Swenson, February 11, 1916, RDSRIACh, roll 14. W marcu i kwietniu niektórzy amerykańscy konsulowie zalecili rodakom przyjazd do miast, ale część misjonarzy uznała, że pozostanie na prowincji, gdyż panował tam spokój. Pod koniec marca Reinsch przedsięwziąl środki ostrożności, obawiając się buntu w armii. Winterhalter to the Secretary of the Navy, March 3, 1916, RDSRIACh, roll 16; Minister Reinsch to the Secretary of State, March 9, 1916, [w:] PRFRUS 1916, s. 64; Johnson to Reinsch, March 13, 1916, RDSRIACh, roll 14; Minister Reinsch to the Secretary of State, March 31 (midnight), 1916, [w:] PRFRUS 1916, s. 67; Reinsch to the Secretary of State, March 31 (8 p.m.), 1916, RDSRIACh, roll 14; Lansing to the American Legation at Peking, April 3, 1916, ibidem; Winterhalter to the Secretary of the Navy, April 3, 1916, RDSRIACh, roll 16; Josselyn to Reinsch, April 19, 1916, RDSRIACh, roll 15.

${ }_{238}$ Reinsch twierdzil, że Brytyjczycy usilnie próbowali zastopować rebelię. Reinsch to the Secretary of State, February 2, 1916, RDSRIACh, roll 14.

239 Patrz np.: Reinsch to the Secretary of State, February 2, 1916, RDSRIACh, roll 14; Reinsch to the Secretary of State, February 24, 1916, ibidem; Guthrie to the Secretary of State, February 29, 1916, ibidem; Peck to the Secretary of State, March 24, 1916, ibidem; 
Japonia działała na dwóch „frontach”. Oprócz pomagania insurgentom miała próbować wymóc na europejskich sojusznikach przyznanie jej wolnej ręki w Chinach. Na przełomie stycznia i lutego Reinsch informował, że Rosja zgodziła się na to i Japonia naciskała teraz na Wielką Brytanię. Przytaczał też krążące pogłoski, że Tokio ponownie przedstawiło Pekinowi żądania z grupy piątej $\mathrm{z}$ poprzedniego $\mathrm{roku}^{240}$. O agresywnych planach Japonii pisał w tym samym czasie Walter Hines Page, amerykański ambasador przy Dworze św. Jakuba. Japonia miała już otrzymać od niektórych mocarstw wstępną zgodę na zachowanie po wojnie „znacznych korzyści i przywilejów” i dążyła do zdobycia przewagi w Chinach i regionie Pacyfiku. Whitehall jak na razie nie zaakceptowal tego, ale jego ostateczna decyzja zależała od wyniku wojny. Gdyby nie została ona rozstrzygnięta, a Niemcy doszczętnie pokonane, wtedy musiałby się zgodzić na żądania Tokio, ponieważ potrzebowałby swojej floty w Europie. W przypadku klęski Rzeszy Brytyjczycy i Amerykanie mogliby współpracować, aby powściągnąć Japonię ${ }^{241}$.

Obawa przed japońską interwencją początkowo powstrzymywała też umiarkowanie nastawionych Chińczyków przed przystąpieniem do powstania. $\mathrm{Z}$ czasem jednak i oni zaczęli coraz silniej manifestować niezadowolenie z rządów Yuana. Powstańczy ferment ogarniał stopniowo kolejne prowincje południowe i promieniował na Chiny Środkowe. W dolinie Jangcy nadal panował spokój, ale dwaj najważniejsi dowódcy na tym obszarze - generał Feng i feldmarszałek Zhang Xun, chociaż pozostali lojalni wobec Yuana, żywili do niego osobistą urazę, podejrzewając, że specjalnie wysłał ich tam obu, aby wzajemnie się pilnowali ${ }^{242}$.

Sammons to Reinsch, April 8, 1916, ibidem; Cunningham to Reinsch, April 13, 1916, RDSRIACh, roll 15; Guthrie to the Secretary of State, April 17, 1916, RDSRIACh, roll 14; Reinsch to the Secretary of State, April 24, 1916, ibidem; Reinsch to the Secretary of State, May 17, 1916, RDSRIACh, roll 15. Co ciekawe, Japończycy podczas rozmów z chińskimi oficjelami insynuowali, że to amerykańskie poselstwo pozostawało w stałym kontakcie $\mathrm{z}$ rewolucjonistami. Reinsch to the Secretary of State, March 9, 1916, RDSRIACh, roll 14.

${ }^{240}$ Reinsch to the Secretaty of State, January 27, 1916, WWP, series 2, reel 77; Reinsch to the Secretaty of State, February 5, 1916, ibidem. Zobacz też: Lansing to the American Embassy at London, February 21, 1916, RDSRPRBChOS, roll 25; Guthrie to the Secretary of State, April 17, 1916, RDSRIACh, roll 14.

${ }^{241}$ Page to Lansing, January 22, 1916, [w: ] PWW, t. 35, s. 517-518. O kwestii japońskiej pisał Page w kontekście brytyjskich planów wprowadzenia pełnej blokady Niemiec. Chciał, aby USA się na nią zgodzily, gdyż wierzyl, że tylko w ten sposób można było doprowadzić do zdruzgotania Niemiec, a to z kolei miało zagwarantować trwały pokój.

${ }^{242}$ Reinsch to the Secretary of State, February 2, 1916, RDSRIACh, roll 14; Minister Reinsch to the Secretary of State, February 23, 1916, [w:] PRFRUS 1916, s. 59-60. 
Pod koniec lutego zagraniczni dyplomaci nadal uważali, że Yuan mógł jeszcze uratować sytuację, poświęcając marzenia o cesarstwie oraz zrzekając się części władzy. Nie byli jednak pewni, czy pojmował on powagę swego położenia ${ }^{243}$.

Yuan, mimo że był zagubiony i utracił zdolność szybkiego podejmowania decyzji, wiedział, że sytuacja wymyka mu się spod kontroli. Kolejnymi ustępstwami próbował zaspokoić żądania powstańców. Zaczął nawet poważnie rozważać przeprowadzenie reform ustrojowych. 23 lutego bezterminowo odroczył swoją intronizację, a 22 marca ogłosił całkowitą rezygnację z wprowadzenia monarchii ${ }^{244}$.

Nie zdało się to na nic. Rebelianci, widząc, że pozycja Yuana słabła, nie zaprzestali walki i domagali się, aby całkowicie ustąpił z życia politycznego (Yuan ponownie objął urząd prezydenta). Celem „trzeciej rewolucji” nie było już bowiem zablokowanie wprowadzenia monarchii, którą zresztą część elit popierała, lecz usunięcie Yuana. Jedyne co - zdaniem Reinscha - mogło go jeszcze uratować, to podjęcie się mediacji przez Fenga, Duana i kilka innych liczących się osób ${ }^{245}$.

Stany Zjednoczone coraz bardziej niepokoiła perspektywa upadku Yuana i przede wszystkim wzrostu wpływów Japonii, która gdyby rebelianci zwyciężyli, a ententa przyznała jej swobodę działania, zyskałaby panowanie nad Chinami. Reinsch, informujący w marcu i kwietniu o tych właśnie zagrożeniach, apelowat, aby nie przyglądać się biernie rozwojowi wydarzeń, tylko wesprzeć Europejczyków w przeciwstawieniu się Japonii i nie pozwolić, aby samodzielnie nadzorowała ona sytuację w Chinach. Można to było osiągnąć poprzez wprowadzenie międzynarodowej kontroli finansów Chin, wystosowanie podobnej deklaracji jak ta z maja 1915 roku, udział Stanów Zjednoczonych w utrzymaniu porządku, gdyby okazało się to potrzebne, i przede wszystkim poprzez wydanie przez mocarstwa wspólnej noty, która potwierdziłaby chęć zachowania status quo w Chinach ${ }^{246}$.

${ }^{243}$ Minister Reinsch to the Secretary of State, February 23, 1916, [w:] PRFRUS 1916, s. 59-60; Minister Reinsch to the Secretary of State, February 24, 1916, [w: ibidem, s. 60-61.

${ }^{244}$ Minister Reinsch to the Secretary of State, February 24, 1916, [w: ] PRFRUS 1916, s. 60-61; Reinsch to the Secretary of State, March 9, 1916, RDSRIACh, roll 14; Minister Reinsch to the Secretary of State, March 22, 1916, [w: ] PRFRUS 1916, s. 66-67; P. Reinsch, An American Diplomat..., s. 192; J. Polit, Odwrót znad Pacyfiku..., s. 101.

${ }^{245}$ Minister Reinsch to the Secretary of State, March 21, 1916, [w:] PRFRUS 1916, s. 65-66; Minister Reinsch to the Secretary of State, March 22, 1916, [w: ] ibidem, s. 66-67; Minister Reinsch to the Secretary of State, April 4, 1916, [w:] ibidem, s. 67-69.

246 Reinsch sugerował również, aby po zakończeniu wojny zwołać osobną konferencję dotyczącą Dalekiego Wschodu, dzięki czemu uniknięto by łączenia spraw chińskich z europejskimi. Reinsch to the Secretary of State, March 13, 1916, RDSRPRBChOS, roll 25; Reinsch to the Secretary of State, April 1, 1916, WWP, series 2, reel 78; Reinsch to the Secretary of State, April 3, 1916, ibidem; Minister Reinsch to the Secretary of State, April 4, 1916, [w:] PRFRUS 1916, s. 67-69. Zob. też: Page to Lansing, March 23, 1916, [w:] PWW, t. 36, s. 411; Lansing to Wilson, April 4, 1916, [w: ibidem. 
W Waszyngtonie podchodzono z pewną ostrożnością do alarmistycznych doniesień Reinscha, zwłaszcza że nie potwierdziły ich Foreign Office i Quai d’Orsay $^{247}$. Na początku kwietnia Lansing, mimo braku pomysłu Wilsona, co można było zrobić, zaproponował jednak Wielkiej Brytanii i Francji wystosowanie wspólnej noty. Odmowa Greya, który stwierdzil, że musiałby mieć zgodę Japonii, zakończyła całą sprawę ${ }^{248}$.

Niepowodzenie nie zraziło Reinscha, który z większym zapałem zwrócił się ku innemu pomysłowi - amerykańskim pożyczkom dla Chin. Kiedy wybuchła „trzecia rewolucja”, przewidywał, że reżim Yuana może potrzebować zagranicznej pomocy finansowej ${ }^{249}$. Pekin z czasem rzeczywiście o nią poprosil. Amerykańscy inwestorzy prowadzili od końca 1915 roku negocjacje z władzami pekińskimi, ale wobec niepewnej sytuacji w Chinach nie śpieszyli się z finalizacją kontraktów. Reinsch starał się ich uspokoić, że pozycja rządu była niezachwiana, i przekonać do udzielenia pożyczki, nawet jeśli naruszyłoby to politykę neutralności. Dopiero 20 marca zmienił pogląd i doradził wstrzymanie rozmów biznesowych, póki sytuacja się nie wyjaśni, tłumacząc, że pożyczki uznano by za ingerencję w konflikt ${ }^{250}$. Jak na ironię niedługo później 7 kwietnia bank Lee, Higginson \& Co., który prowadził najbardziej zaawansowane negocjacje i chciał uprzedzić konkurencję, zdecydował się pożyczyć Yuanowi 5 milionów dol. Z tej sumy zdążył wypłacić tylko milion zaliczki, gdyż w połowie kwietnia nagle wstrzymał całą operację $e^{251}$. Wówczas Reinsch, być może w wyniku fiaska prób nakłonienia mocarstw do wydania wspólnej noty, ponownie zmienił zdanie i zaczął naciskać, aby Lee, Higginson \& Co.

247 Polk to the American Embassy at Paris, March 15, 1916, RDSRPRBChOS, roll 25; The American Embassy at London to the Secretary of State, March 16, 1916, ibidem; Sharp to the Secretary of State, March 29, 1916, ibidem.

${ }^{248}$ Lansing to the American Legation at Peking, April 4, 1916, WWP, series 2, reel 78; Lansing to the American Embassy at London, April 4, 1916, RDSRPRBChOS, roll 25; The American Ambassador at London to the Secretary of State, April 7, 1916, ibidem; Wilson to Lansing, April 7, 1916, [w: ] PWW, t. 36, s. 428; J. Polit, Odwrót znad Pacyfiku ..., s. 106.

${ }^{249}$ Minister Reinsch to the Secretary of State, January 3, 1916, [w:] PRFRUS 1916, s. 51-53; Reinsch to the Secretary of State, January 15, 1916, RDSRPRBChOS, roll 25.

${ }^{250}$ The Secretary of State to Minister Reinsch, December 28, 1915, [w:] PRFRUS 1915, s. 215; Reinsch to the Secretary of State, December 30, 1915, WWP, series 2, reel 76; Minister Reinsch to the Secretary of State, April 28, 1916, [w:] PRFRUS 1916, s. 133; N. Pugach, Paul S. Reinsch ..., s. 188-190; R.W. Curry, Woodrow Wilson and Far Eastern Policy..., s. 151-152. Rebelianci, w tym Liang Qichao, prosili, aby Stany Zjednoczone nie pożyczały pieniędzy Yuanowi. Liang to Reinsch, February 28, 1916, RDSRIACh, roll 14; Sze E. Ming to Sammons, March 10, 1916, ibidem.

${ }^{251}$ Doc. no. 1916/4: United States (Lee, Higginson \& Company) and China. Agreement for a loan, April 7, 1916, [w:] Treaties and Agreements..., t. 2, s. 1279-1286; N. Pugach, Paul S. Reinsch ..., s. 190. 
wypłacił resztę sumy. 27 maja zaapelował o dalsze dwie pożyczki, które opiewałyby łącznie na 28 milionów dol. Wiedzial, że stanowiłyby one ingerencję i zostałyby oprotestowane przez rebeliantów, a być może nawet wywołałyby bojkot amerykańskich towarów ${ }^{252}$, ale załamanie się władzy centralnej i umocnienie pozycji Japonii uznał za groźniejsze ${ }^{253}$. Pekin ze swojej strony też usilnie zabiegał o pomoc z USA. W kwietniu i maju przyznał American International Corporation i Siems-Carey różne koncesje, oczekując, że pomoże to w staraniach o pożyczkę 254 . Do końca „trzeciej rewolucji” Amerykanie nie zdecydowali się jednak wesprzeć Yuana kolejnymi środkami.

Jego sytuacja stawała się tymczasem coraz trudniejsza. Zorientowawszy się, że ustępstwa poczynione pod koniec marca nie uśmierzyly ruchu sprzeciwu, Yuan postanowił rozpocząć rozmowy z przeciwnikami, a gdy te nie dały większych rezultatów, a kolejne prowincje ogłaszały niezależność, zaczął szukać silnego sojusznika (podejrzewano nawet, że poprosi o pomoc Japonię). 22 kwietnia udało mu się namówić do powrotu do rządu swojego szwagra Duana, który został premierem i ministrem wojny. Wraz z nim swoją pozycję zaczęli odbudowywać członkowie frakcji Anhui, upatrujący szansy na pozbycie się konkurentów z frakcji kantońskiej ${ }^{255}$.

Powrót Duana do władzy Reinsch przyjął z mieszanymi uczuciami. Z jednej strony narzekał, że stronnictwo reakcyjne odzyskiwało wpływy, co uznał zresztą

${ }^{252}$ Rebelianci ostro protestowali przeciwko pożyczce udzielonej przez Lee, Higginson \& Co. Pojawiły się wówczas pogłoski o możliwym bojkocie amerykańskich produktów. Sammons to Reinsch, April 8, 1916, RDSRIACh, roll 15; Sammons to Reinsch, April 12, 1916, ibidem; Sammons to Reinsch, April 14, 1916, ibidem; Tang Shao Yi to Sammons, April 18, 1916, ibidem; Kang Yu Wei to Sammons, April 18, 1916, ibidem; Sammons to Reinsch, April 20, 1916, ibidem; Sammons to Reinsch, April 25, 1916, ibidem; Reinsch to the Secretary of State, May 3, 1916, ibidem.

${ }^{253}$ Minister Reinsch to the Secretary of State, April 20, 1916, [w:] PRFRUS 1916, s. 106; Reinsch to the Secretary of State, April 27, 1916, RDSRIACh, roll 14; Minister Reinsch to the Secretary of State, April 28, 1916, [w:] PRFRUS 1916, s. 133; Reinsch to Lansing, May 27, 1916, [w:] PWW, t. 37, Princeton 1981, s. 234-235; N. Pugach, Paul S. Reinsch ..., s. 193-194; R.W. Curry, Woodrow Wilson and Far Eastern Policy ..., s. 151-152.

${ }^{254}$ Doc. no. 1916/5: United States (American International Corporation) and China (Government of Shantung Province). Agreement for the South Grand Canal of Shantung Province 7\% Improvement Gold Loan, April 19, 1916, [w:] Treaties and Agreements ..., t. 2, s. 1287-1297; Doc. no. 1916/6: United States (American International Corporation) and China. Agreement for the Huai River Conservancy Grand Canal Improvement 7\% Gold Loan of 1916, May 13, 1916, [w:] ibidem, s. 1304-1310; Doc. no. 1916/7: United States (Siems \& Carey) and China. Agreement for the construction of certain lines of railway, May 17, 1916, [w:] ibidem, s. 1313-1321; N. Pugach, Paul S. Reinsch ..., s. 194.

${ }_{255}$ PRFRUS 1916, s. 67-69, 73-75, 77; Guthrie to the Secretary of State, May 3, 1916, RDSRPRBChOS, roll 25. 
za paradoks dziejów, że ruch na rzecz zachowania Republiki pomógł wynieść do władzy ludzi o zmurszałych poglądach. Z drugiej strony podkreślał, że tylko rząd centralny mógł dokonać rekonstrukcji systemu politycznego i uspokoić sytuację w kraju, co było konieczne, aby zapobiec interwencji Japonii, coraz jawniej mieszającej się w sprawy Chin. Nowy gabinet zapowiedział ponadto zwołanie parlamentów lokalnych i ogólnonarodowego oraz stopniowo przejmował kompetencje Yuana, który miał jeszcze przez jakiś czas pozostać głową państwa, ale systematycznie byłby pozbawiany wpływów politycznych. Takie rozwiązanie wydawało się Reinschowi najlepsze, ponieważ, podobnie jak Williams podczas „drugiej rewolucji”, krytycznie postrzegał on rebeliantów. Uważał, że ich jedynym celem było wyzucie Yuana z urzędu, nie łączył ich natomiast żaden konstruktywny program. Nie byli też na tyle zorganizowani, aby mogli rządzić po odejściu Yuana. Kłótnie między członkami, tromtadracje osób o wątpliwej reputacji czy próby zamachów politycznych świadczyły dodatkowo na ich niekorzyśćc ${ }^{256}$.

Pozyskanie Duana do współpracy nie poprawiło sytuacji Yuana, którego pozycja cały czas słabła. W maju już nawet Reinsch nie miał złudzeń, że Yuan był politycznie skończony i musiał odejść. Pozostawało tylko pytanie, czy nastąpi to natychmiast, czy stopniowo. Rebelianci obstawali przy niezwłocznym ustąpieniu, ale pewne ich decyzje zrazily generałów i polityków Północy, którzy odebrali je jako dyktat. Skonsolidowało to ich poparcie dla Yuana, którego chcieli jeszcze przez jakiś czas zachować na stanowisku prezydenta. Brak porozumienia Północy z Południem groził rozłamem państwa, co było tym bardziej realne, że rebelianci nadal, przynajmniej w opinii Reinscha, nie wykształcili struktur i kadr gotowych sprawować rządy, a ich ostatnie decyzje personalne podważały rzekomą postępowość. Do rozpadu Chin na trzy lub cztery części miała też dążyć Japonia. Inny przypisywany jej cel polityczny zakładał doprowadzenie do pełnego zwycięstwa powstańców, którzy wdzięczni za uzyskaną pomoc byliby jej podlegli 257 .

Yuan zdawał sobie sprawę z krytycznego położenia. W maju pytał o możliwość azylu w amerykańskim poselstwie i wjazdu do Stanów Zjednoczonych. Znamienne jest, że wcześniej o możliwość wjazdu z pominięciem standardowych procedur starał się Liang Qichao - jeden z przywódców „trzeciej rewolucji”. Reinsch chciał się przychylić do prośby Yuana, ale ostatecznie takowa oficjalnie nie wplynęła ${ }^{258}$. Yuan tymczasem wyraźnie podupadł na zdrowiu i 6 czerwca 1916 roku

256 PRFRUS 1916, s. 67-69, 71-73, 76-77, 79; Reinsch to the Secretaty of State, April 28, 1916, RDSRIACh, roll 15; N. Pugach, Paul S. Reinsch ..., s. 191.

257 Reinsch to the Secretary of State, May 3, 1916, RDSRIACh, roll 15; PRFRUS 1916, s. 79-84.

258 Gauss to Reinsch, January 29, 1915, RDSRIACh, roll 14; Minister Reinsch to the Secretary of State, May 6, 1916, [w:] PRFRUS 1916, s. 79; Minister Reinsch to the Secretary of State, May 24, 1916, [w: ] ibidem, s. 82; Minister Reinsch to the Secretary of State, May 25, 
zmarł zgnębiony w Pekinie, najprawdopodobniej z powodu uremii, chociaż według niektórych popełnił samobójstwo ${ }^{259}$.

Podsumowując dotychczasowe rozważania, można stwierdzić, że wybuch I wojny światowej przyniósł za sobą nowe szanse, ale i zagrożenia dla amerykańskiej polityki wobec Chin. USA otrzymały wówczas większą możliwość oddziaływania na sprawy chińskie i rozszerzania swoich wpływów, musiały za to wziąć większą odpowiedzialność za los cudzoziemców w Chinach, jak i samych Chin.

Przez pierwsze dwa lata Wielkiej Wojny Państwo Środka nadal ogrywało dużą rolę w amerykańskiej polityce zagranicznej, chociaż zapewne mniejszą niż wcześniej. Zmiana ta nie wynikała jednak ze spadku zainteresowania samymi Chinami, lecz raczej ze zrozumiałego wzrostu zainteresowania Europą, gdzie w przeważającej większości rozgrywały się wydarzenia wojenne. Pamiętać należy, że Stany Zjednoczone pozostawały w tym czasie jedynym mocarstwem niebiorącym udziału w wojnie, a ich prezydent miał ambicje, aby zaprowadzić pokój na świecie.

W omawianym okresie rząd Wilsona, podobnie jak wcześniej, koncentrował się na sprawach chińskich ze zmiennym natężeniem. Na wybuch wojny na Dalekim Wschodzie i naruszenie przez Japonię neutralności Chin zareagował powściągliwie, ponieważ nie uważał tego za duże zagrożenie, a nie chciał zostać wplątany w międzynarodowe spory. Jego zaangażowanie wyraźnie wzrosło podczas kryzysu wywołanego przez japońskie 21 żądań, poważnie godzących w chińską suwerenność i amerykańskie interesy. Obok Wielkiej Brytanii Stany Zjednoczone były wówczas głównym mocarstwem mającym wpływ na przebieg negocjacji japońsko-chińskich i przynajmniej pośrednio przyczyniły się do złagodzenia ostatecznych warunków układu. Baczna uwaga, jaką mimo trwającej na świecie wojny zwracano w Waszyngtonie na sprawę japońskich żądań, oraz gotowość do bronienia Pekinu nawet kosztem pogorszenia stosunków z Tokio pokazują, że Chiny zajmowały istotną pozycję w hierarchii amerykańskiej polityki zagranicznej. Cały kryzys zakończył się dla USA w miarę pozytywnie, ale pokazał też, że nawet na najwyższym szczeblu istniała nad Potomakiem poważna rozbieżność zdań na temat polityki wobec Chin, co znalazło odzwierciedlenie w oficjalnych deklaracjach i działaniach. Bardziej sprzyjający Japonii kurs Bryana ustąpił z czasem miejsca wyraźniej prochińskiemu stanowisku Wilsona.

Jednocześnie w 1915 roku zaczęly dojrzewać w Waszyngtonie plany bardziej zdecydowanego i konkretnego wsparcia amerykańskich biznesmenów

1916, [w: ] ibidem; P. Reinsch, An American Diplomat ..., s. 192. Azyl oferowała Yuanowi Japonia, ale odrzucił on propozycję.

259 The Chinese Minister to the Secretary of State, June 6, 1916, [w:] PRFRUS 1916, s. 98; Reinsch to the Secretary of State, June 14, 1916, RDSRIACh, roll 15; W. Rodziński, Historia Chin ..., s. 631. 
w Chinach. Stopniowy powrót do zmodyfikowanej formuly „dyplomacji dolarowej" spowodowany był chęcią przeciwstawienia się japońskim wpływom, wspomożenia władz pekińskich oraz wykorzystania dogodnego okresu wojny do rozszerzenia amerykańskich interesów. Procesowi temu sprzyjała zmiana na stanowisku sekretarza stanu - moralizatorsko i idealistycznie nastawionego Bryana zastąpił Lansing, bardziej dbający o kwestie ekonomiczne. Rozmowy biznesowe postępowały jednak powoli, co wynikało między innymi z niepewnej sytuacji w Państwie Środka. Pomysł odbudowania w Chinach cesarstwa USA przywitały bez entuzjazmu, ale $\mathrm{w}$ przeciwieństwie do innych mocarstw nie oprotestowały go. Ich zainteresowanie Chinami zmalało na początku 1916 roku, gdy raczej biernie przyglądały się rozwojowi „trzeciej rewolucji”, która doprowadziła ostatecznie do upadku Yuana.

Śmierć Yuana zakończyła pewien etap w amerykańskiej polityce wobec Chin. Od wybuchu rewolucji Xinhai Stany Zjednoczone - mimo zmiany gospodarza w Białym Domu - konsekwentnie popierały Yuana, ufając, że był on w stanie zaprowadzić porządek i zreformować państwo. Chociaż wydarzenia kolejnych lat pokazały, że bardziej koncentrował się na spełnianiu osobistych ambicji, USA nie zmieniły stanowiska. Były nawet gotowe zaakceptować, że przejął on pełnię władzy i zamierzał zostać cesarzem, jeśli tylko w Chinach panował spokój, gdyż obawiały się, że po jego upadku kraj pogrąży się w chaosie. Historia dowiodła, że nie było to rozumowanie pozbawione sensu - śmierć Yuana otworzyła jeden z najczarniejszych rozdziałów w dziejach Chin. 


\section{RozDZIAE V}

\section{POLITYKA USA WOBEC CHIN OD ŚMIERCI YUAN SHIKAIA DO ZAKOŃCZENIA I WOJNY ŚWIATOWEJ (1916-1918)}

\section{Amerykańska ocena wewnętrznej i międzynarodowej sytuacji Chin (czerwiec 1916 roku - początek roku 1917)}

Śmierć Yuan Shikaia i rozwój sytuacji międzynarodowej skomplikowały chińską politykę Waszyngtonu. Od połowy 1916 roku rozpoczęła się w Państwie Środka trwająca kilkanaście lat niemal permanentna walka o władzę różnych stronnictw, watażków i polityków, z których, co dodatkowo niepokoiło Amerykanów, wielu związanych było z Japonią. Pozycja tej ostatniej w Chinach stale rosła, nie tylko ze względu na jej kontakty z chińskimi przywódcami oraz ogólne osłabienie wewnętrzne sąsiada, ale również dlatego, że przedłużająca się wojna czyniła jej pomoc coraz cenniejszą i europejskie mocarstwa skłonne były uznać jej preponderancję w Chinach. Dodatkowo, w 1917 roku z dalekowschodniej konfiguracji praktycznie wypadła Rosja, pogrążona w rewolucyjnym chaosie, oraz ostatecznie Niemcy, którym Chiny wypowiedziały wojnę. Wszystko to sprawiało, że jeszcze większa odpowiedzialność spoczywała na Stanach Zjednoczonych, ale i one w perspektywie coraz bardziej realnego starcia z Rzeszą zaczynały mieć inne priorytety. Tak więc od połowy 1916 roku sytuacja wewnętrzna Chin i ich międzynarodowe położenie zaczęly się kształtować dla Waszyngtonu mniej korzystnie.

Wraz ze śmiercią Yuana nastąpił koniec „trzeciej rewolucji”. Zaprzestano dalszych walk i ponownie zjednoczono kraj. Urząd prezydenta objął dotychczasowy wiceprezydent Li Yuanhong, popierany już wcześniej przez Południe. Premierem pozostał gen. Duan Qirui, który przeprowadził reorganizację rządu, włączając do niego osoby z różnych środowisk. Powoli odradzało się dawne życie polityczne kraju. Przywrócono Konstytucję Tymczasową z 1912 roku, odrzucając zmiany wprowadzone przez Yuana dwa lata później. 1 sierpnia 1916 roku ponownie zebrał się rozwiązany za dyktatury Yuana parlament, który miał dokończyć opracowywanie stałej ustawy zasadniczej. 31 października wybrał on na nowego wiceprezydenta gen. Feng Guozhanga ${ }^{1}$.

1 Minister Reinsch to the Secretary of State, June 9, 1916, [w: ] Papers Relating to the Foreign Relations of the United States (dalej PRFRUS) 1916, Washington 1925, s. 84; Minister Reinsch to the Secretary of State, July 14, 1916, [w: ] ibidem, s. 86-89; Minister 
Ponieważ przemiany dokonały się dość spokojnie i nie doszło do poważnych incydentów czy walk, niektórzy obserwatorzy skłonni byli odmalowywać przyszłość Chin w nieco jaśniejszych barwach, niż to dotychczas czynili². Wśród nich znalazł się amerykański poseł Paul Reinsch, który chociaż zdawał sobie sprawę z licznych trudności i zagrożeń, był nastawiony umiarkowanie optymistycznie. Uważał, że istniała szansa na odbudowę władzy rządu centralnego w prowincjach, zaprzestanie waśni politycznych, umocnienie parlamentaryzmu i rozpoczęcie konstruktywnych działań3

Reinsch szybko się wszelako rozczarował. 14 października donosił Woodrowowi Wilsonowi, że na próżno czekał na wykrystalizowanie się sytuacji, ale niestety „rewolucja nie zdołała wynieść na czoło przywódców, którzy wzbudzaliby zaufanie i rząd pozostaje poważnie zdezorganizowany”. Nawet rzekomi postępowcy nie rozumieli, na czym polegała służba publiczna, i dbali przede wszystkim o osobiste korzyści. Odżyły, na chwilę tylko wytłumione, dawne antagonizmy i zacięta rywalizacja polityczna. „Właśnie brak ogólnonarodowego punktu widzenia w tym krytycznym czasie - pisał Reinsch 19 grudnia - jest niszczącym faktem”. Ponury pejzaż dopełniały nieustające trudności finansowe i wrogie zakusy Japonii. Po raz kolejny pojawiło się widmo wojny domowej, rozpadu państwa i japońskiej dominacji ${ }^{4}$.

Reinsch to the Secretary of State, August 2, 1916, [w: ] ibidem, s. 91; Minister Reinsch to the Secretary of State, October 31, 1916, [w: ] ibidem, s. 96; Minister Reinsch to the Secretary of State, December 13, 1916, [w:] ibidem, s. 96-98.

${ }^{2}$ Jedynym poważniejszym incydentem było wypowiedzenie posłuszeństwa rządowi przez marynarkę. Minister Reinsch to the Secretary of State, July 14, 1916, [w:] PRFRUS 1916, s. 86-89.

${ }^{3}$ Minister Reinsch to the Secretary of State, June 13, 1916, [w:] PRFRUS 1916, s. 84-85; Reinsch to the Secretary of State, June 14, 1916, Records of the Department of State Relating to Internal Affairs of China, 1910-1929 (dalej RDSRIACh), The National Archives at College Park, College Park, (mikrofilm), roll 15; Minister Reinsch to the Secretary of State, July 14, 1916, [w:] PRFRUS 1916, s. 86-89; Minister Reinsch to the Secretary of State, July 31, 1916, [w:] ibidem, s. 90-91.

${ }^{4}$ Minister Reinsch to the Secretary of State, September 4, 1916, [w:] PRFRUS 1916, s. 92-94; Reinsch to the President, October 14, 1916, Woodrow Wilson Papers (dalej WWP), Manuscript Division, Library of Congress, Washington, (mikrofilm), series 2, reel 83; Reinsch to the Secretary of State, November 7, 1916, RDSRIACh, roll 16; Reinsch to the Secretary of State, November 15, 1916, ibidem; Reinsch to the Secretary of State, December 9, 1916, ibidem; Minister Reinsch to the Secretary of State, December 13, 1916, [w:] PRFRUS 1916, s. 96-98; Reinsch to the Secretary of State, December 19, 1916, RDSRIACh, roll 16. Podobnie pesymistycznie oceniał sytuację sir John Jordan, brytyjski poseł w Pekinie. Memorandum of a conversation between Sir John N. Jordan, the British Minister, and the Honorable Paul S. Reinsch, the American Minister, November 14, 1916, ibidem. 
Sytuacja w Chinach była skomplikowana, a pretendentów do władzy wielu. W raporcie z 26 stycznia 1917 roku Reinsch wymienił sześciu: a) Duana, stojącego na czele frakcji Anhui (militarystów); b) projapońską nową klikę komunikacyjną na czele z Cao Rulinem, który popierał Duana; c) gen. Xu Shuzhenga i jego zwolenników wśród militarystów; d) Fenga; e) przywódców Kuomintangu (Sun Yat-sena, Tang Shaoyia) ${ }^{5}$; g) przywódców Partii Postępowej (Liang Qichao, Xiong Xilinga $)^{6}$. Oprócz nich w walce o władzę liczyli się: prezydent Li; będący chwilowo w niełasce przedstawiciele frakcji kantońskiej (starej kliki komunikacyjnej); Zhang Xun, który z pewnymi sukcesami próbował zdobyć poparcie w Chinach Środkowych; rosnący w siłę tzw. panowie wojny (warlords), a więc prowincjonalni dowódcy, tacy jak Zhang Zuolin w Fengtianie czy Yan Xishan w Shanxi. Sytuację jeszcze bardziej komplikował fakt, że większość stronnictw podzielona była wewnętrznie ${ }^{7}$.

Dla Waszyngtonu żaden z kandydatów do przejęcia schedy po Yuanie nie był idealny. Najlepszym wydawał się Duan, gdyż miał najsilniejszą pozycję, a tym samym największe szanse na utrzymanie porządku, co dla Amerykanów było priorytetem. Duan mógł zostać po prostu „nowym Yuanem”, którego USA przecież konsekwentnie popierały $^{8}$. Duan był zawodowo i rodzinnie związany z Yuanem, którego siostrę poślubił. Łączyły ich podobne poglądy polityczne - obaj wierzyli w silne rządy autorytarne oparte na armii, wrogo odnosili się do parlamentu i partii politycznych, jak i przejawiali chęć restauracji cesarstwa. Duan nie miał natomiast talentu i doświadczenia zmarłego szwagra. Był też, co musiało niepokoić Stany Zjednoczone, bardziej projapońsko nastawiony.

W drugiej połowie 1916 roku Reinsch zmienił trochę stosunek do Duana. Uprzednio podkreślał jego niepostępowość, obecnie bardziej zwracał uwagę na zasługi. Docenil, że newralgiczny okres przekazywania władzy po śmierci Yuana przebiegł dzięki generałowi bez komplikacji, których obawiali się cudzoziem$\mathrm{cy}^{9}$. W kolejnych raportach przedstawiał go jako zdolnego do kompromisu,

${ }^{5}$ Formalnie nazwę Kuomintang przywrócono dopiero w 1919 roku, ale amerykańscy dyplomaci cały czas się nią posługiwali. J. Polit, Chiny, Warszawa 2004, s. 87.

${ }^{6}$ Reinsch to the Secretary of State, January 26, 1917, RDSRIACh, roll 16.

7 Jameson to Reinsch, September 30, 1916, RDSRIACh, roll 16; Reinsch to the Secretary of State, November 15, 1916, ibidem; Minister Reinsch to the Secretary of State, December 13, 1916, [w:] PRFRUS 1916, s. 96-98; W. Rodziński, Historia Chin, Wrocław 1992, s. 633. W walce o władzę nie brali udziału Cai E i Huang Xing, którzy zmarli jesienią 1916 roku.

${ }^{8}$ Wilson osobiście uczestniczył w nabożeństwie żałobnym w intencji Yuana. Minister Reinsch to the Secretary of State, July 5, 1916, [w:] PRFRUS 1916, s. 100.

${ }^{9}$ Cudzoziemcy do tego stopnia obawiali się o swoje bezpieczeństwo, że w naradzie dowódców straży dzielnicy poselstw wzięli udział przedstawiciele wszystkich państw, w tym ententy i państw centralnych. Okazało się nawet, że dotychczas niemieccy 
w przeciwieństwie do zdominowanego przez Kuomintang parlamentu, który blokował rządowe inicjatywy i starał się zdyskredytować premiera. W tej sytuacji Duan i militaryści mieli rozważać rozwiązanie parlamentu, a nawet przywrócenie monarchii. Reinsch co prawda nie poparł tych planów, ale też nie potępił ich ${ }^{10}$.

Dosyć dobrą opinię miał Reinsch o prezydencie Li i Liang Shiyiu, ale pierwszy, co przyznał sam poseł, nie miał wystarczającego autorytetu i poparcia politycznego, aby zapobiec walkom w kraju, drugi zaś musiał uciec z Chin, gdyż ciążył na nim nakaz aresztowania ze względu na rolę, jaką odegrał w ruchu monarchicznym ${ }^{11}$.

Zdecydowanie mniejszą sympatią darzył Reinsch przywódców Partii Postępowej i Kuomintangu. Zarzucał im intryganctwo, dbanie o partykularne interesy i niezdolność do kompromisu. Najbardziej krytykował wymienianego jako kandydata na premiera Tang Shaoyia za jego nieodpowiedzialne zachowanie ${ }^{12}$. Niewiele lepiej postrzegał Sun Yat-sena, którego jeszcze w 1915 roku charakteryzował jako „szczerego republikanina $[. .$.$] , niepraktycznego marzyciela, fanatyka$ i intryganta" 13 .

żołnierze chronili odcinek muru przebiegający bezpośrednio za belgijskim poselstwem. Pokazuje to, że w kwestii bezpieczeństwa cudzoziemcy w Chinach, mimo wewnętrznych konfliktów, byli zjednoczeni. Reinsch to the Secretary of State, June 14, 1916, RDSRIACh, roll 15; P. Reinsch, An American Diplomat in China, Garden City 1922, s. 193.

10 Reinsch to the Secretary of State, June 14, 1916, RDSRIACh, roll 15; Minister Reinsch to the Secretary of State, June 30, 1916, [w:] PRFRUS 1916, s. 85-86; Minister Reinsch to the Secretary of State, July 14, 1916, [w: ] ibidem, s. 86-89; Minister Reinsch to the Secretary of State, July 31, 1916, [w: ] ibidem, s. 90-91; Minister Reinsch to the Secretary of State, September 4, 1916, [w: ] ibidem, s. 92-94; Reinsch to the Secretary of State, December 9, 1916, RDSRIACh, roll 16; Minister Reinsch to the Secretary of State, December 13, 1916, [w: ] PRFRUS 1916, s. 96-98; Reinsch to the Secretary of State, December 19, 1916, RDSRIACh, roll 16; P. Reinsch, An American Diplomat ..., s. 193-194.

11 Reinsch to the Secretary of State, April 28, 1916, RDSRIACh, roll 15; Minister Reinsch to the Secretary of State, May 6, 1916, [w:] PRFRUS 1916, s. 79; Minister Reinsch to the Secretary of State, May 17, 1916, [w:] ibidem, s. 81-82; Minister Reinsch to the Secretary of State, July 14, 1916, [w: ] ibidem, s. 86-89; P. Reinsch, An American Diplomat..., s. 95-96, 193-194, 198-200.

12 Minister Reinsch to the Secretary of State, April 24, 1916, [w:] PRFRUS 1916, s. 77; Minister Reinsch to the Secretary of State, July 14, 1916, [w:] ibidem, s. 86-89; Minister Reinsch to the Secretary of State, July 31, 1916, [w: ] ibidem, s. 90-91; Minister Reinsch to the Secretary of State, September 4, 1916, [w:] ibidem, s. 92-94; Reinsch to the Secretary of State, November 7, 1916, RDSRIACh, roll 16; Minister Reinsch to the Secretary of State, December 13, 1916, [w:] PRFRUS 1916, s. 96-98; Reinsch to the Secretary of State, December 19, 1916, RDSRIACh, roll 16; P. Reinsch, An American Diplomat ..., s. 200-201.

13 Reinsch to the Secretary of State, May 4, 1915, Records of the Department of State Relating to Political Relations Between China and Other States, 1910-1929 (dalej 
Skomplikowanie chińskiej sytuacji politycznej nie wywołało wielu komentarzy w Waszyngtonie, gdzie szczególnie nie zajmowano się tym, kto stoi na czele rządu pekińskiego, dopóki umiał on utrzymać elementarny porządek. $\mathrm{O}$ wiele bardziej interesowano się w tym czasie działaniami Japonii w odniesieniu do Chin oraz rozwojem tam amerykańskich przedsięwzięć biznesowych. Obie sprawy były ze sobą powiązane. Japonia nierzadko próbowała zablokować amerykańskie inwestycje i pożyczki, Waszyngton postrzegał je zaś jako środek do powstrzymania japońskiej ekspansji.

Po śmierci Yuana Tokio starało się zdominować Chiny już nie dzięki dwóm, lecz trzem typom działań. Oprócz dotychczasowych prób wymuszenia na Pekinie kolejnych przywilejów oraz zabiegania, aby europejskie mocarstwa pozwoliły jej na swobodę poczynań w Chinach, Japonia wykorzystywała swoje kontakty z chińskimi przywódcami. A te, jak donosili Reinsch i różni amerykańscy konsulowie, były rzeczywiście rozległe i dotyczyły większości liczących się osób na politycznej scenie Państwa Środka. Sun i Tang wydawali bankiety na cześć Japończyków i otwarcie mówili o chęci współpracy. Duan na jednego ze swych głównych doradców wybrał gen. Aokiego Norizumiego, szarą eminencję „trzeciej rewolucji”. Cao podejrzewano nie tylko o to, że był sympatykiem Japonii, ale wręcz jej agentem. Projapońskie nastawienie lub związki z potężnym sąsiadem przypisywano również m.in. Li, Fengowi i Liang Qichao ${ }^{14}$. Stanowiło to swoisty paradoks, gdyż rzesze zwykłych Chińczyków, pamiętających upokarzające żądania sprzed roku, odczuwały do Japonii antypatię lub nienawiść. Przywódcy nie przejmowali się tym zbytnio, bo o ich pozycji nie decydowała wola ludu. Japonia miała im natomiast dużo do zaoferowania. Jako jedna z nielicznych mogła udzielić pomocy finansowej, dającej jej beneficjentowi przewagę nad przeciwnikami ${ }^{15}$. A co było nawet istotniejsze, jak pokazały wydarzenia ostatnich miesięcy, bez przychylności Tokio szanse na utrzymanie się u władzy w Pekinie wyraźnie spadały.

Aktywność Japończyków nie ograniczała się wyłącznie do rozwijania wpływów na szczeblu centralnym, podjudzali oni jednocześnie lokalne wystąpienia.

RDSRPRBChOS), The National Archives at College Park, College Park, (mikrofilm), roll 24. Zob. też: Minister Reinsch to the Secretary of State, July 31, 1916, [w:] PRFRUS 1916, s. 90-91.

${ }_{14}$ Sammons to Reinsch, June 8, 1916, RDSRIACh, roll 15; Memo prepared by Commercial Attaché for the Legation, June 13, 1916, ibidem; Sammons to Reinsch, July 22, 1916, ibidem; Sammons to Reinsch, July 29, 1916, ibidem; Sammons to Reinsch, August 9, 1916, ibidem; Sammons to Reinsch, August 17, 1916, ibidem; Jameson to Reinsch, November 28, 1916, RDSRIACh, roll 16; Reinsch to the Secretary of State, January 26, 1917, ibidem; J. Polit, Odwrót znad Pacyfiku? Wielka Brytania wobec Dalekiego Wschodu (1914-1922), Kraków 1999, s. 110-111, 154.

15 Reinsch to the Secretary of State, January 26, 1917, RDSRIACh, roll 16. 
Zdaniem amerykańskich konsulów poddani tennō uwikłani byli w niepokoje w Shandongu, Hankou i Kantonie, pomagali też mandżurskim i mongolskim bandytom. „Podczas ponad dwunastoletniej służby w Chinach, Korei i Japonii - pisał 15 sierpnia 1916 roku konsul generalny w Szanghaju Thomas Sammons - nie byłem świadkiem takiej aktywności [... ] we wszystkich właściwie sprawach dotyczących [Chin - J.P.] [...], jaką przejawiają obecnie Japończycy”"16. Dzięki ingerencjom Japonia odnosiła co najmniej trzy niebagatelne korzyści: a) Chiny pozostawały zdestabilizowane i słabe; b) rząd pekiński musiał wydawać pieniądze na tłumienie rozruchów, przez co nie mógł spożytkować ich na inne cele, a i na ten musiał się zapożyczyć, głównie zresztą u Japończyków; c) różnego rodzaju niepokoje dawały Japonii argument do interwencji ${ }^{17}$.

Japonia nie przestawała też szukać sposobności do zapewnienia sobie przywilejów ujętych w piątej grupie żądań z poprzedniego roku. We wrześniu 1916 roku w związku ze starciem jej żołnierzy z żołnierzami chińskimi w Mandżurii (tzw. incydent w Zhengjiadunie) zażądała, aby m.in. w południowej Mandżurii i wschodniej Mongolii Wewnętrznej chińskie wojska zatrudniały jako doradców japońskich oficerów, Japończycy mieli prawo do wyznaczania policji na tych obszarach, a chińscy oficjele w południowej Mandżurii musieli angażować japońskich doradców policyjnych ${ }^{18}$. Lista żądań, którą liczące na wsparcie Chiny przekazały cudzoziemcom, wywołała zaniepokojenie amerykańskiej dyplomacji. Reinsch alarmowal, że żądania naruszają chińską suwerenność w Mandżurii, a wszelkie ustępstwa tam poczynione zostaną później wykorzystane do ubiegania się o podobne prawa $\mathrm{w}$ innych prowincjach ${ }^{19}$. Także sekretarz stanu Robert Lansing, którego do podjęcia zdecydowanych kroków wzywało American Manufacturers Export Association ${ }^{20}$, był „wielce poruszony” działaniami Japonii, wskazującymi na jej „determinację [...], aby przymusić Chiny i naciskać na swoje żądania z bezwzględną stanowczością". Lansing polecił więc wybadać sprawę w Londynie i Tokio ${ }^{21}$. Odpowiedzi obu rządów okazały się mało satysfakcjonujące. Chociaż sir Edward Grey nie zajął oficjalnie żadnego stanowiska, to rozmawiający z nim

16 Sammons to Reinsch, July 11, 1916, RDSRIACh, roll 15; Cunningham to Reinsch, July 31, 1916, RDSRIACh, roll 16; Cunningham to Reinsch, August 1, 1916, ibidem; Cunningham to Reinsch, August 1, 1916, ibidem; Josselyn to Reinsch, August 14, 1916, ibidem; Sammons to Reinsch, August 15, 1916, RDSRIACh, roll 15; Peck to the Secretary of State, September 6, 1916, RDSRIACh, roll 16.

17 Baker to the Secretary of State, May 3, 1917, RDSRIACh, roll 16.

18 Chinese Foreign Office to the Chinese Legation at Washington, September 2, 1916, The Papers of Woodrow Wilson (dalej PWW), (opr.) A.S. Link, t. 38, Princeton 1982, s. 151-152.

19 Reinsch to the Secretary of State, September 4, 1916, RDSRPRBChOS, roll 25.

20 Herr to Lansing, September 18, 1916, RDSRPRBChOS, roll 25.

${ }^{21}$ Lansing to Wilson, September 6, 1916, [w: $]$ PWW, t. 38, s. 150-151. 
Irwin B. Laughlin, sekretarz amerykańskiej ambasady, odniósł wrażenie, że szef Foreign Office zamierzał w tym przypadku dać Japonii wolną rękę $e^{22}$. Gaimushō potwierdziło z kolei najważniejsze żądania, utrzymując jednak, że nie naruszają one suwerenności Chin i nie są sprzeczne z porozumieniem Root-Takahira, dlatego też Stany Zjednoczone nie powinny mieszać się w całą sprawę. Lansing zaprotestował przeciwko tej ostatniej uwadze, ale w późniejszym okresie amerykańska dyplomacja raczej biernie przyglądała się rozwojowi sytuacji ${ }^{23}$.

Negocjacje chińsko-japońskie, które prowadzili nowy minister spraw zagranicznych Wu Tingfang i cesarski poseł w Pekinie baron Hayashi Gonsuke, zakończyły się zawarciem porozumienia w styczniu 1917 roku. Udało się je osiągnąć głównie dzięki zmianie nastawienia nowego rządu w Tokio. W październiku 1916 roku stanowisko premiera objął gen. hr. Terauchi Masatake, który zaczął prowadzić bardziej ugodową politykę wobec Chin, licząc na ich zjednanie, współpracę i objęcie nad nimi paternalistycznego zwierzchnictwa. Część wpływowych polityków i wojskowych uważało bowiem, że pomyślność i bezpieczeństwo Japonii zależały od tego, czy uda jej się zostać - najlepiej dobrowolnym, a w razie konieczności narzuconym - przywódcą Dalekiego Wschodu, w tym zwłaszcza Chin, gdyż w przyszłości dojdzie najprawdopodobniej do wojny rasy żółtej z rasą białą. Nowa polityka władz japońskich sprawiła, że porozumienie kończące incydent w Zhengjiadunie było korzystne dla Chin, które z wymienionych żądań zgodziły się nieformalnie tylko na zatrudnienie japońskich doradców wojskowych, ale pod warunkiem, że znajdą się oni pod chińską komendą ${ }^{24}$.

Innym wydarzeniem, które zaniepokoiło amerykańską dyplomację, było zawarcie przez Rosję i Japonię 3 lipca 1916 roku jawnej konwencji i tajnego traktatu sojuszniczego. Układające się strony zobowiązały się sobie pomagać, gdyby ich prawa lub interesy na Dalekim Wschodzie zostały zagrożone, oraz przeciwdziałać zdominowaniu Chin przez państwo trzecie ${ }^{25}$. Ów przeciwnik nie został

22 Laughlin to the Secretary of State, September 15, 1916, RDSRPRBChOS, roll 25.

23 Ambassador Guthrie to the Secretary of State, September 11, 1916, [w:] PRFRUS 1917, Washington 1926, s. 244-245; The Secretary of State to Ambassador Guthrie, September 13, 1916, [w: ] ibidem, s. 245.

${ }^{24}$ PRFRUS 1917, s. 241-258; przypis nr 3 w PWW, t. 43, Princeton 1983, s. 83-84; L. Pomerantz-Zhang, $W u$ Tingfang (1842-1922): Reform and Modernization in Modern Chinese History, Hong Kong 1992, s. 246-247; N. Kawamura, Turbulence in the Pacific: Japanese-U.S. Relations during World War I, Westport 2000, s. 6-7, 61-63. Kwestia policji nie została rozstrzygnięta. Japonia uważała, że ma prawo ją utrzymywać, Chiny taką możliwość odrzucały.

25 Doc. no. 1916/9: Japan and Russia. Convention in regard to cooperation in the Far East, July 3, 1916, [w: Treaties and Agreements with and Concerning China, 1894-1919, zebrał i opracował J.V.A. MacMurray, t. 2: Republican Period (1912-1919), s. 1327-1328; T. Dmochowski, Walka polityczna mocarstw o dominację w dorzeczu Amuru, Toruń 1999, 
w dokumencie określony wprost, stąd też część badaczy uważa, że sojusz wymierzony był bardziej przeciwko Stanom Zjednoczonym niż niemającym już realnych wpływów na Dalekim Wschodzie Niemcom ${ }^{26}$. Takie odczytanie wzmocnily „Izwiestia”, które w grudniu 1917 roku, już po dojściu bolszewików do władzy, opublikowały treść tajnego traktatu, opatrując go nagłówkiem „Tajny traktat między Japonią a Rosją dotyczący wspólnej demonstracji zbrojnej przeciwko Ameryce i Wielkiej Brytanii na Dalekim Wschodzie"27.

Informacje o zbliżeniu japońsko-rosyjskim docierały do Waszyngtonu od pewnego już czasu, dlatego podpisanie konwencji nie mogło być całkowitym zaskoczeniem $^{28}$. Podejrzewano, że oprócz punktów zawartych $\mathrm{w}$ opublikowanym tekście sygnatariusze porozumieli się jeszcze $w$ innych kwestiach, ale nie udało się tego potwierdzić. Amerykanów niepokoiła już sama konwencja, ponieważ nie wpisano do niej zwyczajowych formułek o poszanowaniu integralności terytorialnej i suwerenności Chin oraz równości szans kupców. Chociaż część mocarstw traktowała je bardziej jako frazesy dyplomatyczne niż realne zobowiązania, to ich celowe pominięcie mogło oznaczać chęć świadomego nieprzestrzegania. USA zwróciły się więc do Rosji i Japonii z prośbą o potwierdzenie, że oba państwa zamierzają nadal respektować zasady polityki „otwartych drzwi”. Pozytywne odpowiedzi uspokoiły trochę Waszyngton ${ }^{29}$, ale wiadome było, że w obecnej sytuacji na współpracy rosyjsko-japońskiej w Chinach zyskiwała Japonia, która przybliżała się do osiągnięcia jednego z głównych celów - otrzymania od mocarstw europejskich zgody na swobodę działania w Chinach i na uzyskanie tam nabytków.

s. 232-233. Na temat negocjacji rosyjsko-japońskich patrz: M. Kajima, The Diplomacy of Japan 1894-1922, t. 3: The First World War, Paris Peace Conference, Washington Conference, Tokyo 1980, s. 225-276.

${ }_{26}$ Zob. J. Polit, Odwrót znad Pacyfiku..., s. 112; T. Dmochowski, Walka polityczna..., s. 233; R.H. Fifield, Woodrow Wilson and the Far East. The Diplomacy of the Shantung Question, Hamden 1965, s. 52; G. Hudson, The Far East at the End of the First World War, „Journal of Contemporary History” 1969, t. 4, nr 2, s. 168. Zob. też: M. Kajima, The Diplomacy of Japan ..., s. 275. Faktem jest jednak, że Rosja i Japonia obawiały się niemieckich wpływów i intryg w Chinach. Memorandum by Adachi, undated, written around January 1916, [w:] ibidem, s. 233-234; "Wartime Foreign Policy to be Pursued by the Imperial Government", approved by the Japanese Government on January 12, 1917, [w: ] ibidem, s. 187-190.

27 Przypis nr $1 \mathrm{w} P W W$, t. 46, Princeton 1984, s. 539.

28 Heintzleman to the Secretary of State, October 26, 1915, RDSRPRBChOS, roll 25; Memorandum by Williams, December 2, 1915, ibidem; Moser to Reinsch, March 6, 1916, RDSRIACh, roll 14.

29 PRFRUS 1916, s. 442-446. 
Dysponując porozumieniem z rządem carskim, Tokio wznowiło naciski na Londyn. Ostatecznie w lutym 1917 roku Brytyjczycy, którym bardzo zależało, aby Japonia pomogła im w konwojowaniu żołnierzy z dominiów i Indii oraz w walce z u-bootami na Morzu Śródziemnym, zapewnili, że podczas konferencji pokojowej poprą japońskie roszczenia względem Jiaozhou i niemieckich wysp na północ od równika. Było to sprzeczne z przyrzeczeniem, jakie Rząd Jego Królewskiej Mości dał Chinom w sierpniu 1914 roku. Ustalenia japońsko-brytyjskie pozostały tajne, a Japonia w lutym i marcu uzyskała dla swych pretensji aprobatę Rosji, Francji i Włoch ${ }^{30}$.

Nie jest jasne, od kiedy i jak szczegółowo wiedział o tych porozumieniach rząd amerykański. Na pewno ogólnie o sekretnych traktatach zawartych dotychczas przez ententę mówił Amerykanom Arthur Balfour, nowy szef brytyjskiej dyplomacji, który w kwietniu 1917 roku, już po przystąpieniu Stanów Zjednoczonych do wojny, udał się ze specjalną misją za ocean. Ale według Edwarda House'a, który spotkał się z Balfourem, podczas rozmów nie poruszono tematu niemieckich kolonii, Chin, Japonii czy w ogóle Dalekiego Wschodu ${ }^{31}$. Po wojnie Wilson i House utrzymywali, że po raz pierwszy o zgodzie na zatrzymanie przez Japonię niemieckich posiadłości w Shandongu i na Pacyfiku usłyszeli podczas konferencji pokojowej w Paryżu ${ }^{32}$. Lansing, indagowany przez senacką komisję, oświadczył z kolei, że w 1917 roku wiedział o planowanym podziale wysp, ale nie o Shandongu ${ }^{33}$. Słowom sekretarza przeczy jego spuścizna, w której znajdują się zgody państw europejskich na japońskie roszczenia, chociaż nie wiadomo, kiedy

30 Documents relative to the negotiation between Japan and the Allied powers as to the disposal of German rights in respect of Shantung province and the South Sea Islands north of the equator, Robert Lansing Papers (dalej LP), Manuscript Division, Library of Congress, Washington, box 24; M. Kajima, The Diplomacy of Japan ..., s. 187-202; J. Polit, Odwrót znad Pacyfiku ..., s. 115-120; R.H. Fifield, Woodrow Wilson and the Far East ..., s. 53-55; T.D. Saxon, Anglo-Japanese Naval Cooperation, 1914-1918, s. 9-11, online: https://digitalcommons.liberty.edu/hist_fac_pubs/5 (dostęp: 21.08.2018). Na decyzję europejskich członków ententy wpłynęły też starania Niemiec o zawarcie z Japonią osobnego układu pokojowego, o czym ta ostatnia poinformowała swoich sojuszników, licząc, że wzmocni to jej pozycję przetargową. F.W. Iklé, Japanese-German Peace Negotiations during World War I, „The American Historical Review” 1965, t. 71, nr 1, s. 70-71, 76.

${ }^{31}$ April 28, 1917, [w:] The Intimate Papers of Colonel House, (opr.) Ch. Seymour, t. 3: Into the World War, Boston-New York 1928, s. 42-46.

32 Ibidem, s. 61.

33 Ibidem; Memorandum on subjects in the President's statement of war aims on January 8, 1918, which are open to debate, January 10, 1918, LP, box 64. We wspomnieniach Lansing twierdzi, że już w 1916 roku wiedział, że Londyn zgodził się, aby Tokio zatrzymało niemieckie wyspy na Pacyfiku na północ od równika. R. Lansing, War Memoirs of Robert Lansing, Secretary of State, Westport 1970, s. 293. 
wszedł on w ich posiadanie ${ }^{34}$. Jakub Polit, opierając się na źródłach brytyjskich, stwierdza, że Balfour podczas swej misji w Stanach Zjednoczonych przekazał gospodarzom teksty wszystkich tajnych traktatów ${ }^{35}$. O tym, że Amerykanie mogli w pełni o nich wiedzieć, świadczą pośrednio zapewnienia składane przez Balfoura w Izbie Gmin, że „nie ma przed Wilsonem tajemnic” ${ }^{36}$. Wreszcie w czerwcu 1917 roku Wilson miał powiedzieć chińskiemu posłowi w Waszyngtonie, Wellingtonowi Koo, że na początku roku mocarstwa europejskie zgodziły się, aby Japonia zachowała posiadłości w Shandongu ${ }^{37}$. Rozstrzygnięcie, kiedy dokładnie Amerykanie dowiedzieli się o tajnych porozumieniach, nie jest kluczowe dla tej pracy, której cezurę górną wyznacza koniec I wojny światowej, problem Shandongu nabierze zaś ponownie międzynarodowego znaczenia w roku 1919. Dla niniejszych rozważań wystarczające będzie stwierdzenie, że w 1917 roku Stany Zjednoczone powinny były zdawać sobie sprawę, że Tokio otrzymało od sojuszników jakieś przyrzeczenia co do nabytków terytorialnych, skoro podobne obietnice uzyskały różne inne państwa koalicji, a o tym Waszyngton już niewątpliwie wiedzial ${ }^{38}$.

Oprócz rozbudowywania politycznych wpływów i zabiegania o międzynarodowe poparcie Japonia starała się ugruntować swoją pozycję w Chinach poprzez ich finansowe uzależnienie. Podczas „trzeciej rewolucji” Yokohama Specie Bank wstrzymał przekazywanie władzom pekińskim nadwyżki z monopolu soli, chcąc pogłębić trudności Yuana. Kryzys udało się zażegnać dzięki pomocy amerykańskich i europejskich banków, choć i tak wiarygodność finansowa Chin została

${ }^{34}$ Patrz przypis nr 30.

35 J. Polit, Odwrót znad Pacyfiku ..., s. 138.

${ }^{36}$ The Intimate Papers of Colonel House..., s. 61. Tę wersję podważa poniekąd list Balfoura do Wilsona z 18 maja 1917 roku, w którym zgodnie z obietnicą szef Foreign Office przesłał różne traktaty zawarte przez Wielką Brytanię z sojusznikami, ale wśród załączonych dokumentów nie ma tajnego porozumienia z Japonią. Balfour to Wilson, May 18, 1917, [w:] PWW, t. 42, Princeton 1983, s. 327-328.

37 S.G. Craft, Angling for an Invitation to Paris: China's Entry into the First World War, „The International History Review” 1994, t. 16, nr 1, s. 20.

${ }_{38}$ Amerykanom powinno dać też do myślenia wystąpienie Balfoura podczas posiedzenia Imperial War Council z 22 marca 1917 roku, którego streszczenie Balfour przekazał Wilsonowi. Szef Foreign Office powiedział wówczas, że widzi pewien sens w japońskiej polityce swego poprzednika sir Edwarda Greya, która wychodziła z założenia, iż skoro Japonia została wykluczona z wielu części świata, trzeba jej pozwolić na ekspansję w Chinach. Imperial War Council, March 22, 1917, [w:] PWW, t. 42, s. 328-342. Zob. też: The Chargé in Japan (Wheeler) to the Secretary of State, June 27, 1917, [w:] PRFRUS 1917, Supplement 1: The World War, Washington 1931, s. 452; M. Chi, China Diplomacy, 1914-1918, Cambridge 1970, s. 109; H. Hoover, The Ordeal of Woodrow Wilson, New York 1958, s. 78-81. 
nadszarpnięta ${ }^{39}$. Po śmierci Yuana Chiny bardzo potrzebowały pieniędzy na reorganizację, co próbowała wykorzystać Japonia, oferując pożyczki na niekorzystnych warunkach ${ }^{40}$. Jej podejście zmieniło się na bardziej ugodowe, gdy nowy rząd sformował gen. Terauchi. W latach 1917-1918 jego osobisty wysłannik Nishihara Kamezō wynegocjował z Cao serię wysokich pożyczek (tzw. nishiharowskich) dla rządu Duana, które szacuje się łącznie na setki milionów jenów ${ }^{41}$.

\section{Fiasko amerykańskiego programu inwestycyjnego w Chinach}

Odpowiedzią Stanów Zjednoczonych na próby politycznego i ekonomicznego podporządkowania Chin było kontynuowanie i rozwijanie rozpoczętego w 1915 roku programu inwestycji. Obejmował on inwestycje kanałowe, kolejowe oraz bezpośrednie pożyczki. Zagorzałym rzecznikiem programu pozostawał Reinsch, przychylni byli mu również Lansing i Wilson, jak i sami Chińczycy ${ }^{42}$. Pierwsze kontrakty sfinalizowano jeszcze przed śmiercią Yuana. W kwietniu i maju 1916 roku American International Corporation podpisała umowy na sfinansowanie prac kanałowych w Shandongu i Jiangsu ${ }^{43}$. Stanowiło to część

${ }^{39}$ Minister Reinsch to the Secretary of State, April 18, 1916, [w:] PRFRUS 1916, s. 76-77; Reinsch to the Secretary of State, May 27, 1916, [w:] PWW, t. 37, Princeton 1981, s. 234-235; Lansing to Wilson, June 15, 1916, [w:] ibidem, s. 232-233.

${ }^{40}$ Reinsch to the Secretary of State, June 15, 1916, [w:] PWW, t. 37, s. 235-236; Minister Reinsch to the Secretary of State, September 4, 1916, [w:] PRFRUS 1916, s. 92-94.

${ }^{41} \mathrm{Na}$ temat wysokości pożyczek nishiharowskich zobacz: M. Chi, Bureaucratic Capitalists in Operation: Ts'ao Ju-lin and His New Communications Clique, 1916-1919, „The Journal of Asian Studies” 1975, t. 34, nr 3, s. 679-683; J. Polit, Odwrót znad Pacyfiku ..., s. 156-157; W. Rodziński, Historia Chin ..., s. 638; The Cambridge History of China, t. 12: Republican China, 1912-1949, cz. 1, (red.) J.K. Fairbank, Cambridge 1983, s. 266.

42 Reinsch to the Secretary of State, May 27, 1916, [w:] PWW, t. 37, s. 234-235; Reinsch to the Secretary of State, June 14, 1916, [w: ] ibidem, s. 235; Reinsch to the Secretary of State, June 15, 1916, [w:] ibidem, s. 235-236; Reinsch to the Secretary of State, June 15, 1916, [w: ] ibidem, s. 236; Lansing to Wilson, June 15, 1916, [w:] ibidem, s. 232-233; Wilson to Lansing, June 21, 1916, [w: ] ibidem, s. 271; Reinsch to the President, October 14, 1916, WWP, series 2, reel 83; Reinsch to Lansing, December 8, 1916, [w:] PWW, t. 40, Princeton 1982, s. 563-564; Reinsch to the Secretary of State, January 10, 1917, WWP, series 2, reel 85; Reinsch to Wilson, January 10, 1917, [w:] PWW, t. 40, s. 436-438.

${ }^{43}$ Doc. no. 1916/5:United States (American International Corporation) and China (Government of Shantung Province). Agreement for the South Grand Canal of Shantung Province 7\% Improvement Gold Loan, April 19, 1916, [w:] Treaties and Agreements..., s. 1287-1297; Doc. no. 1916/6:United States (American International Corporation) and China. Agreement for the Huai River Conservancy Grand Canal Improvement 7\% Gold Loan of 1916, May 13, 1916, [w: ibidem, s. 1304-1310. AIC miała wyznaczyć wykonawcę prac kanałowych. 
większego projektu dotyczącego rzeki Huai He, który powierzono Amerykanom jeszcze w 1914 roku. Reinsch nie krył entuzjazmu, uznał nawet, że wynegocjowane warunki były „niemal zbyt surowe dla Chin”, a zarazem najkorzystniejsze, jakie kiedykolwiek udało się cudzoziemcom uzyskać ${ }^{44}$. Jednak problemy miały się dopiero pojawić.

Najpierw AIC naciskała, aby umowa dotycząca Jiangsu, podobnie jak ta odnosząca się do Shandongu, otrzymała gwarancje władz lokalnych. Reinsch był temu przeciwny, gdyż podejrzewał, że mogłoby to zrazić władze pekińskie i doprowadzić do mieszania się urzędników lokalnych, nie poprawiając bynajmniej bezpieczeństwa przedsięwzięcia ${ }^{45}$.

Jeszcze poważniejsze okazały się zastrzeżenia na poziomie międzynarodowym. 15 września 1916 roku Japonia zakwestionowała umowę dotyczącą Shandongu, twierdząc, że zgodnie z przyznanym Niemcom w 1898 roku przywilejem, który miał na nią przejść, Chiny, gdy chciały uzyskać pomoc zagraniczną dla przedsięwzięć przemysłowych w Shandongu, musiały najpierw zwrócić się do niej i dopiero po jej odmowie mogły szukać innych cudzoziemskich inwestorów. Pekin odrzucił to roszczenie, wskazując, że nie nastąpiła jeszcze cesja niemieckich praw na rzecz Japonii, a ponadto przywilej pierwszeństwa miał dotychczas zastosowanie jedynie wobec linii kolejowych i kopalni. USA w pełni poparły chińskie stanowisko ${ }^{46}$.

W obliczu oporu Pekinu i Waszyngtonu oraz zgodnie z nową polityką gabinetu Terauchiego Japonia zmieniła taktykę i próbowała skłonić Amerykanów, aby dopuścili kapitał japoński do projektu. W styczniu 1917 roku AIC wyraziła gotowość do nawiązania współpracy. Willard Straight, jeden z jej wiceprezesów, tłumaczył, że póki Japonia protestowała, nie można było zapewnić finansowa$\mathrm{nia}^{47}$. Nie przekonało to Reinscha i Lansinga. Pierwszy był wielce niezadowolony, że sztandarowa amerykańska inicjatywa, z którą wiązał duże nadzieje, gdyż łączyła elementy polityczne, biznesowe i dobroczynne, została wypaczona. Stwierdził,

${ }^{44}$ Minister Reinsch to the Secretary of State, April 20, 1916, [w:] PRFRUS 1916, s. 106; Minister Reinsch to the Secretary of State, April 27, 1916, [w: ibidem, s. 107. Cytat pochodzi z drugiego dokumentu.

45 PRFRUS 1916, s. 119-128.

46 Memorandum from the Japanese Legation to the Chinese Government, September 15, 1916, [w:] PRFRUS 1916, s. 126-127; Minister Reinsch to the Secretary of State, September 25, 1916, [w: ] ibidem, s. 123; The Acting Secretary of State to Minister Reinsch, November 6, 1916, [w: ibidem, s. 127. Podczas negocjacji z AIC Chiny powiadomily Niemcy o planowanej umowie i zaproponowały im udział w pożyczce. Minister Reinsch to the Secretary of State, April 17, 1916, [w:] ibidem, s. 106; Minister Reinsch to the Secretary of State, April 28, 1916, [w: ] ibidem, s. 107-108; Minister Reinsch to the Secretary of State, May 15, 1916, [w: ] ibidem, s. 109-110.

47 Minister Reinsch to the Secretary of State, January 2, 1917, [w:] PRFRUS 1917, s. 207; The Secretary of State to Minister Reinsch, January 8, 1917, [w:] ibidem, s. 207-208. 
że „byłoby niemożliwe znalezienie bardziej nieodpowiedniego przedsięwzięcia do kooperacji”. Przewidywał wielkie oburzenie Chińczyków, kiedy dowiedzą się, że „Amerykanie proponują zanieść Japończyków na swych plecach do Jiangsu”48. Równie rozczarowany był Lansing, który próbował wyperswadować Straightowi pomysł współpracy, ale nic nie zdziałal ${ }^{49}$. Jego reakcja miała inne podłoże niż w przypadku Reinscha. Nie tyle martwił się o utratę przez Amerykanów wiarygodności i autorytetu w Chinach, co obawiał się, że cała sytuacja zostanie odczytana jako zaakceptowanie przez Stany Zjednoczone specjalnych praw Japonii w Shandongu ${ }^{50} .25$ stycznia Lansing wyraźnie zakomunikował więc japońskiemu ambasadorowi Satō Aimaro, że Waszyngton nie uznaje tych praw, tak jak wcześniej nie uczynił tego w stosunku do Niemiec ${ }^{51}$.

Mimo negatywnej opinii rządu AIC postanowiła związać się z japońskim bankiem. Chiny też były temu przeciwne, ale ostatecznie nie mając wyboru, wyraziły zgodę. Departament Stanu zdystansował się od działań AIC, lecz otwarcie ich nie skrytykowal, bo korporacja - $\mathrm{w}$ wyniku pojawiających się trudności, braku stabilizacji politycznej w Chinach oraz możliwości lepszego i bezpieczniejszego zarobku w innych państwach, zwłaszcza po przystąpieniu USA do wojny - traciła zainteresowanie projektem i obawiano się, że z niego zrezygnuje, a wówczas Japonia by go przejęła. Sytuacja stała się doprawdy kuriozalna - wszyscy, może oprócz Japończyków, byli niezadowoleni. Waszyngton nie popierał współpracy, ale uważał ją za mniejsze zło niż rejteradę i sukces Japonii. Podobnie rozumował Pekin. AIC pewnie wolałaby się wycofać, lecz nie chcąc urazić Departamentu Sta$\mathrm{nu}$, kontynuowała negocjacje. Ostatecznie po licznych zawirowaniach 20 listopada 1917 roku podpisano zmodyfikowaną umowę, która jednak nie doczekała się realizacji ${ }^{52}$.

Równie niefortunnie potoczyły się losy inicjatywy kolejowej. Zaczęło się obiecująco - 17 maja 1916 roku firma Siems-Carey podpisała umowę na wybudowanie 1,5 tysiąca mil linii kolejowych w sześciu prowincjach ${ }^{53}$. Stanowiło to

${ }^{48}$ Minister Reinsch to the Secretary of State, January 2, 1917, [w:] PRFRUS 1917, s. 207.

49 The Secretary of State to Minister Reinsch, January 4, 1917, [w:] PRFRUS 1917, s. 207; The Secretary of State to Minister Reinsch, January 8, 1917, [w:] ibidem, s. 207-208.

${ }^{50}$ Lansing to Wilson, January 17, 1917, [w: ] PWW, t. 40, s. 512-513.

${ }^{51}$ A Memorandum by Edward Thomas Williams, January 25, 1917, [w: ] PWW, t. 41, Princeton 1983, s. 38-39.

52 PRFRUS 1917, s. 207-231; B. Beers, Vain Endeavor. Robert Lansing's Attempts to End the American-Japanese Rivalry, Durham 1962, s. 82-83.

${ }_{53}$ Doc. no. 1916/7: United States (Siems \& Carey) and China. Agreement for the construction of certain lines of railway, May 17, 1916, [w:] Treaties and Agreements..., s. 1313-1321. Umowa przewidywała, że po jej wypełnieniu Chiny mogły przyznać amerykańskiej firmie kolejne 1,5 tysiąca mil linii kolejowych do wybudowania. 
jawne wyzwanie wobec stref wpływów różnych mocarstw. Kontrahenci zdawali sobie chyba sprawę $\mathrm{z}$ możliwych trudności, bo w umowie zawarli punkt zakładający, że jeśli pojawią się jakieś przeszkody $\mathrm{z}$ budową konkretnych linii, to linie o takiej samej długości zostaną przyznane w innym miejscu.

Problemy rzeczywiście wystąpiły, i to na kilku płaszczyznach. Po śmierci Yuana nowe władze chińskie wyraziły chęć renegocjowania części warunków. Pod koniec września podpisano umowę uzupełniającą, która skróciła ogólną długość linii do 1,1 tysiąca mil ${ }^{54}$.

Nim to nastąpiło, przeciwko jednej z planowanych linii zaprotestowała Rosja. Powołała się na noty z 1899 roku, wedle których miała mieć wyłączność na konstruowanie przez cudzoziemski kapitał kolei biegnących od Pekinu ku jej granicom. Chiny odrzuciły protest, twierdząc, że ograniczenie dotyczyło tylko linii odchodzących od ich stolicy na północ lub północny-wschód (amerykańska linia miała iść na zachód), Rosja zaś samowolnie rozszerzyła je na pozostałe kierunki. Stany Zjednoczone poparty w sporze Chiny, ale AIC, partner Siems-Careya, oznajmiła, że nie rozpocznie budowy linii budzącej wątpliwości, dopóki kontrowersje rosyjsko-chińskie nie zostaną wyjaśnione ${ }^{55}$.

Reinsch był zdania, że nie należało ulegać rosyjskim pretensjom, zwłaszcza tak nieumocowanym prawnie, gdyż wtedy inne mocarstwa oparlyby swoje strefy wplywów na równie wątlych podstawach i w rezultacie Amerykanie nie mogliby prowadzić interesów nigdzie w Chinach. Zresztą, jak wyjaśnił carski poseł książę Mikołaj Kudaszew, rosyjskiego protestu nie należało traktować jako „zakazu” (prohibition), a raczej jako „zastrzeżenie” (caveat), które pozwoli uzyskać od Chin inne „korzyści”. Reinsch wnioskował więc, że amerykańska firma „nie napotka ostrego sprzeciwu ze strony Rosji” ${ }^{\prime 6}$. Zaniepokojony rozwojem wydarzeń był również Pekin, obawiający się, że odstąpienie przez Amerykanów od kontraktu lub nawet wahanie z ich strony narazi na szwank suwerenność Chin i ośmieli inne mocarstwa do protestu, przez co żadnej z planowanych linii nie uda się wybudowaćs7. AIC nie chciała się jednak wikłać $\mathrm{w}$ spory międzynarodowe i nie zmieniła zdania.

54 Supplementary Agreement, September 29, 1916, [w:] Treaties and Agreements..., s. 1321-1324; Minister Reinsch to the Secretary of State, October 27, 1916, [w: ] PRFRUS 1916, s. 192-195.

55 PRFRUS 1916, s. 188-192, 198-206, 209.

56 Minister Reinsch to the Secretary of State, October 26, 1916, [w:] PRFRUS 1916, s. 191-192; Minister Reinsch to the Secretary of State, October 31, 1916, [w:] ibidem, s. 199205; Minister Reinsch to the Secretary of State, November 10, 1916, [w: ] ibidem, s. 205-206. Cytaty pochodzą z ostatniego dokumentu. Rosja chciała przede wszystkim powstrzymać chińską kolonizację Mongolii. Minister Reinsch to the Secretary of State, October 31, 1916, [w: ] ibidem, s. 199-205.

57 Minister Reinsch to the Secretary of State, October 26, 1916, [w:] PRFRUS 1916, s. 191-192. 
Na początku 1917 roku pojawiły się na horyzoncie nowe przeszkody, które stworzyli poniekąd sami Amerykanie. 3 stycznia Reinsch, zniecierpliwiony i rozczarowany dotychczasowymi rezultatami, postanowil przejść do ofensywy. Wykorzystując ogólnikowe instrukcje Departamentu Stanu, aby zapobiec przystąpieniu kapitału japońskiego do projektu kanałowego w Shandongu i znaleźć inne pole do współpracy, zaproponował Japończykom partnerstwo przy budowaniu kolei w Mandżurii ${ }^{58}$. Poważnie zaalarmowani tym Japończycy udali się po wyjaśnienia bezpośrednio do Lansinga, który odciął się od propozycji swojego posła i potwierdził, że w Mandżurii, w przeciwieństwie do Shandongu, uznaje specjalną pozycję Japonii ${ }^{59}$. Sekretarz stanu określił tym samym nowe założenie chińskiej polityki Waszyngtonu, które zaakceptował następnie Wilson, co mogło dziwić w świetle wcześniejszych wypowiedzi prezydenta ${ }^{60}$. Podejście Lansinga sytuowało się między bardziej przychylną Japonii notą z 13 marca 1915 roku a stanowczym oświadczeniem Wilsona z maja tegoż roku. Nowe stanowisko nie okazało się ostateczne, w ciągu kilkunastu miesięcy sam Lansing parokrotnie je zmieniał.

Po raz pierwszy zrobił to pod wplywem niemal otwartej krytyki ze strony Reinscha. Zdenerwowany poseł pisał, że nie należało rozdawać „prezentów” i bez otrzymania niczego w zamian przystawać na japońskie zdominowanie Mandżurii. Trzeba się było przynajmniej starać, aby Tokio zapewniło, że nie będzie ubiegać się o specjalne przywileje w Chinach właściwych i dopuści Amerykanów do rozwoju gospodarczego Mandżurii. Nim to nastąpi, nie powinno się uznawać „abstrakcyjnej koncepcji” specjalnej pozycji, a jedynie prawa Japonii wynikające $\mathrm{z}$ konkretnych umów ${ }^{61}$. Lansing przyznał właściwie Reinschowi rację,

${ }^{58}$ Minister Reinsch to the Secretary of State, January 3, 1917, [w:] PRFRUS 1917, s. 161-163; Minister Reinsch to the Japanese Minister, January 3, 1917, [w:] ibidem, s. 169. Wydaje się, że Reinsch działał całkowicie bez zgody przełożonych, bo swoją propozycję wystosował 3 stycznia i dopiero 12 stycznia, być może szukając usprawiedliwienia, stwierdzil, że zrobił to zgodnie z instrukcjami pochodzącymi z 8 stycznia. The Secretary of State to Minister Reinsch, January 8, 1917, [w: ibidem, s. 207-208; Minister Reinsch to the Secretary of State, January 12, 1917, [w: ibidem, s. 170.

59 A Memorandum by Edward Thomas Williams, January 25, 1917, [w:] PWW, t. 41, s. $38-39$.

${ }^{60}$ B. Beers, Vain Endeavor ..., s. 95; N. Pugach, Paul S. Reinsch: Open Door Diplomat in Action, Millwood 1979, s. 219.

${ }^{61}$ Minister Reinsch to the Secretary of State, January 30, 1917, [w:] PRFRUS 1917, s. 171-172; Minister Reinsch to the Secretary of State, March 6, 1917, [w:] ibidem, s. 182183. Cytaty zaczerpnięto z wcześniejszego dokumentu. 10 stycznia Reinsch pisal, że jeśli byłoby to „absolutnie konieczne”, to podczas powojennej konferencji pokojowej można byłoby uznać specjalny status Mandżurii i części Mongolii, o ile polityka „otwartych drzwi" zostałaby formalnie potwierdzona na pozostałych obszarach Chin. Reinsch to the Secretary of State, January 10, 1917, WWP, series 2, reel 85. 
mętnie tłumacząc, że chodziło mu tylko o rozróżnienie między sytuacją panującą w Shandongu a sytuacją w Mandżurii, gdzie Japonii przysługiwały specjalne prawa wypływające z porozumień międzynarodowych. Poza tym Stany Zjednoczone ani trochę nie zmienily swojego stanowiska z maja 1915 roku i amerykańscy obywatele mogli nadal swobodnie angażować się $\mathrm{w}$ przedsięwzięcia biznesowe w Mandżurii ${ }^{62}$. Pomijając fakt, że wyjaśnienia były wybitnie nieprzekonujące, to - co gorsza - Lansing nie przekazał ich Japończykom, którzy uważali, iż sekretarz stanu miał na myśli dokładnie to, co powiedział ${ }^{63}$.

Rosja i Japonia nie były jedynymi mocarstwami, z którymi Departament Stanu musiał toczyć dyplomatyczną batalię w obronie kontraktu Siems-Careya ${ }^{64}$. W 1917 roku zaprotestowały przeciwko niemu Francja i Wielka Brytania, mimo że rok wcześniej nie wysuwały żadnych zastrzeżeń. Obecnie, powołując się na sekretne przyrzeczenia dane im przez chińskich oficjeli, rościły sobie prawo do pierwszeństwa w budowaniu przez cudzoziemców linii kolejowych w Guanxi, Hubei i Hunanie ${ }^{65}$. Lansing, za radą Reinscha, odrzucil protesty i uznał, że okoliczności były sprzyjające, aby spróbować podważyć cały system stref wpływów w Chinach. Zdaniem Reinscha przystąpienie USA do wojny sprawiło, że ententa uzyskała przewagę, dzięki czemu Wielka Brytania, Francja i Rosja nie musiały się już obawiać, że Japonia zmieni front (co jakiś czas pojawiały się informacje o prowadzeniu przez nią rozmów z Niemcami) i nie musiały się już podporządkowywać jej woli na Dalekim Wschodzie. Można było więc zabiegać, aby mocarstwa ponownie formalnie zobowiązały się do przestrzegania polityki „otwartych drzwi”, wyrzekły się ogólnych praw pierwszeństwa czy wyłączności na danym obszarze i ograniczyły swoje prawa do konkretnych przedsięwzięćc6 24 sierpnia Lansing napisał do Londynu i Paryża, że nie przyjmuje ich argumentów i za

62 The Secretary of State to Minister Reinsch, February 13, 1917, [w:] PRFRUS 1917, s. 175; The Secretary of State to Minister Reinsch, April 16, 1917, [w:] ibidem, s. 187.

63 B. Beers, Vain Endeavor ..., s. 95.

${ }^{64}$ Japończycy nie tylko interweniowali u Lansinga, ale też odpisali przewrotnie Reinschowi, że o ile współpraca w Mandżurii była mało prawdopodobna, to można by o niej pomyśleć w przypadku kontraktu Siems-Careya. The Japanese Minister to Minister Reinsch, January 20, 1917, [w:] PRFRUS 1917, s. 172.

${ }^{65}$ Minister Reinsch to the Secretary of State, November 28, 1916, [w:] PRFRUS 1916, s. 207; Minister Reinsch to the Secretary of State, April 3, 1917, [w: ] PRFRUS 1917, s. 183-184; Minister Reinsch to the Secretary of State, April 14, 1917, [w:] ibidem, s. 185; The French Ambassador to the Secretary of State, April 21, 1917, [w: ] ibidem, s. 187-188; Minister Reinsch to the Secretary of State, July 14, 1917, [w: ibidem, s. 190; Minister Reinsch to the Secretary of State, August 9, 1917, [w: ] ibidem, s. 190-191.

66 PRFRUS 1917, s. 183-185, 188, 190-191. Zob. też: Memorandum of a conversation between Baron Hayashi, the Japanese Minister, and the Honorable Paul S. Reinsch, the American Minister, November 14, 1916, RDSRIACh, roll 16. 
wiążącą wykładnię polityki „otwartych drzwi” uznaje memorandum Johna Haya z lutego 1902 roku, w którym określono, że równość traktowania dotyczy handlu i kwestii inwestycyjnych, i potępiono tworzenie monopoli inwestycyjnych. Rezerwowanie zatem całych obszarów Chin dla wyłącznej penetracji ekonomicznej jakiegoś mocarstwa było zdaniem Lansinga sprzeczne z polityką „otwartych drzwi”, do przestrzegania której mocarstwa się zobligowały. Za obowiązujące można było jedynie przyjąć konkretne umowy, a i z nich strony powinny się wywiązać w „rozsądnym czasie”, aby nie blokować możliwości rozwoju Chin. Lansing chciał wykorzystać sytuację i skłonić mocarstwa do zaakceptowania rozszerzonej wersji polityki „otwartych drzwi”, która stałaby się podstawą do burzenia stref wpływów ${ }^{67}$.

Próba okazała się mało skuteczna. Balfour odpowiedział, że chociaż ubolewa nad tym, to uformowanie stref wplywów stanowiło fait accompli. Gotowy był jednak zrobić wyjątek dla amerykańskich firm i dopuścić je do budowy kolei w brytyjskiej strefie wpływów, przy założeniu, że dostarczą kapitał, którym Brytyjczycy obecnie nie dysponowali ${ }^{68}$. Lansing nie był w pełni usatysfakcjonowany i odpisał, że wolałby innego rodzaju współpracę - aby oba rządy współdziałały na rzecz uzyskania od innych przyrzeczeń o ściślejszym przestrzeganiu polityki „otwartych drzwi” ${ }^{69}$. Na to Brytyjczycy już nie zareagowali. Nie wycofali też swojego protestu ${ }^{70}$. Przeciągające się kontrowersje dyplomatyczno-prawne i malejące zainteresowanie AIC inwestowaniem w Chinach sprawily, że kontrakt Siems-Careya podzielił los projektu kanałowego i nie doczekał się realizacji ${ }^{71}$.

Jeszcze więcej problemów spiętrzyło się przed trzecim elementem składowym programu inwestycyjnego - pożyczkami dla Chin. W tym bowiem przypadku oprócz protestów międzynarodowych i umiarkowanego zainteresowania bankierów na niekorzyść działały rywalizacja między amerykańskimi bankami

67 The Secretary of State to the British Ambassador, August 24, 1917, [w:] PRFRUS 1917, s. 191-192; The Secretary of State to the French Ambassador, August 24, 1917, [w: ] ibidem, s. 192-194. Na przełomie sierpnia i września Wilson i Lansing zaproponowali też Japonii, aby zrzekła się swojej strefy wpływów w Chinach. Będzie o tym szerzej mowa w dalszej części rozdziału.

68 The British Ambassador to the Secretary of State, handed on September 8, 1917, [w: ] PRFRUS 1917, s. 195-196.

69 The Secretary of State to the British Ambassador, September 20, 1917, [w: ] PRFRUS 1917, s. 197-198.

70 The Secretary of State to Minister Reinsch, October 11, 1917, [w: ] PRFRUS 1917, s. 199-200. O reakcji Wielkiej Brytanii na kontrakt Siems-Careya pisze: C.B. Davis, Limits of Effacement: Britain and the Problem of American Cooperation and Competition in China, 1915-1917, „Pacific Historical Review” 1979, t. 48, nr 1, s. 55-63.

71 B. Beers, Vain Endeavor..., s. 86; R.W. Curry, Woodrow Wilson and Far Eastern Policy, 1913-1921, New York 1968, s. 147-148. 
i chwiejna polityka rządu amerykańskiego. Początki znowu wyglądały obiecująco. Apele Reinscha, który za pomocą pożyczek chciał powstrzymać japońskie zapędy i wzmocnić nowe władze chińskie, zostały przychylnie przyjęte $\mathrm{w}$ Waszyngtonie $^{72}$. W połowie czerwca 1916 roku Lansing stwierdzil, że najlepiej byłoby, aby pożyczki udzieliła amerykańska grupa poprzez konsorcjum mocarstw. Jej powrotu mieli chcieć europejscy członkowie konsorcjum (oczywiście już bez Niemiec), obawiający się zdominowania przez Japonię i liczący, że Wall Street pokryje ich część pożyczki do końca wojny, aż ponownie będą dysponowali wolnymi środkami. Lansing widział dwie zalety takiego rozwiązania - negocjacje w sprawie pożyczki powinny być krótkie, gdyż istniało już dla niej zabezpieczenie w postaci wpływów z monopolu soli, i co ważniejsze, można było zablokować wrogie zapędy wobec Chin ze strony Japonii, która przecież też była członkiem konsorcjum. Jedyna trudność mogła polegać na rywalizacji między amerykańską grupą a bankiem Lee, Higginson \& Co., który w kwietniu udzielił Chinom pożyczki i prowadził rozmowy w sprawie kolejnej. Lansing uznał, że należało doradzić konkurentom połączenie $\operatorname{sil}^{73}$. Pomysł zaakceptował Wilson ${ }^{74}$, chociaż nadal nie był on zwolennikiem konsorcjum, zwłaszcza że trwała właśnie kampania prezydencka, a Partia Demokratyczna w swej platformie wyborczej chciała umieścić ostre potępienie imperializmu i „dyplomacji dolarowej” oraz szczyciła się, że ich kandydat podczas pierwszej kadencji odmówił poparcia prywatnych interesów w Chinach ${ }^{75}$. W tej sytuacji Wilson i jego wspólpracownicy musieli działać ostrożnie, aby nie narazić się na zarzut o hipokryzję, który mógł zmniejszyć szanse na reelekcję.

Od końca czerwca przedstawiciele Departamentu Stanu zaczęli konferować z bankierami. 25 lipca Lansing poprosił amerykańską grupę o niezwłoczne pożyczenie Chinom 4-5 milionów dol. na cele administracyjne. Jej odpowiedź nie była szczególnie zachęcająca. Grupa skłaniała się bowiem ku całkowitemu wycofaniu $\mathrm{z}$ prowadzenia interesów $\mathrm{w}$ Chinach i samorozwiązaniu, a nie angażowaniu się w nowe przedsięwzięcia. Jeśli jednak rząd podtrzymywał swoją prośbę, była gotowa rozpocząć negocjacje, ale - w świetle nie do końca jasnych zobowiązań wobec pozostałych grup, niepewnej sytuacji w Chinach i na światowych ryn-

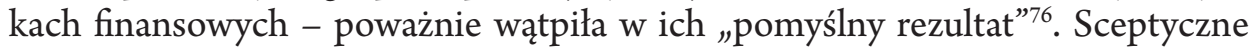

72 Reinsch to the Secretary of State, May 27, 1916, [w:] PWW, t. 37, s. 234-235; Reinsch to the Secretary of State, June 14, 1916, [w:] ibidem, s. 235; Reinsch to the Secretary of State, June 15, 1916, [w:] ibidem, s. 235-236; Reinsch to the Secretary of State, June 15, 1916, [w:] ibidem, s. 236.

${ }^{73}$ Lansing to Wilson, June 15, 1916, [w: ] PWW, t. 37, s. 232-233.

74 Wilson to Lansing, June 21, 1916, [w: ] PWW, t. 37, s. 271.

75 Howe to Wilson, June 9, 1916, [w: ] PWW, t. 37, s. 180-181.

76 The American Group to the Secretary of State, July 26, 1916, [w:] PRFRUS 1916, s. 134-138. 
nastawienie Wall Street sprawiło, że rozmowy na temat pożyczki, prowadzone jeszcze przez jakiś czas, zakończyły się niepowodzeniem ${ }^{77}$. Lansing był rozczarowany, lecz nie zaprzestał starań, zmienił tylko taktykę ${ }^{78}$.

Departament Stanu zwrócił się do różnych banków, aby udzieliły odrębnej pożyczki poza konsorcjum ${ }^{79}$. Pojawił się też pomysł, aby pożyczkę dał bezpośrednio rząd amerykański, ale Wilson był niezbyt entuzjastycznie nastawiony. Przewidywal, że w obecnej sytuacji Kongres się na nią nie zgodzi, zamierzał jednak wysondować nastroje panujące na Kapitolu. Ostatecznie z całej inicjatywy nic nie wyszło ${ }^{80}$.

Lepiej powiodło się z odrębnymi pożyczkami. 16 listopada chicagowski Continental and Commercial Trust and Savings Bank zdecydował się pożyczyć Chinom 5 milionów dol. na cele przemysłowe. Umowa przyznawała ponadto bankowi pierwszeństwo na kolejną pożyczkę do wysokości 25 milionów dol. ${ }^{81}$ Waszyngton był zadowolony, ale szybko musiał ponownie zmierzyć się z protestami międzynarodowymi, tym razem aż dwoma ${ }^{82}$. Najprawdopodobniej z inicjatywy Japonii Francja zaoponowała przeciwko temu, że amerykańska pożyczka otrzymała zabezpieczenie przyznane uprzednio francuskiemu bankowi. Równocześnie członkowie konsorcjum z Wielkiej Brytanii, Francji, Japonii i Rosji uznali, że naruszono ich wynikające z umowy na pożyczkę reorganizacyjną z 1913 roku prawo pierwszeństwa na pożyczki administracyjne, a pożyczka chicagowska na taki de facto cel miała być spożytkowana ${ }^{83}$.

Chiny odrzuciły te protesty, ale obawiając się nacisków ze strony konsorcjum, poprosity Stany Zjednoczone o wsparcie dyplomatyczne ${ }^{84}$. Reinsch i Lansing uważali stanowisko konsorcjum za nieuzasadnione ${ }^{85}$. Ostrzej zareagował

77 Rozmowy przedłużył też spór między bankami na temat składu amerykańskiej grupy w konsorcjum. B. Beers, Vain Endeavor ..., s. 88.

${ }_{78}$ The Secretary of State to Minister Reinsch, December 4, 1916, [w:] PRFRUS 1916, s. 146.

79 B. Beers, Vain Endeavor ..., s. 88-89.

${ }^{80}$ Howe to Wilson, August 5, 1916, [w:] PWW, t. 37, s. 534; Wilson to Howe, August 7, 1916, [w:] ibidem, s. 537.

${ }^{81}$ Doc. no. 1916/13:United States (Continental and Commercial Trust and Savings Bank) and China. Agreement for a loan of U.S. Gold \$5,000,000, November 16, 1916, [w: ] Treaties and Agreements ..., s. 1337-1343.

82 The Secretary of State to the Continental and Commercial Trust and Savings Bank, November 16, 1916, [w: ] PRFRUS 1916, s. 138; N. Pugach, Paul S. Reinsch ..., s. 212-213.

${ }_{83}$ Minister Reinsch to the Secretary of State, November 29, 1916, [w:] PRFRUS 1916, s. 143-145; B. Beers, Vain Endeavor ..., s. 89; N. Pugach, Paul S. Reinsch ..., s. 213.

${ }^{84}$ Minister Reinsch to the Secretary of State, November 29, 1916, [w:] PRFRUS 1916, s. 143-145; Minister Reinsch to the Secretary of State, December 2, 1916, [w:] ibidem, s. 145.

${ }^{85}$ Minister Reinsch to the Secretary of State, November 29, 1916, [w:] PRFRUS 1916, s. 143-145; The Secretary of State to Minister Reinsch, December 4, 1916, [w:] ibidem, s. 146. 
Wilson, którego „ingerencja ze strony [...] bankierów szalenie [...] denerwowała” i który stwierdził, że trzeba przeciw niej zaprotestować „w całkiem wyraźny sposób”. Mimo że Lansing sugerował, aby poczekać na rozwój wydarzeń, bo być może sprawa sama się rozwiąże, Wilson zdecydował się zakomunikować zainteresowanym stronom, że jakiekolwiek próby naginania warunków zawartych kontraktów lub wykluczania amerykańskich bankierów z rynku chińskiego „spotkają

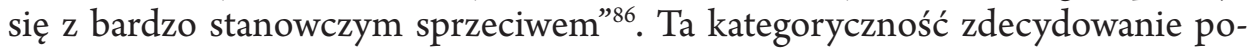
płaciła. Mocarstwa przyjęły amerykański punkt widzenia i przestały podważać umowę banku z Chicago ${ }^{87}$.

Dobre relacje nie trwały długo. Gdy okazało się, że Continental and Commercial Trust and Savings Bank rozpoczął z Pekinem negocjacje na temat kolejnej pożyczki na 25 milionów dol. ${ }^{88}$, a Reinsch wystąpił ze swoją propozycją współpracy w Mandżurii, Japonia podjęła zdecydowane kroki. Ostrzegła Chiny, by nie pożyczały pieniędzy od nikogo spoza konsorcjum, które co prawda obecnie niewiele mogło pomóc, ale w niedalekiej przyszłości udzieli większej pożyczki. Bieżące potrzeby mogła zaspokoić Japonia, oferująca niezwłoczną pożyczkę w wysokości 10 milionów jenów, pod warunkiem że negocjacje z Amerykanami zostaną zerwane ${ }^{89}$. Cesarska ambasada w Waszyngtonie wydała zaś oświadczenie dla prasy, w którym jawnie atakowała bank z Chicago ${ }^{90}$.

Jednocześnie Japonia, obawiając się amerykańskiej konkurencji, zgodziła się ze swymi europejskimi sojusznikami i zaczęła przekonywać Stany Zjednoczone do powrotu do konsorcjum ${ }^{91}$. Lansing, mimo że pół roku wcześniej sam

${ }^{86}$ Wilson to Lansing, December 3, 1916, [w: ] PWW, t. 40, s. 130; Lansing to Wilson, December 4, 1916, [w: ] ibidem, s. 140; Wilson to Lansing, December 5, 1916, [w: ] ibidem, s. 160; The Secretary of State to Minister Reinsch, December 5, 1916, [w:] PRFRUS 1916, s. 146. Cytaty pochodzą z pierwszego i trzeciego listu.

87 Minister Reinsch to the Secretary of State, December 18, 1916, [w:] PRFRUS 1916, s. 148-149; Minister Reinsch to the Secretary of State, December 23, 1916, [w:] ibidem, s. $149-150$.

${ }^{88}$ Minister Reinsch to the Secretary of State, January 13, 1917, [w:] PRFRUS 1917, s. 115; Lansing to Wilson, January 17, 1917, [w:] PWW, t. 40, s. 512-513.

89 Minister Reinsch to the Secretary of State, January 15, 1917, [w:] PRFRUS 1917, s. 116. Japonia zaprzeczyła, że protestowała przeciwko chińsko-amerykańskim negocjacjom, ale Reinsch upewnił się, że tak było. Ambassador Guthrie to the Secretary of State, February 3, 1917, [w: ] ibidem, s. 122; The Secretary of State to Minister Reinsch, February 5, 1917, [w: ] ibidem; Minister Reinsch to the Secretary of State, undated, received February 9, 1917, [w:] ibidem. 17 stycznia Japonia dała pierwszą z pożyczek nishiharowskich na 5 milionów jenów. M. Chi, Bureaucratic Capitalists ..., s. 679, 681.

90 Lansing to Wilson, January 17, 1917, [w: ] PWW, t. 40, s. 512-513.

91 Minister Reinsch to the Secretary of State, December 18, 1916, [w:] PRFRUS 1916, s. 148-149; Minister Reinsch to the Secretary of State, December 23, 1916, [w:] ibidem, 
był zwolennikiem takiego rozwiązania, w rozmowie z ambasadorem Satō odrzucił możliwość powrotu, gdyż konsorcjum miało jego zdaniem polityczne cele i „ograniczało suwerenne prawa Chin”92. Odmowa Lansinga, który osobiście uważał konsorcjum za pożyteczny instrument ${ }^{93}$, podyktowana była co najmniej trzema czynnikami: a) rozczarowującą postawą amerykańskiej grupy ${ }^{94}$; b) faktem, że trzeba by zapewne zrezygnować z negocjowanej właśnie drugiej pożyczki chicagowskiej, a była to jedyna amerykańska pożyczka, która w tym czasie miała szansę zostać zawarta; c) nieprzyjaznymi działaniami Japonii, w tym jej udaną próbą wywalczenia sobie udziału w projekcie kanałowym. Zwłaszcza ten ostatni czynnik budził niezadowolenie sekretarza stanu. „Jestem skłonny sądzić - pisał 17 stycznia 1917 roku - że im więcej ustąpimy Japonii, tym więcej zostanie od nas zażądane, i że stanowcze naleganie na nasze niezaprzeczalne prawa wymusi modyfikację japońskich żądań wobec Chin”. Ale usztywnienie stanowiska stawiało też USA przed poważnym dylematem, który Lansing sam dostrzegł. „Jeśli zdecydujemy się nalegać na nasze prawa $[. .$.$] , chiński rząd będzie oczekiwał na-$ szej pomocy, w razie gdyby Japonia spróbowała go zastraszyć" ${ }^{95}$. Problem stopnia amerykańskiego zaangażowania w Chinach i odpowiedzialności za ich los pozostał na razie otwarty, lecz miał bardzo szybko powrócić w związku z kwestią przystąpienia Chin do wojny.

Wątpliwości w sprawie pożyczki zaczął mieć tymczasem bank z Chicago. Ostrzeżenia Japonii i kierowana przez nią wroga kampania w prasie amerykańskiej, zmniejszające zainteresowanie pożyczką potencjalnych nabywców, sprawiły, że bank zastanawiał się, czy się z niej nie wycofać lub czy nie rozpocząć współpracy z Japonią ${ }^{96}$. Pod koniec stycznia jego wiceprezes John Abbott udał się do

s. 149-150; A Memorandum by Edward Thomas Williams, January 25, 1917, [w:] PWW, t. 41, s. 38-39; Ambassador Guthrie to the Secretary of State, January27, 1917, [w:] PRFRUS 1917, s. 118. Zob. też: Memorandum of a conversation between Baron Hayashi, the Japanese Minister, and the Honorable Paul S. Reinsch, the American Minister, November 14, 1916, RDSRIACh, roll 16. Japonia chciała powrotu Stanów Zjednoczonych do konsorcjum, bo obawiała się ich konkurencji, Europejczycy zaś - bo obawiali się dominacji Japonii. R.W. Curry, Woodrow Wilson and Far Eastern Policy..., s. 153.

92 A Memorandum by Edward Thomas Williams, January 25, 1917, [w:] PWW, t. 41, s. 38-39.

${ }_{93}$ B. Beers, Vain Endeavor ..., s. 88.

94 The Secretary of State to Minister Reinsch, December 4, 1916, [w:] PRFRUS 1916, s. 146.

${ }^{95}$ Lansing to Wilson, January 17, 1917, [w: ] PWW, t. 40, s. 512-513.

${ }^{96}$ Minister Reinsch to the Secretary of State, December 2, 1916, [w:] PRFRUS 1916, s. 145; Minister Reinsch to the Secretary of State, January 15, 1917, [w:] PRFRUS 1917, s. 116; The Secretary of State to Minister Reinsch, February 21, 1917, [w:] ibidem, s. 124; Minister Reinsch to the Secretary of State, February 26, 1917, [w:] ibidem, s. 125. 
Departamentu Stanu, aby dowiedzieć się, na jakie poparcie mógłby liczyć bank, gdyby zdecydował się kontynuować indywidualny kurs, a także jakie było stanowisko rządu na temat współpracy z Japonią. Edward Williams, który przyjął Abbotta, odpowiedział ostrożnie - współpraca była dopuszczalna, ale nie należało o nią zabiegać, aby nie stwarzać wrażenia, że uznaje się dominację Japonii w Chinach. W kwestii poparcia Williams powtórzył standardową formułkę, która raczej nie uspokoiła Abbotta ${ }^{97}$.

Bank z Chicago musiał się też zmierzyć z presją czasu - jego prawo pierwszeństwa wygasało po 60 dniach, a Chiny, ciągle potrzebujące pieniędzy, nie chciały go przedłużyć. Departament Stanu zaangażował się w uzyskanie prolongaty, którą ostatecznie Chiny przyznały. W połowie marca 1917 roku Abbott udał się do Pekinu, aby osobiście prowadzić negocjacje ${ }^{98}$.

W tym czasie Departament Stanu musiał się ustosunkować do nowego problemu. 2 marca konsorcjum zaprosiło amerykańską grupę do uczestnictwa w drugiej pożyczce reorganizacyjnej, o którą Chiny poprosiły w styczniu. Środki na pożyczkę, opiewającą na 10-20 milionów funtów szterlingów i zabezpieczoną podatkiem gruntowym i nadwyżką z monopolu soli, miały pochodzić po równo z Japonii i Stanów Zjednoczonych. Tym razem role się odwrócily - to bankierzy byli bardziej zainteresowani udziałem niż administracja Wilsona. Wyrazili oni gotowość do partycypacji, ale oczekiwali rządowego „błogosławieństwa" Wiele przemawiało za tym, aby go udzielić. $\mathrm{O}$ wznowienie aktywności grupy na rynku chińskim starał się przecież Lansing rok wcześniej. Dzięki udziałowi można było zneutralizować wpływy Japonii w konsorcjum i w Republice Chińskiej, które stałyby się jeszcze bardziej dominujące, gdyby USA się nie przyłączyły ( Japonia najpewniej sama wyłożyłaby pieniądze potrzebne na pożyczkę i zgodnie z przewidywaną umową nadzorowałaby zarządzanie podatkiem gruntowym) ${ }^{100}$. Waszyngton nie zdecydował się jednak udzielić poparcia amerykańskiej grupie. Pomijając fakt, że w tym czasie debatowano nad istotniejszą kwestią przystąpienia do wojny, to Wilson miał nie być jeszcze przekonany do idei międzynarodowego konsorcjum i większego zaangażowania ze strony rządu, a Lansing wydaje

97 N. Pugach, Paul S. Reinsch..., s. 215. Zob. też: A Memorandum by Edward Thomas Williams, April 12, 1917, [w: ] PWW, t. 42, s. 53-54.

98 The Secretary of State to Minister Reinsch, February 21, 1917, [w:] PRFRUS 1917, s. 124; Minister Reinsch to the Secretary of State, February 26, 1917, [w: ibidem, s. 125; The Secretary of State to Minister Reinsch, March 3, 1917, [w: ibidem; The Continental and Commercial Trust \& Savings Bank to the Secretary of State, March 14, 1917, [w: ] ibidem, s. 128; The Secretary of State to Mr. Arthur Reynold, March 15, 1917, [w: ibidem.

99 Morgan, Grenfell \& Co., London, to J.P. Morgan \& Co., New York, March 2, 1917, [w: ] PRFRUS 1917, s. 128; The American Group to the Secretary of State, March 8, 1917, [w: ] ibidem, s. 126-127.

100 N. Pugach, Paul S. Reinsch..., s. 215. 
się, że czekał na rozstrzygnięcie negocjacji prowadzonych przez Abbotta ${ }^{101}$. Te zaś zakończyły się w czerwcu fiaskiem, m.in. dlatego, że w Chinach doszło do kolejnych perturbacji wewnętrznych ${ }^{102}$.

Program amerykańskich inwestycji przyniósł do połowy 1917 roku więcej rozczarowań i porażek niż realnych korzyści. Kosztował nawet Amerykanów utratę części zaufania, jakim Chiny ich darzyły ${ }^{103}$. Stało się tak w wyniku działań Japonii, protestów innych mocarstw, przeciętnego zainteresowania amerykańskich inwestorów oraz zmiennych, a czasem i sprzecznych sygnałów z Departamentu Stanu. Być może program był też za „ambitny” i miał osiągnąć zbyt wiele celów naraz: rozwijać amerykańskie interesy, zablokować Japonię, wspomóc władze chińskie i podważyć istnienie stref wpływów. Przebieg wydarzeń w Chinach w roku 1917 również miał znaczenie - mógł zniweczyć lub wesprzeć amerykańskie wysiłki. Z jednej strony kolejne przewroty i niepokoje wewnętrzne zniechęcały inwestorów, z drugiej, gdyby Chiny przystąpily do wojny, można by im było pomóc jako sprzymierzeńcom.

\section{Stanowisko Waszyngtonu w kwestii przystąpienia Chin do I wojny światowej}

Sprawa przystąpienia Chin do wojny pojawiła się ponownie, gdy 3 lutego 1917 roku Stany Zjednoczone zerwały stosunki dyplomatyczne z Rzeszą, po tym, jak ogłosiła ona prowadzenie od 1 lutego nieograniczonej wojny podwodnej. Aby wzmocnić wydźwięk swej decyzji, administracja Wilsona wezwała państwa neutralne do postąpienia tak samo ${ }^{104}$. Chiny szybko wyrazily gotowość, ponieważ chciały włączyć się do wojny, upatrując w tym szansy na wzmocnienie pozycji międzynarodowej i uzyskanie zaproszenia na przyszłą konferencję pokojową. W Pekinie dostrzegano też negatywne aspekty całej sytuacji. Pomijając

101 Ibidem; R.W. Curry, Woodrow Wilson and Far Eastern Policy ..., s. 154.

102 The Secretary of State to the American Group, April 5, 1917, [w:] PRFRUS 1917, s. 129; The American Group to the Secretary of State, May 29, 1917, [w: ] ibidem, s. 129130; The Secretary of State to Minister Reinsch, June 2, 1917, [w: ] ibidem, s. 130; Minister Reinsch to the Secretary of State, June 4, 1917, [w:] ibidem; The Secretary of State to the American Group, June 6, 1917, [w: ] ibidem, s. 134.

103 Chińczycy wypominali później Amerykanom dopuszczenie Japończyków do kontraktów kanałowych. The Minister in China (Reinsch) to the Secretary of State, March 9, 1917, [w: ] PRFRUS 1917, Supplement 1: The World War, s. 427-430. Zob. też: Jenks to Wilson, April 14, 1917, [w: ] PWW, t. 42, s. 60-64.

104 The Secretary of State to the German Ambassador (Bernstorff), February 3, 1917, [w: ] PRFRUS 1917, Supplement 1: The World War, s. 106-108; The Secretary of State to the Diplomatic Representatives in Neutral Countries, February 3, 1917, [w: ] ibidem, s. 108. 
fakt, że relacje chińsko-niemieckie były do tej pory dobre, a wśród wojskowych sympatie proniemieckie mocno zakorzenione, zastanawiano się przede wszystkim nad reakcją Japonii, mając w pamięci jej weto w 1915 roku. Obawiano się, że może ona ponownie wystąpić z żądaniami z grupy piątej lub - gdyby Chiny rzeczywiście stały się członkiem koalicji - domagać się od sojuszników powierzenia nadzoru nad niezbędną modernizacją armii chińskiej. Milczenie aliantów europejskich tylko potęgowało te niepokoje. Władze pekińskie uzależniły więc zerwanie stosunków z Niemcami od uzyskania amerykańskich zapewnień, że wojska i arsenały pozostaną pod ich wyłączną kontrolą oraz otrzymają pożyczkę z USA na konieczne przygotowania wojenne. Dopytywały się też o prawo udziału w konferencji pokojowej ${ }^{105}$.

Reinsch próbował przekonać Chińczyków bez składania obietnic, ale widząc, że niczego w ten sposób nie osiągnie, poprosił Lansinga o instrukcje. Nim ten zdążył odpisać, Reinsch uznał, że należy działać niezwłocznie i zagwarantował pomoc finansową i zachowanie przez Chiny suwerenności w kwestiach wojskowych i administracyjnych ${ }^{106}$. Usatysfakcjonowany tym Pekin 9 lutego wyraził sprzeciw wobec niemieckich metod wojennych i zagroził, że jeśli protest okaże się nieskuteczny, nastąpi zerwanie stosunków dyplomatycznych. Równocześnie zobowiązał się wobec Stanów Zjednoczonych, że gdy tylko wypowiedzą one wojnę Rzeszy, zareaguje przynajmniej zerwaniem z nią stosunków ${ }^{107}$.

Reinsch był zadowolony z osiągniętego rezultatu, chociaż wiedział, że przekroczył swoje kompetencje. Tłumaczył się, że musiał udzielić gwarancji, aby uprzedzić wrogie wpływy Niemiec i uzyskać jak najlepszy efekt propagandowy ${ }^{108}$.

105 Reinsch to the Secretary of State, February 6, 1917, [w: ] PWW, t. 41, s. 175-176; Reinsch to the Secretary of State, February 6, 1917, [w: ] ibidem, s. 176-177; Reinsch to the Secretary of State, February 7, 1917, [w:] ibidem, s. 177-178; Reinsch to the Secretary of State, February 8, 1917, [w:] ibidem, s. 178-179; The Minister in China (Reinsch) to the Secretary of State, February 14, 1917, [w: ] PRFRUS 1917, Supplement 1: The World War, s. 414-418.

106 Reinsch to the Secretary of State, February 6, 1917, [w: ] PWW, t. 41, s. 175-176; Reinsch to the Secretary of State, February 6, 1917, [w: ibidem, s. 176-177; Reinsch to the Secretary of State, February 7, 1917, [w:] ibidem, s. 177-178; Reinsch to the Secretary of State, February 8, 1917, [w: ] ibidem, s. 178-179; Reinsch to Lansing, February 9, 1917, [w: ] ibidem, s. 182-183.

107 Reinsch to Lansing, February 9, 1917, [w: ] PWW, t. 41, s. 182-183.

108 Reinsch to the Secretary of State, February 7, 1917, [w:] PWW, t. 41, s. 177-178; Reinsch to Lansing, February 9, 1917, [w:] ibidem, s. 182-183; The Minister in China (Reinsch) to the Secretary of State, February 14, 1917, [w:] PRFRUS 1917, Supplement 1: The World War, s. 414-418. Reinsch tłumaczył się też, że musiał samemu podjąć decyzję, bo nie mógł się skontaktować telegraficznie z Departamentem Stanu. P. Reinsch, An American Diplomat..., s. 247-248. 
Inna sprawa, że gwarancje idealnie wpisywały się w jego dotychczasowe zabiegi i oczekiwania - aby Stany Zjednoczone mocniej zaangażowały się w obronę praw Chin, udzieliły im wsparcia finansowego i próbowały zwalczyć przemożne wpływy Japonii.

W Waszyngtonie miano na temat działań Reinscha odmienne zdanie. Po przeczytaniu jego doniesień Wilson przestraszył się, że USA mogą wieść Chiny ku „katastrofie” i same zaciągać zobowiązania, z których nie będą mogły się wywiązać. „To, o co [Chiny - J.P.] poprosity [...] - pisal prezydent do Lansinga - nie jest niedorzeczne, ale czy możemy liczyć na Senat i naszych bankierów, że spełnią $[. .$.$] nadzieje, jakie możemy wzbudzić w Chinach?”"109 Wątpliwości było$ więcej, między innymi ta, czy Stany Zjednoczone były gotowe wziąć odpowiedzialność za Chiny i pomóc im, gdyby Japonia próbowała je bardziej podporządkować. Czarny scenariusz wydawał się zaś Lansingowi bardzo realny - „[...] jeśli Chiny spróbowałyby wzmocnić swoją obronę [skądinąd rzecz leżącą w ich i amerykańskim interesie - J.P.], Japonia najprawdopodobniej uznałaby [to - J.P.] za zagrożenie, które usprawiedliwiałoby żądanie przez nią kontroli nad arsenałami i dowodzenia wojskami" ${ }^{110}$. Problem był tym poważniejszy, że Rosja, Francja i Wielka Brytania właściwie oddały pole Japonii, i jak otwarcie przyznał brytyjski chargé d'affaires w Pekinie Beilby Alston, to ona miała decydujący głos w sprawie przystąpienia Chin do wojny ${ }^{111}$. Wilson i Lansing zdali sobie nagle sprawę, że ich inicjatywa mogła przynieść więcej szkody niż pożytku, a czas ku temu był nad wyraz niesprzyjający. Stojącym u progu wojny Stanom Zjednoczonym zależało na pozyskaniu sprzymierzeńców i wytłumieniu antagonizmów, a nie na wzniecaniu nowych sporów.

Wilson i Lansing postanowili delikatnie, tak aby nie wyjść na niewdzięcznych, wyperswadować Chinom zamiar wzięcia przykładu z USA, tym bardziej że inne ważne państwa neutralne odmówiły przyłączenia się do inicjatywy, więc efekt propagandowy i tak byłby mały ${ }^{112}$. W instrukcji dla Reinscha z 10 lutego odrzucono możliwość dania gwarancji i poradzono Chinom jeszcze raz przemyśleć całą sytuację ${ }^{113}$. Tyle tylko że Chiny swoją decyzję już ogłosiły, a Reinsch gwarancji udzielił i trzeba było się zmierzyć z faktami dokonanymi. Nie wszystko

109 Wilson to Lansing, February 9, 1917, [w: ] PWW, t. 41, s. 175.

110 Lansing to Wilson, February 10, 1917, [w: ] PWW, t. 41, s. 185-186.

111 Reinsch to the Secretary of State, February 6, 1917, [w: ] PWW, t. 41, s. 175-176; Reinsch to the Secretary of State, February 8, 1917, [w: ] ibidem, s. 178-179.

112 R.S. Baker, Woodrow Wilson. Life and Letters, t. 6: Facing War, 1915-1917, New York 1946, s. 467.

113 Lansing to the American Legation at Peking, February 10, 1917, [w:] PWW, t. 41, s. 187. Wilson chciał, by przekazano Chinom, że pragnie im pomóc i „cały czas stara się je ochronić przed zaborczością [selfishness] ich sąsiada”. Wilson to Lansing, February 10, 1917, [w: ] ibidem, s. 186. 
było jednakże przesądzone - gwarancje miały się dopiero stać wiążące, gdy Chiny zerwą stosunki z Niemcami, a na razie jedynie zagroziły, że tak zrobią. Reinsch, któremu nakazano ścisłe trzymanie się wytycznych, miał przekazać Chinom, aby nie śpieszyły się z kolejnymi decyzjami i nie wypowiadały wojny Niemcom, chyba że zostałyby do tego zmuszone przez „nadzwyczajne okoliczności”. Lansing poinformował Reinscha, że nawet gdyby doszło do wojny amerykańsko-niemieckiej, nie będzie nalegał, aby Chiny do niej przystąpiły ${ }^{114}$.

W Pekinie zaczęto się tymczasem skłaniać do przystąpienia do wojny, zwłaszcza że wbrew przewidywaniom Japonia nie tylko nie wyraziła sprzeciwu, ale gorąco to poparła. Zmiana stanowiska Japonii wynikała z faktu, że właśnie w tym czasie otrzymała od europejskich sojuszników przyrzeczenie poparcia jej roszczeń terytorialnych na konferencji pokojowej, dlatego nie obawiała się już udziału Chin w koalicji. Mogło się to nawet dla niej okazać korzystne - ułatwić dalsze podporządkowywanie i eksploatację Państwa Środka. Rząd Terauchiego dostrzegł też w całej sytuacji szansę, aby zrealizować swój plan objęcia politycznego patronatu nad słabszym sąsiadem ${ }^{115}$. Pod presją Japonii, a także z chęci wzmocnienia własnej pozycji, rządzący w Pekinie zdecydowali się 14 marca zerwać stosunki z Niemcami. Mimo nalegań Japonii nie wypowiedzieli wojny Niemcom, ponieważ obawiali się, że Rosja, w której właśnie obalono carat, może zawrzeć separatystyczny pokój i wycofać się z wojny, poważnie osłabiając ententę ${ }^{116}$.

Reinsch po raz kolejny nie zgadzał się z przełożonymi i próbował przekonać ich do zmiany zdania. Alarmował, że bezczynność i wycofanie się z gwarancji pchnie Chiny w ramiona Japonii i wejdą one do wojny jako jej protegowany. Zmniejszy się poza tym ponownie wiarygodność Stanów Zjednoczonych i zaufanie, jakim Pekin je darzy. Potencjalnych negatywów mogło być zdaniem Reinscha więcej. Tokio nie wahało się wyasygnować środków dla projapońskiej grupy w Pekinie, której jednym z celów miało być przywrócenie na tron dynastii

114 Lansing to Reinsch, February 10, [w: ] PWW, t. 41, s. 195; The Secretary of State to the Minister in China (Reinsch), February 17, 1917, [w: ] PRFRUS 1917, Supplement 1: The World War, s. 410-411; The Secretary of State to the Minister in China (Reinsch), February 26, 1917, [w:] ibidem, s. 411; The Secretary of State to the Minister in China (Reinsch), March 2, 1917, [w: ] ibidem, s. 412. Cytat pochodzi z drugiego dokumentu.

115 PRFRUS 1917, Supplement 1: The World War, s. 409, 412-414, 424-425, 427-430; J. Polit, Odwrót znad Pacyfiku ..., s. 125; T. Dmochowski, Walka polityczna..., s. 237-238; N. Kawamura, Turbulence in the Pacific ..., s. 68-72, 74.

116 The Minister in China (Reinsch) to the Secretary of State, February 28, 1917, [w: ] PRFRUS 1917, Supplement 1: The World War, s. 412; The Minister in China (Reinsch) to the Secretary of State, March 1, 1917, [w:] ibidem, s. 424-425; The Minister in China (Reinsch) to the Secretary of State, March 14, 1917, [w:] ibidem, s. 420; S.G. Craft, Angling for an Invitation ..., s. 16-17. 
mandżurskiej. Próba restauracji monarchii na pewno wywołałaby nowe powstanie, kończąc tym samym okres względnego spokoju po śmierci Yuana ${ }^{117}$.

Ani nalegania Reinscha, ani rozwój sytuacji na Dalekim Wschodzie nie wpłynęły na zmianę zdania przez rząd amerykański. Znalazł on zresztą nowy kontrargument - zaczął się obawiać, że współpraca z Chinami mogłaby nie tylko doprowadzić do japońskiej agresji, ale i do zbliżenia japońsko-niemieckiego. Że nie była to wizja nierealna, pokazał Amerykanom „telegram Zimmermanna”, w którego posiadanie weszli akurat pod koniec lutego ${ }^{118}$. Departament Stanu podtrzymał więc decyzję o niemożności udzielenia jakichkolwiek gwarancji, a z tych danych nieopatrznie przez Reinscha postanowil się nie wywiązywać. Chciał je nawet formalnie wycofać, ale zrezygnował z tego, gdyż obawiał się, że wówczas „drzwi zostałyby całkowicie zamknięte” i Chiny przestałyby się konsultować. Amerykańska dyplomacja nie mogła też zapewnić Chinom udziału w konferencji pokojowej, chociaż miała dołożyć starań, aby tak się stało ${ }^{119}$.

Zerwanie relacji z Niemcami zakończyło pierwszy etap przystępowania Chin do wojny. W tym czasie amerykańska dyplomacja poniosła wizerunkową i wymierną porażkę w Państwie Środka. Jej zmienna postawa (z nakłaniającego stała się zniechęcającym, po tym jak nakłaniany wyraził zgodę) i brak spójności działań (inne deklaracje składał Reinsch, inne jego zwierzchnicy) sprawiły, że inicjatywa, która mogła wesprzeć suwerenność Chin, poprawić amerykańskie notowania i osłabić japońskie wpływy, osiągnęła zupełnie przeciwne skutki. Na obronę amerykańskiej dyplomacji należy dodać, że na pewne czynniki nie miała wpływu (odmowa przyłączenia się ze strony innych ważnych państw neutralnych) lub o nich w tym czasie nie wiedziała (zawarcie sekretnych traktatów z Japonią), co nie zmienia ogólnie niekorzystnego bilansu jej działań.

117 Reinsch chyba uznał, że łatwiej uda mu się przekonać do swoich racji Wilsona niż Lansinga, dlatego zdecydował się napisać też bezpośrednio do prezydenta. Reinsch to Lansing, February 10, 1917, [w: ] PWW, t. 41, s. 195; Reinsch to Wilson, February 14, 1917, WWP, series 2, reel 86; Reinsch to Lansing, March 12, 1917, [w:] PWW, t. 41, s. 394; PRFRUS 1917, Supplement 1: The World War, s. 408-409, 412-414, 424-425, 427-430.

118 B. Beers, Vain Endeavor..., s. 102-103. W słynnym telegramie ze stycznia 1917 roku Niemcy oferowały Meksykowi sojusz przeciwko Stanom Zjednoczonym i sugerowały, aby spróbował pozyskać do niego Japonię. Na temat „telegramu Zimmermanna” patrz np.: B.W. Tuchman, Telegram Zimmermanna, przeł. M.J. i A. Michejdowie, Warszawa 1988. O negocjacjach niemiecko-japońskich podczas I wojny światowej pisze: F.W. Iklé, Japanese-German Peace ..., s. 62-76.

119 Lansing to the American Legation at Peking, March 9, 1917, [w:] PWW, t. 41, s. 383-384; Polk to Wilson, March 10, 1917, [w: ibidem, s. 382-383; Lansing to Reinsch, March 13, 1917, [w: ] ibidem, s. 401-402. Cytat pochodzi z drugiego dokumentu. Możliwe działania Chin podczas kształtowania ładu powojennego analizował Reinsch. Reinsch to the Secretary of State, January 10, 1917, WWP, series 2, reel 85. 
Nowe perspektywy pojawiły się w momencie, gdy 6 kwietnia Stany Zjednoczone znalazły się w stanie wojny z Niemcami. Sześć dni później Lansing, stojący na stanowisku, że wojna wiele zmienia, uznał, że przystąpienie Chin do konfliktu było pożądane i można by im wtedy udzielić wsparcia finansowego w ramach programu pomocy dla państw walczących z Niemcami, który w niedługim czasie miał zatwierdzić Kongres ${ }^{120}$. Pożyczkę poparł Williams, wskazując, że w przeciwieństwie do Continental and Commercial Trust and Savings Bank, negocjującego właśnie pożyczkę z Chinami, ale zdecydowanego na współpracę z Japonią, rządowa pożyczka zostałaby udzielona szybciej i bez potrzeby dopuszczania Japonii ${ }^{121}$. Zwolennikiem przystąpienia Chin do wojny i dania im pożyczki pozostawał Reinsch, który wyszukiwał coraz to nowe argumenty. Przekonywał, że powinno do tego jak najszybciej dojść, aby zapobiec wykorzystaniu Chin przez wrogów i ze względu na słabnącą pozycję Rosji po obaleniu caratu. Środki finansowe miały nie tylko sprawić, że Chiny poczyniłyby niezbędne przygotowania militarne, ale także wesprzeć ich niepodległość, rozwój demokracji i instytucji republikańskich ${ }^{122}$. Podobnie myślał Jeremiah Jenks, profesor ekonomii na Uniwersytecie Nowojorskim i doradca chińskiego Ministerstwa Finansów, który w liście do Wilsona stwierdził, że amerykańska pomoc przyczyni się do szerzenia demokracji i cywilizacji ${ }^{123}$.

Wilson zareagowal pozytywnie na te sugestie: „Podjąłem tę sprawę z sekretarzem skarbu [tj. z Williamem McAdoo - J.P.] i jeśli Chiny przystąpią do wojny, nie będzie problemu, aby udzielić im pożyczki. Jedyne trudności będą z trzymaniem Japonii na dystans" ${ }^{124}$. Japońskie obiekcje wziął pod uwagę Williams, proponując rozbroić je poprzez wprowadzenie międzynarodowej kontroli nad armią chińską ${ }^{125}$. Protest Japonii stał się zresztą mniej pewny, gdyż jak donosił Reinsch, od kiedy USA wypowiedziały wojnę Niemcom, przestała ona wywierać presję na Chiny ${ }^{126}$. Według Duana miała też obiecać, że nie będzie próbowała przejąć nadzoru nad wojskami chińskimi ${ }^{127}$.

120 Lansing to Wilson, April 12, 1917, [w: ] PWW, t. 42, s. 53; R.W. Curry, Woodrow Wilson and Far Eastern Policy..., s. 189. Program, którego budżet wynosił 7 miliardów dol., został przyjęty pod koniec kwietnia. Ibidem, s. 166.

121 Williams to the Secretary of State, April 12, 1917, [w:] PWW, t. 42, s. 53-54.

122 The Minister in China (Reinsch) to the Secretary of State, April 12, 1917, [w: ] PRFRUS 1917, Supplement 1: The World War, s. 425-427.

123 Jenks to Wilson, April 14, 1917, [w:] PWW, t. 42, s. 60-64.

124 Wilson to Lansing, April 13, 1917, [w: ] PWW, t. 42, s. 53.

125 Williams to the Secretary of State, April 12, 1917, [w: ] PWW, t. 42, s. 53-54.

126 The Minister in China (Reinsch) to the Secretary of State, April 12, 1917, [w:] PRFRUS 1917, Supplement 1: The World War, s. 425-427.

127 The Minister in China (Reinsch) to the Secretary of State, May 10, 1917, [w: ] PRFRUS 1917, Supplement 1: The World War, s. 445-449. Zob. tez: The Minister in China (Reinsch) to the Secretary of State, April 13, 1917, [w:] ibidem, s. 441-444. 
Zwrot w amerykańskiej polityce starały się wykorzystać władze pekińskie, które coraz częściej sondowały możliwość uzyskania pomocy finansowej, zwłaszcza że warunki zaproponowane przez Japonię okazały się mniej korzystne, niż oczekiwano $^{128}$. Duan twierdzil, że gdyby tylko dysponował odpowiednimi środkami, mógłby wystawić ponad milionową armię ${ }^{129}$. Suma, którą Chiny planowały przeznaczyć na przygotowania, ciągle rosła. O ile w lutym było to 10 milionów dol., to dwa miesiące później Wu Tingfang mówił już o kwocie dziesięciokrotnie wyższej ${ }^{130}$. Zanim ustalono szczegóły dotyczące pożyczki i przystąpienia do wojny, w Chinach doszło do wydarzeń, które odroczyły obie sprawy i wpłynęły na kolejną zmianę amerykańskiego stanowiska.

Konflikt w Chinach, tlący się właściwie od zakończenia "trzeciej rewolucji”, zaostrzył się w pierwszej połowie $1917 \mathrm{roku}$. Na skomplikowanej scenie politycznej ukształtowały się dwa rywalizujące ze sobą obozy. Przeciwko szefowi rządu Duanowi, popieranemu przez wojskowych, klikę Cao i Partię Postępową, wystąpili prezydent Li i parlament, w którym większość miał Kuomintang. Pewną niezależność zachowali wiceprezydent Feng i feldmarszałek Zhang Xun, ale z czasem i oni wybrali strony - pierwszy opowiedzial się za Duanem, drugi, przynajmniej pozornie, za prezydentem. Aktywność polityczną wykazywali też bardziej radykalni przedstawiciele Kuomintangu z Sunem i Tangiem na czele.

Wybuch otwartego konfliktu przyśpieszyła kwestia udziału w wojnie i związanych z tym zagranicznych pożyczek. Duan i jego zwolennicy parli do przyłączenia się do ententy, licząc, że poza innymi korzyściami uzyskają dzięki temu przewagę nad parlamentem, który planowali rozwiązać. Parlamentarzyści i prezydent też popierali udział $\mathrm{w}$ wojnie, ale chcieli gwarancji, że sytuacja nie zostanie wykorzystana przeciwko nim. Domagali się reorganizacji rządu, aby móc kontrolować jego poczynania. Przeciwko przystąpieniu do wojny byli natomiast m.in. Feng, Zhang i Sun (ten ostatni wysłał nawet w tej sprawie telegram do brytyjskiego premiera Davida Lloyda George’a). Aby wzmocnić swoją pozycję i zapewne zastraszyć przeciwników, Duan zwołał w kwietniu do Pekinu konferencję gubernatorów wojskowych, którzy opowiedzieli się za wojenną polityką rządu. Dysponując ich poparciem oraz zapewnieniami japońskiego posła Hayashiego,

128 The Minister in China (Reinsch) to the Secretary of State, April 12, 1917, [w:] PRFRUS 1917, Supplement 1: The World War, s. 425-427; The Minister in China (Reinsch) to the Secretary of State, April 13, 1917, [w:] ibidem, s. 441-444; The Secretary of State to the Minister in China (Reinsch), April 23, 1917, [w:] ibidem, s. 431-432; The Minister in China (Reinsch) to the Secretary of State, May 10, 1917, [w: ] ibidem, s. 445-449.

129 The Minister in China (Reinsch) to the Secretary of State, May 10, 1917, [w:] PRFRUS 1917, Supplement 1: The World War, s. 445-449. Zob. też: The Minister in China (Reinsch) to the Secretary of State, April 27, 1917, [w:] ibidem, s. 432.

130 Reinsch to the Secretary of State, February 6, 1917, [w: ] PWW, t. 41, s. 176-177; The Minister in China (Reinsch) to the Secretary of State, May 10, 1917, [w:] PRFRUS 1917, Supplement 1: The World War, s. 445-449. 
że jeśli wystąpią jakieś problemy w związku z przystąpieniem do wojny, Japonia pomoże się z nimi uporać, Duan wniósł o wypowiedzenie wojny. Posłowie odmówili, nawet mimo ataku opłaconego motłochu. Duan zażądał więc rozwiązania parlamentu, ale Li się na to nie zgodził i 23 maja zdymisjonował Duana, powierzając jego obowiązki proamerykańskiemu Wu. Duan udał się wówczas do Tianjinu, gdzie razem z gubernatorami wojskowymi ustanowił de facto drugi ośrodek władzy, i groził ostatecznym zerwaniem więzi z rządem i atakiem na Pekin, jeśli parlament nie zostanie rozwiązany. Li, nie mając wojsk, postanowił wezwać Zhanga, co miało się dla niego okazać zgubne ${ }^{131}$.

Stany Zjednoczone $\mathrm{z}$ niepokojem przyglądały się rozwojowi wydarzeń. $\mathrm{O}$ narastającym kryzysie Reinsch donosił regularnie od kilku miesięcy. Tylko w jednym momencie, tuż po lutowym wystąpieniu Chin przeciwko niemieckiej wojnie podwodnej, jego relacje przybrały optymistyczny wydźwięk - cały kraj miał się zjednoczyć wokół wspólnej sprawy ${ }^{132}$. Można wszelako domniemywać, że w tym przypadku w relacji Reinscha było więcej życzeń niż prawdy, bo społeczeństwa nie cechowała jednomyślność, a sam poseł stwierdził wcześniej, że jedna z korzyści zerwania stosunków z Niemcami miała właśnie polegać na odwróceniu uwagi od ciągłych walk frakcyjnych ${ }^{133}$. Później Reinsch konsekwentnie pisał już o pogłębiającym się sporze. Wskazywał, że rozwiązanie parlamentu lub próba obalenia prezydenta doprowadziłyby do wybuchu kolejnego powstania na południu i być może podziału państwa. Do wywołania kolejnej rewolucji mieli też dążyć z japońską pomocą Sun i Tang, szermujący hasłami panazjatyzmu, ale ich knowania zdaniem amerykańskich przedstawicieli były mniej groźne. Niechęć, zwłaszcza Reinscha, do obu polityków była nadal wyraźna. Zaczął on za to inaczej oceniać Duana, którego uważał obecnie za bardziej reakcyjnego. Przestrzegł go przed rozwiązaniem parlamentu, ponieważ wywarłoby to złe wrażenie w Stanach Zjednoczonych ${ }^{134}$.

Rozwiązanie przez Chiny parlamentu, aby zgodnie z wolą Stanów Zjednoczonych przystąpić do wojny, postawiłoby te ostatnie w wizerunkowo kłopotliwym położeniu, ale stanowiło to dla nich zapewne mniejszy problem. Gorzej, że doszłoby do kolejnej wojny domowej, osłabienia państwa i być może jego podziału lub interwencji Japonii. Parlamentaryzm był istotny, ale prawdziwym

131 Fragment na podstawie: PRFRUS 1917, s. 46-67; PRFRUS 1917, Supplement 1: The World War, s. 413-451; T. Dmochowski, Walka polityczna ..., s. 238-239.

${ }_{132}$ Reinsch to Lansing, February 10, 1917, [w:] PWW, t. 41, s. 195; The Minister in China (Reinsch) to the Secretary of State, February 14, 1917, [w:] PRFRUS 1917, Supplement 1: The World War, s. 414-418.

133 P. Reinsch, An American Diplomat ..., s. 242. Zob. też: M. Chi, China Diplomacy ..., s. 173.

134 PRFRUS 1917, s. 46-48, 51-52, 54-55; PRFRUS 1917, Supplement 1: The World War, s. 424-425, 437-444, 449-451. 
priorytetem pozostawały stabilność i porządek. Dobrze obrazował to przypadek Yuana, który nie stracił poparcia Waszyngtonu, mimo że zaprowadził rządy autorytarne, gdyż zrobił to po stłumieniu powstania. Duan w porównaniu ze swym szwagrem miał z amerykańskiej perspektywy jeszcze jedną wadę - był on, a przynajmniej osoby z jego otoczenia, nastawiony projapońsko. Lepszą politykę prowadził zdaniem Reinscha Li, który był rozważny, koncyliacyjnie usposobiony i mniej uległy wobec Japonii, ale nie miał zaplecza politycznego i swoich wojsk. Reinsch nie widział możliwości znalezienia kompromisu, chyba że dzięki mediacji mocarstw ${ }^{135}$.

W Waszyngtonie podzielano te obawy. 4 czerwca Lansing wystosował notę do Chin, w której stwierdzil, że ich przystąpienie do wojny było „sprawą o drugorzędnym znaczeniu”, najważniejsze, aby zachowały „jedność polityczną”" ${ }^{136}$. Tego samego dnia sekretarz stanu poprosił Wielką Brytanię, Francję i Japonię o przyłączenie się do wystąpienia ${ }^{137}$. Wszystkie trzy mocarstwa odmówiły. Najbliżej wyrażenia zgody była Francja, która uzależniła ją od jednomyślności wszystkich adresatów, aczkolwiek i tak zaznaczyła, że przystąpienie Chin do wojny pozostawało istotne, tylko powinno być poprzedzone uspokojeniem sytuacji wewnętrznej ${ }^{138}$. Bardziej zdecydowanie, choć zarazem taktownie, aby nie urazić Waszyngtonu, odrzucił propozycję Londyn, ponieważ uważał, że uczestnictwo Chin w wojnie leżało w ich własnym interesie. Ponadto proponowane wystąpienie mocarstw byłoby sprzeczne $\mathrm{z}$ dotychczasowymi staraniami Rządu

${ }_{135}$ The Minister in China (Reinsch) to the Secretary of State, May 10, 1917, [w:] PRFRUS 1917, Supplement 1: The World War, s. 445-449; Minister Reinsch to the Secretary of State, June 2, 1917, [w:] PRFRUS 1917, s. 48; Minister Reinsch to the Secretary of State, June 5, 1917, [w: ] ibidem, s. 51-52; Minister Reinsch to the Secretary of State, June 14, 1917, [w:] ibidem, s. 63-67.

136 The Secretary of State to Minister Reinsch, June 4, 1917, [w:] PRFRUS 1917, s. $48-49$.

137 The Secretary of State to Ambassador Sharp, June 4, 1917, [w: ] PRFRUS 1917, s. 49.

138 The Minister for Foreign Affairs to Ambassador Sharp, June 14, 1917, [w:] PRFRUS 1917, s. 75-76. W sierpniu francuski poseł w Pekinie Alexandre Robert Conty negatywnie ocenił amerykańską notę i stwierdził, że zwalniała ona aliantów z konieczności konsultowania się ze Stanami Zjednoczonymi w kwestii przystąpienia Chin do wojny. Po proteście Departamentu Stanu Quai d'Orsay całkowicie odcięło się od wypowiedzi swojego posła, dodając, że było to jego kolejne uchybienie dyplomatyczne, za które zostanie odwołany. Niedługo później Conty rzeczywiście otrzymał nakaz powrotu do Paryża, zwłaszcza że władze chińskie uznały go za persona non grata. Reinsch to the Secretary of State, August 3, 1917, [w:] PWW, t. 43, s. 362-363; Polk to the American Embassy at Paris, August 4, 1917, [w:] ibidem, s. 364; Sharp to the Secretary of State, August 8, 1917, RDSRIACh, roll 17. 
Jego Królewskiej Mości oraz mogłoby zostać poczytane za opowiedzenie się za którąś ze stron konfliktu ${ }^{139}$.

Największe poruszenie amerykańska akcja wywołała w Japonii. Tamtejsza prasa już wcześniej oskarżała Reinscha o zakulisowe popieranie Li i przyczynienie się do dymisji Duana. W podobnym tonie wypowiedział się wysoki rangą pracownik Gaimusho ${ }^{140}$. Niezadowolenie wzrosło, gdy wyszło na jaw, że Stany Zjednoczone przekazały już notę Chinom, nie czekając na reakcje zaproszonych mocarstw. Japończycy myśleli, że chodziło nie tylko o identyczne, ale i wspólne wystąpienie. Ubolewali, że nie poinformowano ich o tym, a nota wręczona Chinom, której fałszywy tekst opublikowała jedna $z$ gazet japońskich ${ }^{141}$, podgrzewając jeszcze atmosferę podejrzliwości, wsparła, być może wbrew intencjom autorów, stronnictwo prezydenta $\mathrm{Li}^{142}$. Ostatecznie 15 czerwca ambasador Satō przekazał Lansingowi memorandum, w którym odrzucono możliwość przyłączenia się do wystąpienia właśnie ze względu na politykę nieingerencji w wewnętrzne sprawy Państwa Środka ${ }^{143}$. Oczywiście była to dyplomatyczna wymówka, która w świetle wcześniejszych, jak i obecnych poczynań Japonii zakrawała wręcz na szyderstwo $^{144}$. Stanowcza odmowa wynikała $\mathrm{z}$ faktu, że amerykańska inicjatywa krzyżowała starania Japonii, aby nadzorować politykę zagraniczną Chin i stać się pośrednikiem w ich kontaktach $\mathrm{z}$ mocarstwami. Post Wheeler, amerykański chargé d'affaires w Tokio, wskazywał na jeszcze inny motyw - Japonia nie chciała podpisać się pod przekazaną już notą, gdyż wyglądałoby to, jakby podążała za

139 Ambassador Page to the Secretary of State, June 5, 1917, [w:] PRFRUS 1917, s. 50; The Foreign Office to Ambassador Page, June 14, 1917, [w:] ibidem, s. 74-75; M. Chi, China Diplomacy..., s. 125-126.

140 Chargé Wheeler to the Secretary of State, June 1, 1917, [w:] PRFRUS 1917, s. 48; Chargé Wheeler to the Secretary of State, June 14, 1917, [w:] ibidem, s. 68-71. Podobne zdanie o Reinschu mial Alston. M. Chi, China Diplomacy ..., s. 125.

${ }^{141}$ Lansing uważal, że gazeta mogła świadomie podać nieprawdziwą informację. Ambasada w Tokio z kolei podejrzewała, że wcześniejsza nagonka prasowa na Reinscha była zaplanowana. The Secretary of State to Chargé Wheeler, June 12, 1917, [w:] PRFRUS 1917, s. 61; Chargé Wheeler to the Secretary of State, June 14, 1917, [w: ] ibidem, s. 68-71. Amerykanie generalnie skarżyli się na wrogą propagandę i swój nieudolny serwis informacyjny w Chinach, Japonii i Rosji. House to Wilson, May 11, 1917, [w: ] PWW, t. 42, s. 275; Rogers to Creel, August 13, 1917, [w:] PWW, t. 43, s. 456-459.

142 Chargé Wheeler to the Secretary of State, June 8, 1917, [w:] PRFRUS 1917, s. 58; Chargé Wheeler to the Secretary of State, June 9, 1917, [w:] ibidem; Chargé Wheeler to the Secretary of State, June 11, 1917, [w:] ibidem, s. 60-61; Chargé Wheeler to the Secretary of State, June 14, 1917, [w:] ibidem, s. 68-71.

143 The Japanese Ambassador to the Secretary of State, handed on June 15, 1917, [w:] PRFRUS 1917, s. 71-72.

144 Wiosną i latem 1917 roku, kiedy w Chinach doszło do kryzysu wewnętrznego, Japonia kilkakrotnie, czasem poprzez prywatne firmy, udzieliła wsparcia finansowego Duanowi. N. Kawamura, Turbulence in the Pacific..., s. 72-74. 
Stanami Zjednoczonymi, którym w przypadku powodzenia Chiny przypisałyby całą zasługę. Japonia rozważała nawet wysłanie protestu, ale zrezygnowała $\mathrm{z}$ tego, bo nie chciała pogarszać stosunków z Waszyngtonem. Cały epizod utwierdzil ją za to w przekonaniu, że należało ponownie ułożyć relacje ze Stanami Zjednoczonymi w odniesieniu do Chin. Nie omieszkała także postraszyć Pekinu, że jeśli posłucha amerykańskich rad, będzie miał z nią do czynienia ${ }^{145}$.

Warto zauważyć, że Wielka Brytania i Japonia, które obecnie zarzucały, iż wspólna nota stanowiłaby niedopuszczalną ingerencję, dwa lata wcześniej nie miały takich skrupułów - przeciwnie, same zainicjowały wysłanie dwóch (za pierwszym razem nie czekając na pozostałe mocarstwa) ostrzeżeń dla Yuana, aby nie kontynuowal przygotowań do wprowadzenia cesarstwa. Jak na ironię, naówczas to USA nie przyłączyły się, uważając właśnie, że Chiny powinny móc same zdecydować o ustroju, bez presji zewnętrznej. Teraz mocarstwa zamienily się miejscami, tyle że sytuacja była trochę inna. Stany Zjednoczone mogły się poniekąd czuć odpowiedzialne za wywołanie kryzysu, bo podniosły kwestię przystąpienia Chin do wojny. Inne było też zagrożenie porządku - jesienią 1915 roku widmo powstania wydawało się odległe, choć potem okazało się realne, w czerwcu 1917 roku wojna domowa była niemal pewna. Toteż Waszyngton, dla którego priorytetem pozostawała stabilizacja, uznał, że zapobieżenie walkom było ważniejsze niż przystąpienie Chin do wojny czy nawet zasada nieingerencji. Zachowanie tej ostatniej próbowano przynajmniej zamarkować, przekazując ostrzeżenie obu zwaśnionym stronom, niemniej jednak w Chinach zostało ono odczytane jako poparcie dla prezydenta i parlamentu ${ }^{146}$. Częściowo było to zgodne z intencjami amerykańskiej dyplomacji, która chciała wytrącić argument wysuwany przez stronnictwo Duana, jakoby alianci je popierali, częściowo zadziałał przypadek, gdyż wysłanie noty zbiegło się w czasie z apelami Li, Wu i Suna o poparcie ${ }^{147}$. Chociaż według Reinscha nota została przez obie strony przyjęta przychylnie i zwiększała szanse na znalezienie kompromisu, to jej wpływ na przebieg konfliktu w Chinach był właściwie żaden ${ }^{148}$. Pomysł mającej większe szanse

${ }_{145}$ PRFRUS 1917, s. 61-63, 68-74; Reinsch to the Secretary of State, August 24, 1917, RDSRIACh, roll 17; M. Chi, China Diplomacy ..., s. 127.

146 The Secretary of State to Minister Reinsch, June 4, 1917, [w:] PRFRUS 1917, s. 48-49; Minister Reinsch to the Secretary of State, June 11, 1917, [w:] ibidem, s. 60.

147 Minister Reinsch to the Secretary of State, June 5, 1917, [w:] PRFRUS 1917, s. 50; Minister Reinsch to the Secretary of State, June 5, 1917, [w:] ibidem, s. 50-51; Sun to Wilson, June 8, 1917, [w: ] PWW, t. 42, s. 466; Sun to Wilson, June 9, 1917, [w:] ibidem, s. 468; The Secretary of State to Ambassador Sharp, June 9, 1917, [w:] PRFRUS 1917, s. 58-59.

148 Minister Reinsch to the Secretary of State, June 9, 1917, [w:] PRFRUS 1917, s. 59-60; Minister Reinsch to the Secretary of State, June 11, 1917, [w:] ibidem, s. 60; The Secretary of State to Chargé Wheeler, June 12, 1917, [w:] ibidem, s. 61; Minister Reinsch to the Secretary of State, June 23, 1917, [w:] ibidem, s. 77; Reinsch to the Secretary of State, August 24, 1917, RDSRIACh, roll 17. 
wspólnej noty upadł ze względu na brak poparcia ze strony mocarstw. Lansing, prawdopodobnie robiąc dobrą minę do złej gry, miał powiedzieć, że sytuacja na tyle się zmieniła, że nie było już potrzeby wysyłania noty ${ }^{149}$. Wydarzenia w Chinach rzeczywiście toczyły się szybko, ale raczej nie w kierunku, w jakim życzyłby sobie tego sekretarz stanu.

Poproszony przez Li o pomoc i mediację Zhang odpowiedział na wezwanie i w czerwcu przybył z częścią swojej armii do Pekinu. Zhang, zatwardziały monarchista, który podobnie jak jego żołnierze nosił jeszcze warkocz - symbol poddaństwa wobec mandżurskiej dynastii, wymusił na Li rozwiązanie parlamentu, po czym w nocy z 30 czerwca na 1 lipca przeprowadził zamach stanu. Odsunął od władzy prezydenta i ogłosił przywrócenie Cesarstwa Chińskiego, ponownie usadawiając na Tronie Smoka jedenastoletniego wówczas Puyi. Nazajutrz w Pekinie komedia restauracji trwała w najlepsze - mieszkańcy w pośpiechu wywieszali dawne chorągwie ze smokami, doczepiali sobie sztuczne warkocze i przywracali inne atrybuty niegdysiejszej władzy. Szybko się jednak zorientowano, że cały przewrót ograniczał się do stolicy i był właściwie dziełem jednego człowieka - Zhanga, który z ważnych osób w państwie pozyskał tylko Kang Youweia i Liang Dunyana. Obalony prezydent Li, zanim skrył się w japońskim poselstwie, przekazał władzę w państwie wiceprezydentowi Fengowi, a zdymisjonowanego niedawno Duana przywrócił na urząd premiera. W niespełna dwa tygodnie Duan na czele Armii Ocalenia Republiki wkroczył do Pekinu. Żołnierze Zhanga po otrzymaniu żołdu i obcięciu warkoczy swobodnie opuścili stolicę. Ich dowódca zbiegł do poselstwa holenderskiego, podobnie jak Liang Dunyan. Kang wybrał z kolei poselstwo amerykańskie, gdzie przebywał do grudnia ${ }^{150}$. Przetasowania polityczne w następstwie restauracji mandżurskiej były nieznaczne, acz istotne. Duan odzyskał i wzmocnił swoją władzę, tworząc rząd złożony tylko z lojalnych mu osób. Feng objął stanowisko prezydenta, Li zaś wycofał się z życia publicznego ${ }^{151}$. Nie przywrócono rozwiązanego parlamentu, co w niedługiej przyszłości miało się stać jedną z przyczyn dalszych zawirowań w Chinach $^{152}$.

149 Chargé Wheeler to the Secretary of State, June 18, 1917, [w: ] PRFRUS 1917, s. 73.

150 Reinsch to the Secretary of State, December 7, 1917, RDSRIACh, roll 18. Podobnie jak podczas rewolucji Xinhai powstał plan, aby cesarz Puyi schronił się w amerykańskim poselstwie. Minister Reinsch to the Secretary of State, August 9, 1917, [w: ] PRFRUS 1917, s. 90-96.

151 Według jednej z interpretacji Duan zręcznie wykorzystał Zhanga, aby pozbyć się Li. M. Chi, China Diplomacy..., s. 128; The Cambridge History of China ..., s. 309.

152 Fragment na podstawie: PRFRUS 1917, s. 59-96; W. Rodziński, Historia Chin ..., s. 635-636; Pu Yi, Byłem ostatnim cesarzem Chin, przeł. J. Mach, t. 1, Łódź 1988, s. $71-82$. 
Rozdział V. Polityka USA wobec Chin od śmierci Yuan Shikaia...

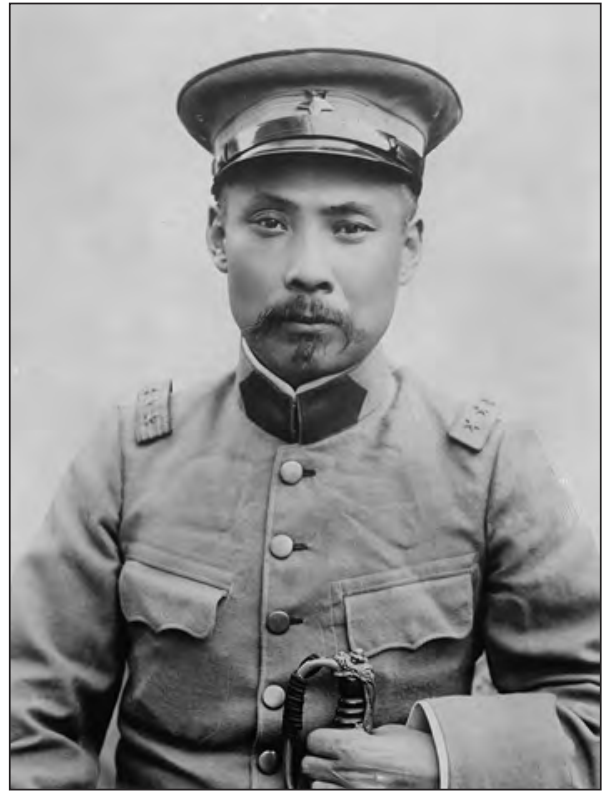

32. Duan Qirui

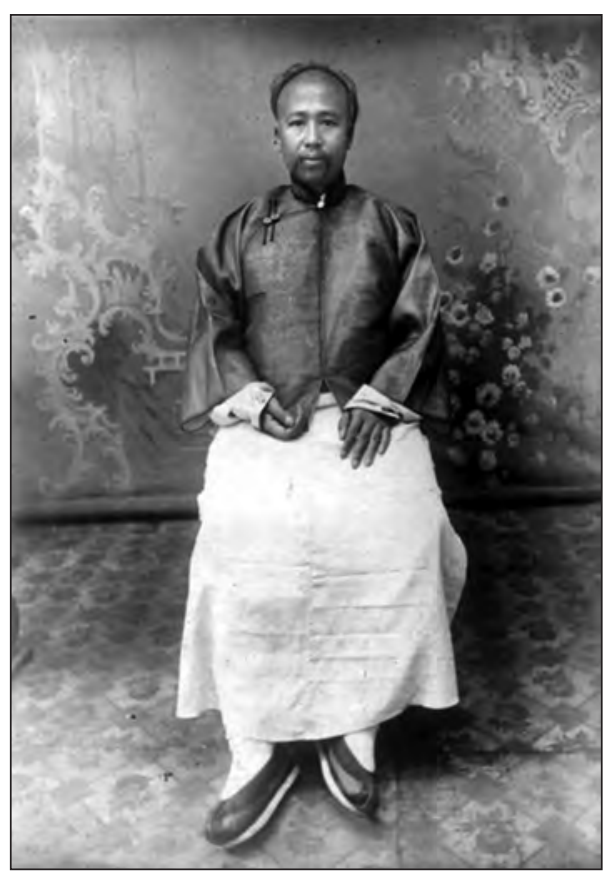

34. Kang Youwei

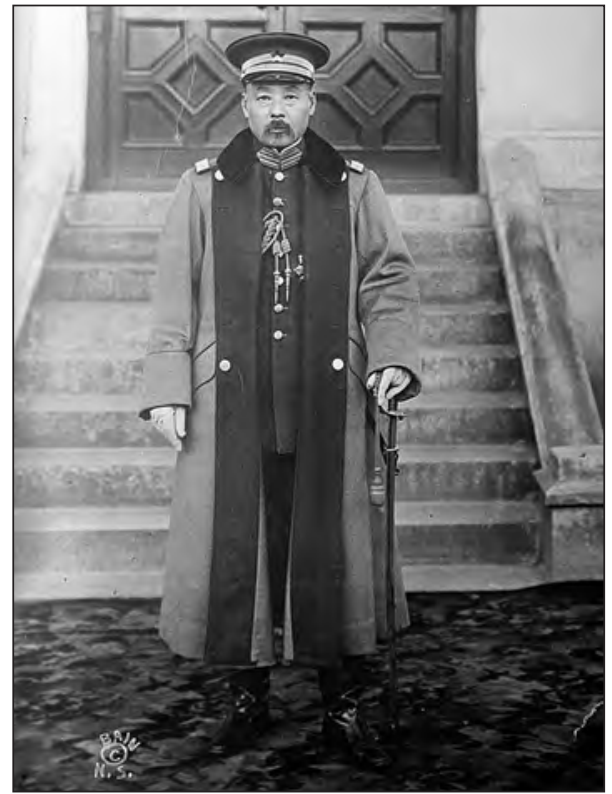

33. Feng Guozhang

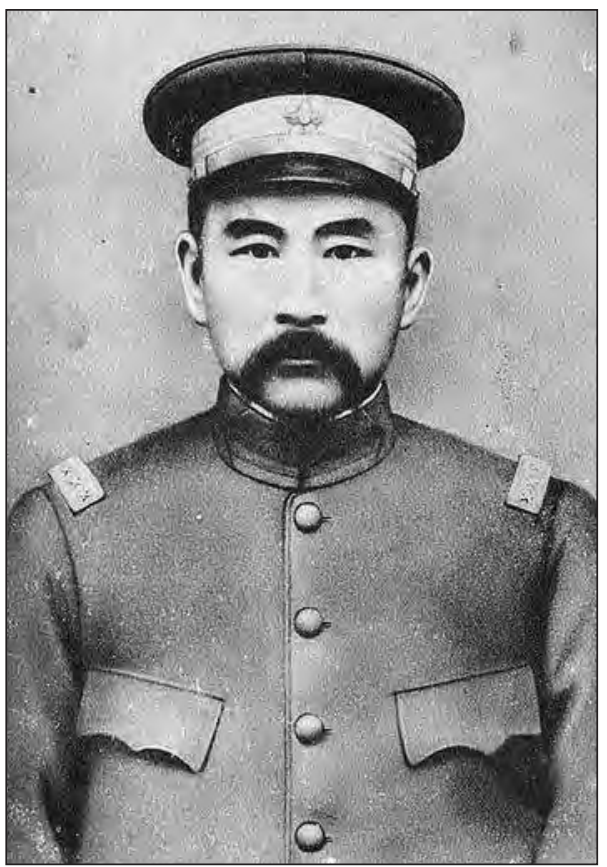

35. Zhang Xun 
Dla Stanów Zjednoczonych restauracja mandżurska była niekorzystna, i to z kilku powodów. Ponownie doszło do walk, które osłabiały Chiny, oddalały je od przystąpienia do wojny, zniechęcały amerykańskich inwestorów i zwiększały niebezpieczeństwo zagranicznej ingerencji ${ }^{153}$. Walki były już zresztą wielostronne (Li kontra Duan, Zhang kontra Li, Zhang kontra Duan oraz niedługo później Południe kontra Północ), co stwarzało ryzyko, że taki stan będzie trwał długo i dojdzie do permanentnej wojny wszystkich ze wszystkimi.

Poważnie zahamowany został również rozwój demokracji i parlamentaryzmu. Jasne było, że nawet po zdławieniu spisku Duan będzie chciał rządzić w sposób autorytarny. Nie mogło to zyskać uznania nad Potomakiem, skoro - jak zadeklarował Wilson w słynnym przemówieniu wojennym z 2 kwietnia 1917 roku - Stany Zjednoczone przystąpiły do wojny właśnie po to, aby zniszczyć autorytaryzm $\mathrm{i}$,uczynić świat bezpiecznym dla demokracji”154. Także sam powrót do monarchii był z pewnością negatywnie oceniany w Waszyngtonie. Jeszcze 8 czerwca Lansing wyjaśnial, że „amerykański rząd nie jest obojętny wobec kwestii utrzymania republikańskich rządów w Chinach. Przeciwnie, liczy na ich nieprzerwaną kontynuację" 155 . USA mogły zaakceptować, ale nie poprzeć wprowadzenie cesarstwa, jak to uczyniły wobec planów Yuana, ale tylko jeśli porządek byłby zagwarantowany. W tym przypadku było zaś odwrotnie - jedyne, co gwarantowal przewrót Zhanga, to wojnę domową. Restauracja mandżurska, nie dość że przeprowadzona na drodze zamachu stanu, była praktycznie dziełem jednoosobowym, co również odróżniało ją od inicjatywy Yuana, mającej przynajmniej pozory legalności i pewne poparcie społeczne. Teraz nawet wojskowi o monarchicznych poglądach, których zwłaszcza na Północy było wcale niemało, w większości zdystansowali się wobec całej akcji lub otwarcie się jej sprzeciwili. Wynikało to po części z faktu, że Zhang nie poczynił niezbędnych przygotowań i nie pozyskał potencjalnych stronników, po części ze względu na przywódczą rolę samego Zhanga, którego „powszechnie się bano i nienawidzono”. Fatalna reputacja feldmarszałka i jego niemal rozbójniczej armii, wsławionej splądrowaniem Nankinu w 1913 roku, jeszcze bardziej zrażała Stany Zjednoczone do pomysłu przywrócenia cesarstwa. Reakcjonista o bandyckiej przeszłości, nierozumiejący

153 Niektórzy współcześni uważali, że za przewrotem Zhanga stali Niemcy, inni, że Japończycy. Por. Minister Reinsch to the Secretary of State, June 14, 1917, [w:] PRFRUS 1917, s. 63-67; Sharp to Lansing, July 24, 1917, [w: ] PWW, t. 43, s. 267-270; Minister Reinsch to the Secretary of State, August 9, 1917, [w: ] PRFRUS 1917, s. 90-96; M. Chi, China Diplomacy ..., s. 127-128; J. Fenby, Chiny. Upadek i narodziny wielkiej potęgi, przel. J. Wąsiński, J. Wołk-Łaniewski, Kraków 2009, s. 222; J. Polit, Odwrót znad Pacyfiku..., s. 127-128.

${ }^{154}$ An Address to a Joint Session of Congress, April 2, 1917, [w: $] P W W$, t. 41, s. 519-527.

155 The Secretary of State to Minister Reinsch, June 8, 1917, [w:] PRFRUS 1917, s. 57-58. 
w ogóle funkcjonowania współczesnego rządu - tak charakteryzował go Reinsch. Właściwie jedyną zaletę Zhanga dostrzegał w tym, że nie uległ japońskim wpływom ${ }^{156}$. W całym przewrocie Reinsch widział zaś inny pozytyw - druga w krótkim czasie nieudana próba restauracji doszczętnie zdyskredytowała ruch monarchiczny, wzmacniając tym samym republikanizm ${ }^{157}$.

Bezsprzecznie zwycięsko z całego epizodu wyszedł Duan, który mógł już teraz realizować swoją politykę bez opozycji ze strony parlamentu i prezydenta. 14 sierpnia Chiny wypowiedziały wojnę Niemcom i Austro-Węgrom. W tym drugim przypadku prawdziwy powód był nieco zaskakujący - Chińczycy bowiem, jak z rozbrajającą szczerością wyznał Wellington Koo, nie odróżniali Niemców od Austriaków i aby uniemożliwić podszywanie się jednych pod drugich, wypowiedzieli wojnę obu ${ }^{158}$.

Chiny nie miały na wojnie wiele zyskać, ale też ich udział w niej był minimalny. Ograniczył się do wysłania ok. 200 tysięcy robotników do Francji, Rosji i Mezopotamii. Myślano też o wyekspediowaniu wojska, ale nigdy do tego nie doszło. Jeśli chodzi o korzyści, to Chiny anulowały porozumienia z państwami centralnymi, uzyskały wstęp na konferencję pokojową oraz pomniejsze ustępstwa od aliantów (m.in. odroczenie spłaty odszkodowania „bokserskiego” na 5 lat, zgodę na podniesienie taryfy celnej do 5\%), w zamian za które musiały jednak spełnić różne żądania ${ }^{159}$.

Stany Zjednoczone powitały decyzję Pekinu z zadowoleniem ${ }^{160}$. Przystąpienie do wojny mogło poprawić międzynarodowe położenie Chin i przekreślało obawy, że kwestia ta stanie się ponownie przedmiotem konfliktu wewnętrznego.

156 Reinsch to the Secretary of State, November 15, 1916, RDSRIACh, roll 16; Minister Reinsch to the Secretary of State, June 9, 1917, [w:] PRFRUS 1917, s. 59-60; Minister Reinsch to the Secretary of State, June 11, 1917, [w:] ibidem, s. 60; Minister Reinsch to the Secretary of State, June 14, 1917, [w:] ibidem, s. 63-67; Minister Reinsch to the Secretary of State, August 9, 1917, [w:] ibidem, s. 90-96. Cytat pochodzi z drugiego z dokumentów. Zła opinia Reinscha o Zhangu wynikała też z faktu, że jednym z pierwszych miast, które dyplomata odwiedził po przyplynięciu do Chin, był dopiero co zdobyty przez wojska Zhanga Nankin. Wizyta wywarla na nim bardzo ponure wrażenie. P. Reinsch, An American Diplomat ..., s. 11-12.

${ }_{157}$ Minister Reinsch to the Secretary of State, August 9, 1917, [w:] PRFRUS 1917, s. 90-96.

158 The Minister in China (Reinsch) to the Secretary of State, August 14, 1917, [w:] PRFRUS 1917, Supplement 1: The World War, s. 456; Williams to the Secretary of State, August 16, 1917, RDSRIACh, roll 17.

159 Więcej na ten temat: M. Chi, China Diplomacy..., s. 128-137; J. Polit, Odwrót znad Pacyfiku..., s. 152-153.

160 Polk to the American Legation at Peking, August 4, 1917, [w:] PWW, t. 43, s. 363-364; The Minister in China (Reinsch) to the Secretary of State, August 12, 1917, [w: ] PRFRUS 1917, Supplement 1: The World War, s. 455; The Secretary of State to the Minister in China (Reinsch), August 14, 1917, [w:] ibidem, s. 456. 
Reinsch uważał, że można było osiągnąć więcej. Jego zdaniem Chiny zaprzepaściły szansę, aby uzyskać potwierdzenie swoich suwerennych praw, na co część aliantów miała się wstępnie zgodzić ${ }^{161}$. Poseł proponował też wysłanie amerykańskiej komisji, która omówiłaby z Chinami sprawę współpracy podczas wojny, dzięki czemu mogłyby one odrzucić oferty wyłącznej pomocy od innych państw, gdyby takowe się pojawiły. Chodziło o uprzedzenie Japonii i niedopuszczenie, aby przejęła kontrolę nad chińską armią. Pomysł nie został zaakceptowany przez Lansinga, ale amerykańskiej dyplomacji udało się uzyskać od Chin zobowiązanie, że zachowają pełną kontrolę nad swoimi siłami zbrojnymi, arsenałami i fabrykami broni ${ }^{162}$. Było to korzystne dla Amerykanów odwrócenie sytuacji z lutego, kiedy to Chiny chciały, aby USA dały im takie gwarancje.

Przystąpienie Chin do wojny poprawiło nadto bezpieczeństwo Amerykanów w tym kraju. Z internowania zwolnione zostały bowiem amerykańskie okręty, które po wycofaniu w 1914 roku europejskich jednostek z chińskich wód zapewniały cudzoziemcom ochronę. Kiedy USA przystąpiły do wojny, Chiny zażądały internowania okrętów. Lansing i sekretarz marynarki Josephus Daniels odmówili, ale na początku maja zmienili decyzję, obawiając się, że Japonia mogłaby się domagać podobnego przywileju ${ }^{163}$. Teraz nie trzeba już było wybierać między japońską ingerencją a chińskim zagrożeniem.

Podsumowując dotychczasowe rozważania, można stwierdzić, że amerykańska polityka w kwestii przystąpienia Chin do wojny była niekonsekwentna, co stawało się cechą charakterystyczną całej polityki administracji Wilsona wobec Chin w czasie światowego konfliktu. W tym konkretnym przypadku brak konsekwencji wynikał z faktu, że owa polityka zależała od co najmniej pięciu czynników: międzynarodowego położenia Stanów Zjednoczonych; stanowiska Japonii; reakcji Chin; sytuacji w Chinach; możliwego wpływu całej sprawy na stosunki amerykańsko-japońskie. Sytuację komplikował ponadto rozdźwięk między sprzecznymi deklaracjami składanymi przez członków amerykańskiej dyplomacji.

161 The Minister in China (Reinsch) to the Secretary of State, September 27, 1917, [w: ] PRFRUS 1917, Supplement 1: The World War, s. 457-458.

162 The Minister in China (Reinsch) to the Secretary of State, August 9, 1917, [w: ] PRFRUS 1917, Supplement 1: The World War, s. 454-455; The Minister in China (Reinsch) to the Secretary of State, August 11, 1917, [w: ] ibidem, s. 455; The Secretary of State to the Minister in China (Reinsch), August 13, 1917, [w: ibidem, s. 455-456; Proposed Reply of the Chinese Government, September 28, 1917, [w:] PRFRUS 1917, Supplement 2: The World War, t. 1, Washington 1932, s. 696. W odniesieniu do tej sprawy zobacz też: The Secretary of State to the Minister in China (Reinsch), March 26, 1917, [w:] PRFRUS 1917, Supplement 1: The World War, s. 422-423.

163 From the Diary of Josephus Daniels, April 13, 1917, [w:] PWW, t. 42, s. 58-59. 
Przystąpienie Pekinu do wojny miało z militarnego punktu widzenia małe znaczenie dla ententy i Waszyngtonu, było natomiast istotne dla samych Chin oraz amerykańskiej i japońskiej polityki w tym państwie. Cała sprawa potwierdziła po raz kolejny, że od wybuchu wojny Stany Zjednoczone odgrywały ważniejszą rolę na Dalekim Wschodzie. Waszyngton i Tokio rywalizowały o to, pod czyimi auspicjami Pekin przyłączy się do wojny. Pogłębiło to wzajemną nieufność między oboma mocarstwami i stanowiło jeden z czynników, który przekonał je, że należy wypracować nowe porozumienie amerykańsko-japońskie.

\section{Polityka Stanów Zjednoczonych wobec chińskiego sojusznika}

Przystąpienie do wojny nie uspokoiło sytuacji w Chinach. Wbrew przewidywaniom Reinscha, że taki ruch może je zjednoczyć i załagodzić konflikty ${ }^{164}$, były one targane kolejnymi wewnętrznymi konwulsjami. Tym razem opozycja wystąpiła na południu kraju. Na przełomie sierpnia i września 1917 roku część posłów (głównie kuomintangowskich) z rozwiązanego w czerwcu parlamentu powołała w Kantonie rząd wojskowy na czele z Sun Yat-senem, któremu nadano tytuł generalissimusa. Rząd południowy domagał się przywrócenia Li na urząd prezydenta, reaktywacji parlamentu, respektowania konstytucji i ukarania osób odpowiedzialnych za ostatnie wydarzenia. Jego oddziaływanie było jednak ograniczone - mógł on co prawda liczyć na poparcie floty, ale w znacznej mierze zależny był od lokalnych wojskowych (klika Guangxi), rywalizujących z Północą. Duan, w przeciwieństwie do Fenga, który preferował rokowania, postanowił siłą dokonać zjednoczenia. Walki trwające od października 1917 roku do wiosny roku następnego nie przyniosły jednak rozstrzygnięcia. Fiasko operacji uwypukliło tarcia w łonie militarystów północnych, które doprowadziły do rozłamu na skupioną wokół Duana klikę Anhui oraz przewodzoną przez Fenga frakcję Zhili. Sytuacja w Chinach stała się ponownie niepewna i pogmatwana ${ }^{165}$.

Stanom Zjednoczonym tradycyjnie już zależało na spokoju i wewnętrznej harmonii w Chinach. W połowie sierpnia Lansing dopytywał się zaniepokojony, czy rzeczywiście dziewięć prowincji popierało rząd kantoński ${ }^{166}$. Kiedy rząd ten został ustanowiony, sekretarz stanu zgodził się bez zastrzeżeń na japońską propozycję, aby nie pomagać wrogom władz pekińskich, które przecież dopiero co stały

${ }^{164}$ Reinsch to the Secretary of State, August 3, 1917, [w: ] PWW, t. 43, s. 362-363.

165 W. Rodziński, Historia Chin ..., s. 636-637; The Cambridge History of China ..., s. 309-311; T. Dmochowski, Walka polityczna ..., s. 241.

166 The Secretary of State to Minister Reinsch, August 16, 1917, [w:] PRFRUS 1917, s. 98. Także Wilson z niepokojem śledził wydarzenia w Chinach. R.S. Baker, Woodrow Wilson..., t. 7: War Leader, 1917-1918, New York 1946, s. 229. 
się sojusznikiem wojennym ${ }^{167}$. Lansingowi tym łatwiej było podjąć taką decyzję, że Reinsch i amerykański konsul w Kantonie Percival Stewart Heintzleman kreślili krytyczny obraz rządu kantońskiego, który „istniał tylko z nazwy”, nie dawał nadziei na stabilizację, nie miał programu ani zaufania społecznego, a na jego czele stali „ekstremalni radykałowie”, jak Sun. Podobnie reaktywowany parlament nie był ich zdaniem reprezentatywny i nie stanowił elementu jednoczącego kraj. Sytuację na Południu pogarszała ponadto nieustająca rywalizacja między różnymi frakcjami ${ }^{168}$. Istotnym powodem niechęci do władz kantońskich była coraz bardziej negatywna opinia, jaką amerykańscy dyplomaci mieli o Sunie. Do listy jego wcześniejszych wad dopisali zarzuty o lapówkarstwo oraz konszachty z Niemcami i Japończykami. W Waszyngtonie dano wiarę tym informacjom - w listopadzie 1918 roku Lansing zdecydowanie odradził Wilsonowi korespondowanie z Sunem, o którym krążyły „paskudne pogłoski”169. Z tych wszystkich powodów Stany Zjednoczone nie udzieliły pomocy, o jaką Południe zabiegało - odmówily dania kredytów, uznania rządu czy chociażby przyznania statusu strony wojującej. Próbowały też zapobiec sprzedaży obligacji przez emisariuszy kantońskich na Hawajach i Filipinach. Zdecydowały się na taką politykę mimo zapewnień ze strony władz południowych, że walczą one w obronie Republiki, demokracji, parlamentu i konstytucji, że podczas nadawania koncesji gospodarczych będą preferowały amerykańskich przedsiębiorców i że chcą przystąpić do wojny pod przewodnictwem USA (we wrześniu Kanton wypowiedział wojnę Berlinowi i Wiedniowi) ${ }^{170}$. Potwierdziło to po raz kolejny, że dla Waszyngtonu

167 The British Ambassador to the Secretary of State, September 3, 1917, [w: ] PRFRUS 1917, s. 102; The Japanese Embassy to the Department of State, handed on September 4, 1917, [w:] ibidem, s. 103; The Secretary of State to the British Ambassador, September 6, 1917, [w: ibidem, s. 103-104; The Secretary of State to the Japanese Ambassador, September 6, 1917, [w: ] ibidem, s. 104.

168 Heintzleman to Reinsch, August 9, 1917, RDSRIACh, roll 17; Minister Reinsch to the Secretary of State, August 23, 1917, [w:] PRFRUS 1917, s. 99-100; Heintzleman to Reinsch, August 27, 1917, RDSRIACh, roll 17; Heintzleman to Reinsch, August 31, 1917, ibidem; Heintzleman to Reinsch, September 13, 1917, ibidem; Minister Reinsch to the Secretary of State, October 12, 1917, [w: ] PRFRUS 1917, s. 107-109; Heintzleman to Reinsch, April 28, 1918, RDSRIACh, roll 19. Cytaty pochodzą z dokumentów napisanych przez Reinscha.

169 Winterhalter to the Navy Department, October 12, 1916, RDSRPRBChOS, roll 25; Heintzleman to Reinsch, August 5, 1917, RDSRIACh, roll 17; Heintzleman to Reinsch, August 9, 1917, ibidem; Wilson to Lansing, November 20, 1918, [w: ] PWW, t. 53, Princeton 1986, s. 138; Lansing to Wilson, November 25, 1918, [w: ] ibidem, s. 197.

${ }^{170}$ Heintzleman to Reinsch, August 3, 1917, RDSRIACh, roll 17; Heintzleman to Reinsch, August 14, 1917, ibidem; Heintzleman to Reinsch, September 7, 1917, ibidem; The Secretary of State to the Secretary of War, November 26, 1917, [w:] PRFRUS 1917, 
najważniejsza była zdolność do zaprowadzenia elementarnego ładu i tylko rząd, który ją posiadał, mógł liczyć na amerykańskie poparcie.

Tymczasem nad Potomakiem zaczęto ponownie myśleć o pomocy dla Chin w postaci pożyczek. Na początku września 1917 roku Lansing zaczął nalegać, aby alianci ustalili konkretny sposób wsparcia rządu pekińskiego, o czym ogólnikowo wspomniała Japonia ${ }^{171}$. Williams zalecal, aby pomoc polegała przede wszystkim na sfinansowaniu rozwoju wewnętrznego i zakupu uzbrojenia ${ }^{172}$. Z amerykańskiej perspektywy pożyczki były uzasadnione, skoro Chiny przystąpiły do wojny. Można im było pożyczyć pieniądze na przygotowania militarne $\mathrm{w}$ ramach programu pomocy dla państw walczących z Niemcami. Inne motywy pozostawały „klasyczne” - stabilizacja, reformy i przeciwdziałanie japońskim wpływom. Rząd Duana też szukał pożyczek, po części z tych samych powodów, ale głównie aby rozprawić się z opozycją. W sierpniu 10 milionów jenów zgodziła się mu pożyczyć Japonia, ale potrzeby były dużo większe ${ }^{173}$. Pekin zwrócił się do wszystkich, którzy mogli pomóc: konsorcjum, Stanów Zjednoczonych i Japonii. We wrześniu Koo wystąpił o pożyczkę rzędu 100 milionów dol., na co otrzymał odpowiedź, że chwilowo może liczyć na 25 milionów, ale jak pokazuje list Williama McAdoo do Wilsona, Departament Stanu poprosił o wyasygnowanie od 25 do 50 milionów, aby, co znamienne, wesprzeć nie tylko przygotowania militarne, ale i amerykańskie interesy w Chinach ${ }^{174}$.

Jednocześnie Waszyngton próbował zablokować udzielenie pożyczki przez innych. Poparł brytyjską propozycję, aby zniechęcić Chiny do starania się o pieniądze od zdominowanego przez Japonię konsorcjum. Pekin nie dał się przekonać, a Londyn pod wpływem Tokio szybko wycofał się z pomysłu, ale nalegał, aby w takim razie Stany Zjednoczone powróciły do konsorcjum, które negocjowało z Chinami kolejną pożyczkę reorganizacyjną w wysokości 20 milionów funtów szterlingów, przeznaczoną na reformę walutową. Jeśliby zatem Amerykanie powrócili do konsorcjum, mogliby kontrolować poczynania Japończyków, będąc

s. 111-112; Heintzleman to Reinsch, January 11, 1918, RDSRIACh, roll 18; Sammons to Reinsch, February 22, 1918, ibidem; Heintzleman to Reinsch, April 1, 1918, RDSRIACh, roll 19; Heintzleman to Reinsch, April 28, 1918, ibidem; Memorandum by the Office of the Solicitor, May 28, 1918, RDSRIACh, roll 18; The Division of Far Eastern Affairs to Harrison, September 3, 1918, RDSRIACh, roll 19.

171 The Secretary of State to the Japanese Ambassador, September 6, 1917, [w:] PRFRUS 1917, s. 104.

172 Williams to the Secretary of State, September 6, 1917, RDSRIACh, roll 17.

173 Reinsch to the Secretary of State, August 3, 1917, [w:] PWW, t. 43, s. 362-363; Minister Reinsch to the Secretary of State, October 9, 1917, [w: ] PRFRUS 1917, s. 146-148. 174 The Secretary of State to Minister Reinsch, September 13, 1917, [w:] PRFRUS 1917, s. 140; McAdoo to Wilson, September 29, 1917, [w: ] PWW, t. 44, Princeton 1983, s. 280-284. 
jedynymi oprócz nich, którzy mają wolne środki. W przeciwnym razie Japonia nie miałaby żadnej przeciwwagi lub gdyby konsorcjum odmówiło dania pożyczki, przypadłaby ona w udziale tylko bankom japońskim ${ }^{175}$.

W Waszyngtonie wahano się między konsorcjum a pożyczką indywidualną ${ }^{176}$. Wyboru nie ułatwiał Reinsch, który raz skłaniał się ku jednej, raz ku drugiej opcji, a w ogóle zalecał ostrożność. Apelował, aby nie dawać Chinom pieniędzy na niesprecyzowane wydatki, ponieważ albo zostaną zdefraudowane, albo wykorzystane do osiągnięcia „wszystkiego, co nikczemne i sprzeczne $\mathrm{z}$ amerykańskimi ideałami”. Mocne słowa wynikały z oceny sytuacji wewnętrznej Chin. Reinsch obawiał się, że pożyczka wzmocni zaprzedanych Japonii ludzi z otoczenia Duana, tym samym przyczyniając się do ugruntowania jej wpływów. O ile samego premiera w myśl konwencji „dobry władca, źli doradcy” prezentował w pozytywnym świetle - jako szczerego, mądrego i mającego autorytet, o tyle o Cao i Liang Qichao miał jak najgorsze zdanie. Innym „nikczemnym" celem spożytkowania środków mogła być kampania wojskowa przeciwko Południu. Chociaż Reinsch miał krytyczny stosunek do rządu kantońskiego, to jednak uważał, że należało bronić parlamentaryzmu przed autokratyczną Północą i dążyć do kompromisu. Zalecał, aby dopilnować, że pieniądze zostaną wydane na pożyteczne cele, np. wysłanie wojsk do Europy i wsparcie banku centralnego. Konieczne było też otrzymanie od Pekinu gwarancji, że przywróci parlament i będzie szukał narodowej zgody oraz że nie zawrze żadnych porozumień godzących w swoją suwerenność, integralność terytorialną czy prawa Amerykanów, co miało stanowić zabezpieczenie przed Japonią ${ }^{177}$. Reinsch próbował zatem połączyć kredyty z innymi ważnymi dla USA sprawami - porządkiem, parlamentaryzmem, reformami, ograniczeniem japońskich wpływów i obroną polityki „otwartych drzwi”. W końcu jednak uznał, że najlepszym rozwiązaniem będzie powrót do konsorcjum ${ }^{178}$.

$\mathrm{Ku}$ temu skłaniał się też Lansing, ale Wilson nadal nie był przekonany. Opinie Lansinga i Reinscha, ciągłe nalegania różnych państw oraz udzielenie przez Japonię pod koniec września kolejnej pożyczki Chinom zapewne przyczyniły się do zmiany zdania przez prezydenta. 9 listopada Lansing poinformował Reinscha,

175 Lansing to Wilson, June 25, 1917, [w: ] PWW, t. 43, s. 7-8; PRFRUS 1917, s. 135-142, 144-145, 148-149.

176 The Secretary of State to the French Ambassador, October 16, 1917, [w:] PRFRUS 1917, s. 150; The Secretary of State to the British Ambassador, October 16, 1917, [w: ] ibidem.

177 PRFRUS 1917, s. 99-100, 104-113, 140-144. Cytat pochodzi z dokumentu z 24 września (s. 142-143).

178 Minister Reinsch to the Secretary of State, November 2, 1917, [w:] PRFRUS 1917, s. $152-153$. 
że USA ponownie staną się członkiem konsorcjum ${ }^{179}$. Zanim to nastąpiło, sfinalizowane zostały rozmowy amerykańsko-japońskie dotyczące Chin.

Przystąpienie Stanów Zjednoczonych do I wojny światowej skłoniło głównych członków ententy do wysłania specjalnych misji do Waszyngtonu, aby omówić warunki współpracy wojennej. Na taki krok zdecydowała się również Japonia, która chciała zarazem wykorzystać dogodną okazję do rozwiązania innych palących problemów w relacjach dwustronnych - przede wszystkim kwestii jej wpływów w Chinach i traktowania jej obywateli w USA ${ }^{180}$.

Stany Zjednoczone, które 12 maja same nieoficjalnie zaproponowały Tokio przysłanie specjalnej misji ${ }^{181}$, też chciały ułożyć stosunki bilateralne i usunąć zarzewia konfliktów, mogących doprowadzić do wycofania się Japonii z wojny, a nawet przejścia na stronę państw centralnych, czego nad Potomakiem cały czas się obawiano. Zaangażowanie w Europie wymagało zapewnienia spokoju i bezpieczeństwa na Dalekim Wschodzie i Pacyfiku, skąd trzeba było wycofać część amerykańskich jednostek. USA liczyły ponadto na wyczarterowanie japońskich statków, aby przewieźć żołnierzy przez Atlantyk. W odniesieniu do Chin zależało im na wypracowaniu modus vivendi z Japonią oraz nakłonieniu jej do potwierdzenia polityki „otwartych drzwi” i zrzeczenia się strefy wpływów ${ }^{182}$.

Japonia miała swoje cele i motywy. Z niepokojem patrzyła na rozbudowę amerykańskich sił zbrojnych, obawiając się, że zostaną przeciwko niej użyte. Doskwierał jej wprowadzony po przystąpieniu USA do wojny zakaz wywozu

179 Lansing to Wilson, June 25, 1917, [w: ] PWW, t. 43, s. 7-8; PRFRUS 1917, s. 134136, 139, 144-146, 148-153; B. Beers, Vain Endeavor ..., s. 142-144.

180 Fragment dotyczący porozumienia Lansing-Ishii pokrywa się w większości z treścią mojego artykułu Okoliczności zawarcia i próba oceny porozumienia Lansing-Ishii, [w: ] R.P. Żurawski vel Grajewski, D. Jeziorny, S.M. Nowinowski (red.), Politycy, dyplomaci $i$ żotnierze. Studia i szkice z dziejów stosunków międzynarodowych w XX i XXI wieku ofiarowane Profesorowi Andrzejowi Maciejowi Brzezińskiemu w 70. rocznicę urodzin, Łódź 2017, s. 53-66.

181 The Japanese Ambassador (Sato) to the Secretary of State, May 12, 1917, [w: ] PRFRUS 1917, Supplement 2: The World War, t. 1, s. 62-63; The Secretary of State to the Japanese Ambassador (Sato), May 15, 1917, [w: ibidem, s. 63.

182 Memorandum of Conference with Japanese Special Ambassador, Viscount Ishii, September 6, 1917, Robert Lansing Papers (dalej RLP), Department of Rare Books and Special Collections, Princeton University Library, Princeton University, Princeton, series 1: official papers, box 2, folder 4, s. 1-5, online: http://findingaids.princeton.edu/collections/MC083/c0015 (dostęp: 22.02.2018); Memorandum of interview with the Chinese Minister, November 12, 1917, ibidem, s. 68-70; R. Lansing, War Memoirs of Robert Lansing..., s. 287; R.W. Curry, Woodrow Wilson and Far Eastern Policy..., s. 171, 176-177; B. Beers, Vain Endeavor ..., s. 102-103; J. Polit, Odwrót znad Pacyfiku ..., s. 141-142. 
amerykańskiej stali, szczególnie potrzebnej do budowy statków. Jako największe zagrożenie swoich aspiracji Japonia odbierała jednak ostatnie działania amerykańskiej dyplomacji w Chinach (propozycję współpracy w Mandżurii, rzekome zakulisowe ingerencje Reinscha, naleganie, aby Pekin zerwał stosunki z Niemcami, notę z 4 czerwca). Chciała więc wykorzystać fakt, że Stany Zjednoczone musiały skoncentrować się na Europie, i uzyskać od nich potwierdzenie swojej pozycji w Państwie Środka oraz ustępstwa w sprawie traktowania jej obywateli. Zamierzała też poinformować Waszyngton, że alianci europejscy wstępnie zgodzili się, aby po wojnie przejęła byłe niemieckie wyspy na Pacyfiku znajdujące się na północ od równika. Wreszcie, wiedziała, że porozumienie z Amerykanami zwiększyłoby jej szanse na zatrzymanie poniemieckiej posiadłości w Shandongu, co mocarstwa europejskie również właśnie zaakceptowały, a co stało się bardziej problematyczne w momencie, gdy USA przystąpiły do wojny i jak się spodziewano odegrają znaczną rolę podczas przyszłej konferencji pokojowej ${ }^{183}$.

Preludium do właściwych rozmów miało miejsce w czerwcu i lipcu. Japonia, niezadowolona $\mathrm{z}$ amerykańskiej noty z 4 czerwca, próbowała wzmocnić swoją pozycję negocjacyjną i sprawdzić, jak daleko USA były gotowe ustąpić w sprawie Chin ${ }^{184} .15$ czerwca ambasador Satō przekazał Lansingowi prośbę swojego rządu o potwierdzenie noty z 13 marca 1915 roku, w której William Jennings Bryan rzekomo uznał, że "Japonia ma specjalne i bliskie stosunki polityczne i ekonomiczne z Chinami” ${ }^{185}$. Japończycy celowo dokonali jednak dwóch istotnych przeinaczeń. Nota z 1915 roku mówiła o „specjalnych stosunkach”, bez precyzowania, że chodzi o stosunki polityczne i ekonomiczne, ale za to ograniczała je do Shandongu, Mandżurii i Mongolii Wewnętrznej ${ }^{186}$. Jeszcze dalej, jeśli chodzi o określenie swojej pozycji, poszli Japończycy w memorandum będącym oficjalną odpowiedzią na propozycję z 4 czerwca. W przekazanym Lansingowi dokumencie

183 House to Wilson, May 11, 1917, [w: ] PWW, t. 42, s. 275; The Japanese Ambassador (Sato) to the Secretary of State, May 12, 1917, [w: ] PRFRUS 1917, Supplement 2: The World War, t. 1, s. 62-63; Motono to Ishii, June 13, 1917, [w: ] M. Kajima, The Diplomacy of Japan..., s. 302; The Chargé in Japan (Wheeler) to the Secretary of State, June 27, 1917, [w: ] PRFRUS 1917, Supplement 2: The World War, t. 1, s. 110-111; Motono to Ishii, July 24, 1917, [w: ] M. Kajima, The Diplomacy of Japan ..., s. 302-306; The Intimate Papers of Colonel House..., s. 22-23, 27-28; R. Lansing, War Memoirs of Robert Lansing..., s. 285-286; S. Pash, The Currents of War: A New History of American-Japanese Relations, 1899-1941, Lexington 2014, s. xiii, 35-37; N. Kawamura, Turbulence in the Pacific..., s. 78, 84-86.

184 Patrz przypis nr 145.

185 Memorandum read by the Japanese Ambassador to Lansing, June 15, 1917, [w: ] PWW, t. 43, s. 55-56.

186 B. Beers, Vain Endeavor ..., s. 106. 
znalazło się już bowiem sformułowanie o „nadrzędnych interesach”, a nie tylko o „specjalnych i bliskich stosunkach” ${ }^{187}$.

Lansing, który początkowo nie zorientował się w japońskich manewrach i przychylnie odniósł się do przedstawionej mu prośby i memorandum, czym dał Tokio złudne nadzieje, nie zamierzal jednak akceptować jednostronnych zmian $^{188}$. Za wystosowaniem stanowczego protestu był już tradycyjnie Reinsch, który przekonywał, że gdyby przyjąć japońską interpretację, oznaczałoby to, że Bryan „przyznal, że Chiny przestały być niepodległym państwem” i stały się „japońskim protektoratem”. Byłoby to równoznaczne ze zdradą Chin i przekreśleniem wszystkich amerykańskich wysiłków w tym państwie od ponad stu lat. Już przyznanie Japonii wyłączności w Mandżurii - czym Reinsch nawiązywał do styczniowego stanowiska Lansinga - było zdaniem posła wystarczającym dowodem przyjaźni ${ }^{189}$.

Tym razem Reinsch na pewno nie rozczarował się reakcją Departamentu Stanu. 6 lipca Lansing, z aprobatą Wilsona, zdecydowanie odrzucił japońskie zmiany i stwierdzil, że w najmniejszym stopniu nie zamierza odchodzić ani od litery, ani ducha noty swego poprzednika. Implicite ostrzegł nawet, że chociaż na razie honorował oświadczenie dotyczące Shandongu, Mandżurii i Mongolii, to opierając się na nocie z maja 1915 roku, mógł się z niego wycofać ${ }^{190}$. Miało to skłonić Japonię do powstrzymania się przed kolejnymi próbami reinterpretowania amerykańskiej noty. Tokio nie podjęło już sprawy i czekało na wynik specjalnej misji wysłanej do Stanów Zjednoczonych.

Japońska misja, na czele której stał wicehrabia Ishii Kikujirō, przybyła do Waszyngtonu w drugiej połowie sierpnia 1917 roku. 23 sierpnia Ishii, wielce chwalony przez amerykańskich dyplomatów ${ }^{191}$, został przyjęty przez Wilsona. Prezydent opowiedział się wówczas za zniesieniem stref wpływów w Chinach, co wynikało z jego troski o Państwo Środka, ale byłoby również korzystne dla USA ${ }^{192}$.

187 The Japanese Ambassador to the Secretary of State, handed on June 15, 1917, [w: ] PRFRUS 1917, s. 71-72.

${ }^{188}$ Chargé Wheeler to the Secretary of State, June 18, 1917, [w:] PRFRUS 1917, s. 259; The Chargé in Japan (Wheeler) to the Secretary of State, June 22, 1917, [w: ] PRFRUS, The Lansing Papers, 1914-1920, t. 2, Washington 1940, s. 430; N. Kawamura, Turbulence in the Pacific..., s. 82-84.

189 Minister Reinsch to the Secretary of State, June 25, 1917, [w:] PRFRUS 1917, s. 77-78.

190 Wilson to Lansing, July 3, 1917, [w: ] PWW, t. 43, s. 80; The Secretary of State to the Japanese Ambassador, July 6, 1917, [w: ] PRFRUS 1917, s. 260-262.

191 Sharp to Wilson, June 30, 1917, [w: ] PWW, t. 43, s. 57-58; R.W. Curry, Woodrow Wilson and Far Eastern Policy..., s. 176. Zob. też: J. Daniels, The Wilson Era: Years of War and After, 1917-1923, Chapel Hill 1946, s. 53-55.

192 M. Kajima, The Diplomacy of Japan ..., s. 307; M. Chi, China Diplomacy..., s. 171; R.S. Baker, Woodrow Wilson..., t. 7, s. 230. 
We wrześniu Ishii rozpoczął negocjacje z Lansingiem. W trakcie kolejnych konferencji zajmowano się prawie wyłącznie sprawą chińską. Poruszono ją już podczas pierwszego spotkania, gdy Ishii otwarcie zapytał Lansinga: „Czy ma Pan coś do zaproponowania w odniesieniu do Chin?”. Lansing odparł, że chciałby, aby Japonia odnowiła przyrzeczenie respektowania polityki „otwartych drzwi” i zrzekła się swojej strefy wpływów. Ishii był sceptyczny, uważał, że taka deklaracja, bez wspomnienia o specjalnych interesach Japonii, wywołałaby falę krytyki w jego ojczyźnie. Rząd, do którego zwolenników notabene Ishii nie należał, byłby atakowany przez opozycję za to, że nie uzyskał niczego w zamian. Lansing wyraził gotowość do uznania specjalnych interesów Japonii wynikających z bliskości geograficznej, bo uważał je za naturalne. Rozumial, że wzrastająca populacja i potrzeba rozwoju przemysłowego zmusiły Japonię do zajęcia Korei i zainteresowania się Mandżurią. Nie zgadzał się natomiast, aby interesom specjalnym nadać znaczenie nadrzędnych.

Tymczasem decydenci w Tokio stanowczo opowiedzieli się za zachowaniem status quo w Chinach. Gdy Ishii zakomunikował to Lansingowi, ten zrezygnował z dalszego naciskania na wyrzeczenie się strefy wpływów, a skoncentrował się na znalezieniu sformułowania akceptowalnego dla obu stron, które potwierdziłoby politykę „otwartych drzwi” i specjalne interesy Japonii.

26 września Lansing przedstawił projekt dokumentu, który został przychylnie przyjęty przez Japonię. Ponad miesiąc trwało następnie ustalanie ostatecznej wersji porozumienia. Japonia chciała zamienić sformułowanie „specjalne stosunki” na „specjalne interesy i wpływy”, ale Lansing nie zgodził się na słowo „wpływy", które miało jego zdaniem konotacje polityczne. Druga kontrowersja dotyczyła passusu, w którym oba państwa miały się zobligować, że nie wykorzystają sytuacji wojennej i nie będą zabiegać o przywileje w Chinach godzące w prawa pozostałych aliantów. Zgodnie $\mathrm{z}$ wolą Japonii fragment ten usunięto, ale zachowano go w niejawnym protokole, a tekst właściwy zmodyfikowano w taki sposób, aby przynajmniej częściowo oddać sens usuniętego fragmentu ${ }^{193}$.

Oficjalne podpisanie porozumienia nastąpiło 2 listopada. W identycznych notach wymienionych przez Lansinga i Ishiiego USA i Japonia zobowiązały się przestrzegać obu zasad polityki „otwartych drzwi” i oznajmiły, że sprzeciwiają się, aby jakiekolwiek państwo te zasady naruszało. Jednocześnie Stany Zjednoczone uznały, że „bliskość terytorialna stwarza specjalne stosunki między państwami” i dlatego „Japonia ma specjalne interesy w Chinach, szczególnie w tej części, z którą jej posiadłości graniczą" ${ }^{94}$.

193 Fragment na podstawie: RLP, series 1: official papers, box 2, folder 4, s. 1-49; M. Kajima, The Diplomacy of Japan ..., s. 307-313, 317-329; N. Kawamura, Turbulence in the Pacific..., s. 87-98.

194 Lansing to Ishii, November 2, 1917, RLP, series 1: official papers, box 2, folder 4, s. 51-52; Ishii to Lansing, November 2, 1917, ibidem, s. 52-53. Polskie tłumaczenie porozumienia znajduje się w załączniku 3. 
Rozdziat V. Polityka USA wobec Chin od śmierci Yuan Shikaia...

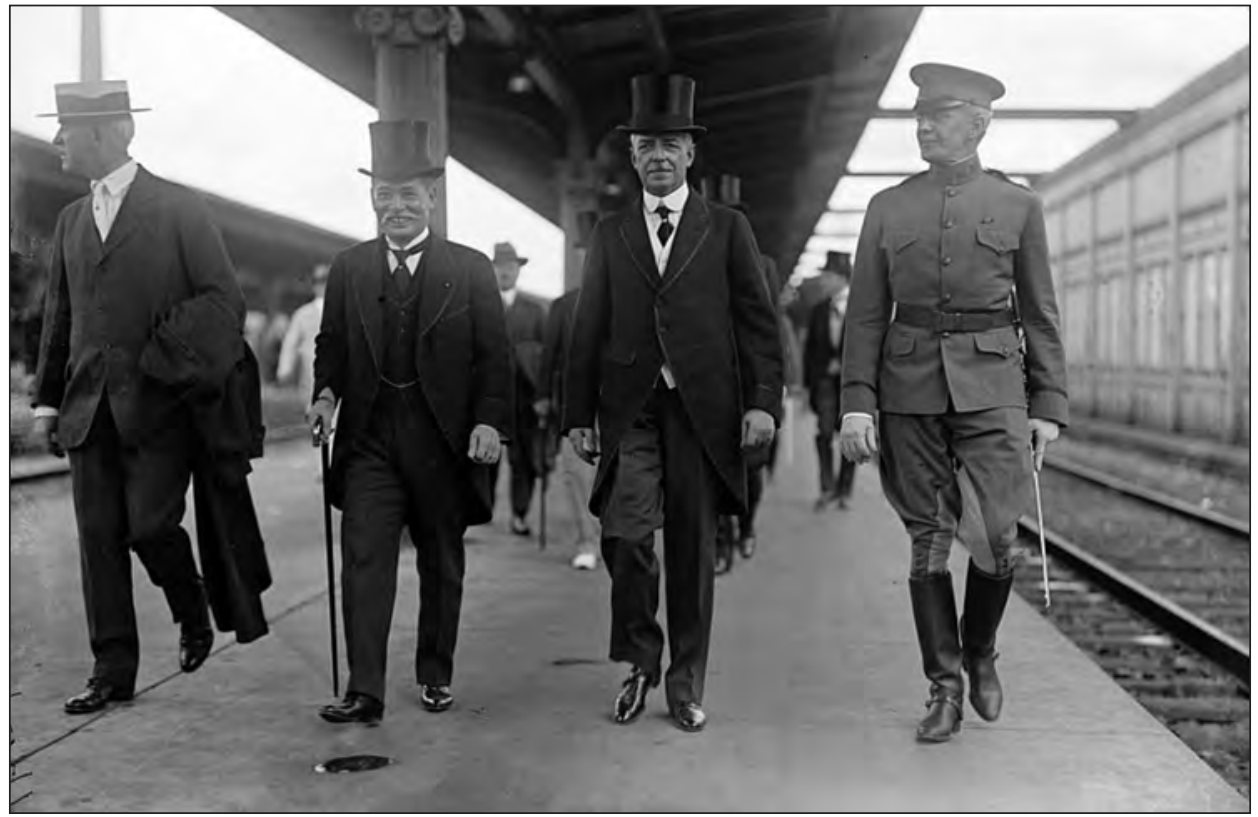

36. Ishii Kikujirō i Robert Lansing

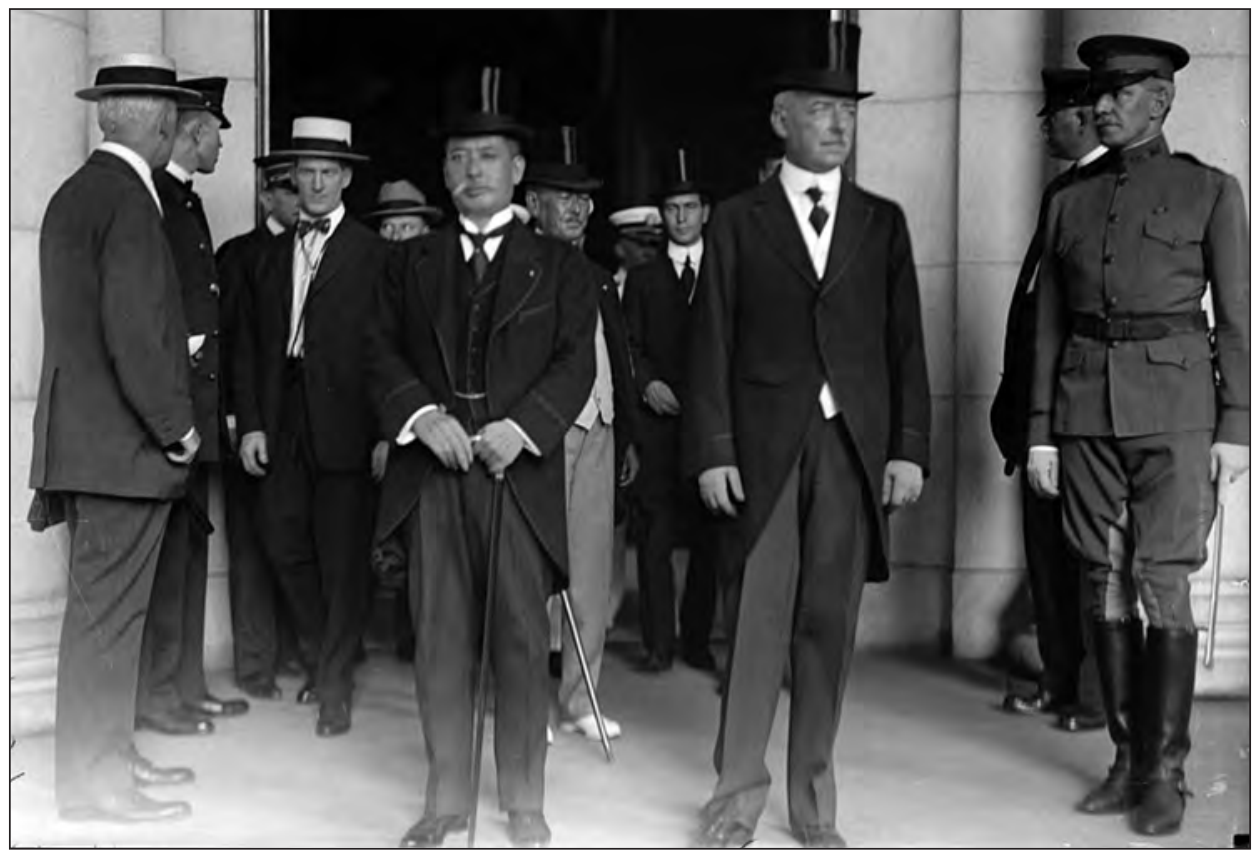

37. Ishii Kikujirō i Robert Lansing 
Głównym autorem porozumienia po stronie amerykańskiej był Lansing. To on prowadził całe negocjacje i przedstawił projekt noty, która odzwierciedlała jego koncepcje. Już wcześniej opowiadał się za uznaniem pozycji Japonii, zwłaszcza na terenie Mandżurii, w zamian za uzyskanie pewnych korzyści. W 1915 roku miało to być rozwiązanie sprawy imigrantów, teraz - ponowne zadeklarowanie wierności polityce „otwartych drzwi”, chroniącej Chiny i amerykańskie interesy. Początkowo Lansing próbował także, zgodnie z oczekiwaniami Wilsona, nakłonić Japonię do zrzeczenia się strefy wpływów, co stanowiło część szerszych jego starań mających na celu zniesienie całego systemu stref wplywów w Chinach. W tym samym bowiem czasie, o czym była już mowa, zaproponował on, aby Wielka Brytania i Francja właściwie zrezygnowały ze swoich stref. Negatywna odpowiedź z Tokio - podobnie zresztą jak i z Londynu - skłoniła go do zaprzestania dalszych działań w tym kierunku i szukania z Japonią kompromisu na innych warunkach.

Do ułożenia stosunków z Japonią na zasadzie quid pro quo udało się Lansingowi przekonać House’a, a ten zaczął przekonywać Wilsona ${ }^{195} .18$ września House pisał do prezydenta:

Nie możemy spełnić oczekiwań Japonii co do [naszych zakazów dotyczących posiadania - J.P.] ziemi i imigracji i o ile nie pójdziemy na ustępstwa $w$ odniesieniu do jej strefy wpływów na Wschodzie, problemy wcześniej czy później na pewno się pojawią. Japonia jest wykluczona ze wszystkich nierozwiniętych [sic!] miejsc na Ziemi i jeśli jej wplywy na Wschodzie nie zostaną uznane za do pewnego stopnia ważniejsze niż mocarstw zachodnich, dojdzie do rozrachunku.

House uważał, że można było „sformułować politykę, która pozostawi drzwi otwarte, odnowi Chiny i usatysfakcjonuje Japonię". Wilson musiał tylko zdecydować, czy popiera takie rozwiązanie ${ }^{196}$. Wiele wskazuje na to, że odpowiedział twierdząco. Co prawda wcześniej prezentował on raczej nieustępliwą postawę wobec Japonii, ale już w styczniu 1917 roku zaakceptował stanowisko Lansinga, że Japonia miała specjalne interesy w Mandżurii. Podczas pertraktacji z Ishiim prezydent był cały czas $\mathrm{w}$ pełni informowany o ich przebiegu i za każdym razem wyrażał zgodę ${ }^{197}$. Po zawarciu porozumienia Wilson, odpierając zarzut o sprzeniewierzenie się interesom Chin i USA, z przekonaniem napisał do Lansinga: „Nie tylko nie nastąpiła zmiana [amerykańskiej - J.P.] polityki, ale

${ }^{195}$ Beers twierdzi, że Lansing specjalnie chciał wykorzystać House’a, aby dotrzeć do Wilsona, bo stosunki między nim samym a prezydentem były napięte. B. Beers, Vain Endeavor ..., s. 100-101, 108-109.

196 House to Wilson, September 18, 1917, [w:] The Intimate Papers of Colonel House..., s. 24-25.

${ }^{197}$ R.S. Baker, Woodrow Wilson ..., t. 7, s. 262-263. 
Chiny odniosły wyraźną korzyść" ${ }^{198}$. Pokazuje to, że wbrew opiniom niektórych historyków Wilson nie był wcale przeciwny kompromisowi z Japonią ${ }^{199}$, a jego stanowisko wyrażone $\mathrm{w}$ rozmowie $\mathrm{z}$ Ishiim na początku rokowań należy raczej traktować jako życzenie i próbę uzyskania dodatkowej korzyści. Warto również pamiętać, że sposób prowadzenia polityki zagranicznej podczas urzędowania Wilsona, kiedy prezydent sam często wcielał się w rolę sekretarza stanu, sprawiał, iż mało prawdopodobna stawała się sytuacja, w której jakieś ważne porozumienie międzynarodowe zostałoby zawarte bez przynajmniej ogólnej jego akceptacji. Ponieważ Wilson, Lansing i House poparli ugodowy kurs wobec Japonii, odmienne głosy wyrażane przez różnych pracowników Departamentu Stanu, takich jak Williams, radca Frank Polk, trzeci asystent sekretarza stanu Breckinridge Long czy Reinsch, którego Lansing przezornie nie powiadomił o przebiegu rozmów, okazały się bez znaczenia ${ }^{200}$.

Ocena porozumienia Lansing-Ishii wypada dla Stanów Zjednoczonych raczej negatywnie. Pomijając fakt, że noty były wewnętrznie sprzeczne - bo potwierdzały politykę „otwartych drzwi” i specjalne interesy, ale tego pewnie nie dało się uniknąć, gdyż chciano połączyć dwie w istocie przeciwstawne koncepcje - popełniono dwa poważne błędy. Na wymowę not rzutowało słowo „szczególnie”, którego - jak słusznie pisze Jakub Polit - „trudno było nie traktować [...] jako przyznanie, że wobec tego mniej szczególne, ale jednak nadal specjalne interesy Japonia posiada na terenie CAŁYCH Chin"201. Był to błąd trudny do wytłumaczenia, gdyż nie wynikał ani z przebiegłości Japonii, ani z pośpiechu, ani z chęci wprowadzenia specjalnie dwuznacznego sformułowania akurat w tym miejscu. Słowo „szczególnie” znajdowało się już w zaproponowanej przez Amerykanów na początku negocjacji wstępnej wersji porozumienia. Nie zostali oni więc „finezyjnie wymanewrowani”

198 Wilson to Lansing, November 7, 1917, [w: ] PWW, t. 44, s. 530.

199 Zob. B. Beers, Vain Endeavor ..., s. 111-114; N. Kawamura, Turbulence in the Pacific..., s. 92; D.D. Lazo, An Enduring Encounter: E.T. Williams, China, and the United States, nieopublikowany doktorat, University of Illinois at Urbana-Champaign, Urbana 1977, s. 294-296. Zmienną opinię miał na ten temat Ishii. W trakcie negocjacji uważał, że to Wilson był bardziej nieprzejednany niż Lansing. Po latach napisał natomiast, że prezydent był zdecydowanie bardziej przychylny japońskim postulatom i tylko dzięki jego interwencji negocjacje nie zostały zerwane. Ishii twierdzil, że z Lansingiem trudno mu się negocjowało w sprawach chińskich, gdyż sekretarz stanu był uparty i - ze względu na swego teścia Johna Fostera - prochińsko nastawiony. Podobną opinię o Lansingu wyraził brytyjski ambasador w Waszyngtonie Cecil Spring-Rice, z którym Ishii spotkał się na początku września. M. Kajima, The Diplomacy of Japan ..., s. 308-309, 318, 337, 340; N. Kawamura, Turbulence in the Pacific ..., s. 98.

200 M. Chi, China Diplomacy ..., s. 107-108; D.D. Lazo, An Enduring Encounter ..., s. 293-296, 310.

${ }^{201}$ J. Polit, Odwrót znad Pacyfiku..., s. 139-140. 
przez Japończyków, jak sugeruje J. Polit, sami się raczej mało finezyjnie pomylili, co dziwi tym bardziej, że Lansing miał przykładać dużą wagę do języka noty ${ }^{202}$. Błąd sprawił, że nie trzeba było mieć złej woli, aby porozumienie odczytać diametralnie różnie, niż chciały tego Stany Zjednoczone.

Druga zasadnicza wada polegała na niesprecyzowaniu, że „specjalne interesy" nie oznaczają wpływów politycznych. Chociaż Lansing kilkakrotnie podkreślił to zastrzeżenie $\mathrm{w}$ trakcie rozmów, to nie znalazło się ono w tekście porozumienia. Odmiennie całą sytuację przedstawiał Ishii, który twierdził, że podczas kluczowego spotkania 22 września dobitnie wytłumaczył swemu rozmówcy, iż specjalne interesy utożsamiał głównie ze sprawami politycznymi. Ponadto podczas jednego z kolejnych spotkań Lansing miał mu powiedzieć, że sformułowanie „specjalne interesy” daje dużą swobodę interpretacyjną ${ }^{203}$. Nie sposób jednoznacznie ocenić wiarygodności relacji obu dyplomatów. Jeśli jednak Ishii napisał prawdę, to Lansing nie powinien się dziwić, że Japończycy w ten właśnie sposób odczytali porozumienie.

Samo zresztą uznanie specjalnej pozycji ze względu na bliskość terytorialną miało jeszcze jedną negatywną konsekwencję, a mianowicie, co przyznał Lansing w rozmowie z domagającym się wyjaśnień Koo, była to zasada uniwersalna, mająca także zastosowanie wobec Rosji, Francji i Wielkiej Brytanii ${ }^{204}$. Tym samym nawet jeśli przyjąć tłumaczenie Lansinga, że specjalne interesy ograniczały się do interesów gospodarczych, to stanowiłoby ono potwierdzenie większości stref wpływów innych mocarstw, gdyż strefa wpływów Francji znajdowała się na północ od Indochin, Rosji wzdłuż jej granicy, a Wielkiej Brytanii także na terenach przylegających do jej posiadłości w Indiach i Birmie (nie wpisywała się w ten schemat tylko główna brytyjska strefa wpływów w dolinie Jangcy). Gdyby zaś przyjąć interpretację Japonii, uwzględniającą wpływy polityczne, oznaczałoby to umocnienie owych stref. Oba warianty były dla Waszyngtonu niekorzystne, a drugi nawet skrajnie niekorzystny. Ponadto równoczesne uznanie specjalnych interesów i polityki „otwartych drzwi” osłabiało tę politykę, ponieważ pokazywało, że można było od niej uczynić istotne wyjątki.

Rozważając ujemne strony porozumienia Lansing-Ishii, należy również wspomnieć, że stanowiło ono kolejny cios dla amerykańskiego prestiżu

202 J. Polit, Chiny..., s. 81; D.D. Lazo, An Enduring Encounter ..., s. 295.

203 M. Kajima, The Diplomacy of Japan ..., s. 310-311; N. Kawamura, Turbulence in the Pacific..., s. 93-95; M. Chi, China Diplomacy ..., s. 111, 172. Madeleine Chi thumaczy wypowiedź Lansinga tym, że kilka dni wcześniej otrzymał on informację o rzekomym sekretnym porozumieniu japońsko-niemieckim i wolał dać Japonii jakieś korzyści w Chinach, niż dopuścić do zmiany przez nią frontu.

${ }^{204}$ Memorandum of interview with the Chinese Minister, November 12, 1917, RLP, series 1: official papers, box 2, folder 4, s. 68-70. 
w Chinach. Chińczycy odczytali je jako przyznanie Japonii swobody działania i wycofanie się Stanów Zjednoczonych z Chin. Taką interpretację wzmacniała oczywiście japońska dyplomacja, próbująca wmówić Chinom, że muszą odtąd konsultować z nią wszystkie posunięcia w polityce zagranicznej ${ }^{205}$. Także japońscy dziennikarze podgrzewali atmosferę - np. jedna $\mathrm{z}$ agencji prasowych podała całkowicie nieprawdziwą informację, jakoby rząd waszyngtoński oficjalnie ogłosił, że Japonia może „styranizować” Chiny ${ }^{206}$.

Istniały również obawy, że układ Lansing-Ishii negatywnie wpłynie na amerykańskie interesy gospodarcze w Chinach. Bardzo krytycznie ocenili go członkowie American Manufacturers Export Association i National Foreign Trade Council. Układ odbierany przez część osób jako wyraz malejącego zainteresowania rządu Chinami i oddania pola Japonii mógł zniechęcić - i tak już pełnych wątpliwości - biznesmenów do prowadzenia interesów w Chinach ${ }^{207}$. Zaniepokojona całą sytuacją była też druga strona. Amerykański konsul w Xiamenie Clarence Gauss informował, że kilku Chińczyków zwróciło się do niego z pytaniem, czy układ Lansing-Ishii zabraniał udziału amerykańskiego kapitału w przedsięwzięciach kopalnianych w Fujianie ${ }^{208}$.

$\mathrm{Na}$ inną niepożądaną konsekwencję porozumienia wskazywał Thomas Millard, znany amerykański dziennikarz i wydawca w Chinach. Jego zdaniem porozumienie mogło ugruntować na arenie międzynarodowej doktrynę bliskości terytorialnej, sprzeczną z popieraną przez administrację Wilsona koncepcją samookreślenia narodów. Doktryna bliskości terytorialnej, która dawała silniejszym państwom prawo do ingerowania w sprawy słabszych sąsiadów, była tym bardziej niebezpieczna, że mogła być stosowana w innych miejscach na świecie ${ }^{209}$.

205 Hanson to Reinsch, December 3, 1917, RDSRPRBChOS, roll 26; The Minister in China (Reinsch) to the Secretary of State, April 30, 1918, [w:] PRFRUS 1918, Washington 1930, s. 89-93; Baker to the Secretary of State, October 31, 1918, RDSRPRBChOS, roll 26.

206 Reinsch to the Secretary of State, November 25, 1917, RDSRPRBChOS, roll 26; Lansing to the American Legation at Peking, November 27, 1917, ibidem. Cytat pochodzi $\mathrm{z}$ pierwszego dokumentu.

207 Oudin to Redfield, November 22, 1917, RDSRPRBChOS, roll 26; Memorandum by Millard: Conditions Affecting American Commercial and Financial Interests in China in Respect to the Lansing-Ishii Agreement, 1917 [brak daty dziennej, dokument pochodzi $\mathrm{z}$ listopada lub grudnia], ibidem.

208 Gauss to Reinsch, December 11, 1917, RDSRPRBChOS, roll 26. Fujian leżał naprzeciwko należącego do Japonii Tajwanu, można było zatem uznać, że prowincja ta „graniczyła” z japońskimi posiadłościami.

209 Memorandum by Millard: The Doctrine of "Territorial Propinquity" as Advanced in the Lansing-Ishii Agreement about China and its Possible Application, 1917 [brak daty dziennej, dokument pochodzi z listopada lub grudnia], RDSRPRBChOS, roll 26. 
Lista korzyści wynikających z porozumienia była dla USA przynajmniej częściowo bardziej potencjalna niż realna. Mogły one żywić nadzieję, że nastąpi koniec napięć amerykańsko-japońskich, a Japonia, usatysfakcjonowana uznaniem jej pozycji, nie podejmie dalszych prób zdominowania Chin. Waszyngton spotkał jednak srogi zawód, zwłaszcza w tej drugiej kwestii. Wymiernym efektem porozumienia była zgoda Tokio na wyczarterowanie statków oraz możliwość przemieszczenia części amerykańskich okrętów z Pacyfiku na Atlantyk. Porozumienie dawało też większą pewność, że Japonia nie zmieni frontu, ale taka ewentualność była raczej mało prawdopodobna, skoro Japonia właśnie bardziej angażowała się w walkę z Rzeszą ${ }^{210}$.

W momencie podpisywania porozumienia jego dwaj główni architekci, Ishii i Lansing, byli ukontentowani. Później okazało się, że dla pierwszego stało się ono źródłem chwały, dla drugiego krytyki. W Japonii porozumienie odebrano bardzo pozytywnie, zwłaszcza że według przyjętej tam interpretacji specjalne interesy obejmowały wpływy polityczne. Tak miał też powiedzieć Hayashi, gdy 4 listopada, wcześniej niż ustalili to sygnatariusze, przekazał tekst układu rządowi pekińskiemu ${ }^{211}$. Lansing próbował zdementować tę interpretację, z przeciętnym jednak skutkiem. Żalił się później, że Japonia z premedytacją przeinaczyła sens porozumienia, w który wiele osób, łącznie z władzami chińskimi, uwierzyło. Tłumaczy1, że musial „rozbroić” notę z marca 1915 roku, a uznając japońskie zainteresowanie Chinami, uznał tylko „prawo natury”, gdyż podobne zainteresowanie wynikające z bliskości geograficznej wykazywała np. Francja w Belgii, USA w Kanadzie czy Włochy w Austrii (wyjaśnienia pochodzą z 1921 roku) ${ }^{212}$.

Żale Lansinga brzmiały o tyle nieprzekonująco, że jeszcze przed podpisaniem porozumienia otrzymał on informacje na temat prawdziwych intencji Japonii. W październiku rosyjski ambasador w Waszyngtonie Borys Bachmietiew pokazał mu telegramy świadczące o tym, że w Tokio zupełnie inaczej postrzegano

210 J. Polit, Odwrót znad Pacyfiku..., s. 141-142; idem, Japońska polityka zagraniczna, 1895-1945, Kraków 2015, s. 128; T.D. Saxon, Anglo-Japanese Naval Cooperation..., s. $11-12$.

211 Minister Reinsch to the Secretary of State, November 5, 1917, [w:] PRFRUS 1917, s. 266; Morris to the Secretary of State, November 16, 1917, RDSRPRBChOS, roll 26; R. Lansing, War Memoirs of Robert Lansing..., s. 302; W. Phillips, Ventures in Diplomacy, Boston 1953, s. 86-87; M. Kajima, The Diplomacy of Japan ..., s. 333-339; N. Kawamura, Turbulence in the Pacific..., s. 100-102.

212 Memorandum on Lansing-Ishii Agreement, October 3, 1921, LP, box 64; R. Lansing, War Memoirs of Robert Lansing..., s. 302-303, 305; W. Phillips, Ventures in Diplomacy..., s. 86-87. Ishii skomentował, że „był całkowicie oniemiały”, gdy usłyszał tłumaczenie Lansinga, jakoby specjalne interesy nie oznaczały wpływów politycznych, tylko ekonomiczne. Uważał, że wówczas porozumienie nie miałoby żadnego znaczenia. M. Kajima, The Diplomacy of Japan ..., s. 333-334. 
negocjowane właśnie porozumienie. Podczas rozmów z rosyjskim ambasadorem Wasilijem Krupienskim szef Gaimushō wicehrabia Motono Ichirō jednoznacznie przedstawil punkt widzenia swojego kraju. Japonia uważała, że układ ze Stanami Zjednoczonymi potwierdzi jej specjalną pozycję na terenie całych Chin, a nie tylko jakiejś konkretnej prowincji. Co więcej, specjalna pozycja będzie jak najbardziej oznaczała wpływy polityczne, m.in. prawo nadzorowania kontaktów zagranicznych Chin. Japonia nie przykładała za to dużej wagi do ponownego uznania zasad „otwartych drzwi”, gdyż nie nakładało to nowego ograniczenia na jej politykę. Lansing zbagatelizował te doniesienia. Ostrzeżenia rosyjskich dyplomatów, że istniała wyraźna rozbieżność między amerykańską a japońską interpretacją porozumienia, co niechybnie doprowadzi do zatargu, zbył stwierdzeniem, że $\mathrm{w}$ razie nieporozumień wyśle do Tokio notę wyjaśniającą̨ ${ }^{213}$. Przewidywania rosyjskich dyplomatów spełnily się i Lansing bardzo szybko musiał tłumaczyć swoje stanowisko. Jego wysiłki nie zdały się na wiele, nie udało mu się nawet do końca przekonać opinii publicznej we własnym kraju ${ }^{214}$.

Jedną z oburzonych osób był Reinsch, który został jeszcze dodatkowo ośmieszony, bo nic nie wiedział o porozumieniu, dopóki nie pokazał mu go Hayashi. Reinsch z nieskrywaną złością poprosił o wyjaśnienie „akcji, która tak głęboko wplywa na interesy [Chin - J.P.] i która na pierwszy rzut oka wydaje się odwróceniem amerykańskiej polityki w Chinach"215. Lansing zapewnił, że żadna zmiana stanowiska nie nastąpiła, lecz nie przekonał ani Reinscha, ani Chińczyków ${ }^{216}$.

Chiny od początku były zaniepokojone misją Ishiiego. Koo wielokrotnie dopytywał się w Departamencie Stanu o cel i przebieg negocjacji ${ }^{217}$. Chiny wysłały też do Waszyngtonu brytyjskiego pisarza i dziennikarza Bertrama Lenoxa Simpsona (bardziej znanego pod pseudonimem literackim Putnam Weale), który miał przedstawiać ich racje. Obawiały się, że Japonia będzie dążyć do uzyskania od Stanów Zjednoczonych zgody na żądania z grupy piątej z 21 żądań, wycofanie

${ }^{213}$ Kroupenski to the Russian Minister of Foreign Affairs, October 9, 1917, RDSRPRBChOS, roll 25; Document written by the Third Assistant Secretary, October 25, 1917, ibidem; Memorandum written by the Division of Far Eastern Affairs, July 9, 1921, ibidem.

${ }^{214}$ R. Lansing, War Memoirs of Robert Lansing..., s. 305; W. Phillips, Ventures in Diplomacy ..., s. 86-87.

${ }^{215}$ Minister Reinsch to the Secretary of State, November 4, 1917, [w:] PRFRUS 1917, s. 265-266; Minister Reinsch to the Secretary of State, November 5, 1917, [w:] ibidem, s. 266. Cytat zaczerpnięto z pierwszego dokumentu.

216 The Secretary of State to Minister Reinsch, November 5, 1917, [w:] PRFRUS 1917, s. 268; The Secretary of State to the Minister in China (Reinsch), January 29, 1918, [w:] PRFRUS 1918, s. 214.

${ }_{217}$ M. Chi, China Diplomacy ..., s. 113; R.W. Curry, Woodrow Wilson and Far Eastern Policy..., s. 175; D.D. Lazo, An Enduring Encounter ..., s. 310. 
amerykańskich wojsk z Dalekiego Wschodu oraz stałe przejęcie poniemieckich wysp na Pacyfiku ${ }^{218}$.

Gdy w Chinach dowiedziano się o porozumieniu, rząd pekiński oficjalnie zaprotestował przeciwko byciu związanym układami zawartymi przez inne państwa ${ }^{219}$. Swój protest wystosowały też władze południowe ${ }^{220}$. Lansing wyjaśnił Koo, że zdecydował się nie informować Chin o toczących się negocjacjach, ponieważ gdyby to zrobil, a Chiny nie zaprotestowały, mogłoby to oznaczać, że uznają porozumienie za wiążące. Sekretarz stanu przyznał też szczerze, że ze względu na udział w wojnie USA potrzebowały pieniędzy na własne wydatki i inwestowanie ich w Chinach wydawało się mniej atrakcyjne, zwłaszcza jeśli trzeba by rywalizować z Japonią. Sytuacja wymagała porozumienia się z nią, bo inaczej Amerykanie w ogóle wycofaliby się z Chin. Lansing stwierdził z przekonaniem, że układ służył interesom Chin, które mogły mieć analogicznie specjalne interesy u swoich sąsiadów ${ }^{221}$. Zwłaszcza ta ostatnia sugestia musiała w ówczesnej sytuacji geopolitycznej brzmieć tyleż niedorzecznie, co arogancko.

Po zawarciu porozumienia Lansing-Ishii Waszyngton zdecydował się ostatecznie poprzeć powrót amerykańskich banków do konsorcjum. Ułożenie stosunków z Japonią pozwalało mieć nadzieję, że nie będzie ona już prowadzić obstrukcyjnej polityki wobec amerykańskich przedsięwzięć w Chinach, ale zarazem głoszona przez nią interpretacja porozumienia pokazywała, że nie zamierza ona rezygnować z podporządkowania Chin. Lansing i sekretarz handlu William Redfield chcieli też, aby pożyczki stanowiły jasny sygnał, że wbrew krytycznym opiniom Amerykanie nie stracili zainteresowania Chinami ani nie porzucili ich na pastwę Japonii ${ }^{22}$. Nad Potomakiem uznano, że łatwiej można było wesprzeć Chiny i przeciwstawić się japońskim planom, będąc członkiem konsorcjum, niż pozostając poza nim i rywalizując samemu z Japonią lub połączonymi siłami japońsko-brytyjsko-francuskimi. Williams $\mathrm{w}$ memorandum na ten temat pisat, że byłoby „o wiele lepiej być jednym z członków czterostronnego konsorcjum, nawet jeśli musielibyśmy «ponieść» Anglię i Francję, ponieważ możemy [...]

218 Long to the Secretary of State, August 12, 1917, WWP, series 5a, reel 383.

219 The Chinese Minister to the Secretary of State, November 12, 1917, [w:] PRFRUS 1917, s. 270. Podobno wysłanie protestu doradził Pekinowi Reinsch. R.W. Curry, Woodrow Wilson and Far Eastern Policy..., s. 182.

${ }^{220}$ Members of the Legitimate Parliament to Wilson, November 14, 1917, RDSRPRBChOS, roll 25.

${ }^{221}$ Document written by the Division of Foreign Intelligence, November 5, 1917, RDS$R P R B C h O S$, roll 25; Memorandum of interview with the Chinese Minister, November 12, 1917, RLP, series 1: official papers, box 2, folder 4, s. 68-70; Lansing to the American Embassy at Tokyo, November 22, 1917, RDSRPRBChOS, roll 26.

${ }_{222}$ Redfield to Lansing, January 8, 1918, RDSRPRBChOS, roll 26; Lansing to Redfield, January 11, 1918, ibidem. 
liczyć na poparcie tych dwóch państw, gdyby Japonia wykazywała chęć nieuczciwego wykorzystania Chin"223.

Dla Stanów Zjednoczonych ponowne przystąpienie do konsorcjum było zasadne. W zmienionym konsorcjum, zrzeszającym cztery mocarstwa, oczywiście bez Niemiec i ogarniętej rewolucyjnym chaosem Rosji, miałyby one bardzo ważny głos, skoro byłyby jednym z dwóch państw mogących wyłożyć potrzebne pieniądze, nie wspominając o ich ogólnie silnej pozycji wynikającej z militarnego i finansowego wkładu w wojnę. Może nie mogłyby dyktować warunków, ale jako primus inter pares wyznaczałyby kierunek działań. Powrót do konsorcjum pozwoliłby częściowo zneutralizować i kontrolować poczynania Japonii, zarówno indywidualne, jak i w jego ramach. W konsorcjum, zdominowanym dotychczas przez Japonię, to USA mogłyby uzyskać przewagę dzięki poparciu Wielkiej Brytanii i Francji, które były niechętne japońskiej polityce w Chinach i dla których Waszyngton od momentu przystąpienia do wojny stał się cenniejszym sojusznikiem niźli Tokio ${ }^{224}$. Innymi słowy, konsorcjum z instrumentu japońskiego mogło się stać instrumentem amerykańskim.

Podjąwszy decyzję o przystąpieniu, w Waszyngtonie zaczęto rozważać szczegółowe kwestie - np. czy reaktywować dawną amerykańską grupę, czy powołać nową, a jeśli tak, to według jakiego klucza. Zdecydowano się na drugi wariant, a misję sformowania grupy powierzono Continental and Commercial Trust and Savings Bank. Williams sugerował, aby zaprosić do niej banki z różnych części kraju, dzięki czemu Wall Street nie miałoby w niej przewagi ${ }^{225}$.

Zanim doszło do zorganizowania grupy, pojawiły się dwa problemy. 9 listopada Chiny zwróciły się do konsorcjum o jak najszybsze wypłacenie 2 milionów funtów szterlingów zaliczki z planowanej na 20 milionów drugiej pożyczki reorganizacyjnej na rzecz reformy walutowej. Zaliczki gotowa była udzielić Japonia, ale obawiano się, że w zamian zażąda przywilejów ograniczających suwerenność finansową Chin ${ }^{226}$. Reinsch proponował, aby poinformować Londyn i Paryż o chęci przystąpienia do konsorcjum, a wtedy państwa europejskie mogłyby wnioskować o odroczenie negocjacji na temat zaliczki, do momentu gdy USA byłyby gotowe wziąć w nich udział ${ }^{227}$. Departament Stanu spróbował trochę innego rozwiązania - starał się nakłonić Wielką Brytanię i Francję, aby

${ }^{223}$ Memorandum by Williams, November 21, 1917, [w:] PWW, t. 45, Princeton 1984, s. 98-100. Z Williamsem zgadzał się Lansing. Lansing to Wilson, November 22, 1917, [w: ibidem, s. 96-97.

${ }_{224}$ Memorandum by Williams, November 21, 1917, [w: ] PWW, t. 45, s. 98-100.

${ }^{225}$ Ibidem.

226 Minister Reinsch to the Secretary of State, November 10, 1917, [w: ] PRFRUS 1917, s. 153; Minister Reinsch to the Secretary of State, November 20, 1917, [w:] ibidem, s. 155.

${ }^{227}$ Minister Reinsch to the Secretary of State, November 20, 1917, [w: ] PRFRUS 1917, s. 155. 
uczestniczyły w zaliczce, deklarując, że gdy amerykańska grupa zostanie zorganizowana, rozważy możliwość sfinansowania brytyjskiej i francuskiej części reszty pożyczki ${ }^{228}$.

Tymczasem ewentualny udział Stanów Zjednoczonych w pożyczce dla Chin poważnie się oddalił. Sprzeciwił się jej sekretarz skarbu McAdoo, gdyż w tym czasie priorytetem była dla niego „druga pożyczka wolności” (Second Liberty Loan $)^{229}$. Sprawa powrotu do konsorcjum została na kilka miesięcy odroczona. Gdy ponownie podjęto ją w czerwcu 1918 roku, sytuacja była już inna.

Japonia poczyniła do tego czasu kolejne kroki w kierunku podporządkowania Chin. W marcu i maju 1918 roku oba państwa zawarly układy o współpracy wojskowej przeciwko Niemcom i Austro-Węgrom, które miały im zagrażać w wyniku upadku pogrążonej w wojnie domowej Rosji. Stanowiło to dogodny pretekst do rozciągnięcia przez Japonię kurateli nad sferą wojskowości Chin ${ }^{230}$. Jednocześnie kontynuowała ona rozszerzanie wpływów na terytorium sąsiada za pomocą kolejnych pożyczek nishiharowskich i dostaw broni, za które otrzymywała koncesje gospodarcze (np. prawo do skonstruowania sześciu linii kolejowych w różnych prowincjach $)^{231}$.

Japońska polityka w Chinach była tematem wielu alarmistycznych doniesień amerykańskich przedstawicieli. Ich zdaniem Japonia mniej lub bardziej jawnie wspierała wszystkie frakcje rywalizujące w Państwie Środka, pogłębiając panujące tam zamieszanie, interweniowała, aby nie zdymisjonowano najbardziej zaprzedanych jej ministrów w rządzie pekińskim, oraz prowokowała różne konflikty. Nie przestrzegała polityki „otwartych drzwi” i próbowała storpedować amerykańskie inicjatywy inwestycyjne. Jej obywatele, zachowujący się na ogół agresywnie i impertynencko, nastawiali Chińczyków wrogo wobec innych cudzoziemców. Dzięki takim działaniom Japonia, w opinii amerykańskiego ambasadora w Tokio Rolanda Morrisa, chciała osiągnąć trzy cele: a) zabezpieczyć swoją pozycję

228 The Secretary of State to Ambassador Sharp, November 22, 1917, [w:] PRFRUS 1917, s. 156-157. Paryż wyraził zgodę na amerykańską propozycję, Londyn się zastanawial. Ambassador Sharp to the Secretary of State, December 21, 1917, [w: ] ibidem, s. 158; Ambassador Page to the Secretary of State, December 21, 1917, [w: ] ibidem, s. 159.

229 The Secretary of State to President Wilson, June 20, 1918, [w:] PRFRUS 1918, s. 169-171; R.W. Curry, Woodrow Wilson and Far Eastern Policy ..., s. 190; B. Beers, Vain Endeavor ..., s. 144.

230 Doc. no. 1918/4: Japan and China. Exchanges of Notes in regard to Military Cooperation, March 25, 1918, [w:] Treaties and Agreements..., s. 1407-1410; Doc. no. 1918/4: Note 1: Text of the Military Agreement, May 16, 1918, [w:] ibidem, s. 14111412; Doc. no. 1918/4: Note 1: Text of the Naval Agreement, May 19, 1918, [w:] ibidem, s. $1412-1413$.

231 V.K. Wellington Koo's Foreign Policy. Some Selected Documents, zebrał W. King, Shanghai 1931, s. 106-109, 111-114. 
polityczną w południowej Mandżurii, wschodniej Mongolii Wewnętrznej, Shandongu i Fujianie; b) mieć istotny wpływ na rząd centralny, niezależnie od tego, kto ostatecznie go utworzy; c) uzyskać prymat gospodarczy w Chinach ${ }^{232}$.

Od końca 1917 roku Amerykanie obserwujący z bliska japońskie zakusy coraz częściej apelowali do swojego rządu, aby ocalił Chiny przed zniewoleniem. Twierdzili, że gdyby ziścił się czarny scenariusz, reperkusje byłyby poważne. Oprócz stosunkowo łatwych do przewidzenia, wskazywali na mniej oczywiste. Podkreślali, że istniał wyraźny rozdźwięk między amerykańskim zaangażowaniem w walkę o wolność, demokrację i prawo słabszych narodów do samookreślenia w Europie a jednoczesnym przyzwalaniem na triumf przeciwnych wartości na Dalekim Wschodzie. W efekcie ofiara obecnie ponoszona mogłaby się okazać daremna, w niedalekiej przyszłości zaś trzeba byłoby stoczyć kolejną wojnę w obronie tych samych ideałów. Japonia, którą wielu Amerykanów w Chinach postrzegało jako azjatycki odpowiednik militarystycznych Niemiec, stanowiła już teraz zagrożenie dla światowego pokoju. Gdyby jeszcze udało jej się podporządkować Chiny, zyskując dzięki temu dostęp do nieograniczonych zasobów naturalnych i ludzkich, wówczas starcie między nią (czy szerzej rasą żółtą) a Stanami Zjednoczonymi (światem Zachodu, rasą białą) byłoby nieuniknione. Oprócz tego Chińczycy pod jej panowaniem przeistoczyliby się z pokojowo $\mathrm{w}$ agresywnie nastawionych. Mogłoby się zatem okazać, że obecna wojna, która - jak zapowiedział Wilson, cytując słynne zdanie H.G. Wellsa - miała „zakończyć wojnę”, stanowila jedynie wstęp do kolejnej wojny ${ }^{233}$.

${ }^{232} \mathrm{~W}$ RDSRPRBChOS i RDSRIACh znajduje się kilkadziesiąt dokumentów na ten temat, tutaj przywołuję tylko wybrane. Reinsch to the Secretary of State, October 26, 1917, RDSRPRBChOS, roll 25; Arnold to the Chief of the Bureau of Foreign and Domestic Commerce, October 27, 1917, ibidem; Lansing to the American Legation at Peking, November 20, 1917, RDSRIACh, roll 17; Reinsch to the Secretary of State, November 22, 1917, ibidem; Reinsch to the Secretary of State, December 8, 1917, RDSRPRBChOS, roll 26; Reinsch to the Secretary of State, February 11, 1918, RDSRIACh, roll 18; Morris to the Secretary of State, March 7, 1918, RDSRPRBChOS, roll 26; Baker to the Secretary of State, April 8, 1918, ibidem; Sherfesee to Heiser, April 27, 1918, ibidem; Reinsch to the Secretary of State, May 31, 1918, ibidem; Reinsch to the Secretary of State, November 4, 1918, ibidem; Reinsch to the Secretary of State, November 7, 1918, ibidem.

233 Arnold to the Chief of the Bureau of Foreign and Domestic Commerce, October 27, 1917, RDSRPRBChOS, roll 25; Scott to Brown, December 30, 1917, RDSRPRBChOS, roll 26; Reinsch to the Secretary of State, February 12, 1918, WWP, series 2, reel 94; Sherfesee to Heiser, April 27, 1918, RDSRPRBChOS, roll 26; Baker to the Secretary of State, August 6, 1918, ibidem; Reinsch to the Secretary of State, October 19, 1918, RDSRIACh, roll 19; Reinsch to the Secretary of State, November 7, 1918, RDSRPRBChOS, roll 26; Memorandum by Peck: Suggestions in regard to the Future of Japan on the Mainland of Asia, November 21, 1918, ibidem. 
Argumenty dotyczące zagrożenia wolności, demokracji i pokoju - obok działań samej Japonii w Chinach i na Syberii oraz jej zachowania po zawarciu układu Lansing-Ishii - przyczyniły się do tego, że w Waszyngtonie narastały wobec Tokio podejrzliwość, niechęć, a nawet wrogość. Oznaką tego była wypowiedź Wilsona, który w momencie podejmowania decyzji o zerwaniu stosunków dyplomatycznych z Niemcami stwierdził nieoczekiwanie, że utrzymanie na świecie przewagi rasy białej nad rasą żółtą dyktowałoby raczej pozostanie z dala od konfliktu. Prezydent najprawdopodobniej postrzegał różnice rasowe nie tylko w kategoriach odmiennego koloru skóry, ale odmienności cywilizacyjnej. Japonia została przez niego wskazana jako potencjalnie największe zagrożenie, zwłaszcza gdyby sprzymierzyła się z Rosją i zdominowała Chiny. Jej ekspansja nie oznaczałaby jedynie zawłaszczenia jakiegoś terytorium czy uzyskania wpływów, lecz rozprzestrzenienie się obcych wzorców, będących przeciwieństwem amerykańskich wartości ${ }^{234}$.

Stosunek Waszyngtonu do Japonii zmienił się na krótko po podpisaniu układu Lansing-Ishii. W listopadzie 1917 roku Departament Stanu postanowił nie zwracać się o wyjaśnienia na temat planowanej przez nią sprzedaży broni Chinom, właśnie dlatego, że dopiero co doszedł z nią do porozumienia ${ }^{235}$. W późniejszym czasie podejście Stanów Zjednoczonych do Japonii ponownie stało się bardziej nieprzychylne i nieufne. W czerwcu 1918 roku Wilson z rezerwą odniósł się do francuskich nalegań na udział Japonii w planowanej alianckiej interwencji przeciwko bolszewikom na Syberii ${ }^{236}$. W rozmowie z Henrim Bergsonem, wybitnym francuskim filozofem, który został wysłany za Atlantyk ze specjalną misją, prezydent jasno stwierdził, że nie zgodzi się, aby w nagrodę za zaangażowanie przyznać Japonii nabytki terytorialne, czego ta ostatnia z pewnością będzie się domagać. Na sugestię Bergsona, że być może zadowoli się ona „korzyściami handlowymi" w Chinach, Wilson odparl, że takie rozwiązanie byłoby akceptowalne, pod warunkiem że Chiny także wyraziłyby na nie zgodę $e^{237}$. Widać zatem, że USA nie zamierzały porzucić Chin i przyznać Japonii swobody działania. Miały jednak

234 D. Houston, Eight Years with Wilson's Cabinet, 1913 to 1920, t. 1, Garden City 1926, s. 229; R. Lansing, War Memoirs of Robert Lansing ..., s. 212; N. Kawamura, Turbulence in the Pacific..., s. 62.

235 The Division of Far Eastern Affairs to Long, November 7, 1917, RDSRPRBChOS, roll 25.

${ }^{236}$ Więcej na temat interwencji na Syberii patrz np.: T. Dmochowski, Interwencja mocarstw na Syberii i Dalekim Wschodzie (1918-1922), Toruń 2002; W. Materski, Bolszewicy i samuraje. Walka dyplomatyczna i zbrojna o rosyjski Daleki Wschód (1917-1925), Warszawa 1990; J. Polit, Japonia, Anglosasi i interwencja na Syberii, 1917-1925, „Arcana” 1999, nr 26, s. 168-181.

237 Bergson to Pichon, undated, written on June 26, 1918, [w: ] PWW, t. 48, Princeton 1985, s. 441-444. 
ograniczone możliwości przeciwstawienia się wzrostowi japońskich wpływów, póki wojna trwała.

Tuż po jej zakończeniu, w listopadzie 1918 roku, Wilson powiedział Koo, że darzy Chiny sympatią oraz uważnie przygląda się sytuacji na Dalekim Wschodzie, ponieważ w jego ocenie właśnie tam najpewniej dojdzie do kolejnej wojny ${ }^{238}$. Chociaż prezydent nie wskazał, kto miałby ją wywołać, to Japonia wydawała się jednym z głównych kandydatów na agresora. O krok dalej szli amerykańscy wojskowi, którzy zaczęli uważać Japonię nie tylko za potencjalnego naruszyciela pokoju, ale i za najbardziej prawdopodobnego wroga w przyszłości. Po drugiej stronie Pacyfiku myślano podobnie - japońska marynarka wojenna uznawała USA za największe zagrożenie. Do zakończenia I wojny światowej oba państwa pozostały sojusznikami, lecz ich stosunki poważnie się pogorszyły. Najważniejszym powodem narastających animozji była polityka prowadzona przez nie w Chinach, co pokazuje, że zarówno dla Waszyngtonu, jak i Tokio Chiny miały zasadnicze znaczenie ${ }^{239}$.

W Chinach tymczasem do końca wojny stale wzrastały japońskie wpływy. Wynikało to także z faktu, że silną pozycję w Pekinie odzyskał projapońsko nastawiony Duan, który co prawda w listopadzie 1917 roku w wyniku nacisków Fenga ustąpił z fotela premiera, ale w marcu następnego roku powrócił nań, dystansując prezydenta. Duan kontynuował kampanię przeciwko Południu, wykorzystując m.in. japońskie fundusze i armię utworzoną na poczet udziału Chin w wojnie światowej. Walki nie przyniosły jednak rozstrzygnięcia, wobec czego militaryści na Północy, którzy sami coraz wyraźniej rozpadali się na zwalczające się obozy, postanowili przeprowadzić wybory. Zwyciężyli w nich zorganizowani w klubie Anfu zwolennicy Duana, którzy sukces zawdzięczali głównie fałszerstwom, łapówkom i zastraszaniu. Gdy w sierpniu 1918 roku zebrał się nowy parlament, Feng zrezygnował ze stanowiska prezydenta (jego kadencja i tak kończyła się w październiku) i przestał brać udział w życiu politycznym. Na nową głowę państwa wybrano należącego do klubu Anfu Xu Shichanga. Przywództwo frakcji Zhili przejęli z czasem po Fengu Cao Kun i Wu Peifu. Zmiany zaszły także we władzach kantońskich. Jeszcze w maju Sun został zmuszony do ustąpienia ze stanowiska i niedługo potem wyjechał do Szanghaju. Chiny stawały się krajem coraz bardziej podzielonym, ze słabnącą, w niektórych miejscach wręcz iluzoryczną władzą centralną, krajem szarpanym paroksyzmami niszczącej walki wewnętrznej, która miała się tylko nasilać 240 .

238 Memorandum by Wellington Koo, November 26, 1918, [w: ] PWW, t. 57, Princeton 1987, s. 632-634.

239 S. Pash, The Currents of War ..., s. 43, 46-47; T.D. Saxon, Anglo-Japanese Naval Cooperation..., s. 11-12; N. Kawamura, Turbulence in the Pacific ..., s. 1-3.

240 Fragment na podstawie: PRFRUS 1917 s. 107-113; PRFRUS 1918, s. 83-137;

W. Rodziński, Historia Chin ..., s. 637-639; J. Polit, Chiny ..., s. 80-84, 86-87. 
Degeneracji życia politycznego i atrofii aparatu państwa przyglądali się Amerykanie z nieskrywanym smutkiem. 12 lutego Reinsch do listu adresowanego do Wilsona załączył „depresyjny raport na temat [... sytuacji w Chinach" ${ }^{241}$. Wiele jego doniesień do końca wojny miało pesymistyczny wydźwięk. W podobnym tonie utrzymane były wypowiedzi innych amerykańskich przedstawicieli, na przykład Charles Denby jr., specjalny reprezentant Departamentu Stanu, pisał, że nie było właściwie różnicy między Północą a Południem - obie strony walczyły tylko o wplywy i korzyści, a na scenie politycznej nie pojawiła się żadna osoba, której „kariera nie byłaby splamiona przekupstwem, wymuszeniem i przestępstwem”242.

Walki w Chinach okazały się na tyle zacięte i brutalne, że zaczęły zagrażać cudzoziemcom. W styczniu 1918 roku wojska Południa ostrzelały na Jangcy amerykańską kanonierkę „Monocacy”, w wyniku czego jeden marynarz zginął, a dwóch zostało rannych. Ten i podobne ataki skłonily USA, Wielką Brytanię i Japonię do wysłania w rejon walk dodatkowych okrętów. Reinsch proponował, aby mocarstwa wspólnie patrolowały niektóre odcinki rzeki, ale wobec argumentu, że stanowiłoby to naruszenie chińskiej suwerenności, do czego nie należało jeszcze bardziej zachęcać Japonii, poprzestano na konwojowaniu amerykańskich statków handlowych ${ }^{243}$. Pod koniec maja Reinsch razem z Hayashim i brytyjskim posłem sir Johnem Jordanem złożyli protest przeciwko „barbarzyńskiemu zachowaniu” chińskich wojsk wobec ludności cywilnej w Hunanie, które zagrażało także życiu i mieniu cudzoziemców ${ }^{244}$. Tradycyjnie już okresowi walk wewnętrznych towarzyszyła plaga pospolitego bandytyzmu. Pojawiły się też nastroje antycudzoziemskie, w ostatnim czasie przytłumione (pomijając antyjapońskie). Zagraniczni misjonarze przebywający w głębi kraju alarmowali, że pod tym względem sytuacja była najgorsza od czasu powstania „bokserów”245.

241 Reinsch to Wilson, February 12, 1918, WWP, series 2, reel 94.

242 Denby to the Secretary of State, June 24, 1918, RDSRIACh, roll 19.

243 Reinsch to the Secretary of State, January 18, 1918, RDSRIACh, roll 18; Roberts to Commander-in-Chief of the U.S. Asiatic Fleet, January 18, 1918, ibidem; Williams to Polk, January 21, 1918, ibidem; Reinsch to the Secretary of State, January 25, 1918, ibidem; Reinsch to the Secretary of State, January 28, 1918, ibidem; Lansing to the American Legation at Peking, February 1, 1918, ibidem; J. Polit, Odwrót znad Pacyfiku..., s. 159. Amerykański attaché morski w Pekinie przypisywał Japończykom część odpowiedzialności za ataki na cudzoziemskie statki w Chinach. Uważal, że specjalnie zachęcali oni Chińczyków do takich działań, machiawelicznie licząc na doprowadzenie do konfliktu Chin z innym państwem, co z kolei sprawi, iż Japonia zostanie poproszona o interwencję, aby przywrócić porządek. Williams to the Solicitor, March 13, 1918, RDSRIACh, roll 18.

${ }^{244}$ Joint note from the American, British, and Japanese Ministers in China to the Chinese Minister for Foreign Affairs (Lu Cheng-hsiang), May 29, 1918, [w:] PRFRUS 1918, s. 97-98.

${ }^{245}$ Josselyn to the Secretary of State, April 27, 1918, RDSRIACh, roll 19. 
Reinsch myślał o różnych działaniach na rzecz zjednoczenia Chin, wzmocnienia ich i zabezpieczenia przed ingerencją Japonii. Popierał wysłanie chińskiej ekspedycji wojskowej do Europy, co nie tylko przysłużyłoby się sprawie alianckiej, wzmocniłoby Chiny na arenie międzynarodowej i mogłoby doprowadzić do zgody w kraju, ale również pozwoliłoby Duanowi, który dowodziłby ekspedycją, uniezależnić się od szkodliwych doradców i podnieść swój prestiż. Reinsch proponował ponadto, aby udzielić Chinom pożyczek, pomóc im w przygotowaniach wojennych i rozwijaniu kraju, wystosować apel o zaprzestanie walk, wyrazić niezadowolenie z poczynań Japonii, a nawet cofnąć uznania dla rządu pekińskiego $^{246}$. Spośród tych sugestii administracja Wilsona, która $\mathrm{z}$ racji udziału w wojnie w Europie z mniejszym zainteresowaniem śledziła pogmatwaną sytuację w Chinach $^{247}$, najbardziej zaangażowała się w kwestię pożyczek i doprowadzenie do pokoju między Północą a Południem.

W czerwcu 1918 roku Lansing ponownie zwrócił się do Wilsona o zgodę na zorganizowanie amerykańskiej grupy i udzielenie Chinom pożyczek, czemu nie sprzeciwiał się już Departament Skarbu. Oprócz uprzednio wspomnianych motywów Lansing wskazywał na ostatnią japońską ofensywę finansową w Chinach, jaskrawo kontrastującą z amerykańską biernością, oraz na gotowość Wielkiej Brytanii i Francji do zrzeczenia się roszczeń do części stref wpływów, w których Amerykanie pomogliby im dokończyć inwestycje kolejowe. Kolejnym czynnikiem był aktualny wówczas problem rzekomego niemieckiego zagrożenia na Dalekim Wschodzie po wycofaniu się Rosji z wojny oraz planowanej interwencji na Syberii. Lansing uważał, że skoro Pekin przystąpił do wojny z inicjatywy Stanów Zjednoczonych, to miał prawo oczekiwać od nich pomocy, w momencie gdy niebezpieczeństwo pojawiło się na horyzoncie ${ }^{248}$.

246 Reinsch to the Secretary of State, December 12, 1917, [w: ] PWW, t. 45, s. 308; Reinsch to the Secretary of State, February 12, 1918, WWP, series 2, reel 94; Reinsch to Lansing, February 21, 1918, [w:] PWW, t. 46, s. 499; Williams to Lansing, February 21, 1918, [w: ] ibidem, s. 500-501; Memorandum by Reinsch, August 14, 1918, [w:] PWW, t. 49, Princeton 1985, s. 311; Reinsch to Wilson, August 31, 1918, [w:] ibidem, s. 406-408; PRFRUS 1917, s. 111; PRFRUS 1918, s. 83-84, 112-114, 116.

247 Świadczy o tym chociażby pytanie, które prawdopodobnie sekretarz Wilsona napisał na liście od Fenga - „Czy to chiński prezydent?”. Feng to Wilson, received July 12, 1918, WWP, series 4: case files, 226, reel 242; R.W. Curry, Woodrow Wilson and Far Eastern Policy..., s. 355. Zob. też: Reinsch to the Secretary of State, February 11, 1918, RDSRIACh, roll 18.

${ }^{248}$ Lansing to Wilson, June 20, 1918, [w:] PWW, t. 48, s. 371-374; The Acting Secretary of State to the Ambassador in Great Britain (Page), July 30, 1918, [w: ] PRFRUS 1918, s. 181-182; The Acting Secretary of State to the Chargé in China (MacMurray), July 30, 1918, [w: ] ibidem, s. 182-183. 
Wilson, który ciągle nie był przekonany do konsorcjum, wyraził zgodę, ale zastrzegł, że należy zrobić wszystko, by chronić Chiny przed próbami narzucenia wygórowanych warunków, jakie miały miejsce za czasów poprzedniego konsorcjum, gdyż obecne okoliczności nawet bardziej temu sprzyjały. Bankierzy mieli też informować rząd o wszystkich posunięciach i uzgodnieniach, zwłaszcza dotyczących składu grupy, aby nie zamknęli do niej dostępu innym bankom ${ }^{249}$.

Mając prezydenckie pozwolenie, Departament Stanu przystąpił do tworzenia amerykańskiej grupy. Proces ten przebiegł sprawnie, w ciągu dwóch tygodni ustalono zasady współpracy między rządem a bankami (m.in. nowa amerykańska grupa miała się składać z banków z różnych części kraju, jej skład musiał uzyskać akceptację Departamentu Stanu, podobnie jak warunki umów z Chinami), wyznaczono zakres odpowiedzialności obu stron oraz skład grupy, której trzon miało stanowić osiem banków, w tym wszystkie z dawnej amerykańskiej grupy i Continental and Commercial Trust and Savings Bank ${ }^{250}$.

Trudności pojawily się, gdy w lipcu 1918 roku USA wystąpiły do Francji, Wielkiej Brytanii i Japonii z propozycją utworzenia nowego konsorcjum czterech mocarstw. Wszystkie trzy państwa miały wątpliwości i zastrzeżenia. Londyn i Tokio nie chciały m.in. przystać na amerykański warunek, aby nowe konsorcjum otrzymało wyłączność zarówno na pożyczki administracyjne, jak i przemysłowe. Paryż sugerował, aby w nowej organizacji zarezerwować miejsce dla Rosji ${ }^{251}$. Te i późniejsze obiekcje mocarstw sprawiły, że konsorcjum udało się powołać dopiero po zakończeniu Wielkiej Wojny ${ }^{252}$.

Mniej komplikacji napotkała druga inicjatywa - doprowadzenie do porozumienia między zwaśnionymi stronami w Chinach. O interwencję dyplomatyczną Stanów Zjednoczonych zabiegali sami Chińczycy, i to zarówno bliscy współpracownicy Xu, jak i np. Sun, który w osobistym liście prosił Wilsona, aby „ocalił demokrację w Chinach, tak jak uczynił to w Europie”253. 10 października

249 Wilson to Lansing, June 21, 1918, [w: ] PWW, t. 48, s. 382; Wilson to Lansing, July 4, 1918, [w:] ibidem, s. 517.

250 PRFRUS 1918, s. 172-188, 193-196.

251 PRFRUS 1918, s. 175-177, 179-181, 188-193. Pod koniec 1917 roku Wielka Brytania, Francja, Rosja i Japonia zgodziły się, że po wojnie do konsorcjum dołączy Belgia. The British Secretary of State for Foreign Affairs (Balfour) to the American Ambassador (Page), August 14, 1918, [w: ibidem, s. 189-190.

252 Więcej na ten temat patrz: R.W. Curry, Woodrow Wilson and Far Eastern Policy..., s. 198-204; T. Matsuda, Woodrow Wilson's Dollar Diplomacy in the Far East: The New Chinese Consortium, 1917-1921, nieopublikowany doktorat, University of Wisconsin, Madison 1979.

${ }^{253}$ The Chargé in China (MacMurray) to the Secretary of State, September 17, 1918, [w: PRFRUS 1918, s. 110; Memorandum by Long, September 17, 1918, RDSRIACh, roll 19; Wu to Morrison, September 29, 1918, ibidem; MacMurray to the Secretary of State, October 4, 1918, ibidem; MacMurray to the Secretary of State, October 8, 1918, ibidem; Sun 
- w momencie obejmowania urzędu przez $\mathrm{Xu}$, a jednocześnie w kolejną rocznicę wybuchu rewolucji Xinhai - Wilson zaapelował do Chińczyków, aby zakończyli walki wewnętrzne i zjednoczyli się. Dopóki tego nie zrobią, nie będą mogli uczestniczyć w alianckich staraniach zaprowadzenia ładu światowego, co można było odczytać jako zawoalowaną groźbę nieotrzymania zaproszenia na przyszłą konferencję pokojową ${ }^{254}$. List Wilsona wywarł duże wrażenie w Chinach i przyśpieszył działania na rzecz porozumienia. Stało się tak między innymi dlatego, że Chińczycy ponownie zaczęli darzyć Stany Zjednoczone estymą (nadszarpniętą przez układ Lansing-Ishii), doceniając ich wkład w zwycięstwo aliantów. Chińczycy liczyli, że Wilson, który wyrósł na nieformalnego przywódcę koalicji, będzie odgrywał najważniejszą rolę podczas konferencji pokojowej i będzie mógł wydatnie im pomóc (nadzieje te amerykański prezydent niemiłosiernie zawiódl) ${ }^{255}$.

Wbrew chińskim obawom, że Japonia może nie dopuścić do zawarcia pokoju, okazało się, że nie tylko nie była ona temu przeciwna, ale sama chciała w tym pomóc. Pod koniec października wystąpiła z propozycją, aby czołowe mocarstwa alianckie wezwały władze w Pekinie i Kantonie do rekoncyliacji. USA postanowiły przyłączyć się, chociaż Wilson wyraził zaniepokojenie, że inicjatywa wesprze Południe przeciwko rządowi pekińskiemu, będącemu jedyną legalną i uznawaną na arenie międzynarodowej władzą w Państwie Środka. Nie chciała tego także Japonia, która zaznaczyła, że wspólna nota mocarstw nie będzie oznaczać uznania rządu w Kantonie. Sprawa interwencji alianckiej w Chinach, głównie ze względu na zakończenie wojny w Europie, przeciągnęła się do 2 grudnia, kiedy to przedstawiciele Wielkiej Brytanii, Francji, Włoch, Japonii i Stanów Zjednoczonych zgodnie z ustaleniami wręczyli memorandum obu chińskim rządom. W odpowiedzi na nie prezydent Xu zwołał konferencję pokojową, która dawała nadzieje na trwałe uspokojenie sytuacji w Chinach ${ }^{256}$.

to Wilson, November 19, 1918, ibidem; Reinsch to the Secretary of State, November 23, 1918, RDSRIACh, roll 20. List Suna został napisany już po apelu Wilsona, ale dobrze pokazuje nastroje panujące wśród przywódców Południa.

${ }^{254}$ President Wilson to President Hsü Shih-ch'ang, October 10, 1918, [w:] PRFRUS 1918, s. 111.

${ }^{255}$ Reinsch to the Secretary of State, November 8, 1918, RDSRIACh, roll 19; Hanson to Reinsch, November 20, 1918, ibidem; Memorandum by Wellington Koo, November 26, 1918, [w: ] PWW, t. 57, s. 632-634.

256 Sokobin to Reinsch, October 22, 1918, RDSRIACh, roll 19; The Japanese Embassy to the Department of State, undated, handed on October 25, 1918, [w:] PRFRUS 1918, s. 114-115; Lansing to Wilson, October 26, 1918, [w:] PWW, t. 51, Princeton 1985, s. 457; A Translation of a Telegram from Viscount Kikujiro Ishii to the Foreign Office, November 1, 1918, [w: ] ibidem, s. 548-551; The Department of State to the Japanese Embassy, November 16, 1918, [w:] PRFRUS 1918, s. 120; The Secretary of State to the Minister in China (Reinsch), November 16, 1918, [w:] ibidem; The Minister in China (Reinsch) to the Secretary of State, December 2, 1918, [w:] ibidem, s. 134; Pontius to Reinsch, December 3, 1918, RDSRIACh, roll 20; M. Chi, China Diplomacy ..., s. 141-142. 
Kres zmagań wojennych w Europie, który nadszedł w listopadzie 1918 roku, stanowił też symboliczny koniec kolejnego etapu chińskiej polityki Stanów Zjednoczonych. W opisywanym tutaj okresie od śmierci Yuana do podpisania rozejmu w Compiègne wyraźnie przyśpieszył proces dezintegracji Chin. Od połowy 1916 roku rozpoczął się trwający kilkanaście lat wewnętrzny konflikt między różnymi stronnictwami politycznymi i frakcjami militarystów. Rządzący w Pekinie, którzy zresztą często się zmieniali, nie mieli kontroli nad całym krajem. W Kantonie powstał konkurencyjny rząd, a na części obszarów faktyczną władzę sprawowali lokalni watażkowie. Ponieważ brak stabilizacji zagrażał amerykańskiej polityce, Waszyngton kontynuował zabiegi o zaprowadzenie elementarnego ładu w Chinach i ich wzmocnienie. $Z$ tego powodu popierał rząd pekiński, a zwłaszcza Duana (chociaż robił to z mniejszym przekonaniem niż w przypadku Yuana), wierząc, że miał on największą szansę na uporządkowanie sytuacji w kraju. Waszyngton podejmował też różne inicjatywy na rzecz załagodzenia konfliktu w Chinach.

Stany Zjednoczone negatywnie oceniały postępujący rozpad Chin również dlatego, że sprzyjał on zyskiwaniu politycznych, ekonomicznych i wojskowych wplywów przez Japonię. Po śmierci niechętnego jej Yuana w Państwie Środka doszli do głosu różni bardziej przychylni jej przywódcy, a sama ich wielość dawała możliwość wygrywania jednych przeciwko drugim i podsycania niepokojów. Pozycja Japonii w Chinach rosła także ze względu na coraz większe ograniczenia i słabość mocarstw europejskich. Przedłużający się konflikt światowy zmuszał je do przyznania Tokio jeśli nie carte blanche, to przynajmniej decydującego głosu w wielu sprawach dotyczących Chin. Ponadto Rosja, pogrążona od 1917 roku w rewolucyjnym chaosie, praktycznie straciła możliwość oddziaływania na wydarzenia dalekowschodnie. W tych okolicznościach większa odpowiedzialność za los Chin spoczywała na Stanach Zjednoczonych. Nad Potomakiem $\mathrm{z}$ niepokojem przyglądano się japońskim dążeniom do zdominowania słabszego sąsiada, upatrując w nich zagrożenia nie tylko dla amerykańskiego i chińskiego interesu narodowego, ale i ogólniej dla przyszłego pokoju na świecie. Relacje między USA a Japonią, walczącymi formalnie po tej samej stronie, stawały się coraz bardziej napięte, a głównym powodem tego była odmienna polityka prowadzona przez oba mocarstwa w Chinach. Próba znalezienia konsensusu zakończyła się zawarciem mało korzystnego dla Waszyngtonu porozumienia Lansing-Ishii, które nie uzdrowiło stosunków bilateralnych, a w dłuższej perspektywie właściwie je zaogniło.

Jednym ze sposobów na zahamowanie japońskich zapędów i zarazem rozszerzenie własnych wpływów biznesowych w Chinach była intensyfikacja amerykańskiego programu inwestycyjnego. $Z$ różnych powodów nie przyniósł on jednak zbyt satysfakcjonujących rezultatów. Niemniej Waszyngton pokazał, że ponownie chciał aktywniej wspierać swoich obywateli w walce o rynek chiński. 
Wykorzystując swoją pozycję po przystąpieniu do wojny, próbował też nakłonić pozostałych aliantów do zrzeczenia się stref wpływów w Chinach, na co jednak nie wyrazili oni zgody.

Polityczne i ekonomiczne zaangażowanie w Chinach oraz eskalacja napięć z Japonią na tym tle pokazują, że w latach 1916-1918 Stany Zjednoczone - mimo narastającego zagrożenia wojną, a następnie w niej udziału - nie straciły zainteresowania Chinami i nadal traktowały je jako ważny punkt na swej politycznej mapie świata. Możliwości działania i skuteczność amerykańskiej dyplomacji były jednak mniejsze niż wcześniej. Omawiany okres charakteryzował się bowiem znacznym sprzężeniem różnych kwestii odnoszących się do Chin. Przystąpienie Chin do wojny, ich sytuacja wewnętrzna, amerykański program inwestycyjny, próby zdominowania sąsiada przez Japonię oraz porozumienie Lansing-Ishii - wszystkie te sprawy wzajemnie się przenikały i oddziaływały na siebie. Owa plątanina nie sprzyjała prowadzeniu skutecznej polityki przez Stany Zjednoczone. Kolejna przeszkoda wynikała z ich przystąpienia do wojny w Europie, co automatycznie spychało wydarzenia w Azji na dalszy plan. Także rosnąca determinacja Japonii, aby zdominować Chiny, i coraz większe przyzwolenie na jej działania ze strony mocarstw europejskich stawiały Waszyngton w mniej korzystnym położeniu. Ale oprócz czynników zewnętrznych, słabość amerykańskiej polityki w Chinach tkwiła w jej zmienności, a chwilami wewnętrznej sprzeczności. Częste wolty lub modyfikacje stanowiska utrudniały osiągnięcie doraźnych i długofalowych celów.

Wydawało się, że pomyślniejszy okres nastanie po wojnie, gdy zmieniła się międzynarodowa pozycja mocarstw mających wpływy w Chinach. Z „samobójczej” dla Europy wojny, jak określa ją Andrzej Chwalba ${ }^{257}$, nawet zwycięskie państwa europejskie wyszły osłabione, dzięki czemu amerykańska wizja zniesienia stref wpływów w Chinach stała się bardziej realna. Zarazem wojenne powiązania przestały determinować postawę Wielkiej Brytanii i Francji wobec Dalekiego Wschodu, co pozwalało Waszyngtonowi mieć nadzieję na uzyskanie ich poparcia przeciwko Japonii. Ponadto wzrost potęgi i międzynarodowego prestiżu USA, połączony z możliwością przynajmniej częściowego wywierania nacisków na pozostałych członków koalicji ze względu na ich zobowiązania finansowe, dawał amerykańskiej dyplomacji istotny głos w kształtowaniu ładu światowego, w tym także w odniesieniu do Chin. Z wykorzystaniem nadarzających się szans było już jednak różnie.

${ }^{257}$ A. Chwalba, Samobójstwo Europy. Wielka Wojna 1914-1918, Kraków 2014. 



\section{ZAKOŃCZENIE}

Omawiany w pracy okres, trwający od wybuchu rewolucji Xinhai do zakończenia Wielkiej Wojny, miał istotne znaczenie dla amerykańskiej polityki wobec Chin. W wyniku doniosłych wydarzeń, jakie wówczas nastąpiły, zmieniła się wewnętrzna i międzynarodowa sytuacja Chin, dzięki czemu Stany Zjednoczone mogły nadrobić dystans dzielący je od pozostałych mocarstw mających swe wpływy w Państwie Środka, a nawet uzyskać nad nimi przewagę. Od momentu bowiem, gdy pod koniec XIX wieku w Chinach rozgorzała walka o koncesje, pozycja Stanów Zjednoczonych była tam niezbyt silna, zwłaszcza na tle konkurentów. Jako jedyne nie utworzyły one swojej strefy wpływów, nie miały też - w tym przypadku podobnie jak Niemcy - posiadłości graniczących z Chinami (trudno w ten sposób traktować Filipiny, skoro ich główna wyspa znajduje się ponad $800 \mathrm{~km}$ od chińskich wybrzeży). Ponadto USA, znowu jako jedyne, pozostawały poza systemem sojuszów, który się w tym czasie zacieśnial, oraz - w przeciwieństwie do np. Rosji i Japonii - nie przewidywały użycia wojsk, skądinąd podówczas dość jeszcze szczupłych, w celu wsparcia swojej polityki chińskiej.

Zręczny manewr, którym w tych okolicznościach było zainicjowanie i rozwijanie doktryny „otwartych drzwi”, nie mógł jednak przesłonić faktu, że Stany Zjednoczone znajdowały się w Chinach w mniej korzystnej sytuacji niż pozostałe mocarstwa. Ich położenie osłabiało także niewielkie faktyczne, w odróżnieniu od deklaratywnego, zaangażowanie amerykańskich kupców i inwestorów. Powstało swoiste błędne koło - politycy musieli działać w miarę adekwatnie do rzeczywistego zainteresowania swoich obywateli, ci zaś nie garnęli się do podboju rynku chińskiego, oczekując zarazem, że rząd udzieli im poparcia i zabezpieczy możliwość przyszłej ekspansji. Zaradzić temu próbowała administracja Tafta, która w ramach „dyplomacji dolarowej” chciała, aby obie siły - polityczna i ekonomiczna - wspóldziałały i wzajemnie się wzmacniały. Efekty tych starań były umiarkowanie satysfakcjonujące, ale rząd przynajmniej wyraźnie pokazał, że zamierzał prowadzić aktywną politykę w Chinach i wspierać tam amerykańskich inwestorów.

Nowe perspektywy pojawily się w następstwie rewolucji Xinhai, która zmiotła nieudolną dynastię mandżurską, jak i samo Cesarstwo. Władzę przejął Yuan Shikai i jego stronnicy, początkowo dzieląc się nią z rewolucjonistami. Dawało to nadzieje na wejście Chin na ścieżkę modernizacji i wzrost wplywów USA, którym obie strony wydawały się przychylne. Działania rewolucjonistów wywołały też aplauz amerykańskiej opinii publicznej, która doceniła ich postępowość 
oraz fakt, że ustanowili republikę i chcieli się wzorować na amerykańskich rozwiązaniach. Tego entuzjazmu nie podzielali politycy w Waszyngtonie, uważając, że rewolucjoniści nie potrafili utrzymać porządku, a decyzja o zmianie ustroju była przedwczesna. Wynik samego powstania oceniono jednak nad Potomakiem pozytywnie, ponieważ po niezbyt długich $\mathrm{i}$ krwawych walkach (przynajmniej jak na wojnę wewnętrzną) do władzy doszedł Yuan, którego postrzegano jako najbardziej odpowiednią osobę do jej sprawowania.

Jeszcze większe szanse dla USA pojawily się w momencie wybuchu I wojny światowej. Znacząco zmieniła ona układ sił w Chinach, gdzie do 1914 roku krzyżowały się wpływy niemal wszystkich mocarstw. Poważne osłabienie przeważających tam dotychczas wpływów europejskich oznaczało automatycznie awans Stanów Zjednoczonych, które miały okazję wzmocnić swoją pozycję i rozwijać różnorakie interesy.

Wypada się zastanowić, czy możliwości, jakie zarysowały się przed Waszyngtonem w latach 1911-1918, zostały wykorzystane, i jak wyglądał bilans jego działań. Wydaje się, że na pierwsze pytanie odpowiedź brzmi: w ograniczonym stopniu, na drugie zaś: umiarkowanie, czyli ani szczególnie pozytywnie, ani negatywnie. Niewątpliwie w omawianym okresie Stany Zjednoczone prowadzily aktywną politykę $\mathrm{w}$ Chinach i podejmowały różne inicjatywy dyplomatyczne, polityczne, gospodarcze, społeczne i militarne. Ich pozycja wzrosła w trakcie I wojny światowej, kiedy to nie uchylały się od nowych obowiązków i odgrywały istotniejszą rolę niż wcześniej. Uwidoczniło się to chociażby w podjętej przez nie próbie nakłonienia mocarstw do zrzeczenia się stref wpływów, a także podczas kryzysu wywołanego przez 21 żądań. Wzrost pozycji nie przełożył się jednak na bardziej znaczące sukcesy. Osiągnięcie ich utrudnily nieprzemyślane lub zgoła błędne decyzje, opór mocarstw, zmienne zainteresowanie Amerykanów rynkiem chińskim, ale i czynniki w znacznej mierze od Waszyngtonu niezależne. Wydarzenia, które stwarzały dla niego nowe szanse, niosły bowiem za sobą jeszcze większe zagrożenia.

Patrząc z perspektywy czasu, można stwierdzić, że rewolucja Xinhai - niczym chińska puszka Pandory - rozpoczęła wieloletni okres walk i nieporządku. Chociaż u schyłku panowania Qingów także miały miejsce różne niepokoje wewnętrzne, to skala i natężenie fermentu i rozruchów po ich abdykacji były nieporównywalnie większe. W kolejnych latach doszło jeszcze do dwóch rewolucji, licznych wystąpień lokalnych, rozplenienia się pospolitego bandytyzmu, a po śmierci Yuana do niemal ciągłej konfrontacji między zwalczającymi się stronnictwami militarystów. Nastąpiło osłabienie władzy centralnej, nasilił się proces emancypacji prowincji i dezintegracji państwa. Można uznać, że o ile słabość Chin na przełomie XIX i XX wieku wynikała bardziej z zewnętrznej presji mocarstw, to przez dwie dekady od rewolucji Xinhai (aż do japońskiej napaści w 1931 roku) spowodowana była przede wszystkim konfliktami wewnętrznymi. 
Brak stabilizacji był jednym z podstawowych problemów, z jakimi musiała się zmierzyć dyplomacja amerykańska. Wewnętrzne rozchwianie zagrażało bezpieczeństwu cudzoziemców, zniechęcało inwestorów, dawało mocarstwom powód do interwencji oraz sprawiało, że Chiny pozostawały państwem słabym, zacofanym i podatnym na wpływy zewnętrzne. Dlatego też w omawianym okresie lejtmotywem wszystkich amerykańskich działań i kalkulacji było dążenie do zaprowadzenia elementarnego porządku w Chinach i ich wzmocnienia. Chociaż podczas otwartych starć Waszyngton pozostawał neutralny, to po ich wygaśnięciu wspierał władze centralne, udzielając im poparcia politycznego, starając się zaaranżować pomoc finansową oraz odmawiając uznania ich przeciwników. $\mathrm{Na}$ szczególną przychylność mogły liczyć osoby dające największą gwarancję utrzymania porządku. Było to kryterium nadrzędne, istotniejsze niż jakiekolwiek inne, ponieważ dopiero po uspokojeniu sytuacji i zaprowadzeniu ładu można było myśleć o realizacji dalszych celów. Stąd też wynikała na przykład akceptacja dla autorytarnych rządów Yuana i jego planów przywrócenia monarchii. Stanom Zjednoczonym, w przeciwieństwie do niektórych mocarstw, nie zależało na utrzymaniu Kraju Środka w chaosie, gdyż nic by na tym nie zyskały, lecz tylko straciły. Zależało im, zapewne bardziej niż innym mocarstwom, na wzmocnieniu go, ponieważ wtedy mógłby przynajmniej w jakiejś mierze oprzeć się naciskom z zewnątrz. Celem dyplomacji amerykańskiej nie było też jednak wzmocnienie Chin do tego stopnia, aby - jak pisze Thomas J. McCormick - mogły „same zamknąć drzwi” ${ }^{1}$, ale taka perspektywa wydawała się w tym czasie niezmiernie odległa.

Podobnie jak rewolucja Xinhai także I wojna światowa okazała się dla chińskiej polityki Stanów Zjednoczonych bardziej wyzwaniem niż sprzyjającą okolicznością. Zaburzenie dotychczasowej równowagi między mocarstwami na Dalekim Wschodzie, fakt, że członkowie ententy byli zmuszeni do większej pobłażliwości wobec Japonii, oraz determinacja tej ostatniej, aby wykorzystać sprzyjający moment dziejowy, sprawiły, że amerykańska dyplomacja musiała bardziej koncentrować się na powstrzymywaniu Chryzantemowego Tronu niż na rozszerzaniu własnych interesów. Jej wysiłki zakończyły się połowicznym sukcesem. Gdy wybuchła wojna, nie udało jej się zapobiec naruszeniu neutralności Chin. Wkolejnych latach Japonia zrealizowała niemałą część swoich zamiarów - doprowadziła do upadku Yuana i osadzenia w Pekinie bardziej jej przychylnych polityków. Uzyskała nowe przywileje i rozbudowała wpływy polityczne, militarne i ekonomiczne, m.in. uzależniając Chiny finansowo. Cały czas podjudzała w nich niepokoje, tak by pozostały słabe i wewnętrznie podzielone. Skutecznie blokowała ich przystąpienie do wojny, aż do momentu, w którym uznała, że może to być dla niej korzystne. Nakłoniła europejskich

1 T.J. McCormick, China Market. America's Quest for Informal Empire, 1893-1901, Chicago 1970, s. 145. 
sojuszników do akceptacji swoich roszczeń po wojnie, a na czas wojny przyznania jej decydującego głosu w wielu sprawach dotyczących Chin. Specjalną pozycję Tokio przynajmniej na niektórych obszarach Chin uznał również parokrotnie Waszyngton (nota z marca 1915 roku, stanowisko Lansinga ze stycznia 1917 roku, porozumienie Lansing-Ishii). Próbował się on przeciwstawić japońskim zakusom za pomocą amerykańskich inwestycji i działań dyplomatycznych, ale jego starania okazały się umiarkowanie skuteczne. Udało mu się natomiast uchronić Chiny przed pełną wasalizacją. Przyczynił się m.in. do rezygnacji Japonii z najbardziej wygórowanych spośród 21 żądań.

Część tych niepowodzeń wynikała z braku ciągłości i koherencji w amerykańskiej polityce. Przede wszystkim kolejne rządy odchodzily od kursu obranego przez poprzedników, w pewnych aspektach wręcz go negując. Administracja Tafta, wbrew wcześniejszym dążeniom administracji Theodorea Roosevelta, aby załagodzić napięte stosunki z Japonią i uznać jej preponderancję w Mandżurii, podjęła $\mathrm{w}$ Chinach działania mające na celu m.in. podważenie pozycji japońskiej. Kiedy nowym prezydentem został Wilson, nastawienie dyplomacji amerykańskiej także uległo poważnej zmianie. Niemal natychmiast po zaprzysiężeniu Wilson wycofał poparcie dla udziału amerykańskich bankierów w konsorcjum mocarstw, które negocjowało w tym czasie udzielenie dużej pożyczki rządowi pekińskiemu, oraz samodzielnie uznał Republikę Chińską, mimo że wcześniej USA zgodziły się współdziałać w tej kwestii z pozostałymi mocarstwami. Obie decyzje były zaprzeczeniem głównych założeń dotychczasowej polityki.

Zmiany w polityce zachodziły też w obrębie poszczególnych administracji, i to na dwóch płaszczyznach. Nie tylko zmieniały one zdanie w kluczowych sprawach (np. gabinet Tafta wobec Mandżurii, gabinet Wilsona w odniesieniu do konsorcjum, 21 żądań czy przystąpienia Chin do wojny), ale politycy i dyplomaci miewali nierzadko różne opinie i składali nawet rozbieżne deklaracje (np. częste tarcia między amerykańskimi posłami w Pekinie a zwierzchnikami nad Potomakiem, różne podejścia w rządzie waszyngtońskim wobec japońskich żądań). Część tych zmian wymuszała dynamicznie rozwijająca się sytuacja w Chinach i na arenie międzynarodowej, część zaś wynikała z czynników wewnętrznych. Zmienność chińskiej polityki USA sprawiła, że była ona elastyczna i można ją było modelować odpowiednio do okoliczności, zarazem jednak okazała się dość chwiejna. Zbyt często zmiany stanowisk i ich niespójność przeważały nad kontynuacją i spokojem.

Powstaje pytanie, czy USA tylko reagowały na wydarzenia rozgrywające się w Chinach i posunięcia innych mocarstw, czy miały swoją wizję polityki w tym państwie. Za prezydentury Tafta owa wizja była bardziej skrystalizowana i spójna, za prezydentury Wilsona bardziej zmienna i nieostra. Różne było też natężenie zainteresowania Chinami ze strony obu administracji. W przypadku pierwszej było ono dość stałe, w przypadku drugiej podlegało większym wahaniom, co 
wynikało po części z większej liczby innych kluczowych wydarzeń na świecie za jej urzędowania.

Mimo że administracje Tafta i Wilsona wzajemnie krytykowały swą politykę w Chinach, to na pewnej płaszczyźnie była ona podobna - łączyła interesy amerykańskie i chińskie. Ani administracja Tafta nie działała wyłącznie na rzecz rozszerzania swoich wpływów, jak chcieliby niektórzy jej przeciwnicy, ani administracja Wilsona nie dbała jedynie o dobro Chin, jak chcieliby niektórzy jej apologeci. Obie zastanawiały się raczej, jak zmieszać te dwa elementy i w jakiej proporcji to zrobić.

Innym problemem była mnogość celów, jakie Waszyngton chciał osiągnąć. Zależało mu na zachowaniu integralności terytorialnej Chin, ich stabilizacji, wzmocnieniu, modernizacji i demokratyzacji, ale także na utrzymaniu zasady równych szans w handlu i rozszerzeniu jej na sprawy inwestycyjne. Dążył jednocześnie do zniesienia stref wpływów, zablokowania działań Japonii, pobudzenia aktywności amerykańskich biznesmenów i szerzenia wartości chrześcijańskich. Próba realizacji tak wielu celów naraz musiała być bardzo trudna, jeśli nie niemożliwa.

$\mathrm{Z}$ nadmierną liczbą celów łączył się inny słaby punkt amerykańskiej polityki w Chinach, mianowicie wielość pomysłów, które rozważano lub zaczęto realizować, ale które w wyniku braku konsekwencji i wystarczającego zaangażowania nie doczekały się finalizacji. Nadal istniał rozdźwięk między deklarowanymi przez Amerykanów chęciami a ich rzeczywistymi działaniami.

Należy też pamiętać, że polityka wobec Chin stanowiła tylko fragment całej amerykańskiej polityki zagranicznej. A ta, wraz z coraz znaczniejszym wkraczaniem Stanów Zjednoczonych na arenę światową, stawała się bardziej skomplikowana i rozbudowana. Niosło to za sobą dwa zagrożenia - polityka wobec Chin mogła zostać podporządkowana amerykańskim interesom $\mathrm{w}$ innych państwach lub zepchnięta na dalszy plan przez inne wydarzenia. Oba niebezpieczeństwa pojawiły się w omawianym okresie. Waszyngton rozważał możliwość porozumienia się z Japonią kosztem Chin i swoich praw, a w ostatnich latach wojny jego zainteresowanie Państwem Środka osłabło.

Niemniej, mimo że lata 1911-1918 obfitowały w wydarzenia z amerykańskiej perspektywy przełomowe lub ważne (takie jak: rewolucja meksykańska, narastający konflikt w Europie i Wielka Wojna, upadek caratu i przewrót bolszewicki), miejsce Pekinu w polityce zagranicznej Stanów Zjednoczonych było istotne. O tym, że miał on niebagatelne znaczenie, świadczyły wypowiedzi, plany i działania członków amerykańskiej dyplomacji oraz czas, jaki poświęcali oni sprawom chińskim. Zainteresowanie to nie było jednak ciągle takie samo. Można uznać, że za prezydentury Tafta Chiny - mimo znacznego oddalenia geograficznego - znajdowały się wręcz na drugiej pozycji w rankingu ważności, wyprzedzane jedynie przez kraje Ameryki Środkowej. Na obszarze Chin, tak jak w Ameryce Środkowej, realizowano bowiem „dyplomację dolarową”, stanowiącą trzon 
zagranicznych działań ówczesnej administracji. Gdy w Białym Domu zamieszkał Wilson, pozycja Chin nie była już aż tak wysoka, głównie ze względu na wybuch Wielkiej Wojny i bardziej ogólnoświatowe ambicje nowego prezydenta. Ale nawet wówczas zainteresowanie Waszyngtonu Państwem Środka pozostało znaczne, może oprócz ostatniego roku wojny, kiedy to USA były już w pełni zaangażowane w walki w Europie.

Dowodem na wysoką rangę Chin w amerykańskiej polityce zagranicznej był fakt, że Stany Zjednoczone gotowe były narazić relacje z innymi państwami, aby realizować swoje zamysly w Chinach lub przeciwdziałać tam posunięciom innych mocarstw. W ten sposób pogorszyły się stosunki USA z Rosją i Japonią. Zwłaszcza w przypadku tego drugiego państwa sytuacja wyglądała poważnie. W omawianym okresie przyśpieszył proces znacznego spadku notowań Japonii w Waszyngtonie, a głównym powodem tego była polityka prowadzona przez nią w Chinach. O ile jeszcze na przełomie XIX i XX wieku nad Potomakiem doceniano Japonię za błyskawiczną modernizację i postrzegano jako Wielką Brytanię Dalekiego Wschodu, to po zakończeniu I wojny światowej uważano ją już za dalekowschodni odpowiednik Niemiec i najbardziej prawdopodobnego wroga w przyszłości ${ }^{2}$ Podobne odczucia i przewidywania wojenne, tyle że w odwrotnym kierunku, pojawiły się w Tokio. Tam jednak wydawały się bardziej zrozumiałe, gdyż Chiny, ze względu na bliskość, wielkość i olbrzymi potencjał, musiały mieć dla Japonii priorytetowe znaczenie. Warto jeszcze przypomnieć, że Japonia była natenczas o wiele silniejszym państwem niż Chiny, amerykańsko-japońska wymiana handlowa zaś wyraźnie przewyższała wymianę handlową między USA a Chinami ${ }^{3}$. Skoro zatem Stany Zjednoczone obstawały przy swojej polityce chińskiej, wiedząc, że może antagonizować Japonię, dowodziło to, iż Chiny odgrywały istotną rolę w amerykańskiej polityce zagranicznej.

Administracje Tafta i Wilsona, mimo że stosowały różne strategie i z różnym natężeniem, to prowadziły aktywną politykę w Chinach. Ich zaangażowanie było niewspółmiernie większe niż przez cały czas umiarkowane rzeczywiste interesy Amerykanów, co świadczy o tym, że w Stanach Zjednoczonych żywe pozostawały dwa od dawna zakorzenione mity - dotyczące niezwykle chłonnego rynku chińskiego i specjalnej więzi łączącej oba narody. Dołączyło do tego przekonanie o nieuniknionym wzroście pozycji Chin, które obudziwszy się z letargu, kiedyś ponownie staną się jeśli nie Państwem Środka sensu stricto, to przynajmniej ważnym graczem światowym.

2 S. Pash, The Currents of War: A New History of American-Japanese Relations, 1899-1941, Lexington 2014, s. 46-47.

3 R. Nakagawa, Japan-U.S. Trade and Rethinking the Point of No Return toward the Pearl Harbor, „Ritsumeikan Annual Review of International Studies” 2010, t. 9, s. 105106. 


\section{BIBLIOGRAFIA}

\section{Archiwalia}

Library of Congress, Manuscript Division, Washington:

William Jennings Bryan Papers

Philander C. Knox Papers

Robert Lansing Papers

William H. Taft Papers

Woodrow Wilson Papers

The National Archives at College Park, College Park:

Records of the Department of State Relating to Internal Affairs of China, 1910-1929, (mikrofilm), roll 1, 10-20.

Records of the Department of State Relating to Political Relations Between China and Other States, 1910-1929, (mikrofilm), roll 2, 23-26.

Records of the Department of State Relating to Political Relations of the United States with China, 1910-1929, (mikrofilm), roll 1-2.

Princeton University Library, Department of Rare Books and Special Collections, Princeton University, Princeton:

Robert Lansing Papers, online: http://findingaids.princeton.edu/collections/MC083/c0001 (dostęp: 09.06.2018).

Cornell University Library, Division of Rare and Manuscript Collections, Cornell University, Ithaca:

Willard Dickerman Straight Papers, online: http://ecommons.cornell.edu/handle/1813/22047

(dostęp: 08.06.2018).

\section{Dokumenty opublikowane}

British Documents on the Origins of the War 1898-1914, (opr.) G.P. Gooch, H. Temperley, t. 1-11, London 1926-1938.

Butt A.W., Taft and Roosevelt: The Intimate Letters of Archie Butt, t. 1, Garden City 1930.

The Collected Works of William Howard Taft, (opr.) D.H. Burton, t. 1-6, Athens 2001-2003.

Conflict and Tension in the Far East: Key Documents, 1894-1960, (opr.) J.M. Maki, Seattle 1961. 
Conger S.P., Letters from China, with Particular Reference to the Empress Dowager and the Women of China, Chicago 1910.

Congressional Records, t. 48-56, Washington 1912-1918.

Documents Diplomatiques Français, 1871-1914, 2 érie: 1901-1911, t. 14, 3e série: 1911-1914, t. 1-11, Paris 1929-1955.

The Intimate Papers of Colonel House, (opr.) Ch. Seymour, t. 1-4, Boston-New York 1926-1928.

Kajima M., The Diplomacy of Japan 1894-1922, t. 2-3, Tokyo 1978-1980.

The Kuomintang: Selected Historical Documents, 1894-1969, (opr.) M.J.T. Shieh, New York 1970.

The Letters of Franklin K. Lane: Personal and Political, (opr.) A.W. Lane, L.H. Wall, Boston-New York 1922.

The Letters of Theodore Roosevelt, (opr.) E.E. Morison, t. 1-8, Cambridge 1951-1954.

Manchuria. Treaties and Agreements, Washington 1921.

The Papers of Woodrow Wilson, (opr.) A.S. Link, t. 23-53, Princeton 1977-1986.

Papers Relating to the Foreign Relations of the United States 1899-1918, Washington 1901-1930.

Papers Relating to the Foreign Relations of the United States 1914-1918, Supplement: The World War, Washington 1928-1933.

Papers Relating to the Foreign Relations of the United States, The Lansing Papers, 1914-1920, t. 1-2, Washington 1939-1940.

Prawo międzynarodowe i historia dyplomatyczna. Wybór dokumentów, wstęp i oprac. L. Gelberg, t. 1, Warszawa 1954.

Shantung. Treaties and Agreements, Washington 1921.

The Sino-Japanese Negotiations of 1915. Japanese and Chinese Documents and Chinese Official Statement, Washington 1921.

Treaties and Agreements with and Concerning China, 1894-1919, zebrał i opracował J.V.A. MacMurray, t. 1-2, New York 1921.

United States Policy Toward China. Diplomatic and Public Documents, 1839-1939, (opr.) P.H. Clyde, Durham 1940.

V.K. Wellington Koo's Foreign Policy. Some Selected Documents, zebrał W. King, Shanghai 1931.

\section{Prasa}

„The New York Times”

\section{Autobiografie, pamiętniki, wspomnienia}

Bryan W.J., Bryan M.B., The Memoirs of William Jennings Bryan, Chicago 1925.

The Cabinet Diaries of Josephus Daniels, (opr.) E.D. Cronon, Lincoln 1963.

Grey E., Twenty-five Years 1892-1916, t. 1-2, New York 1925.

Hoover H., The Memoirs of Herbert Hoover, t. 1: Years of Adventure, 1874-1920, New York 1952.

Houston D.F., Eight Years with Wilson's Cabinet, 1913 to 1920, t. 1-2, New York 1926.

Koo Hui-Lan [Madame Wellington Koo], An Autobiography, New York 1943.

Lansing R., The Big Four and Others of the Peace Conference, Boston-New York 1921.

Lansing R., The Peace Negotiations: A Personal Narrative, Boston-New York 1921.

Lansing R., War Memoirs of Robert Lansing, Secretary of State, Westport 1970. 
Phillips W., Ventures in Diplomacy, Boston 1953.

Powell J.B., My Twenty-five Years in China, New York 1945.

$\mathrm{Pu}$ Yi, Bytem ostatnim cesarzem Chin, przeł. J. Mach, t. 1, Łódź 1988.

Reinsch P., An American Diplomat in China, Garden City 1922.

Roosevelt T., An Autobiography, New York 1914.

Sun Yat-sen, Memoirs of a Chinese Revolutionary: A Programme of National Reconstruction for China, New York 1970.

Wilson Huntington F.M., Memoirs of an Ex-Diplomat, Boston 1945.

Yen W.W., East-West Kaleidoscope, 1877-1946: An Autobiography, New York 1974.

\section{Literatura przedmiotu}

Allen H.C., Great Britain and the United States: A History of Anglo-American Relations (17831952), New York 1955.

Alvarez D.J., The Department of State and the Abortive Papal Mission to China, August, 1918, „The Catholic Historical Review” 1976, t. 62, nr 3, s. 455-463.

Ambrosius L.E., Wilsonian Statecraft: Theory and Practice of Liberal Internationalism during World War I, Wilmington 1991.

Ambrosius L.E., Woodrow Wilson and the American Diplomatic Tradition: The Treaty Fight in Perspective, Cambridge 1987.

Armentrout Ma L.E., Revolutionaries, Monarchists, and Chinatowns: Chinese Politics in the Americas and the 1911 Revolution, Honolulu 1990.

Bailey J., Great Power Strategy in Asia: Empire, Culture and Trade, 1905-2005, London 2007.

Bailey T.A., The Lodge Corollary to the Monroe Doctrine, „Political Science Quarterly” 1933, t. 48, nr 2, s. 220-239.

Baker R.S., Woodrow Wilson. Life and Letters, t. 1-5, Garden City 1927-1935, t. 6-8, New York 1946.

Bartnicki A., Walka o Mandżurię. Z dziejów ekspansji kolonialnej na Dalekim Wschodzie, Warszawa 1965.

Bau M.J., The Foreign Relations of China, New York 1921.

Bau M.J., The Open Door Doctrine in Relation to China, New York 1923.

Bayer J., Dziak W., Historia polityczna Chin 1839-2014. Kronika najważniejszych wydarzeń, Warszawa 2015.

Bayer J., Problem chińskiego nacjonalizmu do chwili proklamowania Chińskiej Republiki Ludowej, „Azja-Pacyfik” 2011, t. 14, s. 70-86.

Bazylow L., Historia Mongolii, Wrocław 1981.

Bazylow L., Historia powszechna 1789-1918, Warszawa 2000.

Beale H.K., Theodore Roosevelt and the Rise of America to World Power, Baltimore-London 1987.

Beers B., Robert Lansing's Proposed Bargain with Japan, „Pacific Historical Review” 1957, t. 26, nr 4, s. 391-400.

Beers B., Vain Endeavor. Robert Lansing's Attempts to End the American-Japanese Rivalry, Durham 1962.

Bemis S.F., A Diplomatic History of the United States, New York 1955.

Bianco L., Origins of the Chinese Revolution, 1915-1949, Stanford 1971.

Blum J.M., Woodrow Wilson and the Politics of Morality, Boston 1956. 
Bonavia D., China's Warlords, New York 1995.

Braisted W.R., The United States and the American China Development Company, „The Far Eastern Quarterly" 1952, t. 11, nr 2, s. 147-165.

British Foreign Policy under Sir Edward Grey, (red.) F.H. Hinsley, Cambridge 1977.

Brogan H., Historia Stanów Zjednoczonych Ameryki, przeł. E. Macauley, Wrocław 2004.

Brzeziński A.M., Międzynarodowy aspekt antagonizmu brytyjsko-rosyjskiego na przetomie XIX i XX w., „Acta Universitatis Lodziensis” 1979, seria I, nr 52, s. 31-43.

Buehrig E., Woodrow Wilson and the Balance of Power, Bloomington 1955.

Burk K., Great Britain in the United States, 1917-1918: The Turning Point, „The International History Review” 1979, t. 1, nr 2, s. 228-245.

Burton D.H., Taft, Wilson and World Order, Madison 2003.

Burton D.H., William Howard Taft: Confidential Peacemaker, Philadelphia 2004.

The Cambridge History of China, t. 11: Late Ch'ing, 1800-1911, cz. 2, (red.) J.K. Fairbank, KwangChing Liu, Cambridge 1980.

The Cambridge History of China, t. 12: Republican China, 1912-1949, cz. 1, (red.) J.K. Fairbank, Cambridge 1983.

Cameron M.E., American Recognition Policy toward the Republic of China, 1912-1913, „Pacific Historical Review" 1933, t. 2, nr 2, s. 214-230.

Campbell Ch.S., jr., American Business Interests and the Open Door in China, [w:] W.A. Williams (red.), The Shaping of American Diplomacy, Chicago 1956, s. 414-424.

Challener R.D., Admirals, Generals, and American Foreign Policy, 1898-1914, Princeton 1973.

Chan K.C., British Policy in the Reorganization Loan to China 1912-1913, „Modern Asian Studies” 1971, t. 5, nr 4, s. 355-372.

Chan R.P.S., The Great Powers and the Chinese Revolution, 1911-1913, nieopublikowany doktorat, Fordham University, New York 1971.

Ch'ên J., Yuan Shih-k'ai, 1859-1916: Brutus Assumes the Purple, London 1961.

Chi M., Bureaucratic Capitalists in Operation: Ts'ao Ju-lin and His New Communications Clique, 1916-1919, „The Journal of Asian Studies” 1975, t. 34, nr 3, s. 675-688.

Chi M., China Diplomacy, 1914-1918, Cambridge 1970.

China in Revolution: The First Phase, 1900-1913, (red.) M.C. Wright, New Haven-London 1968.

Chong K.R., Americans and Chinese Reform and Revolution, 1898-1922: The Role of Private Citizens in Diplomacy, Lanham 1984.

Chu Ch. Chia-hwei, The China Policy of the Taft-Knox Administration, 1909-1913, nieopublikowany doktorat, The University of Chicago, Chicago 1956.

Chu Pao-chin, V.K. Wellington Koo. A Case Study of China's Diplomat and Diplomacy of Nationalism, 1912-1966, Hong Kong 1981.

Chung H., The Oriental Policy of the United States, New York 1919.

Chwalba A., Historia powszechna. Wiek XIX, Warszawa 2010.

Chwalba A., Samobójstwo Europy. Wielka Wojna 1914-1918, Kraków 2014.

Clements J., Wellington Koo: China, London 2008.

Clements K.A., The Presidency of Woodrow Wilson, Lawrence 1992.

Clements P.H., The Boxer Rebellion. A Political and Diplomatic Review, New York 1915.

Clubb E., $20^{\text {th }}$ Century China, New York 1972.

Cohen P.A., History in Three Keys: The Boxers as Event, Experience and Myth, New York 1997.

Cohen W.I., America's Response to China: An Interpretative History of Sino-American Relations, New York 1971. 
Coletta P., The Presidency of William Howard Taft, Lawrence 1987.

Coletta P., William Jennings Bryan, t. 1-3, Lincoln 1964-1969.

A Companion to Theodore Roosevelt, (red.) S. Ricard, Chichester-Malden 2011.

Connaughton R.M., The War of the Rising Sun and the Tumbling Bear: A Military History of the Russo-Japanese War 1904-5, London 1988.

Cooper J.M., jr., Woodrow Wilson: A Biography, New York 2011.

Craft S.G., Angling for an Invitation to Paris: China's Entry into the First World War, „The International History Review” 1994, t. 16, nr 1, s. 1-24.

Craft S.G., John Bassett Moore, Robert Lansing, and the Shandong Question, „Pacific Historical Review” 1997, t. 66, nr 2, s. 231-249.

Craft S.G., V.K. Wellington Koo and the Emergence of Modern China, Lexington 2004.

Crane D.M., Breslin T.A., An Ordinary Relationship: American Opposition to Republican Revolution in China, Gainesville 1986.

Croly H., Willard Straight, New York 1924.

Curry R.W., Woodrow Wilson and Far Eastern Policy, 1913-1921, New York 1968.

Damski P.P., Dyplomacja brytyjska wobec zabiegów Rosji o wyłaczne wplywy w Mandżurii (październik 1901 r. - sierpień 1903 r.), „Acta Universitatis Lodziensis. Folia Historica” 2012, t. 89, s. 23-52.

Damski P.P., „Najbliższe narody”. Stosunki brytyjsko-amerykańskie w dobie prezydentury Theodore'a Roosevelta (1901-1909), Warszawa 2014.

Daniels J., The Life of Woodrow Wilson, 1856-1924, Westport 1971.

Daniels J., The Wilson Era: Years of Peace, 1910-1917, Chapel Hill 1946.

Daniels J., The Wilson Era: Years of War and After, 1917-1923, Chapel Hill 1946.

Davis C.B., Limits of Effacement: Britain and the Problem of American Cooperation and Competition in China, 1915-1917, „Pacific Historical Review” 1979, t. 48, nr 1, s. 47-63.

DeConde A., A History of American Foreign Policy, New York 1978.

Dennett T., Americans in Eastern Asia: A Critical Study of the Policy of the United States with reference to China, Japan and Korea in the $19^{\text {th }}$ Century, New York 1922.

Dennett T., John Hay: From Poetry to Politics, New York 1934.

Dennett T., The Open Door Policy as Intervention, „Annals of the American Academy of Political and Social Science" 1933, t. 168, s. 78-83.

Dennett T., Roosevelt and Russo-Japanese War, Garden City 1925.

Dennis A.L.P., Adventures in American Diplomacy, 1896-1906, New York 1928.

Dmochowski T., Interwencja mocarstw na Syberii i Dalekim Wschodzie (1918-1922), Toruń 2002.

Dmochowski T., Interwencje mocarstw w Chinach w 1900 roku, „Zeszyty Naukowe «Cywilizacje w Czasie i Przestrzeni»” 2000, nr 6, s. 87-100.

Dmochowski T., Przystąienie Stanów Zjednoczonych do walki o imperium mundi (doktryna „otwartych drzwi”), „Zeszyty Naukowe «Cywilizacje w Czasie i Przestrzeni»” 2000, nr 6, s. 81-85.

Dmochowski T., Walka polityczna mocarstw o dominację w dorzeczu Amuru, Toruń 1999.

Dobrzycki W., Historia stosunków międzynarodowych w czasach nowożytnych 1815-1945, Warszawa 1996.

Dragon and Eagle: United States-China Relations: Past and Future, (red.) M. Oksenberg, R.B. Oxnam, New York 1978.

Dulles F.R., America's Rise to World Power, 1898-1954, New York 1963.

Dulles F.R., China and America: The Story of their Relations Since 1784, Princeton 1946. 
Dutt V.P., The First Week of Revolution: The Wuchang Uprising, [w: ] M.C. Wright (red.), China in Revolution: The First Phase, 1900-1913, New Haven-London 1968, s. 383-416.

Dyskant J.W., Michałek A., Port Artur. Cuszima 1904-1905, Warszawa 2005.

Edwards E.W., China and Japan, 1911-1914, [w:] F.H. Hinsley (red.), British Foreign Policy under Sir Edward Grey, Cambridge 1977, s. 368-381.

Edwards E.W., Great Britain and China, 1905-1911, [w: ] F.H. Hinsley (red.), British Foreign Policy under Sir Edward Grey, Cambridge 1977, s. 351-361.

Elleman B., Wilson and China. A Revised History of the Shandong Question, Armonk 2002.

Ellison D.C., The United States and China, 1913-1921: A Study of the Strategy and Tactics of the Open Door Policy, nieopublikowany doktorat, The George Washington University, Washington 1974.

Emdad-ul Haq M., Drugs in South Asia: From the Opium Trade to the Present Day, Basingstoke 2000.

Esherick J.W., The Origins of the Boxer Uprising, Berkeley 1987.

Esthus R.A., The Changing Concept of the Open Door, „The Mississippi Valley Historical Review” 1959 , t. 46, nr 3, s. 435-454.

Esthus R.A., Double Eagle and Rising Sun: The Russians and Japanese at Portsmouth in 1905, Durham 1988.

Esthus R.A., Taft-Katsura Agreement - Reality or Myth?, „The Journal of Modern History” 1959, t. 31, nr 1, s. 46-51.

Fairbank J.K., Chinese-American Interactions: A Historical Summary, New Brunswick 1975.

FairbankJ.K., Historia Chin: nowe spojrzenie, przeł. T. Lechowska, Z. Słupski, Gdańsk 1996.

Fairbank J.K., The United States and China, Cambridge 1972.

Fenby J., Chiny. Upadek i narodziny wielkiej potęgi, przeł. J. Wąsiński, J. Wołk-Łaniewski, Kraków 2009.

Ferrell R.H., American Diplomacy. A History, New York 1975.

Fifield R.H., Woodrow Wilson and the Far East. The Diplomacy of the Shantung Question, Hamden 1965.

Fish C.R., The Path of Empire: A Chronicle of the United States as a World Power, New Haven 1919.

Floto I., Colonel House in Paris: A Study of American Policy at the Paris Peace Conference 1919, Princeton 1980.

Fung E.S.K., The Military Dimension of the Chinese Revolution: The New Army and its Role in the Revolution of 1911, Vancouver 1980.

Gardner L.C., Safe for Democracy: The Anglo-American Response to Revolution, 1913-1923, New York 1984.

Gawlikowski K., Cechy szczególne Rewolucji Xinhai i jej paradoksy, „Azja-Pacyfik” 2011, t. 14, s. 31-48.

Gawlikowski K., Chiny wobec Europy. Reformy wojskowe XIX wieku, Wrocław 1979.

Gerritsen J.-W., The Control of Fuddle and Flash: A Sociological History of the Regulation of Alcohol and Opiates, Boston 2000.

Gould L., The Spanish-American War and President McKinley, Lawrence 1982.

Gould L., The William Howard Taft Presidency, Lawrence 2009.

Gowen R.J., Great Britain and the Twenty-One Demands of 1915: Cooperation versus Effacement, „The Journal of Modern History” 1971, t. 43, nr 1, s. 76-106.

Góralczyk B., Rewolucja Xinhai w chińskich dziejach, „Azja-Pacyfik” 2011, t. 14, s. 11-30.

Góralczyk Z., Komunistyczna Partia Chin a Stany Zjednoczone (lipiec 1921 - czerwiec 1950), Warszawa 1981. 
Gregory R., To Do Good in the World: Woodrow Wilson and America's Mission, [w:] F.J. Merli, T.A. Wilson (red.), Makers of American Diplomacy. From Benjamin Franklin to Henry Kissinger, New York 1974, s. 359-383.

Grenville J.A.S., Young G.B., Politics, Strategy, and American Diplomacy: Studies in Foreign Policy, 1873-1917, London-New Haven 1969.

Griswold A.W., The Far Eastern Policy of the United States, New York 1938.

Halik T., Powstanie Yihetuan (1898-1901), [w:] R. Sławiński (red.), Nowożytna historia Chin, Kraków 2005, s. 95-105.

Hatch A., Edith Bolling Wilson: First Lady Extraordinary, New York 1961.

Healy D., US Expansionism. The Imperialist Urge in the 1890s, Madison 1970.

Heckscher A., Woodrow Wilson, New York 1991.

Herrick G.F., Herrick J.O., The Life of William Jennings Bryan, Chicago 1925.

Historia Stanów Zjednoczonych Ameryki, (red.) A. Bartnicki, D.T. Critchlow, t. 3: 1848-1917, Warszawa 1995.

Hodgson G., Woodrow Wilson's Right Hand: The Life of Colonel Edward M. House, New Haven 2006.

Hoover H., The Ordeal of Woodrow Wilson, New York 1958.

Hornbeck S., Contemporary Politics in the Far East, New York-London 1916.

Hubbard G.E., British Far Eastern Policy, New York 1943.

Hudson G., The Far East at the End of the First World War, „Journal of Contemporary History” 1969 , t. 4, nr 2, s. 165-179.

Hunt M.H., The American Remission of the Boxer Indemnity: A Reappraisal, „The Journal of Asian Studies"1972, t. 31, nr 3, s. 539-559.

Hunt M.H., Americans in the China Market: Economic Opportunities and Economic Nationalism, 1890s-1931, „The Business History Review” 1977, t. 51, nr 3, s. 277-307.

Hunt M.H., Frontier Defense and the Open Door. Manchuria in Chinese-American Relations 18951911, New Haven 1973.

Hunt M.H., The Making of a Special Relationship: The United States and China to 1914, New York 1983.

Ikei M., Japan's Response to the Chinese Revolution of 1911, „The Journal of Asian Studies” 1966, t. 25, nr 2, s. 213-227.

Iklé F.W., Japanese-German Peace Negotiations during World War I, „The American Historical Review” 1965, t. 71, nr 1, s. 62-76.

Iriye A., Across the Pacific. An Inner History of American East Asian Relations, New York 1967.

Iriye A., From Nationalism to Internationalism. US Foreign Policy to 1914, Boston 1977.

Iriye A., Pacific Estrangement: Japanese and American Expansion, 1897-1911, Chicago 1994.

Israel J., Progressivism and the Open Door: America and China, 1905-1921, Pittsburgh 1971.

Jansen M.B., The Japanese and Sun Yat-sen, Cambridge 1954.

Jiang A.X., The United States and China, Chicago 1988.

Jessup P.C., Elihu Root, t. 1-2, New York 1938.

Jones M.A., Historia USA, przeł. P. Skurowski, P. Ostaszewski, Gdańsk 2002.

Joseph P., Foreign Diplomacy in China, 1894-1900: A Study in Political and Economic Relations with China, London 1928.

Kahn H.D., Willard D. Straight and the Great Game of Empire, [w:] F.J. Merli, T.A. Wilson (red.), Makers of American Diplomacy. From Benjamin Franklin to Henry Kissinger, New York 1974, s. 333-358. 
Kański W., Chiny a świat zewnętrzny. Zarys stosunków handlowych z zagranica, Warszawa 1979.

Kaplan L., Homer Lea: American Soldier of Fortune, Lexington 2010.

Kawamura N., Turbulence in the Pacific: Japanese-U.S. Relations during World War I, Westport 2000.

Kazin M., A Godly Hero: The Life of William Jennings Bryan, New York 2007.

Kent A.E., Down from the Ivory Tower: Paul Samuel Reinsch, Minister to China, „The Wisconsin Magazine of History" 1951, t. 35, nr 2, s. 114-118.

King W., China at the Paris Peace Conference in 1919, New York 1961.

King W., China at the Washington Conference, 1921-1922, New York 1963.

Kissinger H., Dyplomacja, przeł. S. Głąbiński, G. Woźniak, I. Zych, Warszawa 2003.

Kissinger H., O Chinach, przeł. M. Komorowska, Wołowiec 2017.

Kiwerska J., Między izolacjonizmem a zaangażowaniem. Europa w polityce Stanów Zjednoczonych od Wilsona do Roosevelta, Poznań 1995.

Konflikty kolonialne i postkolonialne w Afryce i Azji 1869-2006, (red.) P. Ostaszewski, Warszawa 2006.

Lazo D.D., An Enduring Encounter: E.T. Williams, China, and the United States, nieopublikowany doktorat, University of Illinois at Urbana-Champaign, Urbana 1977.

LeMenager S., Manifest and Other Destinies: Territorial Fictions of the Nineteenth Century United States, Lincoln 2004.

Li Tien-yi, Woodrow Wilson's China Policy, 1913-1917, Kansas City 1952.

Liew K.S., Struggle for Democracy: Sung Chiao-jen and the 1911 Chinese Revolution, Berkeley 1971.

Link A.S., Wilson the Diplomatist: A Look at His Major Foreign Policies, Baltimore 1957.

Link A.S., Wilson: Campaigns for Progressivism and Peace, 1916-1917, Princeton 1965.

Link A.S., Wilson: Confusions and Crises, 1915-1916, Princeton 1964.

Link A.S., Wilson: The New Freedom, Princeton 1956.

Link A.S., Wilson: The Road to the White House, Princeton 1947.

Link A.S., Wilson: The Struggle for Neutrality, 1914-1915, Princeton 1960.

Link A.S., Woodrow Wilson and the Progressive Era, 1910-1917, New York 1954.

Lorence J.L., Organized Business and the Myth of the China Market: The American Asiatic Association, 1898-1937, „Transcriptions of the American Philosophical Society” 1981, t. 71, cz. 4, s. $1-112$.

Lowe P., Great Britain and Japan 1911-1915: A Study of British Far Eastern Policy, London-New York 1969.

Lowe P., Great Britain, Japan and the Fall of Yuan Shih-K'ai, 1915-1916, „The Historical Journal” 1970, t. 13, nr 4, s. 706-720.

Luo Z., National Humiliation and National Assertion: The Chinese Response to the Twenty-One Demands, „Modern Asian Studies” 1993, t. 27, nr 2, s. 297-319.

Łuczko M., Itō Hirobumi i Yamagata Aritomo. Czołowi politycy Japonii okresu Meiji (1868-1912), Warszawa 2006.

MacKinnon S.R., Power and Politics in Late Imperial China: Yuan Shi-kai in Beijing and Tianjin, 1901-1908, Berkeley 1980.

Madancy J., Unearthing Popular Attitudes towards the Opium Trade and Opium Suppression in Late Qing and Early Republican Fujian, „Modern China” 2001, t. 27, nr 4, s. 436-483.

Mahan A.T., The Influence of Sea Power upon History 1660-1783, Boston 1890.

Manchurian Railways and the Opening of China: An International History, (red.) B. Elleman, S. Kotkin, Armonk 2010. 
Mania A., Department of State 1789-1939. Pierwsze 150 lat udziatu w polityce zagranicznej USA, Kraków 2011.

Manifest Destiny and Empire: American Antebellum Expansionism, (red.) S.W. Haynes, Ch. Morris, College Station 1997.

Marks F.W. III, Velvet on Iron: The Diplomacy of Theodore Roosevelt, Lincoln 1979.

Materski W., Bolszewicy i samuraje. Walka dyplomatyczna i zbrojna o rosyjski Daleki Wschód (19171925), Warszawa 1990.

Matsuda T., Woodrow Wilson's Dollar Diplomacy in the Far East: The New Chinese Consortium, 1917-1921, nieopublikowany doktorat, University of Wisconsin, Madison 1979.

May E.R., American Policy and Japan's Entrance into World War I, „Mississippi Valley Historical Review” 1953, t. 40, nr 2, s. 279-290.

McCormick T.J., China Market. America's Quest for Informal Empire, 1893-1901, Chicago 1970.

Metallo M.V., American Missionaries, Sun Yat-sen, and the Chinese Revolution, „Pacific Historical Review” 1978, t. 47, nr 2, s. 261-282.

Metallo M.V., The United States and Sun Yat-sen, 1911-1925, nieopublikowany doktorat, New York University, New York 1974.

Michałek K., Amerykańskie stulecie: historia Stanów Zjednoczonych Ameryki, 1900-2001, Warszawa 2004.

Michałek K., Na drodze ku potędze. Historia Stanów Zjednoczonych Ameryki, 1861-1945, Warszawa 1999.

Michałek K., Poza granice kontynentu. Teoria pogranicza Fredericka Jacksona Turnera a idea ekspansji dalekowschodniej w amerykańskiej polityce zagranicznej 1893-1922, Warszawa 1992.

Mierzejewski D., Wyzwania chińskiej dyplomacji u progu ery republikańskiej, „Azja-Pacyfik” 2011, t. 14 , s. $131-150$.

Minger R.E., William Howard Taft and American Foreign Policy: The Apprenticeship Years, 19001908, Urbana 1975.

Morgan H.W., America's Road to Empire: The War with Spain and Overseas Expansion, New York 1965.

Munro D.G., American Commercial Interests in Manchuria, [w:] W.A. Williams (red.), The Shaping of American Diplomacy, Chicago 1956, s. 466-472.

Munro D.G., Intervention and Dollar Diplomacy in the Caribbean, 1900-1921, Princeton 1964.

Nakagawa R., Japan-U.S. Trade and Rethinking the Point of No Return toward the Pearl Harbor, „Ritsumeikan Annual Review of International Studies” 2010, t. 9, s. 101-123.

Nimmo W.F., Stars and Stripes Across the Pacific: The United States, Japan and the Asia/Pacific Region, 1895-1945, Westport 2001.

Nish I.H., Alliance in Decline: A Study in Anglo-Japanese Relations, 1908-1923, London 1972.

Nish I.H., Great Britain, Japan and North-East Asia, 1905-1911, [w:] F.H. Hinsley (red.), British Foreign Policy under Sir Edward Grey, Cambridge 1977, s. 362-367.

Nish I.H., Japan and China, 1914-1916, [w:] F.H. Hinsley (red.), British Foreign Policy under Sir Edward Grey, Cambridge 1977, s. 452-465.

Nish I.H., The Origins of the Russo-Japanese War, London 1985.

Notter H., The Origins of the Foreign Policy of Woodrow Wilson, New York 1965.

Nowikiewicz M., Yuan Shikai jako reformator armii chińskiej u schytku panowania dynastii Qing (1895-1908), [w:] J. Jędrysiak, D. Koreś, G. Strauchold, K. Widziński (red.), Kadry decyduja. o wszystkim. Studia z zakresu biografistyki wojskowej, Wrocław 2015, s. 423-448. 
Nowożytna historia Chin, (red.) R. Sławiński, Kraków 2005.

Olender P., Wojna amerykańsko-hiszpańska na morzu 1898, Warszawa 1995.

Olender P., Wojna rosyjsko-japońska 1904-1905. Działania na morzu, Kraków 2010.

Opium Regimes: China, Britain, and Japan, 1839-1952, (red.) T. Brook, B.T. Wakabayashi, Berkeley 2000.

Otte T.G., The China Question. Great Power Rivalry and the British Isolation 1894-1905, OxfordNew York 2007.

Pajewski J., Historia powszechna 1871-1918, Warszawa 2002.

Pajewski J., Pierwsza wojna światowa 1914-1918, Warszawa 2004.

Pajor J., Memorandum Johna Haya z 1 lutego 1902 r. Kontynuacja i próba rozszerzenia zakresu polityki „otwartych drzwi” w Chinach, „Acta Universitatis Lodziensis. Folia Historica” 2012, t. 88, s. 161-175.

Pajor J., Okoliczności zawarcia i próba oceny porozumienia Lansing-Ishii, [w:] R.P. Żurawski vel Grajewski, D. Jeziorny, S.M. Nowinowski (red.), Politycy, dyplomaci i żotnierze. Studia i szkice $z$ dziejów stosunków międzynarodowych w XX i XXI wieku ofiarowane Profesorowi Andrzejowi Maciejowi Brzezińskiemu w 70. rocznicę urodzin, Łódź 2017, s. 53-66.

Pajor J., Stanowisko USA wobec Chin podczas powstania Yihetuan, „Azja-Pacyfik” 2011, t. 14, s. $183-210$.

Pajor J., Waszyngton wobec „Drugiej Rewolucji” w Chinach i wzrostu dążé autorytarnych Yuan Shikaia (marzec-grudzień 1913), „Dzieje Najnowsze” 2014, R. 46, nr 4, s. 55-72.

Pajor J., Wielka Brytania wobec ksztaltowania się amerykańskiej polityki „otwartych drzwi” $w$ Chinach (1898-1900), „Acta Universitatis Lodziensis. Folia Historica” 2012, t. 89, s. 7-21.

Pałasz-Rutkowska E., Cesarz Meiji (1852-1912). Wizerunek władcy w modernizowanej Japonii, Warszawa 2012.

Pałasz-Rutkowska E., Starecka K., Japonia, Warszawa 2004.

Panikkar K.M., Azja w dominacji zachodu. Epoka Vasco da Gamy w dziejach Azji 1498-1945, przel. K. Kęplicz, Warszawa 1972.

Pash S., The Currents of War: A New History of American-Japanese Relations, 1899-1941, Lexington 2014.

Pastusiak L., Droga Stanów Zjednoczonych do mocarstwowości, Łódź 2007.

Pastusiak L., Dyplomacja Stanów Zjednoczonych (XVIII-XIX w.), Warszawa 1978.

Pastusiak L., Pót wieku dyplomacji amerykańskiej 1898-1945, Warszawa 1974.

Pastusiak L., Prezydenci Stanów Zjednoczonych Ameryki, Warszawa 2002.

Peffer N., The Far East: A Modern History, Ann Arbor 1958.

Pletcher D.M., The Diplomacy of Involvement: American Economic Expansion Across the Pacific, 1784-1900, Columbia 2001.

Polit J., Chiny, Warszawa 2004.

Polit J., Dyplomacja brytyjska, japońska i amerykańska w Chinach, 1895-1949, „Dzieje Najnowsze” 2010, R. 42, nr 1, s. 19-40.

Polit J., Japonia, Anglosasi i interwencja na Syberii, 1917-1925, „Arcana” 1999, nr 26, s. 168-181.

Polit J., Japońska polityka zagraniczna 1895-1945, Kraków 2015.

Polit J., Mocarstwa wobec Rewolucji Xinhai, „Azja-Pacyfik” 2011, t. 14, s. 87-106.

Polit J., Odwrót znad Pacyfiku? Wielka Brytania wobec Dalekiego Wschodu (1914-1922), Kraków 1999.

Polit J., Pod wiatr. Czang Kaj-szek 1887-1975, Kraków 2008. 
Polit J., Wojny chińskich warlordów 1916-1928, Zabrze-Tarnowskie Góry 2017.

Pomerantz-Zhang L., Wu Tingfang (1842-1922): Reform and Modernization in Modern Chinese History, Hong Kong 1992.

Pringle H.F., The Life and Times of William Howard Taft: A Biography, t. 1-2, New York 1939.

Pugach N., American Friendship for China and the Shantung Question at the Washington Conference, „The Journal of American History” 1977, t. 64, nr 1, s. 67-86.

Pugach N., Embarrassed Monarchist: Frank J. Goodnow and Constitutional Development in China, 1913-1915, „Pacific Historical Review” 1973, t. 42, nr 4, s. 499-517.

Pugach N., Keeping an Idea Alive: The Establishment of a Sino-American Bank, 1910-1920, „The

Business History Review" 1982, t. 56, nr 2, s. 265-293.

Pugach N., Making the Open Door Work: Paul S. Reinsch in China, 1913-1919, „Pacific Historical Review” 1969, t. 38, nr 2, s. 157-175.

Pugach N., Paul S. Reinsch: Open Door Diplomat in Action, Millwood 1979.

Pugach N., Standard Oil and Petroleum Development in Early Republican China, „The Business History Review" 1971, t. 45, nr 4, s. 452-473.

Purcell V., The Boxer Uprising: A Background Study, Cambridge 1963.

Rauchway E., Willard Straight and the Paradox of Liberal Imperialism, „Pacific Historical Review” 1997, t. 66, nr 3, s. 363-397.

Reed J., The Missionary Mind and American East Asia Policy, 1911-1915, Cambridge 1983.

Reid J.G., The Manchu Abdication and the Powers, 1908-1912: An Episode in Pre-war Diplomacy, Westport 1973.

Remer C.F., Foreign Investments in China, New York 1968.

Rodziński W., Historia Chin, Wrocław 1992.

Rojek W., Ekspansja mocarstw w Chinach i jej wptyw na rozwój stosunków międzynarodowych w latach 1895-1914, Kraków 1990.

The Russo-Japanese War in Global Perspective: World War Zero, (red.) J.W. Steinberg, B.W. Menning, D. Schimmelpenninck van der Oye, D. Wolff, S. Yokote, Leiden-Boston 2005.

Safford J.J., Wilsonian Maritime Diplomacy, 1913-1921, New Brunswick 1978.

Saxon T.D., Anglo-Japanese Naval Cooperation, 1914-1918, online: https://digitalcommons. liberty.edu/hist_fac_pubs/5 (dostęp: 21.08.2018).

Scanlan P.J., No Longer a Treaty Port: Paul S. Reinsch and China 1913-1919, nieopublikowany doktorat, University of Wisconsin, Madison 1973.

Schiffrin H.Z., The Enigma of Sun Yat-sen, [w: ] M.C. Wright (red.), China in Revolution: The First Phase, 1900-1913, New Haven-London 1968, s. 443-474.

Schiffrin H.Z., Sun Yat-sen and the Origins of the Chinese Revolution, Berkeley-Los Angeles 1968.

Scholes W., Scholes M., The Foreign Policies of the Taft Administration, Columbia 1970.

The Shaping of American Diplomacy, (red.) W.A. Williams, Chicago 1956.

Sheridan J.E., China in Disintegration: The Republican Era in Chinese History, 1912-1949, New York 1975.

Smith D.M., Aftermath of War: Bainbridge Colby and Wilsonian Diplomacy, 1920-1921, Philadelphia 1970.

Smith D.M., Robert Lansing and American Neutrality, 1914-1917, New York 1972.

Steiger G.N., China and the Occident: The Origin and Development of the Boxer Movement, New Haven 1927. 
Straight W., China's Loan Negotiations, „The Journal of Race Development” 1913, t. 3, nr 4, s. 369-411.

Talbert B.W., The Evolution of John Hay's China Policy, nieopublikowany doktorat, The University of North Carolina at Chapel Hill, Chapel Hill 1974.

Tan Ch., The Boxer Catastrophe, New York 1955.

Thayer W.R., The Life and Letters of John Hay, t. 1-2, Boston-New York 1915.

Tindall G.B., Shi D.E., Historia Stanów Zjednoczonych, przeł. A. Bartkowicz, H. Jankowska, J. Ruszkowski, Poznań 2002.

Tomimas S., The Open-Door Policy and The Territorial Integrity of China, New York 1919.

Trani E.P., The Treaty of Portsmouth: An Adventure in American Diplomacy, Lexington 1969.

Trani E.P., Woodrow Wilson, China, and the Missionaries, 1913-1921, „Journal of Presbyterian History" 1971, t. 49, nr 4, s. 328-351.

Tubielewicz J., Historia Japonii, Wrocław 1984.

Tuchman B.W., Stilwell and the American Experience in China, 1911-1945, New York 1970.

Tuchman B.W., Telegram Zimmermanna, przeł. M.J. i A. Michejdowie, Warszawa 1988.

Turner F.J., The Frontier in American History, New York 1948.

Valone S.J., "A Policy Calculated to Benefit China": The United States and China Arms Embargo, 1919-1929, New York 1991.

Varg P.A., The Making of a Myth: the United States and China, 1897-1912, Westport 1980.

Varg P.A., Open Door Diplomat. The Life of W.W. Rockhill, Urbana 1952.

Vevier Ch., The United States and China, 1906-1913: A Study in Finance and Diplomacy, New York 1968.

Walker W.O. III, Opium and Foreign Policy: The Anglo-American Search for Order in Asia, 19121954, Chapel Hill 1991.

Walworth A., America's Moment, 1918: American Diplomacy at the End of World War I, New York 1977.

The Washington Conference, 1921-22: Naval Rivalry, East Asian Stability and the Road to Pearl Harbor, (red.) E. Goldstein, J. Maurer, London 2004.

Weinberg A.K., Manifest Destiny: A Study of Nationalist Expansionism in American History, Baltimore 1935.

Wheeler W.R., China and the World-War, New York 1919.

White J.A., The Diplomacy of the Russo-Japanese War, Princeton 1964.

Widenor W.C., Henry Cabot Lodge and the Search for an American Foreign Policy, Berkeley 1980.

Williams W.A., The Tragedy of American Diplomacy, New York 1962.

Winid B., Santiago 1898, Warszawa 1995.

Woodrow Wilson and a Revolutionary World, 1913-1921, (red.) A.S. Link, Chapel Hill 1982.

Wright M.C., Introduction: The Rising Tide of Change, [w:] M.C. Wright (red.), China in Revolution: The First Phase, 1900-1913, New Haven-London 1968, s. 1-63.

Wu Tingfang, American Through the Spectacles of an Oriental Diplomat, New York 1914.

Xu Guoqi, China and the Great War. China's Pursuit of a New National Identity and Internationalization, Cambridge 2005.

Yen Ching Hwang, The Overseas Chinese and the 1911 Revolution. With Special Reference to Singapore and Malaya, Kuala Lumpur 1976.

Young E.P., Yuan Shih-k'ai's Rise to the Presidency, [w:] M.C. Wright (red.), China in Revolution: The First Phase, 1900-1913, New Haven-London 1968, s. 419-442. 
Young M.B., The Rhetoric of Empire: American China Policy, 1895-1901, Cambridge 1968.

Zabriskie E.H., American-Russian Rivalry in the Far East: A Study in Diplomacy and Power Politics, 1895-1914, Philadelphia 1946.

Zaremba P., Demokracja w stanie wojny. Woodrow Wilson i jego Ameryka. Dzieje polityczne Stanów Zjednoczonych od roku 1900, t. 2, Warszawa 2014.

Zaremba P., Uzbrojona demokracja. Theodore Roosevelt i jego Ameryka. Dzieje polityczne Stanów Zjednoczonych od roku 1900, t. 1, Warszawa 2012.

Zyblikiewicz L., USA, Warszawa 2004. 



\section{ZAEĄCZNIKI}

\section{Załącznik 1}

Mapa: Chiny w 1911 roku

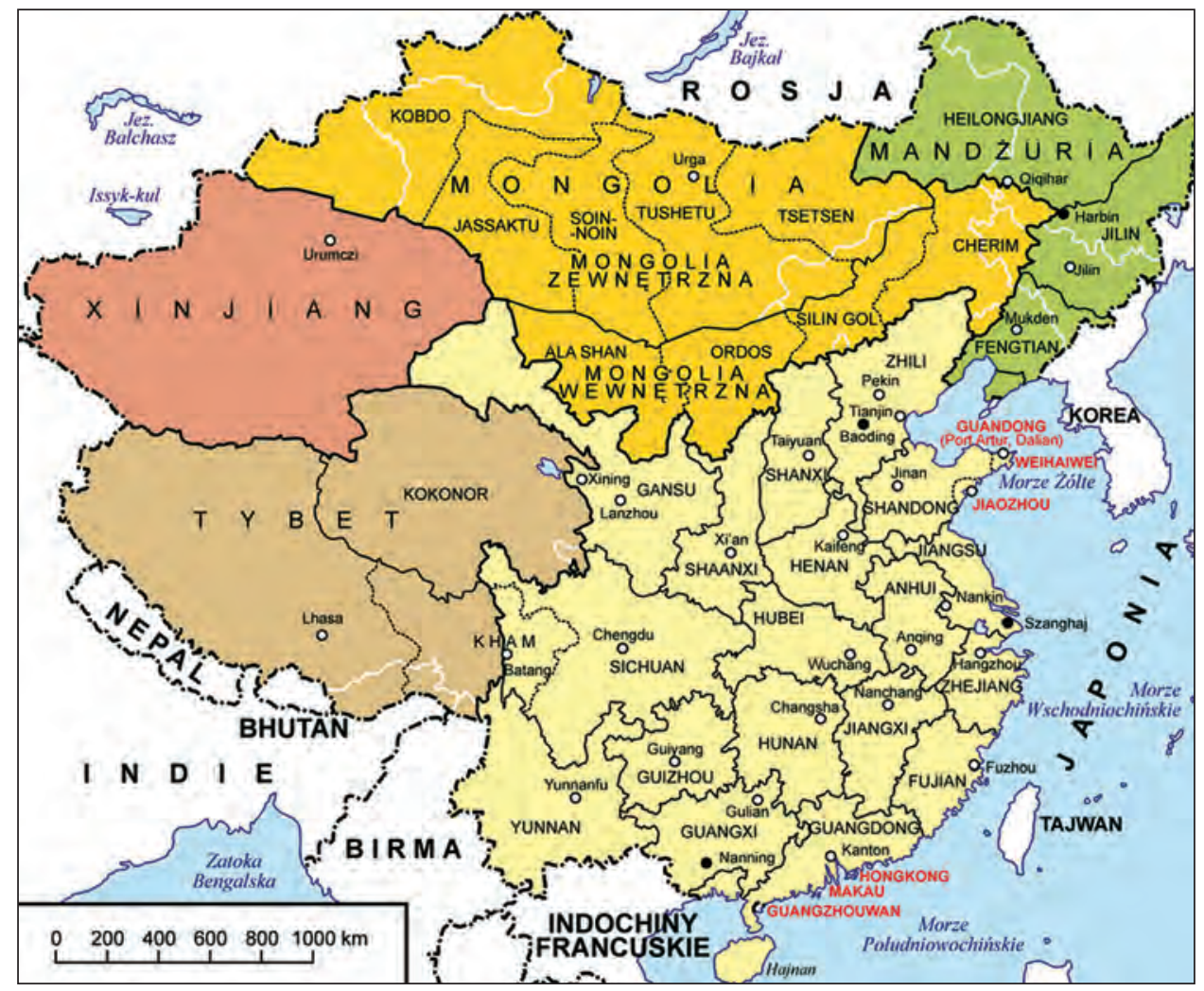

Mapę sporządziła Anna Wosiak na podstawie mapy zamieszczonej na stronie internetowej: http://www.euratlas.net/history/hisatlas/china/1911ChinaTRZ.html (dostęp: 09.03.2018) 


\section{Załącznik 2}

\section{Dwadzieścia jeden żądań \\ 18 stycznia 1915 roku}

Polskie tłumaczenie zaczerpnięto ze zbioru dokumentów: Prawo międzynarodowe i historia dyplomatyczna. Wybór dokumentów, wstęp i oprac. L. Gelberg, t. 1, Warszawa 1954, s. 324-327. W tekście dostosowano nazwy chińskie do transkrypcji pinyin.

Rząd japoński i rząd chiński, pragnąc utrzymać powszechny pokój w Azji Wschodniej oraz osiągnąć dalsze wzmocnienie przyjacielskich i dobrosąsiedzkich stosunków istniejących między obu narodami, zgadzają się na następujące postanowienia:

Art. 1. Rząd chiński zobowiązuje się udzielić pełnej zgody we wszystkich sprawach, które rząd japoński może w przyszłości uzgodnić z rządem niemieckim w zakresie rozporządzenia wszelkimi prawami, interesami i koncesjami, które Niemcy nabyły na mocy traktatów lub na innej podstawie w stosunku do prowincji Shandong.

Art. 2. Rząd chiński zobowiązuje się, że w żadnym przypadku nie ustąpi ani nie wydzierżawi trzeciemu mocarstwu żadnego obszaru ani żadnej wyspy położonych w obrębie prowincji Shandong lub wzdłuż jej brzegów.

Art. 3. Rząd chiński zgadza się na zbudowanie przez Japonię kolei żelaznej z Yantai lub Longkou w celu uzyskania połączenia z koleją żelazną Jiaozhou-Jinan.

Art. 4. Rząd chiński zobowiązuje się otworzyć jak najprędzej w interesie handlu i w celu umożliwienia pobytu cudzoziemcom pewne ważne miasta w prowincji Shandong jako porty handlowe. W oddzielnym porozumieniu zdecyduje się wspólnie, jakie miejscowości mają być otwarte.

Rządy Japonii i Chin, z uwagi na to, że rząd chiński zawsze uznawał specjalne stanowisko Japonii w południowej Mandżurii i we wschodniej części Mongolii Wewnętrznej, zgadzają się na następujące postanowienia:

Art. 1. Obie Umawiające się Strony zgadzają się wspólnie, że okres dzierżawy Port Artur i Dalianu oraz południowomandżurskiej kolei żelaznej i kolei żelaznej Andong-Mukden przedłużony będzie na lat 99.

Art. 2. Poddani japońscy będą mieli w południowej Mandżurii i we wschodniej części Mongolii Wewnętrznej prawo dzierżawienia lub nabycia na własność gruntu potrzebnego bądź dla zbudowania odpowiednich budynków dla celów handlowych lub przemysłowych, bądź dla gospodarstwa rolnego. 
Art. 3. Poddani japońscy będą mogli swobodnie przebywać i podróżować w południowej Mandżurii i we wschodniej części Mongolii Wewnętrznej oraz zajmować się wszelkiego rodzaju handlem i przemysłem.

Art. 4. Rząd chiński zgadza się przyznać poddanym japońskim prawo uruchamiania kopalń w południowej Mandżurii i we wschodniej części Mongolii Wewnętrznej. W kwestii, jakie kopalnie mają być otwarte, podejmie się wspólną decyzję.

Art. 5. Rząd chiński zgadza się, że odnośnie (dwóch) wymienionych tu poniżej przypadków, przed przystąpieniem do działania konieczna będzie uprzednia zgoda rządu japońskiego:

a) w przypadku udzielania poddanemu trzeciego mocarstwa zezwolenia na budowę kolei żelaznej lub na zaciągnięcie u trzeciego mocarstwa pożyczki na budowę kolei żelaznej w południowej Mandżurii lub we wschodniej części Mongolii Wewnętrznej;

b) w przypadku zaciągania u trzeciego mocarstwa pożyczki zabezpieczonej podatkami lokalnymi południowej Mandżurii i wschodniej części Mongolii Wewnętrznej.

Art. 6. Rząd chiński zgadza się, że w razie gdyby miał on zatrudnić doradców albo instruktorów politycznych, finansowych lub wojskowych w południowej Mandżurii lub we wschodniej części Mongolii Wewnętrznej, zasięgnie on najpierw rady rządu japońskiego.

Art. 7. Rząd chiński zgadza się, że kontrola i zarząd kolei żelaznej Jilin-Changchun przekazane będą rządowi japońskiemu na okres 99 lat, począwszy od dnia podpisania niniejszego układu.

\section{III}

Rządy Japonii i Chin, biorąc pod uwagę, że finansiści japońscy i spółka Hanyeping Co. pozostają ze sobą obecnie w ścisłych stosunkach oraz pragnąc poprzeć wspólne interesy obu narodów, zgadzają się na następujące postanowienia:

Art. 1. Obie Umawiające się Strony zgadzają się wspólnie, że skoro tylko nadejdzie odpowiednia chwila, spółka Hanyeping Company stanie się wspólnym przedsiębiorstwem obydwu krajów oraz że bez uprzedniej zgody Japonii - Chiny nie będą same rozporządzały jakiegokolwiek rodzaju prawami i własnością wspomnianej spółki ani też nie będą nakłaniać tej spółki, aby dowolnie nimi rozporządzała.

Art. 2. Rząd chiński zgadza się, ażeby eksploatacja wszystkich kopalń położonych w pobliżu kopalń stanowiących własność spółki Hanyeping, a zarządzanych przez osoby nienależące do niej, uzależniona była od zgody tej spółki. Rząd chiński wyraża ponadto zgodę, iż w razie przeprowadzenia jakiegokolwiek przedsięwzięcia, które mogłoby pośrednio lub bezpośrednio naruszyć interesy wspomnianej spółki, konieczna będzie uprzednia jej zgoda. 
Rząd japoński i rząd chiński, mając na względzie skuteczne zachowanie integralności terytorialnej Chin, zgadzają się na następujący artykuł specjalny:

Rząd chiński zobowiązuje się nie odstępować ani wydzierżawiać trzeciemu mocarstwu żadnej przystani, zatoki lub wyspy położonej u brzegów Chin.

\section{$\mathrm{V}$}

Art. 1. Centralny rząd chiński zatrudni wpływowych Japończyków jako doradców w sprawach politycznych, finansowych i wojskowych.

Art. 2. Japońskie szpitale, kościoły i szkoły uzyskają prawo nabywania na własność gruntów.

Art. 3. Ponieważ rząd japoński i rząd chiński spotkały się z wieloma przypadkami sporów między policją japońską a policją chińską, które wywołały poważne nieporozumienia, konieczne jest, aby komendy policji w ważniejszych miejscowościach (w Chinach) były administrowane wspólnie przez Japończyków i Chińczyków lub aby komendy policji w tych miejscowościach zatrudniały dostatecznie dużą liczbę Japończyków, tak aby mogli oni jednocześnie pomagać w opracowywaniu planów szkolenia chińskiej służby policyjnej.

Art. 4. Chiny zakupią od Japonii ustaloną ilość sprzętu wojennego (mniej więcej 50\% tego, co jest potrzebne rządowi chińskiemu) albo utworzony zostanie w Chinach wspólnie zarządzany arsenał chińsko-japoński. Zatrudnieni w nim będą japońscy eksperci techniczni i zakupywany będzie materiał japoński.

Art. 5. Chiny zgadzają się na udzielenie Japonii prawa zbudowania kolei żelaznej łączącej Wuchang z Jiujiangiem i Nanchangiem, drugiej linii między Nanchangiem a Hangzhou oraz trzeciej między Nanchangiem a Chaozhou.

Art. 6. Gdyby Chiny potrzebowały obcych kapitałów dla eksploatacji kopalń oraz budowy kolei żelaznych i urządzeń portowych (włączając w to doki) w prowincji Fujian, zasięgną najpierw rady Japonii.

Art. 7. Chiny zgadzają się, że poddani japońscy będą mieli prawo uprawiania działalności misjonarskiej w Chinach. 


\section{Załącznik 3}

\section{Porozumienie Lansing-Ishii \\ 2 listopada 1917 roku}

Źródło: Robert Lansing Papers, Department of Rare Books and Special Collections, Princeton University Library, Princeton University, Princeton, series 1: official papers, box 2, folder 4, s. 51-53, online: http://findingaids.princeton.edu/collections/ MC083/c0015 (dostęp: 22.02.2018).

Wasza Ekscelencjo,

$$
\begin{array}{r}
\text { Departament Stanu } \\
\text { Waszyngton } \\
2 \text { listopada } 1917 \text { roku }
\end{array}
$$

w niniejszym piśmie mam zaszczyt przekazać moje pojmowanie porozumienia zawartego przez nas podczas naszych niedawnych rozmów dotyczących kwestii będących przedmiotem zainteresowania naszych Rządów w odniesieniu do Republiki Chińskiej.

W celu położenia kresu wrogim pogłoskom rozpowszechnianym co jakiś czas, uznaliśmy, że należałoby jeszcze raz publicznie ogłosić zamiary i intencje podzielane przez nasze dwa Rządy w odniesieniu do Chin.

Rządy Stanów Zjednoczonych i Japonii uznają, że bliskość terytorialna stwarza specjalne stosunki między państwami i w rezultacie Rząd Stanów Zjednoczonych uznaje, że Japonia ma specjalne interesy w Chinach, szczególnie w tej części, z którą jej posiadłości graniczą.

Terytorialna suwerenność Chin pozostaje mimo to nienaruszona, a Rząd Stanów Zjednoczonych ma pełne zaufanie do zapewnień wielokrotnie powtarzanych przez Cesarski Rząd Japoński, że chociaż w wyniku położenia geograficznego Japonia ma takie specjalne interesy, nie zamierza działać na szkodę handlu innych państw ani ignorować praw handlowych dotychczas przyznanych przez Chiny w traktatach $\mathrm{z}$ innymi mocarstwami.

Rządy Stanów Zjednoczonych i Japonii zaprzeczają, jakoby miały najmniejszy zamiar w jakikolwiek sposób naruszyć niepodległość lub integralność terytorialną Chin i deklarują ponadto, że zawsze przestrzegały zasady tzw. otwartych drzwi lub równych szans dla handlu i przemystu w Chinach.

Poza tym wspólnie deklarują, że sprzeciwiają się uzyskaniu przez jakiekolwiek państwo jakichkolwiek specjalnych praw lub przywilejów, które naruszyłyby niepodległość bądź integralność terytorialną Chin lub uniemożliwiłyby poddanym albo obywatelom jakiegokolwiek państwa pełne korzystanie z równych szans w handlu i przemyśle Chin. 
Będę wdzięczny, jeśli Wasza Ekscelencja potwierdzi to pojmowanie zawartego przez nas porozumienia.

Proszę przyjąć, Wasza Ekscelencjo, ponowne zapewnienie mojego najwyższego uznania.

Robert Lansing

Jego Ekscelencja

wicehrabia Kikujirō Ishii

Ambasador Nadzwyczajny i Pełnomocny Japonii w misji specjalnej 
Waszyngton, 2 listopada 1917 roku

Szanowny Panie,

mam zaszczyt potwierdzić odbiór Pańskiej dzisiejszej noty przekazującej mi Pańskie pojmowanie porozumienia zawartego przez nas podczas naszych niedawnych rozmów dotyczących kwestii będących przedmiotem zainteresowania naszych Rządów w odniesieniu do Republiki Chińskiej.

Jestem rad, że mogę z upoważnienia mojego Rządu potwierdzić Panu rzeczone pojmowanie przedstawiające się następująco:

W celu położenia kresu wrogim pogłoskom rozpowszechnianym co jakiś czas, uznaliśmy, że należałoby jeszcze raz publicznie ogłosić zamiary i intencje podzielane przez nasze dwa Rządy w odniesieniu do Chin.

Rządy Stanów Zjednoczonych i Japonii uznają, że bliskość terytorialna stwarza specjalne stosunki między państwami i w rezultacie Rząd Stanów Zjednoczonych uznaje, że Japonia ma specjalne interesy w Chinach, szczególnie w tej części, z którą jej posiadłości graniczą.

Terytorialna suwerenność Chin pozostaje mimo to nienaruszona, a Rząd Stanów Zjednoczonych ma pełne zaufanie do zapewnień wielokrotnie powtarzanych przez Cesarski Rząd Japoński, że chociaż w wyniku położenia geograficznego Japonia ma takie specjalne interesy, nie zamierza działać na szkodę handlu innych państw ani ignorować praw handlowych dotychczas przyznanych przez Chiny w traktatach $\mathrm{z}$ innymi mocarstwami.

Rządy Stanów Zjednoczonych i Japonii zaprzeczają, jakoby miały najmniejszy zamiar w jakikolwiek sposób naruszyć niepodległość lub integralność terytorialną Chin i deklarują ponadto, że zawsze przestrzegały zasady tzw. otwartych drzwi lub równych szans dla handlu i przemysłu w Chinach.

Poza tym wspólnie deklarują, że sprzeciwiają się uzyskaniu przez jakiekolwiek państwo jakichkolwiek specjalnych praw lub przywilejów, które naruszyłyby niepodległość bądź integralność terytorialną Chin lub uniemożliwiłyby poddanym albo obywatelom jakiegokolwiek państwa pełne korzystanie $\mathrm{z}$ równych szans w handlu i przemyśle Chin.

Korzystam z okazji, aby przekazać Panu zapewnienia mojego najwyższego uznania.

K. Ishii

Ambasador Nadzwyczajny i Pełnomocny Japonii w misji specjalnej

Szanowny Pan Robert Lansing

Sekretarz Stanu 



\section{INDEKS OSÓB}

Indeks nie obejmuje nazwisk wymienionych w bibliografii i przypisach odsyłających do dokumentów i prac innych autorów. Podano w nim jedynie strony, na których pojawia się nazwisko danej osoby.

Abbott John 261-263

Adams Brooks 19

Adams Henry 149

Adee Alvey 125-126

Aglen Francis 181

Alston Beilby 265, 272

Ambrosius Lloyd 12

Anderson Chandler P. 119

Aoki Norizumi 245

Arnold Julean 205

Bachmietiew Borys 292

Bai Lang 221

Baker Edward Carleton 171

Baker Ray Stannard 12, 119

Balfour Arthur 220, 249-250, 257

Bashford James Whitford 75, 112, 152, 158, 207

Bau Mingchien J. 18

Beers Burton 13, 193, 200, 288

Bergson Henri 298

Bernstorff Johann Heinrich von 197

Bezobrazow Aleksandr 26

Blum John Morton 12

Bonaparte Napoleon 78

Brent Charles 104

Breslin Thomas A. 13, 137

Bryan William Jennings 10-12, 109-111, 114-117, 119-123, 125-128, 144, 146149, 151-153, 155, 159, 168-169, 171, $175,183,189-190,192-211,214,216-$ $218,223,226,239-240,284-285$

Brzeziński Andrzej M. 16

Burton David 12

Burton Ernest 153
Cai E 182, 229, 231, 243

Calhoun William 36-37, 47-51, 53, 55-58, $61,65-68,74-75,77-79,83,85,89,91$, 93-95, 98, 100, 102, 132, 152

Cao Kun 299

Cao Rulin 243, 245, 251, 269, 282

Capen Samuel B. 153

Ch'ên Jerome 142

Chi Madeleine 14, 290

Chinda Sutemi 189, 196-198, 202, 205-206, 209-212, 214, 229

Chwalba Andrzej 305

Cixi 24, 66

Clements Kendrick 12

Cleveland Grover 109

Colby Bainbridge 110

Coletta Paolo 12

Conant Charles 19

Conty Alexandre Robert 271

Cooper John Milton jr. 12

Crane Charles 36, 154, 158

Crane Daniel M. 13, 137

Crisp Charles Birch 96-97, 99

Curry Roy Watson 13, 151, 191, 193

Daniels Josephus 11, 119, 135, 278

Davidson Henry P. 119

Delcassé Théophile 212

Denby Charles jr. 300

Díaz Porfirio 146

Dmochowski Tadeusz 14

Duan Qirui 166, 182, 222, 229-230, 235, 237-238, 241, 243-245, 251, 268-277, 279, 281-282, 299, 301, 304 
Einstein Lewis 79

Eliot Charles 153

Elleman Bruce A. 213

Ellis William 153

Feng Guozhang 166, 229-230, 234-235, $241,243,245,269,274-275,279,299,301$

Fifield Russell H. 13

Folk Joseph 153

Foster John W. 158, 219, 289

Fowler John 139, 169

Gardner Lloyd 13, 118, 124

Gauss Clarence 230, 291

Goodnow Frank 149, 157, 165, 218, 222, 225-226

Gould Lewis 12

Grant Jesse 153

Greene Conyngham 201

Grenville John A.S. 30

Grey Edward 11, 212, 214-215, 236, 246, 250

Griswold Alfred W. 13, 180

Griswold Benjamin Howell jr. 218-219

Gu Weijun - zob. Koo Wellington

Guangxu 24, 62, 66

Guthrie George 183, 188-189, 194, 197, 201, 205-206

Hapgood Norman 153

Harriman Edward 35, 39-40

Hay John 7, 22, 25, 27, 116, 195, 202, 257

Hayashi Gonsuke 247, 269, 292-293, 300

Heckscher August 12

Heintzleman Percival Stewart 280

Herrick Myron 116

Hioki Eki 186-187, 189, 198, 207, 210

Hodgson Godfrey 12

Hoover Herbert 11, 222

House Edward M. 12, 111, 120, 195-196, $218,232,249,288-289$

Houston David F. 11, 109, 127

Huang Xing 46, 142-143, 168-169, 221, 243

Huerta Victoriano 146-147, 149

Hunt Michael H. 13

Huntington-Wilson Francis Mairs - zob. Wilson Huntington
Iriye Akira 13

Ishii Kikujirō 15, 283, 285-294, 298, 303$305,310,331-333$

Jansen Marius B. 14

Jenks Jeremiah 153, 268

Jordan David Starr 116

Jordan John 52, 61, 66, 111, 130, 212, 215, 242,300

Kang Youwei 24, 274-275

Katō Takaaki 180-181, 184, 186, 189, 197$198,201,206,212,215$

Katsura Tarō 29

Kazin Michael 12

Kiwerska Jadwiga 16

Knox Philander C. 10, 32, 34, 36, 38, 40-41, $43,49,53,55-56,58,62,75,88,90,94-95$, 98, 102-103, 105, 107, 121, 194

Kokoszko Maciej 16

Koo Wellington (Gu Weijun) 15, 182, 250, 277, 281, 290, 293-294, 299

Krupienski Wasilij 293

Kudaszew Mikołaj 254

Lafferty Walter 69

Lane Franklin K. 153

Lansing Robert 10-12, 15, 110-111, 175, $182-183,185,190,193,195-196,198-$ 199, 201, 213, 215, 217-220, 224-229, 232, 236, 240, 246-247, 249, 251-253, 255-262, 264-268, 271-272, 274, 276, 278-295, 298, 301, 303-305, 310, 331333

Laughlin Irwin B. 247

Lazo Dimitri Daniel 13, 193-194, 200

Lea Homer 70, 75

Li Tien-yi 13, 190, 193, 215

Li Yuanhong 48, 63, 68, 133, 145, 241, 243245, 269-274, 276, 279

Liang Dunyan 166, 274

Liang Qichao 24, 166, 229, 236, 238, 243, 245,282

Liang Shiyi 166, 222, 226, 229, 244

Link Arthur 12, 110, 189, 193, 199, 201, 210 
Lloyd George David 269

Lodge Henry Cabot 90

Long Breckinridge 289

Longyu 62, 75

Lowe Peter 13

Lu Zhengxiang 93, 134

MacMurray John V.A. 12, 157, 175, 179, 182, 207, 223-224

MacMurray Lois ( $\mathrm{z}$ domu Goodnow) 157

Madero Francisco 146

Mahan Alfred Thayer 19

Mania Andrzej 14

Maryniak Agata 16

Materski Wojciech 14

McAdoo William 120, 168, 268, 281, 296

McCormick Thomas J. 13, 32, 309

McKinley William 21, 27, 32

McReynolds James 119

Meiji (za życia Mutsuhito) 34, 90, 194

Michałek Krzysztof 14

Millard Thomas 291

Miller Ransford 38, 119, 158

Minger Ralph 12

Monroe James 30, 90, 147, 190

Moore John Bassett 111, 158, 175, 182

Morgenthau Henry sen. 151, 153

Morris Roland 296

Motono Ichirō 293

Mott John 153, 158

Murdock Joseph 68, 75

Nicholson Reginald 132, 139, 142

Nishihara Kamezō 251

Notter Harley 12

Ōkuma Shigenobu 184, 186, 188, 208, 212

Osborne John 158

Page Walter Hines 234

Pastusiak Longin 14

Peck Willys 147

Pershing John J. 34, 232

Phillips William 11, 35, 37-38

Pletcher David M. 13
Polit Jakub 14, 16, 181, 227, 250, 289-290

Polk Frank 289

Pugach Noel 13

Pujo Arsène 117

Pulun 223

Puyi 11, 42, 45, 62-63, 274

Rea George Bronson 158, 163

Redfield William 117, 120, 128, 294

Reed James 13, 69, 73

Reeves James 68

Reinsch Paul 7, 11-12, 149, 154-158, 160$168,173,175,179,183-186,188-192$, 196-198, 201, 203-212, 214, 217-219, 223-238, 242-246, 251-256, 258-260, 264-268, 270-273, 277-280, 282, 284285, 289, 293-295, 300-301

Rockhill William 36, 149

Rodziński Witold 14, 176, 222, 227

Rojek Wojciech 14, 20

Roosevelt Theodore 11, 14, 23, 27-30, 32$33,36,174,310$

Root Elihu 30, 36, 43, 75, 175, 182, 247

Ross Edward 153

Sammons Thomas 246

Satō Aimaro 253, 261, 272, 284

Sazonow Siergiej 87-88, 212

Scanlan Patrick John 13

Scholes Marie V. 13, 58

Scholes Walter V. 13, 58

Scott Charles E. 112

Simpson Bertram Lenox (pseud. Putnam Weale) 293

Smith Daniel 12

Song Jiaoren 46, 130-131, 134-135, 141, 143, 146, 166

Spring-Rice Cecil 289

Stimson Henry 213

Straight Dorothy 49

Straight Willard 10, 35, 37-38, 49, 57-58, 62, $65,68,73,83,86,90,97,99,119,121,158$, $219,252-253$

Strong Josiah 19

Sulzer William 69 
Sun Yat-sen 11, 46, 48, 53, 59, 62-63, 67-68, $70,73,130,136,146,158,166,168-169$, $211,217,221,229,243-245,269-270$, 273, 279-280, 299, 302-303

Taft Helen (z domu Herron) 33

Taft William H. 9-10, 12, 15, 23, 29, 31-33, 35-36, 39, 43, 51, 69, 74, 79-80, 83, 88, 94-95, 99, 103, 105-106, 117, 121, 124, $126,132,142,171,307,310-312$

Taishō (za życia Yoshihito) 176

Takahira Kogorō 30, 36, 43, 175, 182, 247

Tan Sitong 24

Tang Shaoyi 36, 76, 81, 83-85, 91-92, 243245, 269-270

Tenney Charles 68

Terauchi Masatake 247, 251-252, 266

Trani Eugene P. 155

Turner Frederick Jackson 19, 155

Vanderlip Frank 219

Varg Paul A. 13

Vevier Charles 13

Villa Pancho 208, 232

Wang Chonghui 70

Warburg Paul 119

Weale Putnam - zob. Simpson Bertram Lenox

Wells Herbert George 297

Wheeler Post 272

Wilder Amos 138, 141-142, 147

Williams Edward T. 12, 38, 47-48, 51, 57-58, $65,72,75,77-79,122,125,127-129$, $131-136,138-142,144,147-148,158-$ 160, 183, 185, 190, 192-199, 207, 238, $262,268,281,289,294-295$

Williams William Appleman 117-118, 120

Willoughby Westel W. 225

Willoughby William F. 218, 225

Wilson Ellen (z domu Axson) 176

Wilson Huntington 11, 35, 37-38, 80, 98, $119,121,158$
Wilson Thomas Woodrow 7, 10, 12, 15, 23, $35,99,104-107,109-122,124,126-$ $128,132,135,142,144,146-155,157$, 159-161, 163, 168-171, 176, 183, 185, 189-190, 195-198, 200-203, 205-209, 211-214, 216-219, 223, 225-227, 229, 232, 236, 239, 242-243, 249-251, 255, 257-260, 262-263, 265, 267-268, 276, 278-282, 285, 288-289, 291, 297-303, 310-312

Woodbridge Samuel I. 112

Wosiak Anna 16, 327

Wu Peifu 299

Wu Tingfang 68, 70, 247, 269-270, 273

Wu Zhaolin 48

Xiong Xiling 159-160, 163, 166, 243

Xu Shichang 299, 302-303

Xu Shuzheng 243

Yan Xishan 243

Yikuang, książę Qing 45, 93

Yoshihito - zob. Taishō

Young Ernest P. 77

Young George B. 30

Young Marilyn Blatt 13

Younghusband Francis 28

Yuan Shikai 12, 15, 35-36, 53, 55, 57-58, 61-62, 64-67, 69, 71-72, 76-78, 82-83, 92-93, 97, 106, 115, 122, 125-137, 140$150,158,163-166,168-169,172,178$, $186-188,204,207,211,215,217,221-$ 231, 233-241, 243, 245, 250-251, 254, $267,271,273,276,304,307-309$

Zaifeng, książę Chun 45, 62-63, 66 Zhang Jian 159, 163, 166

Zhang Xun 142, 234, 243, 269-270, 274-277

Zhang Zuolin 243

Zhao Bingjun 166

Zimmermann Arthur 267

Żurawski vel Grajewski Radosław 16 


\section{SPIS ILUSTRACJI}

\section{Theodore Roosevelt i William Taft}

Autorem zdjęcia jest studio fotograficzne Harris \& Ewing. Zdjęcie należy do domeny publicznej i dostępne jest na stronie internetowej Library of Congress, https://www.loc.gov/item/2016856230/ (dostęp: 18.04.2018).

\section{William Taft}

Autorem zdjęcia jest studio fotograficzne Harris \& Ewing. Zdjęcie należy do domeny publicznej i dostępne jest na stronie internetowej Library of Congress, https://www.loc.gov/item/2016856198/ (dostęp: 18.04.2018).

\section{William Taft}

Autorem zdjęcia jest studio fotograficzne Harris \& Ewing. Zdjęcie należy do domeny publicznej i dostępne jest na stronie internetowej Library of Congress, https://www.loc.gov/item/2016856219/ (dostęp: 18.04.2018).

\section{William Taft z żoną Helen Taft}

Autorem zdjęcia jest studio fotograficzne Harris \& Ewing. Zdjęcie należy do domeny publicznej i dostępne jest na stronie internetowej Library of Congress, https://www.loc.gov/item/2016856229/ (dostęp: 18.04.2018).

\section{Philander Knox}

Autorem zdjęcia jest studio fotograficzne Harris \& Ewing. Zdjęcie należy do domeny publicznej i dostępne jest na stronie internetowej Library of Congress, https://www.loc.gov/item/2016856385/ (dostęp: 18.04.2018).

\section{Philander Knox}

Autorem zdjęcia jest studio fotograficzne Harris \& Ewing. Zdjęcie należy do domeny publicznej i dostępne jest na stronie internetowej Library of Congress, https://www.loc.gov/item/2016870094/ (dostęp: 18.04.2018).

\section{Amerykańska delegacja na pogrzebie cesarza Meiji w 1912 roku}

Autorem zdjęcia jest studio fotograficzne Harris \& Ewing. Zdjęcie należy do domeny publicznej i dostępne jest na stronie internetowej Library of Congress, https://www.loc.gov/item/2016856384/ (dostęp: 18.04.2018). 


\section{William Calhoun}

Zdjęcie należy do domeny publicznej i dostępne jest na stronie internetowej https://commons.wikimedia.org/wiki/File:Portrait_of_William_J._Calhoun.jpg (dostęp: 18.04.2018).

\section{Huntington Wilson}

Autorem zdjęcia jest studio fotograficzne Harris \& Ewing. Zdjęcie należy do domeny publicznej i dostępne jest na stronie internetowej Library of Congress, https://www.loc.gov/item/2016856643/ (dostęp: 18.04.2018).

\section{Willard Straight}

Zdjęcie należy do domeny publicznej i dostępne jest na stronie internetowej https://commons.wikimedia.org/wiki/File:Williard_Straight,_portrait_bust LCCN2014680658_(2)_(cropped).jpg (dostęp: 18.04.2018).

\section{William Phillips}

Zdjęcie należy do domeny publicznej i dostępne jest na stronie internetowej https://commons.wikimedia.org/wiki/File:Latest_photo,_just_received_ from_Holland,_of_W._Phillips,_American_Minister_to_Holland.jpg (dostęp: 18.04.2018).

\section{Edward T. Williams}

Autorem zdjęcia jest Bain News Service. Zdjęcie należy do domeny publicznej i dostępne jest na stronie internetowej Library of Congress, https://www.loc. gov/item/2014709278/ (dostęp: 18.04.2018).

\section{Puyi z ojcem (Zaifengiem) i młodszym bratem}

Zdjęcie należy do domeny publicznej i dostępne jest na stronie internetowej https://commons.wikimedia.org/wiki/File:PuYi_1909.jpg (dostęp: 18.04.2018).

\section{Puyi}

Autorem zdjęcia jest Bain News Service. Zdjęcie należy do domeny publicznej i dostępne jest na stronie internetowej Library of Congress, https://www.loc. gov/item/2014701616/ (dostęp: 18.04.2018).

\section{Sun Yat-sen}

Zdjęcie należy do domenypubliczneji dostępnejest nastronie internetowej https:// commons.wikimedia.org/wiki/File:Sunzhongshan_2.jpg (dostęp: 18.04.2018). 


\section{Li Yuanhong i Sun Yat-sen}

Zdjęcie należy do domeny publicznej i dostępne jest na stronie internetowej https://commons.wikimedia.org/wiki/File:Sun_Yat-sen_Li_Yuanhong_Wuchang_1912.jpg (dostęp: 18.04.2018).

\section{Yuan Shikai}

Zdjęcie należy do domeny publicznej i dostępne jest na stronie internetowej https://commons.wikimedia.org/wiki/File:YuanShikaiPresidente1915.jpg (dostęp: 18.04.2018).

\section{Yuan Shikai podczas zaprzysiężenia na urząd tymczasowego prezydenta Republiki Chińskiej (10 marca 1912 roku)}

Zdjęcie należy do domeny publicznej i dostępne jest na stronie internetowej https://commons.wikimedia.org/wiki/File:Yuan_Shikai_sworn_in_as_Provisional_President_-_10_March_1912.jpg (dostęp: 18.04.2018).

\section{Woodrow Wilson}

Autorem zdjęcia jest studio fotograficzne Harris \& Ewing. Zdjęcie należy do domeny publicznej i dostępne jest na stronie internetowej Library of Congress, https://www.loc.gov/item/2016865613/ (dostęp: 18.04.2018).

\section{Woodrow Wilson}

Autorem zdjęcia jest studio fotograficzne Harris \& Ewing. Zdjęcie należy do domeny publicznej i dostępne jest na stronie internetowej Library of Congress, https://www.loc.gov/item/2016857917/ (dostęp: 18.04.2018).

\section{Rząd Woodrowa Wilsona}

Autorem zdjęcia jest studio fotograficzne Harris \& Ewing. Zdjęcie należy do domeny publicznej i dostępne jest na stronie internetowej Library of Congress, https://www.loc.gov/item/2016858384/ (dostęp: 18.04.2018).

\section{William J. Bryan}

Autorem zdjęcia jest studio fotograficzne Harris \& Ewing. Zdjęcie należy do domeny publicznej i dostępne jest na stronie internetowej Library of Congress, https://www.loc.gov/item/2016856655/ (dostęp: 18.04.2018).

\section{William J. Bryan i Woodrow Wilson}

Autorem zdjęcia jest Bain News Service. Zdjęcie należy do domeny publicznej i dostępne jest na stronie internetowej Library of Congress, https://www.loc. gov/item/2014691271/ (dostęp: 18.04.2018). 


\section{William J. Bryan w otoczeniu przedstawicieli Chinese Chamber of Com- merce}

Autorem zdjęcia jest studio fotograficzne Harris \& Ewing. Zdjęcie należy do domeny publicznej i dostępne jest na stronie internetowej Library of Congress, https://www.loc.gov/item/2016866446/ (dostęp: 18.04.2018).

\section{Song Jiaoren}

Zdjęcie należy do domeny publicznej i dostępne jest na stronie internetowej https://commons.wikimedia.org/wiki/File:Sung_Chiao-jen.jpg (dostęp: 18.04.2018).

\section{Huang Xing}

Zdjęcie należy do domeny publicznej i dostępne jest na stronie internetowej https://commons.wikimedia.org/wiki/File:Huang_xing.jpg (dostęp: 18.04.2018).

\section{Paul Reinsch}

Zdjęcie należy do domeny publicznej i dostępne jest na stronie internetowej https://commons.wikimedia.org/wiki/File:Portrait_of_Paul_Samuel_Reinsch.jpg (dostęp: 18.04.2018).

\section{John V.A. MacMurray}

Zdjęcie należy do domeny publicznej i dostępne jest na stronie internetowej https://commons.wikimedia.org/wiki/File:John_Van_A._MacMurray, Asst._Sec._of_State.jpg (dostęp: 18.04.2018).

\section{Robert Lansing}

Autorem zdjęcia jest studio fotograficzne Harris \& Ewing. Zdjęcie należy do domeny publicznej i dostępne jest na stronie internetowej Library of Congress, https://www.loc.gov/item/2016867162/ (dostęp: 18.04.2018).

\section{Arthur Balfour i Robert Lansing}

Autorem zdjęcia jest studio fotograficzne Harris \& Ewing. Zdjęcie należy do domeny publicznej i dostępne jest na stronie internetowej Library of Congress, https://www.loc.gov/item/2016867620/ (dostęp: 18.04.2018).

\section{Robert Lansing}

Autorem zdjęcia jest studio fotograficzne Harris \& Ewing. Zdjęcie należy do domeny publicznej i dostępne jest na stronie internetowej Library of Congress, https://www.loc.gov/item/2016893382/ (dostęp: 18.04.2018). 


\section{Duan Qirui}

Zdjęcie należy do domeny publicznej i dostępne jest na stronie internetowej https://commons.wikimedia.org/wiki/File:DuanQirui.jpg (dostęp: 18.04.2018).

\section{Feng Guozhang}

Autorem zdjęcia jest Bain News Service. Zdjęcie należy do domeny publicznej i dostępne jest na stronie internetowej Library of Congress, https://www.loc. gov/item/2014703897/ (dostęp: 18.04.2018).

\section{Kang Youwei}

Zdjęcie należy do domeny publicznej i dostępne jest na stronie internetowej https://commons.wikimedia.org/wiki/File:Kang_Youwei_circa_1920.jpg (dostęp: 18.04.2018).

\section{Zhang Xun}

Zdjęcie należy do domeny publicznej i dostępne jest na stronie internetowej https://commons.wikimedia.org/wiki/File:Zhangxun.jpg (dostęp: 18.04.2018).

\section{Ishii Kikujirō i Robert Lansing}

Autorem zdjęcia jest studio fotograficzne Harris \& Ewing. Zdjęcie należy do domeny publicznej i dostępne jest na stronie internetowej Library of Congress, https://www.loc.gov/item/2016868271/ (dostęp: 18.04.2018).

\section{Ishii Kikujirō i Robert Lansing}

Autorem zdjęcia jest studio fotograficzne Harris \& Ewing. Zdjęcie należy do domeny publicznej i dostępne jest na stronie internetowej Library of Congress, https://www.loc.gov/item/2016868264/ (dostęp: 18.04.2018). 
